\title{
Vejigantes: From Traditional to Contemporary
}

Chelsea M. Glidden Bosch

$\mathrm{PhD}$ in Art: Production and Research Director: Dr. Sara Vilar García 
Vejigantes: From Traditional to Contemporary 


\section{Dedication}

To papi. 


\section{Acknowledgments}

I would like to thank my family for the support and encouragement of my studies.

With the help of the following people, I was able to conquer above and beyond as a student and as an artist.

\section{Special thank you for the support from:}

Annette Bosch

Carmen Raquel Bosch

Gary Lee Glidden Jr.

\section{Thank you for the participation from:}

Miguel Conesa Osuna

Humberto Figueroa

Norberto Martell

Edwin Muñiz Pérez

Luis Alberto Pérez

Raquel "Cucha" Rentas

Héctor Rodríguez

Ednisa Torres Ramos 


\section{Abstract}

The purpose of this thesis is to document the change of the vejigante mask, from a folkloric object to a contemporary icon. The research focuses on a further understanding of the mask, magnified through traditions and heritage, executed with an advanced examination of ethnographic research. The investigation theorizes the impact of clashing cultures by analyzing the impact the United States of America has had on Puerto Rico through the use of cultural assimilation. In conjunction with the research, an experimentation with my personal artwork was completed by using unconventional mediums and combinations of classical and contemporary techniques. This provided the platform to encompass the appreciation and the aftereffects of the vejigante's encounter in contemporary contexts. Documentation on the subject is insufficient. Interviews were conducted to contribute evidence to the investigation where the literature lacked. Art historians, artisans, and artists were interviewed, and presented a local perspective and response to the undeniable changes that have taken place in the Carnival. This provided another form of research known as word-of-mouth, which is necessary in the contribution to the history of the vejigante. It is important to include the oral history that derives from word-of-mouth, stories passed down generation to generation, allowing a cultural history to thrive with limited information on the subject. The results display the vejigante mask experienced a shift in cultural depiction and representation due to the United States of America. Although, with the introduction to American culture, the concept of the vejigante was enabled to transform from Carnival traditions to contemporary contexts. 


\section{Resumen}

El propósito de esta tesis es documentar el cambio de la máscara de vejigante, de objeto folklórico a icono contemporáneo. La investigación se centra en un mayor entendimiento de la máscara, magnificada a través de las tradiciones y el patrimonio, en la misma también se utilizó la investigación etnográfica. La investigación postula la teoría que presenta el efecto de culturas en conflicto, analizando el impacto que los Estados Unidos de América han tenido en Puerto Rico a través de la asimilación cultural. Junto con la investigación, completé una experimentación con mi obra personal en la cual se emplearon medios no convencionales y combinaciones de técnicas clásicas y contemporáneas. Esto ha proporcionado una plataforma en la que se abarca la apreciación y las secuelas del encuentro del vejigante en contextos contemporáneos. La documentación escrita sobre el tema es limitada. Se realizaron entrevistas para añadir información a la investigación donde escaseaba la literatura. Se entrevistó a historiadores del arte, artesanos y artistas, quienes presentaron una perspectiva local y una respuesta a los innegables cambios que se han producido en el Carnaval. Esto proporcionó otra forma de investigación derivada de la historia oral que ha sido necesaria para obtener una perspectiva mas amplia del vejigante. Es importante incluir estas historias transmitidas de generación en generación, ya que permiten que una historia cultural prospere aun cuando la información escrita disponible es limitada. Los resultados muestran que la máscara de vejigante experimentó un cambio en su representación física y cultural debido a la influencia y presencia de los Estados Unidos de América en la isla. Con la introducción de la cultura Americana, el concepto de vejigante ha logrado transformarse y evolucionar de las tradiciones carnavalescas a contextos contemporáneos. 


\section{Resum}

El propòsit d'aquesta tesi es documentar el canvi de la màscara de vejigante, d'objecte folklòric a icona contemporània. La investigació se centra en un major enteniment de la màscara, magnificada a través de les tradicions i el patrimoni, en la mateixa també es va utilitzar la investigació etnogràfica. La investigació postula la teoria que presenta l'efecte de cultures en conflicte, analitzant l'impacte que els Estats Units d'Amèrica han tingut en Puerto Rico a través de l'assimilació cultural. Junt amb la investigació, hem completat la experimentació amb la meua obra personal en la qual es van emprar mitjans no convencionals i combinacions de tècniques clàssiques i contemporànies. Açò ha proporcionat una plataforma en la que es comprèn l'apreciació i les seqüeles de la trobada del vejigante en contextos contemporanis. La documentació escrita sobre el tema és limitada. Es van realitzar entrevistes per afegir informació a la investigació on escassejava la literatura. Es van entrevistar historiadors de l'art, artesans i artistes, que van presentar una perspectiva local i una resposta als innegables canvis que s'han produït en els Carnestoltes. Açò va proporcionar una altra forma d'investigació derivada de la història oral que ha sigut necessària per a obtindre una perspectiva mes àmplia del vejigante. És important incloure estes històries transmeses de generació en generació, ja que permeten que una història cultural prospere encara que la informació escrita disponible és limitada. Els resultats mostren que la màscara de vejigante va experimentar un canvi en la seua representació física i cultural a causa de la influència i presència dels Estats Units d'Amèrica en l'illa. Tot i la introducció de la cultura Americana, el concepte de vejigante ha aconseguit transformar-se i evolucionar de les tradicions carnavalesques a contextos contemporanis. 
Dedication 3

Acknowledgments 4

Abstract $\quad 5$

\begin{tabular}{lr} 
Chapter One: Introduction & 10 \\
\hline $1.00 v e r v i e w$
\end{tabular}

1.0 Overview

1.1 Colonization

1.2 Historical Origins

1.3 Cultural Links

1.4 Americanization

Chapter Two: The Vejigante

44

2.0 Overview

2.1 Definition and Concept

2.2 Significance of the Carnival Ceremonies

2.3 Ponce Vejigante Mask

85

2.4 Loíza Vejigante Mask

90

2.5 Decline in Creation and Consumption

Chapter Three: The Line Between

107

3.0 Overview

3.1 Artisan vs. Artist

3.2 Tourist Trinkets vs. Folkloric Objects

116

3.3 Decolonization of Artifacts

Chapter Four: Word-of-Mouth

135

4.0 Overview

4.1 Guidelines

4.2 Interview Guide

4.3 The Artisan and Historian Participants

4.3.1 Humberto Figueroa

4.3.2 Norberto Martell

4.3.3 Raquel "Cucha" Rentas

162

4.3.4 Héctor Rodríguez

4.4 The Artists Participants 
4.4.3 Ednisa Torres $\quad 180$

Chapter Five: Traditional Creation $\quad 183$

4.0 Overview 184

4.1 Engrudo $\quad 185$

4.2 Material and Process $\quad 190$

4.3 Certification as an Artisan $\quad 208$

Chapter Six: Personal Artwork $\quad 217$

$\begin{array}{ll}6.0 \text { Overview } & 218\end{array}$

6.1 Introduction to Personal Artwork $\quad 219$

6.1.1 Traditional Masks $\quad 222$

6.1.2 Contemporary Masks $\quad 239$

$\begin{array}{ll}\text { 6.2 Public Art } & 257\end{array}$

6.2.3 Los Vejigantes de Beetlejuice $\quad 259$

6.2.4 Los Vejigantes del Huracán María $\quad 263$

6.2.5 Los Vejigantes: Paste Ups $\quad 269$

6.3 Publication of Children's Book: "Carnavalera" 277

Chapter Seven: Conclusion $\quad 284$

$\begin{array}{ll}7.0 \text { Overview } & 285\end{array}$

7.2 Findings, Implications, and Future Outlooks 286

Bibliography $\quad 298$

Appendix $\quad 310$ 


\section{Chapter One: Introduction}




\subsection{Overview}

The traditions and heritage that accompany vejigantes masks are identified mainly with the towns of Ponce and Loíza Aldea, Puerto Rico. This investigation focuses on the masks from Ponce. Vejigantes are a product of the first colonization of Puerto Rico by Spain. As a result, the merge of multiple cultures enabled the tradition of the Carnival, and inevitably, the vejigante. After the United States of America (USA) invaded Puerto Rico, the impact of the American culture affected its historical heritage. The folkloric customs adjusted to a new set of norms. Now it is clear prevalent changes occurred in present-day Puerto Rican culture. The research conducted presents a timeline of the gradual changes of the vejigante, and adjoined festivities.

This investigation focuses on the cultural influences that have impacted the heritage of Puerto Rico, specifically focusing on vejigantes from Ponce and La Playa de Ponce. It displays the evolution from primitive tradition to cultural assimilation. It highlights the impact of the American culture on the folkloric traditions, and more importantly, the impact it continues to have on the vejigante mask. The research provides the needed timeline to understand, in depth, the undeniable transformation of the modernday representation of vejigantes. 


\subsection{Colonization}

The discovery invasion of Borikén, the island now known as Puerto Rico, began the inevitable change of the identities of an indigenous culture to a colonized culture. (Figure 1) Tainos were the original inhabitants of the island of Puerto Rico. (Figures 2-6) When the island was discovered by Christopher Columbus, it was already inhabited by the Tainos, Arawak Indians who settled there by 1000 C. E. 1

The [Tainos] were easily conquered by the Spaniards beginning in 1493 . Enslavement, starvation, and disease reduced them to a few thousand by 1520 and to near extinction by 1550 . Those who survived [were] mixed with Spaniards, Africans, and others. [Taino] culture was largely wiped out...In 1998 the United Confederation of [Taino] People was created as an umbrella organization for the affirmation and restoration of [Taino] culture, language, and religion. Whereas the [Tainos] are not officially recognized as a group by any [government], those who consider themselves [Tainos] claim the right to self-determination. ${ }^{2}$

\footnotetext{
1 Thomas G. Mathews, Olga J. Wagenheim, and Kal Wagenheim, “History,” Encyclopædia Britannica (Encyclopædia Britannica, Inc., February 15, 2020), https://www.britannica.com/place/Puerto-Rico/History\#ref515893.

2 The Editors of Encyclopaedia Britannica, “Taino,” Encyclopædia Britannica (Encyclopædia Britannica, Inc., February 15, 2020), https://www.britannica.com/topic/Taino.
} 


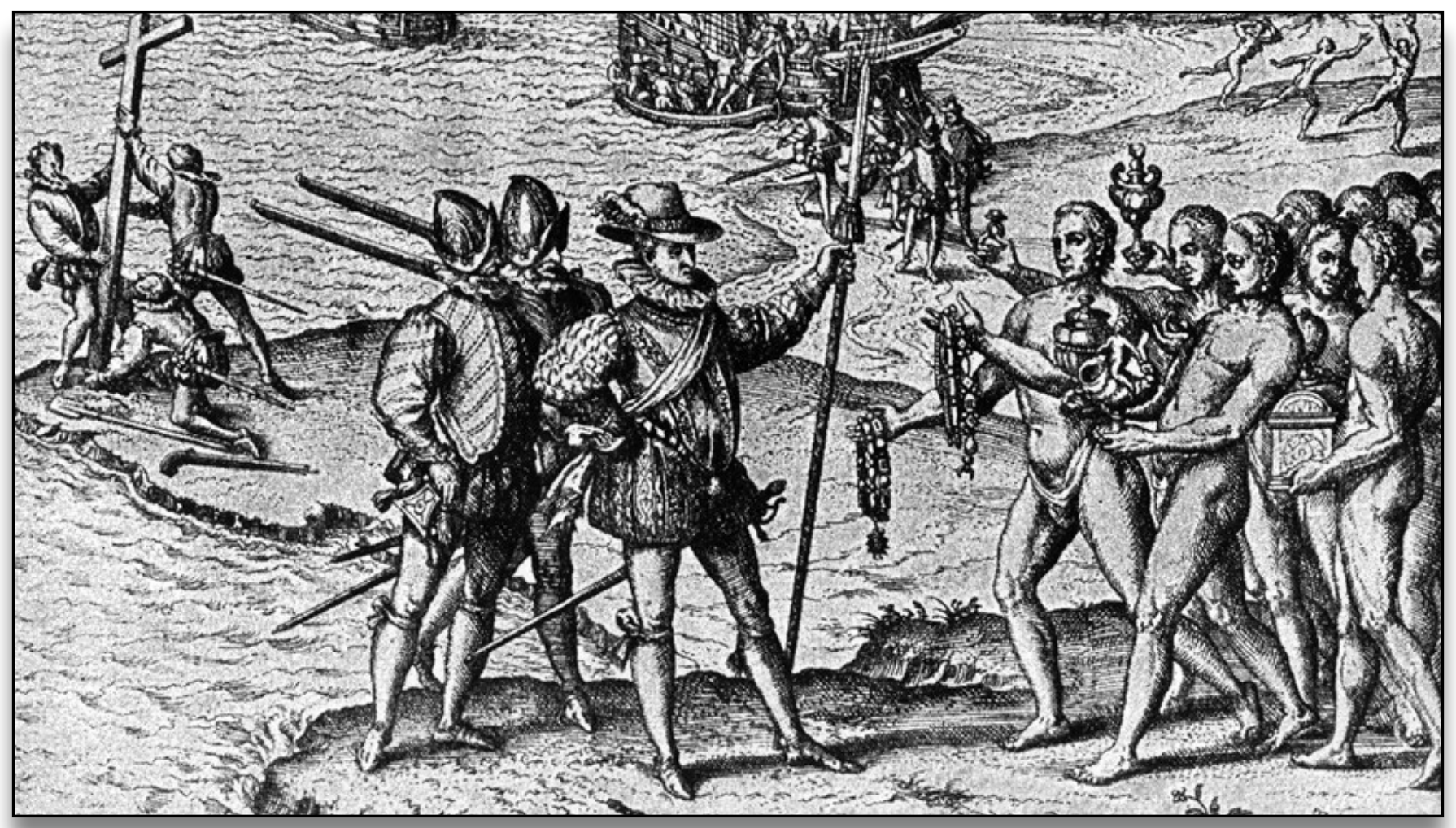

Figure 1 Untitled [digital image]. Retrieved June 24, 2020 from https://www.nbcnews.com/news/latino/puerto-rico-seekspreserve-taino-history-revive-culture-n344841 


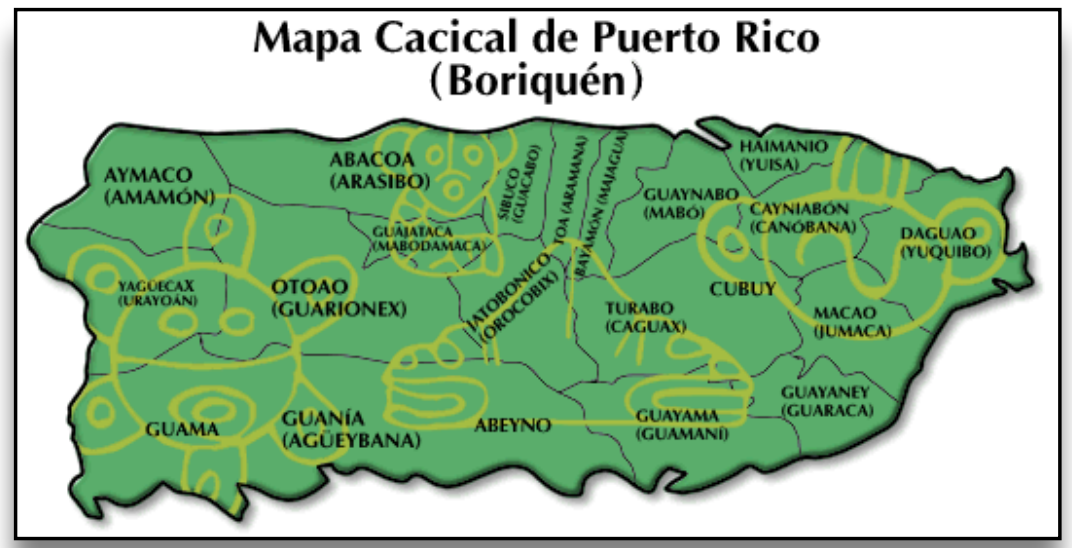

Figure 2 Untitled [digital image]. Retrieved June 24, 2020 from http:// www.hartford-hwp.com/archives/41/299.html

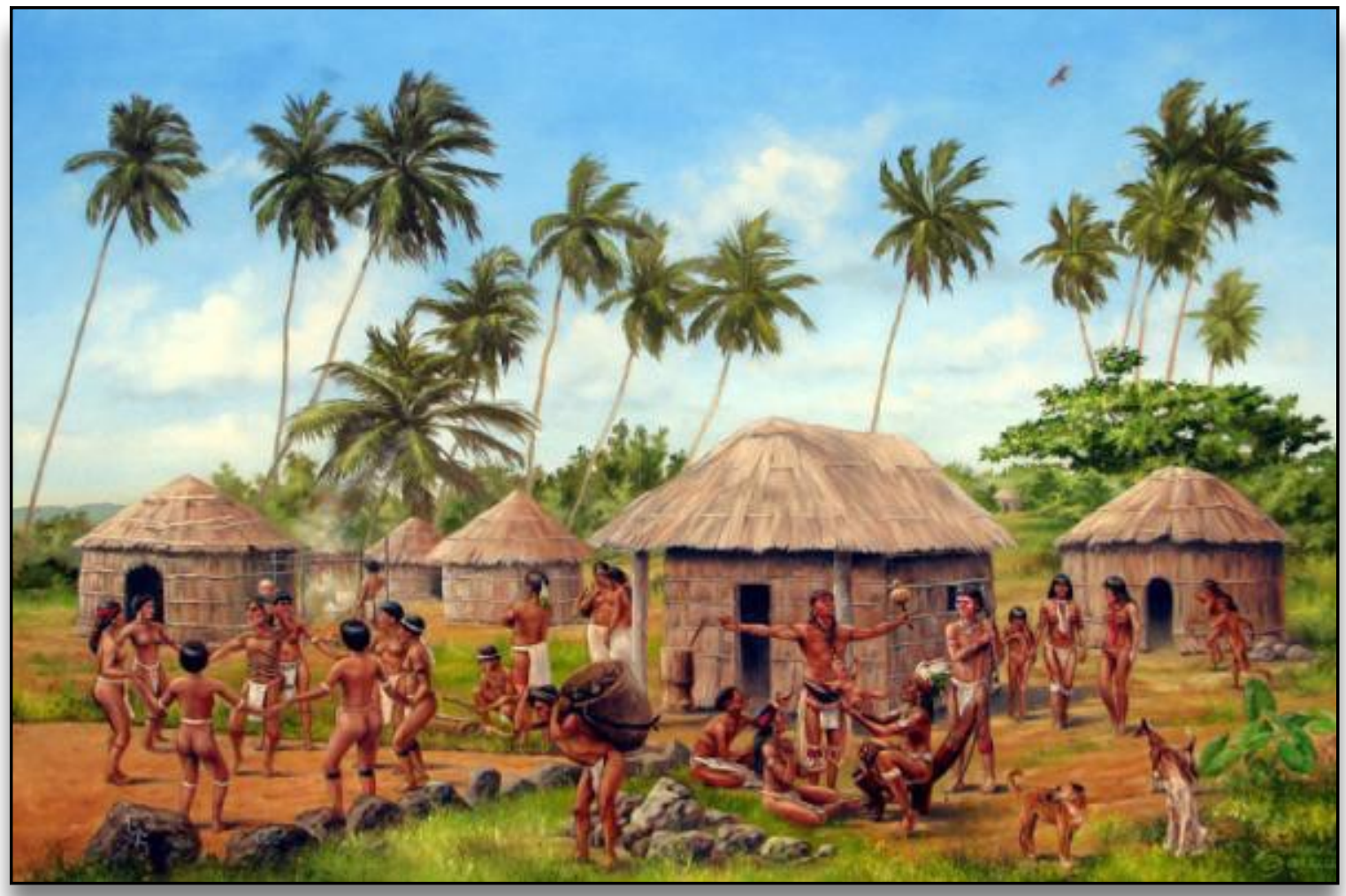

Figure 3 Untitled [digital image]. Retrieved June 24, 2020 from https://hablemosdeculturas.com/culturatainos/ 


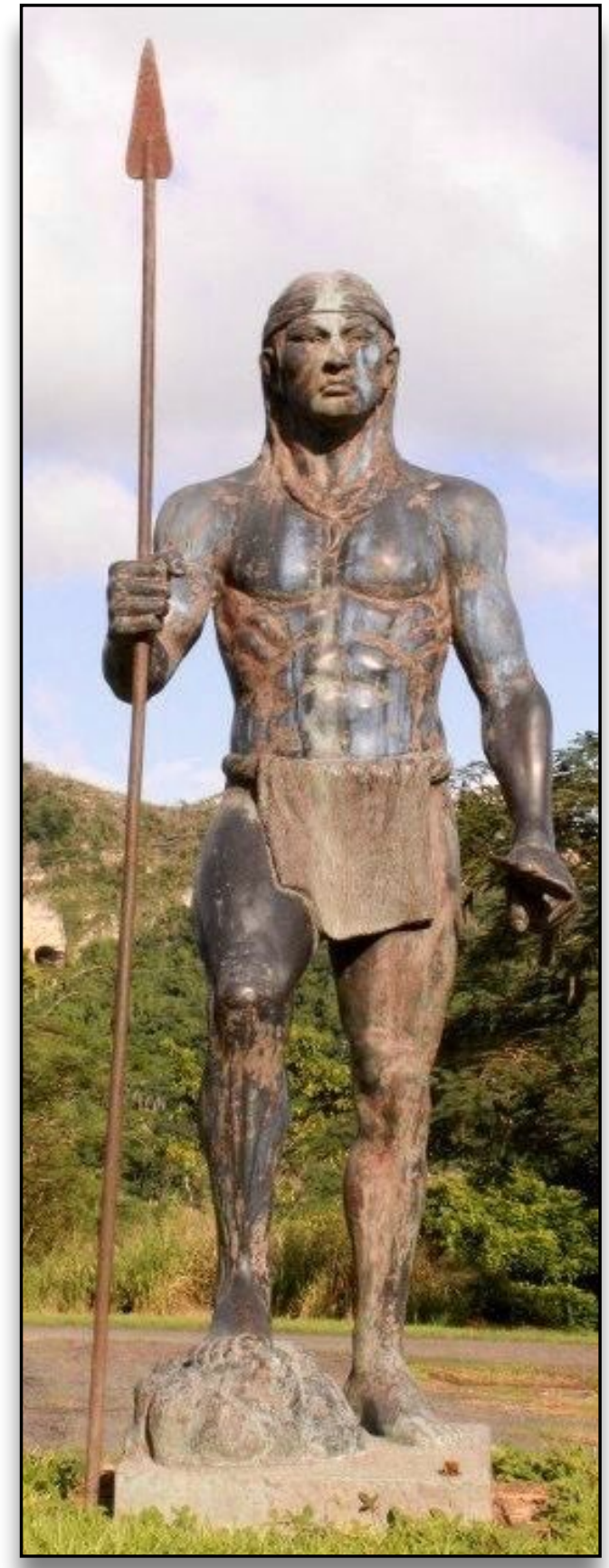

Figure 4 Untitled [digital image]. Retrieved June 24, 2020 from https:// www.pinterest.com/pin/ 650277633671136195/-tainos/

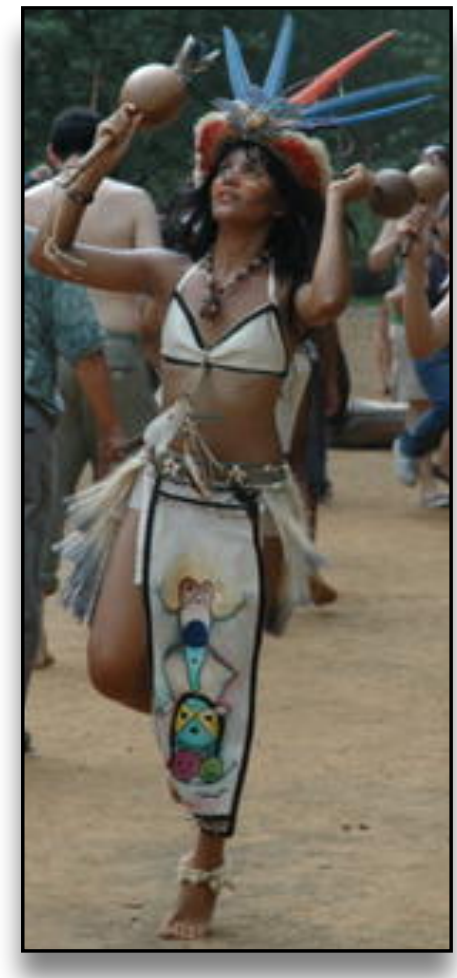

Figure 5 Untitled [digital image]. Retrieved June 24, 2020 from http:// www.prfdance.org/ taino.history.ALL.htm

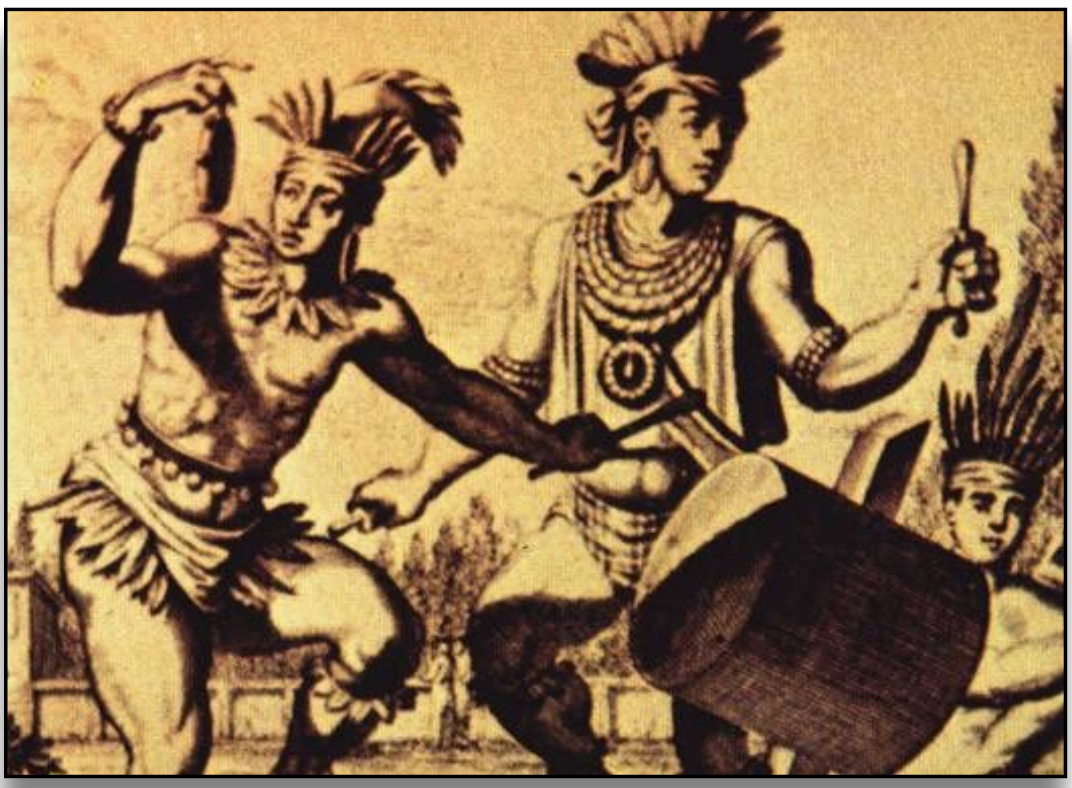

Figure 6 Untitled [digital image]. Retrieved June 24, 2020 from https:// juanp39.wordpress.com/2012/04/29/los-tainos/ 
The recolonizing and rebranding of what is now known as Puerto Rico by the USA further impacted an already desecrated, indigenous society. (Figure 7) Even though the American culture corrupted the innate folklore, it conjointly contributed to a contemporary tendency. This is apparent through the documentation of the testimonies of the transformation of local, artisanal arts. The representation of the culture of Puerto Rico has adopted an ideology of a false paradise and has continued to identify with it in order to increase tourism. ${ }^{3}$

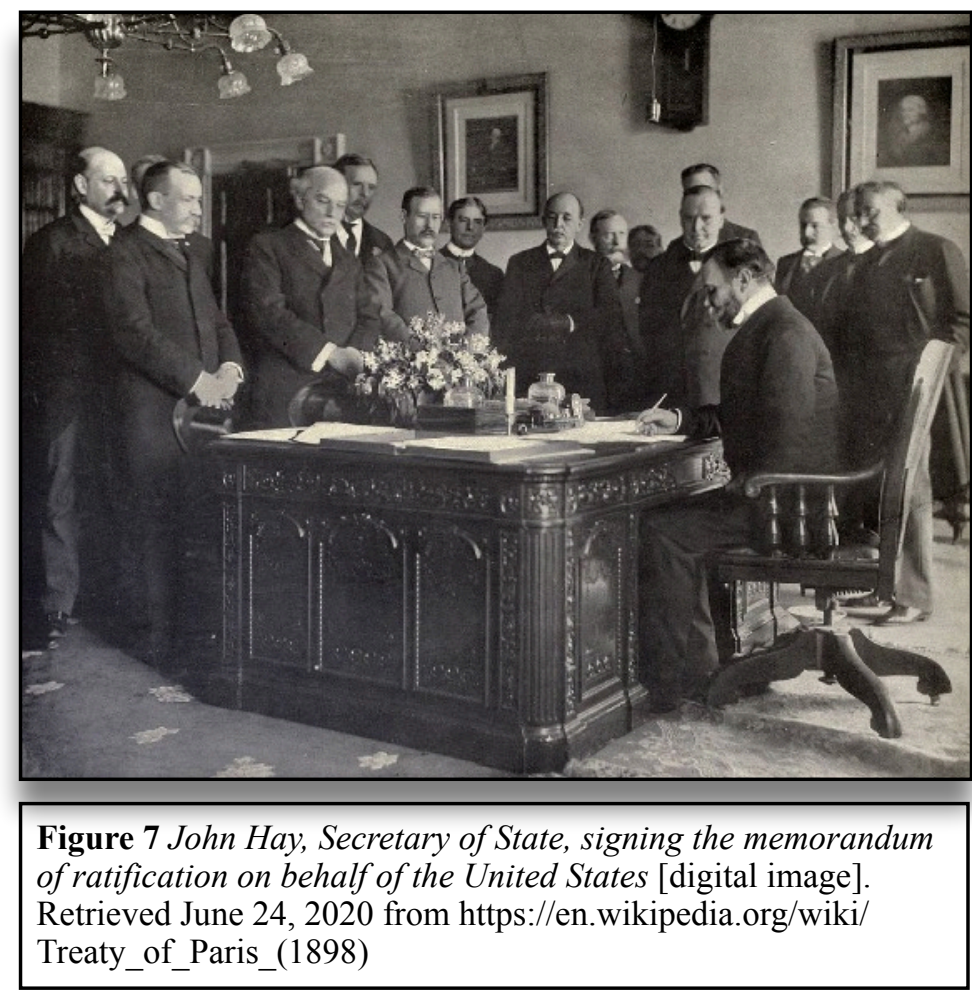

\footnotetext{
${ }^{3}$ Ramón López, Cuadernos De Cultura: EL Valor Histórico de la Artesanía Puertorriqueña, 2nd ed., vol. 6 (Instituto de Cultura Puertorriqueña, 2001), 6-31.
} 


\subsection{Historical Origins}

The presentation of the available, verified, and/or published resources on the history enables a conclusion on the present-day depiction of the vejigante. Publications on this specific subject are scarce, but are gradually developing. Analysis is needed on how the Carnaval, the Carnival, has adapted to the island's colonization by the USA, more broadly, into an Americanized culture. It is important to highlight that the documentation, although limited, is sufficient to create an accurate timeline. The investigative research based on the word-of-mouth further improved and clearly captured the Carnival's transcendence into cultural assimilation of the USA on the island of Puerto Rico.

The origins of the mask, through research and the timeline, will display connections to consider traditional creation to the current perspective of the vejigante. In final, the Ponce Carnival is an example of how the USA has impacted and altered the original concept and depiction of the vejigante in its historical, cultural, and artistic contexts.

The impact of the heritage from other countries, especially Spain, enabled this rich culture that embodies Puerto Rico. "Spain colonized these countries and that the arrival of these settlers included farmers, craftworkers and musicians, as well as a whole 
array of cultural and religious expressions, including of course, Christianity." 4 It is also documented, during Spanish rule in Puerto Rico, the vejigante was an adaptation of the mask known in Spain as the bojiganga. ${ }^{5}$ (Figure 8) The etymology of the word bojiganga, derives from voxiga, a variant of the word vejiga. ${ }^{6}$ The bojiganga is documented in the well-known novel Don Quixote, by Miguel de Cervantes Saavedra. Historically, the original use of the vejigante was defined as a way to frighten the populace to return to the church. The melting-pot of cultures that settled in Puerto Rico adapted the religious practices and “...the Carnival evolved in such a way that it has become a cultural activity, filled with expression of joy, color and community involvement."

\footnotetext{
${ }^{4}$ Norberto Martell Morales and Héctor J. Rodríguez Torres, Las Caretas del Vejigante Ponceño, 2.

5 Teodoro Vidal, Las Caretas De Cartón Del Carnaval De Ponce (San Juan, PR: Ediciones Alba, 1983), 31.

6 "Bojiganga - Definition and Synonyms of Bojiganga in the Spanish Dictionary," Educalingo, the Dictionary for Curious People, https://educalingo.com/en/dic-es/bojiganga.

${ }^{7}$ Norberto Martell Morales and Héctor J. Rodríguez Torres, Las Caretas del Vejigante Ponceño, 7-8.
} 


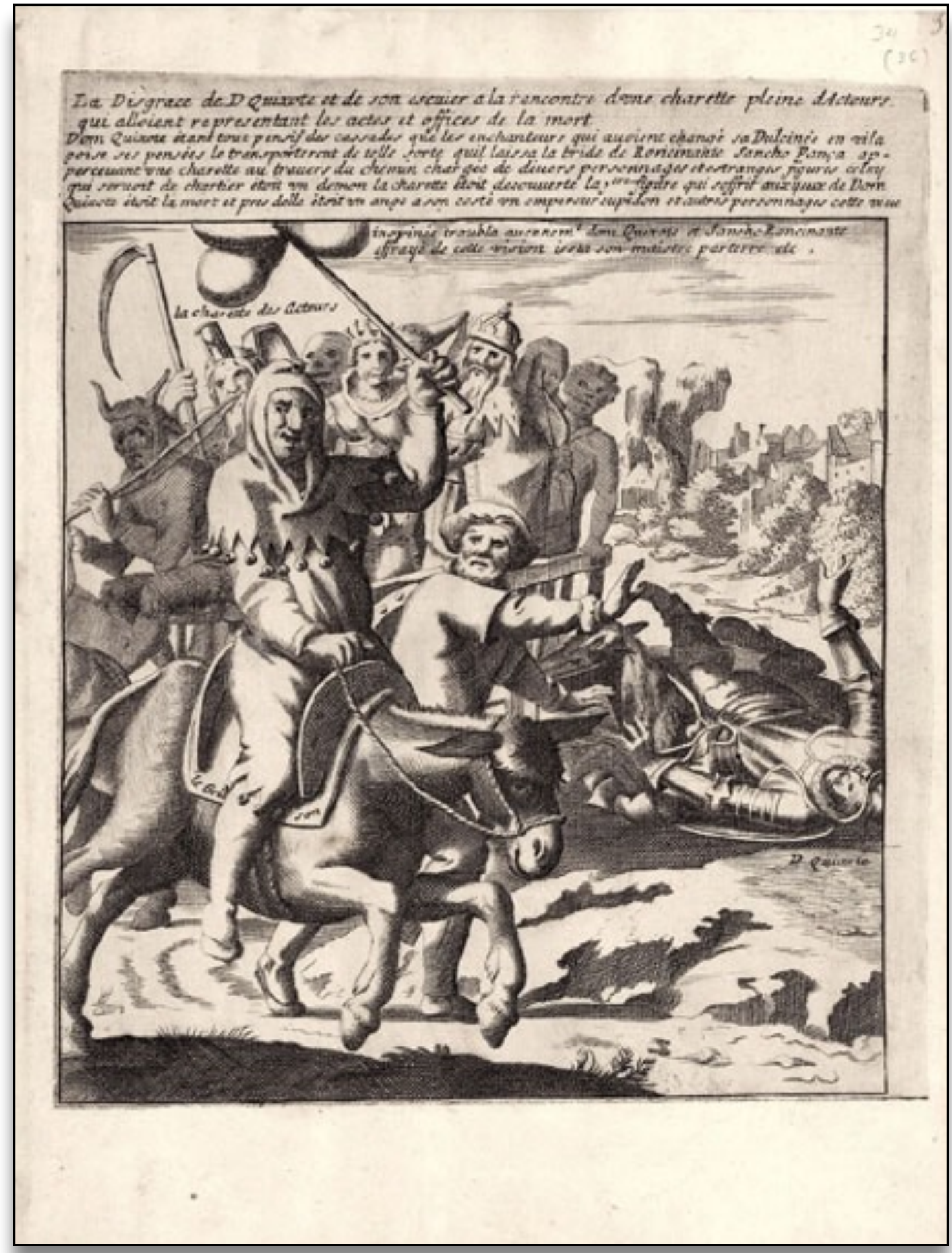

Figure 8 La Disgrace de D Quixote et de son escuier a la rencontre $d$ une charette pleine dActeurs qui alloient representant les actes et offices de la mort [digital image]. Retrieved December 20, 2020 from http://www.cervantesvirtual.com/portales/ quijote_banco_imagenes_qbi/ficha_imagen/?id=6998 
The Moors ruled Spain from 711 to 1492 . During this 800 years, conflict and disagreement was always prevalent between the Moors and Spaniards. (Figure 9) Even though conflict was present, the culture of the two morphed and evolved into a single defining culture and language which "coexist[ed], particularly during the thirteenth and fourteenth centuries..."8 It is speculated the vejigante mask represented the devil, directly affiliated with the Christian religion brought by the Spanish to the island.${ }^{9}$ Moreover, other theories state that the mask is the representation of "demonic Moorish warriors." 10 Even though the Festivals of Moros y Cristianos celebrate the Spanish victory over the Moors, the rituals themselves are a cultural continuation of the Carnivalesque, Moorish heritage. 11 "Like the other countries of Spanish America, Puerto Rico was colonized at the end of the fifteenth century." 12 The Moorish dominance over Spain was present during the time of the colonization of Puerto Rico. Inevitably, the Spaniards brought these Moorish customs to the colonies. And, therefore, influencing the vejigante with Moorish characteristics.

\footnotetext{
${ }^{8}$ María Herrera-Sobek, Celebrating Latino Folklore: An Encyclopedia of Cultural Traditions (Santa Barbara: ABCCLIO, 2012), 808.

${ }_{9}$ Stephen Keeling and Alison Roberts, The Rough Guide to Puerto Rico (London: Rough Guides, 2011), 6.

10 Stephen Keeling and Alison Roberts, The Rough Guide to Puerto Rico (London: Rough Guides, 2011 ), 6.

${ }^{11}$ María Herrera-Sobek, Celebrating Latino Folklore: An Encyclopedia of Cultural Traditions (Santa Barbara: ABCCLIO, 2012), 809.

12 Victor C. Simpson, Colonialism and Narrative in Puerto Rico: a Study of Characterization in the Novels of Pedro Juan Soto (New York: Peter Lang, 2004), 1.
} 


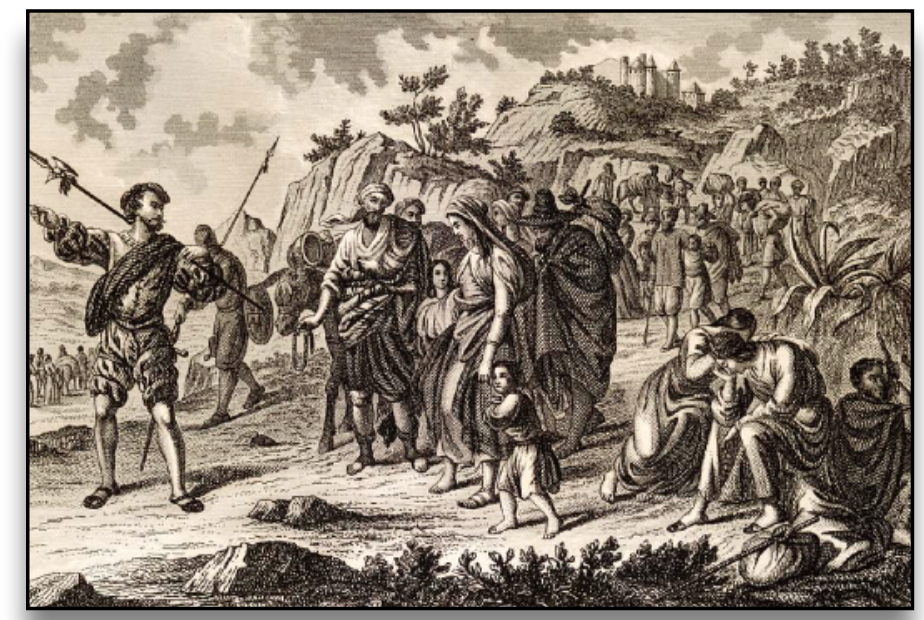

Figure 9 Expulsion Of The Moors In Spain, 1610 [digital image]. Retrieved June 20, 2020 from https://

fineartamerica.com/featured/expulsionof-the-moors-in-spain-1610-kenwelsh.html

Although Ponce is not the capital of Puerto Rico, it established its importance during the Spanish Colonial times by its gravitation and migration of affluent settlers. Elitists impacted the city's beautiful, distinct architecture by combining multiple characteristics and creating a one-of-a-kind city. Ponce was “...the city with a unique architectural personality. This can be seen in the system of street corners...designed to provide order to intersections, thus differentiating Ponce from other Puerto Rican towns and cities."13 (Figure 10) The settlement of the Spanish and the French created a city in Puerto Rico with an exclusive aesthetic. "Some of Ponce's Spanish settlers wanted to bring to this new land architectural styles that were more in keeping with their homelands." 14 The Spanish and French influence in Ponce is undeniable through the confirmation of the architecture that still stands to this day.

\footnotetext{
13 “Ponce,” Art Nouveau European Route : Cities, accessed February 5, 2020, http://www.artnouveau.eu/en/city.php? id=44).

14 “Ponce,” Art Nouveau European Route : Cities, accessed February 5, 2020, http://www.artnouveau.eu/en/city.php? $\mathrm{id}=44)$.
} 


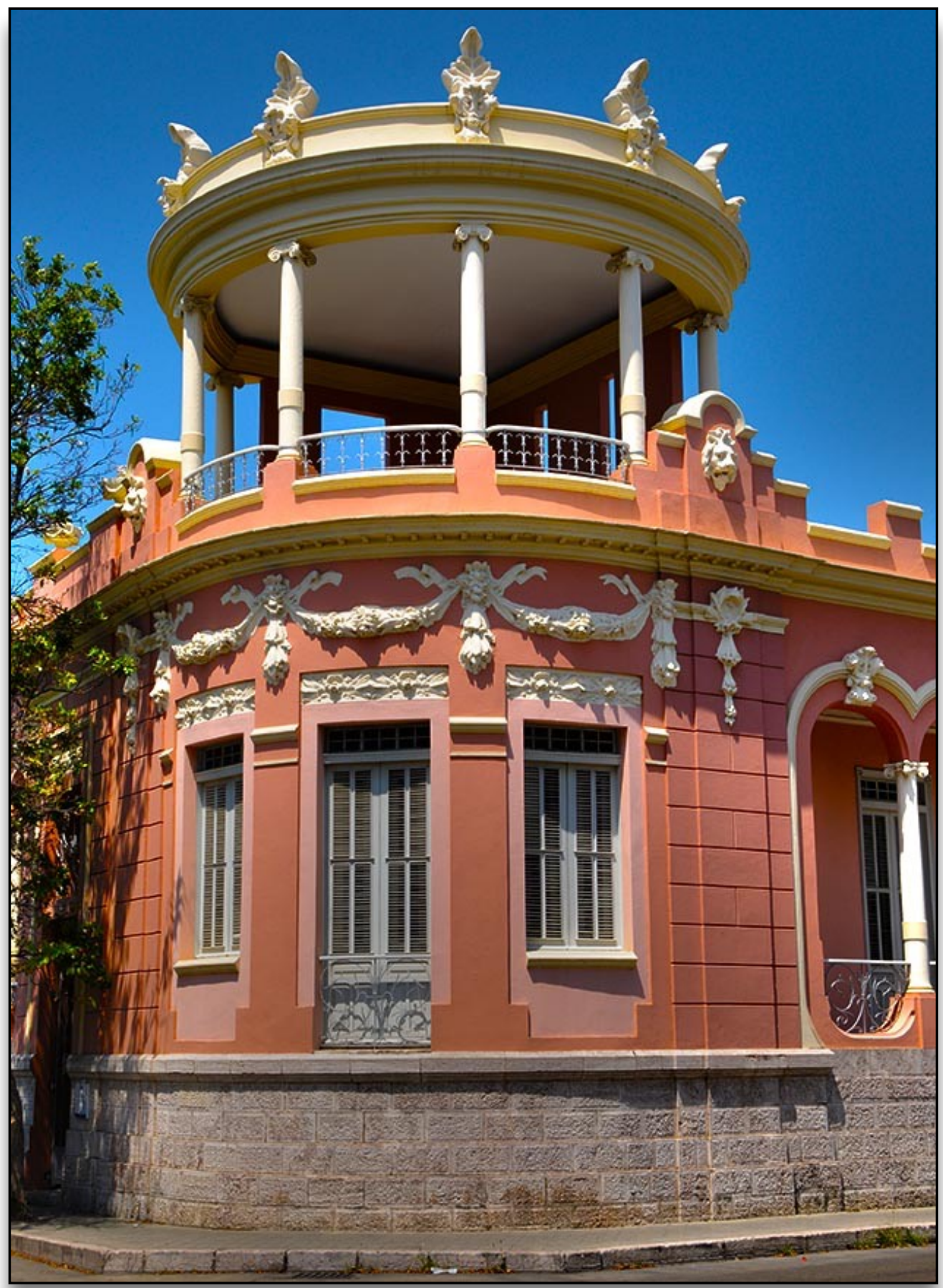

Figure 10 Untitled [digital image]. Retrieved June 20, 2020 from https:// www.worldatlas.com/webimage/countrys/namerica/caribb/poncephotos/ poncephotopage.htm 
The final implication that transformed the concept of the vejigante was the colonization of Puerto Rico by the USA. This was the second colonization of Puerto Rico. The American annexation of Puerto Rico took place in 1898.15 (Figure 11) "It is certainly the most important event in the island's history since Spanish colonization and has determined the course of its history over the past one hundred years and into the foreseeable future." 16 The citizens of the island were granted American citizenship, and at the same time the USA took control of the island economically, judicially, and legislatively by a means of military and the American central government. ${ }^{17}$ (Figure 12) The second colonization was a deciding historical event for Puerto Rico. Although a USA territory, to this day, the main language of Puerto Rico is Spanish and the communities continue to practice cultural traditions developed under Spanish rule. "Even though cultural resistance has been effective, the effect of American influence is still evident in all spheres of the island's life. The course of Puerto Rican history has been shaped almost entirely by outside forces exercising control over the island's destiny." 18 The impact of change to the everyday cultural existence was inevitable under USA control and "...has

\footnotetext{
15 Ruíz Vicki and Korrol Virginia Sánchez, eds., Latinas in the United States: A Historical Encyclopedia (Bloomington: Indiana University Press, 2006), 591.

16 Victor C. Simpson, Colonialism and Narrative in Puerto Rico: a Study of Characterization in the Novels of Pedro Juan Soto, 1.

17 Victor C. Simpson, Colonialism and Narrative in Puerto Rico: a Study of Characterization in the Novels of Pedro Juan Soto, 2.

18 Victor C. Simpson, Colonialism and Narrative in Puerto Rico: a Study of Characterization in the Novels of Pedro Juan Soto, 4.
} 
brought about a fundamental transformation in the economy of the country and significantly influenced its cultural, social and political development..."19 It is important to underline that Puerto Rican resistance to colonization is grouped into two standpoints:

1. Total independence from the USA.

2. Puerto Rico to become an official state of the USA.

Although the two positions are opposing each other, both unite against colonialism and, interestingly enough, both are invested in the preservation of language, culture, and heritage.

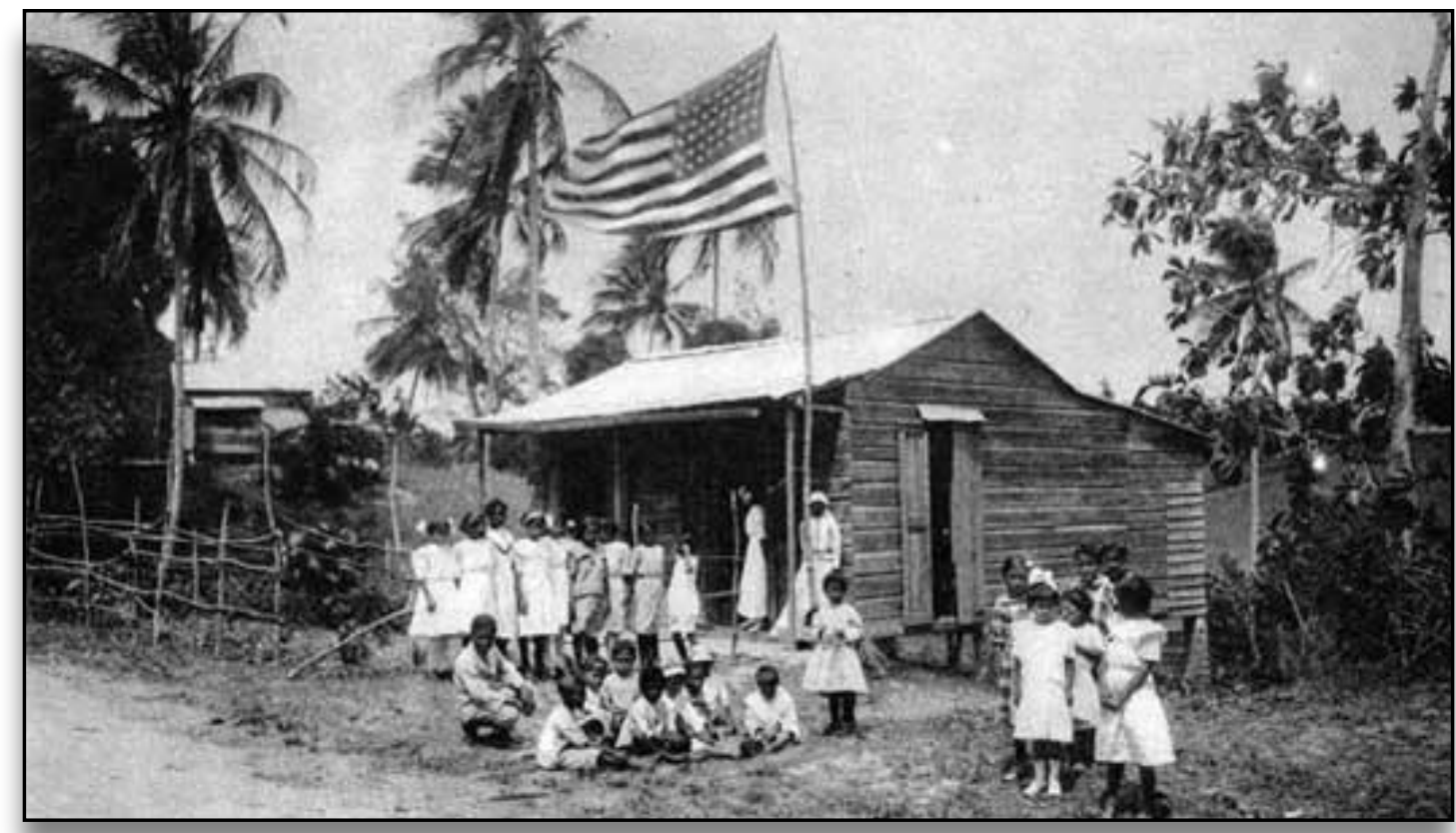

Figure 11 The Invasion of Puerto Rico on this Day in 1898 [digital image]. Retrieved June 20, 2020 from https://pdxretro.com/2019/07/invasion-of-puerto-rico-on-this-day-in-1898/

19 Victor C. Simpson, Colonialism and Narrative in Puerto Rico: a Study of Characterization in the Novels of Pedro Juan Soto, 1. 


"Ube Nem Haxk שi

5.146.

NEW YORK. WEDNESDAY. JULY 27, 1898.-TWELVE PA

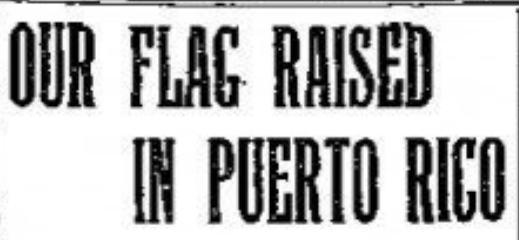

Fow Spaniards Fall in the First Fight of the Inyasion.

\section{AMERIGANS ESCAPE UNHURT}

Guanioa, on the Southern Coast, the Scene of the Landing.

\section{ENEMY IS SURPRISED}

Excellent senttary Food Leads to San Jran, 85 Xlles Dietant-Good Work Done by the Gloucester.

Copyright, tKox, by The Axsochated Fress. OIIANTCA, Islind of Poerto RICO. July 23 - Vla SL Thomak. D. W. I. July 26.-The Onlted states anilitary expedition, undet the coinmend of Mnjor Gen. Nelson A. Miles, whlch left Onantanamo Bay curiss the evenine of Thureday zagt. was innded bero successtully to-day, ntter a alkirmatsh wetts a Acthebaent of the spanish trombs and a crow of thirty betonetak to the lauach of the United states auxliary gunboat glovenkter.

Four of the gpantards work hithed, but to Amcrietang were burt.

The American troops will be puthed for ware prompels. is order to moture the raslroad leading to Ponce, which is only nbout tes malles east of tals place. From Ponce there $1 \mathrm{~A}$ on excellent military rosd. running elghty-five mllez aorth to Ben Juan se Puerto Rico, the capital af tha 1slend.

The storps lest Guantanacro Bay Thuratay evening, with the Xfargethuratts, eommandAl by Capt. F. J. Hitrisson, leeding. Cam. Higelabon was th charge of the naval expeditim, which constated of the Columbia.
MAP OF THE ISLAND OF PDERTO RICO.

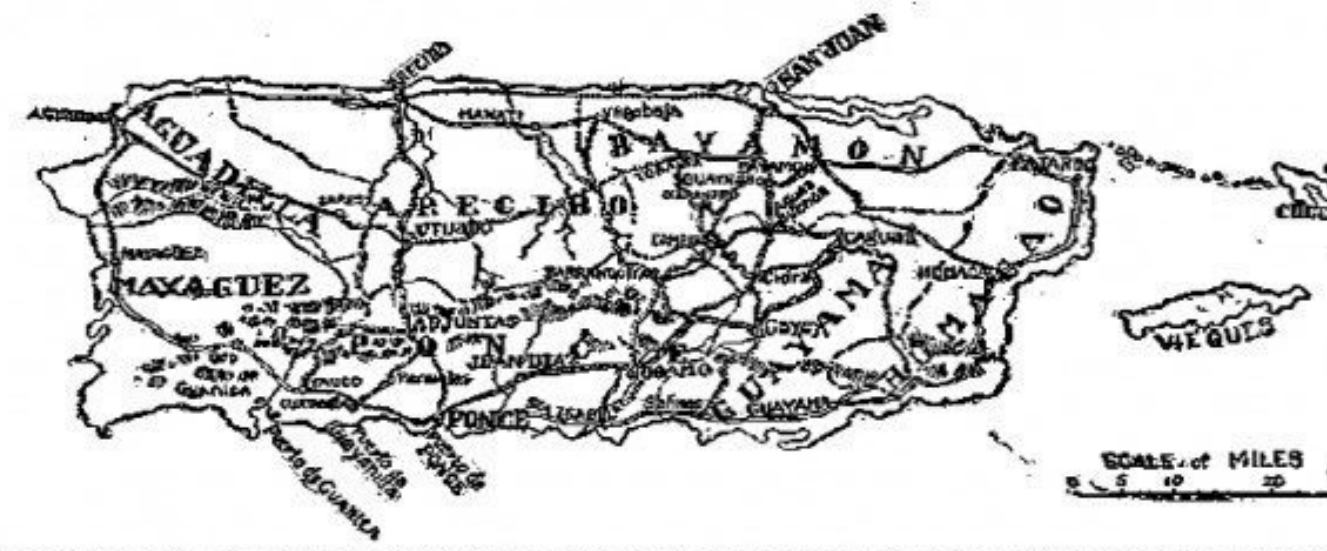

Crosked itne Indicate raliroads; shaded tines, main roadg; perallel Ines, cart roads; singte thes with dots, hor of Gualea, but the Colt sun leilied four of them.

By that vime the Glocester hed tho range of the town and of the blockchouse, and all ber Runt were spitting flre the costor and toe Psyraster beiping to sorve the kuns

Soon atterward white-conted, gelloping cavgl men were geen elimbing the lislls to the westwerd, snd the rost polliers werb the westwerd, and the root noldiers wert courryins along the fences trots the town. By 9sab, with the exeeption of a few kverrins shots, the town was won and the enewy was difvea out of lis nelghborbova.

The Red Crosa nusses on the Lemparan and o obachenent of reculars were the first to tund trom the crampors.

Innofng Well Maragred.

After Llauk Hass had eaptured the place he deptoyed hlg anall force thto che subarbe. Dut he wae eoon reinforces by the reculary. who were followed by Company G. of the stxth Intinots, and then by other troope fa quitek sudoosston. All the boets of the men-et-war and the trapsports were geed in the work of landing the krnops ench gtesm latingh to whes four or five bonts leaded to be radls wits olleter. Everything progresses in an orderly mannet. according to tho plans of Gen. Mulles. The latter weat achore sbout noon. aner gtoppting to board the Gloucester and thank Lient. Commander piatn miricht tor hin gollant action. Gen, Miles sold:

Gen, dailes sald: rocted portion of the boland. Matter, the Insurceat leader lives at Yonco, on fow miles intand. Had we landed at Cape Saa hita a Khe of rillo pita might bave otopped our edvance."

Tho Irthoos and Marachuaetta continIng was Fajardo, on the northeat cast. When Gen. Mifies lett Guanteramo the authorities here exjected him to go to Fajarta.

Geazlca in a torn of 1,000 inhabitante on the soutbers coast of the Iatand. On a roosh calculation, it is less than twenty miles in an alr line distant frow Ponce, and sixty-fire anlita froce San Juan, agkingt which the Assavit is to be directed. Guantea is about stx miles souith of Yades, of which elty it forms the port, and pith which it ts comected hy a good raal.

The town is stunted on a bay of the same nsme, wrieh forins on of the best ports in the whole delend. The banks to the riktht are atewp axd form a rood naturel where. Three wetsels can lle slongelle and untoed oy nteans of cant planks. Vessels of thisty peet draught can enter the bay eanlly, and proceed close in thore. The conaplcuous advantaze of thin part. aside trom fta excellent harbor factities for the transperta, in the absence of fortffications ac asines.

Fang nom tor the Adranes.

Whlle the distence from Ponce to Sen Juan is miech arealez than from the point ortgitionly seiceted for Mrleg's landing. there $\mathrm{fs}$, sccolding to the milltery informa. thon chartz, a splendid fourteen-tooe macAdnentzed rosd leadiag difeotly wcross the tsiand to Exn Junn, on the north shore, Fingh \& road as thas if at is properly deacribed to the archives of the War Dabartmont. woutd be very kitle afrected by the torrentlal rains of this seabon, so that th might be possible for our troops, soc yenpanisd, as they wim be, by fleid artinery. to make the murch teroes the neventy mites Detween Ponce and San Juen ta Ins ume two with alx Qve-inch rtlos of wich six soved-then howitzers of forty gues. Aad these to pleces wich which the sxped vided and its artingey equipu be wost tormidable.

WARSHIPS GO TO Copritert, 1549, by Thi Assoc ST. THOMAs, D. W. 1 . bas fust ntrived here from $\mathrm{P}$ nica, Puerto Rtea via Ces While of the latter polnt Cnited slates monitor Terror bosta Annapolis and waop. orders io join the llest at $P$ nien trmmediately. Pocee w1 barded uotal the rest of the we

\section{GRANT'S BRIGADE IS} GICKAMAUQA, Ga, J Corps, Gen. Ftrad D. Grant eo Unte leparturt. Tats betgad. the Firat Bentweky. Buth Disn. Keptucky, the Third Battelles teenth Pransyivants befine. attr The Furat Kontucky did not Koteville wath to-night,

The Firts Imlnote th daler of camp at 6 o'olook to-morrow complanted by the Tzird Bat sixteenth Poonsylvania Tbe cueky will lesvo onmp at of sow thorithe.

OHIO TROOPS TO SEE Third Brigade of the Burat ectued orders ta-day to propa

Figure 12 The New York Times Archives [digital image]. Retrieved June 20, 2020 from https://www.nytimes.com/1898/07/27/archives/ our-flag-raised-in-puerto-rico-four-spaniards-fall-in-the-first.html 
Puerto Ricans take pride in their aboriginal, Taino heritage. And although Spain's colonization of the island resulted in the diminishment of the Taino's population to just a few thousand, Spain is seen as the "motherland" of Puerto Rico. The Spaniards colonized the island of Borikén and in the process, oppressed and killed the Tainos. Spain's presence in Puerto Rico is more apparent than the original natives. Nonetheless, Puerto Ricans still take pride in their cultural identity: “...intellectuals had recourse to the Spanish elements of the island's heritage as a bulwark against growing American influence. This struggle was played out largely in the area of language and culture and remained a major issue for many decades." 20 And to this day, Puerto Rico is known for its rich Spanish heritage. Since 1898, Puerto Rico has been a US Territory, or colony. It was a Spanish colony from 1493 to $1897 .{ }^{21}$ Puerto Rico is considered to be "the world's oldest colony." 22 Over 500 years of foreign control has created an irreversible impact to Puerto Rico and its culture.

\footnotetext{
20 Victor C. Simpson, Colonialism and Narrative in Puerto Rico: a Study of Characterization in the Novels of Pedro Juan Soto, 2.

21 “Puerto Rico: The World's Oldest Colony,” ArtRage Gallery: The Norton Putter Gallery, (June 20, 2020).

22 “Puerto Rico: The World's Oldest Colony,” ArtRage Gallery: The Norton Putter Gallery, (June 20, 2020).
} 


\subsection{Cultural Links}

The mask has been influenced by many variables on a global scale: from France, Spain, England, reaching to obvious influences from Africa. "There is a great challenge for the history of art in Puerto Rico to reflect upon the true difference and diversity of the Occidental global cultures that predominate in [the] country to recognize cultural otherness and its forms of knowledge." 23 All of these influences molded and sculpted, not only in the form of the vejigante mask, but also the concept and context. The mask can be seen as a symbol of the people that began to inhabit the island during the Spanish colonial times, influencing the already populated parts of the island by the Tainos. This changed the aboriginal culture and customs due to the force of adaptation to the religious customs of the conquistadors:

...to understand how common meanings have evolved from a diversity of languages to build subjectivities and identities that define the forms in which certain arts are represented thought out, and practiced in the Americas of the present. These arts represent the symbols of [the] ancestors, allusions to the spirits, spiritual syncretism, and masks, among other. What links such diverse elements is the discursive perspective that seeks precisely to pay attention to the ancestral knowledge of the Africans spirituality and culture in...Latin America. ${ }^{24}$

\footnotetext{
${ }^{23}$ Fernando Cros, Marta Morena Vega, and María Elba Torres Muñoz, "Tradiciones Afrocaribeñas: Espiritualidad, Arte Y Resistencia,” Tradiciones Afrocaribeñas: Espiritualidad, Arte Y Resistencia § (2007), 24.

${ }^{24}$ Fernando Cros, Marta Morena Vega, and María Elba Torres Muñoz, "Tradiciones Afrocaribeñas: Espiritualidad, Arte Y Resistencia,” Tradiciones Afrocaribeñas: Espiritualidad, Arte Y Resistencia § (2007), 23.
} 
Masks, overall, have been re-interpreted and redefined through the globalization of cultures. Much of the customs well-known in Puerto Rico come from the slaves that were brought there, the majority being from Nigeria. ${ }^{25}$ To be more specific, the Yoruba people were brought to Puerto Rico as slaves. ${ }^{26}$ "In 1825, visitors from neighboring islands would come to migrate to Puerto Rico, bringing with them groups of Africans to participate in these masquerade balls..."27 (Figure 13) Many of the slave communities settled in Loíza, Puerto Rico. ${ }^{28}$ The introductions of slaves to Puerto Rico was a turning point on the culture, creating strong roots to African culture:

The continued presence of African sacred traditions attest to the philosophies, aesthetic principles, ritual and secular practices, creative manifestations and culturally grounded expressions that are living legacies of the multiplicity of West and Central ethnic tradition brought to the Americas. More than 15 million Africans were torn from their motherland during the Atlantic Slave Trade that lasted more the 400 years from the 15 th-19th centuries.

These Africans shared and contributed living legacies too often marginalized and demonized by colonial and post-colonial oppressors. Africans and their descendants in their divine intelligence took refuge in the cultural practices of the varied colonial societies that they were forcibly taken masking African based traditions...29

\footnotetext{
25 Antonio D. Tillis, ed., Critical Perspectives on Afro-Latin American Literature, vol. 4 (Routledge, 2012 ), 237.

${ }^{26}$ Abraham Ajibade. Adeleke, Intermediate Yoruba: Language, Culture, Literature, and Religious Beliefs, Part II (Bloomington, IN: Trafford Pub, 2011), XXI.

27 Norberto Martell Morales and Héctor J. Rodríguez Torres, Las Caretas del Vejigante Ponceño, 8.

28 Antonio D. Tillis, ed., Critical Perspectives on Afro-Latin American Literature, vol. 4 (Routledge, 2012 ), 237.

${ }^{29}$ Fernando Cros, Marta Morena Vega, and María Elba Torres Muñoz, “Tradiciones Afrocaribeñas: Espiritualidad, Arte Y Resistencia,” Tradiciones Afrocaribeñas: Espiritualidad, Arte Y Resistencia § (2007), 27.
} 


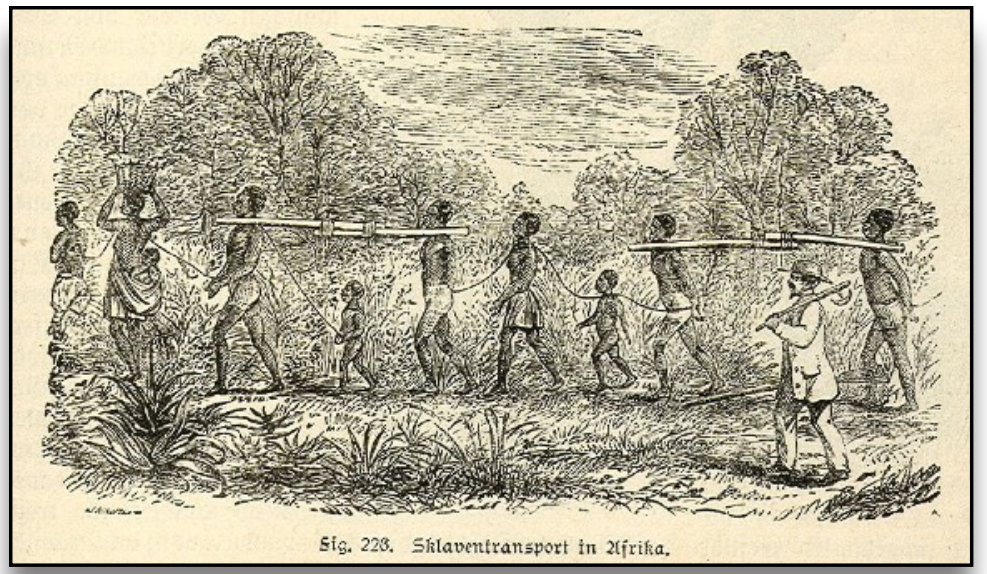

Figure 13 Slave transport in Africa, depicted in a 19thcentury engraving [digital image]. Retrieved June 20, 2020 from https://en.wikipedia.org/ wiki/Afro-Puerto Ricans

Roughly around the 1950s, due to Puerto Rico's status as a USA territory, Ponce Carnival was further influenced. The Carnaval Ponceño, the Ponce Carnival, adapted to the parades traditional in American culture with the addition of floats, marching bands, dance troupes, etc. (Figure 14) The shift to USA culture reshaped the course of the Carnaval, and therefore, the vejigante. One example of this is Bomba y Plena: A“... percussion-driven musical traditions from Puerto Rico that move[s] people to dance." 30 The ritual of vejigantes dancing to this has decreased. Without the continuation of this tradition, it can become extinct. (Figure 15) The introduction of pop culture music into the Carnival, in substitution of Bomba y Plena, also contributed to the diminishment of cultural accuracy in the Carnaval Ponceño.

\footnotetext{
30 "Puerto Rican Bomba and Plena: Shared Traditions — Distinct Rhythms," Smithsonian Folkways Recordings, accessed December 26, 2020, https://folkways.si.edu/puerto-rican-bomba-plena-shared-traditions-distinct-rhythms/ latin-world/music/article/smithsonian.
} 


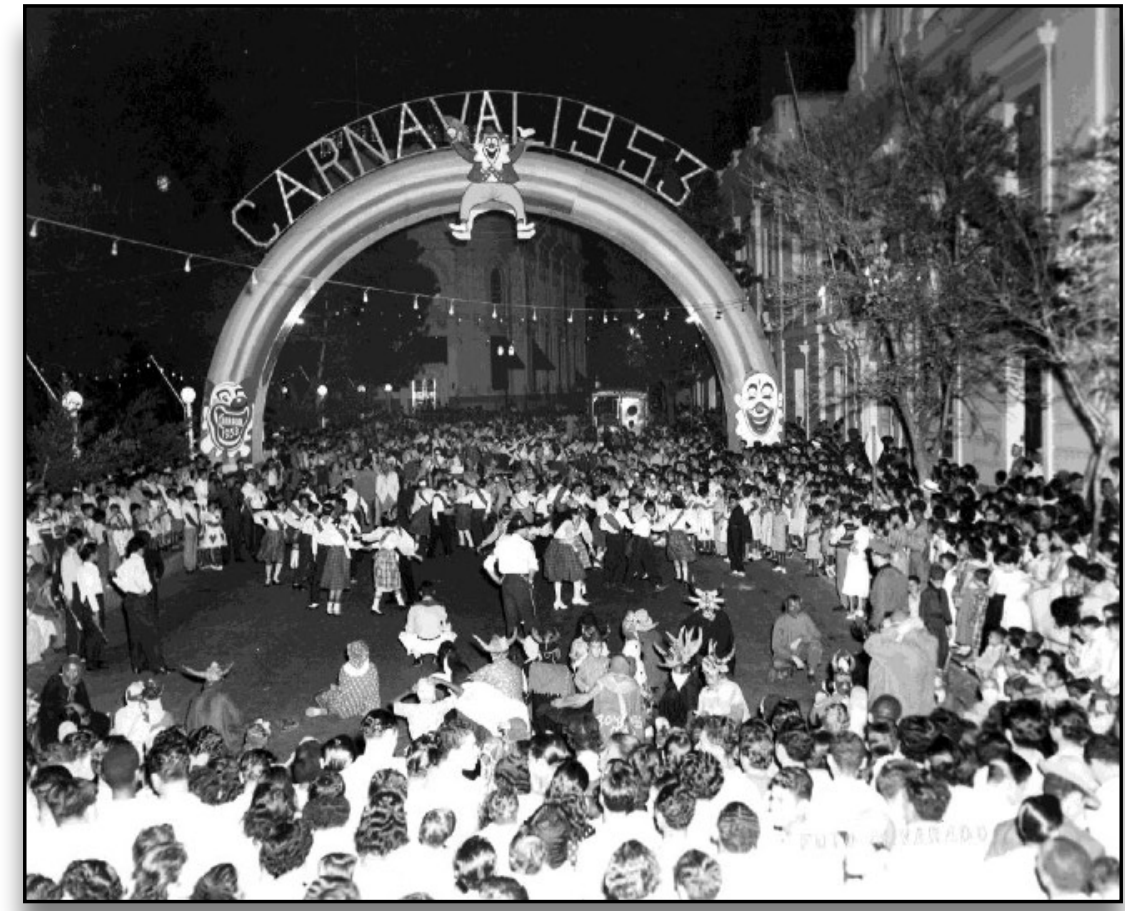

Figure 14 Carnaval de 1953 [digital image]. Retrieved October 4, 2019 from Jaime L. Martell Morales: “Ceiba:” Año 9 Núm. 1 [Segunda Época] Agosto 2009 - Mayo 2010, (78 - 101).

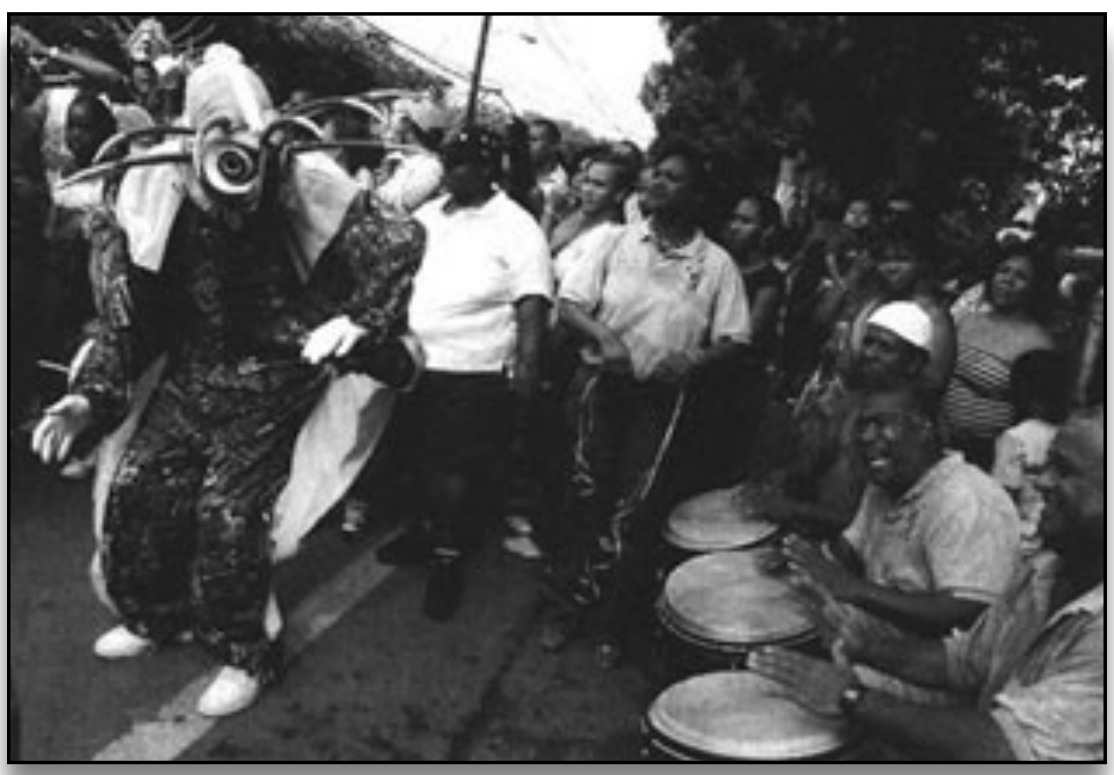

Figure 15 Vejigante bailando bomba con los Hermanos Ayala [digital image]. Retrieved June 20, 2020 from https://go.gale.com/ps/anonymous? $\mathrm{id}=\mathrm{GALE} \%$ 7CA368075184\&sid $=$ googleScholar\& $\mathrm{v}=2.1 \& \mathrm{it}=\mathrm{r} \&$ linkaccess $=\mathrm{f}$ ulltext\&issn $=01630350 \& p=A O N E \& s w=w$ 
Through "colonial domination," 31 the Carnival traditions were created and distilled in Puerto Rico:

Colonial domination has conditioned [Afro-Caribbeans] in a way that has forced these traditions to be maintained in an unequal manner. Thus, some traditions could leave their footprints and allow [them] today to cross the bridge to [their] African ancestry. After centuries of their presence, they represent a hybridism in which [Afro-Caribbeans] run across elements that were inherited directly from [their] different African ancestors since their arrival to the Americas, but which today are interwoven among them, thus loosing their dividing lines from one tradition to the other. Its permanence, continuity and relevance in [their] Antillean expressions testify of how strongly rooted and consistent central African spirituality has been in [their] culture. ${ }^{32}$

The mask originally held a specific purpose, but was altered due to invasion, slavery, colonization, and a second colonization. As multiple cultures blended, the formation of the Puerto Rican history and heritage created a unique identity only known as Puerto Rican culture.

The contour of the vejigante mask has been adapted formerly from the Spanish colonizers. Initially, the Spanish masks were intended to frighten the people to the find

\footnotetext{
${ }^{31}$ Fernando Cros, Marta Morena Vega, and María Elba Torres Muñoz, “Tradiciones Afrocaribeñas: Espiritualidad, Arte Y Resistencia,” Tradiciones Afrocaribeñas: Espiritualidad, Arte Y Resistencia § (2007), 23.

32 Fernando Cros, Marta Morena Vega, and María Elba Torres Muñoz, “Tradiciones Afrocaribeñas: Espiritualidad, Arte Y Resistencia,” Tradiciones Afrocaribeñas: Espiritualidad, Arte Y Resistencia § (2007), 23.
} 
refuge in the church. ${ }^{33}$ In Zaragoza, Spain the vejigantes are identified as descendants of the cuco, the prankster. (Figure 16)

A creature akin to the boogeyman has also loomed large within the recesses of the darkness in many Latinx cultures. He (though sometimes it is a she) is known variously as El Coco, El Cucuy, and El Cuco, and is a supernatural creature with malevolent intent. (Here we use the variant names and refuse to settle on one.) El Coco is a creature that is an especial menace for children, and is frequently used as a means for children, and is frequently used as a means of scaring children into appropriate behavior.

The history of El Coco traces as far back as Portugal and Spain before those nations set forth to colonize the Americas. It has proven to be a durable legend, perhaps because it is effective within the imaginations of children. ${ }^{34}$

In addition, the Spaniards from Zaragoza classify the original concept of vejigantes as devilish clowns. ${ }^{35}$ To reiterate, the original premise of the mask in Spain was to frighten the townspeople, 36 the vejigante from Ponce is used to exude the evil spirit from people. The variable to dissipate evil is still relevant in the purpose of the vejigante. Although the character of the vejigante is often misinterpreted as a threatening, in actuality, they are playful and mischievous. The character of the vejigante can be compared to a jester from

\footnotetext{
33 Olga R. and Kuharets, Venture Into Cultures: A Resource Book of Multicultural Materials and Programs (American Library Association, 2001), 23.

${ }^{34}$ Frederick Aldama and Christopher González, Latinx Studies: The Key Concepts (London: Routledge, 2018 ), p. 2.

35 Carlos Vargas-Ramos and Antonio M. Stevens-Arroyo, Blessing La Politica: the Latino Religious Experience and Political Engagement in the United States (Westport: Praeger Publishers Inc., 2012), 95.

36 Olga R. and Kuharets, Venture Into Cultures: A Resource Book of Multicultural Materials and Programs (American Library Association, 2001), 23.
} 
the Renaissance. And, much like a jester, the essence of the vejigante is to cause chaos, but above all, to entertain. (Figures 17-18)

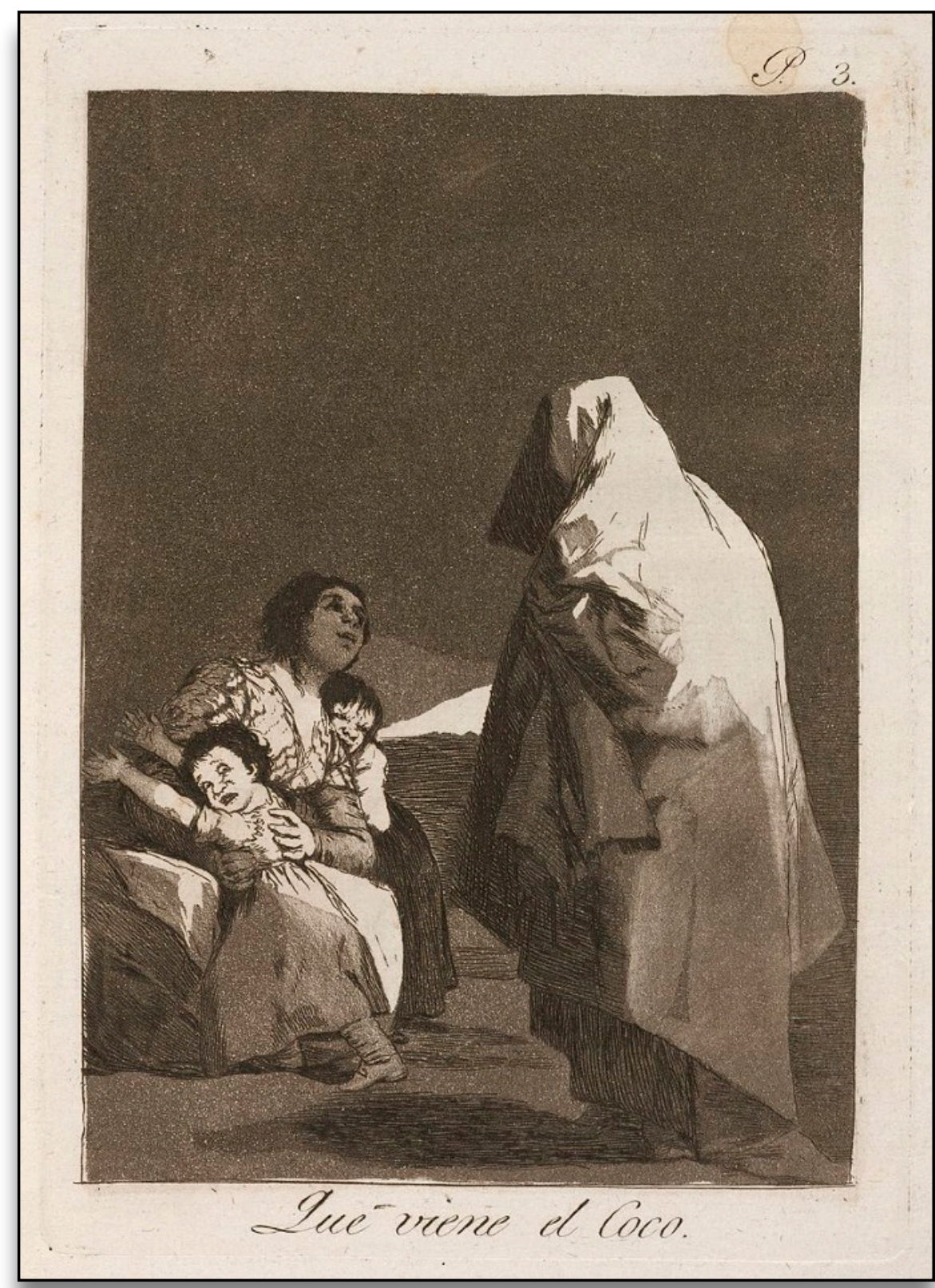

Figure 16 Que viene el coco, de Goya (1799). [digital image]. Retrieved June 20, 2020 from https://es.wikipedia.org/wiki/ Coco_(folclore) 


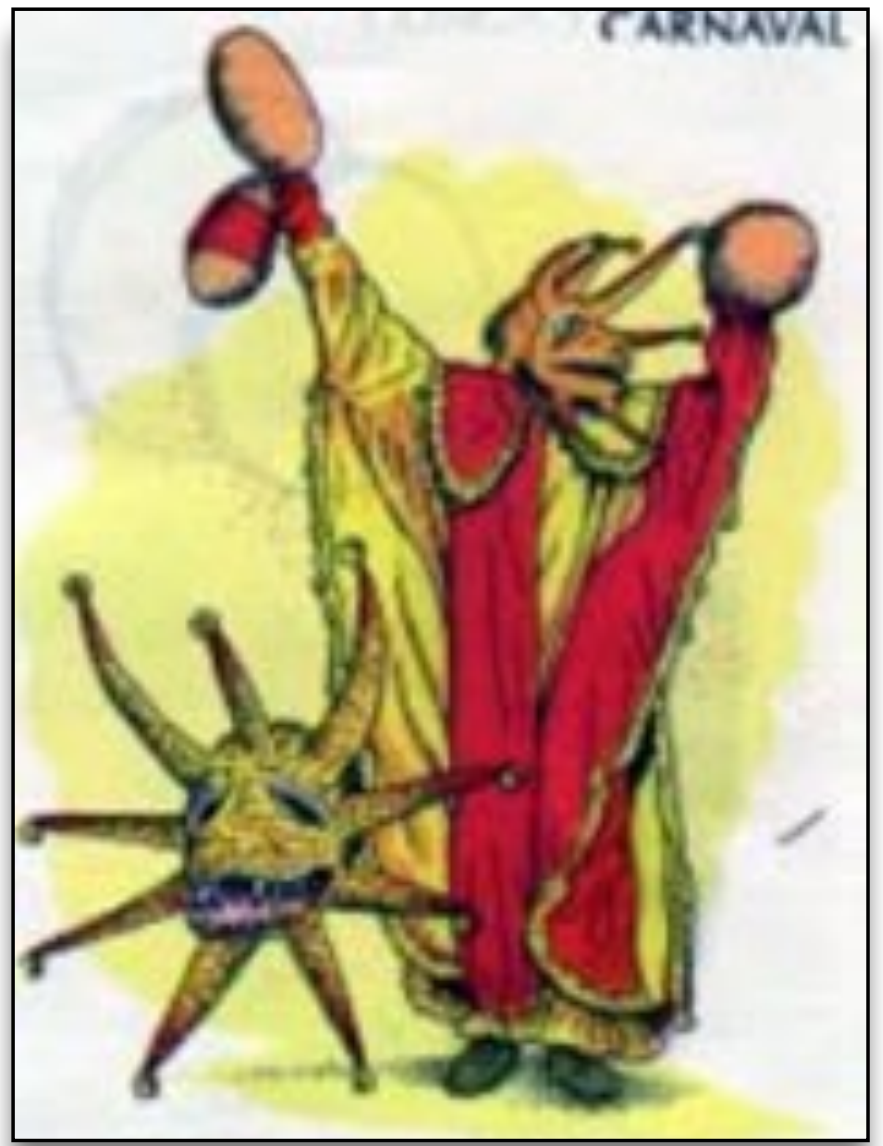

Figure 17 Vejigante de Ponce [digital image]. Retrieved June 20, 2020 from https://www.mapr.org/ webcast_educacion/toco_toco/mascara_legado2.htm

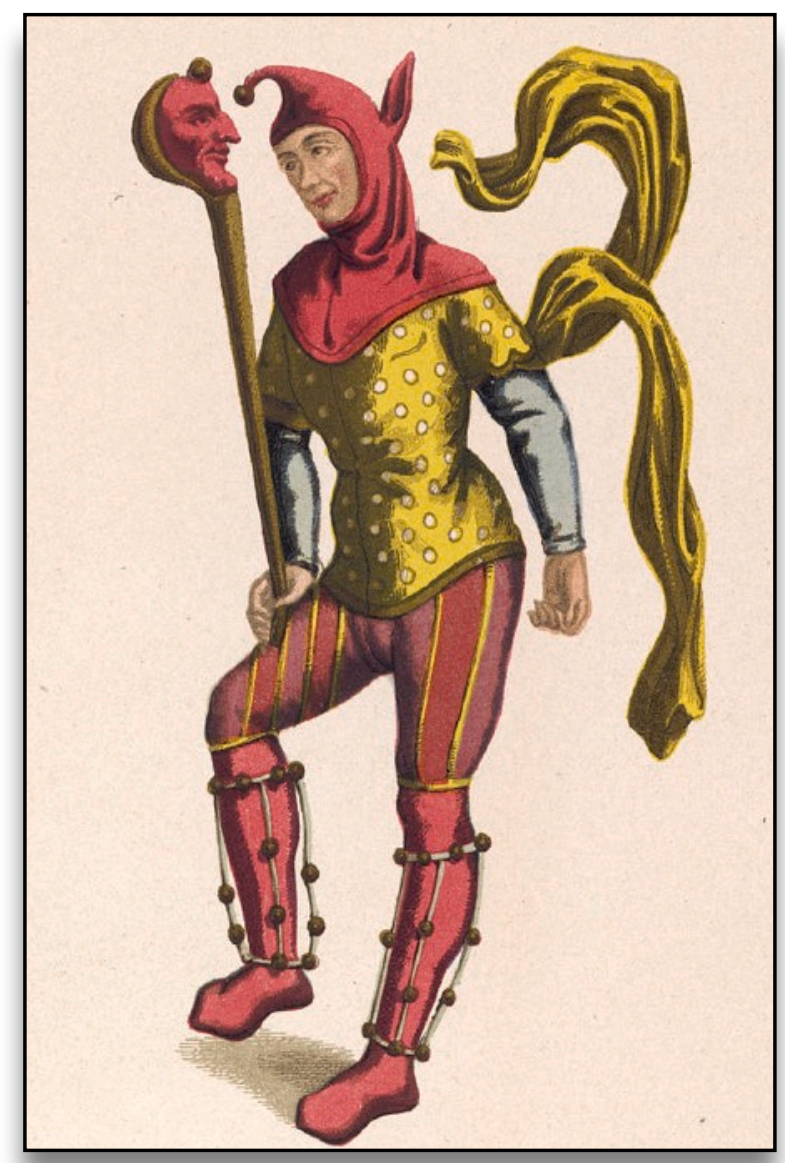

Figure 18 A French Jester, Holding A 'ninny [digital image]. Retrieved June 20, 2020 from https://fineartamerica.com/featured/a-french-jesterholding-a-ninny-mary-evans-picture-library.html 


\subsection{Americanization}

Puerto Rican separatists view themselves as an independent entity from the USA and crave adamantly for total independence, nonetheless, it is evident the impact the USA has had on Puerto Rico. Within the context of this thesis, this impact of the USA is not to be viewed negatively nor positively, but solely acknowledged. Although Puerto Rico is a territory recognized by the USA, it cannot be compared to the mainland. The differences are clear upon arrival in Puerto Rico: Spanish is the official language, the distinctive customs, culture, beliefs and heritage are still present.

Even though Puerto Rico contrasts from the USA, Puerto Ricans still continue to migrate to the mainland due to economic factors. Large Puerto Rican communities have developed all over the USA, but specifically in two locations: New York and Florida. Florida being the closest state to Puerto Rico. Trends of lifestyle, iconography, and American culture are brought to the island by the Puerto Ricans traveling to and from the mainland combined with the circulation of media, i.e. social media, television, movies, magazines, etc. This enabled a change in the values and beliefs within Puerto Rico. The concept of Americanization is defined as “...the process by which people or countries 
become more and more similar to Americans and the United States." ${ }^{37}$ Globalization and communications have allowed an undeniable influence within the Puerto Rican culture and the island's way of life. This impact enabled the change of norms from a Puerto Rican, cultural upbringing to an American lifestyle. Author Lowell Fiet, in El Teatro Puertorriqueño Reimaginado: Notas Críticas Sobre la Creación Dramática y el Performance speaks about the "omnipresence" of the technology that provides access to products globally. ${ }^{38}$ By a means of social media, aspects such as: Hollywood movies/ television, fashion trends, and all things Disney created a new-found uprising of American culture that changed the norms and created an idealistic desire in Puerto Rico. This changed and altered the culture, and therefore the timeline of the vejigante mask.

The vejigante mask has experienced a shift in its appreciation as an artisanal artifact from culture of Puerto Rico. The reduced usage of the traditional vejigante mask within the festivities is the largest most noticeable impact on the representation of the culture. The depletion of the vejigante mask has opened an opportunity to replace the traditional mask with the substitute mask, such as Halloween masks. (Figures 19-20) Although Halloween is not celebrated in Puerto Rico as it is celebrated in the USA, Halloween costumes are still available on the island. Carnival can be compared to

\footnotetext{
37 “Americanization Definition and Meaning | Collins English Dictionary,” Collins Online Dictionary | Definitions, Thesaurus and Translations, accessed December 27, 2020, https://www.collinsdictionary.com/dictionary/english/ americanization.

${ }^{38}$ Lowell Fiet, El Teatro puertorriqueño Reimaginado: Notas críticas Sobre La creación dramática y El Performance (San Juan, P.R.: Ediciones Callejón, 2004), 371.
} 
Halloween for their shared similarities. The predominant commonality between the Carnival and Halloween is the opportunity for indulging in celebration and dressing up with costumes. Even though there are parallels between the Carnival and Halloween, the two holidays are incomparable.

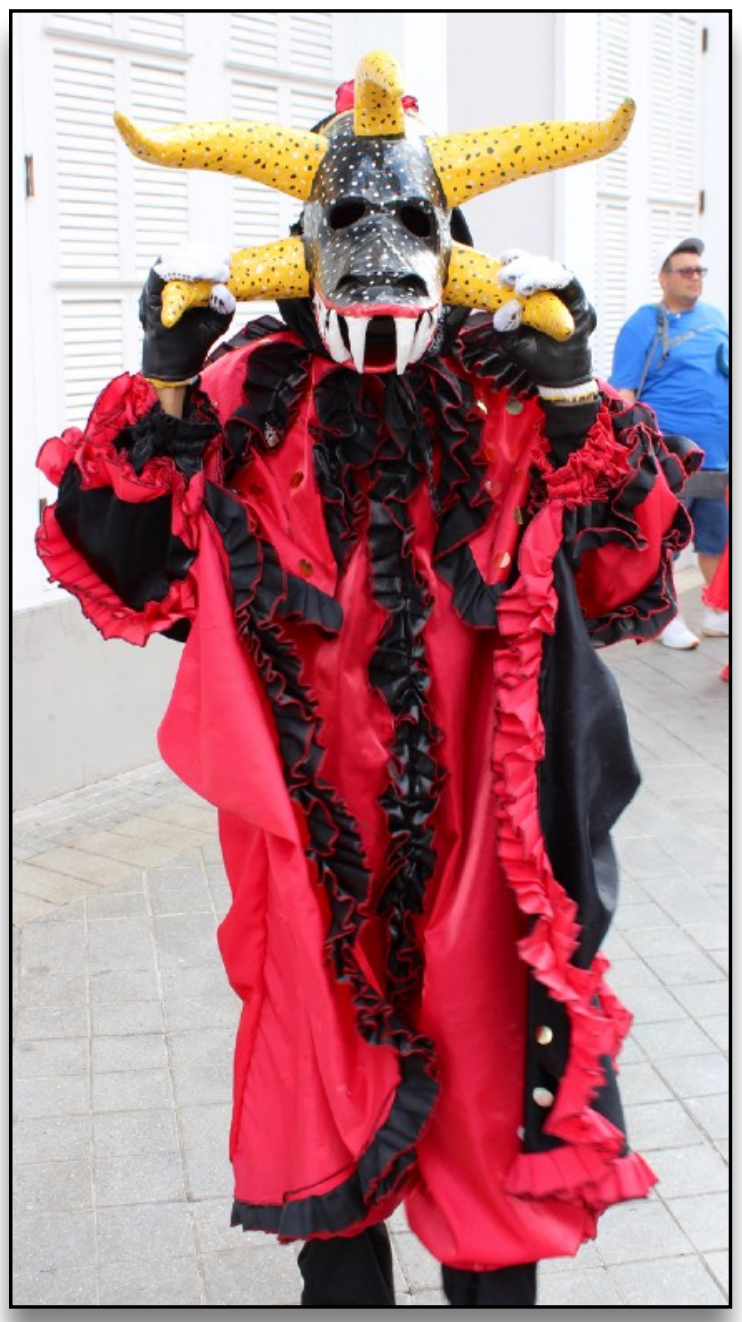

Figure 19 Traditional Vejigante with Traditional Mask, Carnaval Ponceño 2017 [digital image]. By Author. February 24, 2017

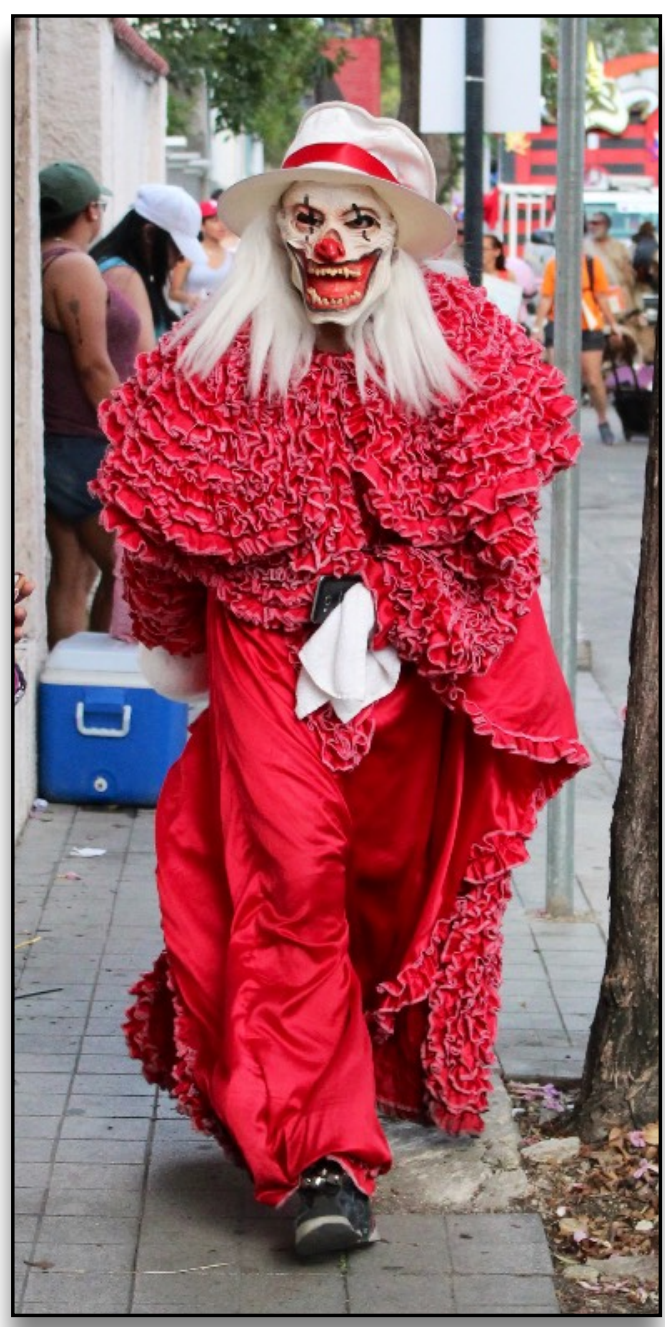

Figure 20 Traditional Vejigante Attire with Halloween Mask, Carnaval Ponceño 2017 [digital image]. By Author. February 24, 2017 
The main factor and cause of the diminishment of the traditional masks within the festivities, and the substitution with Halloween masks, is the introduction of USA national chain stores within Puerto Rico. The USA has enabled this change by branching out mainstream stores to the island, such as "Party City," a popular chain store dedicated to the sale of costumes and merchandise for parties, (Figures 21-23) and "Walmart:" “... store chain expansion has been going on in spite of the Puerto Rico's government Department of Justice Office of Monopolistic Affairs..." 39 When Puerto Rico became jurisdiction of the USA, it also became free game for well-known, chain stores, brand name stores and chain restaurants established in American culture. For example, it is stated that in Puerto Rico the growth of "Walgreens" pharmacy chain store began in 1962, and later on, the introduction of "Walmart" to the island in 1992. These national level stores Americanized the lifestyle, and thus the consumption, that enable the consumer to obtain products that are often not available in locally owned stores on the island. "Puerto Rico is the US jurisdiction with the highest concentration per square mile of Walgreens and Walmart stores."40 (Figures 24-28) The expansion of American stores within the island was inevitable.

\footnotetext{
39 Joel Cintrón Arbasetti, "Puerto Rico First in the World with Walgreens and Walmart per Square Mile," Centro de Periodismo Investigativo, September 29, 2018, https://periodismoinvestigativo.com/2014/05/puerto-rico-first-in-theworld-with-walgreens-and-walmart-per-square-mile/).

40 Joel Cintrón Arbasetti, "Puerto Rico First in the World with Walgreens and Walmart per Square Mile," Centro de Periodismo Investigativo, September 29, 2018, https://periodismoinvestigativo.com/2014/05/puerto-rico-first-in-theworld-with-walgreens-and-walmart-per-square-mile/).
} 


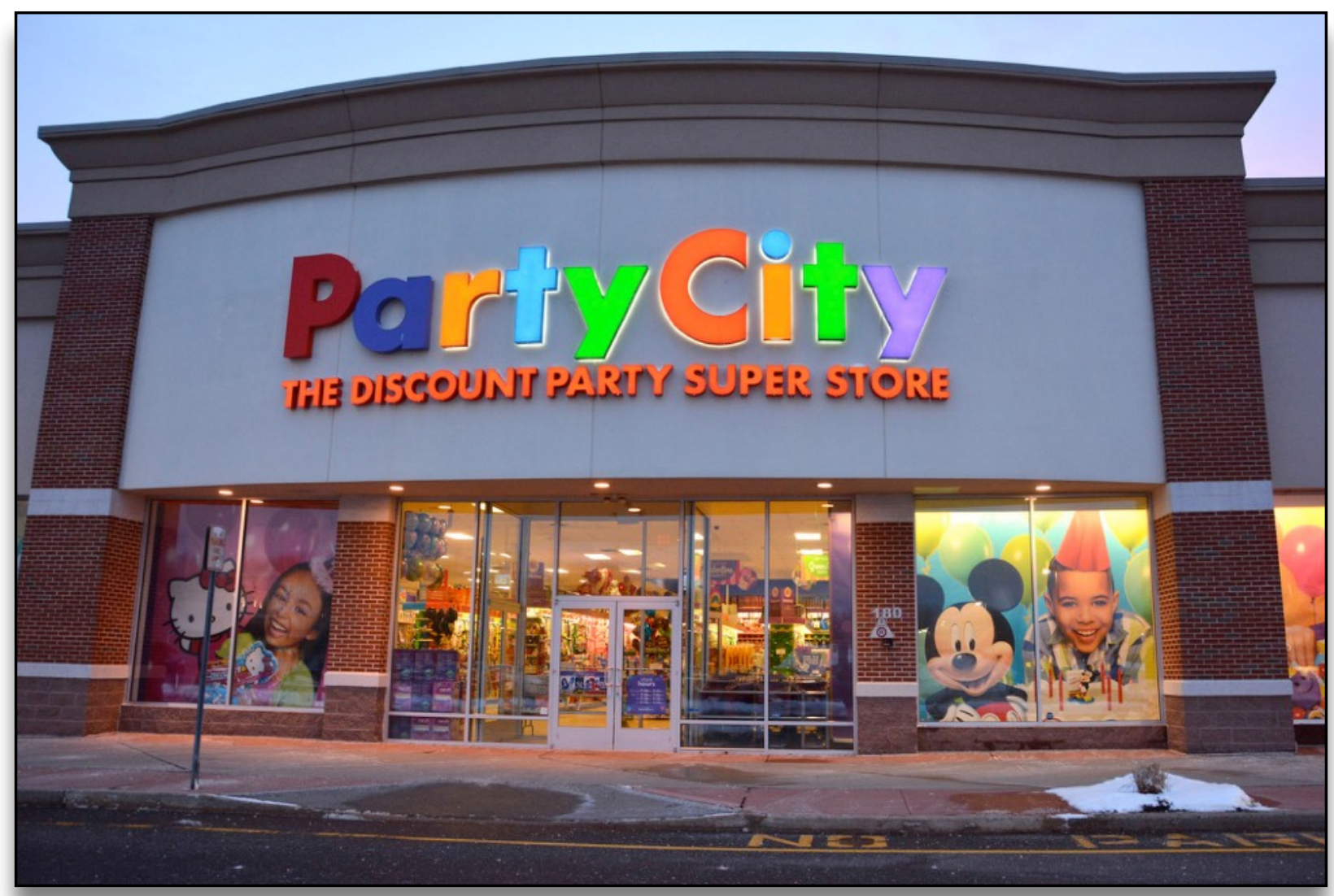

Figure 21 Party City store in Hamilton, New Jersey by Dorann Weber / Getty Images [digital image]. Retrieved June 24, 2020 from https://www.cnbc.com/2018/08/09/another-retailer-lands-a-deal-with-amazon-this-time-itsparty-city.html

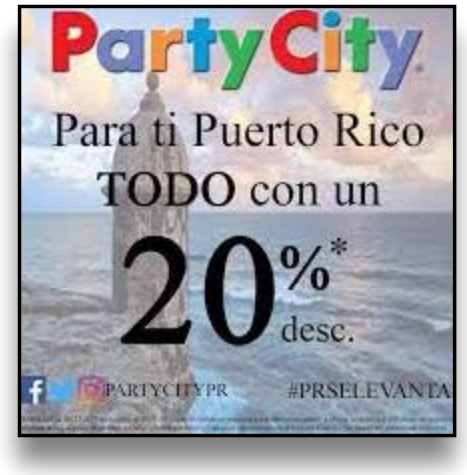

Figure 22 Untitled

[digital image]. Retrieved June 24, 2020 from https://

www.facebook.com/ partycitypr/photos/partycity-se-levanta-conpuerto-rico-se-extiendeel-20-de-descuento-hastael-mi/1481749288577233/

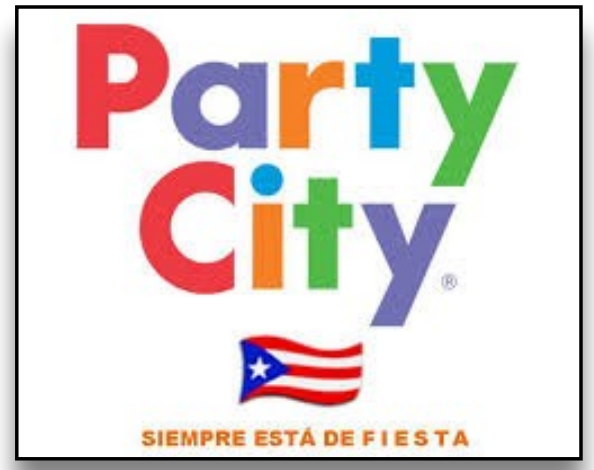

Figure 23 Untitled [digital image]. Retrieved June 24, 2020 from https:// www.facebook.com/partycitypr/ 


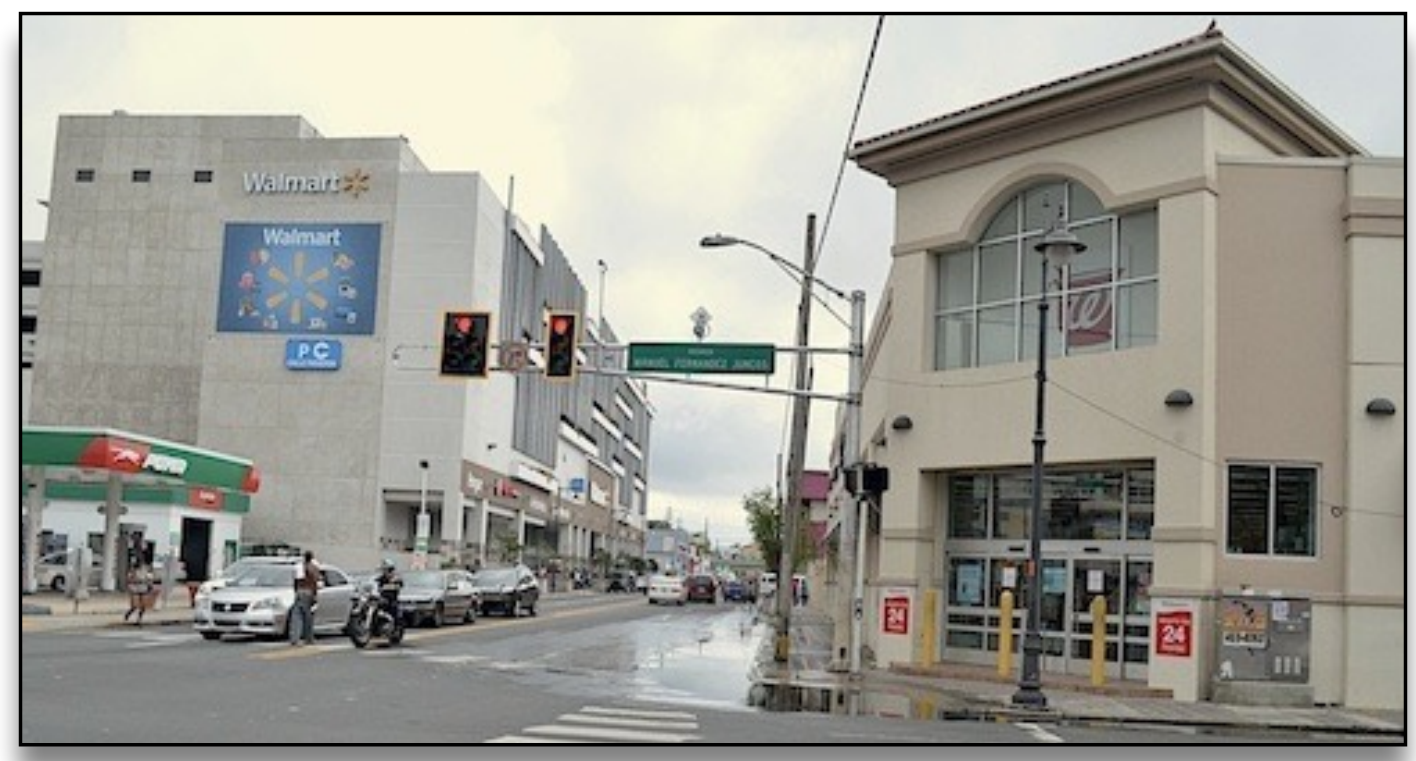

Figure 24 Joel Cintrón Arbasetti / CPIPR [digital image]. Retrieved June 24, 2020 from https:// periodismoinvestigativo.com/2014/05/puerto-rico-first-in-the-world-with-walgreens-andwalmart-per-square-mile/

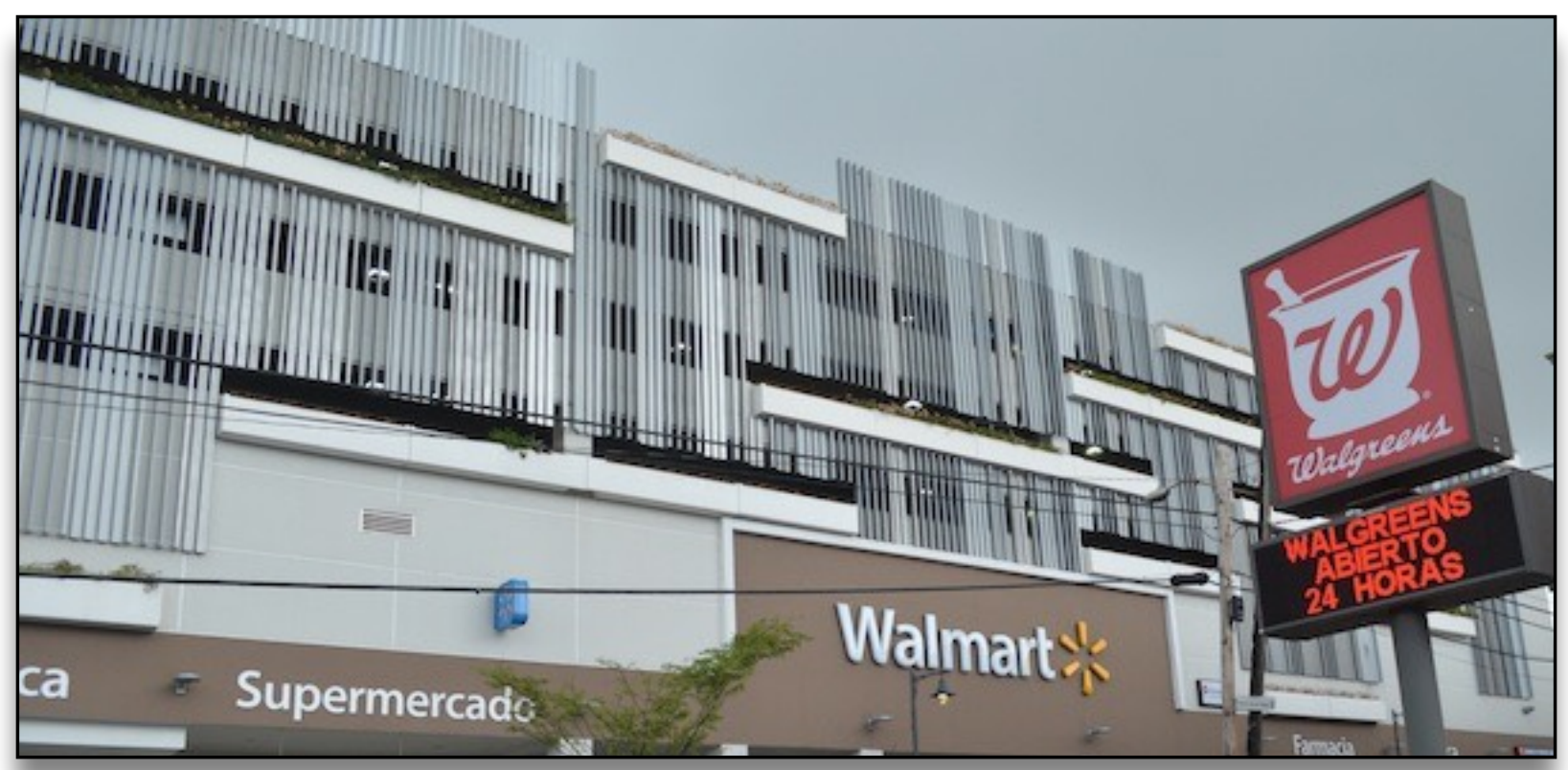

Figure 25 Joel Cintrón Arbasetti / CPIPR [digital image]. Retrieved June 24, 2020 from https:// periodismoinvestigativo.com/2014/05/puerto-rico-first-in-the-world-with-walgreens-and-walmart-per-squaremile/ 


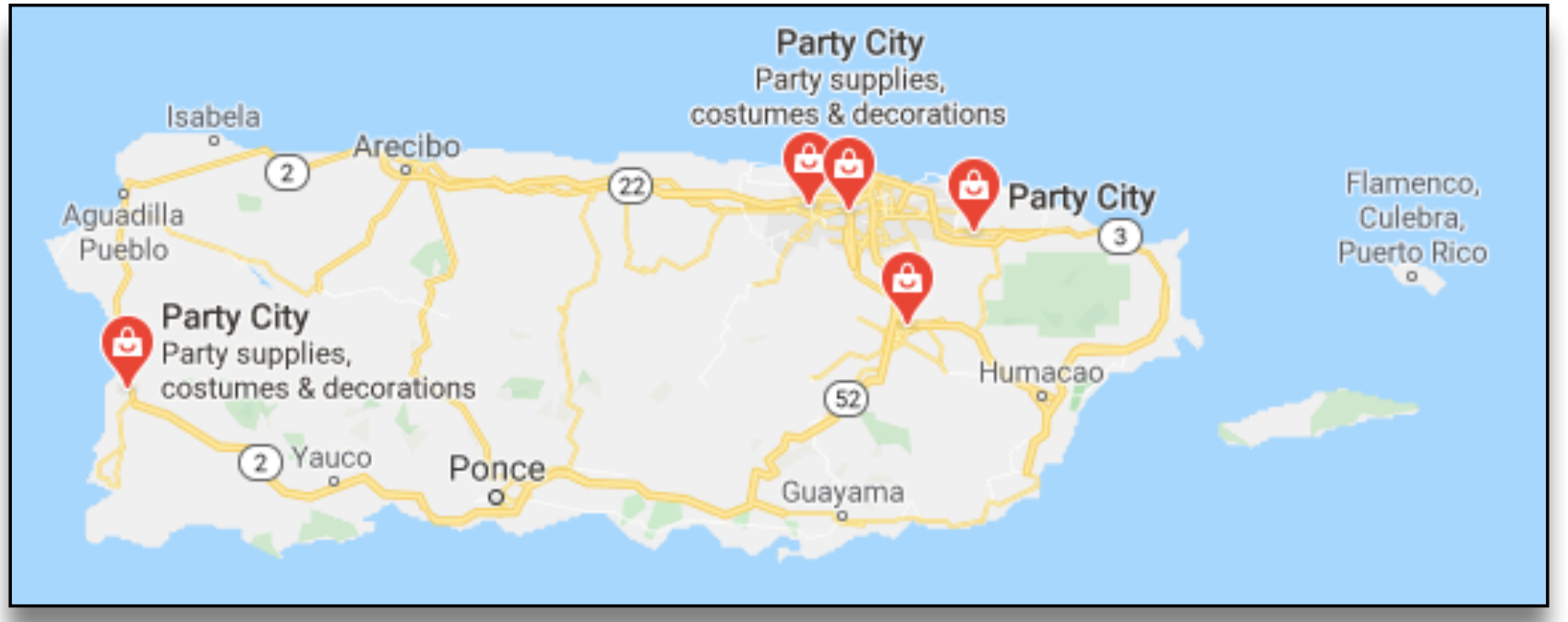

Figure 26 Untitled [digital image]. Retrieved June 24, 2020 from https://www.google.com/maps/search/ party+city+puerto+rico/@18.3036555,-67.0984753,8.51z?hl=en

\section{Towns of ruefro aico WALGREENS}

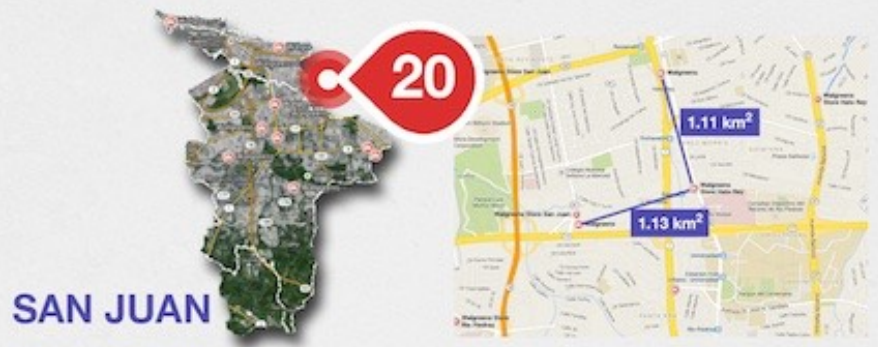

PONCE

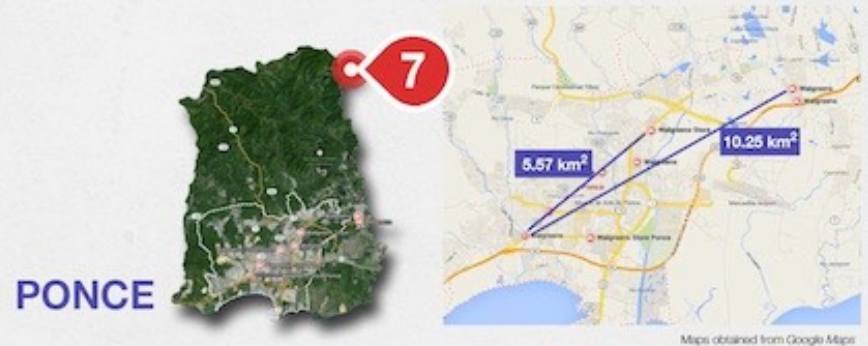

Figure 27 Infographics: Melanie PérezRivera [digital image]. Retrieved June 24, 2020 from https://

periodismoinvestigativo.com/2014/05/ puerto-rico-first-in-the-world-withwalgreens-and-walmart-per-square-mile/ 


\section{THE AMOUNT OF \\ WALMART $\mathbb{I N}$}

\section{Puerto Rico}

population: $3,930,065$

territory: $3,435 \mathrm{mi}^{2}$
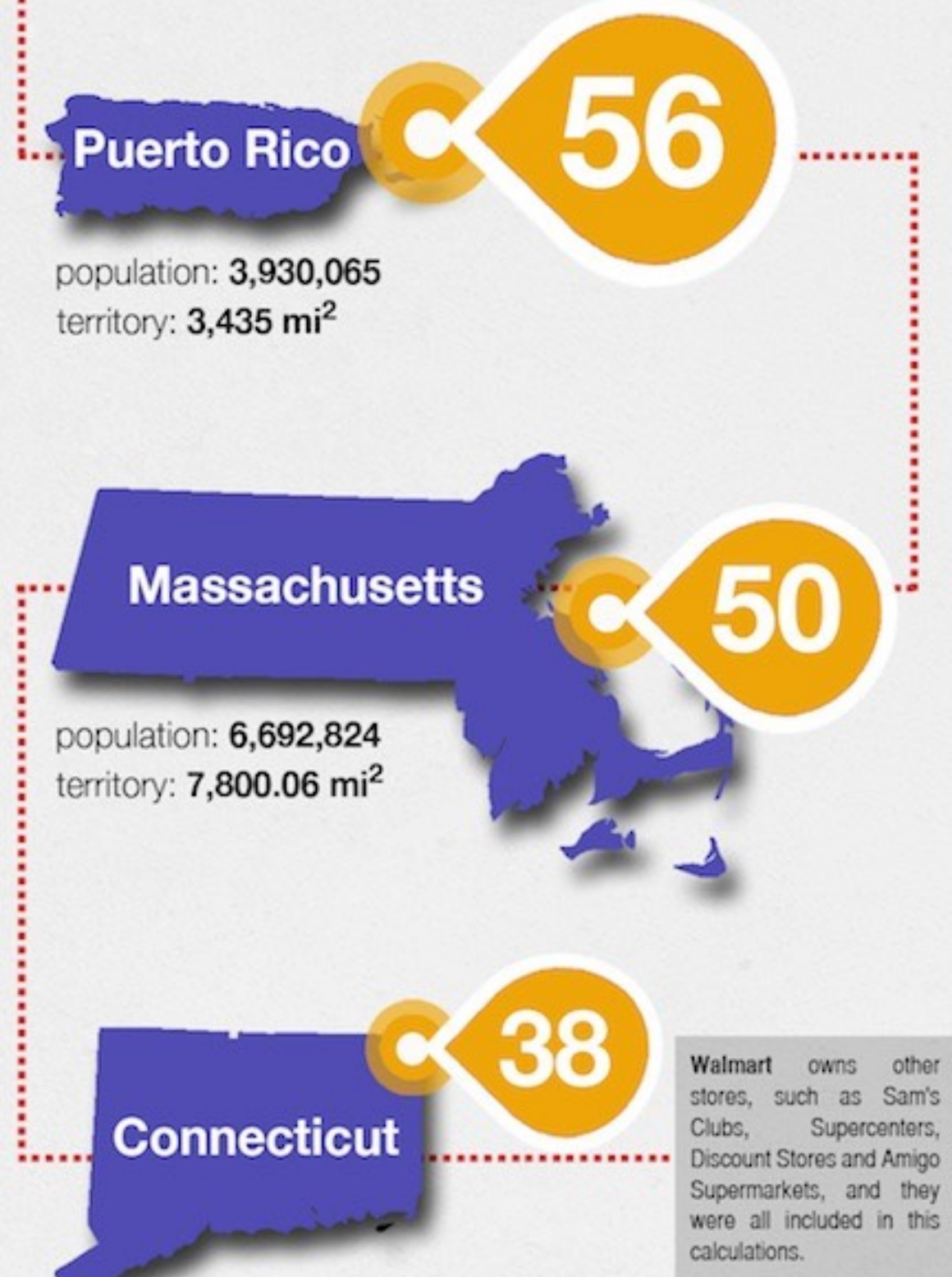

\section{population: $3,596,080$}

territory: $4,842.36 \mathrm{mi}^{2}$

Figure 28 Infographics:

Melanie Pérez-Rivera [digital image]. Retrieved June 24, 2020 from https://

periodismoinvestigativo.com/ 2014/05/puerto-rico-first-inthe-world-with-walgreens-andwalmart-per-square-mile/ 
It is clear that the growth of American, chain stores facilitated a modification in the festivities, specifically the diminished presence of the traditional vejigante mask within the cultural customs. "Humanist writer Teodoro Vidal came to research about the Carnival and, as a native born son, warned us that Ponce's traditional mask was in imminent danger of disappearing from the Carnival." 41 The availability of cheaper masks has lowered the consumption of traditional masks amongst the locals, creating less demands, therefore less sales of the vejigante mask. The lower consumption rate has pushed the artisan to attract the consumer with the creation of larger, extravagant work to catch the eye of a potential buyer. Further, the targeted buyer has transposed from locals to the Puerto Rican diaspora community, or Stateside Puerto Ricans, defined as: "belonging to or situated in the [USA]..."42 Many Puerto Ricans, living on the mainland, desire autochthonous memorabilia from their homeland. The change of clientele, combined with the ongoing demand from tourism, recreated the context of the mask for the artisans. This has enabled the vejigante mask, an anthropological artifact, to enter into the contemporary art world.

\footnotetext{
41 Norberto Martell Morales and Héctor J. Rodríguez Torres, Las Caretas del Vejigante Ponceño, ed. Pavlova Mezquida Greber and Héctor J. Rodríguez Torres, trans. Moisés Hernández, Verónica Kicliter, and Helen Rodríguez, 1 st ed. (Compañía de Fomento Industrial de Puerto Rico, 1999), 14.

42 "Stateside | Definition of Stateside by Oxford Dictionary on Lexico.com Also Meaning of Stateside," Lexico Dictionaries | English, accessed October 20, 2020, https://www.lexico.com/definition/stateside.
} 
Chapter Two: The Vejigante 


\subsection{Overview}

This chapter will cover the following: An in-depth definition of the vejigante by understanding through origin and overlying concept. The significance of the ceremonies and the responsibility of the vejigante within this context. This will also highlight the importance and significance of the ceremonies within the Carnival. An evaluation of the different types of traditional vejigante masks, with a brief comparison to the vejigante mask that originates from Loíza Aldea. And finally, an analysis and evaluation of all variables that have created the tangible and intangible concepts of the vejigante. Through the provided research in this chapter, the definition of vejigante within and out of context of the Carnival and its celebrations will be explained.

A brief summary of the results of the examination into the intercontinental ancestries of the mask showcases that the Puerto Rican culture has adapted and formed a new-found culture. It is clear that numerous variables from international influences have molded the mask through forced assimilation, "the process whereby individuals or groups of differing ethnic heritage are absorbed into the dominant culture of a society." ${ }^{43}$ In addition, the combination of colonization and the nomadic habits developed by the island's population have caused a medley of cultures and heritage. The concept of the

43 Elizabeth Prine Pauls, “Assimilation,” Encyclopædia Britannica (Encyclopædia Britannica, Inc., August 21, 2019), https://www.britannica.com/topic/assimilation-society). 
vejigante mask was globalized through the impact of other countries ideals, religions and ethnic conception of their depiction and use of the mask. In final, a synopsis of the additional exploration into literature and documentation that is related and has clearly influenced the vejigante mask evolutionized the initial heritage of the mask to create what is represented in present-day. 


\subsection{Definition and Concept}

Masks have existed in civilizations for thousands of years. ${ }^{44}$ The earliest evidence of physical masks "were created in the Judean Hills and the Judean Desert [in Israel] and are the oldest human portraits known..." 45 These prehistoric masks were determined to be from the Neolithic Period, approximately 9,000 years ago. ${ }^{46}$ (Figures 29-30) The purpose of each mask varies from culture to culture, i.e. marriage, deaths, births, ceremonies, religious customs, etc. In addition, the mediums used to create each mask varies according to the culture. ${ }^{47}$ A mask is an extension of the body: "From the moment a mask is worn, the personality of the wearer vanishes, and the spirit embodied by the mask enters and empowers him." 48 Masks are an expressive tool used to define a moment, portray a character, or express an emotion.

\footnotetext{
44 Norberto Martell Morales and Héctor J. Rodríguez Torres, Las Caretas del Vejigante Ponceño, 24.

45 Tami Michaeli, ed., "Face to Face: The Oldest Masks in the World," trans. Nancy Benovitz, accessed June 24, 2020 , https://museum.imj.org.il/exhibitions/2014/face-to-face/en/index.html.

46 Tami Michaeli, ed., "Face to Face: The Oldest Masks in the World," trans. Nancy Benovitz, accessed June 24, 2020 , https://museum.imj.org.il/exhibitions/2014/face-to-face/en/index.html.

47 Norberto Martell Morales and Héctor J. Rodríguez Torres, Las Caretas del Vejigante Ponceño, 24.

48 Tami Michaeli, ed., "Face to Face: The Oldest Masks in the World," trans. Nancy Benovitz, accessed June 24, 2020, https://museum.imj.org.il/exhibitions/2014/face-to-face/en/index.html.
} 


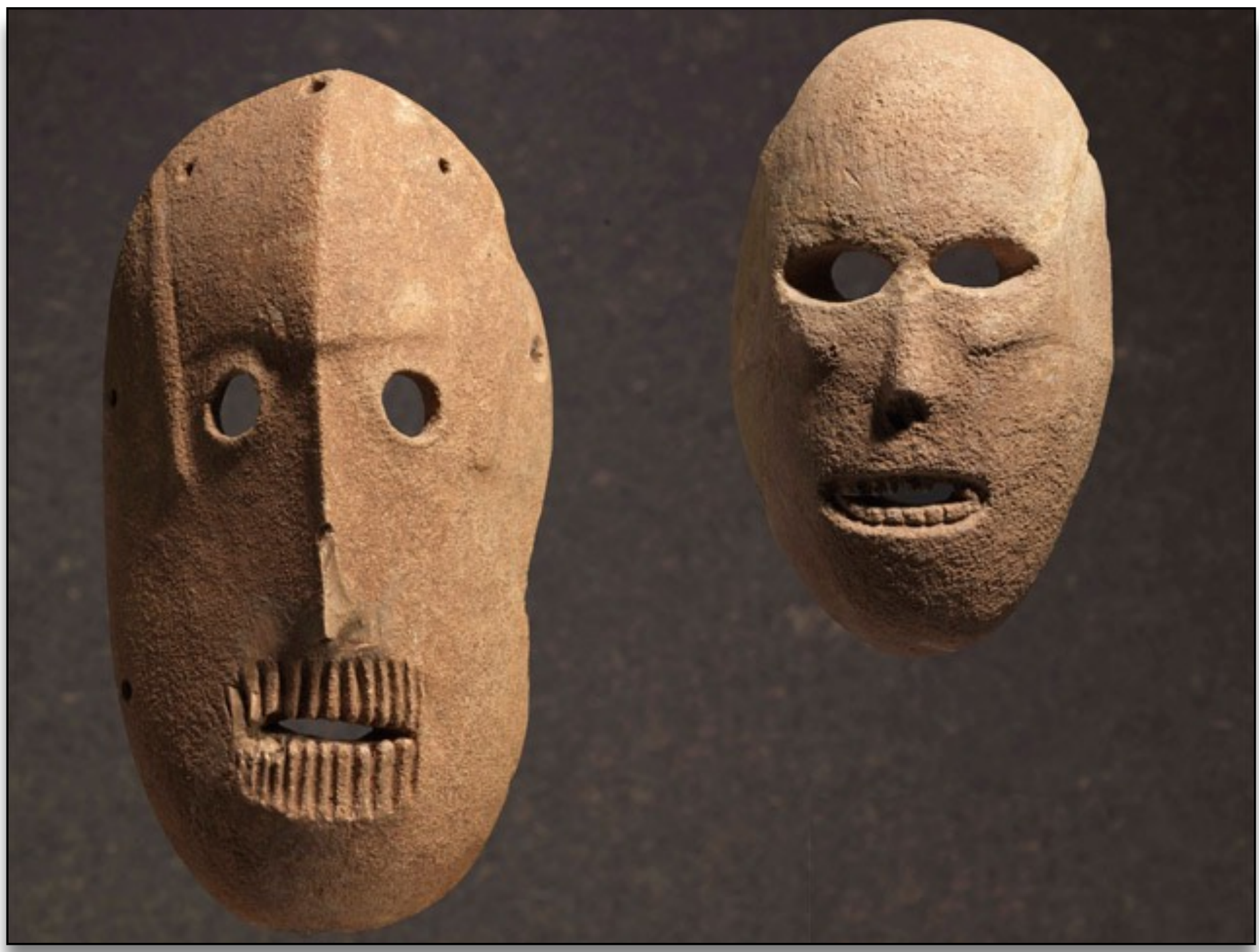

Figure 29 Face to Face: The Oldest Masks in the World / C Israel Museum, Jerusalem [digital image]. Retrieved June 24, 2020 from https://mfa.gov.il/MFA/IsraelExperience/History/Pages/Oldest-masks-in-the-world-at-Israel-Museum-12-Mar-2014.aspx 


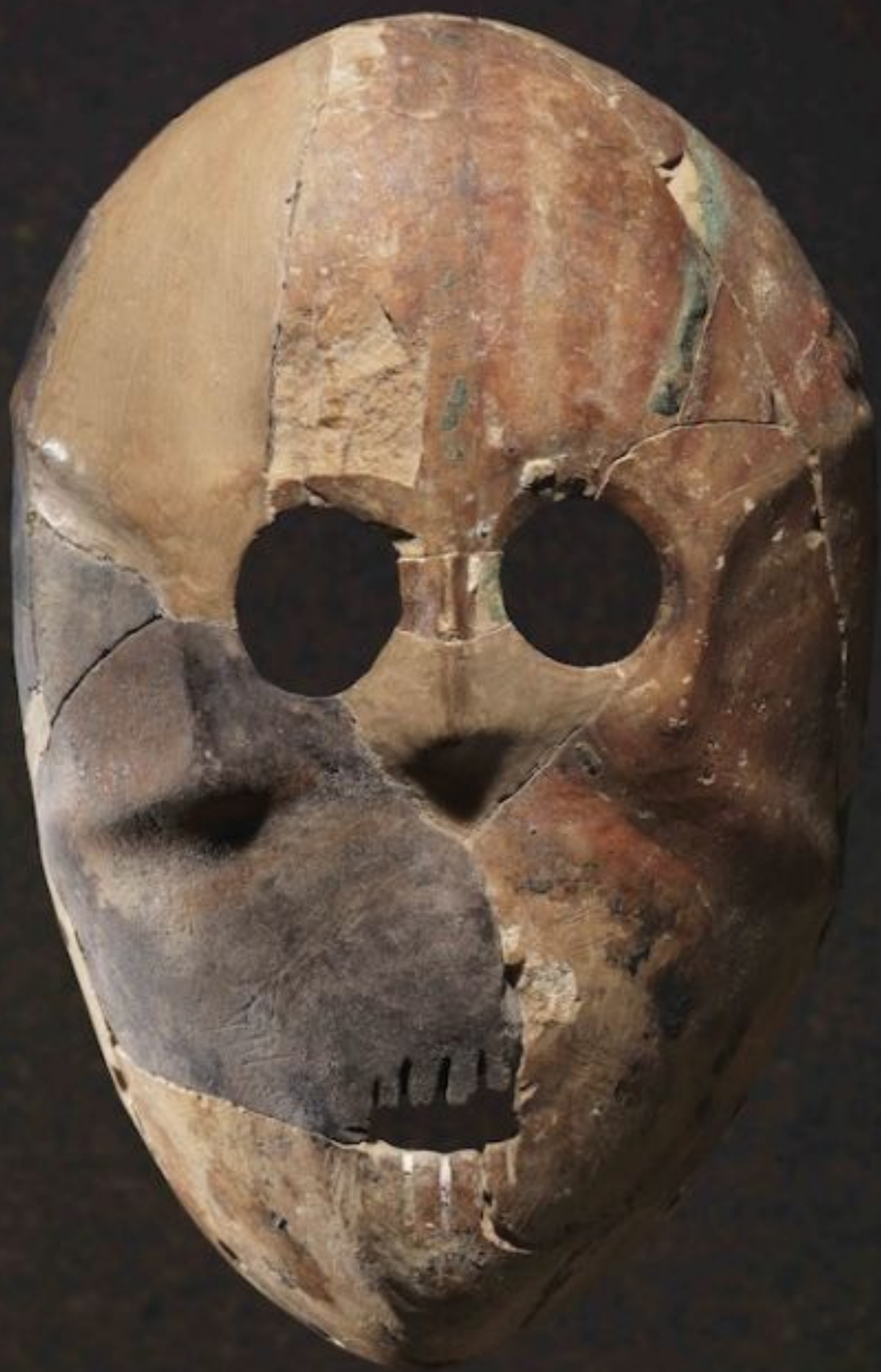

Figure 30 Researchers think these masks could have been worn comfortably on the face during ancient rituals. This mask comes from the site of Horvat Duma in the Judean Hills / Image: (C) Elie Posner / Israel Museum [digital image]. Retrieved June 24, 2020 from https:// www.livescience.com/44078-stone-age-masks-israel-museum.html 
Vejigantes are folkloric characters celebrated in the culture and heritage of Puerto Rico and portrayed within the ceremonies of the Carnaval. Although at first sight they are daunting, the affable concept of the vejigante originated to drive away the evil spirits. ${ }^{49}$ The physical attributes of a vejigante mask are animalistic features with horns protruding outward. ${ }^{50}$ The careta, meaning mask, is the word normally used to identify the vejigante mask in Puerto Rico. (Figures 31-32) The careta antigua references the classical, papier-mâché vejigante mask that are often made by artisans. The costume that accompanies the careta is the atuendo, this word is used to reference the vejigante costume. The atuendo covers the entire body with "bat-like sleeves that make the character look bigger and more menacing, ${ }^{51}$ in corresponding colors to the mask. (Figure 33) During the Carnaval and the celebrations, people join in the street dressing in these colorful masks and vibrant costumes, running through the city intertwining, interacting, and causing mischief with the bystanders..$^{52}$ The official inauguration of the Carnaval, as a city event, was held in 1859 in La Ciudad Señorial, terminology used when referring to Ponce. ${ }^{53}$ With this timeline, it is clear the birth of the vejigante began in Ponce. Although,

\footnotetext{
49 Valerie Petrillo, Scott Rattray, and Gail Rattray, A Kids Guide to Latino History: More than 50 Activities (Chicago, IL: Chicago Review Press, 2009), 97.

50 Olga R. and Kuharets, Venture Into Cultures: A Resource Book of Multicultural Materials and Programs (American Library Association, 2001), 23.

${ }^{51}$ Daniel Shafto, Carnival (Infobase Publishing, 2009), 61.

52 Miguel A. De La Torre, Hispanic American Religious Cultures, vol. 1 (Santa Barbara, CA: ABC-CLIO, 2009$), 263$.

53 Norberto Martell Morales and Héctor J. Rodríguez Torres, Las Caretas del Vejigante Ponceño, 11.
} 
the vejigantes are also present in another city in Puerto Rico: Loíza Aldea. (Figure 34) Ponce and Loíza Aldea exhibit different interpretations and connotations of the vejigante mask. Two different cities of the island have created contrasting editions of the mask's form, purpose, and symbolism.

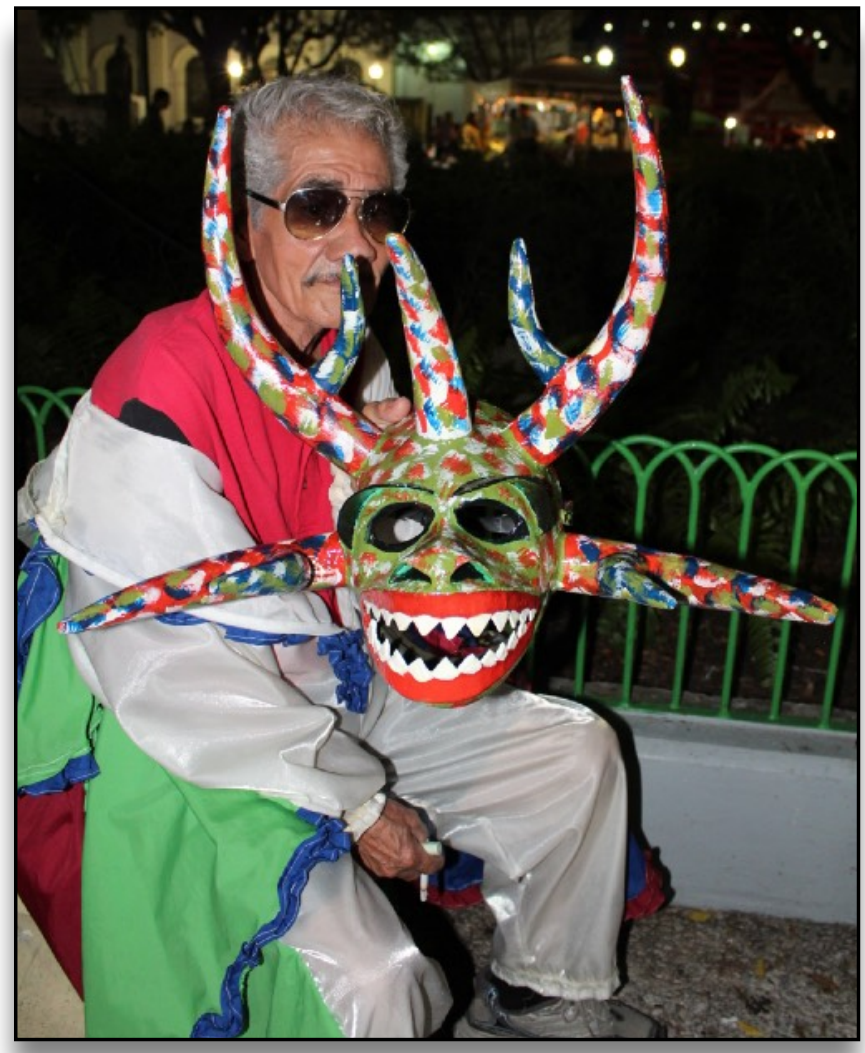

Figure 31 Vejigante in Careta, Carnaval Ponceño 2017 [digital image]. By Author. February 24, 2017

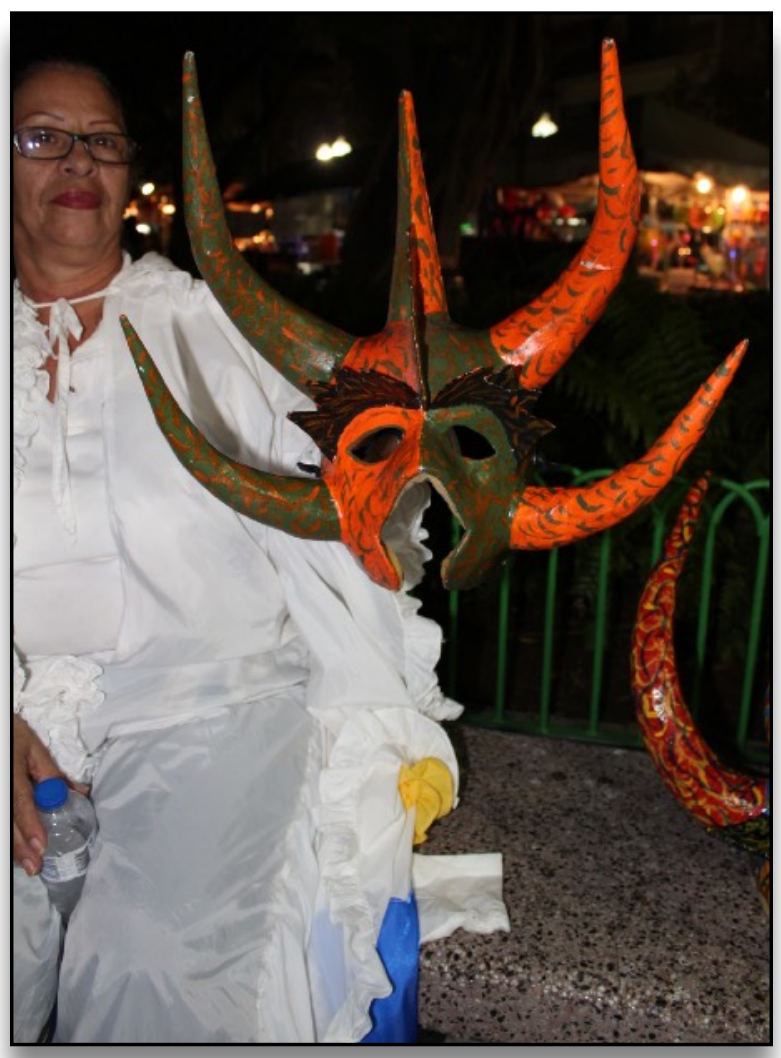

Figure 32 Vejigante in Antifaz Mask, Carnaval Ponceño 2017 [digital image]. By Author. February 24, 2017 


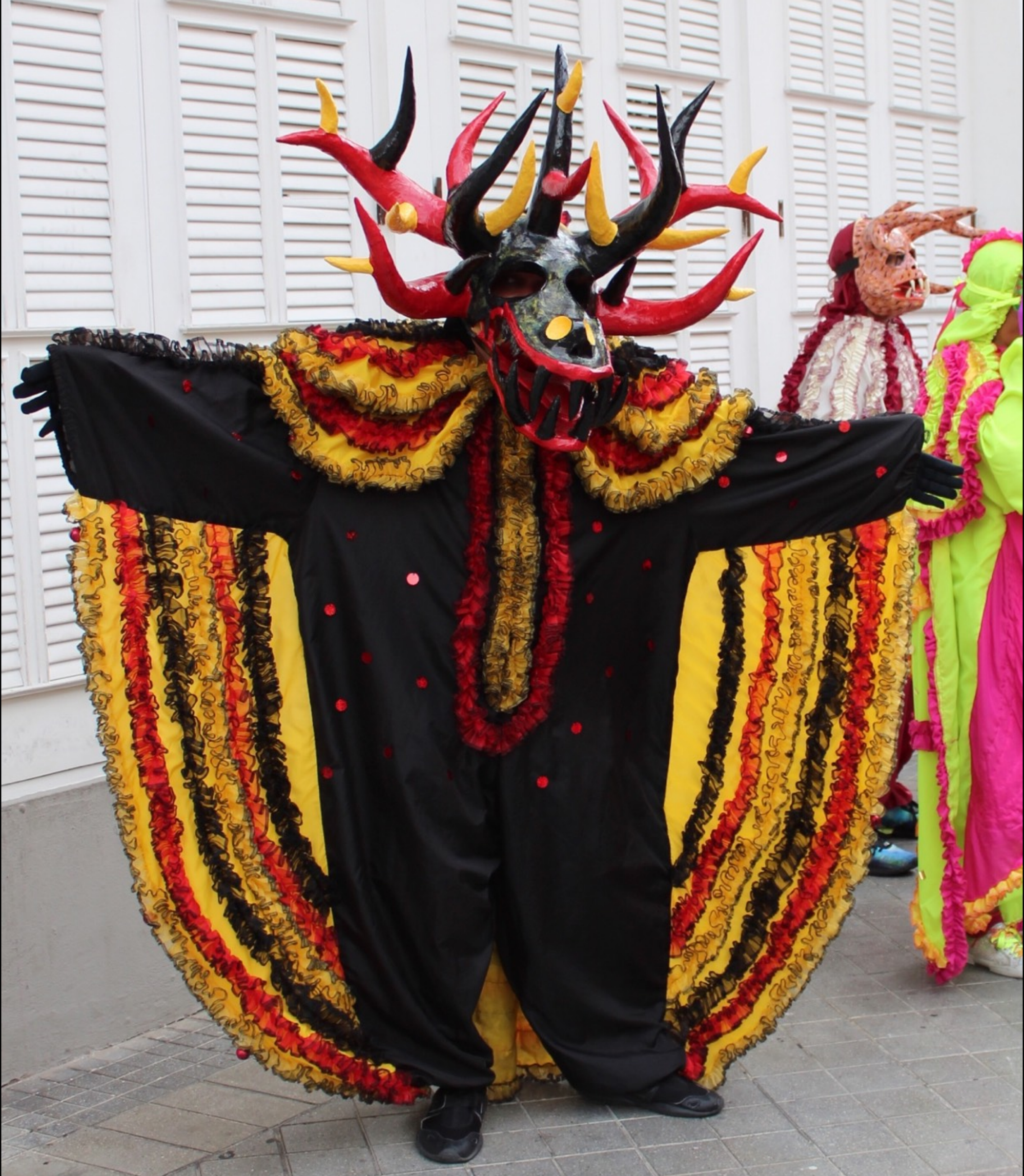




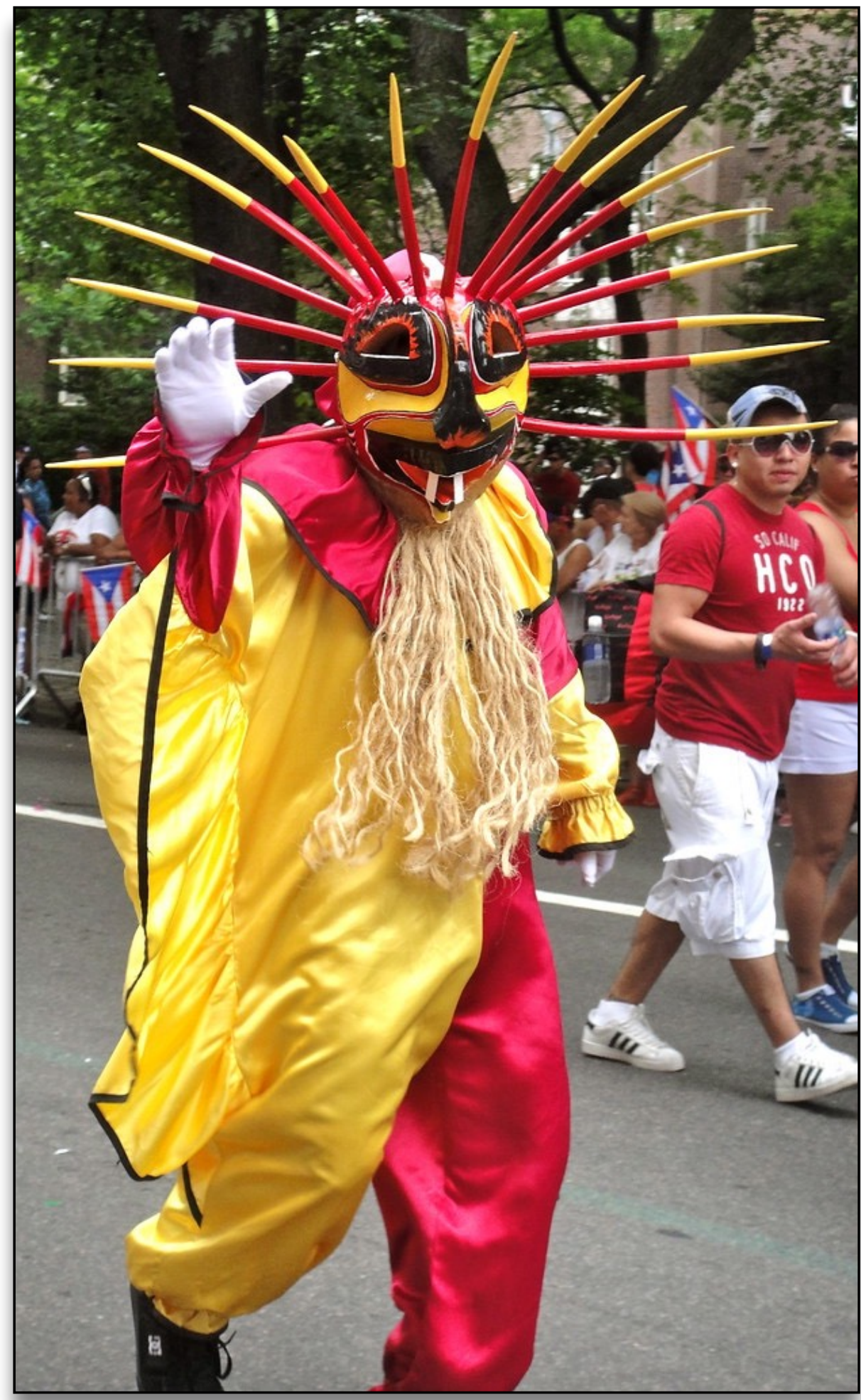

Figure 34 Vejigante a la bolla...Pan y Cebolla / Mask made of coconut shell. Vejigante de Loiza, Parada Puertorriqueña, NY / (C) All rights reserved by wburgos [digital image]. Retrieved June 24, 2020 from https:// flic.kr/p/8ahwJ7 
The Ponceño vejigante aided in the battle between good and evil within the townspeople with the use of the vejiga: ${ }^{4}$ inflated, dried cow bladder. ${ }^{55}$ The vejiga is an inflated cow bladder, and the tool the vejigante uses to exude the evil out of a person. (Figures 35-36) Vejigantes used this to hit bystanders, "supposedly to chase away the evil spirits" 56 of the person, specifically, out of the young and the women. The vejiga is the origin of the name vejigante, a combination of gigante, giant, and vejiga, meaning cow bladder. (Figure 37) “Vejigantes embody the indomitable spirit of the island's people and are now considered to be objects of good fortune that can repel bad omens and mischievous spirits." ${ }^{57}$ Although the context of the vejigante has changed, the underlying purpose to exude evil from the life of the bystander remains to this day.

\footnotetext{
54 Admin, "Vejigantes,” Nana Abreu, September 28, 2018, http://www.nanaabreu.com/vejigantes/).

55 Puerto Rico Day Trips Travel Guide, accessed September 1, 2019, https://www.puertoricodaytrips.com/poncecarnival/).

56 Admin, "Vejigantes," Nana Abreu, September 28, 2018, http://www.nanaabreu.com/vejigantes/).

57 Admin, "Vejigantes," Nana Abreu, September 28, 2018, http://www.nanaabreu.com/vejigantes/).
} 


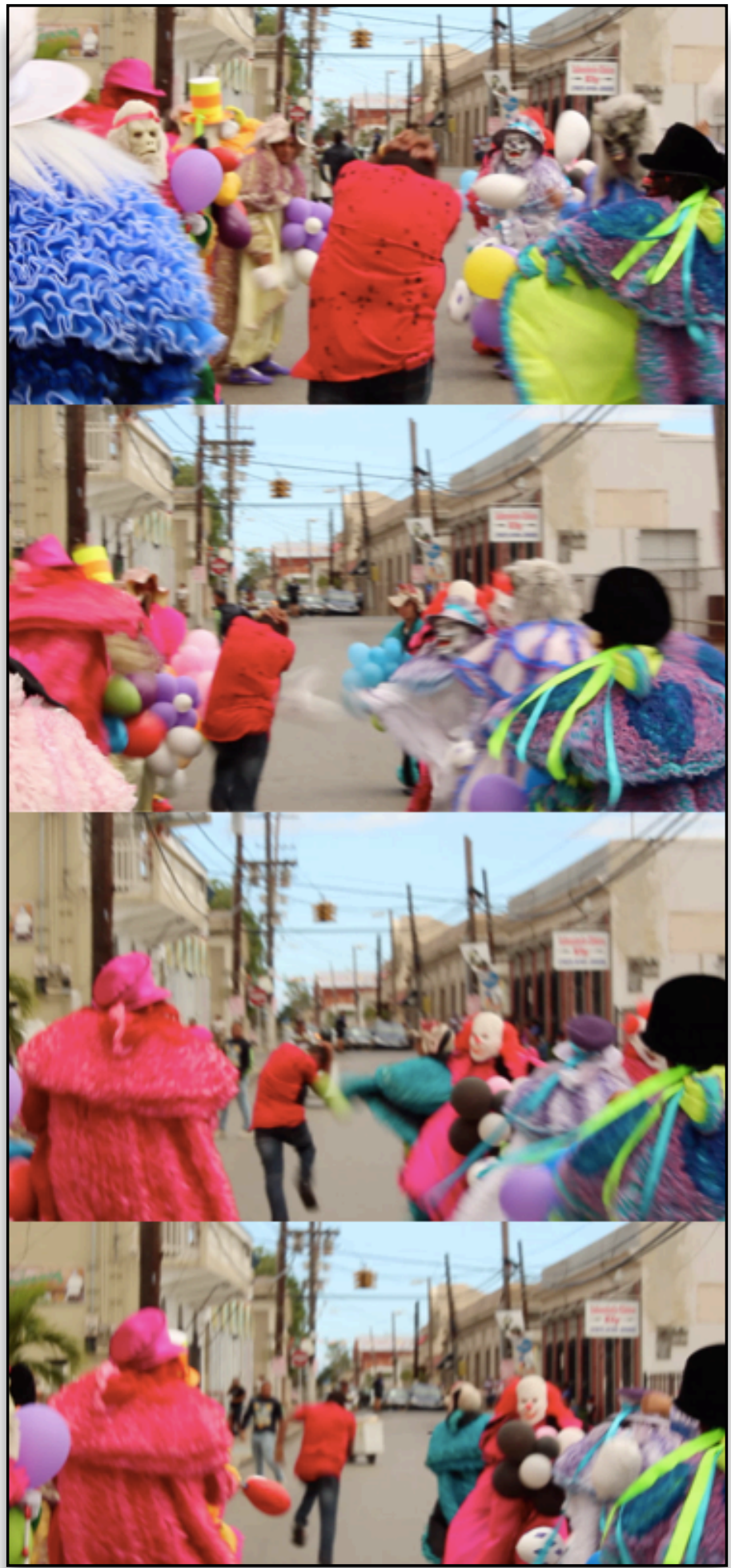

Figure 35 Vejigantes hitting a man with Vejigas, Carnaval de La Playa de Ponce 2018 [digital image]. By Author. February 24, 2018

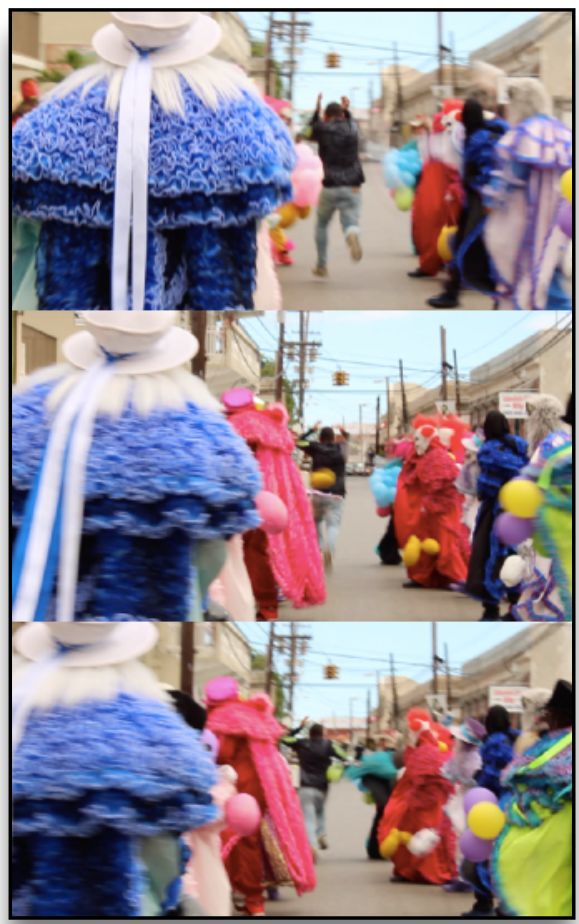

Figure 36 Vejigantes hitting a man with Vejigas, Carnaval Ponceño 2017 [digital image]. By Author. February 24, 2017

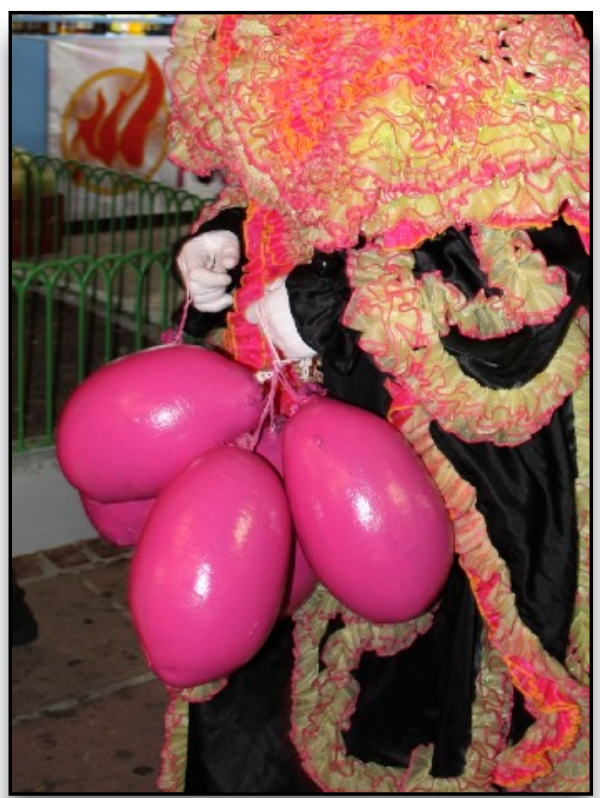

Figure 37 Vejigante holding Vejigas, Carnaval Ponceño 2017 [digital image]. By Author. February 24, 2017 
Originally, the vejigante mask had symbolism in its aesthetic composition. Each horn on the mask was significant for defining the status or the position of the person wearing the mask, in reference to a group setting. Allegedly, one horn identified the leader vejigante, which the others should follow and imitate in the comparsa, ${ }^{58}$ an organized troupe of vejigantes. (Figure 38) Most vejigantes in the comparsa had more horns, two to three horns, signifying a lesser authority within the troupe. ${ }^{59}$ Two horns on a mask are to be worn by the children or the younger vejigantes within the troupe. (Figure 39) The mask was usually shaped in form of a demonic character, originating from the Spanish form of the mask, but the Puerto Ricans have altered the shape of the mask to reference local animals on the island, such as: sheep, goats, lizards, pigs, donkeys, etc. ${ }^{60}$ (Figure 40) Author Nelson García Santos, well-known in La Playa de Ponce, states in his book, Vivencias en La Playa de Ponce, how he felt while he was dressed as a vejigante. Nelson says that he had a strange yet satisfying sensation while wearing the costume. $\mathrm{He}$ was able to represent an important figure in the Carnival that people respected and feared. The bystanders feared and screamed in expectation for the blows of the vejigante will give with its vejiga. He concludes with saying he felt like a true actor. ${ }^{61}$

\footnotetext{
58 Norberto Martell, Interview by author, Video recording, Ponce, February 6, 2018.

59 Norberto Martell, Interview by author, Video recording, Ponce, February 6, 2018.

${ }^{60}$ Erinn Banting, Puerto Rico: the People and Culture (New York: Crabtree, 2003), 22.

${ }^{61}$ Nelson García Santos, Vivencias en La Playa De Ponce: Andadas En Mis Tiempo De Vejigante (Juana Díaz, PR: Imprenta Llorens, Inc., 2009), 17.
} 

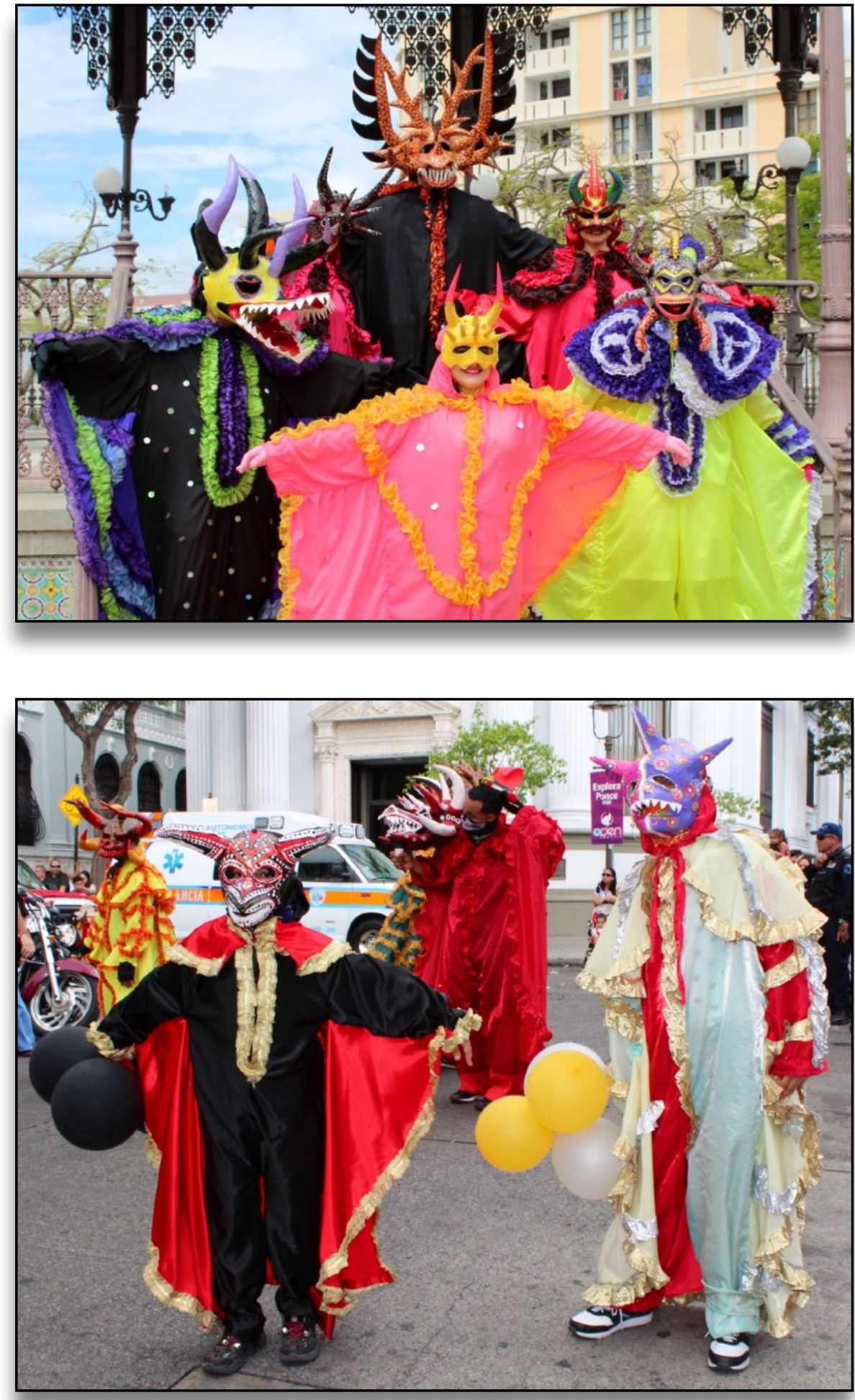

Figure 38 Comparsa of

Vejigantes, Carnaval Ponceño 2018 [digital image]. By Author.

February 24, 2018
Figure 39 Children Vejigantes, Carnaval Ponceño 2017 [digital image]. By Author. February 24, 2017 


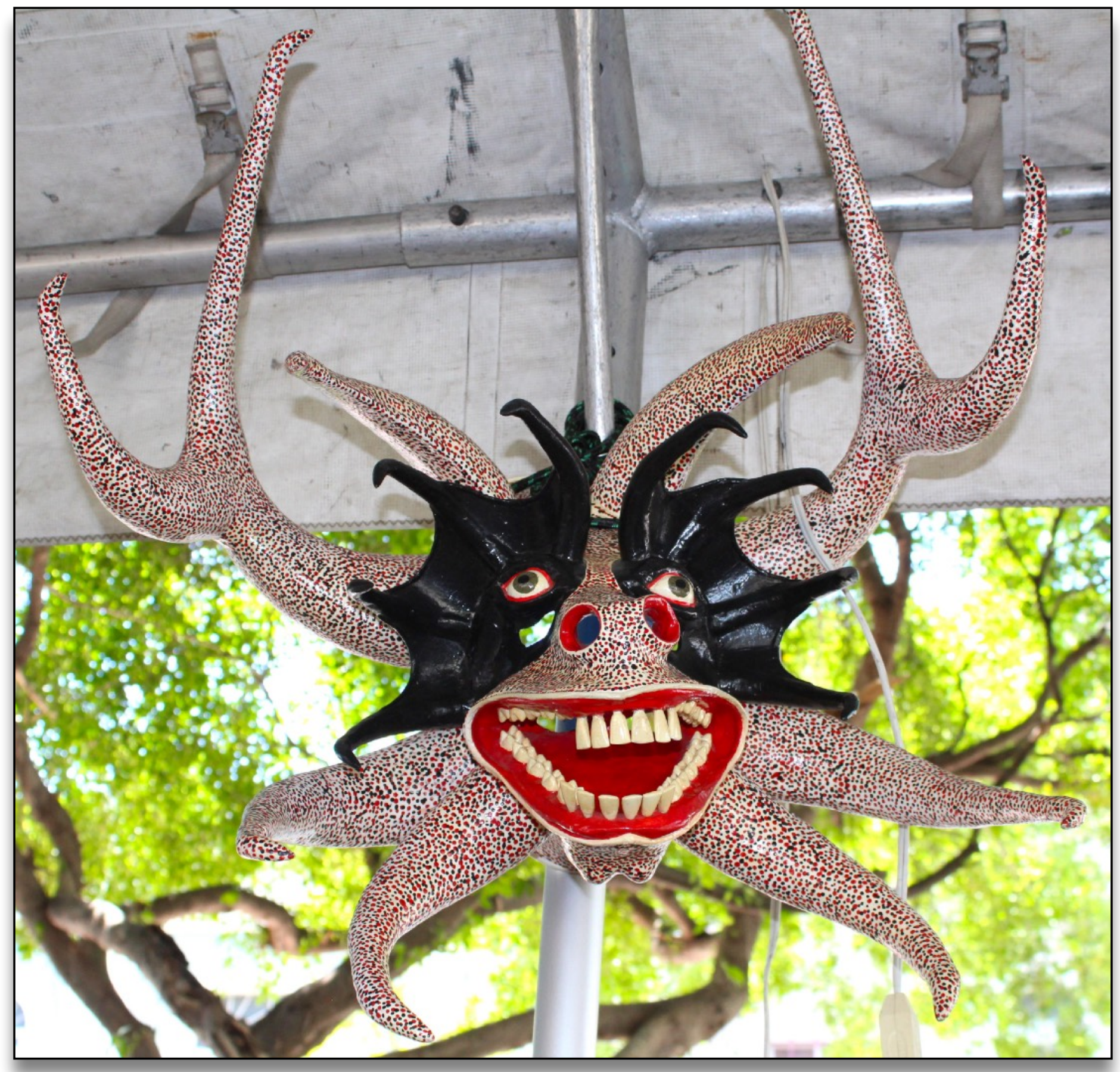

Figure 40 Vejigante Mask resembling a combination of a Horse and a Bat, Carnaval Ponceño 2017 [digital image]. By Author. February 24, 2017 
The vejigante has no gender nor race. The costume combined with the mask hides the identity completely of the one wearing it. It conceals the participant's face, skin, eyes, and hands. (Figure 41) The costume reaches to the floor, covering the arms and legs. Additionally, it is often made with a hood to conceal the ears, hair, and the back of the head. The hood is designed to be tucked under the mask, cover the head completely from sight. The costume is often accompanied with gloves, concealing their hands, and a bandana, covering their neck. (Figure 42) Gloves, specifically, are worn so the audience does not recognize the person by their hands. ${ }^{62}$ Thus, absolutely nothing will hint at the gender nor skin color of the person in disguise. This gives the vejigante full power to control the situation through confusion and the unknown.

62 Teodoro Vidal, El Vejigante Ponceño, 11. 


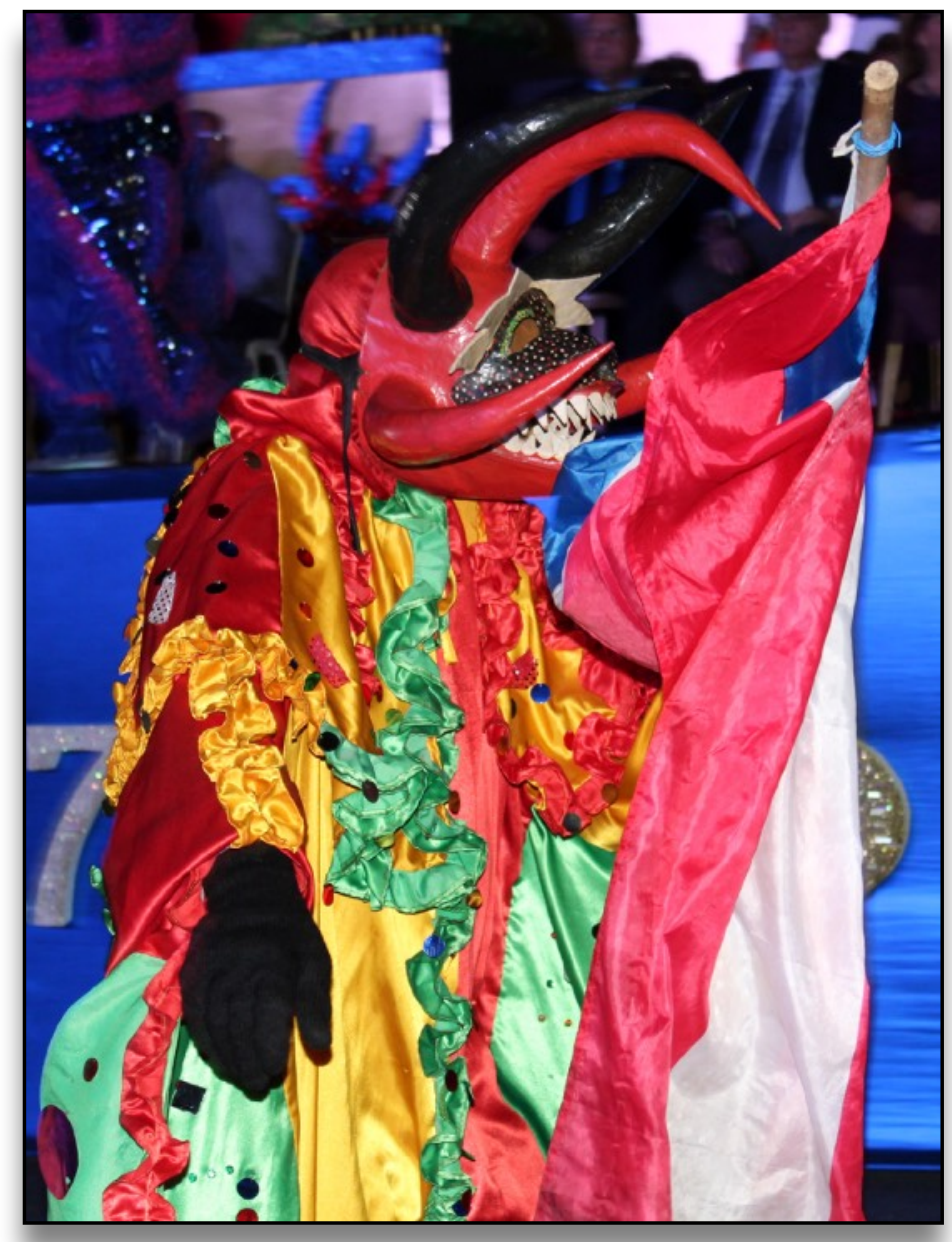

Figure 41 Vejigante with gloves holding the Puerto Rican Flag, Carnaval Ponceño 2017 [digital image]. By Author. February 24, 2017

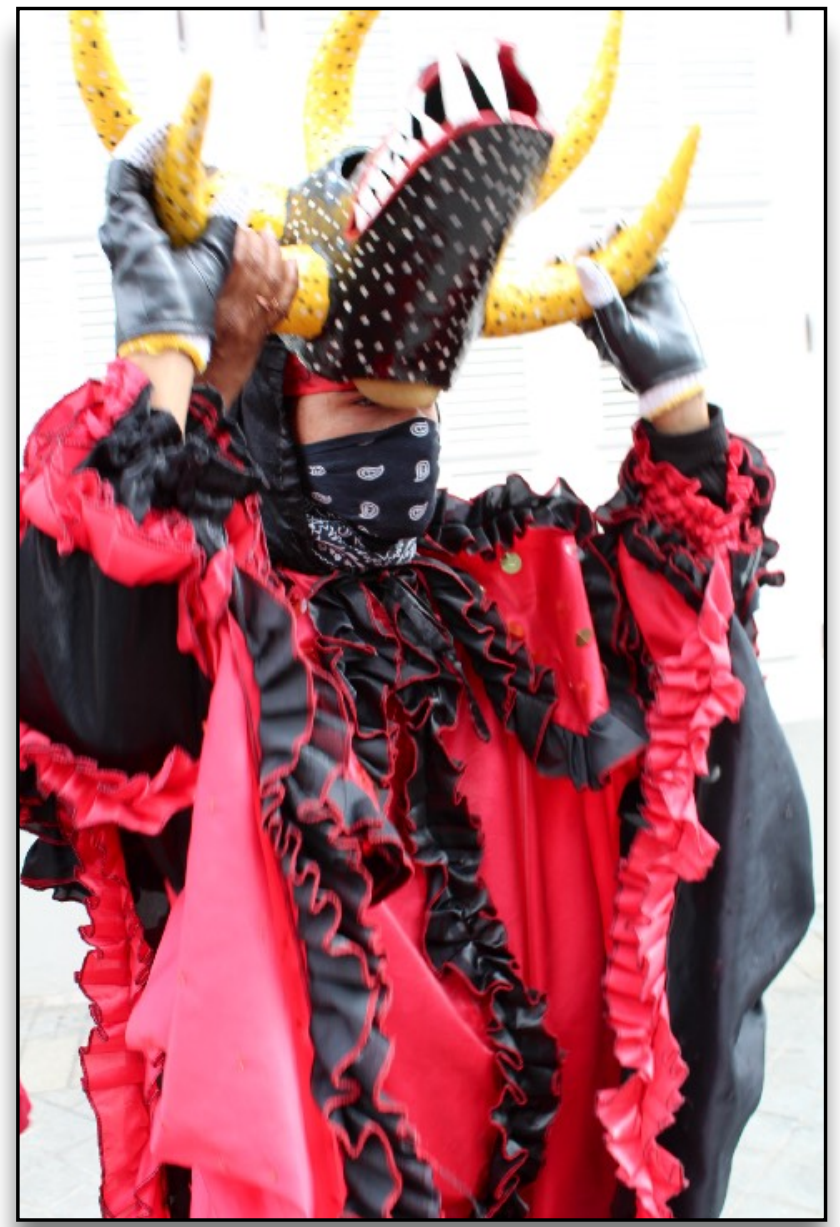

Figure 42 Vejigante adjusting Mask, Carnaval Ponceño 2017 [digital image]. By Author. February 24, 2017 
While the traditional vejigante is genderless, these sharp-toothed, long-horned, exaggeration characters were usually portrayed by the young men of the town. ${ }^{63}$ This aspect aided the creation of the modern version of the character, which is geared toward females. This popularized version of the vejigante mask is known as the antifaz. (Figure 43) This mask does not cover the mouth in order to show the attributes of the feminine face. Women normally wearing the antifaz use colorful lipstick, and dress in a costume adorned with sparkles and beads. In comparison to the traditional atuendo, the vejigante costume that accompanies the anitfaz is much more embellished. (Figure 44) It can be linked as a cross inspiration of the original masks made for women known as mascaritas, "little masks," 64 or a masquerade styled mask. "...In the thirties, forties and towards the end of the fifties, a very antique wire mask was used....Before wire was used to create these masks, mask makers resorted to the use of tulle and other fine sheer net fabrics. This allowed the users to see through their masks without being recognized." ${ }^{65}$ (Figure 45) While this feminine version of the vejigante is still presently seen, the traditional costume, combined with full face mask, is more commonly used.

\footnotetext{
63 Patricia Levy and Nazry Bahrawi, Puerto Rico, 118.

64 Norberto Martell Morales and Héctor J. Rodríguez Torres, Las Caretas del Vejigante Ponceño, 39.

65 Norberto Martell Morales and Héctor J. Rodríguez Torres, Las Caretas del Vejigante Ponceño, 39.
} 


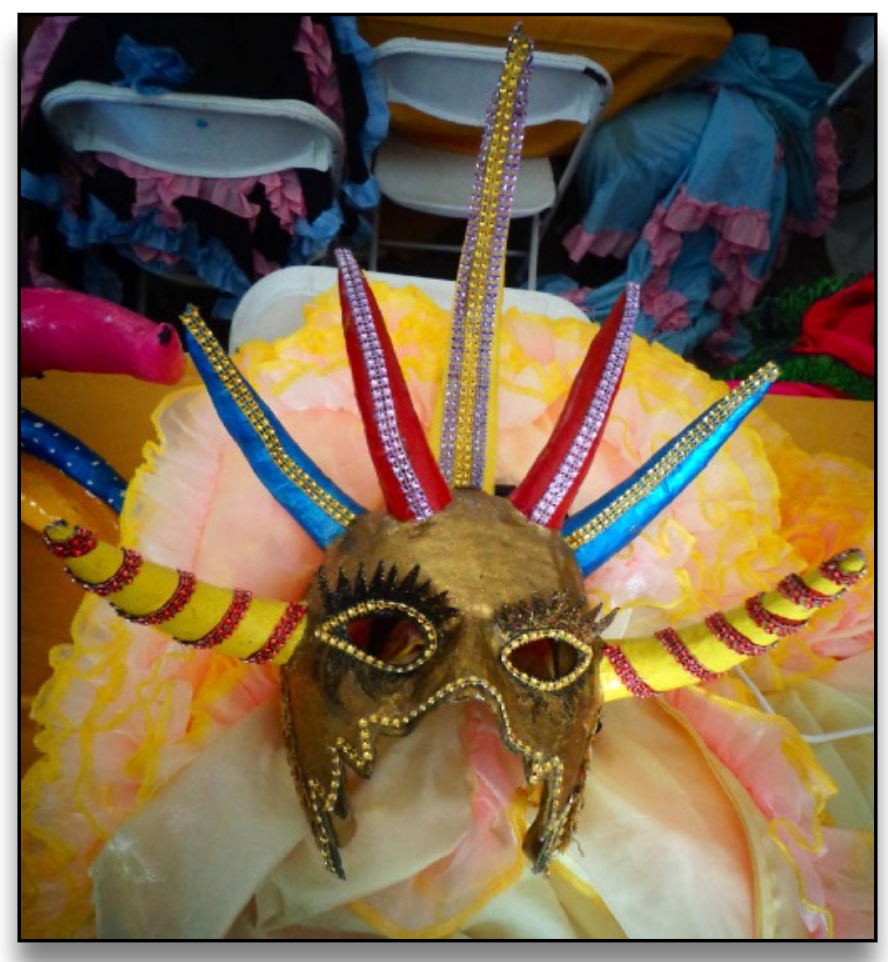

Figure 43 Antifaz Vejigante Mask, Carnaval Ponceño 2018 [digital image]. By Author. July 24, 2018

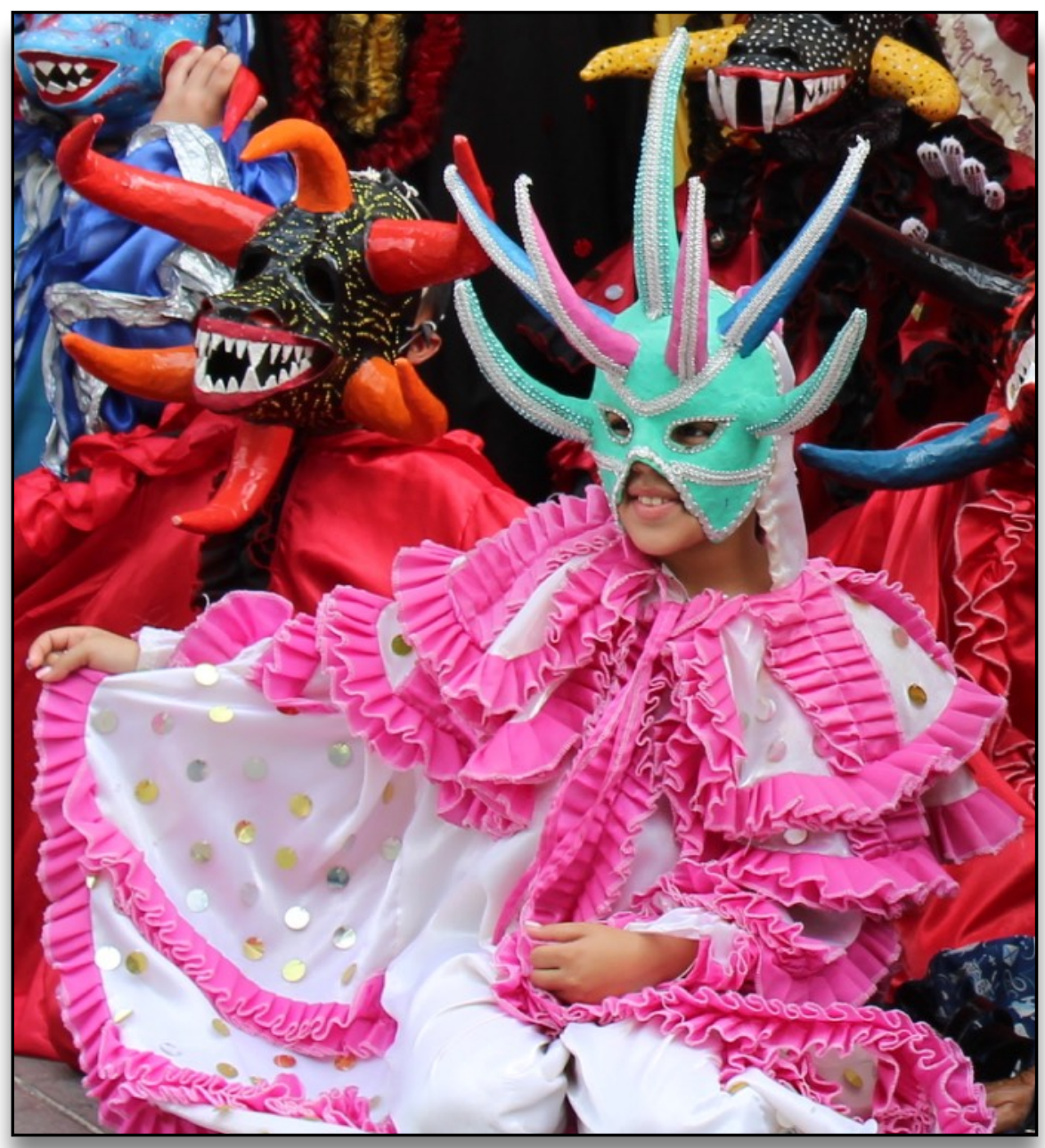

Figure 44 Young Girl Vejigante with Antifaz, Carnaval Ponceño 2017 [digital image]. By Author. February 24, 2017 


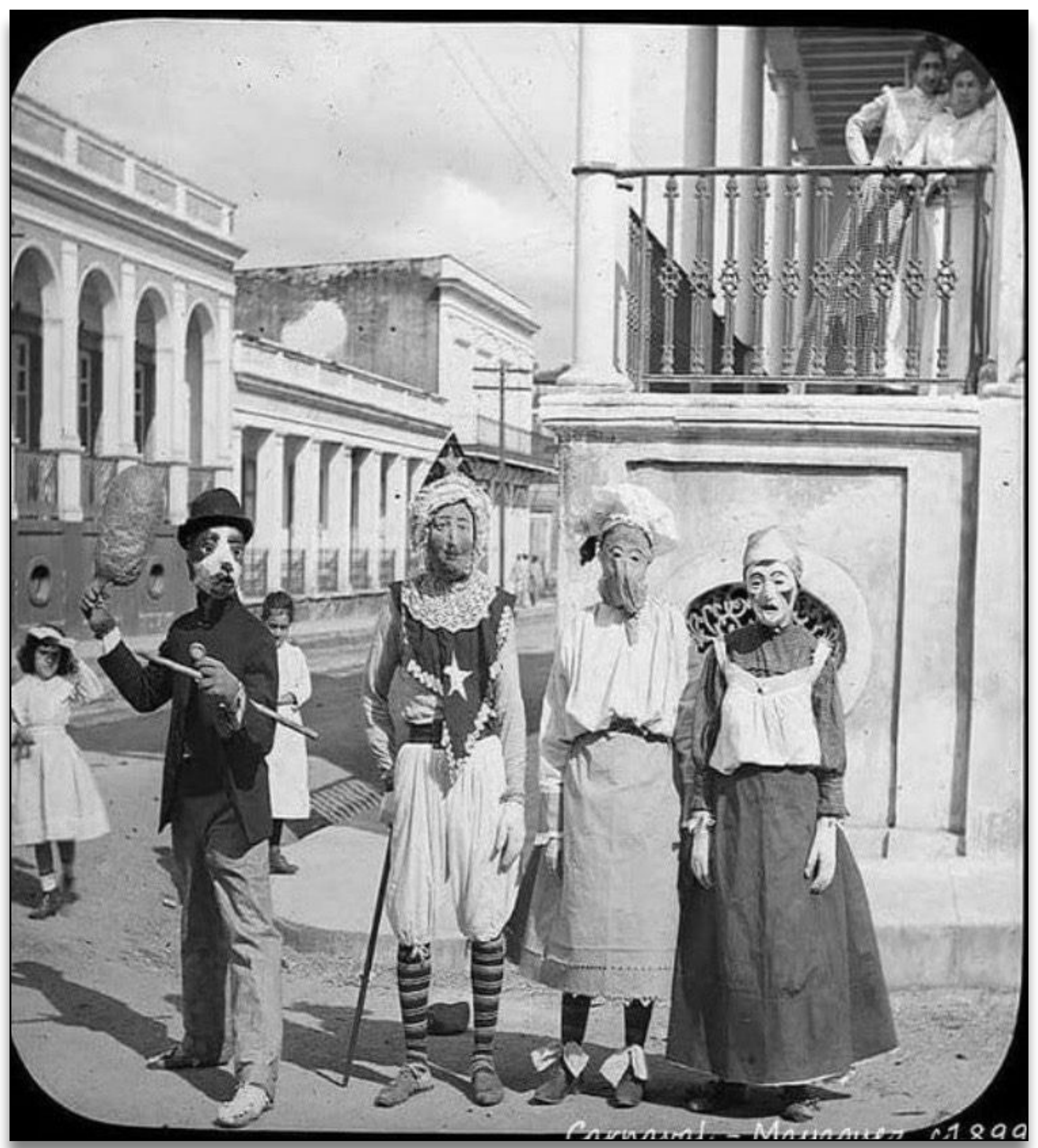

Figure 45 Carnaval en Mayaguez 1899 [digital image]. Retrieved June 24, 2020 from https://www.pinterest.co.uk/pin/ $344525440244524889 /$ 
The purpose of the vejigante, as stated before, is to create chaos in the Carnival, but to also cleanse the spirit and the soul of the person receiving the blows from the vejigas. The reality is that the concept and symbolism of the vejigante is not well-known or understood amongst the people in Puerto Rico. As a matter of fact, the character of the vejigante is loosing its importance within the festivals and Carnivals. The Carnival itself has transformed into a rationale to party in the main square of Ponce, Plaza de Las Delicias. Participants, within the Carnival parade, compete in showcasing their most extravagant costumes as royals, i.e. queen, king, prince, princess etc. (Figure 46) And through the subtle changes within the Carnaval, it has lost its cultural accuracy. But, it has as well enabled the opportunity for the vejigante to evolve into a more intricate and aesthetically focused representation. (Figures 47-48)

The Carnivals originally were a celebration of the heritage, using the festivals as a reminder to the public of their historical culture, and, more importantly, as an aid to educate the younger generations of their roots. The original basis of the Carnaval has altered to a new Americanized festival, as seen in many other notorious Carnivals, such as Mardi Gras in New Orleans. Even though the embrace of American culture into the Carnaval has facilitated creativity and expression, the question stands whether or not the sacrifice of authentic, cultural practice was worth its attempt to stay current. 


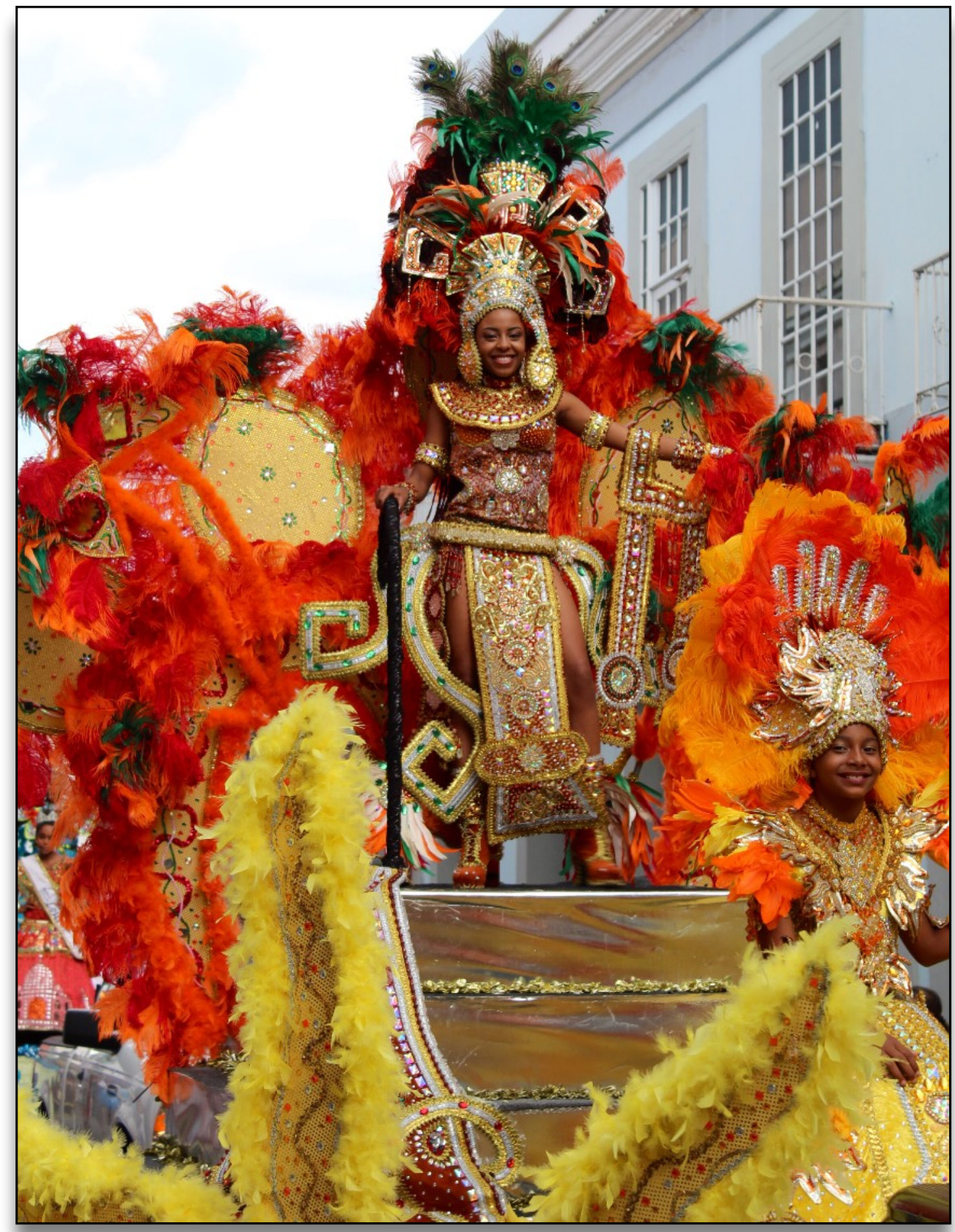

Figure 46 Princesses on a Float, Carnaval Ponceño 2017 [digital image]. By Author. February 24, 2017 


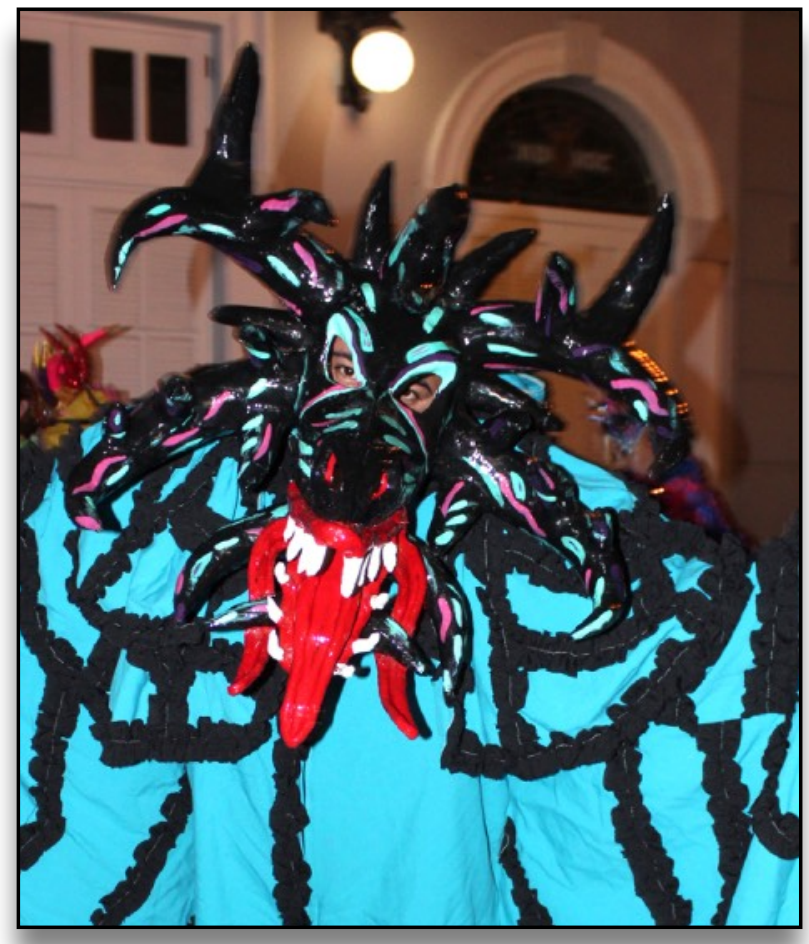

Figure 47 Extravagant Vejigante Mask, Carnaval Ponceño 2017 [digital image]. By Author. February 24, 2017

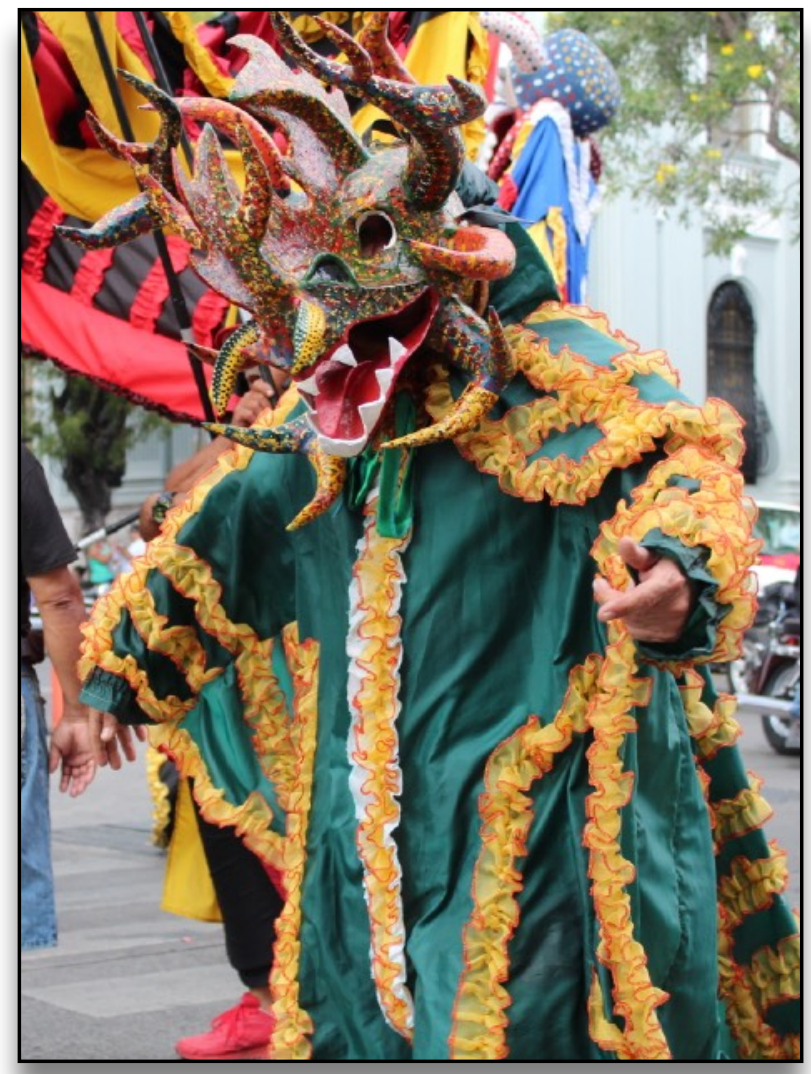

Figure 48 Extravagant Vejigante Mask, Carnaval Ponceño 2017 [digital image]. By Author. February 24, 2017 


\subsection{Significance of the Carnival Ceremonies}

The Carnival has long been a practicing pagan event throughout history. Its presence is shown in Greek Mythology, giving evidence to its existence in "the preChristian era."66 The festivity also had a presence in Babylonia, Egypt, Greece, and Rome. Carnaval stems from the original meaning: "farewell to carnal affairs," 67 also relating to the word carnelevarium, which means to "take away or remove meat."68 The tradition of the Carnival is "...associated with pre-Lenten activities..." 69 Also, it is stated in the year 1000, the first millennium, the people feared the coming of an apocalypse: the time of the devil to rise from hell to roam freely on the earth. This concept was used to scare the people to take refuge in the church, and exercise confession in order to cleanse themselves. When the date had passed to 1001 , the community rejoiced and celebrated. ${ }^{70}$ And thus the tradition was established. A mask was used in representation of the devil,

\footnotetext{
${ }^{66}$ Harold Bloom, and Janyce Marson, eds, Bloom's Modern Critical Views: Nathaniel Hawthorne. (Infobase Publishing, 2007), 175.

${ }^{67}$ Norberto Martell Morales and Héctor J. Rodríguez Torres, Las Caretas del Vejigante Ponceño, 2.

68 The Editors of Encyclopaedia Britannica, “Carnival,” (Encyclopædia Britannica, Inc., May 8, 2020), https:// www.britannica.com/topic/Carnival-pre-Lent-festival.

${ }^{69}$ Harold Bloom, and Janyce Marson, eds, Bloom's Modern Critical Views: Nathaniel Hawthorne. (Infobase Publishing, 2007), 175.

70 Norberto Martell Morales and Héctor J. Rodríguez Torres, Las Caretas del Vejigante Ponceño, 4.
} 
scaring the people to return to the church, ${ }^{71}$ and therefore religion. This kept the people behaving well and devoted to the church and state. Based on this, it is assumed that the vejigante derived from this notion..$^{72}$

The Carnaval Ponceño has been celebrated continuously since 1858.73 (Figures 49-52) The Carnival has links and influence from the European Carnivals and festivities that were brought to Puerto Rico during colonization: "This celebration originally brought from Roman Catholic France and Spain and to a lesser degree from England, is a traditional time of merry-making before the serious period of Lent begins." 74 This tradition has origins going as far back as 5,000 years ago, ${ }^{75}$ and to this day, people continue to celebrate the Carnaval Ponceño with traditional dress, dance and music. ${ }^{76}$

\footnotetext{
71 Olga R. and Kuharets, Venture Into Cultures: A Resource Book of Multicultural Materials and Programs (American Library Association, 2001), 23.

72 Olga R. and Kuharets, Venture Into Cultures: A Resource Book of Multicultural Materials and Programs (American Library Association, 2001), 23.

73 Norberto Martell Morales and Héctor J. Rodríguez Torres, Las Caretas del Vejigante Ponceño, 11.

74 Olga R. and Kuharets, Venture Into Cultures: A Resource Book of Multicultural Materials and Programs (American Library Association, 2001), 23.

75 "The History of Carnival - The Story of the World's Oldest Party!" (Carnivaland, February 27, 2020), https:// www.carnivaland.net/origin-history-carnival-worlds-oldest-party/.

76 Daniel Shafto, Carnival (Infobase Publishing, 2009), 61.
} 


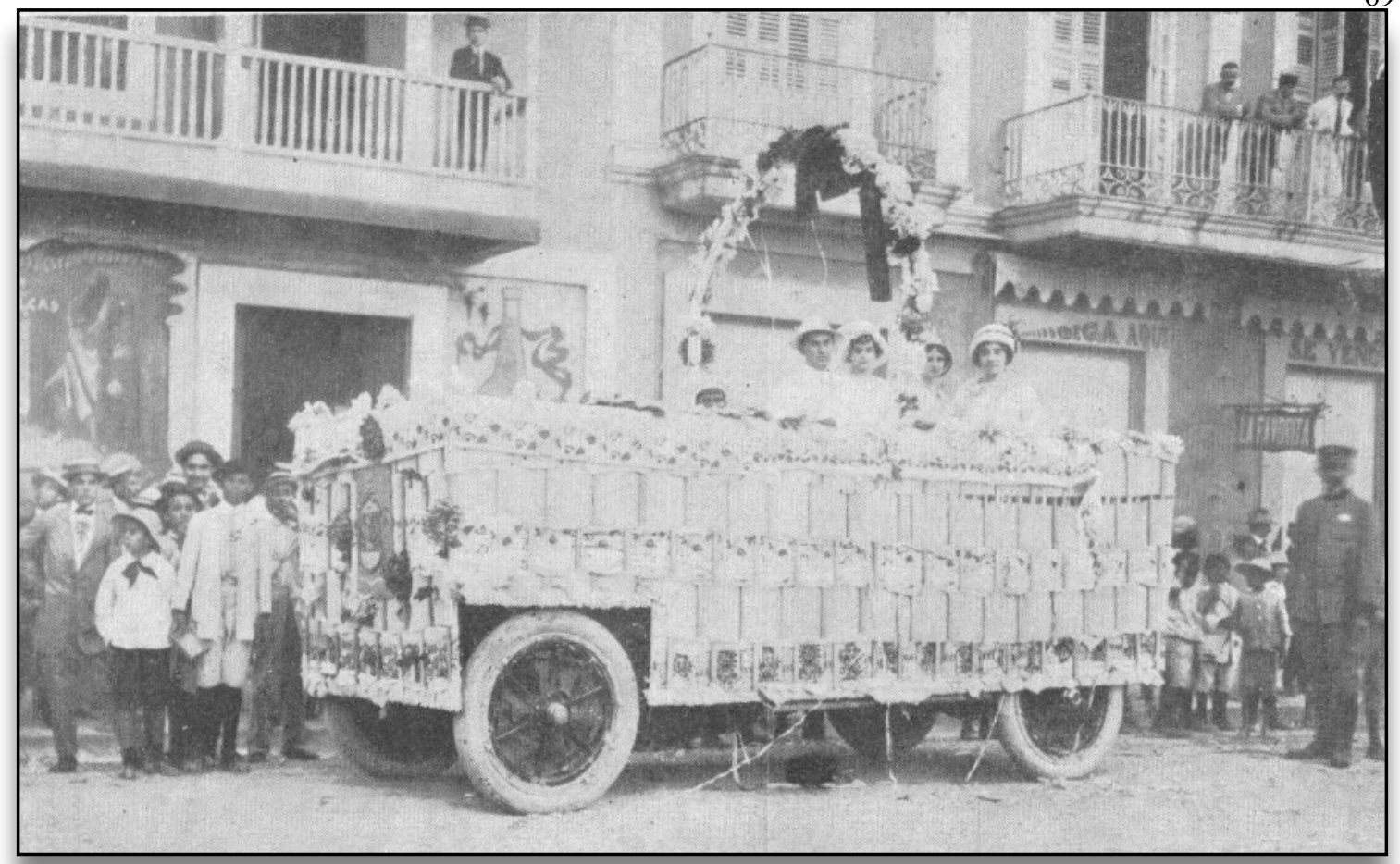

Figure 49 Carrozas del Carnaval de 1912 [digital image]. Retrieved October 4, 2019 from Jaime L. Martell Morales: “Ceiba:” Año 9 Núm. 1 [Segunda Época] Agosto 2009 - Mayo 2010, (78 - 101).

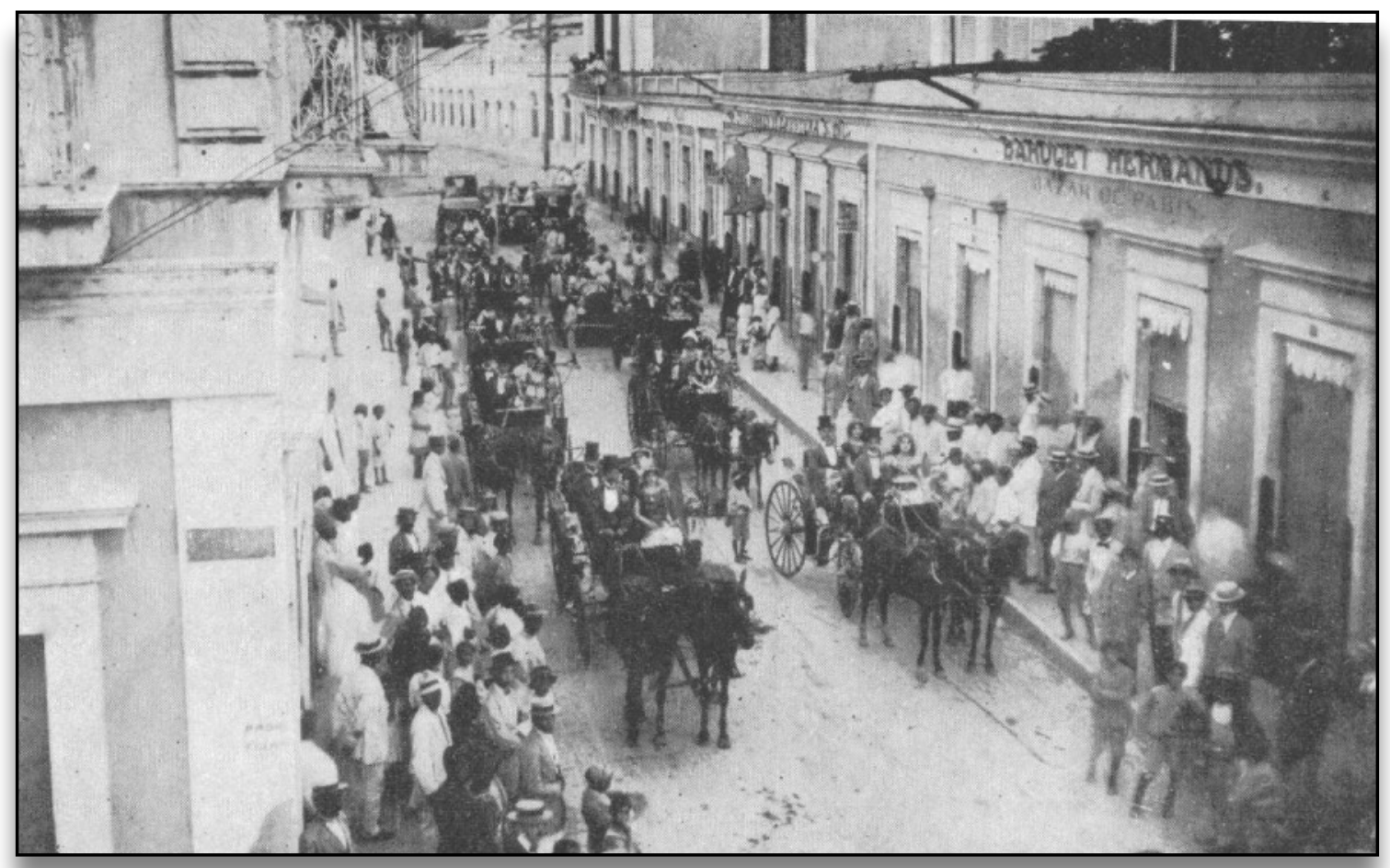

Figure 50 Desfile del Carnaval de 1912 [digital image]. Retrieved October 4, 2019 from Jaime L. Martell Morales: “Ceiba:” Año 9 Núm. 1 [Segunda Época] Agosto 2009 - Mayo 2010, (78 - 101). 


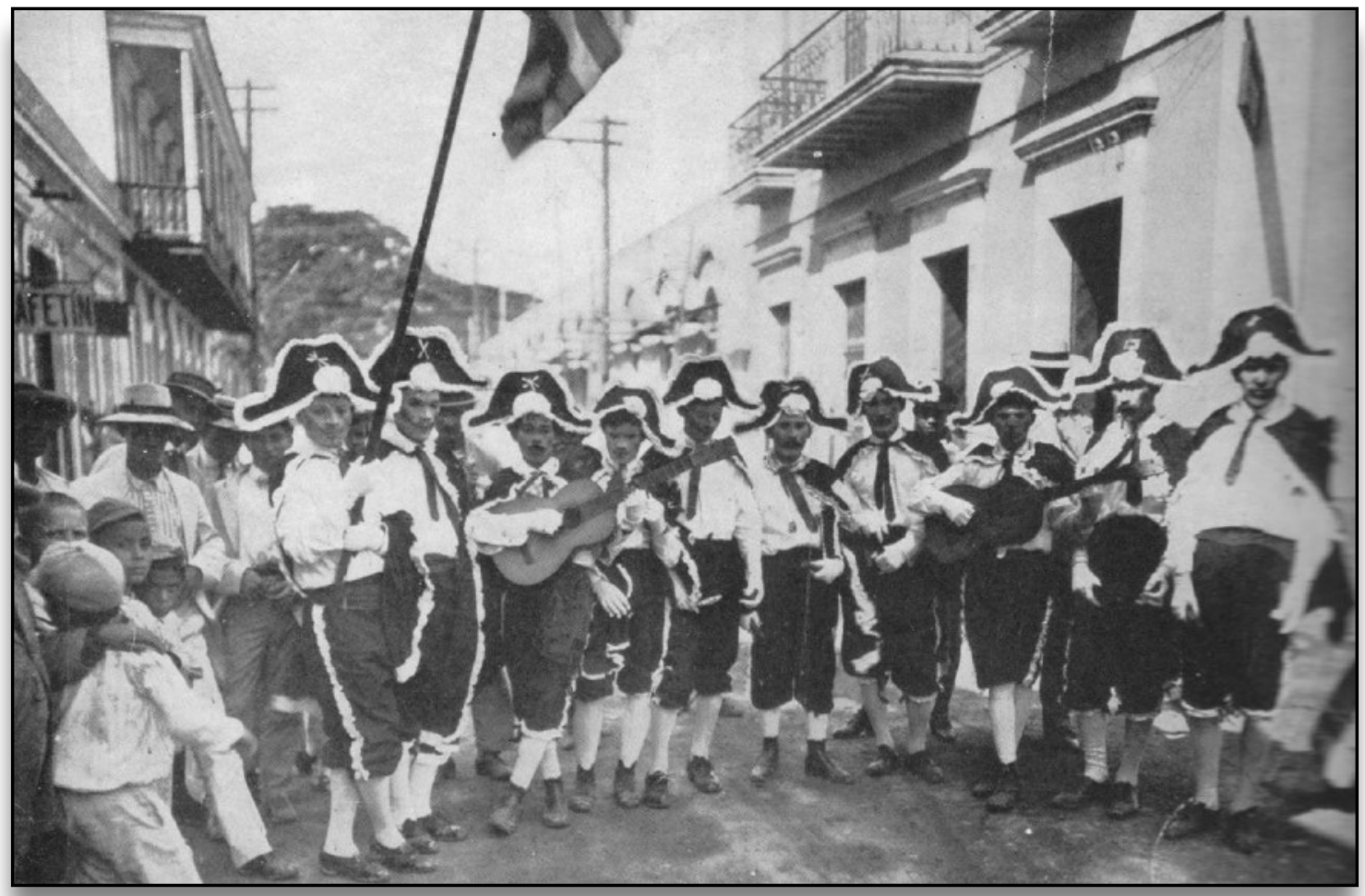

Figure 51 Primera Comparsa estudiantina que sale a la calle para comenzar el Carnaval de 1912 [digital image]. Retrieved October 4, 2019 from Jaime L. Martell Morales: “Ceiba:” Año 9 Núm. 1 [Segunda Época] Agosto 2009 - Mayo 2010, (78 - 101).

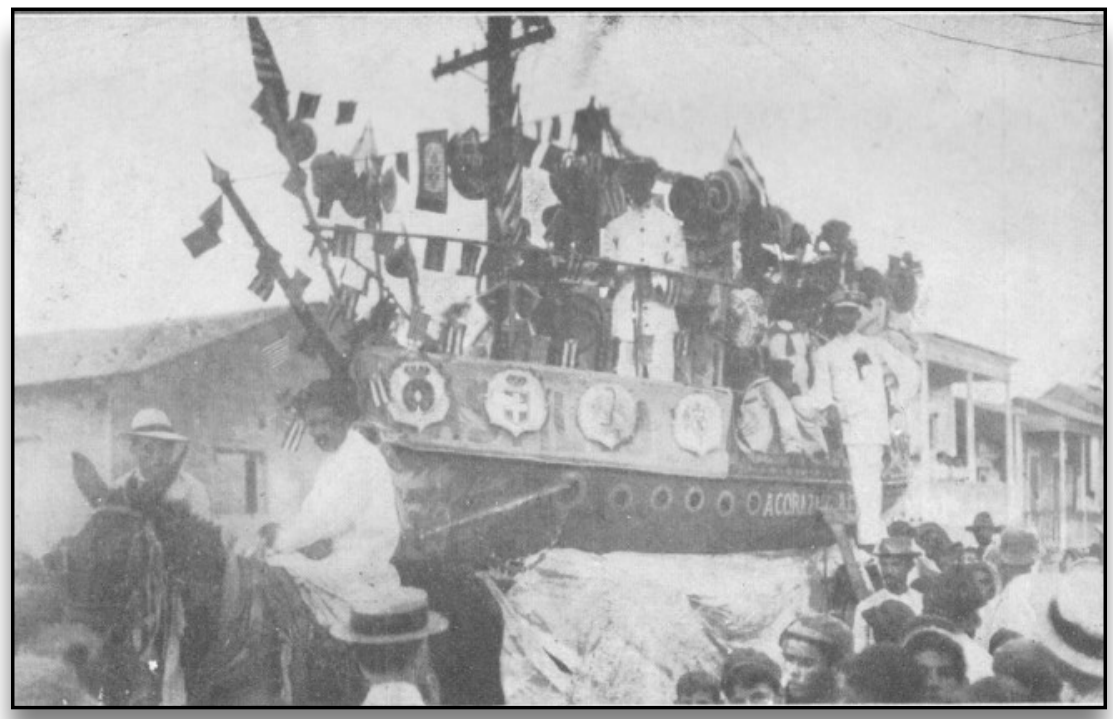

Figure 52 Carrozas del Carnaval de 1912 [digital image]. Retrieved October 4, 2019 from Jaime L. Martell Morales: “Ceiba:” Año 9 Núm. 1 [Segunda Época] Agosto 2009 - Mayo 2010, (78 - 101). 
In summary, Carnaval Ponceño is a full week of activities held in the center square of the town, Plaza de las Delicias. "Figures of saints are carried in the procession and special Masses are celebrated in church. The usual traveling sideshows and fairground rides, small gambling games, and lots of drinking take place alongside the religious element of the festival." "77 All generations gather in the town to watch and participate in this event. As well as, many people travel from other towns to witness the week-long festivities. (Figure 53) The Carnival is usually held in the month of February or March, before Lent. And the Carnival ends before Ash Wednesday. The festival always is inaugurated with the entrance of vejigantes marching in the plaza. (Figure 54) The vejigantes cause chaos and mayhem in the square amongst the bystanders. And finally, the festival closes with the appearance of the vejigantes. The Carnival ends with epilogue of dance and celebration.

\footnotetext{
77 Patricia Levy and Nazry Bahrawi, Puerto Rico, 118.
} 


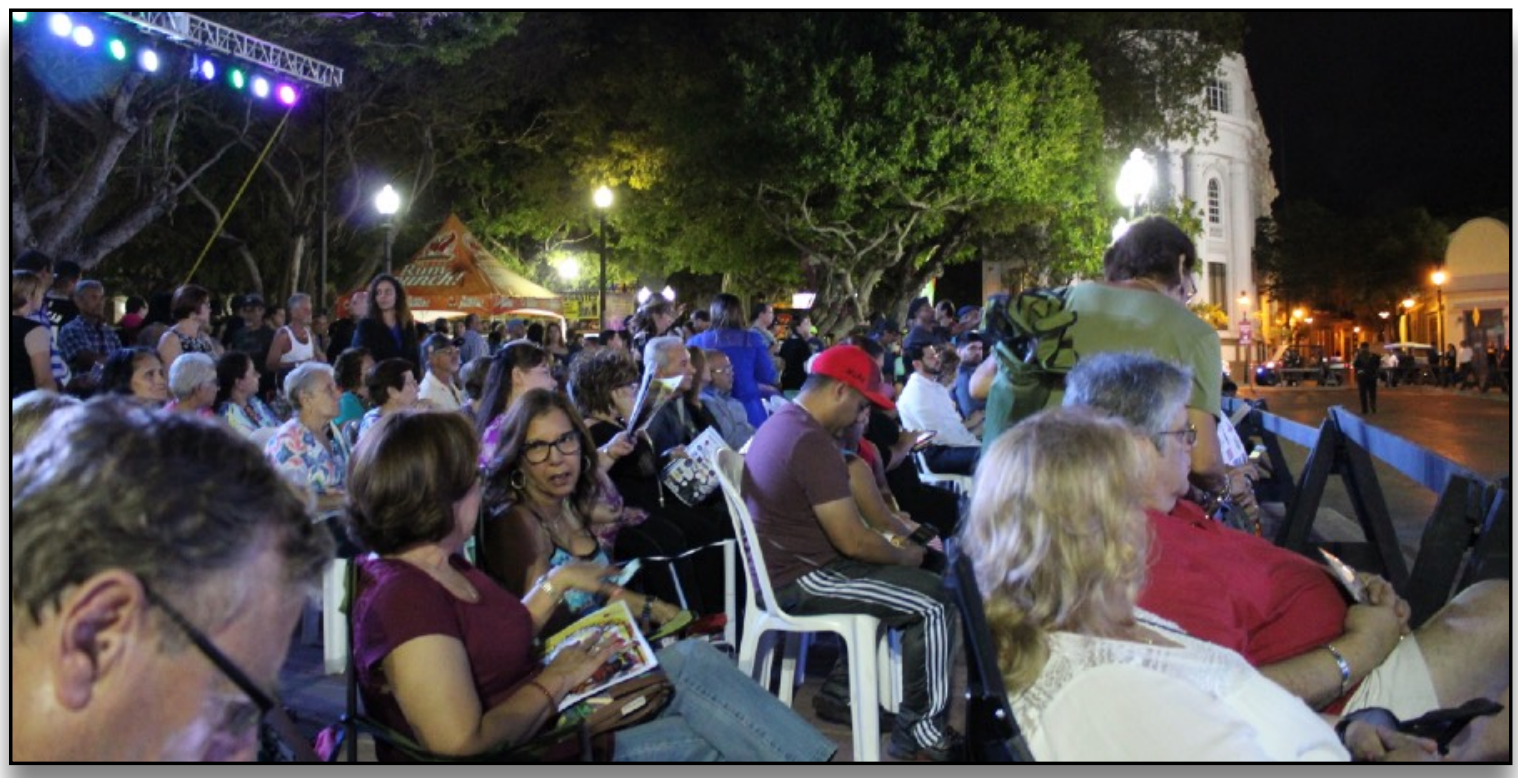

Figure 53 Crowd in Plaza de las Delicias, Carnaval Ponceño 2017 [digital image]. By Author. February 24. 2017

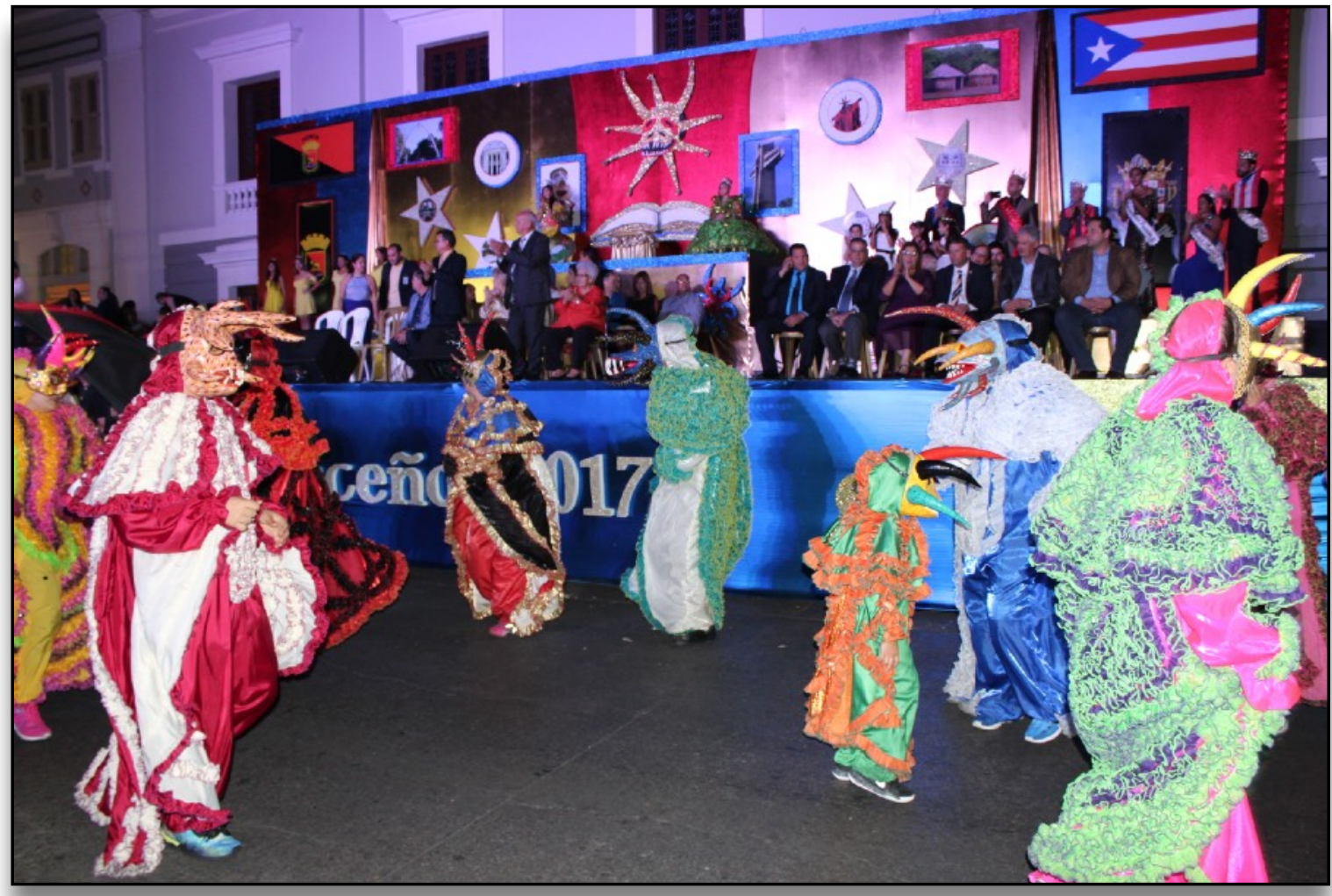

Figure 54 Entrance of the Vejigantes, Carnaval Ponceño 2017 [digital image]. By Author. February 24, 2017 
The first day, the vejigantes enter dancing and scaring the people, causing screams and laughter through the crowd. Followed by community engagement of schools with marching bands, dance troupes, and/or choirs. Through the involvement of schools, talent groups, and local businesses, the community displays their support by the attendance of the individual events. This is an example of the existing cultural values and purpose of the festivities. (Figure 55) The second day is mainly focused on the first appearance of Rey Momo, King Momo. "The King or Spirit of the Carnival is Momo (Papiamento popchi disfrasa: a disguised doll) derived from the Greek god of censure and mockery, Momus or Momos. The model of King Momo comes from Spain's Rey Momo."78 Currently in Puerto Rico, Rey Momo is usually a male resident, who is well-known in the town, and is recognized for his positive involvement in the community. A person is selected through the recognition of the work he does, the morals he represents and positive lifestyle. It is considered an honor to be chosen to be Rey Momo. This person is then dressed in a large mascot costume to conceal his face. His identity is kept a secret from the townspeople until the end of the festival, when the people are encouraged to attempt to guess who is Rey Momo. (Figure 56) Day three and four consist of the crowning of the royals of the Carnival, who are always escorted and accompanied by the vejigantes. (Figure 57) During this event, the vejigantes are subdued because they are in

78 G. L. Green and P. W. Scher, Trinidad Carnival: The Cultural Politics of a Transnational Festival (Indiana University Press, 2007), 145. 
the presence of the royal court, and therefore on better behavior. (Figure 57) The fifth day is the parade. The parade starts from a sports stadium near the entrance of Ponce and ends in the downtown square, Plaza de las Delicias. The parade is full of floats, previous royals, present royals, vejigantes, Rey Momo, previous Carnivals' Rey Momos, and even appearances of troupes from cities around the island. The parade usually lasts the entire day, starting in daytime and ending in the evening. (Figures 59-60) Day six is full of musical events and dances. Again, the support is prevalent through the incorporation of local music, dance and theater into the festival. (Figure 61) The final day, day seven, is the burial of the sardine, representing the sacrifice that will accompany the days of Lent, 79 (Figure 62) accompanied by weeping of the lloronas, weeping women, locas, crazy women, the royals and, of course, the vejigantes. (Figure 63) Before the final event of the festival, the audience is invited to guess who is Rey Momo, followed by the reveal of his identity, and the person who guessed correctly receives an award. ${ }^{80}$ (Figure 64) The Carnival is concluded with the burning of the Jua, a rag doll, (Figures 65-66) representing bad luck and the negativity from that year. The vejigantes, and all the

\footnotetext{
79 Let's Go Inc., Let's Go Puerto Rico, ed. Noga Leah. Ravid and St. Martin's Press, 3rd ed. (Let's Go Publications, 2007), 212.

${ }^{80}$ Let's Go Inc., Let's Go Puerto Rico, ed. Noga Leah. Ravid and St. Martin's Press, 3rd ed. (Let's Go Publications, 2007), 212.
} 
characters of the festival, including the townspeople wave the smoke away, (Figure 67) signifying the ending of the festivities. ${ }^{81}$

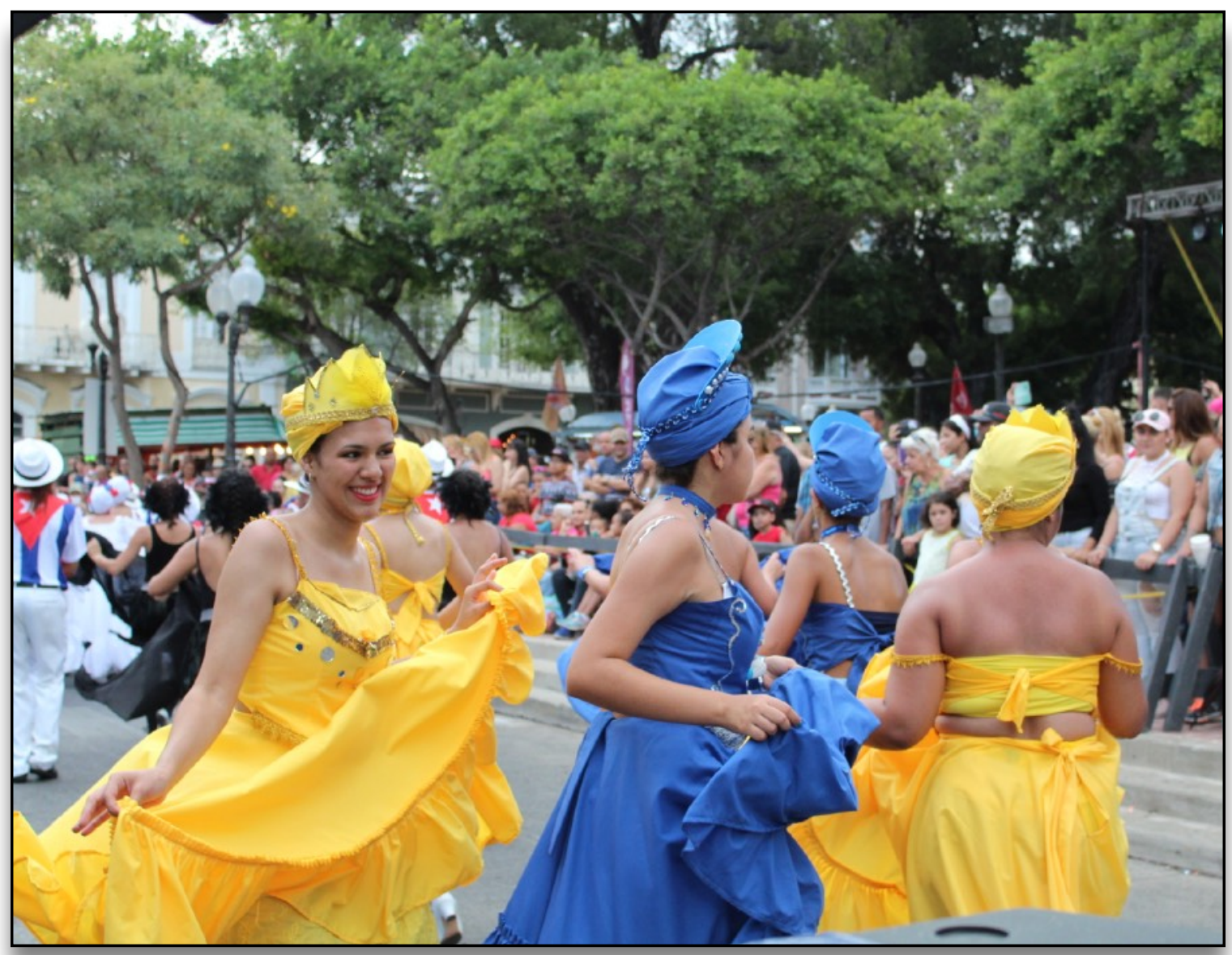

Figure 55 Bomba y Plena School Dance, Carnaval Ponceño 2017 [digital image]. By Author. February 24,2017

${ }^{81}$ Norberto Martell Morales and Héctor J. Rodríguez Torres, Las Caretas del Vejigante Ponceño, 22. 


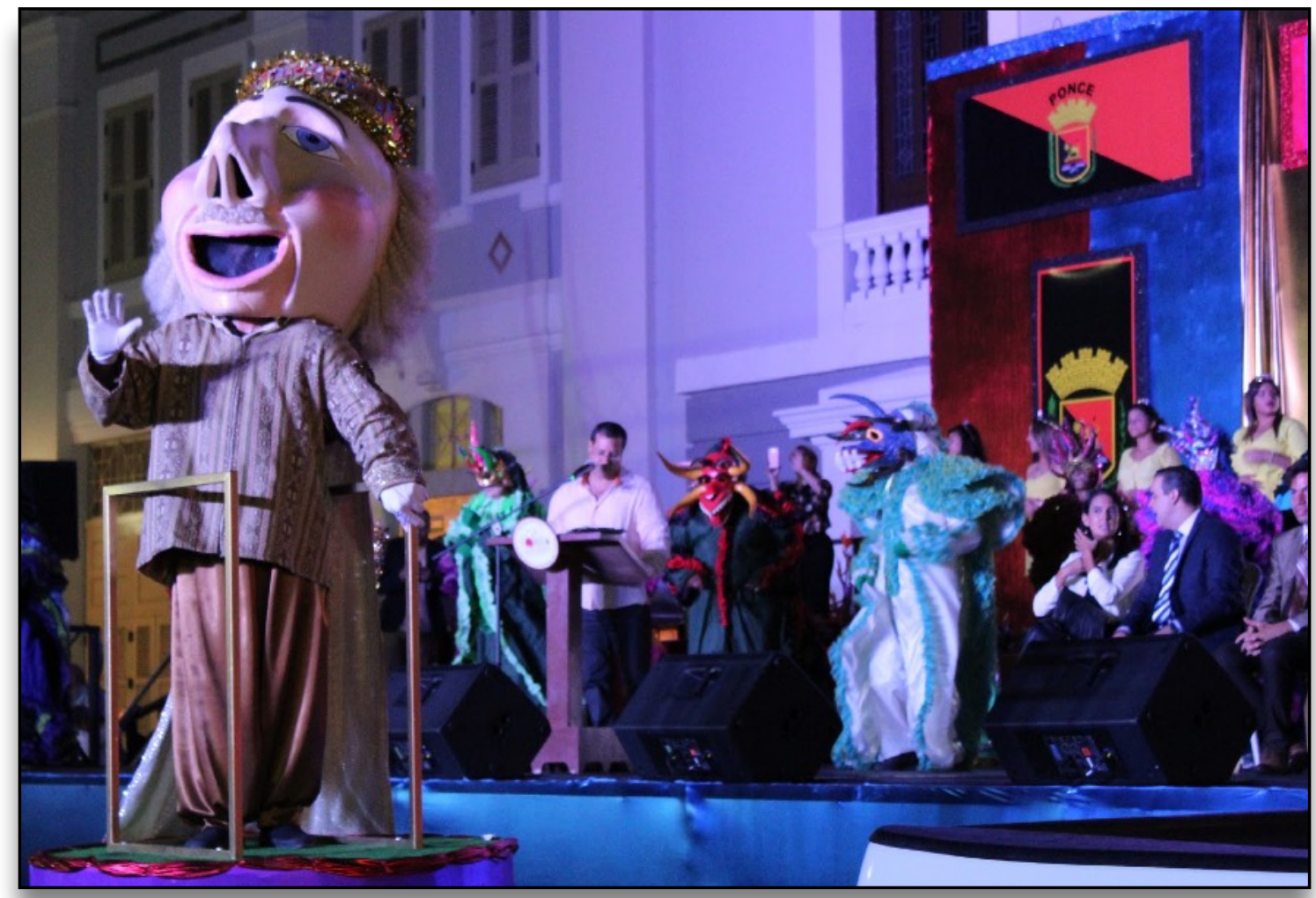

Figure 56 The Entrance of Rey Momo, Carnaval Ponceño 2017 [digital image]. By Author. February 24,2017

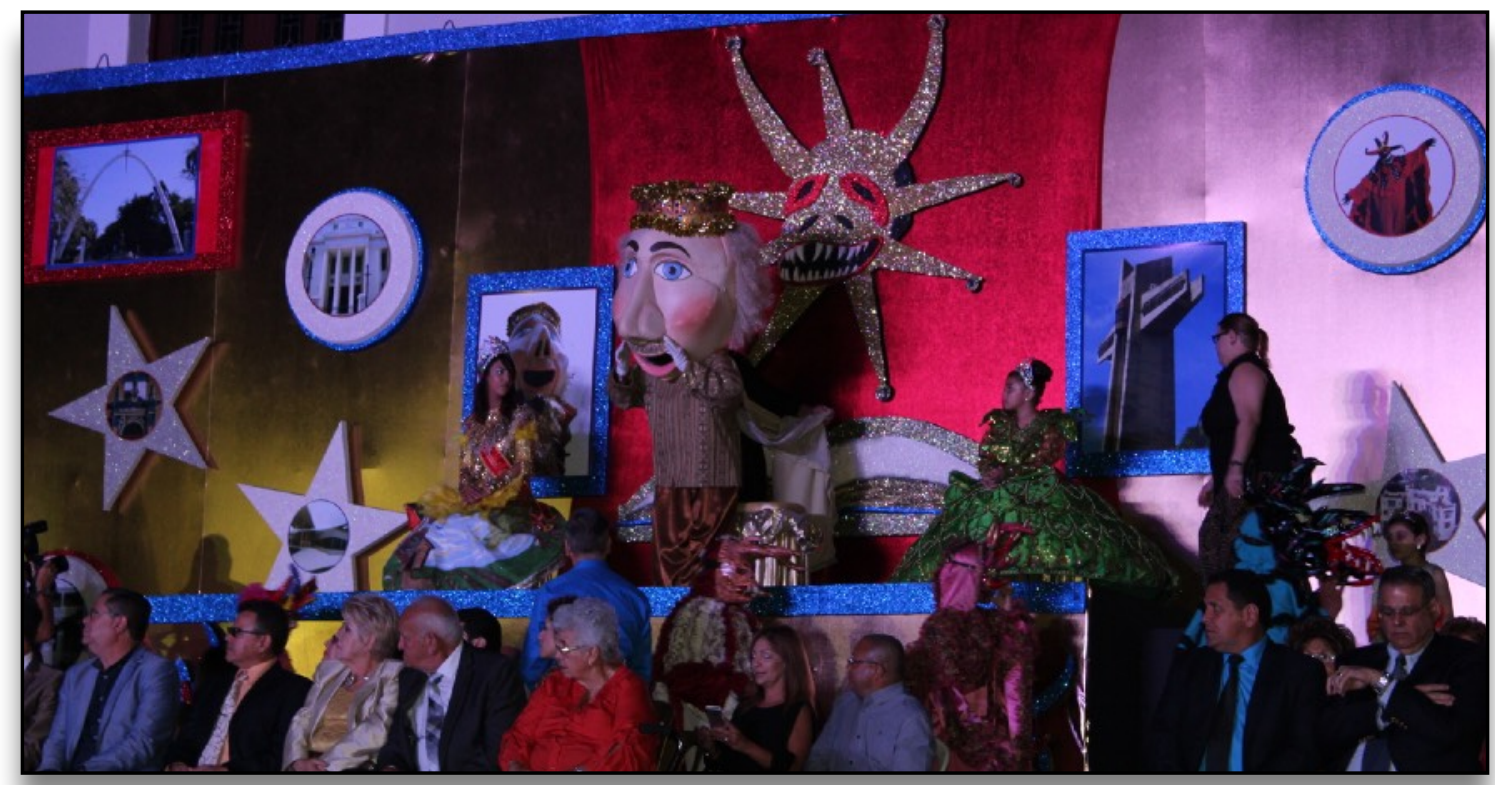

Figure 57 The Royals with Rey Momo, Carnaval Ponceño 2017 [digital image]. By Author. February 24,2017 


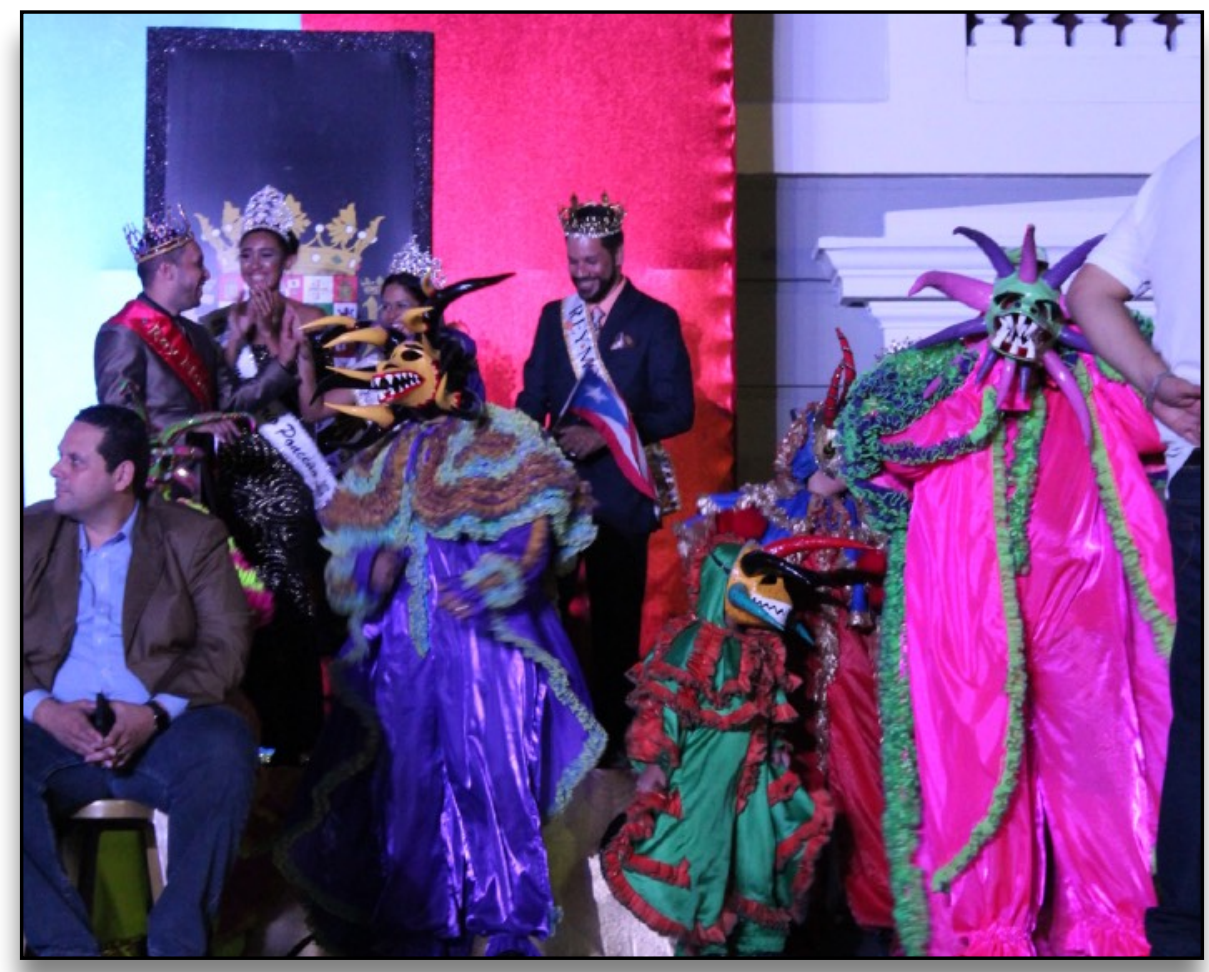

Figure 58 Royals with Vejigantes, Carnaval Ponceño 2017 [digital image]. By Author. February 24, 2017

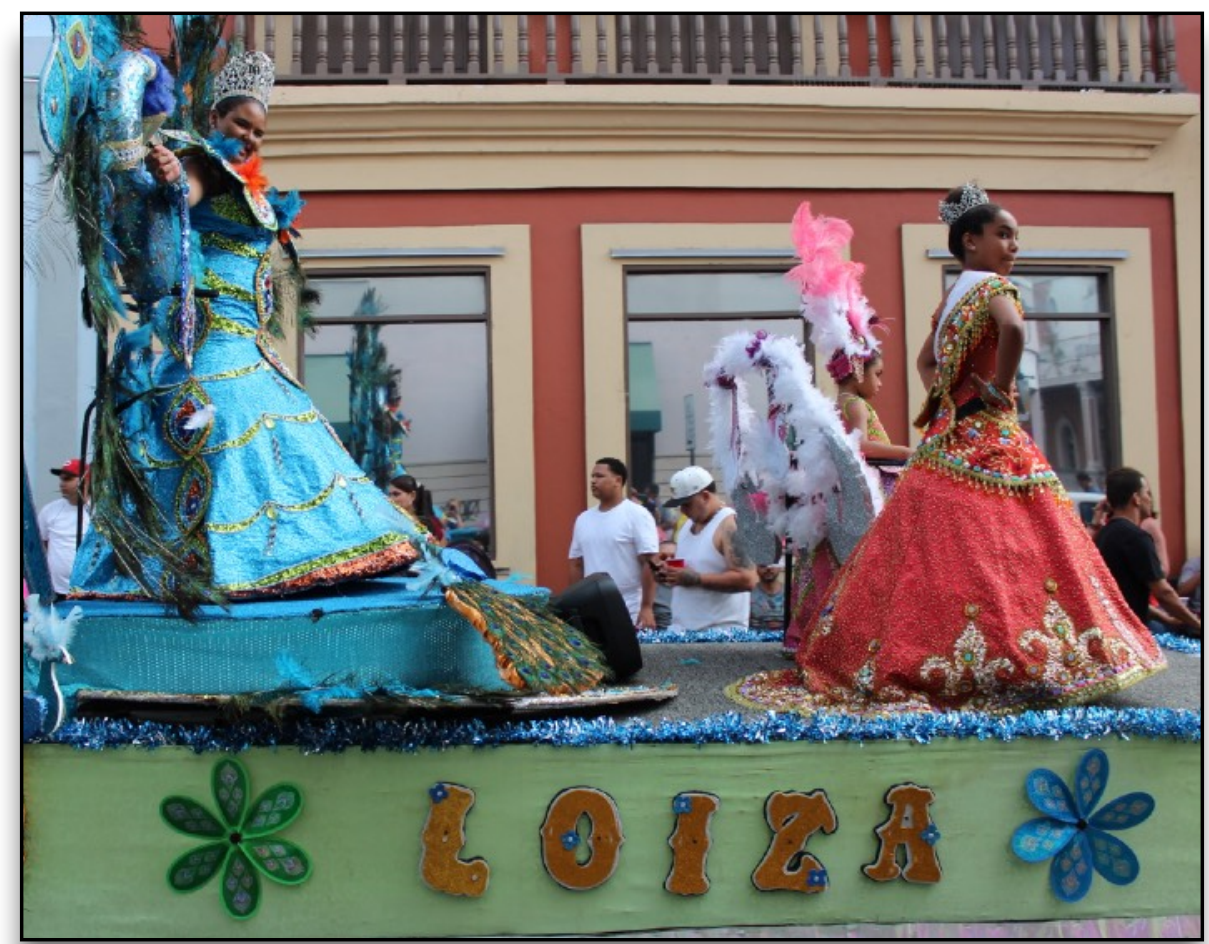

Figure 59 Royals from Loíza on a Float, Carnaval Ponceño 2017 [digital image]. By Author. February 24, 2017 


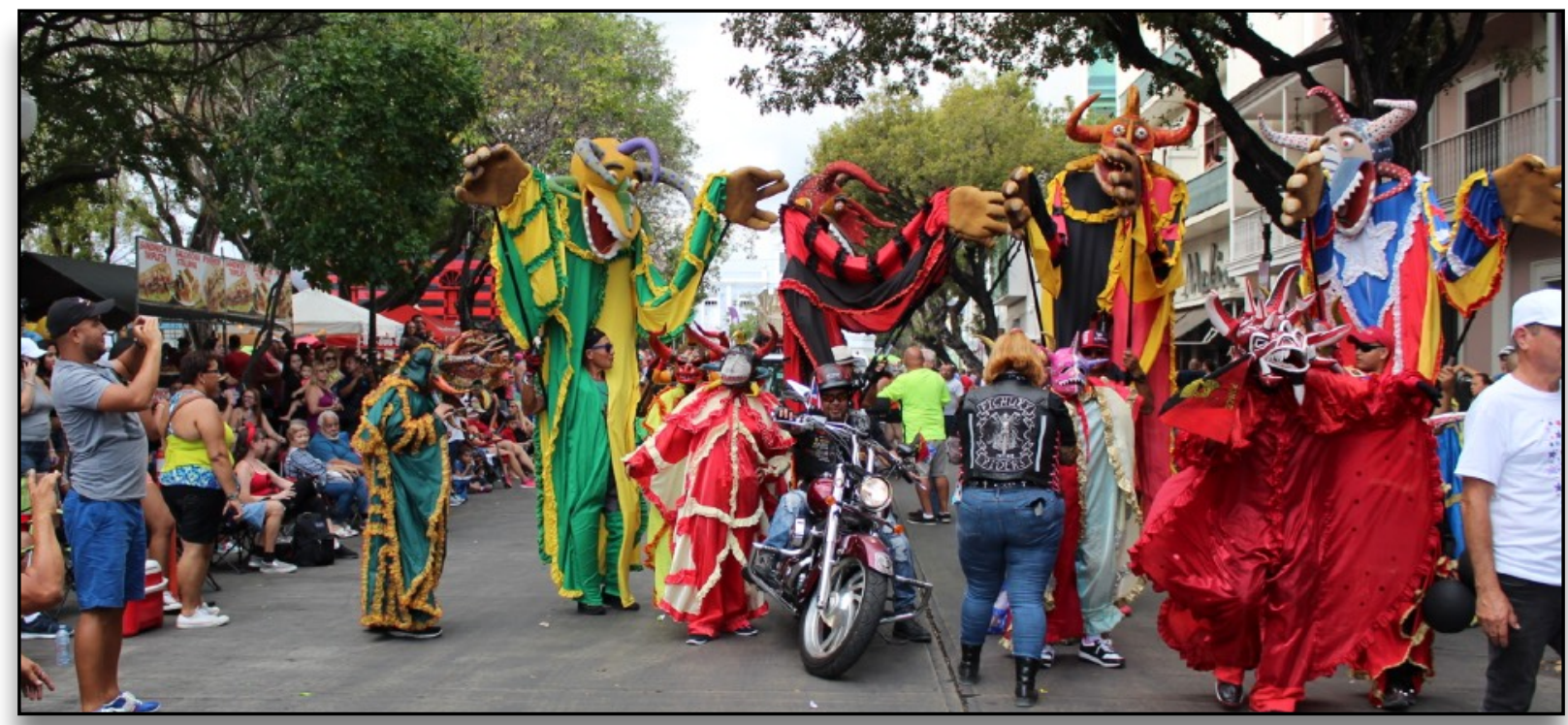

Figure 60 Vejigantes in the Parade, Carnaval Ponceño 2017 [digital image]. By Author. February 24, 2017

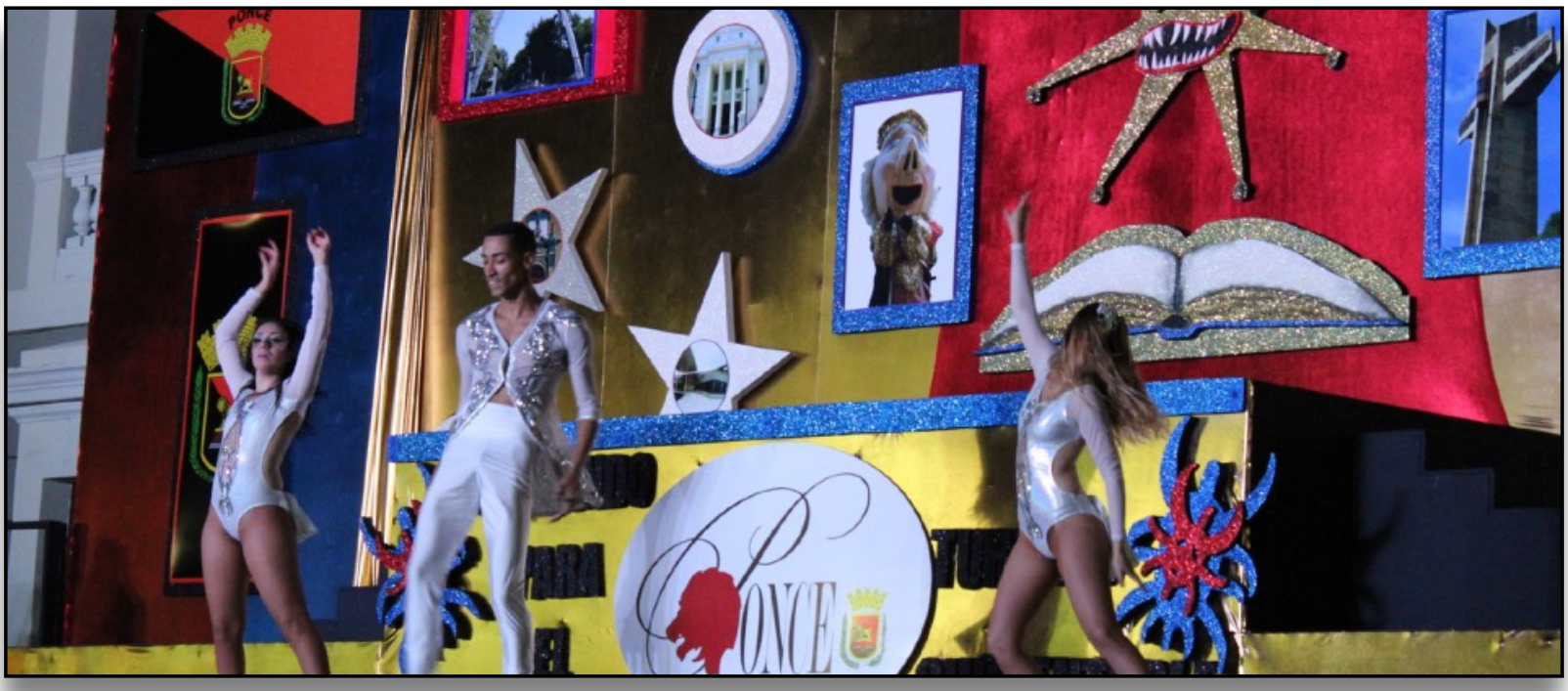

Figure 61 Advance Dance Group, Carnaval Ponceño 2017 [digital image]. By Author. February 24, 2017 


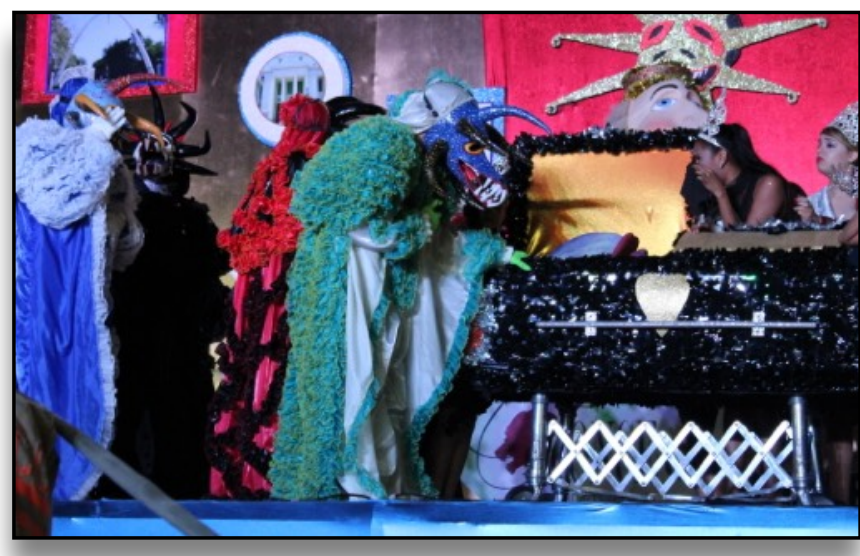

Figure 62 Vejigantes mourning the Burial of the Sardine, Carnaval Ponceño 2017 [digital image]. By Author.

February 24, 2017

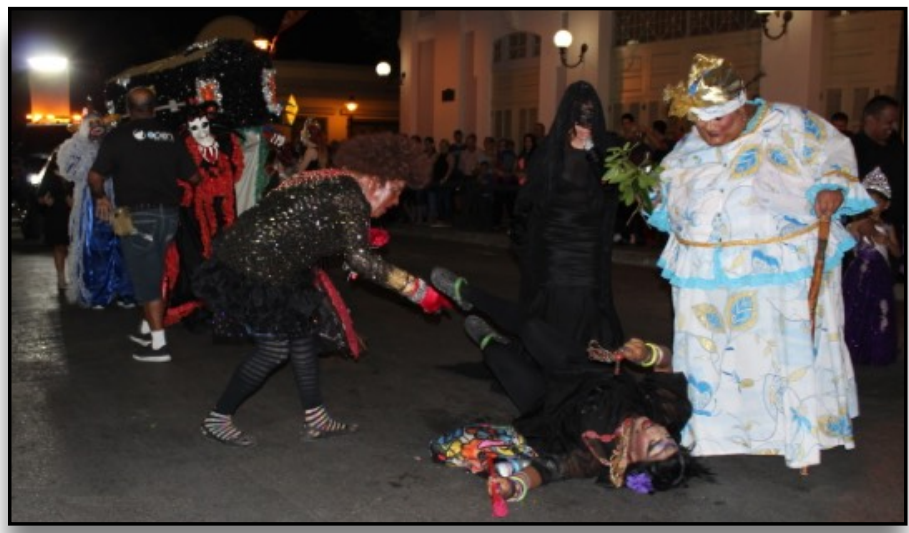

Figure 63 La Llorona, las Locas, and Vejigantes at the Burial of the Sardine, Carnaval Ponceño 2017 [digital image]. By Author. February 24, 2017

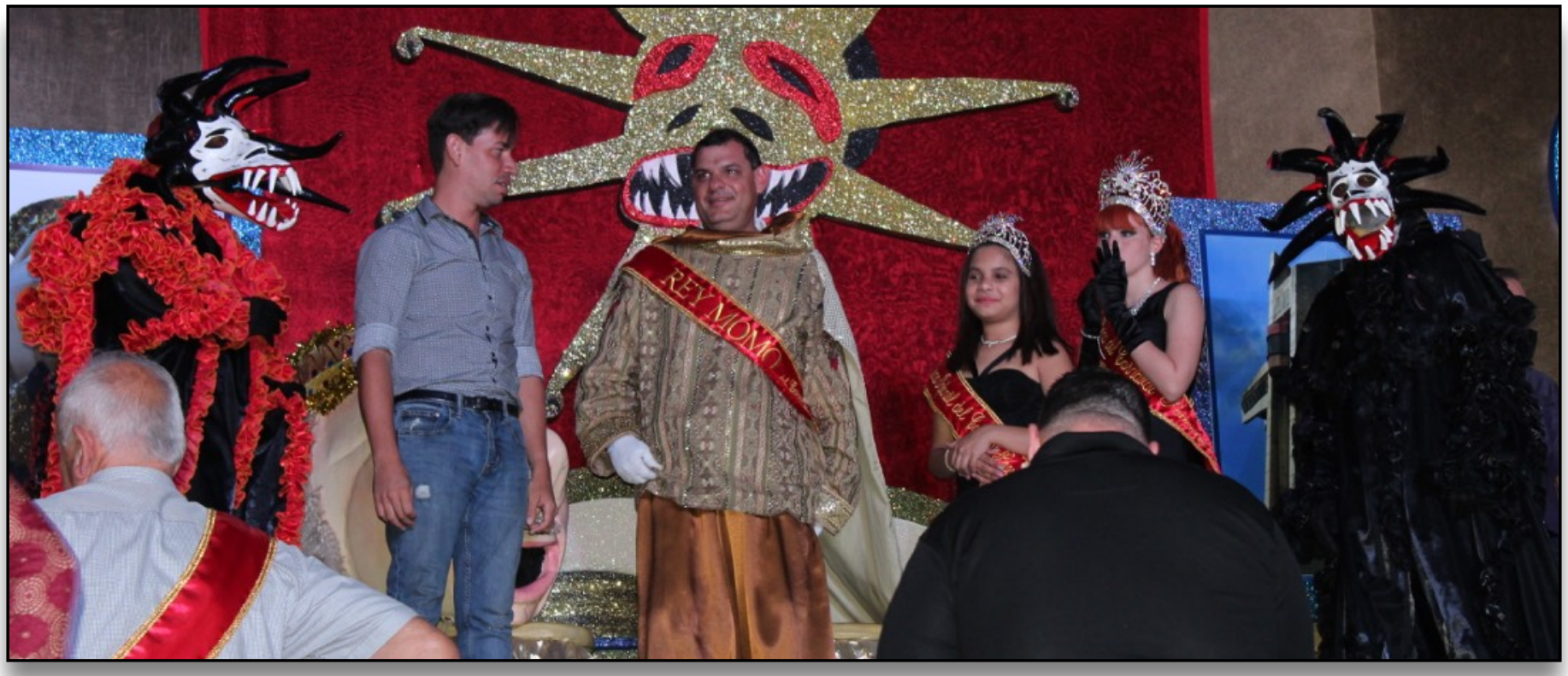

Figure 64 Revealing who is Rey Momo, Carnaval Ponceño 2017 [digital image]. By Author. February 24, 2017 


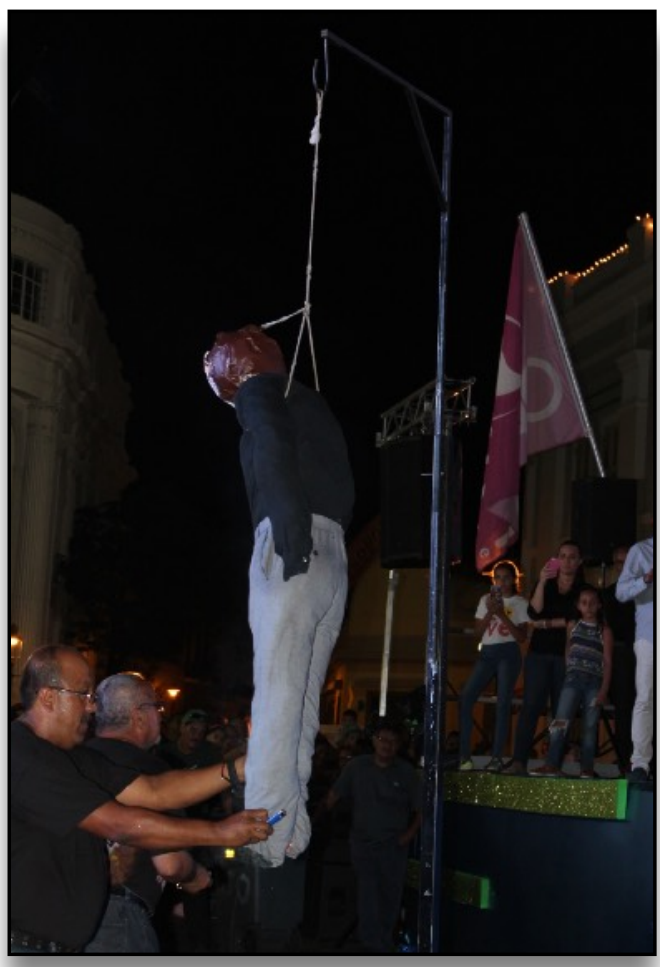

Figure 65 The Jua, Carnaval Ponceño 2017 [digital image]. By Author. February 24,2017

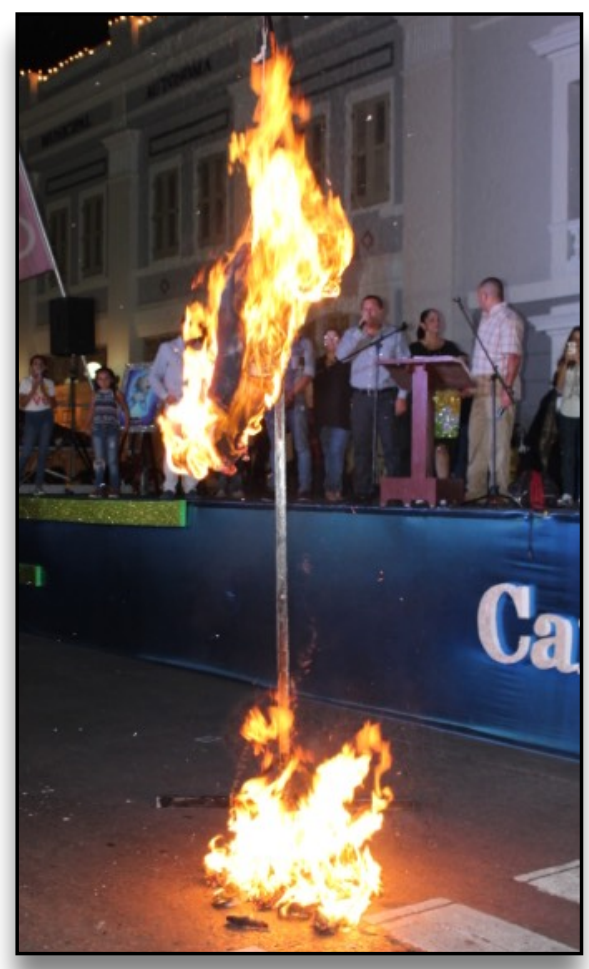

Figure 66 The Burning of the Jua, Carnaval Ponceño 2017 [digital image]. By Author. February 24, 2017

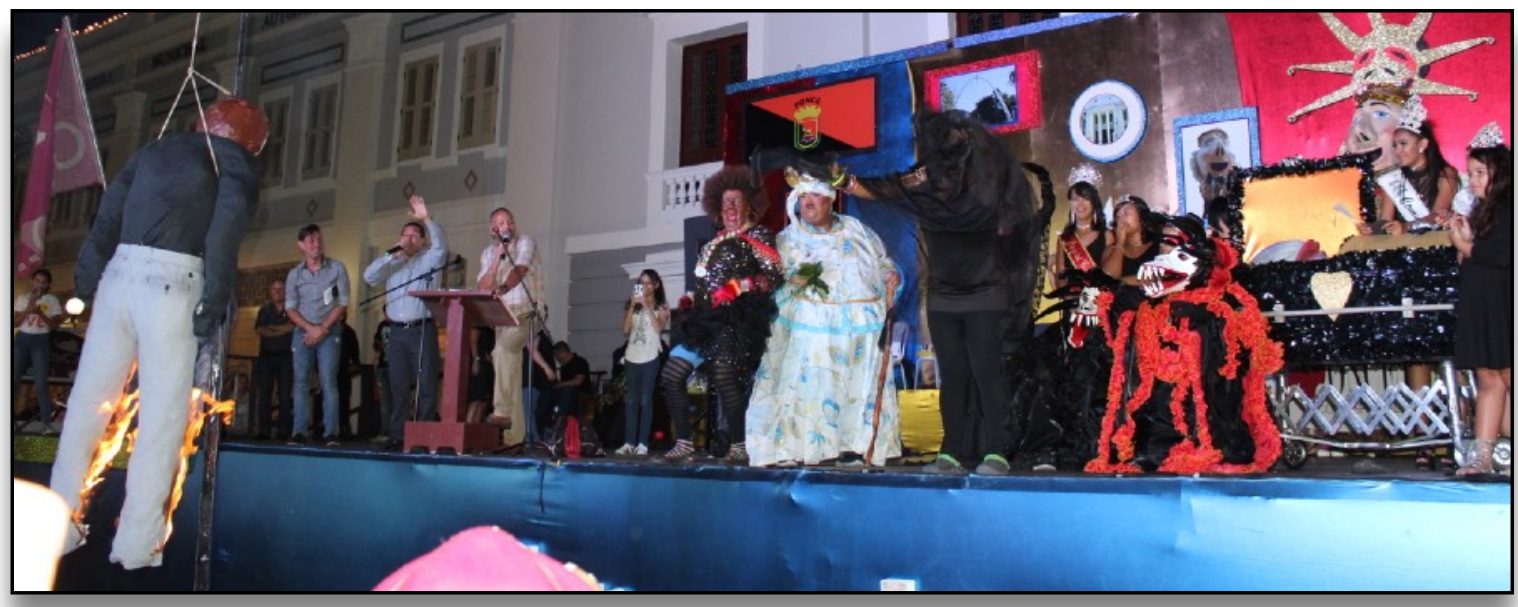

Figure 67 Waving away the Smoke from the Jua, Carnaval Ponceño 2017 [digital image]. By Author. February 24, 2017 
I was an audience member during the Carnaval Ponceño 2017. I was also able to join a comparsa to dance as a vejigante in the Carnaval Ponceño 2018 and the Carnaval de La Playa de Ponce 2018. If one would like to dance officially within any Carnaval, one needs to join a comparsa. To join a group, you must know a leader of a comparsa, or a preexisting member, who can vouch for you. I was fortunate to know people already within comparsas for both Carnivals. This gave me the opportunity to dance in the Carnival in Ponce and in La Playa de Ponce. It was a very interesting experience dancing as a vejigante. While wearing the costume and the careta was a privilege and honor, it was a challenge to breathe, particularly inside the careta antigua. When wearing the mask, it gives a chocking sensation. There are tricks I learned from fellow vejigantes to stop the irritation while wearing the careta, such as inserting and gluing foam directly inside the mask. Unfortunately, this does not completely stop the discomfort. In addition, the costume is made out of materials that are not breathable, such as polyester, and having the body covered from head to toe can cause the body to overheat, especially considering the tropical weather in Puerto Rico, normally ranging from $80-100 \pm{ }^{\circ} \mathrm{F}$. Hydration is the key to staying safe when dressed in the costume and mask. There were moments that I would have to break the illusion of the vejigante and take off the mask, and even, at times, open up the costume to prevent myself from over heating. Although observing the entire Carnival in 2017 was fascinating, being a participant in 2018, 
especially as a vejigante, was revealing and enlightening. It gave me not just local perspective, but an intimate understanding of the Carnaval. This was an opportunity to immerse myself into a group of people that promote culture and preserve the tradition in Ponce. Moreover, it was an eye-opening experience that showed another perspective of the vejigante from inside the mask.

The Carnival has shown assimilation towards American culture. While the festival's original purpose was centered around religion, the function today is to support and showcase the town's talents and achievements. An example of the change in the Carnival is the parade. While past parades were focused on the culture, heritage and history of the island, the present-day imitates parades as seen in amusement parks. (Figure 68) Continuing, the royals display parallels with beauty pageants, with use of extravagant costumes, jewelry and make-up. Furthermore, they are presented on large floats waving to the public, (Figure 69) resembling a Disney prince or princess. Float after float pass having embellished designs with vibrant colors and flashing lights accompanied by a large group of dancers and/or marching band. Even though the customs of the festivities have changed drastically, the underlying factor of family unity and community engagement are prevalent throughout the activity. The people gather in the square laughing, dancing, eating and drinking; in honor of their celebration unifying communities surrounding Ponce. I have witnessed this firsthand. The 
expectation of a traditional Carnival does not coincide with the reality of what is depicted present-day. And although the Carnival has transformed, the people of Ponce join in celebration of their history through the representation of their heritage by their own generational voice. (Figures 70-71)
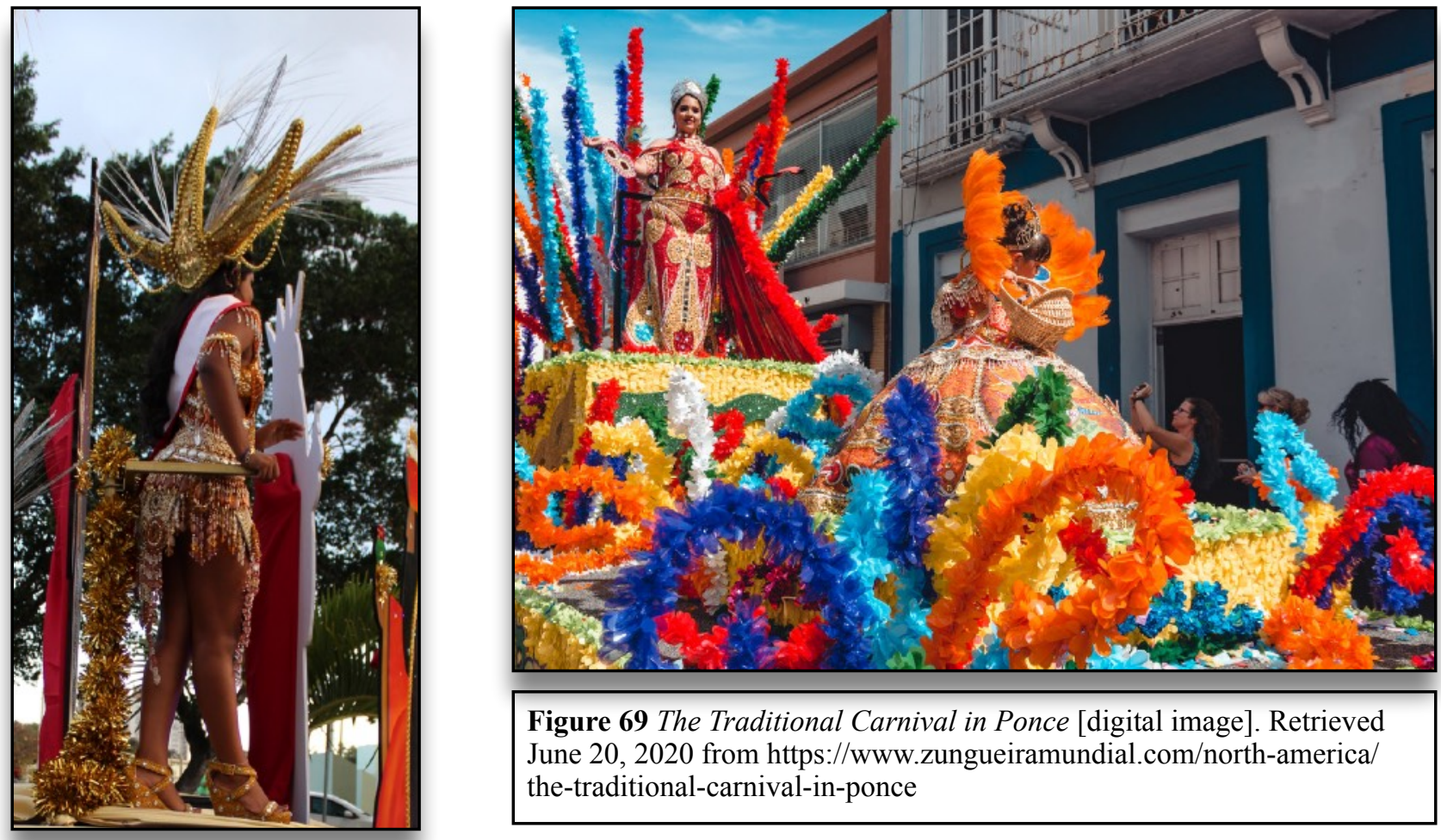

Figure 69 The Traditional Carnival in Ponce [digital image]. Retrieved June 20, 2020 from https://www.zungueiramundial.com/north-america/ the-traditional-carnival-in-ponce

Figure 68 Extravagant Costume, Carnaval Ponceño 2017 [digital image]. By Author. February 24, 2017 

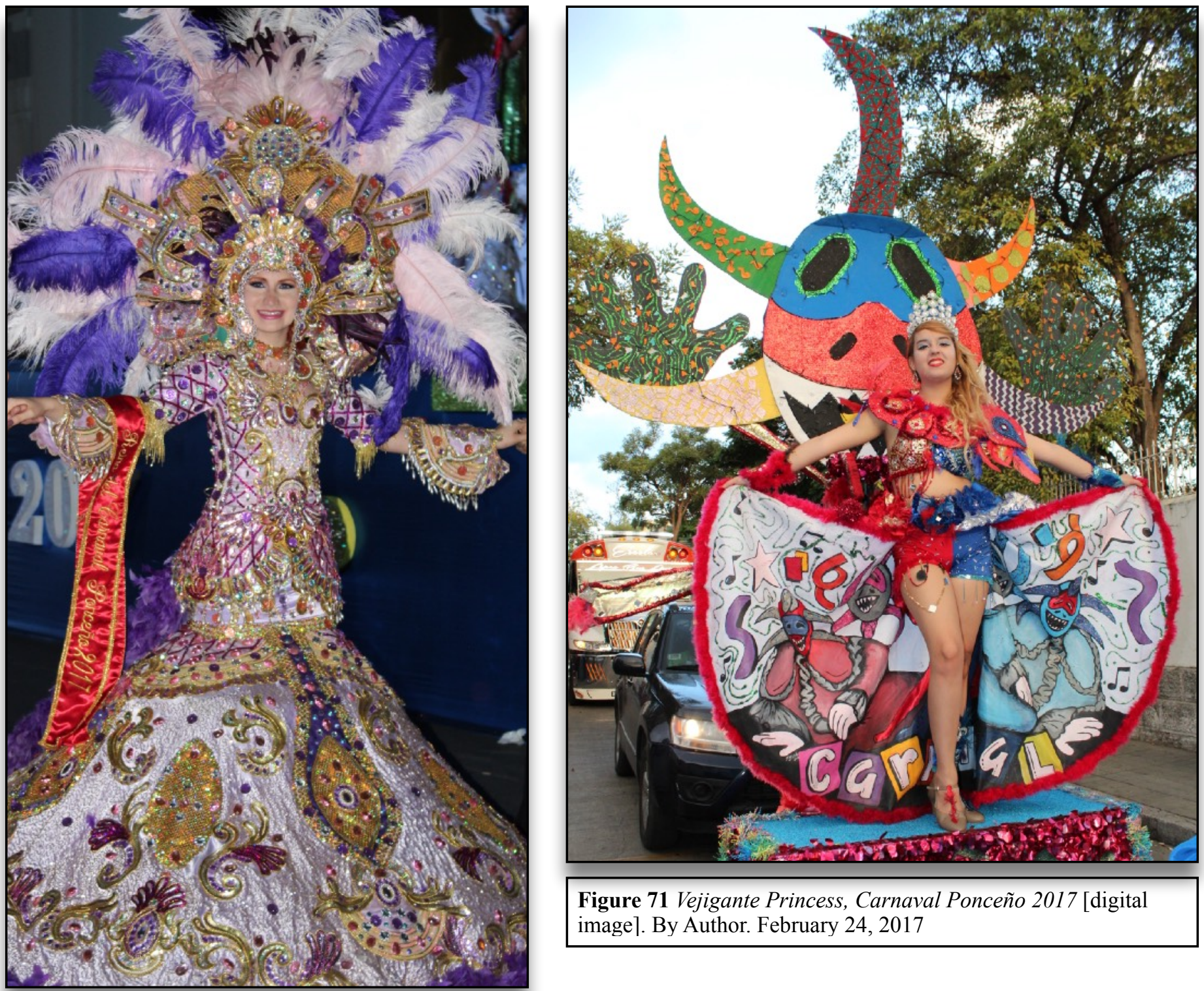

Figure 71 Vejigante Princess, Carnaval Ponceño 2017 [digital image]. By Author. February 24, 2017

Figure 70 Princess in Extravagant Costume, Carnaval Ponceño 2017 [digital image]. By Author. February 24, 2017 


\subsection{Ponce Vejigante Mask}

The first Puerto Rican interpretation of vejigantes dates back to 1747 in San Juan Puerto Rico, and not in Ponce. ${ }^{82}$ During the year 1783, the concept of the vejigante mask was incorporated into the local community by the Spaniards, even though Ponce was a French Settlement at that time, ${ }^{83}$ specifically in the sector of La Playa de Ponce. The combination of multiple cultures in Puerto Rico created the vejigante.

An example of influences from varies cultures can be seen in the available documentation of the history of Puerto Rico: Napoleon Bonaparte, French emperor and military leader during the French Revolution, prohibited masquerades and balls in 1797, in fear of the enemy using this to their benefit. While the Emperor Bonaparte did not have masquerades and balls in his home country, he allowed these events to be held in other territories. Napoleon allowed the masquerades to be held in Puerto Rico, specifically in Ponce. ${ }^{84}$ Through the presented evidence, it is undeniable the presence of the Spanish and French. These two distinctive and contrasting cultures contributed in defining characteristics to form the vejigante, and the Carnival, in Ponce.

\footnotetext{
82 Norberto Martell Morales and Héctor J. Rodríguez Torres, Las Caretas del Vejigante Ponceño, 8.

83 Norberto Martell Morales and Héctor J. Rodríguez Torres, Las Caretas del Vejigante Ponceño, 8.

${ }^{84}$ Norberto Martell Morales and Héctor J. Rodríguez Torres, Las Caretas del Vejigante Ponceño, 8.
} 
The impact of the French influence is displayed in a unique form of vejigante mask made specifically for women, known as the antifaz. (Figure 72) This feminine vejigante mask resembles the French masks used for masquerades. The antifaz is purposely designed to display the makeup, in particular the lipstick. This mask showcases the eyes and lips, and is much more comfortable in respect to vision and speech compared to the original vejigante careta. The horns of the antifaz always point upwards and/or towards the back and are usually very adorned with glitter and jewels. The mask will match the vejigante costume, and it is important to note, the women are usually never seen carrying vejigas. (Figure 73) The antifaz was solely invented to exhibit the beauty of the woman wearing it.

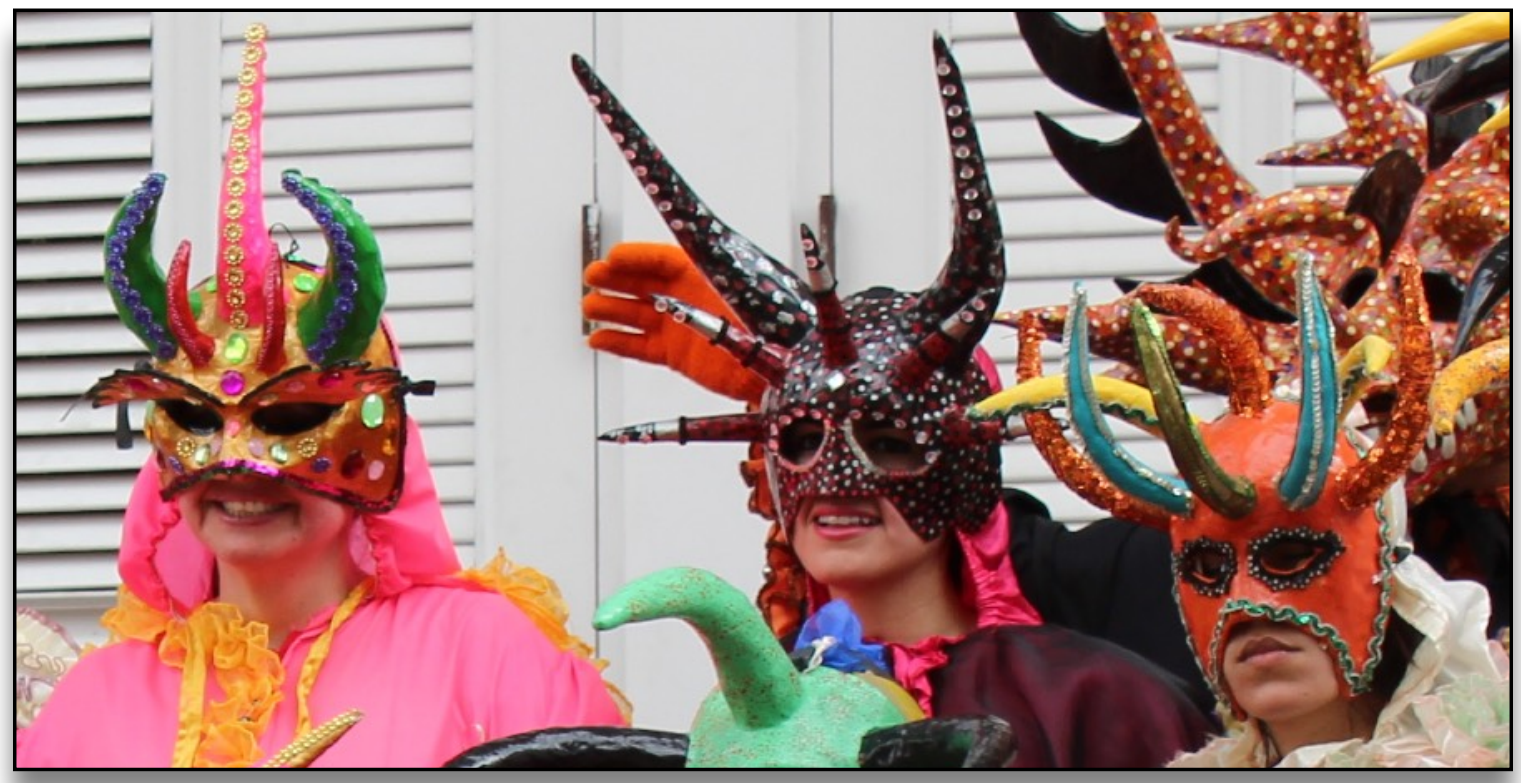

Figure 72 Vejigantes in Antifaz Masks, Carnaval Ponceño 2017 [digital image]. By Author. February 24, 2017 


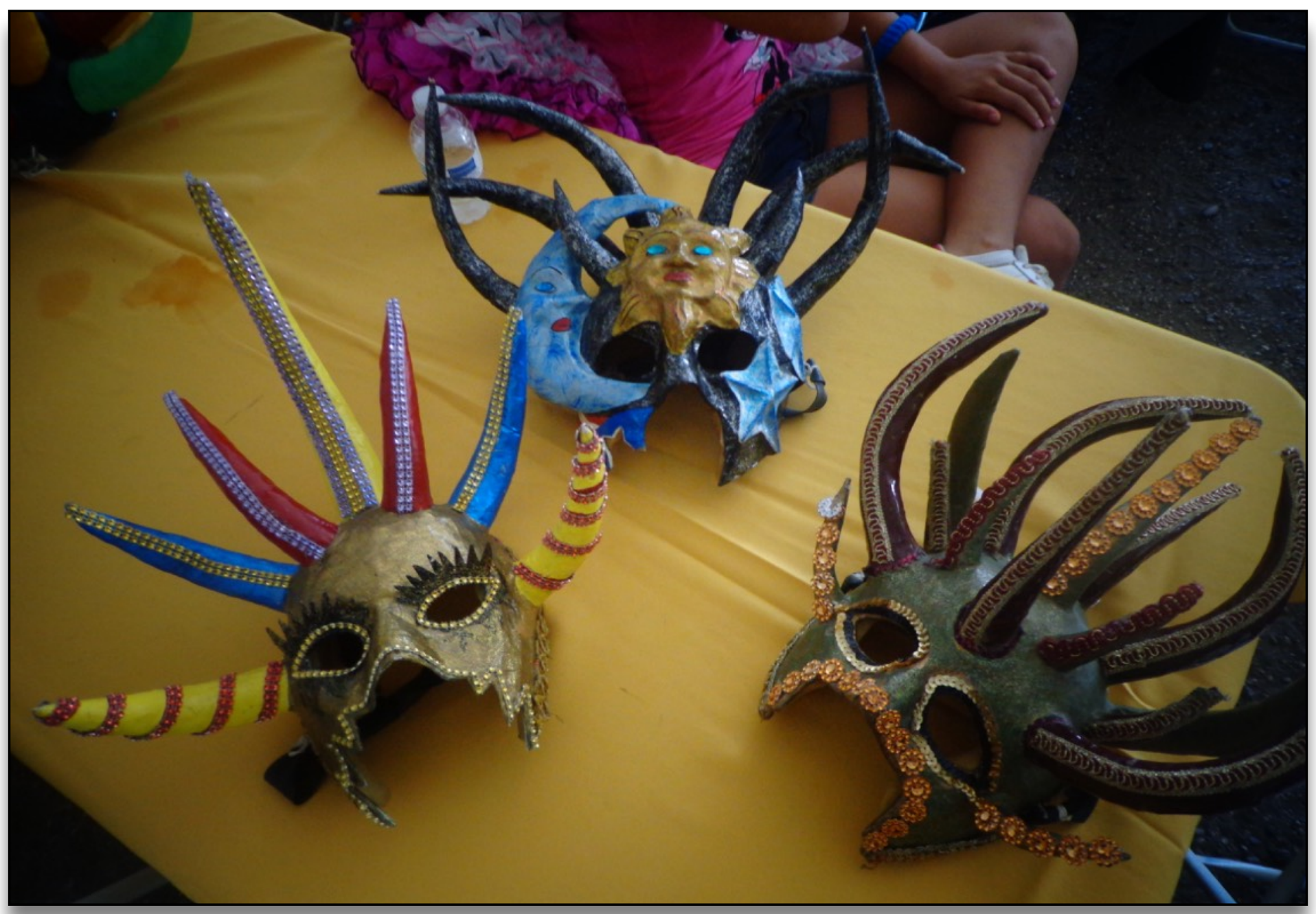

Figure 73 Antifaz Masks, Carnaval Ponceño 2018 [digital image]. By Author. July 24, 2018 
The creation of the vejigante mask has evolved and adapted over the years. It is customary in Puerto Rico to identify the traditional mask made from papier-mâché, as the careta antigua, antique mask. Papier-mâché is known to have origins in China around the time of the second century, and perhaps even having presence in India as well. ${ }^{85} \mathrm{But}$ its well-known name, papier-mâché meaning "chewed paper," emerged from its popularity in France in the sixteenth, seventeenth, ${ }^{86}$ and early eighteenth century. ${ }^{87}$ Although there was a decline in the use of papier-mâché in the nineteenth century, it is still prevalent in today's society. ${ }^{88}$ The use of papier-mâché to create the careta antigua has diminished in demand in Puerto Rico. (Figure 74) Although individuals from the 1990s can remember participating in careta antigua workshops, unfortunately this is not available for today's younger generations.

\footnotetext{
85 Daniel Reeder, Papier-Mache Monsters (Layton: Gibbs Smith, 2009), 7.

86 Daniel Reeder, Papier-Mache Monsters (Layton: Gibbs Smith, 2009), 7.

87 The Editors of Encyclopaedia Britannica, "Papier-mâché," (Encyclopædia Britannica, Inc., June 20, 2020), https:// www.britannica.com/art/papier-mache.

88 The Editors of Encyclopaedia Britannica, "Papier-mâché," (Encyclopædia Britannica, Inc., June 20, 2020), https:// www.britannica.com/art/papier-mache.
} 


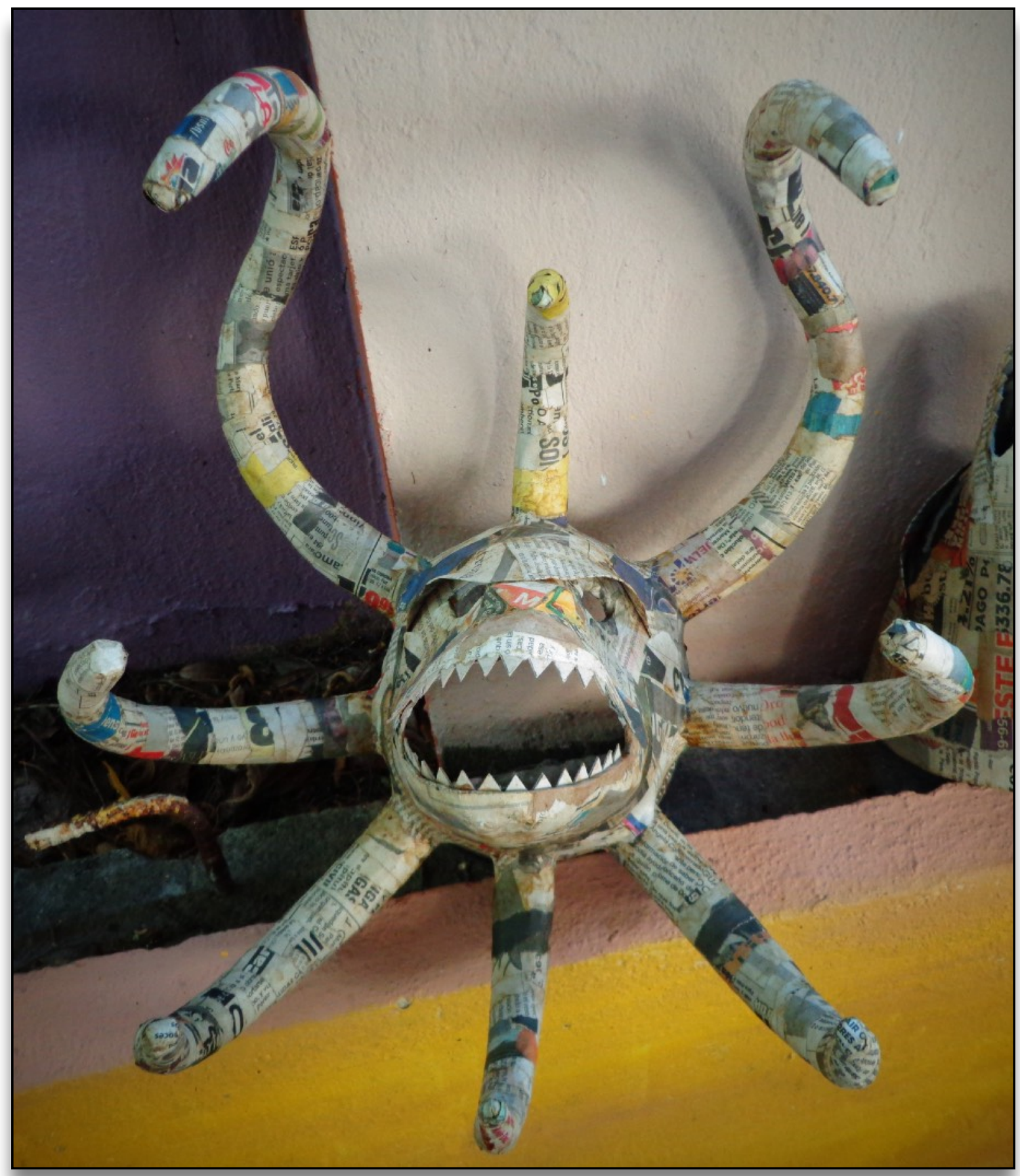

Figure 74 Papier-mâché Vejigante Mask, La Playa de Ponce Workshop [digital image]. By Author. July 24, 2018 


\subsection{Loíza Vejigante Mask}

Vejigante masks traditionally are organically made. The masks are often created using nature and/or recycled material. It is relevant to understand the similarities and contrasts between the vejigante masks of the different regions in Puerto Rico. (Figure 75) In the North, in the town of Loíza Aldea, vejigante masks are made of coconuts and wood. (Figures 76-78) While in the South, in Ponce, the masks are made from old newspapers by method of papier-mâché and engrudo, glue made with flour.

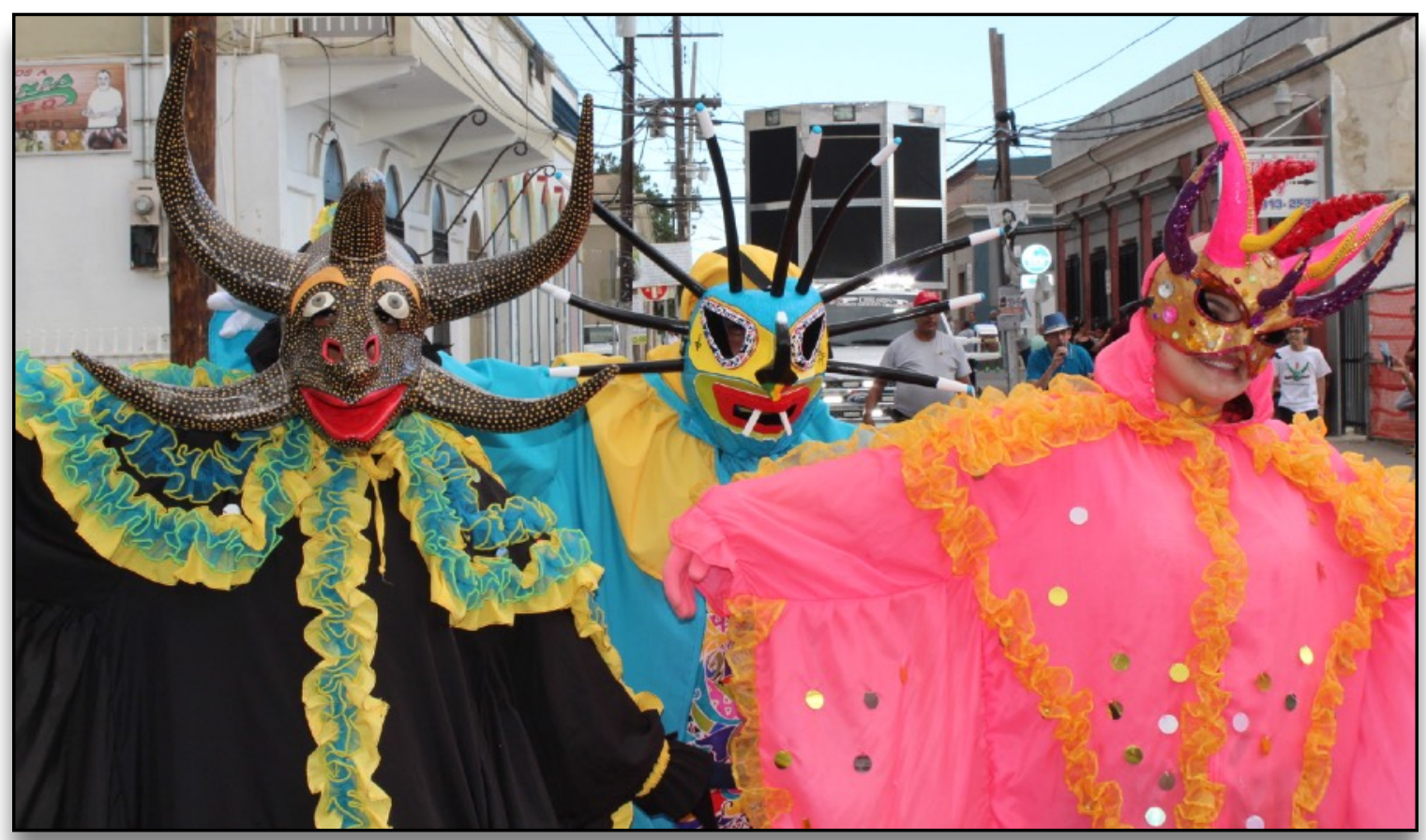

Figure 75 Ponce Vejigante, Loiza Vejigante and a Vejigante with an Antifaz, Carnaval de La Playa de Ponce 2018 [digital image]. By Author. February 24, 2018 


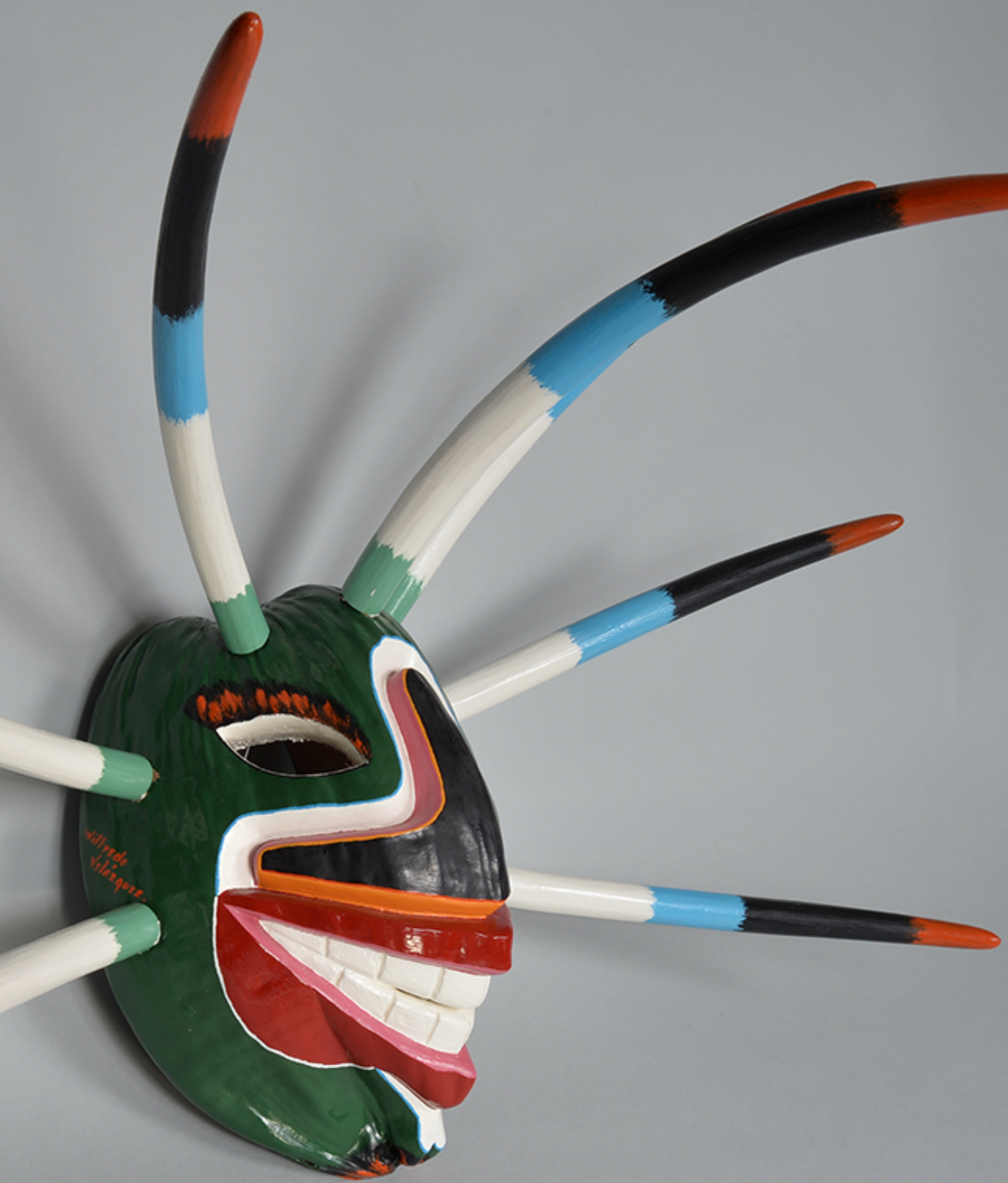




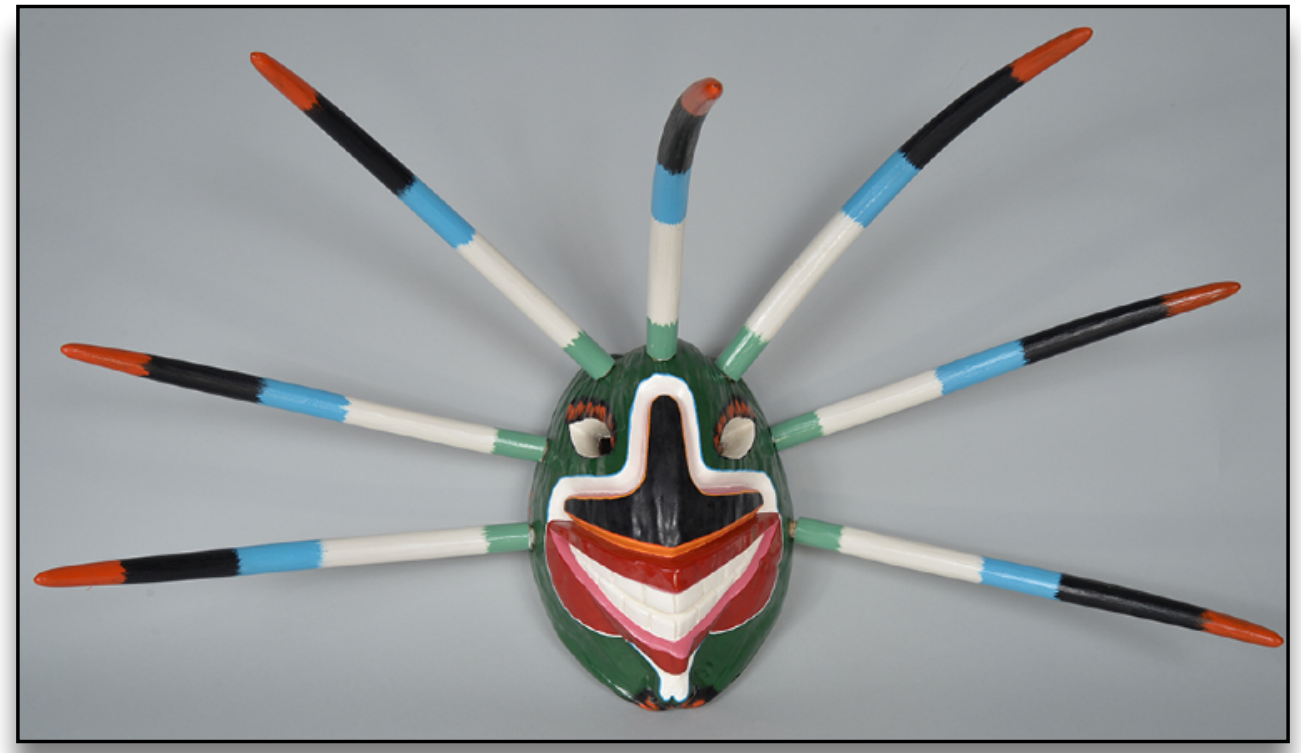

Figure 77 Vejigante [digital image]. Retrieved June 20, 2020 from https:// www.maskmuseum.org/mask/vejigante-loiza-1/

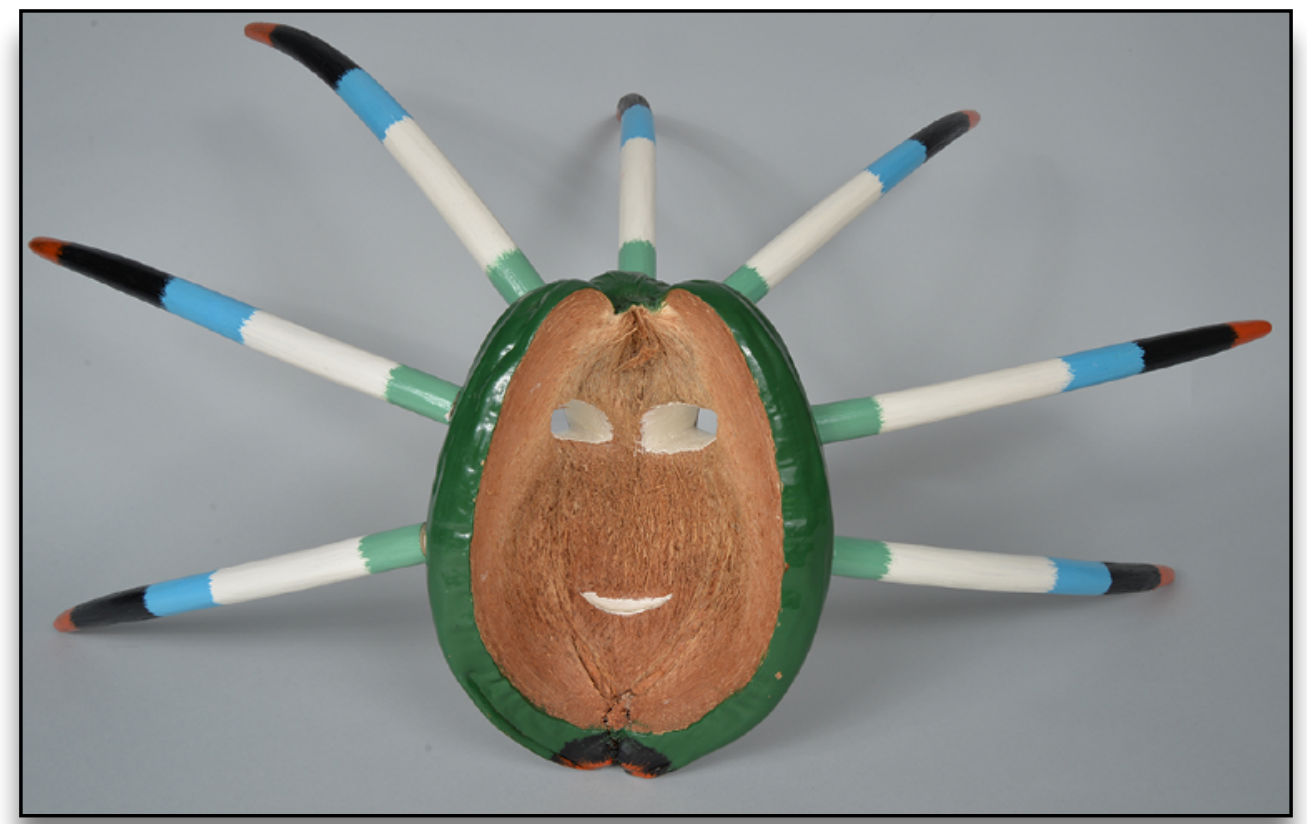

Figure 78 Vejigante [digital image]. Retrieved June 20, 2020 from https:// www.maskmuseum.org/mask/vejigante-loiza-1/ 
While the mask of Loíza may resemble the mask of Ponce, either through the presence of horns or by the use of similar colors, the Carnivals are distinct in the significance. In Loíza Aldea:

[Vejigante masks] are worn at the festival of Santiago Apóstol, the feast day of St. James the Apostle, which is celebrated for three days starting July 25. Each day during the fiesta, a different statue of St. James, the patron saint of Spain, is carried through the town. Some people dress as Spanish caballeros, or knights, with wire mesh masks and protect the statue from evil. Others dress as vejigantes, viejos (old men), and locas, (crazy women)...The festival is a symbol of the richness of the Spanish and African cultural mix found in Puerto Rico. When slaves originally came to Puerto Rico, they brought their own religious figures with them. In time, the Nigerian gods became associated with some of the Catholic saints and Shango became associated with St. James.

...For many, African slaves, Carnival was a period of time when they were free from the hard toil for a short time. By dressing up in fanciful clothing, sometimes in imitation of their masters, they were able to lampoon their owners' behavior... these activities were tolerated in the Caribbean colonies. ${ }^{89}$

The vejigantes purpose within the Carnival of Loíza Aldea is different from the role of the vejigantes in the Ponce Carnival. In both Carnivals the vejigantes represent some form of evil. (Figure 79) "The festival is of Spanish origin but has many African features." 90 The heritage of Puerto Rica include descendants from Africa. ${ }^{91}$ The representation of African influence is seen in the caretas and atuendos used in present-

\footnotetext{
89 Olga R. and Kuharets, Venture Into Cultures: A Resource Book of Multicultural Materials and Programs (American Library Association, 2001), 23.

90 Patricia Levy and Nazry Bahrawi, Puerto Rico (New York: Marshall Cavendish Benchmark, 2006), 118.

${ }^{91}$ Albert James. Arnold, J. Michael. Dash, and Rodríguez-Luis Julio, A History of Literature in the Caribbean: Volume 1: Hispanic and Francophone Regions (Amsterdam/Philadelphia: John Benjamins Publishing Company, 1994$), 242$.
} 
day Loíza Aldea. The vejigante costume shows similarities to the traditional dress used for rituals and ceremonies still used by the people residing in the Yoruba district, located in Nigeria. ${ }^{92}$

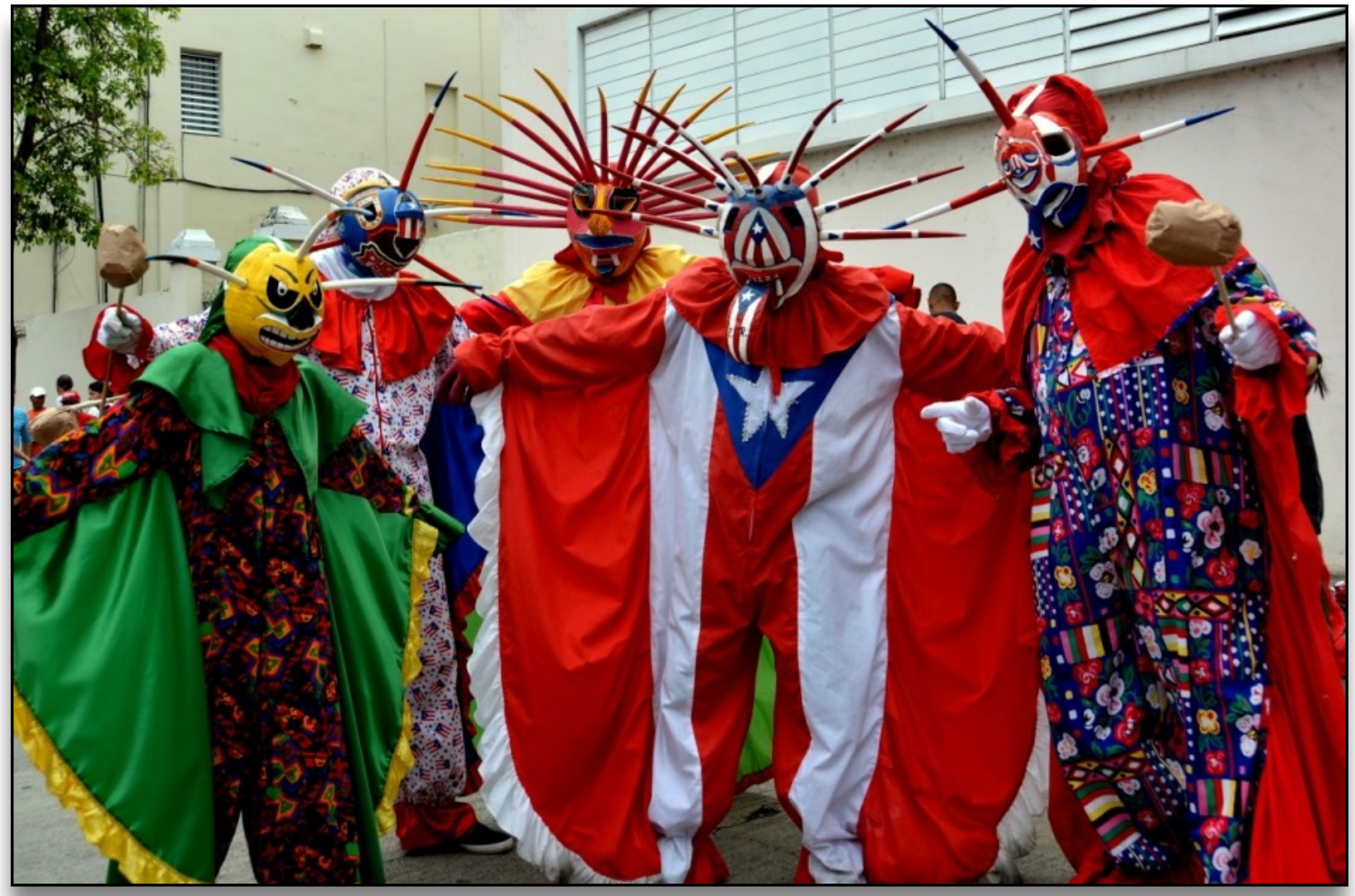

Figure 79 Vejigantes Loíceños / (C) All rights reserved by Carlos A. Aviles [digital image]. Retrieved October 4, 2019 from https://flic.kr/p/rjJ7z2

92 Patricia Levy and Nazry Bahrawi, Puerto Rico, 118. 
Bomba y Plena are a musical traditions originating from Puerto Rico,“...Bomba is very much a conversation between the drummer and the dancer, [and] Plena's emphasis is on the lyrics, which often narrate or comment on current events." 93 These musical genres reflect the vast African heritage in Puerto Rico's complex culture. ${ }^{94}$

Bomba dates back to the early European colonial period in Puerto Rico. It comes out of the musical traditions brought by enslaved Africans in the 17th century. To them, $[B o m b a]$ music was a source of political and spiritual expression. The lyrics conveyed a sense of anger and sadness about their condition, and songs served as a catalyst for rebellions and uprisings. But [Bomba] also moved them to dance and celebrate, helping them create community and identity. The music evolved through contact between slave populations from different Caribbean colonies and regions, including the Dutch colonies, Cuba, Santo Domingo, and Haití....

Plena developed from [Bomba] music around the beginning of the 20th century in southern Puerto Rico. Plena lyrics are narrative. They convey a story about events, address topical themes, often comment on political protest movements, and offer satirical commentaries.... ${ }^{95}$

This folkloric music uses Bomba drums, which is "an instrument made from a wooden barrel." 96 used for its sixteen rhythms. ${ }^{97}$ The rhythm and speed of the drums is

93 María Herrera-Sobek, Celebrating Latino Folklore: An Encyclopedia of Cultural Traditions (Santa Barbara: ABCCLIO, 2012), 718.

94 "Puerto Rican Bomba and Plena: Shared Traditions — Distinct Rhythms," Smithsonian Folkways Recordings, accessed December 26, 2020, https://folkways.si.edu/puerto-rican-bomba-plena-shared-traditions-distinct-rhythms/ latin-world/music/article/smithsonian.

95 "Puerto Rican Bomba and Plena: Shared Traditions — Distinct Rhythms," Smithsonian Folkways Recordings, accessed December 26, 2020, https://folkways.si.edu/puerto-rican-bomba-plena-shared-traditions-distinct-rhythms/ latin-world/music/article/smithsonian.

96 Patricia Levy and Nazry Bahrawi, Puerto Rico, 118.

97 "Puerto Rican Bomba and Plena: Shared Traditions — Distinct Rhythms," Smithsonian Folkways Recordings, accessed December 26, 2020, https://folkways.si.edu/puerto-rican-bomba-plena-shared-traditions-distinct-rhythms/ latin-world/music/article/smithsonian. 
customarily lead by the dancers with their movements. (Figure 80) While, on the other hand, "Plena has only one basic rhythm."98 (Figure 81) In present-day Carnival, specifically looking at Ponce, Bomba y Plena have become overshadowed by pop culture music artists, such as Marc Anthony and Olga Tañón. An example of this is seen on the TV Special created by Banco Popular, aired in December 2018. The themes song of the TV Special was "La Vida es un Carnaval," sung by special guest: Olga Tañón. (Figures 82-83) Although popular music has influenced the Carnival in Ponce, the festivals of Loíza Aldea continue to use the traditional music of Bomba y Plena.

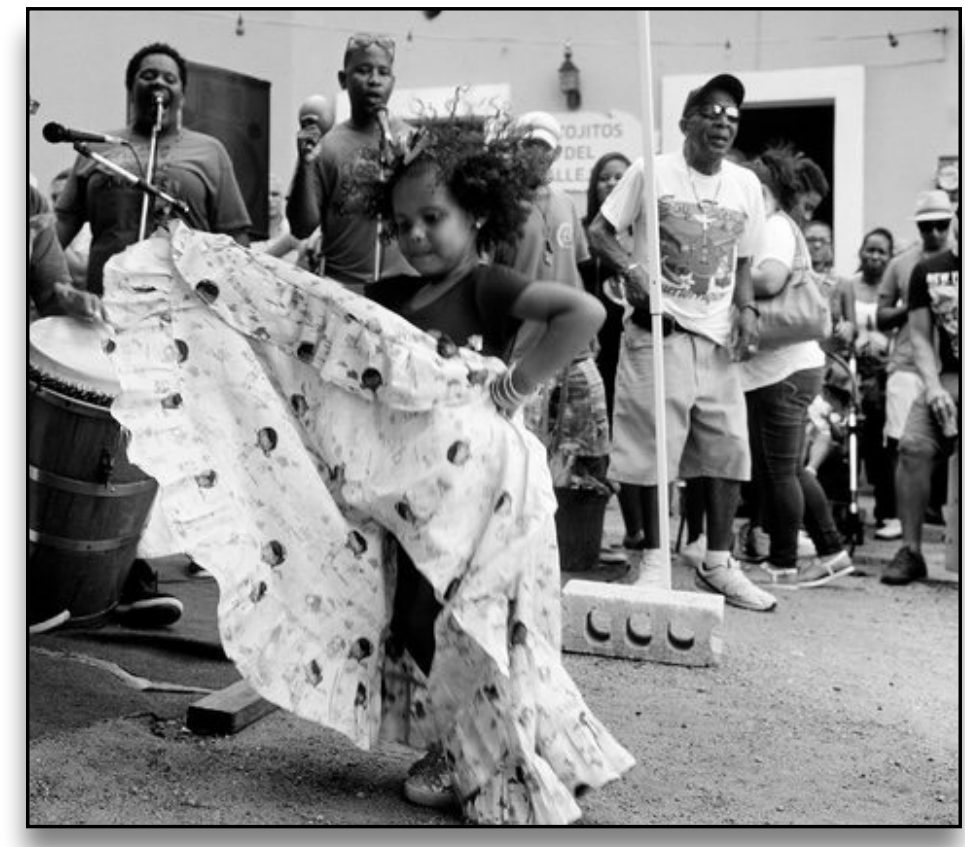

Figure 80 Untitled [digital image]. Retrieved October 4, 2019 from https://lens.blogs.nytimes.com/ 2016/01/12/los-rostros-de-los-queresisten-la-crisis-econmica-depuerto-rico/

98 "Puerto Rican Bomba and Plena: Shared Traditions — Distinct Rhythms," Smithsonian Folkways Recordings, accessed December 26, 2020, https://folkways.si.edu/puerto-rican-bomba-plena-shared-traditions-distinct-rhythms/ latin-world/music/article/smithsonian. 


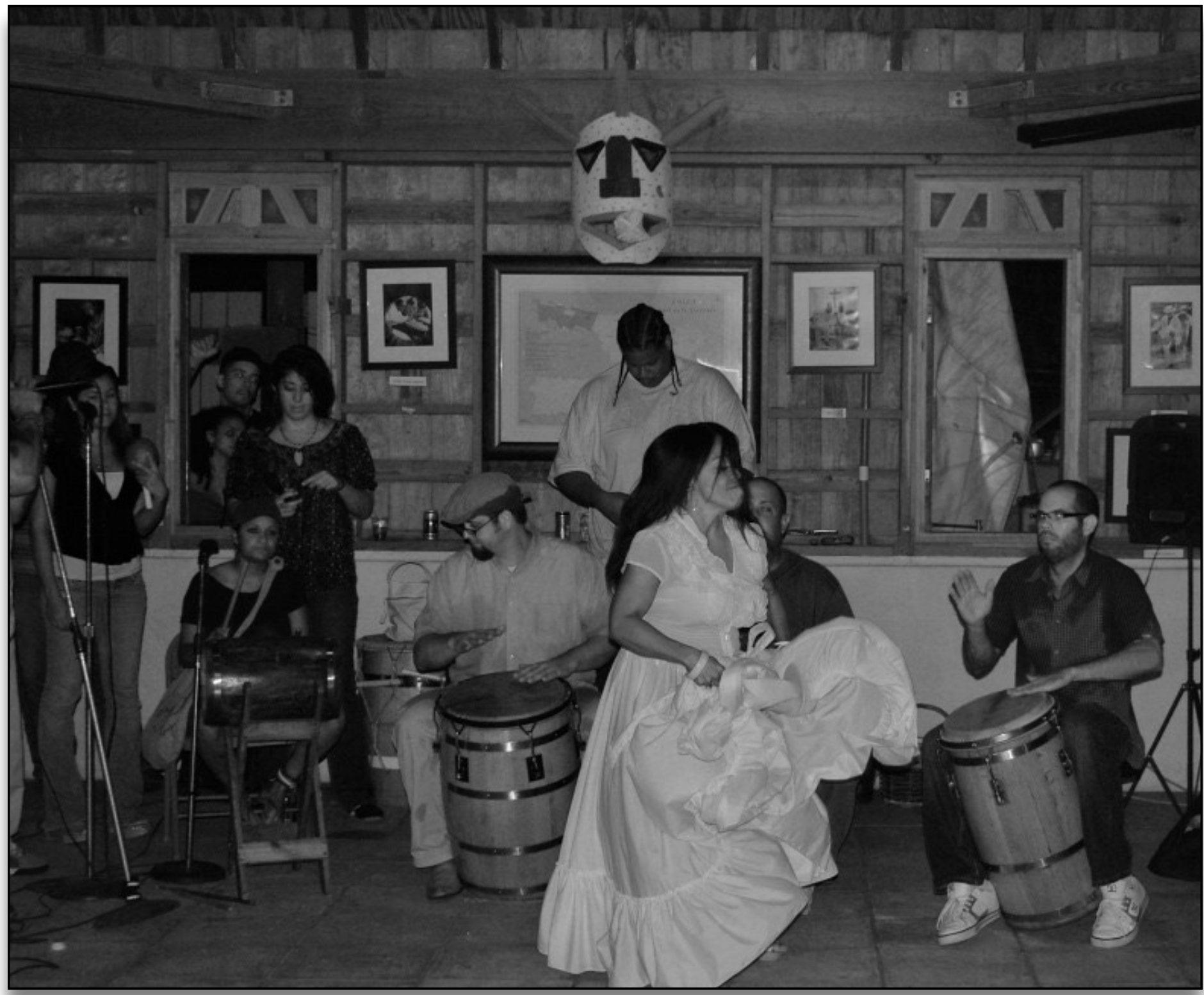

Figure 81 Vejigantes Loíceños / (C) All rights reserved by Kalifon [digital image]. Retrieved June 20, 2020 from https://flic.kr/p/ 8BZkC1 


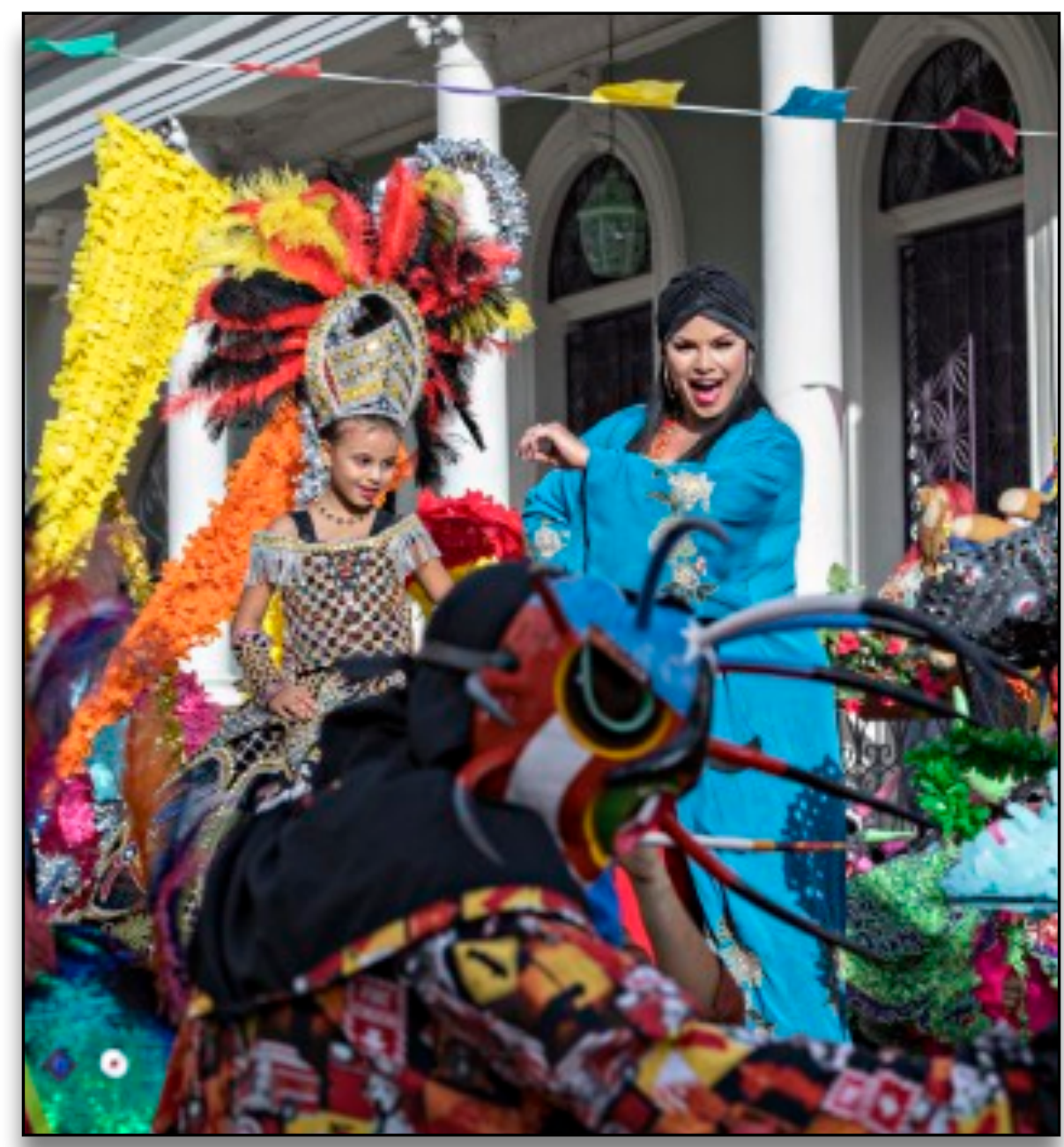

Figure 82 Olga Tañón interpreta el tema musical "La vida es un carnaval" para la filmación llevada a cabo en Ponce / Business Wire [digital image]. Retrieved June 20, 2020 from https://lens.blogs.nytimes.com/2016/01/12/los-rostros-de-losque- resisten-la-crisis-econmica-de-puerto-rico/

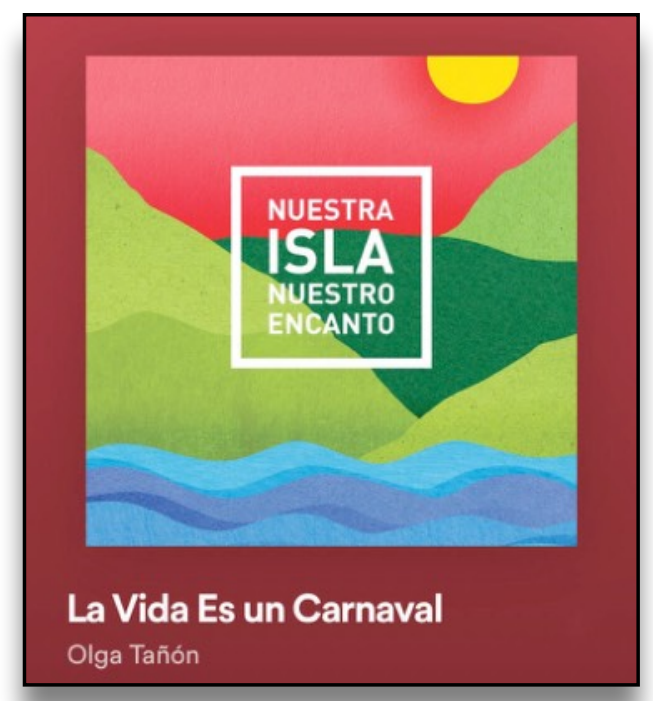

Figure 83 La Vida Es un Carnaval Olga Tañón [digital image]. Retrieved June 20, 2020 from https://www.spotify.com/ 


\subsection{Decline in Creation and Consumption}

During my observations of the vejigante in the twenty-first century, the careta antigua is only used for participants of the Carnival and the parades. But those who wander the streets as bystanders, dressed as vejigantes, do not necessarily use the traditional mask, but instead a rubber Halloween mask combined with the atuendo. It is theorized that this was introduced for the purpose of comfort and cost. A basic vejigante mask is priced between 100 to 200 United States Dollars (USD). (Figures 84-85) A more adorned vejigante mask can cost between 500 to 1,000 USD. (Figures 86-87) In addition, these masks, although lightweight, have an extremely hard texture, and are fastened to the head in an antiquated manner that is uncomfortable. Puerto Rico has gained access to stores such as "Party City," where low budget Halloween items are found, such as 20 USD soft, rubber masks. The higher quality rubber latex masks have a price range from 30 to 50 USD. (Figures 88-91) Nonetheless, the rubber, Halloween masks have a lower cost, but additionally have more comfort in comparison to the traditional vejigante mask. By the use of the store-bought, Halloween masks, the focus transfers from the mask to the atuendo. While the careta antigua is less prevalent within the community, the people dressed with the traditional costume accompanied by a Halloween mask, usually carry traditional vejiga. These are made locally by a matador, a person who slaughters 
livestock, and bought at the low price of 5 to 15 USD, depending on the matador. Even though the creation of the vejiga contradicts animal rights laws in the USA, it is still possible to locate matadors who make vejigas. (Figure 92) And because of this, the vejiga is more commonly seen and used compared to the careta antigua, due to its affordable price.

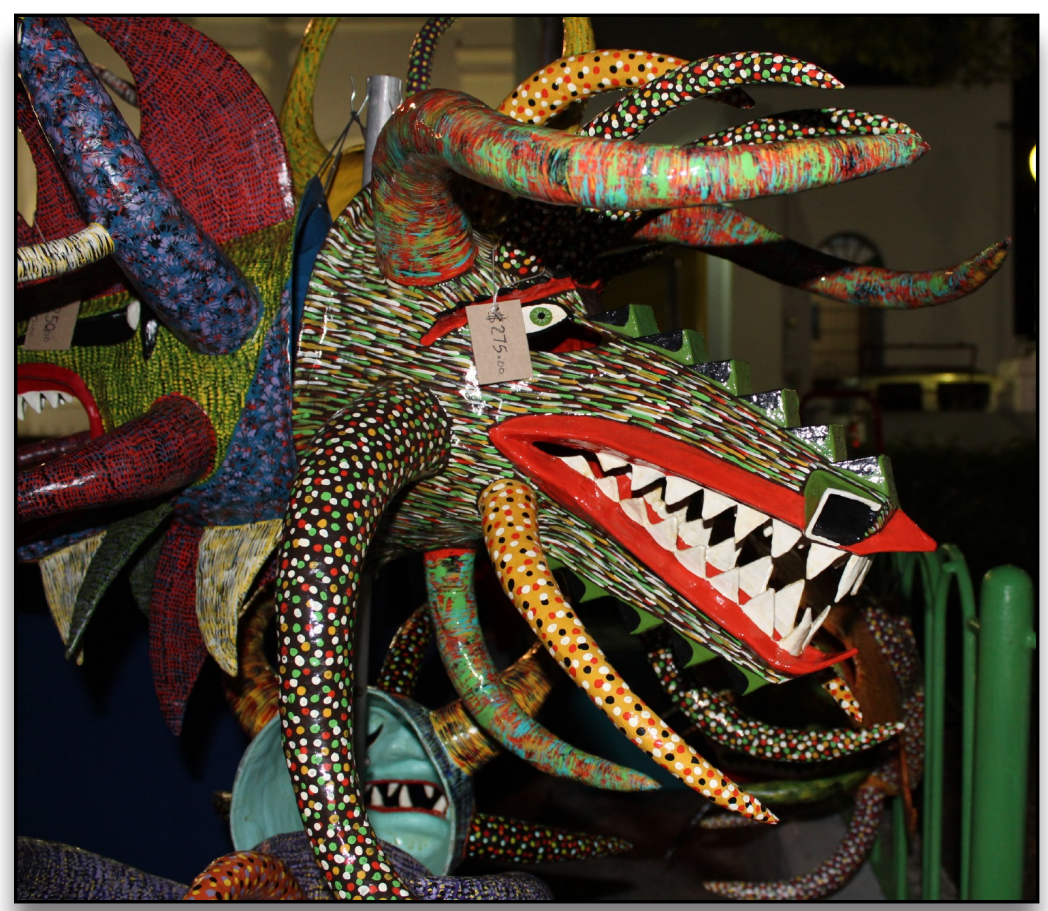

Figure 84 Traditional Vejigante with a Price Tag of \$275, Carnaval Ponceño 2017 [digital image]. By Author. February 24, 2017

Figure 85 Traditional Vejigante with a Price Tag of $\$ 275$,

Carnaval Ponceño 2017 [digital image]. By Author. February 24, 2017 


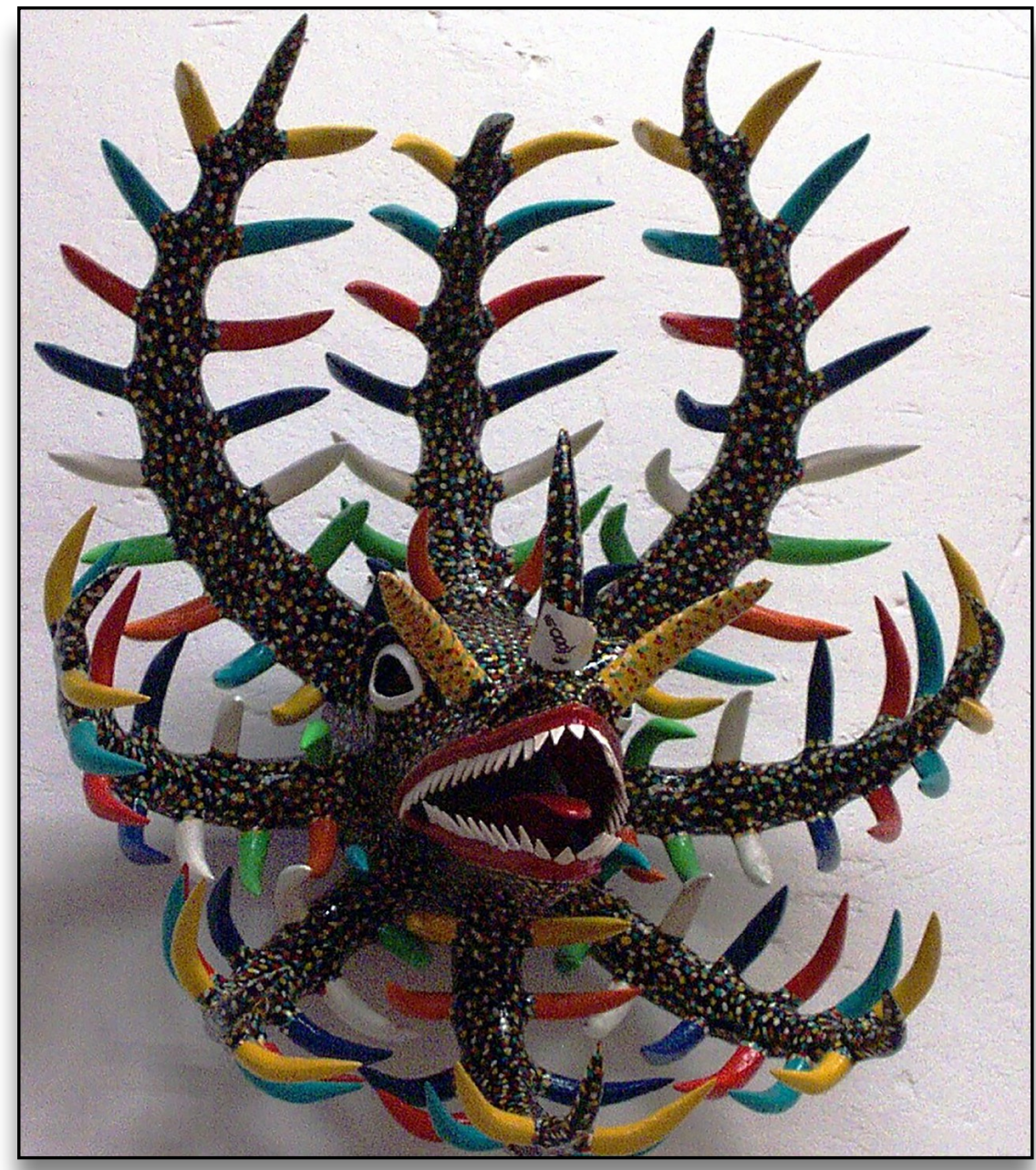

Figure 86 Careta Mask of Puerto Rico [digital image]. Retrieved June 20, 2020 from https://

www.pinterest.com/bishopjazz/ careta-mask-of-puerto-rico/

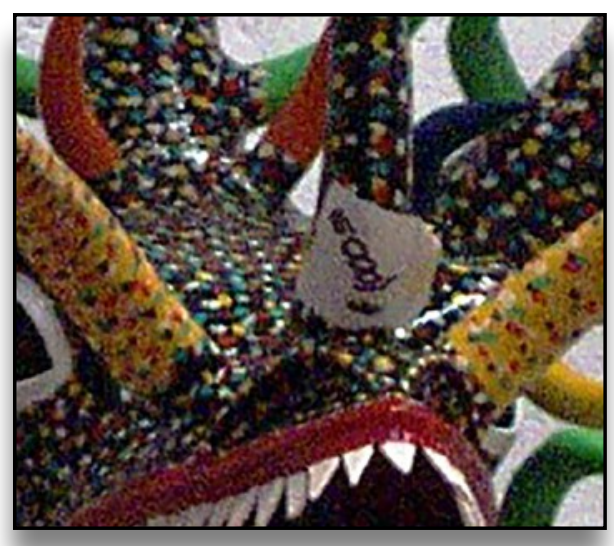

Figure 87 Careta Mask of

Puerto Rico [digital image]. Retrieved June 20, 2020 from https://www.pinterest.com/ bishopjazz/careta-mask-ofpuerto-rico/ 


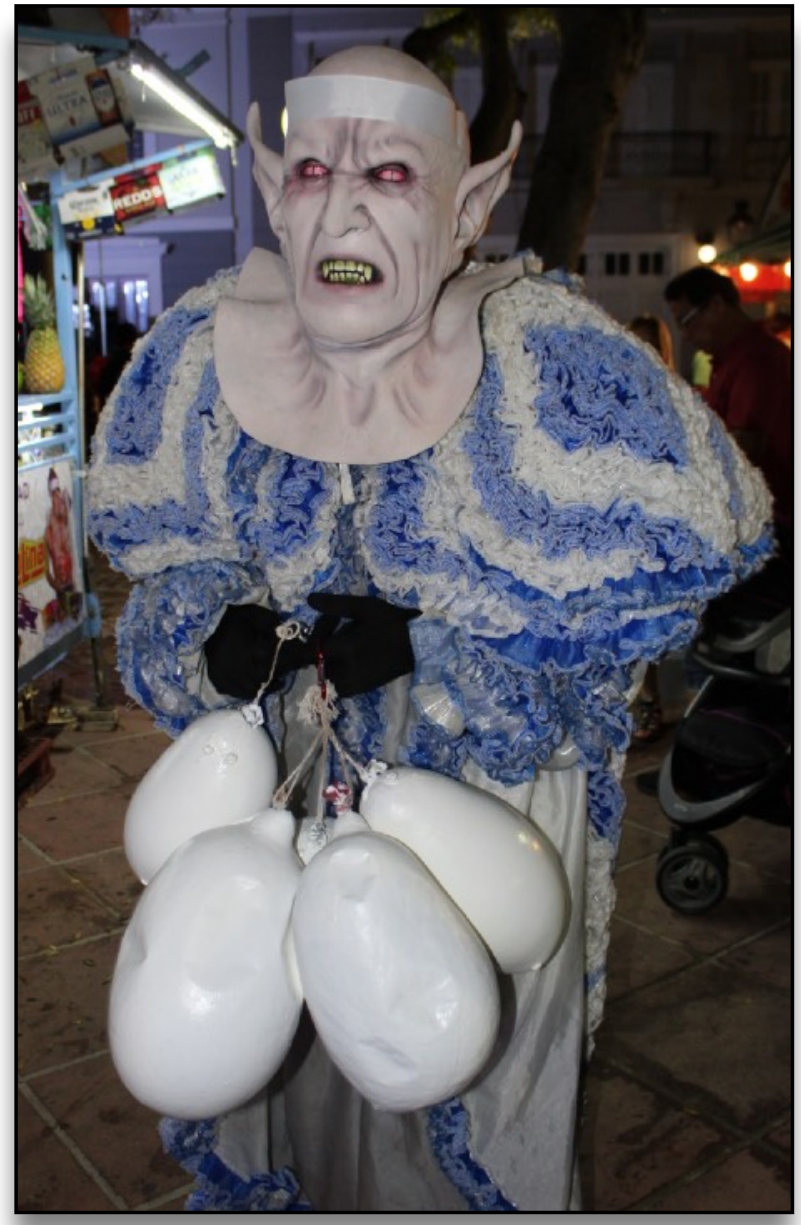

Figure 88 Vejigante in a Rubber Halloween Mask with 5 Vejigas, Carnaval Ponceño 2017 [digital image]. By Author. February 24, 2017

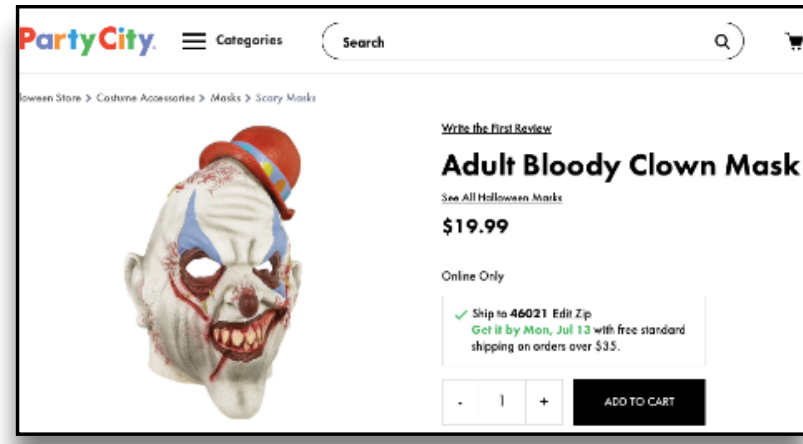

Figure 89 Adult Bloody Clown Mask [digital image]. Retrieved June 20, 2020 from https://

www.partycity.com/adult-bloody-clown-

mask-752300.html

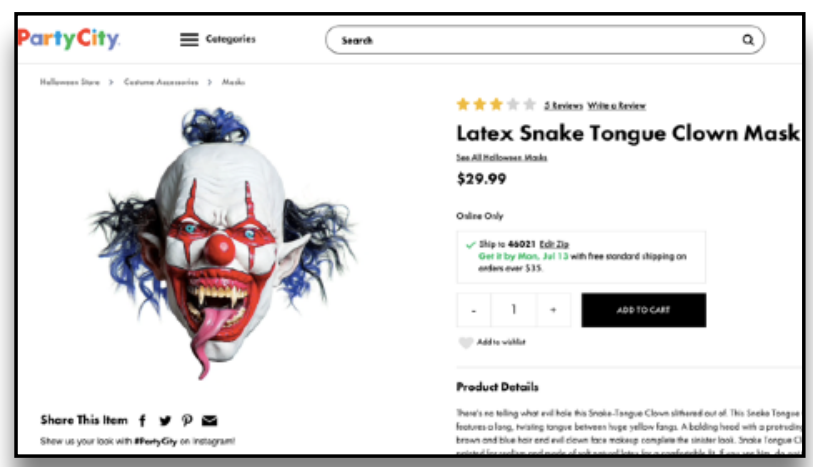

Figure 90 Latex Snake Tongue Clown Mask [digital image]. Retrieved June 20, 2020 from https:// www.partycity.com/latex-snake-tongue-clownmask-481849.html?cgid=costume-accessories-clownmasks

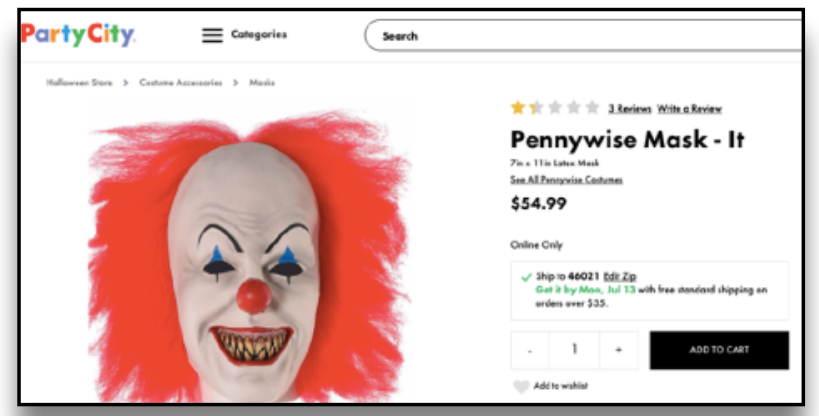

Figure 91 Pennywise Mask - It [digital image]. Retrieved June 20, 2020 from https:// www.partycity.com/pennywise-mask--it-687940.html 


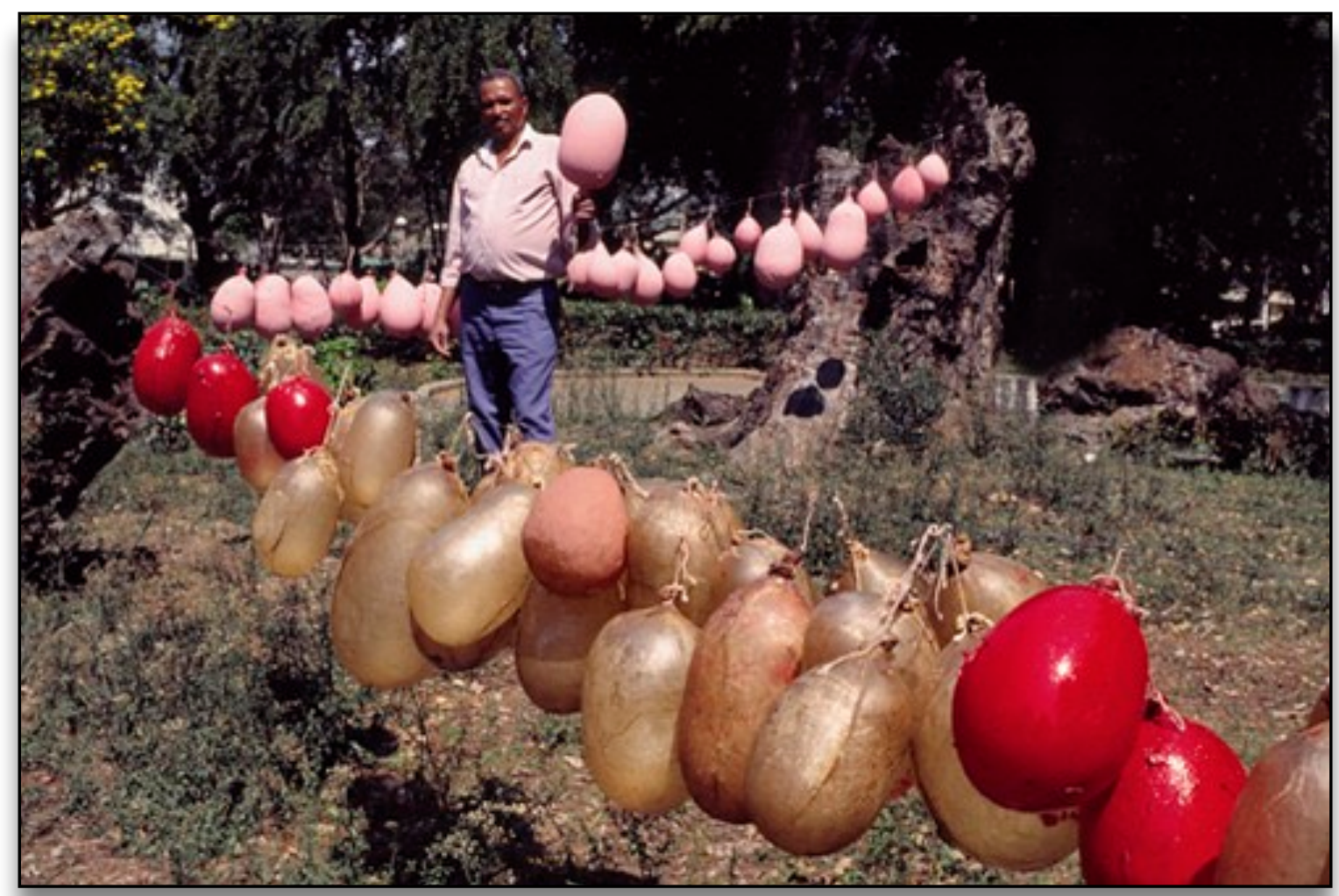

Figure 92 CARNAVAL POPULAR DOMINICANO [digital image]. Retrieved June 20, 2020 from https:// www.flickriver.com/photos/marianohdez/sets/72157606971736473/

Vejigante mask making is a dying art due to the lack of artisans continuing to teach and pass the knowledge to future generations. Not many people know how to sculpt these masks, and, in many cases, the artisans are not willing to share their methods and techniques. Few classes are available but not at affordable prices. Raquel "Cucha" Rentas, a local artisan and vejigante from La Playa de Ponce, gives classes starting at 150 USD per mask, not including a workshop to create the details of the mask, such as the eyes and the mouth. Another artisan, Edwin Muñiz Pérez, a local from Ponce, gives 
classes in La Playa de Ponce, at the price of 10 USD per class. Each class lasts for three to four hours covers the basic creation of the mask, including the details: eyes, nose, and teeth. Although his classes are affordable, the process is lengthy and require months to complete a mask. These are the only artisans providing careta antigua workshops to the public in Ponce. Even though this is the city known for the creation of the careta antigua, Ponce does not have readily available classes and/or workshops. The resources for learning the craftsmanship of the traditional vejigante mask are limited.

The economic aspect is an important element in order to understand why the vejigante mask is not accurately represented within the Carnivals. The classes to make the careta are not abundant and are either expensive or time consuming, therefore, the art of creating a vejigante mask is slowly disappearing. Vejigante masks are expensive and it is unaffordable and unrealistic for many of the locals who are willing to participate in Carnivals. The masks are popular with the mainland tourists visiting the island. And with the USA income being higher than Puerto Rico, ${ }^{99}$ tourists are willing and able to spend high dollar for a unique, cultural souvenir.

The diminishing presence of the careta antigua is evident in comparison to previous Carnivals. The elevated cost has hindered the desire to own, and therefore use, the vejigante mask. In addition, the affordable alternatives available at USA chain stores

\footnotetext{
99 “Puerto Rico," Data USA, accessed October 20, 2020, https://datausa.io/profile/geo/puerto-rico/?compare=unitedstates.
} 
within Puerto Rico accelerated the extinction the of the careta antigua de vejigante. Even though the mask has become unaffordable for many locals, the consumption and demand of the careta antigua from the tourist market created the foundation to merge the concept of the vejigante mask into a contemporary context. The ability to appreciate the mask in its original state, the careta antigua, enabled the change from artisanal craft of an artifact to an iconic representation of cultural artwork. In addition, artists are creating an experimental outlook of the representation of the iconic concept of the vejigante mask as a patriotic symbol of resistance. The vejigante has been presented in sculptural expression, painting and drawing, and more recently in murals. (Figure 93) These representations are examples of how the cultural appreciation evolved the context of the folklore vejigante into a contemporary art. 


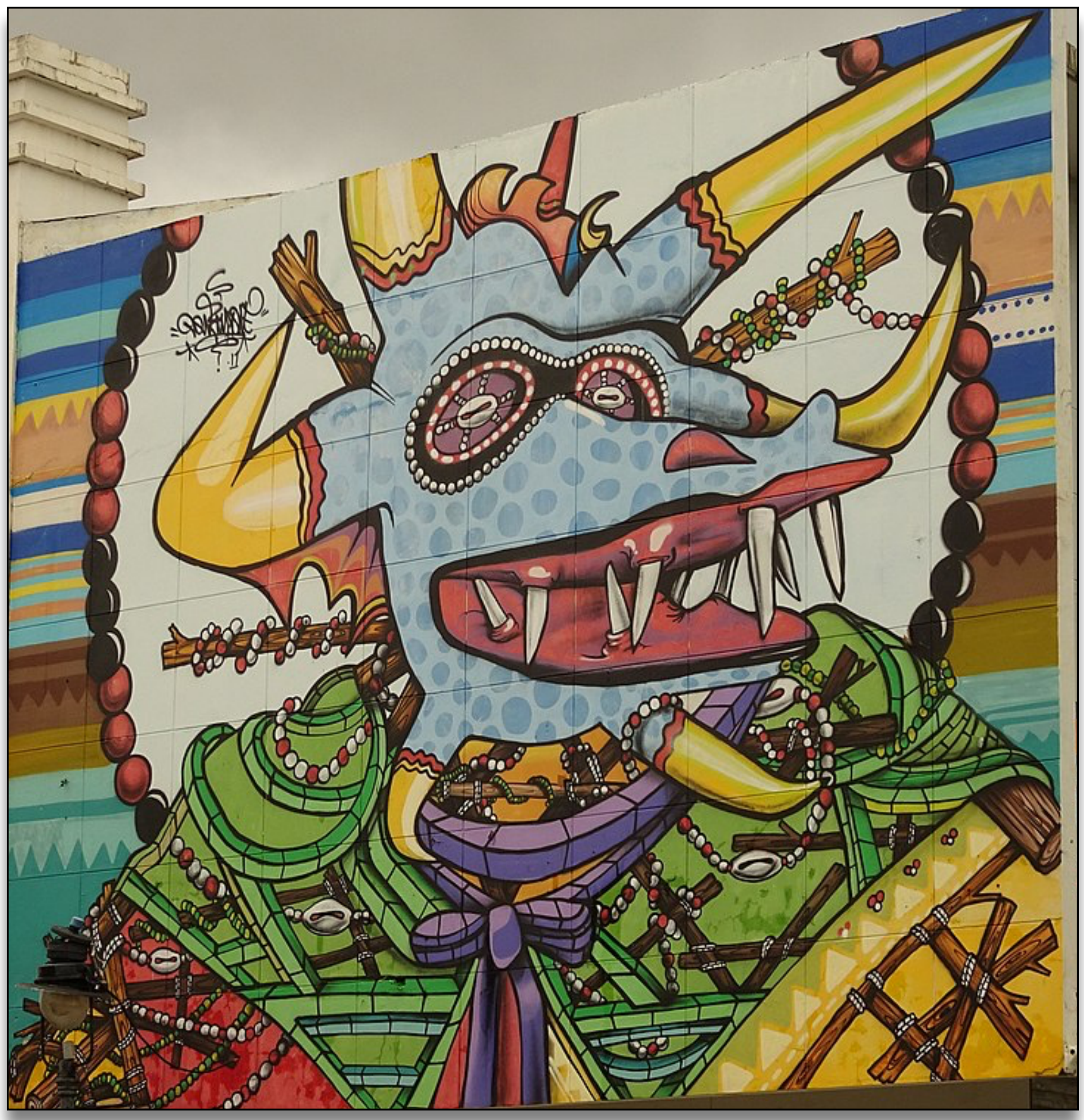

Figure 93 El Vejigante on Calle Sol and Calle Mayor, was the first Ponce es Ley mural to be completed [digital image]. Retrieved June 20, 2020 from https://en.wikipedia.org/wiki/Street_art_in_Ponce,_Puerto_Rico 
Chapter Three: The Line Between 


\subsection{Overview}

This chapter will analyze and explain the similarities and dissimilarities between the artisan and the artist. It will discuss the elements needed to dismantle the boundaries of the artisan in order to shift into the category of artist. This section will also contemplate the line between a folkloric object and a work of art. The differences between the various subjects will be outlined and clearly explained.

In addition, it will also touch on the misrepresented image that is still passed on which created the concept of Puerto Rico as a paradise. As tourism become a source of income for Puerto Rico, it has also become a dependency.

Even though these imageries began as false identities to the people of Puerto Rico, as time has passed they have become part of the culture and the people do identify with the representation provided for the island culture. Although the Puerto Rican people know their roots and culture, there is still a connection with this kitsch art form. 


\subsection{Artisan vs. Artist}

In Puerto Rico there is a dispute between being categorized as an artisan or an artist. More often than not, an artisan can be creating artisanal work and artwork on the same platform, but the likelihood of an artisan achieving status as an artist is an on-going debate. This straddle between artist and artisan can cause tension amongst the artistic community. Although it is possible to be considered both, it should be made clear that this hybrid is the exception. It is not common to find person who can fit into both categories and stand on both sides of the line. Nonetheless, to define it simply, the characteristics that differentiate an artist from artisan is: the work of the artisan is created on a mass scale and has little to no variation. The categorical differentiation of artist versus artisan has further defined folkloric objects. Moreover, the transition of artisan to artist is an aspect that benefited and stimulated the vejigante's passage into contemporary art. (Figure 94) 


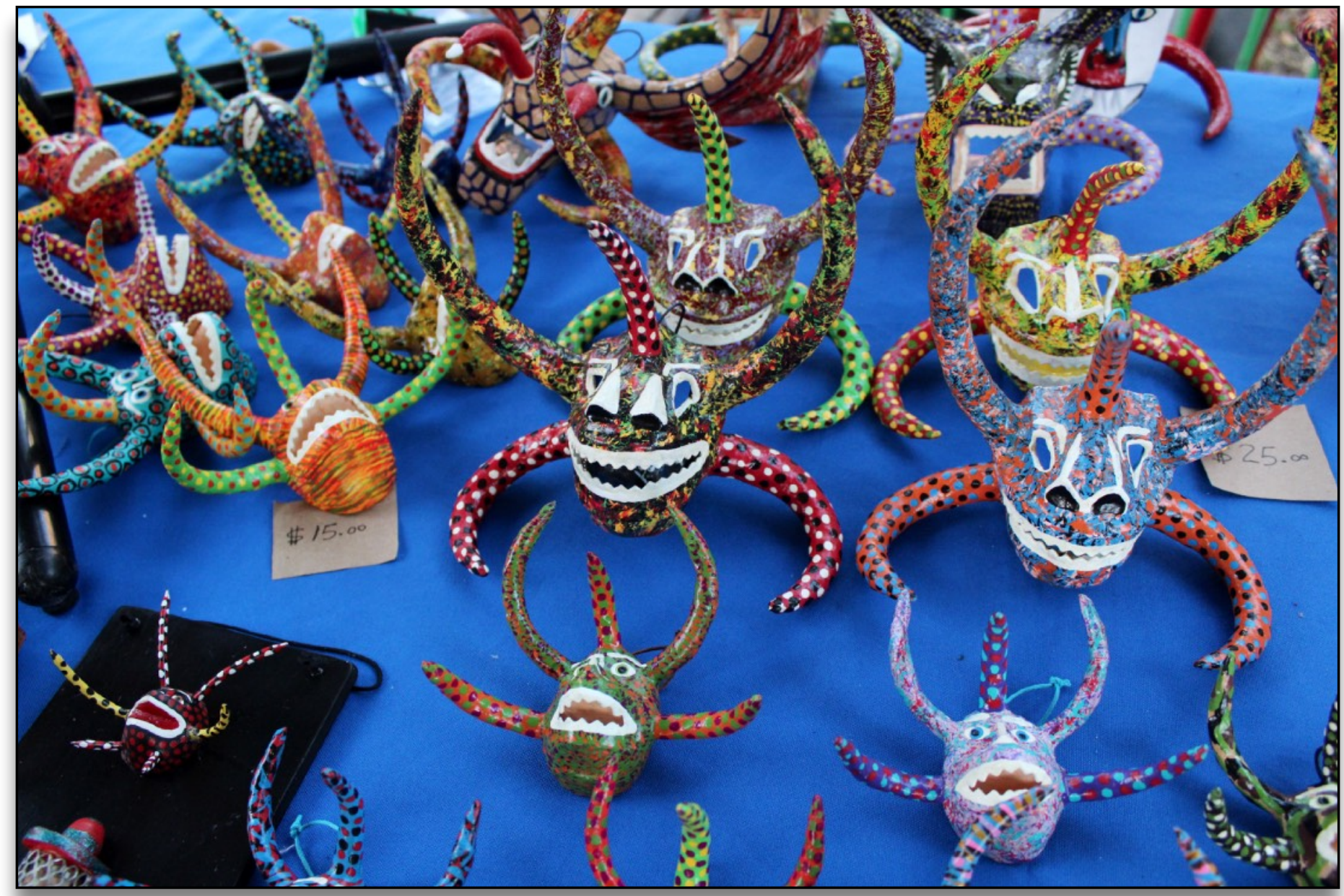

Figure 94 Artisan Table with Mass Production of Miniature Vejigante Masks, Carnaval Ponceño 2017 [digital image]. By Author. February 24. 2017 
Artisans are categorized as people who create popular collectables that combine both the beauty and tradition in a form of expression. This repetitive manual labor is described as "sociohistorical”100 by Ramón López in EL Valor Histórico de la Artesanía Puertorriqueña. Sociohistorical is defined as "relating to, or involving social history or a combination of social and historical factors." 101 While the artisan crafts objects, these pieces cannot be placed in the same category as art. The artisanal objects convey culture rather than an artistic dialogue. "The creativity of the artisan is not limited but is an expression inside the limits of the tradition." 102 On the other hand, the artists creates works of art that are individual and a personal form of expression. While there are fewer artisans than before, the small amount that are left continue their work with the help of the thriving tourism of Puerto Rico. Ramon López states that the artisans are becoming extinct, ${ }^{103}$ and continues: "The government's promotion of artisans has...failed to distinguish artisans from [artists]." $104 \mathrm{He}$ claims the line between these two different forms of creation exist, but is difficult to define. "Puerto Rico's most exquisite form of 'folk art' actually borders on 'fine art:' santos, the carved religious figures that have been

\footnotetext{
100 Ramón López, Cuadernos De Cultura: EL Valor Histórico de la Artesanía Puertorriqueña, 8.

101 “Sociohistorical," Merriam-Webster (Merriam-Webster), accessed August 8, 2019, https://www.merriamwebster.com/dictionary/sociohistorical).

102 Ramón López, Cuadernos De Cultura: EL Valor Histórico de la Artesanía Puertorriqueña, 8.

103 Ramón López, Cuadernos De Cultura: EL Valor Histórico de la Artesanía Puertorriqueña, 8. 104 Ramón López, Cuadernos De Cultura: EL Valor Histórico de la Artesanía Puertorriqueña, 11.
} 
produced [there] since the 1500s."105 The distinction between artisanal craft and a contemporary/popular artwork can be difficult to distinguish, but exists. Ramon López states that contemporary art illustrates a unique aesthetic, rather than showcasing a craft and skill. ${ }^{106} \mathrm{He}$ continues by clarifying that fine art does not have the value in the brand of the artist but in the artwork itself. (Figures 95-97) The artisanal craft begins to gain access to the art world even with the continuation of creating objects that represent the culture of Puerto Rico.107 The question stands whether or not the artisan has the opportunity of transforming into an artist. This brings to light how artisans and cultural artifacts began the journey into the contemporary art world. (Figure 98) Jorge L. Dávila stated: "The creation of arts and crafts in Puerto Rico has always been an essential element of our culture and tradition.”108 (Figure 99) Even though the use of the vejigante mask has diminished, it will always be an iconic representation of the Carnival. Its existence is still prevalent through the artisans and art historians who continue to preserve the tradition. (Figure 100)

\footnotetext{
105 Insight Guides, Insight Guides: Puerto Rico, vol. 109 (Singapore: APA Publications, 2007), 88.

106 Ramón López, Cuadernos De Cultura: EL Valor Histórico de la Artesanía Puertorriqueña, 6-31.

107 Ramón López, Cuadernos De Cultura: EL Valor Histórico de la Artesanía Puertorriqueña, 10. 108 Norberto Martell Morales and Héctor J. Rodríguez Torres, Las Caretas del Vejigante Ponceño, V.
} 


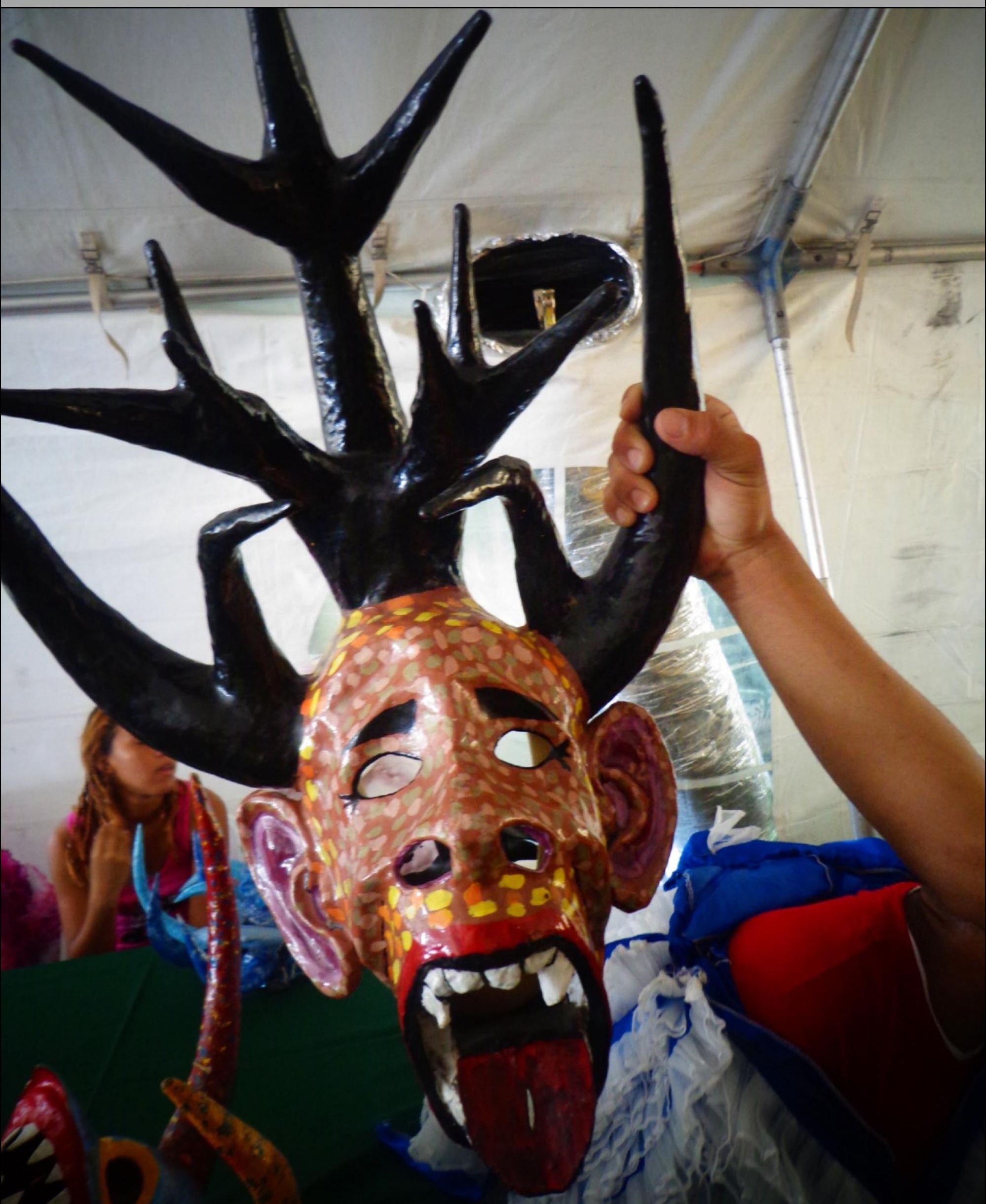




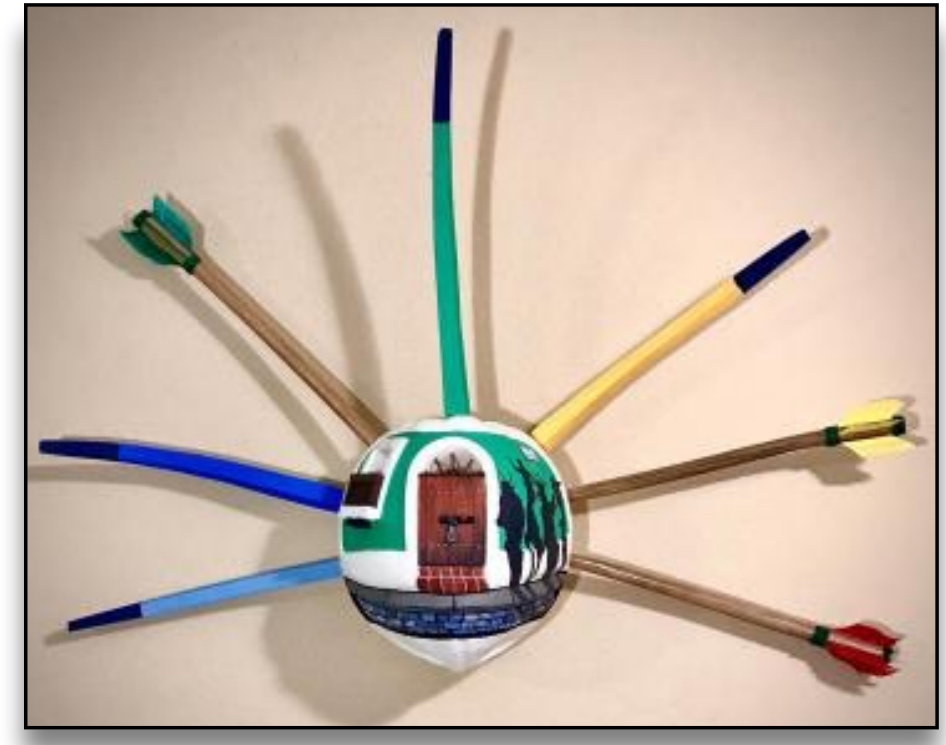

Figure 96 Untitled [digital image].

Retrieved June 20, 2020 from https:// conectatetvpr.com/impresionanteexhibicion-de-mascaras-artesanalesrinde-tributo-al-viejo-san-juan/

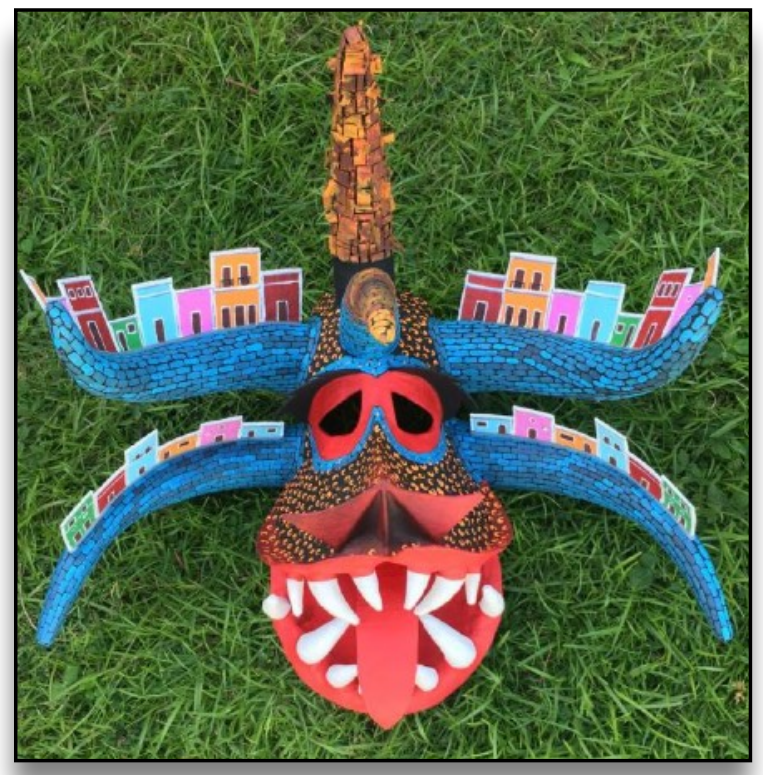

Figure 97 Untitled [digital image]. Retrieved June 20, 2020 from https://conectatetvpr.com/ impresionante-exhibicion-de-mascaras-artesanalesrinde-tributo-al-viejo-san-juan/ 


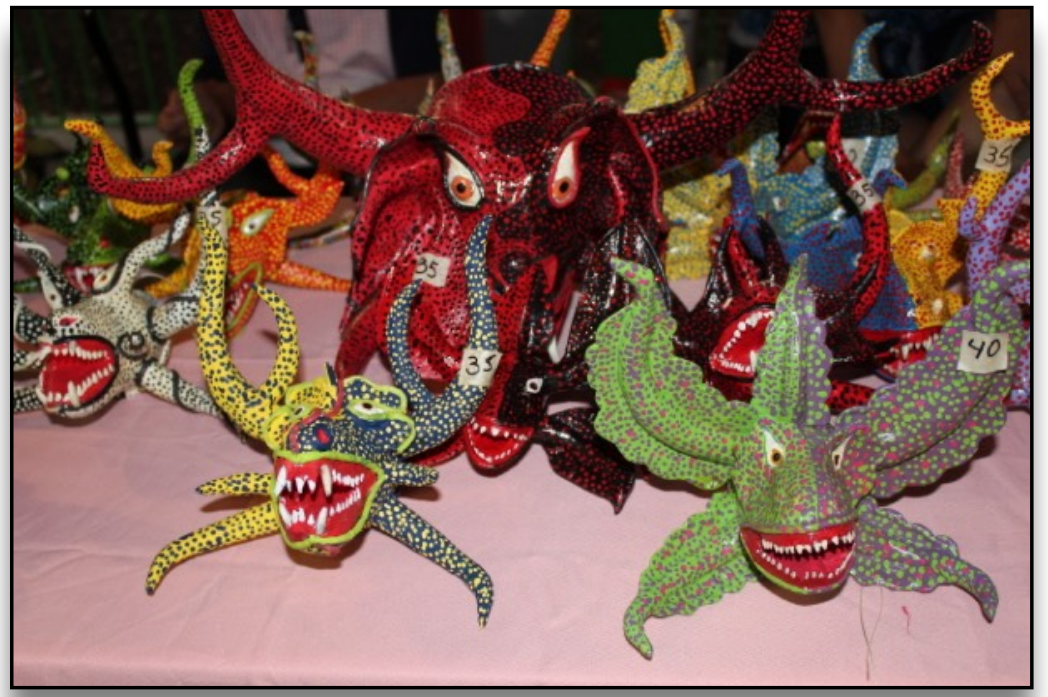

Figure 98 Artisan Table with Mass Production of Various Sizes of Vejigante Masks, Carnaval Ponceño 2017 [digital image]. By Author. February 24, 2017

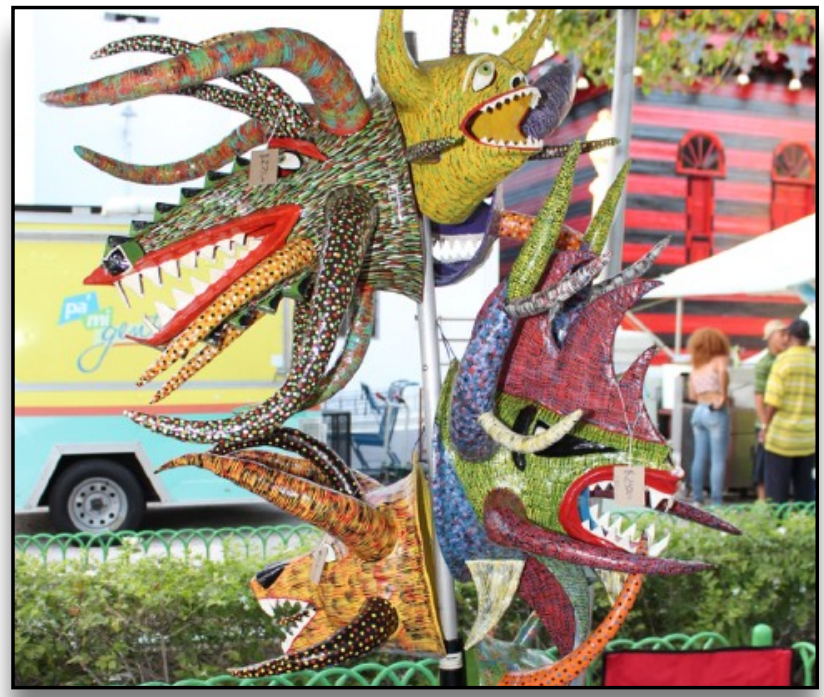

Figure 99 Artisan Table with Vejigante Masks and other Products, Carnaval Ponceño 2017 [digital image]. By Author. February 24, 2017

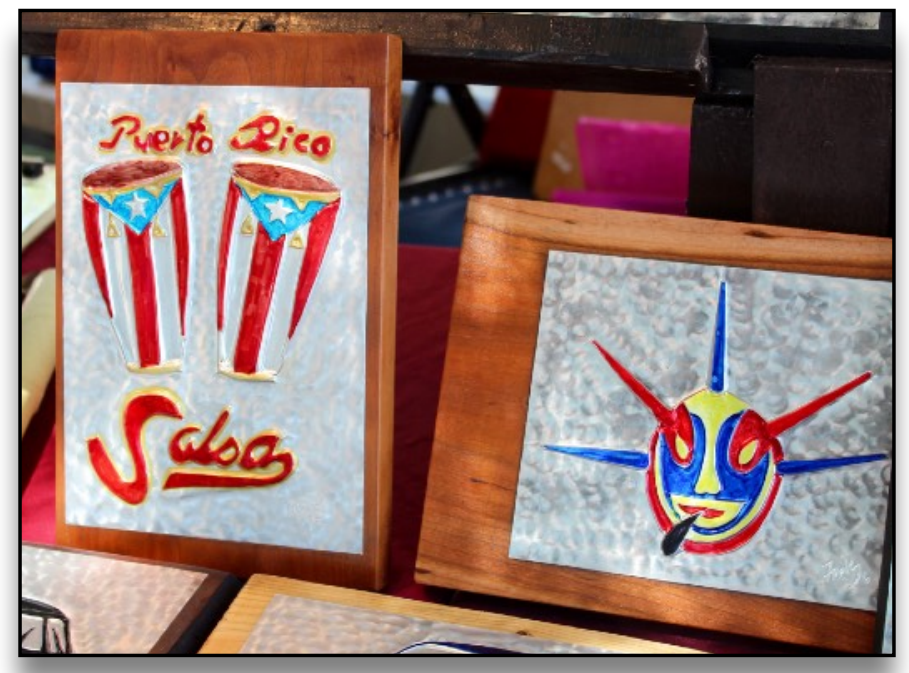

Figure 100 Artisan Table with Artisinal Objects, Carnaval Ponceño 2017 [digital image]. By Author. February 24, 2017 


\subsection{Tourist Trinkets vs. Folkloric Objects}

Puerto Rico was dependent on tourism. It is stated in the Almanaque Puertorriqueño Asenjo - 1939 - that tourism was one of the main contributors in the economical support of Puerto Rico. ${ }^{109}$ From past to present, the island was, and is, advertised as a tropical paradise to attract tourists. (Figure 101-104) And to this day, Puerto Rico has a constant flow of tourism to the island.

In the late 1800 s, Puerto Rico was known for its vast agricultural economy. Furthermore, Ponce, currently the fourth largest city in Puerto Rico, (Figure 105) experienced economic growth in the second half of the 19th century due to the introduction of sugar plantations, labored by slaves and managed by foreign families. ${ }^{110}$ This is an example of the preservation of their advancement and conservation in agricultural history. Ponce was acknowledged as being the economic and cultural capital of the south. When the USA invaded the Puerto Rico in 1898,111 the export of Puerto Rican goods began to diminish. The establishment of the USA centralist political system and reduction of exports to Cuban and Spanish markets identified the decline of its

\footnotetext{
109 “Enero,” Almanaque Puertorriqueño Asenjo, 1939), 6.

110 “Ponce,” Art Nouveau European Route : Cities, accessed February 5, 2020, http://www.artnouveau.eu/en/city.php? id=44).

111111 "Ponce,” Art Nouveau European Route : Cities, accessed February 5, 2020, http://www.artnouveau.eu/en/ city.php?id=44).
} 
socioeconomic importance. 112 The export industry's recession transitioned its focus from local economies to tourism.

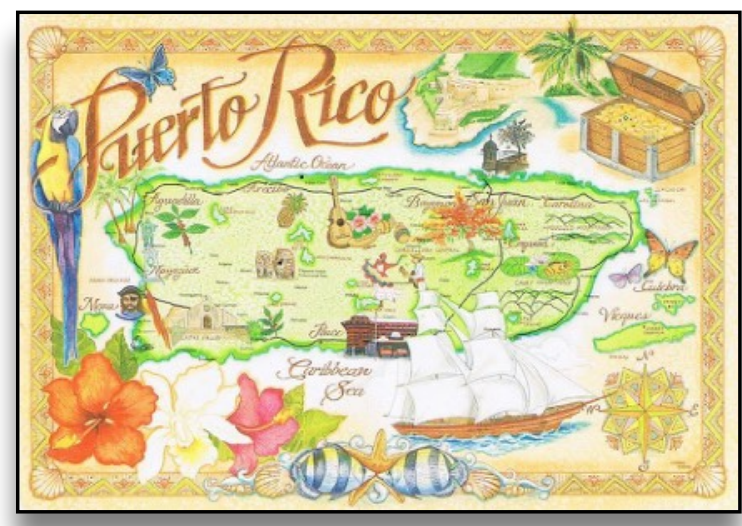

Figure 101 Puerto Rico Postcard [digital image]. Retrieved June 20, 2020 from http:// postcardcollector.org/forum/index.php? $\mathrm{p}=\% 2 \mathrm{Fdiscussion} \% 2 \mathrm{~F} 640 \% 2 \mathrm{Fmap}$-post-cardsvour-area-and-more $\% 2 \mathrm{Fp} 1$

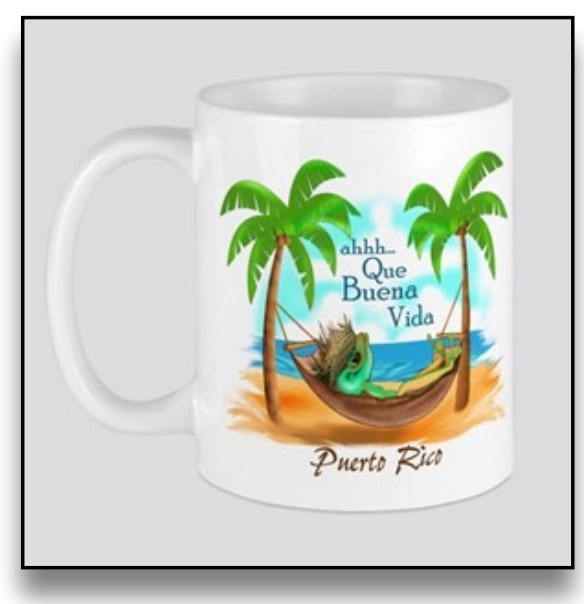

Figure 103

Puerto Rico

Coqui Mugs -

CafePress [digital

image]. Retrieved

June 20, 2020

from https://

www.cafepress.co

$\mathrm{m} /$ +puerto-rico-

coqui + mugs

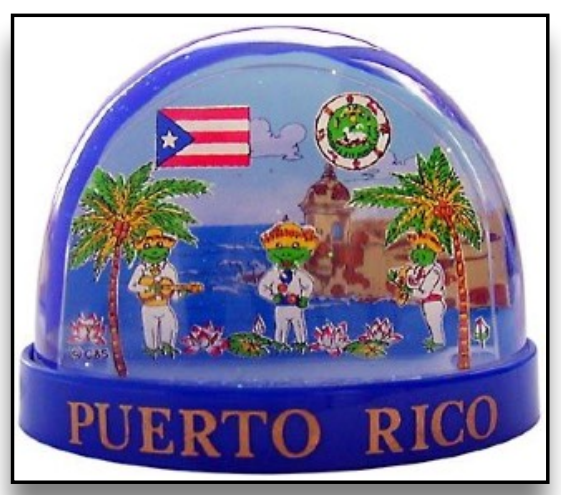

Figure 102 Puerto Rico Souvenir Snow Globe [digital image].

Retrieved June 20, 2020 from https://

www.museumofthemode rnsnowglobe.com/ collection

112 “Ponce," Art Nouveau European Route : Cities, accessed February 5, 2020, http://www.artnouveau.eu/en/city.php? $\mathrm{id}=44)$.

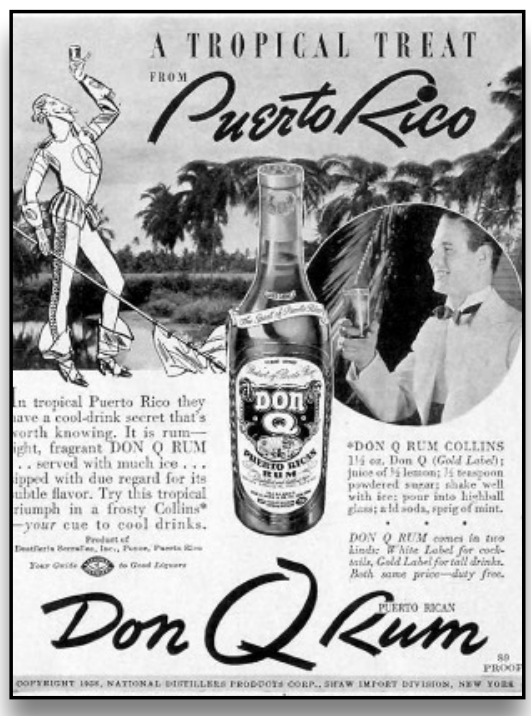

Figure 104 Puerto Rico Coqui Mugs CafePress [digital image]. Retrieved June 20, 2020 from https:// www.cafepress.com/ +puerto-ricocoqui + mugs 


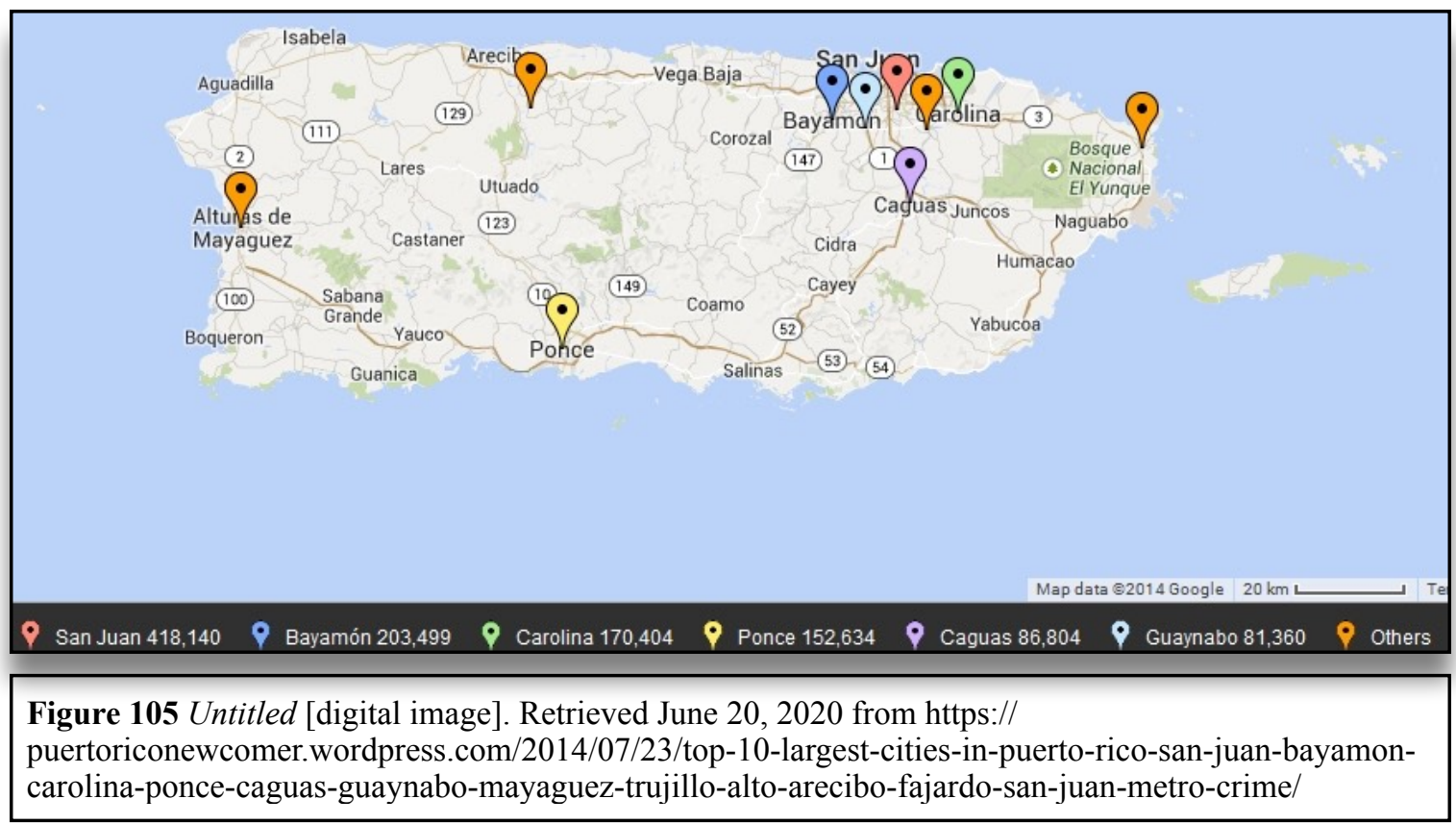

Tourism is one of the biggest contributors to the initial development of the Puerto Rican economy ${ }^{113}$ since the USA invasion. The presence of artisans within the culture, for touristic gains exploit the vejigante as a tourist attraction. Furthermore, tourism impacted the vejigante mask and granted access to cross into other cultures. This provided a platform to the continuous change and evolution of its conceptual meaning, traditional construction, and symbolism through the facilitated dialogue between Puerto Rican culture and American culture. (Figure 106)

113 “Enero," Almanaque Puertorriqueño Asenjo, 1939), 6. 


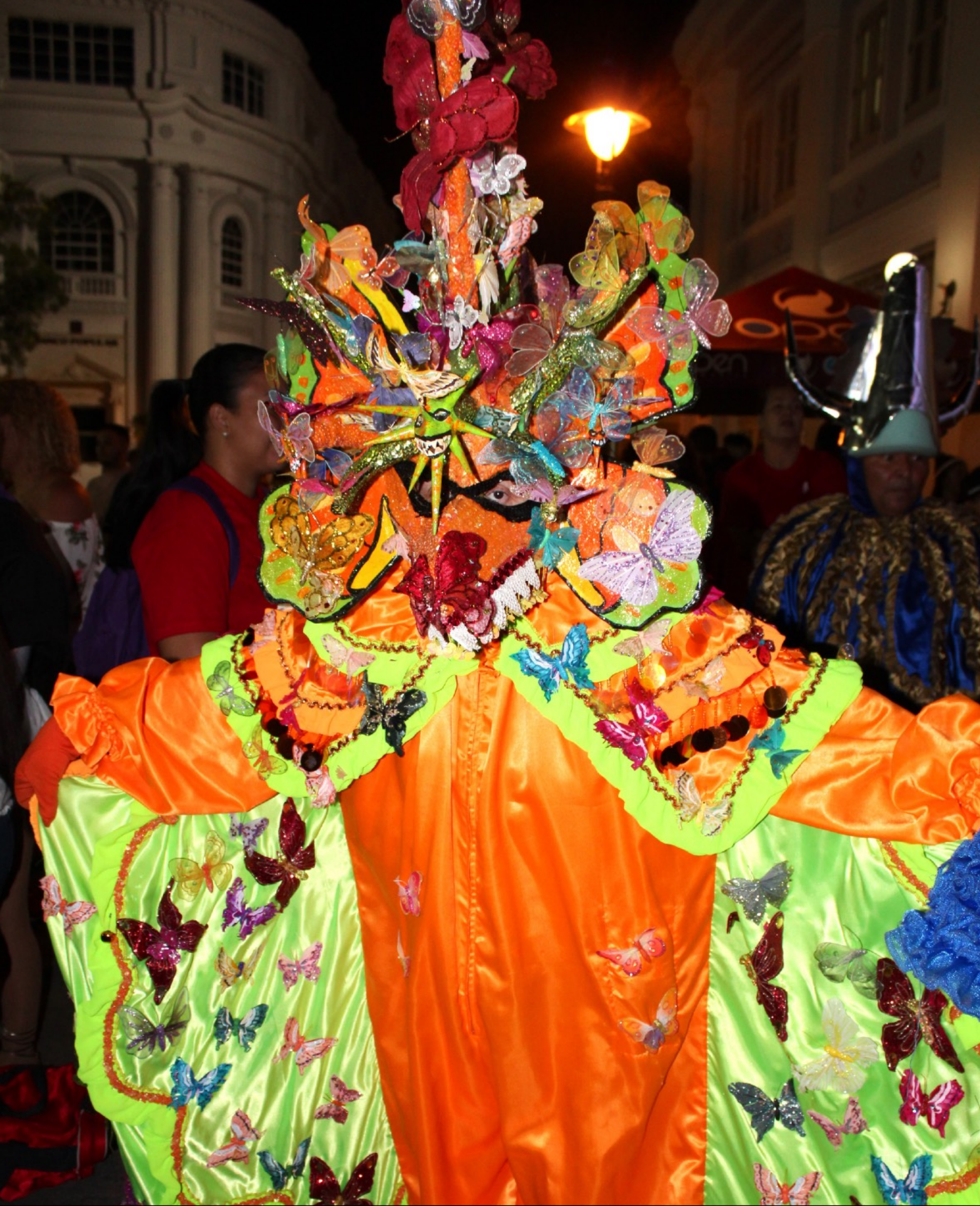


Puerto Rico has been established as a tourist destination. More often than not, the tourists who visit the island desire tangible objects as proof of the travels. The touristic consumer demand has introduced a kitsch/cliche type of artisanal craft which certain elements are used to coax buyers to purchase exaggerated portrayals and misrepresented concepts of Puerto Rico. Oddly enough, Puerto Ricans have embraced this false imagery. And further, they have endorsed it by means of practicing this touristic consumerism. Ramon López addresses this in his book El Valor Histórico de la Artesanía Puertorriqueña, and identifies this problem as "the culture of tourism." $114 \mathrm{He}$ claims that this ideology of tourism is no accident, but rather, a direct and purposeful shift towards a false illusion of exotic life. ${ }^{115}$

...[T] oday the conditions have changed. We have the responsibility of repossessing the plastic richness from our specific locations in our American countries and enrich the artistic manifestations with the color and vitality that we carry in our veins. We value the Afro-Caribbean visual and visual arts that are exposed here as very concrete expression which helps to overcome the invisibility that for such a long time has stigmatized our reality and our history. ${ }^{116}$

López states that there are "genuine" artisanal souvenirs, (Figure 107) but they have been simplified and morphed with "superficial elements" to quench the thirst for the exotic

\footnotetext{
114 Ramón López, Cuadernos De Cultura: EL Valor Histórico de la Artesanía Puertorriqueña, 11.

115 Ramón López, Cuadernos De Cultura: EL Valor Histórico de la Artesanía Puertorriqueña, 11.

116 Fernando Cros, Marta Morena Vega, and María Elba Torres Muñoz, “Tradiciones Afrocaribeñas: Espiritualidad, Arte Y Resistencia,” Tradiciones Afrocaribeñas: Espiritualidad, Arte Y Resistencia § (2007), 23.
} 
illusion. ${ }^{117}$ While the positive aspects are clear, as this is a source of income for the artisans, and elevates tourism revenue in Puerto Rico, but when the consumer is a resident born into the culture, this then distorts the understanding of Puerto Rican history and heritage. López adds, "The Puerto Rican people started consuming the foreign souvenirs, to identify with them and to accept them as their own false, cheapen images."118 The tourism has affected the culture and has alerted what Puerto Ricans identify with, and inevitable impacting the traditions and identity.

Nonetheless, the artisans thrive through the touristic outlet, but the false representation of Puerto Rico cannot be justified. The artisans creates works that are "exotic illusions,"119 by combining "superficial objects"120 with "superficial elements"121 creating conformative pieces that the tourists expect and desire from Puerto Rico. ${ }^{122}$ (Figures 108-110) Through the depiction of artisans, Puerto Ricans began to accept this as a reality. Furthermore, this is an example of how tourism and Americanization start to influence the culture of the island and its residents. In addition, these factors also impact misconception of the vejigante mask. The mask recreation focus on aesthetics rather than

\footnotetext{
117 Ramón López, Cuadernos De Cultura: EL Valor Histórico de la Artesanía Puertorriqueña, 10.

118 Ramón López, Cuadernos De Cultura: EL Valor Histórico de la Artesanía Puertorriqueña, 10.

119 Ramón López, Cuadernos De Cultura: EL Valor Histórico de la Artesanía Puertorriqueña, 11.

120 Ramón López, Cuadernos De Cultura: EL Valor Histórico de la Artesanía Puertorriqueña, 11.

121 Ramón López, Cuadernos De Cultura: EL Valor Histórico de la Artesanía Puertorriqueña, 11.

122 Ramón López, Cuadernos De Cultura: EL Valor Histórico de la Artesanía Puertorriqueña, 11.
} 
historical meaning in order to appeal to the tourist consumer. While this decreased the authenticity of the vejigante, this also enabled the transition of the mask into art. This can be recognized as positive from an artistic perspective, although, it is also negative due its detrimental impact to heritage and culture.

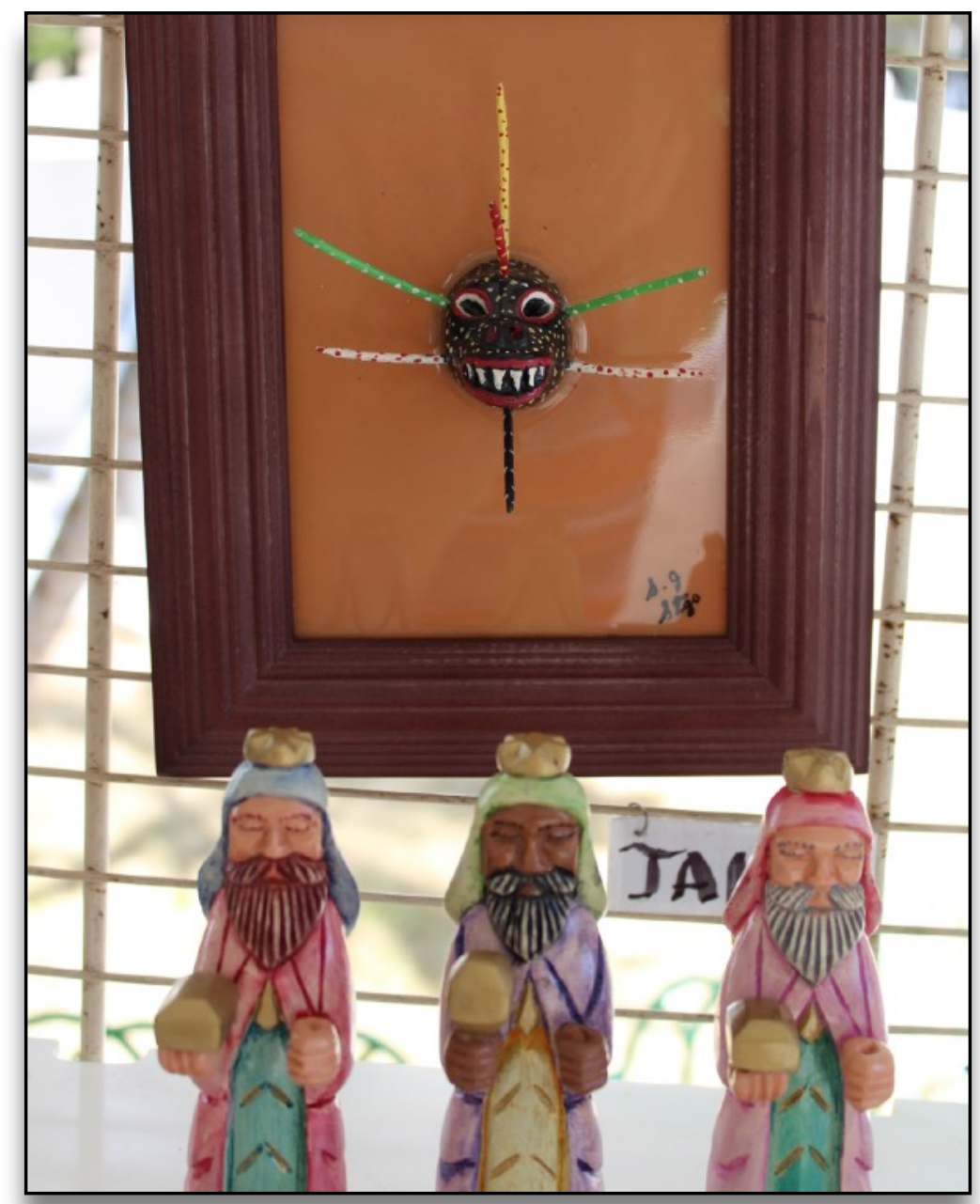

Figure 107 Artisan Table Displaying a Vejigante and the Wise Kings, Carnaval Ponceño 2017 [digital image]. By Author. February 24, 2017 


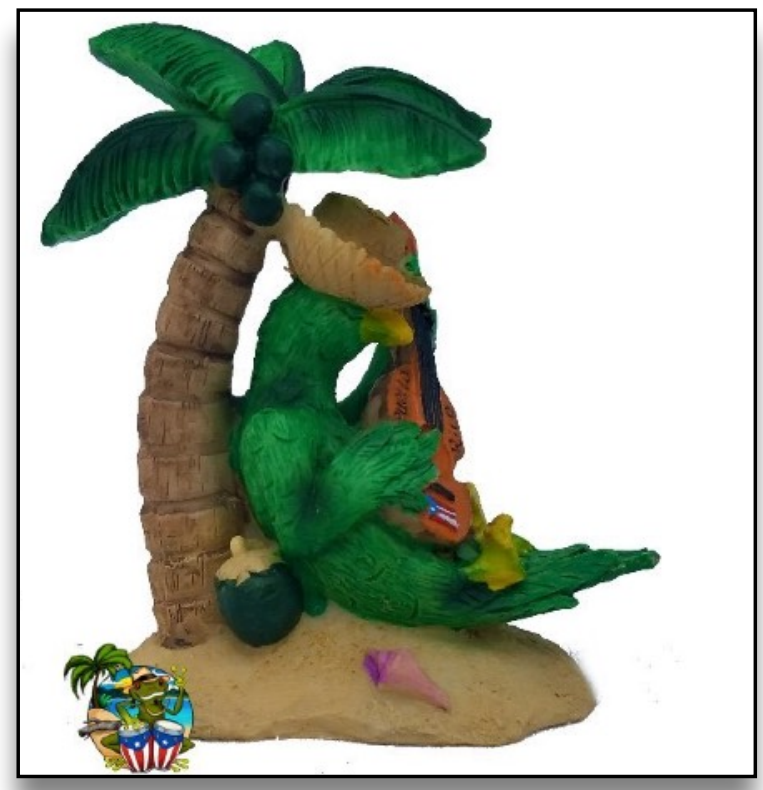

Figure 108 Puerto Rico Flag \& Cotora Figures 4" Inches [digital image]. Retrieved June 20, 2020 from https://prsouvenirs.com/index.php? main_page $=$ product_info\&cPath $=21 \&$ products_id $=539$

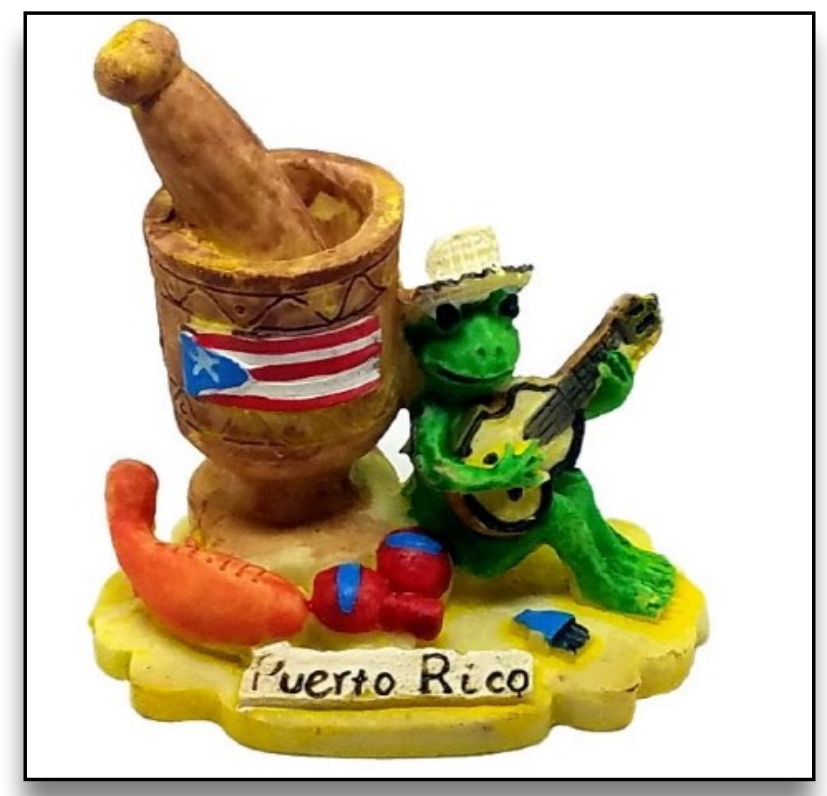

Figure 109 Puerto Rico Coqui \& Pilon Figures 2.5" Inches [digital image]. Retrieved June 20, 2020 from https://prsouvenirs.com/index.php?

main_page $=$ product_info\&products_id $=592$

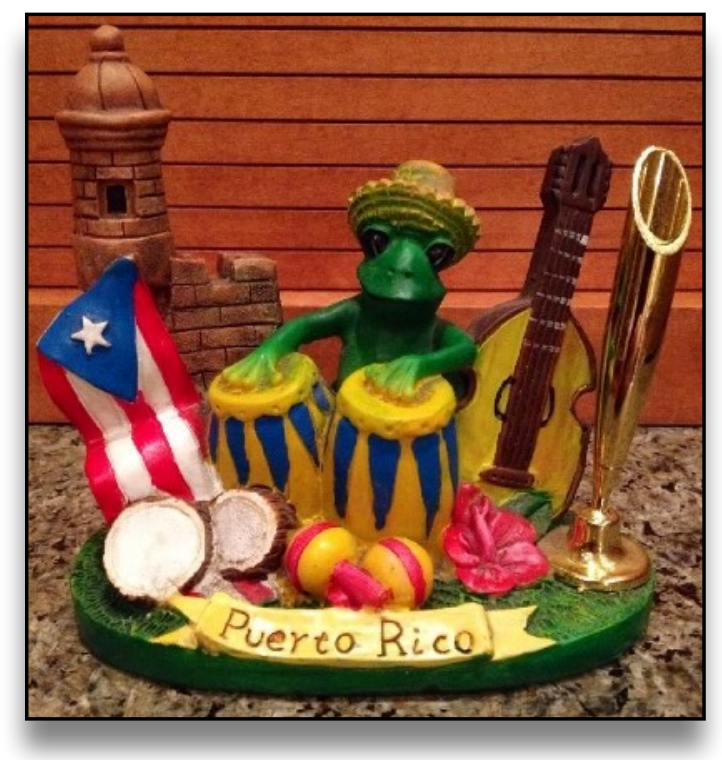

Figure 110 US Territory Souvenirs \& Memorabilia [digital image]. Retrieved June 20, 2020 from https://www.pinterest.com/pin/ $321866704597667460 /$ 
The vejigante mask, specifically from Ponce, has evolved and adapted to the Americanized culture that has permeated the Puerto Rican culture. On the other hand, the Loíza vejigante mask maintained its accurate depiction. Although there are interpretation of the mask from Loíza, its evolution is at a lesser degree compared to the mask from Ponce. This can be attributed to the materials and techniques used for either vejigante mask creation. While the papier-mâché method enables the mask from Ponce to be sculpted up, the mask from Loíza must be carved out. It was stated by Humberto Figueroa: "The [vejigante] mask [is] a folk object is an expression as a plastic and formal exercise that provides the space for the imagination that is nourished by ancient iconography and contemporary sensitivity." 123

Artists such as Alberto González Negrón, date of birth unknown, began to break from the traditional representation of the vejigante. He began to challenge the classical form of the mask, such as the notion of symmetry, and introduced various asymmetrical forms. (Figure 111) Alberto also decorated his masks with a controversial style of a modern art painter: Pollock. "Paul Jackson Pollock (January 28, 1912 - August 11, 1956) was an American painter and a major figure in the abstract expressionist movement. $\mathrm{He}$ was well-known for his unique style of drip painting."'124 (Figure 112-113) The artisans

\footnotetext{
123 Humberto Figueroa, “Mascara: La Faz Revelada," Mascara: La Faz Revelada (Instituto Cultural Puertorriqueña, 2002).

124 Tate, “Jackson Pollock 1912-1956,” Tate, January 1, 1970, https://www.tate.org.uk/art/artists/jacksonpollock-1785).
} 
and artists that experimented with various techniques of the decorative paint of the vejigante mask explored: "expressionism, abstract, pointillism, realism or cubism." 125 The crossover of the mask into contemporary art is attributed to the personal expressions of the artist: "The mask transcends the customary craftsmanship and becomes a piece of art, sculptural, and pictorial." 126 And with these depictions, the artists begin to redefine the mask. (Figures 183-184) As artisans and artists began to expand on the traditional methods and combined contemporary art techniques with a folkloric object, the mask had then entered the art world in full force. Although the vejigante's defining cultural aspects deteriorated, the mask's reinvention joined the artisans and artists on equal grounds.

\footnotetext{
125 Alberto Gonzáles, “Nueva Técnica En Máscaras,” El Reportero, January 8AD).

${ }^{126}$ Alberto Gonzáles, “Nueva Técnica En Máscaras,” El Reportero, January 8AD).
} 
Figure 111 A Modern Interpretation of a Vejigante by Alberto González Negrón, Circa 1988- 89, Owned by Humberto Figueroa [digital image]. By Author. February 4, 2018

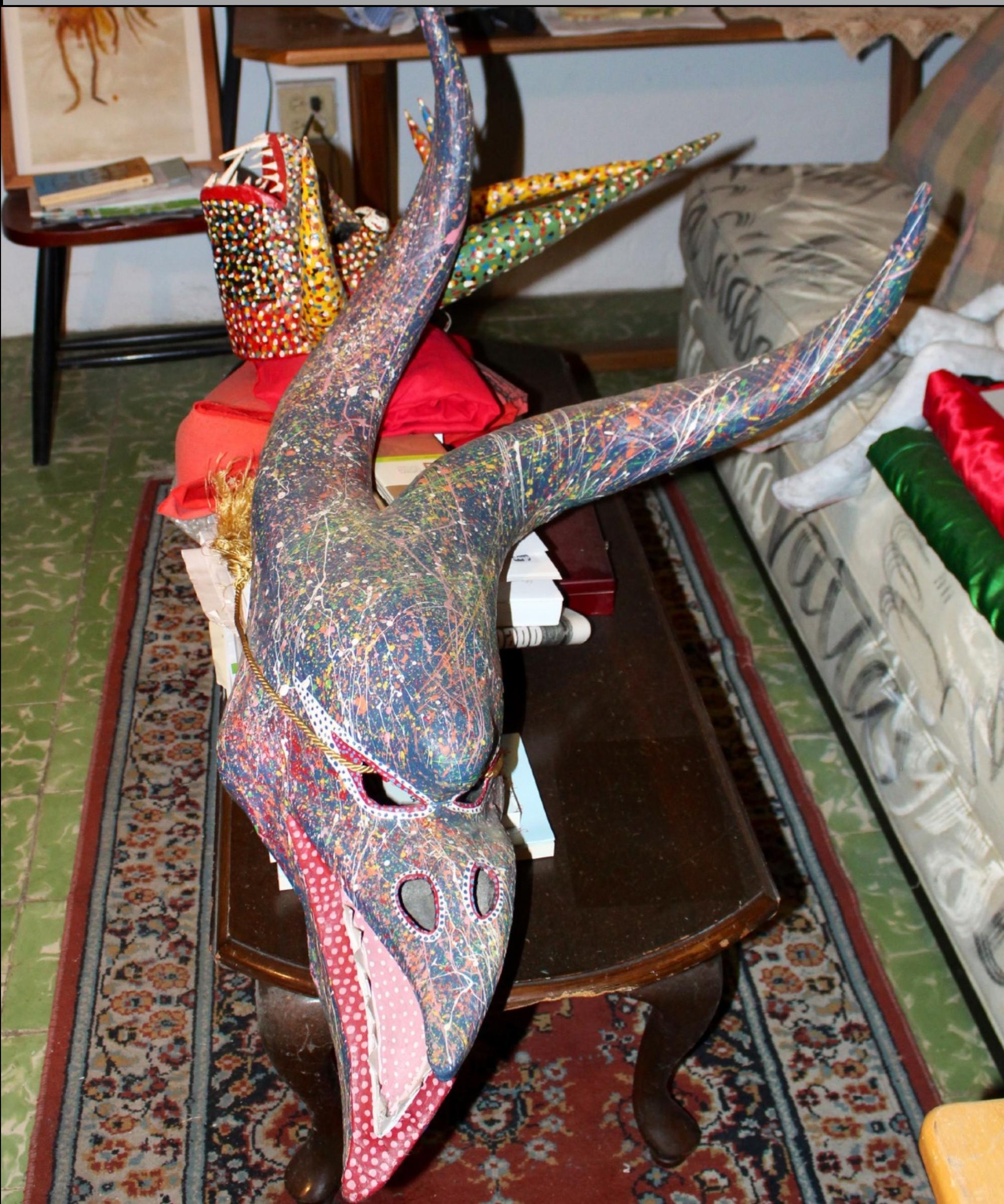




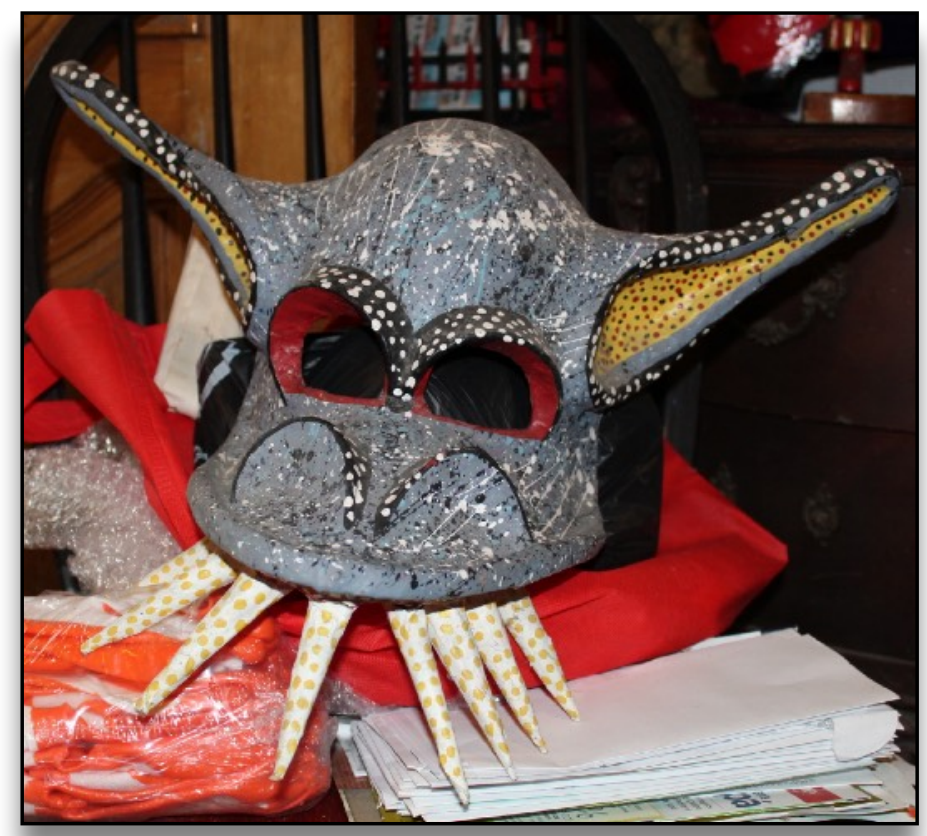

Figure 112 A Modern Interpretation of a Vejigante by Alberto González Negrón, Circa 1988- 89, Owned by Humberto Figueroa [digital image]. By Author. February 4, 2018

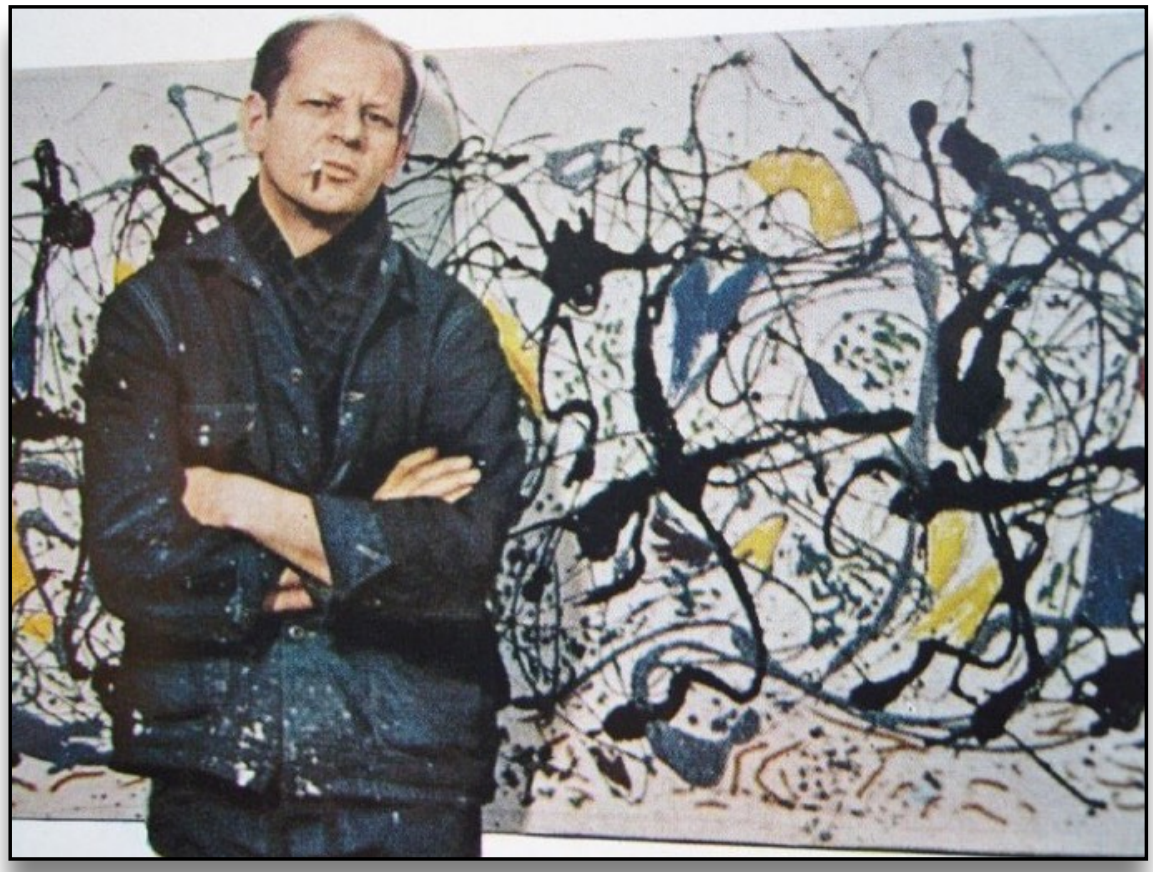

Figure 113 Jackson Pollock in front of 'Summertime: Number 9A' for LIFE magazine, 1949 [digital image]. Retrieved June 20, 2020 from https://www.kazoart.com/ blog/en/art-in-a-minute-jackson-pollock/ 


\subsection{Decolonization of Artifacts}

The artists from Puerto Rico, specifically Ponce, continue to use cultural heritage as a main subject of their artwork. Although, this does not place the artist within the artisanal category:

When we evaluate the masks in museums, exhibition halls, in warehouses or in the homes of collectors, we are before an object that, in its time, was an instrument of transformation or transportation. As a work of art, the mask, due to its external and superficial appearance, can hide its purpose. As cultural material, the masks are studied by ethnographers, anthropologists, artists, theater men, artisans, folklorists, sociologists and historians among others interested in these three-dimensional objects. Throughout time the mask has served as an object that covers and conceals, hides and reveals the real face of the visible and invisible world. Behind the masks there is transformation or metamorphosis ... ${ }^{127}$

The environment it is represented in has an effect on its representation and becomes the direct frame of reference. It is important to recognize and distinguish the traditional state from its current contextual definition. "All these processes point to something important: the elaboration of an anti-colonial image."128 It is documented as far back as before the 1960s, the depiction of "socially committed art," (Figures 114-116) and the struggle with "nationalism and identity issues." 129 The primitive symbolism of the Carnival ceremonies

\footnotetext{
127 Humberto Figueroa, "Mascara: La Faz Revelada," Mascara: La Faz Revelada (Instituto Cultural Puertorriqueña, 2002).

128 Ramón López, Cuadernos De Cultura: EL Valor Histórico de la Artesanía Puertorriqueña, 31.

129 Fodor's Travel Guides, Fodor's Puerto Rico, vol. 8 (New York: Fodor's Travel, 2014).
} 
was a distorted interpretation of a culturally assimilated religion. This constructed new customs and rituals that identify Puerto Rican heritage. Even though the vejigante mask was a symbol of "anti-colonialism," 130 it re-entered the context of colonialism through USA popular culture brought to Puerto Rico by tourism and Americanization.

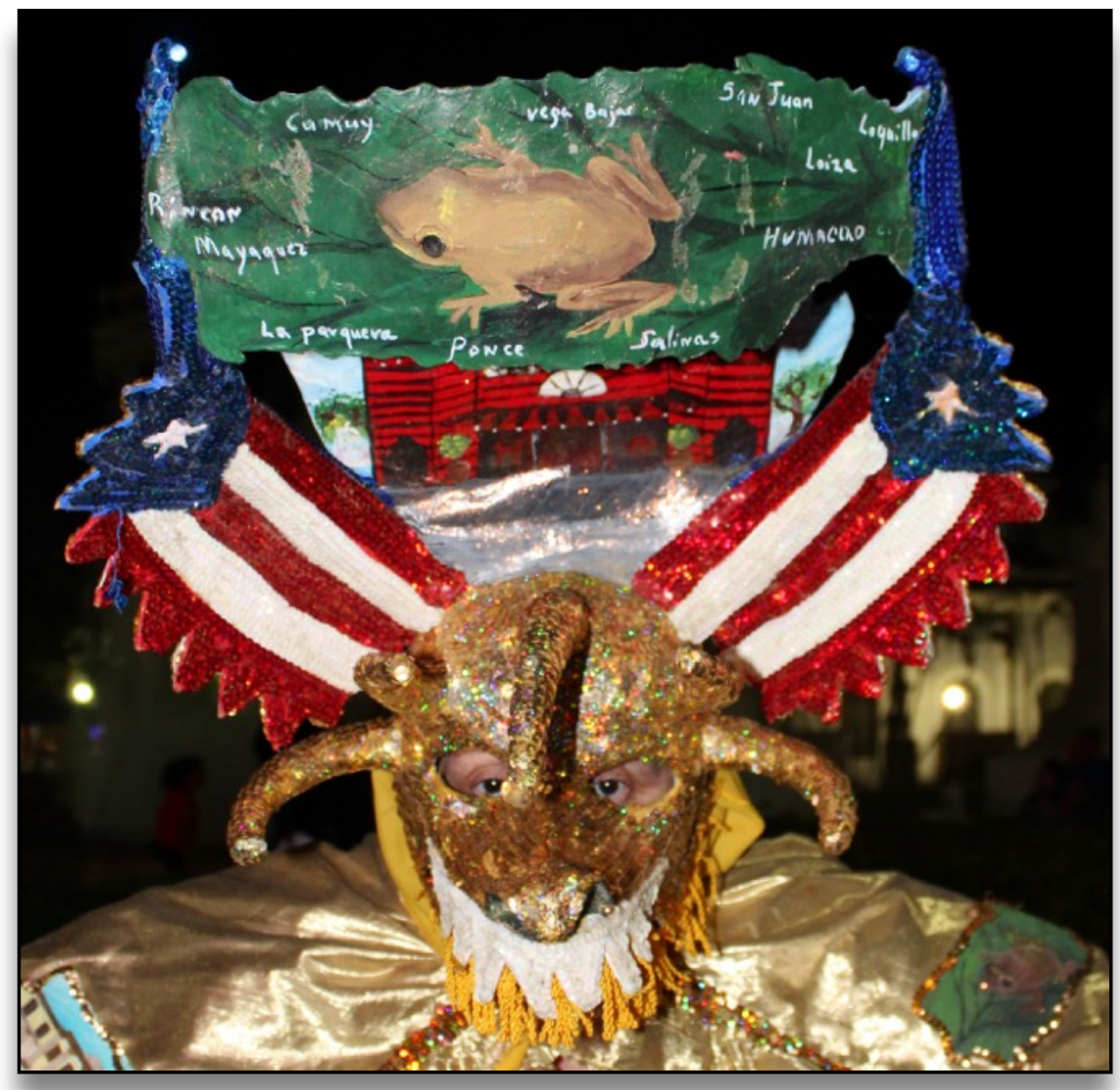

Figure 114 A Modern Interpretation of a Vejigante Mask, Carnaval Ponceño 2017 [digital image]. By Author. February 24, 2017

130 Ramón López, Cuadernos De Cultura: EL Valor Histórico de la Artesanía Puertorriqueña, 31. 


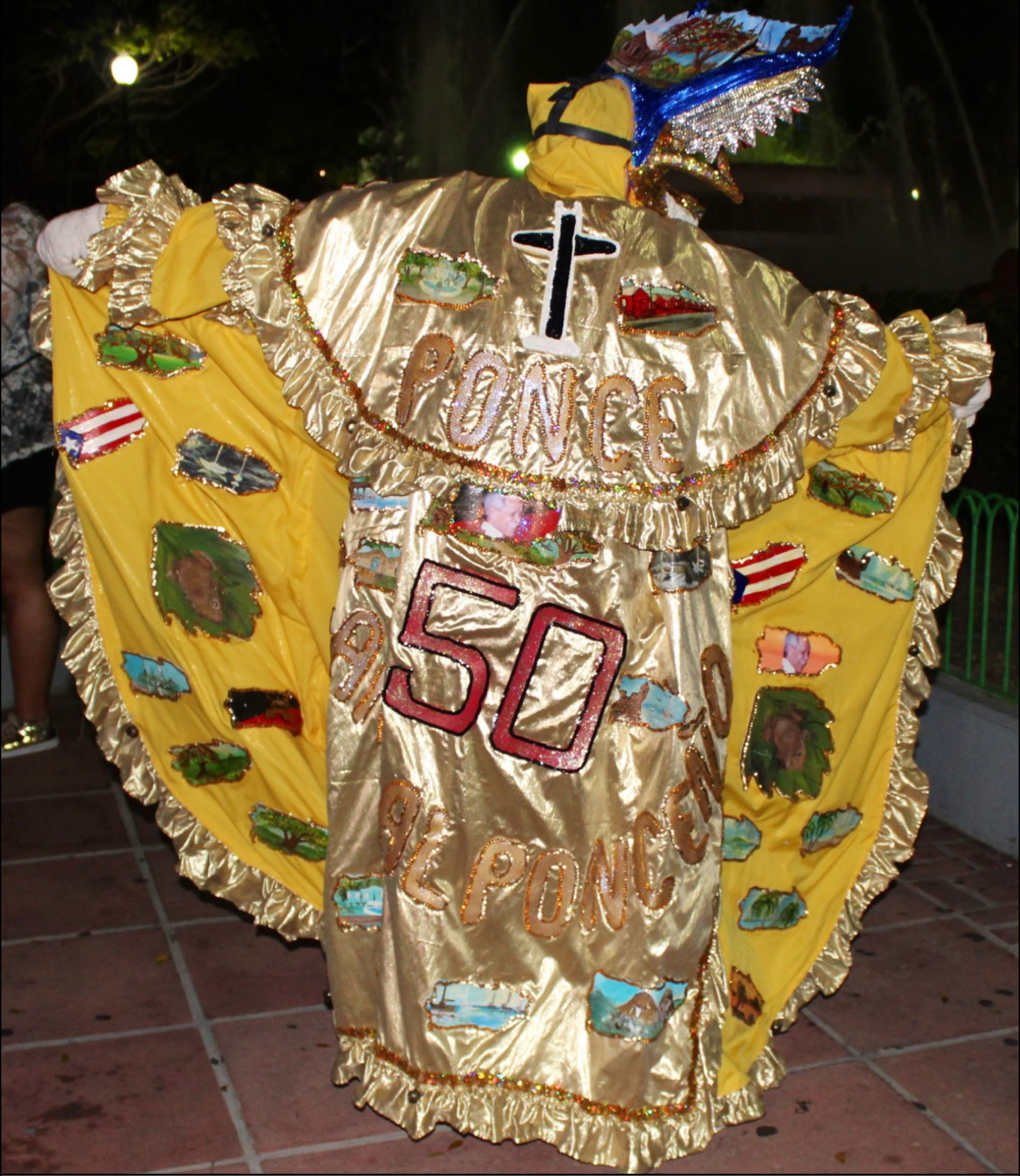

Figure 116 A Modern interpretation of a Vejigante, Carnaval Ponceño 2017 [digital image]. By Author. February 24, 2017 
Vejigante masks and other cultural objects are often found within the anthropological section of any given museum. This is because they are only considered artifacts. Although it is crucial to preserve of antique vejigante masks, the existence of contemporary interpretations should be introduced to the dialogue as well:

It's not just about inviting indigenous and other marginalized people into the museum to help the institution improve its exhibitions; it's an overhauling the entire system. Otherwise, museums are merely replicating systems of colonialism, exploiting people of color for their emotional and intellectual labor within their institutions without a corollary in respect and power. ${ }^{131}$

Cultural art is confined because of its subject matter. To begin the decolonization of the museum, all artwork must be appreciated equally. Furthermore, the institutions must deconstruct their former reasoning of categorizing and sub-sectioning art:

...[T]he decolonizing project will...have difficult conversations and reflections about the meaning of museums and who the institutions are intended to serve. New models of decolonization will continue to arise and give inspiration to other institutions struggling to figure out how to change their own institutions. But [an] open and true dialogue will remain an integral point with all members of communities. 132

The concept of decolonization within the art world will begin with the art institutions.

"Some museums are developing strategic plans to redevelop their conception of their

\footnotetext{
131 Elisa Shoenberger, "What Does It Mean to Decolonize a Museum?,” MuseumNext, June 4, 2020, https:// www.museumnext.com/article/what-does-it-mean-to-decolonize-a-museum/).

132 Elisa Shoenberger, “What Does It Mean to Decolonize a Museum?,” MuseumNext, June 4, 2020, https:// www.museumnext.com/article/what-does-it-mean-to-decolonize-a-museum/).
} 
collection and auditing the institutions as a whole."133 The colonization of certain cultures irreversibly changed the perspective, and therefore the possibility of decolonizing the institutions. The presentation of historical artwork must change:

[Decolonizing] the art institution usually means reviewing the canon and questioning its ability to include different voices or perspectives (remembering that [decolonization] is not the same as diversity). It also includes the practice of going beyond the dominant cultural groups and resisting the reproduction of colonial taxonomies. ${ }^{134}$

The museum and its institution should have representatives of the culture to aid the accurate portrayal and depiction of the art and or artifacts. The narrative must be evaluated: "The struggle against the colonialism of yesterday and the Neo-colonialism of today has defined the Latin American culture."135 Following the discussion of decolonizing museums, vejigantes masks become a complex subject that represents the first wave of colonialism in Puerto Rico. The masks are probably one of the most popular artifacts of the culture of Puerto Rico. In reality, vejigantes are a result of the colonization of the island by Spain. Puerto Rico has long viewed Spain as the motherland. Quintín Rivera Toro captures accurately the essence of the two colonial powers, which have ruled

\footnotetext{
133 Elisa Shoenberger, “What Does It Mean to Decolonize a Museum?,” MuseumNext, June 4, 2020, https:// www.museumnext.com/article/what-does-it-mean-to-decolonize-a-museum/).

134 Zofia Cielatkowska, "Decolonising Art Criticism," Kunstkritikk, May 15, 2020, https://kunstkritikk.com/ decolonising-art-criticism/).

135 Katherine M. Hedeen, "Decolonizing Culture: Visual Arts, Development Narratives, and Performance in the Americas.," Latin American Research Review 40, no. 3 (2005): pp. 244-253, www.jstor.org/stable/3662834).
} 
Puerto Rico for over 500 years. He refers to Spain as "la madre España,"136 mother Spain, and the USA as "el padre norteamericano,"137 the North American father. Ironically, the vejigante mask is currently a symbol of pride and cultural identification, but in reality, is the direct result of colonization.

136 Quintín Rivera Toro, "Una cultura en llamas: arte puertorriqueño de resistencia en el siglo XXI," (PhD diss., Universitat Politècnica de València, 2019).

137 Quintín Rivera Toro, "Una cultura en llamas: arte puertorriqueño de resistencia en el siglo XXI," (PhD diss., Universitat Politècnica de València, 2019). 


\section{Chapter Four: Word-of-Mouth}




\subsection{Overview}

The participants of this study are three artists and four artisans/art historians from Puerto Rico. The participants were not chosen at random. The artists have either participated or witnessed several Carnivals in Ponce, or have been involved in the depiction of a contemporary interpretation of vejigantes. The four artisans and/or art historians were chosen for their knowledge on the subject and their influence on the community in relation to the theme of the Carnival. The participants were members of the community who focused on the perception of vejigantes.

Each set of questions were tailored to the individual groups. The questions were focused on the gradual change of the Carnival, from past to present. Each participant, from both groups began with the origins of the mask concept, and the basics of the mask, i.e. the materials used and the process of making a careta, and/or if they have acquired/ created any vejigante masks. The subject which followed was prevalent changes of the vejigante mask within the Carnival. The final discussion was focused on the shift of the vejigante mask into a contemporary context within the art community. Concluding with experiences that took place during the Carnival.

The interviews of the seven participants will showcase how generations continue the history and heritage by passing information through word-of-mouth. The locals' 
perspective of the Carnival is necessary in order to understand the representation of cultural history in Puerto Rico. The questions presented to both groups concludes the investigative evidence of word-of-mouth provided vital information not yet documented in any written resources. 


\subsection{Guidelines}

Each person willing to participate within the interviews agreed to the provided guidelines. Each were asked the same questions and permitted to contribute additional information. As well as, they were permitted to not answer any question. The interviews were video and audio recorded for the purposes of research. Not all answers received during the interviews were documented in this thesis. The interview questions follow: 


\subsection{Interview Guide}

\section{Interview for Artisans/Art Historians}

1. How are the vejigante masks made? What are the materials used?

2. What is the traditional color scheme of the vejigante? Please compare from past to present.

3. What is the meaning of the horns on the vejigante mask? Please compare from past to present.

4. How has the Carnival changed? Please compare from past to present.

5. Can you compare the difference from previous Carnivals to the presentday Carnival?

6. How do you see the Carnival changing in the future?

7. Do you think the culture and the influence of the Carnival celebration has had an effect on the people?

8. Do you believe locals have/had an accurate knowledge of the Carnival, specifically the purpose of the vejigantes in the Carnival? Please compare from past to present.

9. What are the origins of the vejigante from Ponce? And the vejigante from Loíza Aldea? 
10. Compare and contrast the vejigante mask from Ponce and the vejigante mask from Loíza Aldea.

11. Do the vejigantes from Ponce act different from vejigantes from Loíza Aldea?

12. How has the vejigante mask transformed from the careta antigua to what the people use currently?

13. Do you see the vejigante mask making as a dying art?

14. What changes have you seen in the vejigante mask from traditional representation to a contemporary context? Do you view the vejigante mask as contemporary art?

15. Any additional comments or recants. 


\section{$\underline{\text { Interview for Artists }}$}

1. What does the vejigante do? Please compare from past to present.

2. How does the vejigante move? Do they dance? Please compare from past to present.

3. How does the vejigante act? Please compare from past to present.

4. What does the vejigante eat? Please compare from past to present.

5. How does the vejigante sound like? Please compare from past to present.

6. What songs does the vejigante sing? Please compare from past to present.

7. How many horns does the vejigante have?

8. What colors do you see in a vejigante mask and costume, and have seen any change in color scheme? Please compare from past to present.

9. What is the vejiga? Why does the vejigante carry it? What does the vejigante do with it? And what does it represent?

10. Are vejigantes intimidating to you? Please compare from past to present.

11. Are the vejigantes masks scary to you? Please compare from past to present.

12. Does the vejigante costume have gender or race? Why? Please compare from past to present.

13. Was it acceptable for women to dress as a vejigante in the past? Please compare from past to present. 
14. Have you dressed as a vejigante? If so, how did it feel? Please narrate the experience.

15. Have you created any a vejigante mask? Or any art in relation to the theme? Please describe the experience.

16. Can you compare the difference from previous Carnivals to present-day Carnivals?

17. How has the vejigante mask transformed from the careta antigua to what the people use currently?

18. Can you see the presence of vejigantes in contemporary art? Please elaborate.

19. Any additional comments or recants. 
4.3 The Artisan and Historian Participants 


\subsubsection{Humberto Figueroa}

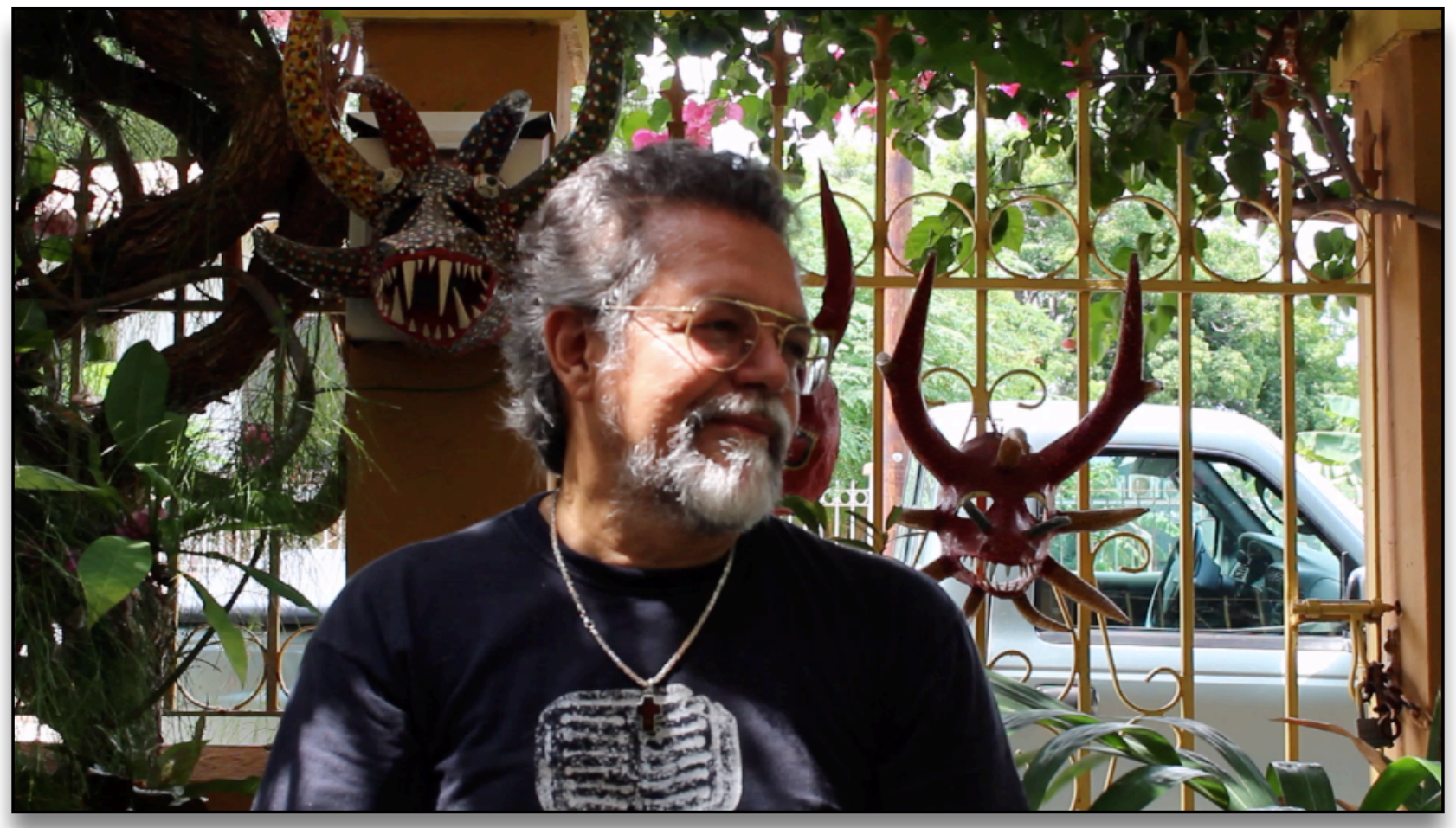

Figure 117 Humberto Figueroa, Art Historian [digital image]. By Author. February 4, 2018 
Humberto Figueroa completed Bachelors in Visual Arts in New York in 1979, later on he pursued a Master's degree in painting, drawing and installation. (Figure 117) Humberto's artwork focuses the exploration of religious objects linked to festivities and cultural Carnivals from the Caribbean, specifically from Puerto Rico. ${ }^{138}$ After his studies were completed, he returned to Ponce to learn the traditional methods of creating vejigante masks. 139

The most influential person within the community of artisans, for Humberto, was Juan Alindato, September 15, $1921^{140}$ — May 28, 2010.141 (Figure 118) Alindato is a was a well-established mascarero, mask artisan, during the 1950s in La Playa de Ponce. He was respected for his work within the artisan community. (Figure 119-120) Alindato was born into a family who traditionally created vejigante masks. He continued the tradition within his family, to the point, his wife helped him paint his masks. Humberto marks this as the beginning of women's involvement with the artisanal craft of vejigante mask making in Puerto Rico. Events such as this enabled women to enter into what was considered a "man's" activity. ${ }^{142}$

\footnotetext{
138 Humberto Figueroa, Interview by author, Video recording, Ponce, February 4, 2018.

139 Humberto Figueroa, Interview by author, Video recording, Ponce, February 4, 2018.

140 "Juan Alindato," National Endowment for the Arts National Endowment for the Arts, n.d.https://www.arts.gov/ honors/heritage/juan-alindato.

141 “Puerto Rican Mask Maker Juan Alindato García Dies," Repeating Islands, last modified May 29, 2010, https:// repeatingislands.com/2010/05/29/puerto-rican-mask-maker-juan-alindato-garcia-dies/.

142 Humberto Figueroa, Interview by author, Video recording, Ponce, February 4, 2018.
} 


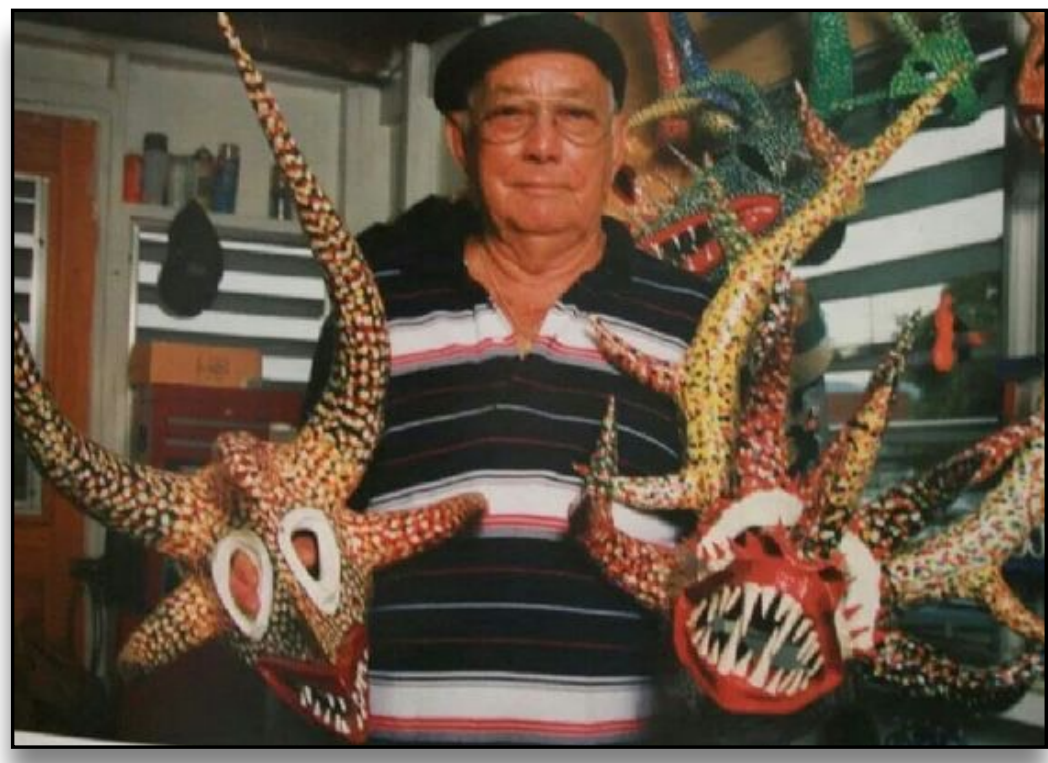

Figure 118 DON JUAN ALINDATO [digital image]. Retrieved June 20, 2020 from https://www.pinterest.com/pin/509258670344354932/

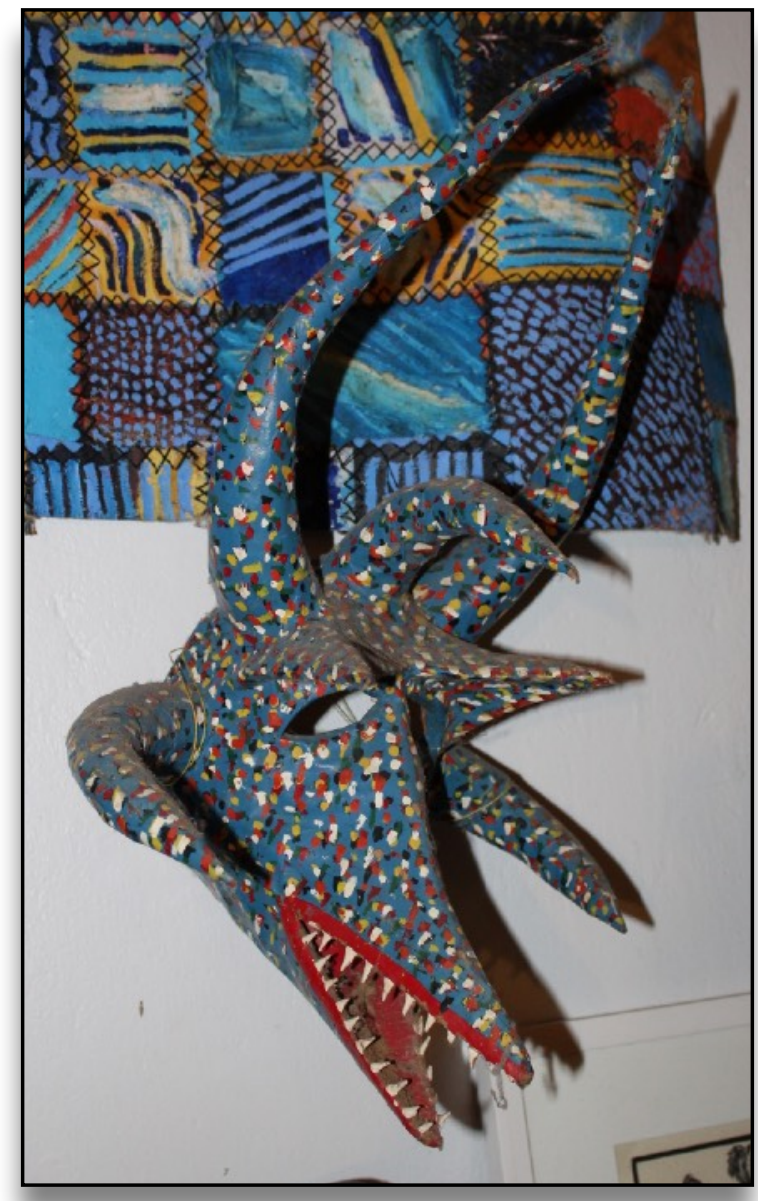

Figure 119 Vejigante Mask by Juan Alindato, Circa 1978- 1980, Owned by Humberto Figueroa [digital image]. By Author. February 4, 2018 


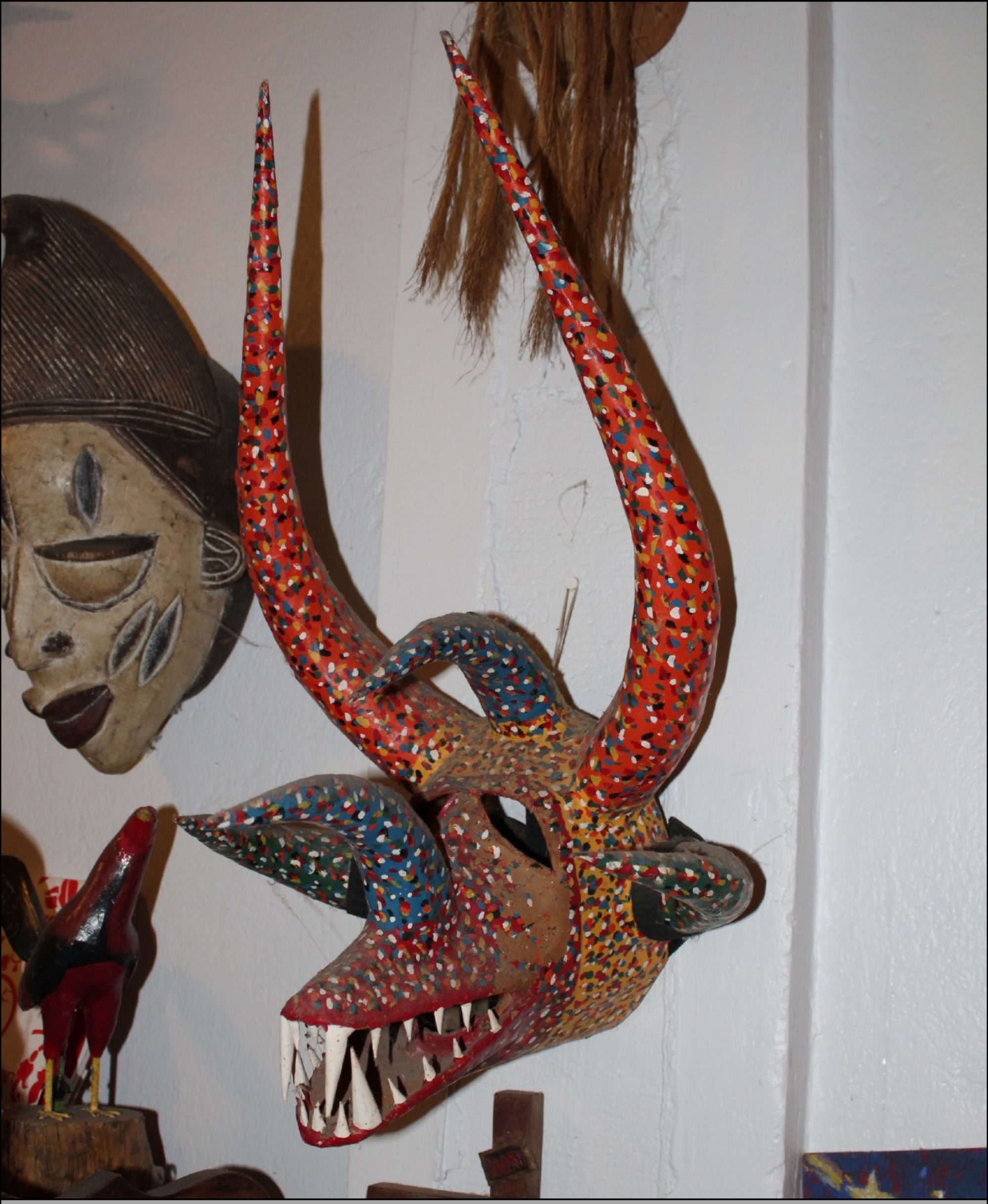

Figure 120 Vejigante Mask by Juan Alindato, Circa 1978- 1980, Owned by Humberto Figueroa [digital image]. By Author. February 4, 2018 
Humberto was captivated by the masks by Juan Alindato displayed during the Carnaval Ponceño. His work was contrasting to the other masks created at the time. His work marks the transition of the careta antigua to a work of art. Furthermore, Alindato's masks were representative of a modern art rather than a folkloric craft. ${ }^{143}$

Humberto turns the discussion to other well-known mascareros: the Caraballos. Miguel Angel Caraballo, born July 12, 1940, ${ }^{144}$ and Miguel Caraballo Jr., born May 5, $1966,{ }^{145}$ are a father and son duo that create iconic vejigante masks. ${ }^{146}$ (Figure 121) Humberto stated the Caraballo mask fans out and opens upward, creating a distinct, aesthetic. These vejigante masks are linear and precise. He added, the Caraballos have a unique technique for vejigante horns: The Caraballos create their own horn molds out of fiberglass. This allows them to create larger horns. (Figures 122-124) The technique is inspired by boat construction. ${ }^{147}$ The one-of-a-kind form and shape of the Caraballo mask distinguishes their work form other artisans.

\footnotetext{
${ }^{143}$ Humberto Figueroa, Interview by author, Video recording, Ponce, February 4, 2018.

144 Artesanias Caraballos, Facebook Interview, May 12, 2021.

145 Artesanias Caraballos, Facebook Interview, May 12, 2021.

146 Lorelei Albanese, "Like Father, Like Son," The San Juan Star, September 14, 1985, 19.

147 Humberto Figueroa, Interview by author, Video recording, Ponce, February 4, 2018.
} 

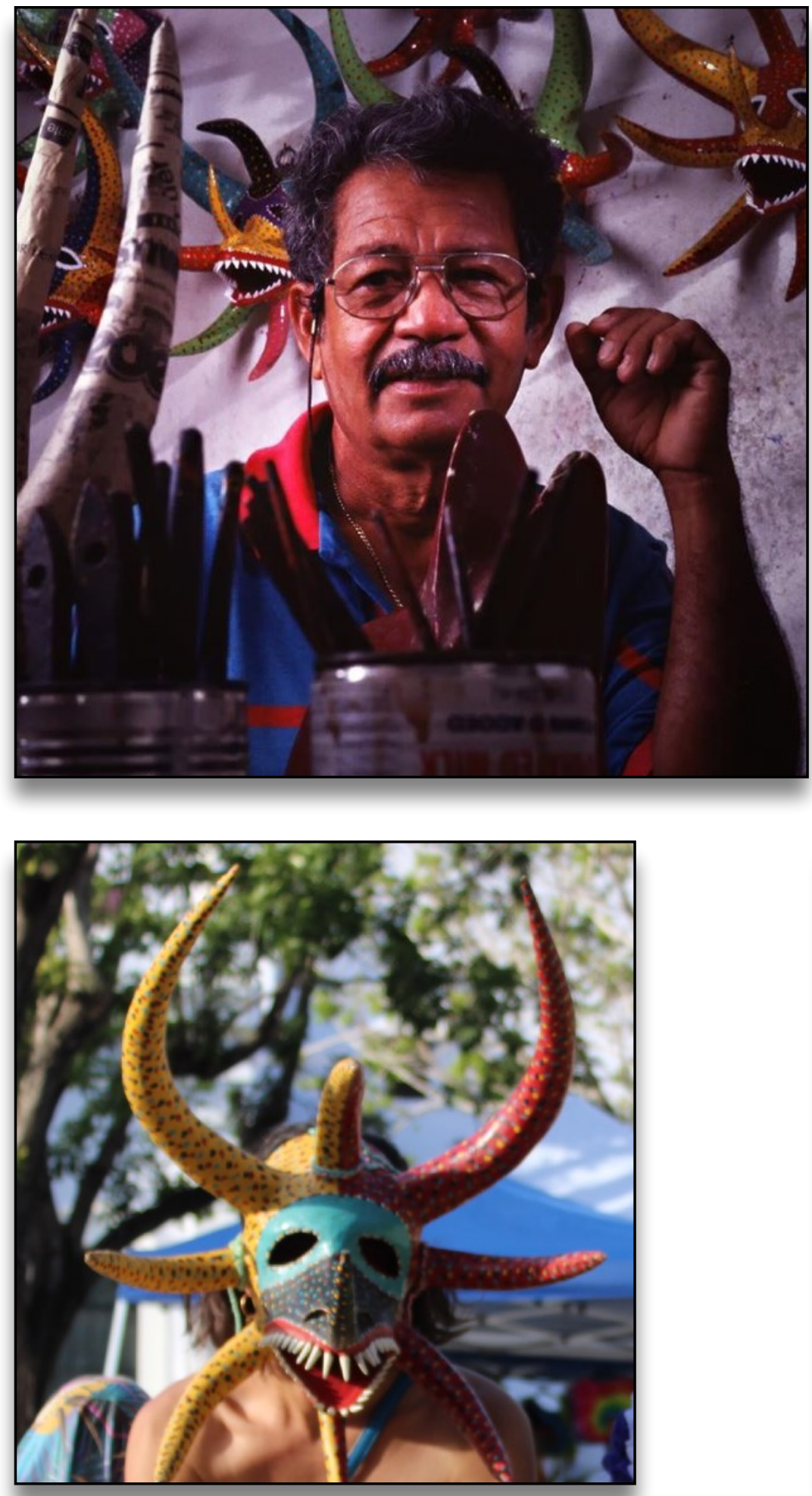

Figure 122 Vejigante Mask by Miguel Caraballo [digital image]. By Author. February 4, 2018
Figure 121 Don Miguel Caraballo, artesano de máscaras, Playa de Ponce, Puerto Rico. [digital image]. Retrieved June 20, 2020 from https://www.picuki.com/media/ 2121952381658032197

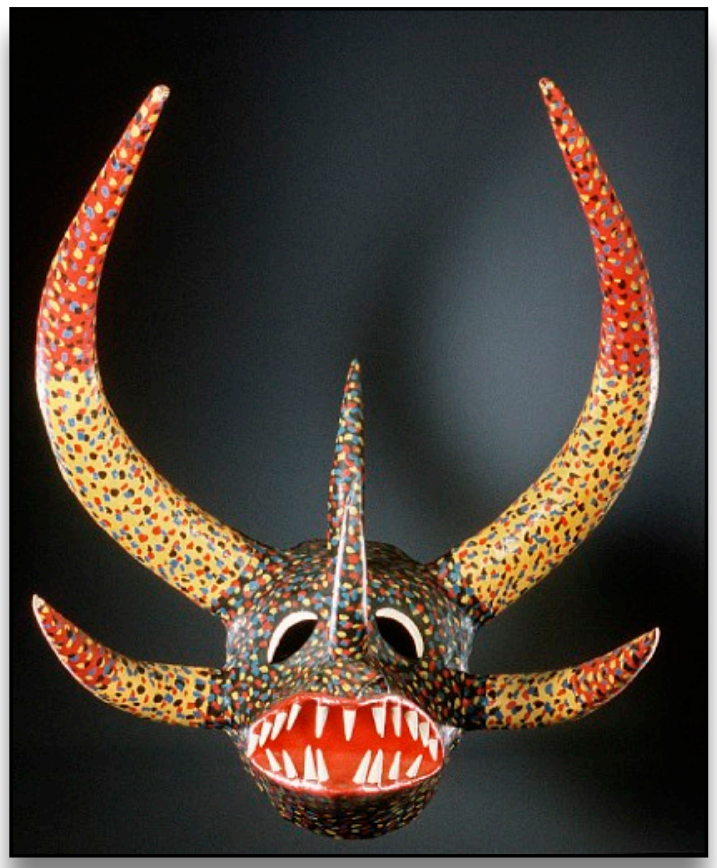

Figure 123 Carnival Mask [digital image]. Retrieved October 4, 2019 from http://n2t.net/ ark:/65665/ng49ca746a4-464b-704be 053-15f76fa0b4fa 


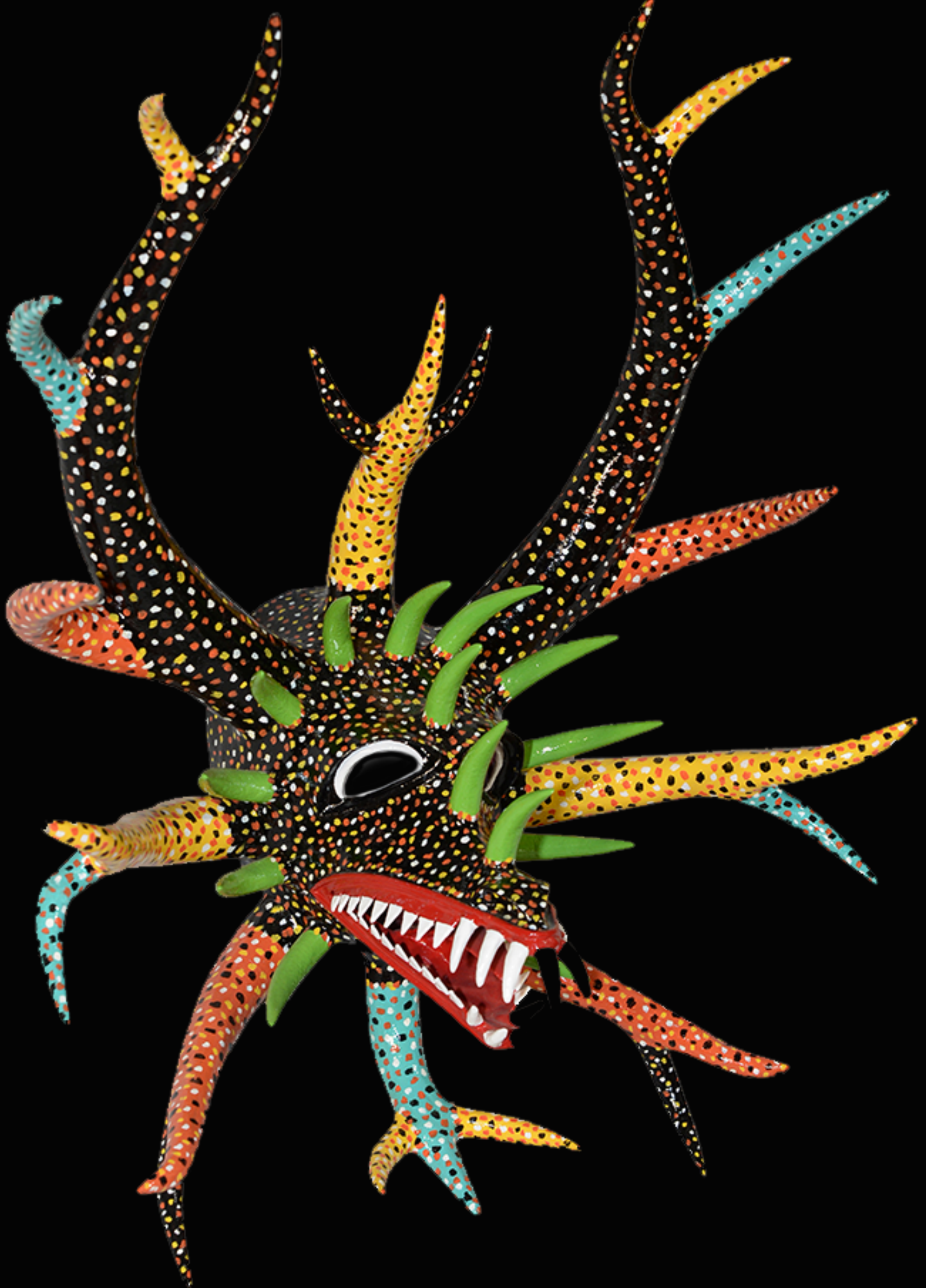


Another well-established artisan from Ponce is Leonardo Pagán, November 6, 1929 - February 10, 2002.148 He is well-known for his El Diablito Rojo masks. (Figure 125) “Leonardo Pagán learned his craft from a neighbor called Juan Careta, John Mask, who died almost 50 years ago and is still remembered as one of the great mascareros... Pagán still uses Juan Careta's diablito molds..."149 (Figure 126) Leonardo created a different technique for horn molds: He utilizes plants, tree branches, and/or roots for the horn molds. (Figure 127) Leonardo collects roots and branches and carves the desired shape. And finally, he cleans and cures the wood in preparation for use. Humberto states: "This enables Leonardo to construct different sizes of horns, forming something that imitates a grove. He is known to create vejigante masks with up to 200 horns. His masks are light weight and affordable. Therefore, people can purchase and wear them in the Carnival."150 In contrast, while Leonardo strived for his masks to be functional, the Caraballos and Alindato produce masks that are high quality works of art. They targeted collectors in the art community, as well as, tourist and transplanted affluent Puerto Ricans. And, present-day, many of the vejigante masks by Caraballo and Alindato are in private art collections and/or museums. ${ }^{151}$

\footnotetext{
${ }^{148}$ Leonardo J. Colón Pagán, Instagram Interview, May 12, 2021.

149 Mark Kurlansky, "SHOPPER'S WORLD; Puerto Rican Carnival Masks," The New York Times, February 11, 1990, 6.

${ }^{150}$ Humberto Figueroa, Interview by author, Video recording, Ponce, February 4, 2018.

${ }^{151}$ Humberto Figueroa, Interview by author, Video recording, Ponce, February 4, 2018.
} 


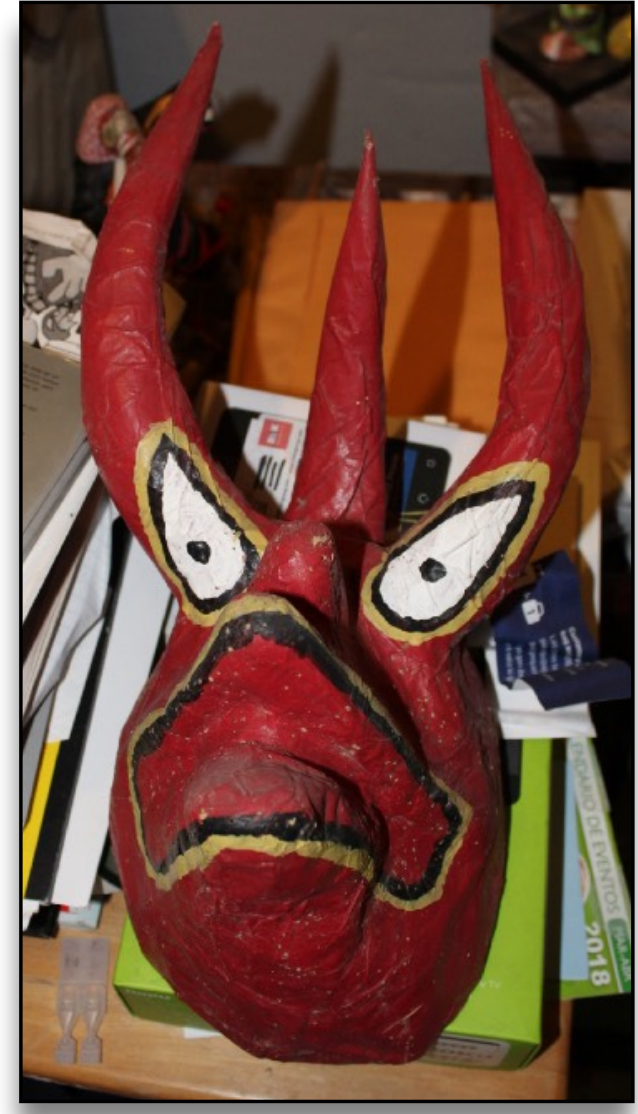

Figure 125 “El Diablito Rojo” Vejigante Mask by Leonardo Pagán, Circa 1985, Owned by Humberto Figueroa [digital image]. By Author. February 4, 2018

\section{LAS CARETAS DE CARTON del Carnaval de Ponce}

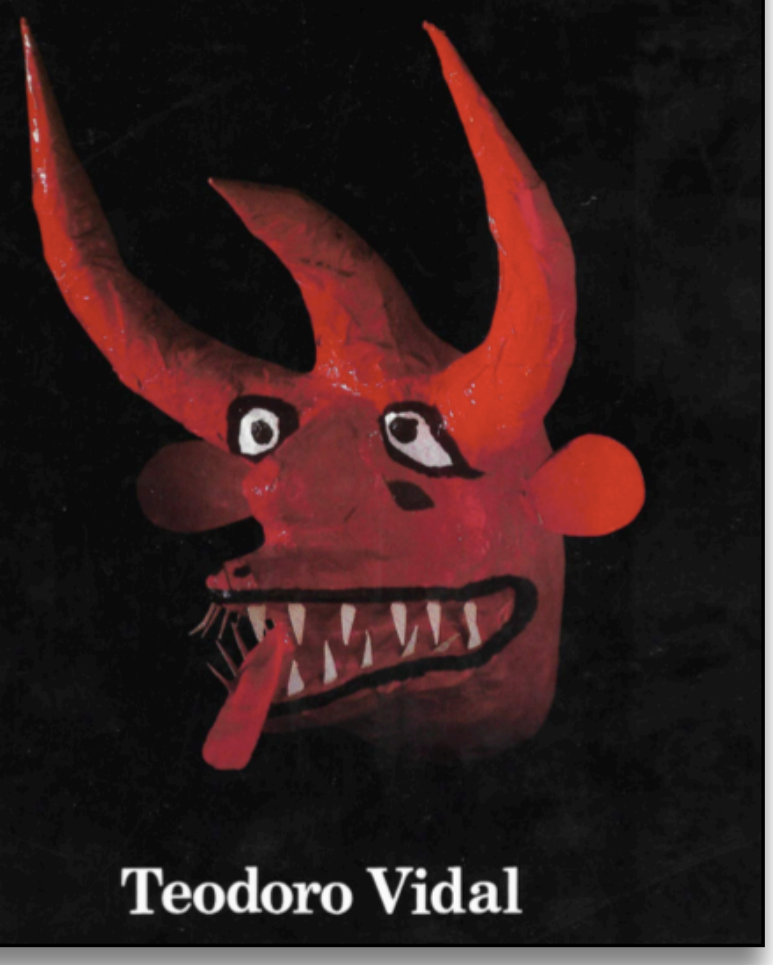

Figure 126 Las Caretas de Cartón del Carnaval de Ponce [digital image]. Retrieved June 20, 2020 from https:// www.amazon.com/Las-Caretas-Cartón-Carnaval-Ponce/dp/ B07GZVRTNK 
Luis Rodríguez Munet, date of birth unknown, was a self-taught, experimental mascarero. He additionally was an art teacher focused on color theory, animation, and film. By applying his knowledge from his studies to his artisanal work, he was one one the few artisans who began to break the boundaries of the traditional careta antigua. Luis acknowledged the challenges of the vejigante masks. The careta antigua was uncomfortable due to the weight the front of the mask bears. This limited the movements of the user wearing the mask. Luis began to experiment with the shape of the careta antigua. ${ }^{152}$ Luis created a mask that held onto the cranium of the person wearing the mask. The mask would no longer put strain on the face and head as traditional vejigante mask does. He instilled an evolution focused on form and function of the mask, beginning its interlude into the depiction of the vejigante as a functioning artwork. ${ }^{153}$ Luis created the cranium base with the use of aluminum foil. He placed the aluminum foil directly on his head and taped it to grasp the form more accurately. (Figure 128) Luis sealed the mold with either brown paper or newspaper and glue. This was used as the base of the mold. The only glue available in Puerto Rico during that time was the brand Elmer's Glue. He used this glue to substitute for the classic engrudo often used by

\footnotetext{
152 Humberto Figueroa, Interview by author, Video recording, Ponce, February 4, 2018.

153 Humberto Figueroa, Interview by author, Video recording, Ponce, February 4, 2018.
} 
artisans in Ponce. Even though Luis experimented with form and function, he still upheld the use of some aspects o traditional technique, truly combining folkloric and fine art. ${ }^{154}$

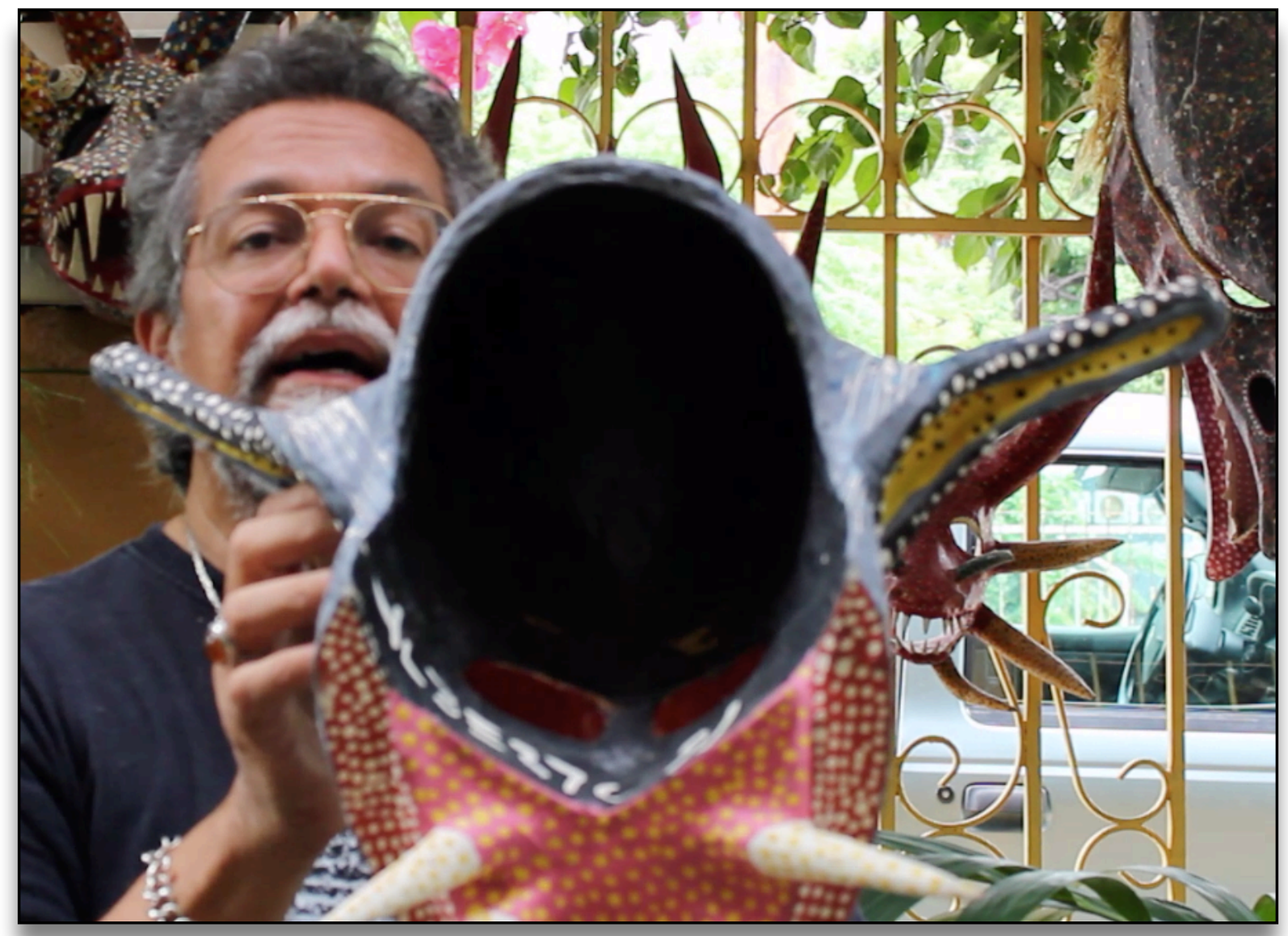

Figure 128 Vejigante Cranium Mask (Technique by Luis Rodríguez Munet) Created by Alberto González Negrón, Circa 1988- 89, Owned by Humberto Figueroa [digital image]. By Author. February 4, 2018

${ }^{154}$ Humberto Figueroa, Interview by author, Video recording, Ponce, February 4, 2018. 
Although it was recognized in the community that Luis Rodríguez Munet developed the cranium vejigante mask, it was Alberto González Negrón who elevated this concept and created works of art. (Figures 129-130) Alberto utilized some of the traditional methods of vejigante masks, but also began to experiment with the development of his own signature horns. Alberto created inventive and unconventional horns with a cardboard base, instead of completely from papier-mâché. This was disliked by the master artisans, and frowned upon in the artisan community. ${ }^{155}$ (Figure 131)

Humberto strives to communicate to the artisan community that the vejigante masks is a very important, valuable artifact of the production of the cultural materials in Puerto Rico. He explains the importance of the form of the mask as an extraordinary important object for the sculptors and painters:

You don't have to look much, the presence of the mask is planted in the space of painting and graphic art, from a very early time, specifically the $30 \mathrm{~s}$ the $40 \mathrm{~s}$. This is because the Carnival is a festivity that encases the different cultures that came to Puerto Rico from Europe, more than anything, the Spanish, the Canary Islands, the French that arrived from Corsica and North Europe. This mixed and created a mask that we cannot forget... 156

The mask is an aesthetic creation of the Puerto Rican culture. Humberto explains that the artists in Puerto Rico are beginning to experiment with the concept of the vejigante mask

\footnotetext{
155 Humberto Figueroa, Interview by author, Video recording, Ponce, February 4, 2018.

156 Humberto Figueroa, Interview by author, Video recording, Ponce, February 4, 2018.
} 
within their artwork. ${ }^{157}$ In combination of artisans experimenting with masks, and artists introducing the vejigante in their work, the context changed from folkloric to contemporary within this dialogue.

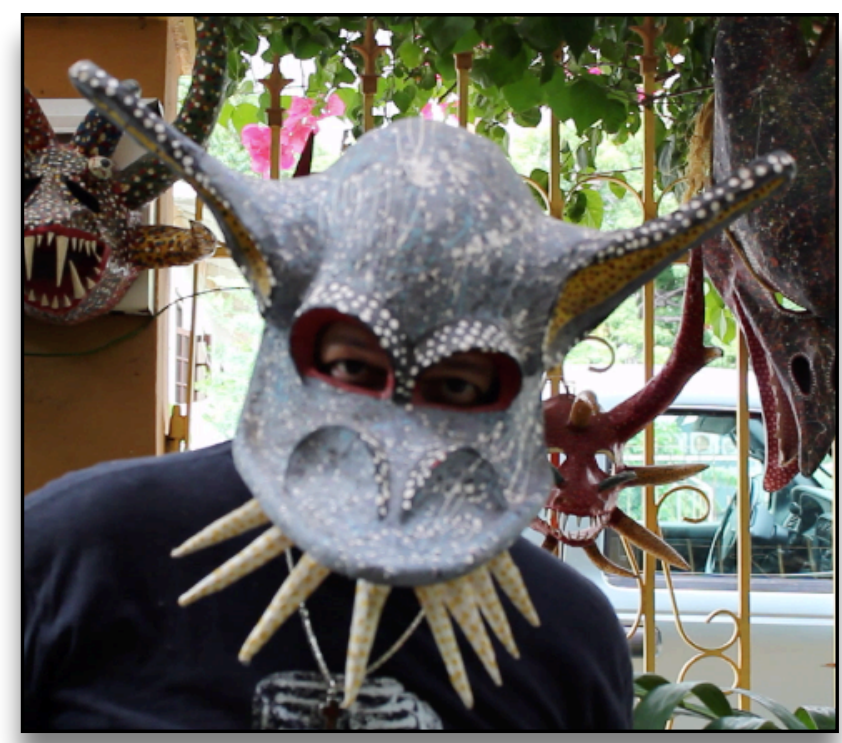

Figure 129 Vejigante Cranium Mask (Technique by Luis Rodríguez Munet) Created by Alberto González Negrón, Circa 1988- 89, Owned by Humberto Figueroa [digital image]. By Author. February 4, 2018

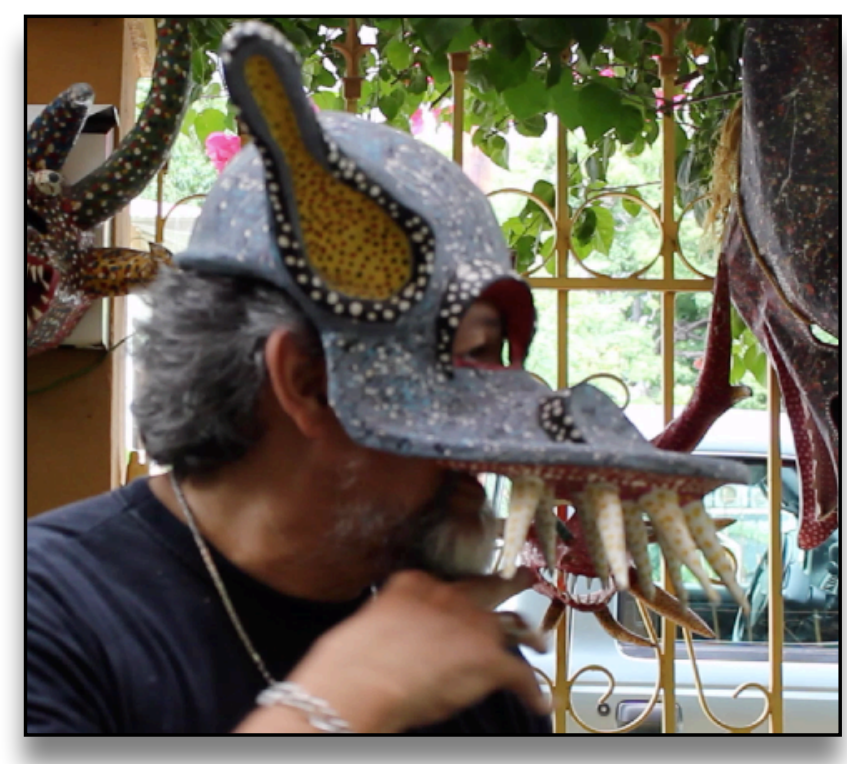

Figure 130 Vejigante Cranium Mask (Technique by Luis Rodríguez Munet) Created by Alberto González Negrón, Circa 1988- 89, Owned by Humberto Figueroa [digital image]. By Author. February 4, 2018

${ }^{157}$ Humberto Figueroa, Interview by author, Video recording, Ponce, February 4, 2018. 


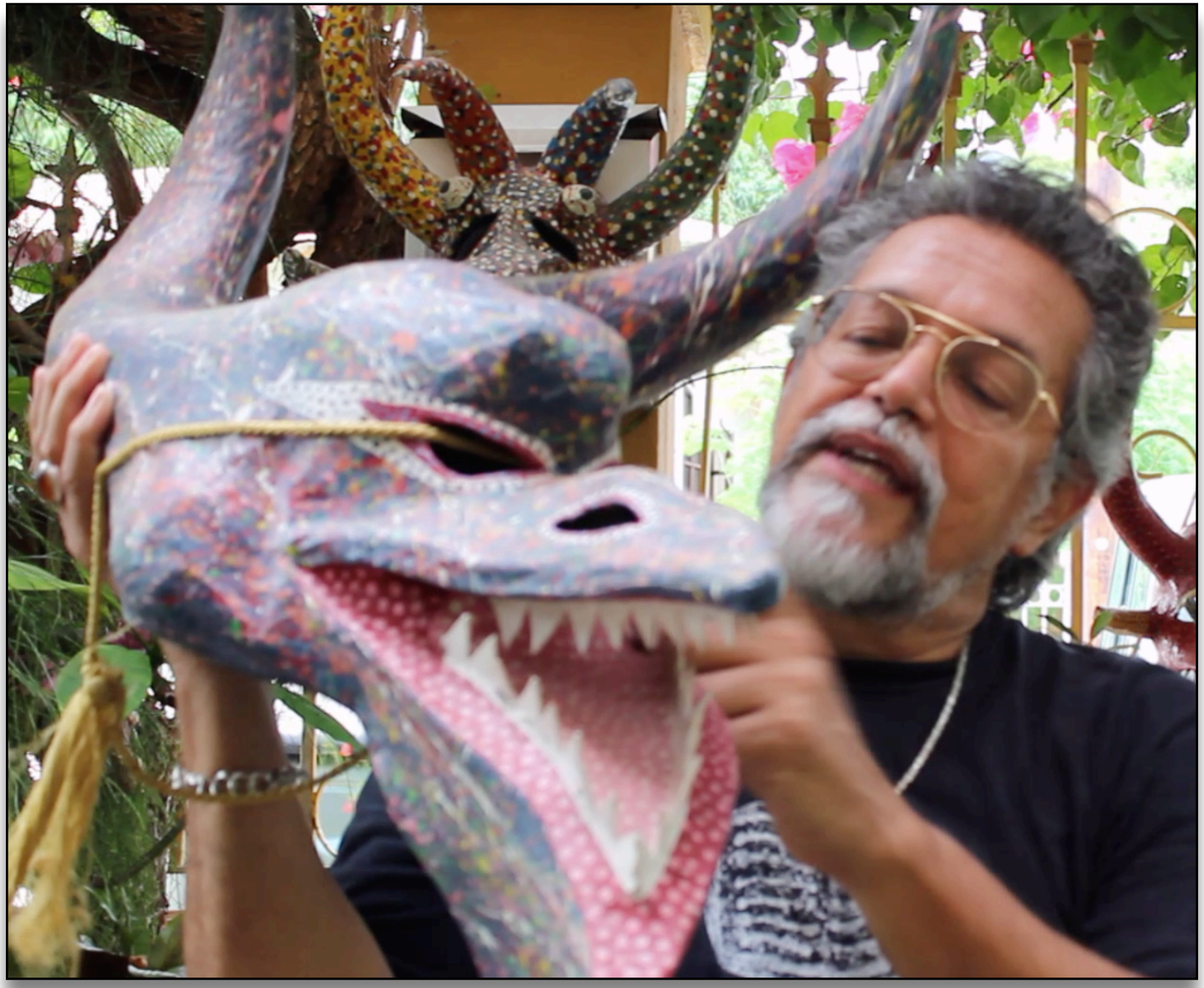

Figure 131 A Modern Interpretation of a Vejigante by Alberto González Negrón, Circa 1988- 89, Owned by Humberto Figueroa [digital image]. By Author. February 4, 2018 


\subsubsection{Norberto Martell}

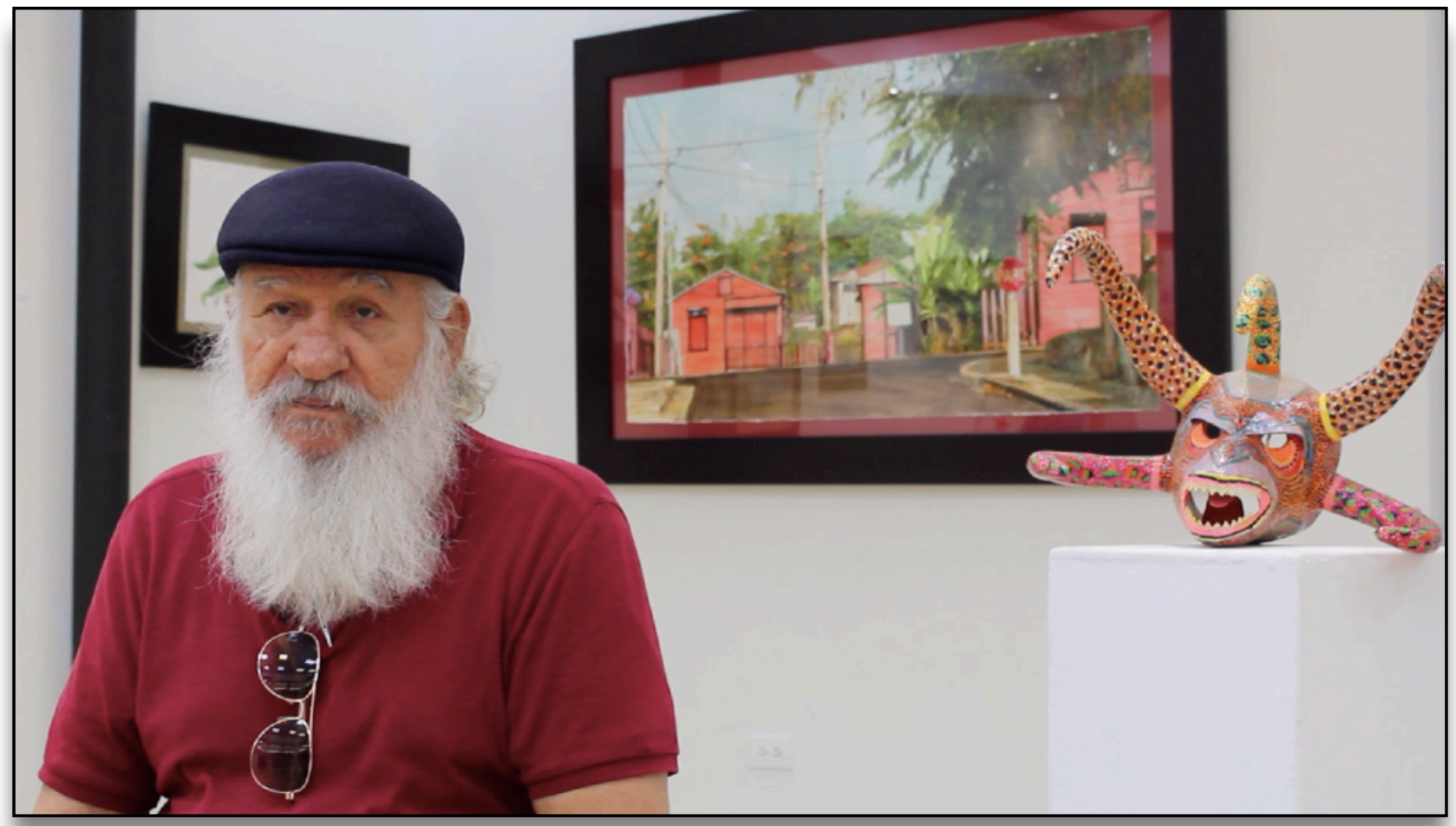

Figure 132 Norberto Martell, Art Historian [digital image]. By Author. February 6, 2018 
Norberto Martell is an art historian, specifically focusing on the history of the vejigante mask. (Figure 132) Norberto was directly involved with the research and collection of the information for the creation of the Las Caretas del Vejigante Ponceño. This literature is the most updated, recent documentation of a broad understanding of the history the vejigante.

Norberto discusses the changes of the vejigante mask over the years, and one significant change is the number of horns. Before, the careta antigua usually carried one to three horns, three being the maximum amount of horns on the mask. The most common number of horns on the antigua mask, historically, were two horns, one coming from each side of the mask. ${ }^{158}$ Norberto speaks further about the historical meaning of the horns on the vejigante mask: "The person who used a vejigante masks with one horn was the leader the comparsa. And the masks with two and three horns were the followers..."159 This is information not found in any documentation, but only available through word-of-mouth. Originally, the horns on the careta antigua had meaning and significance, currently, the horns now are only used for decorative purposes. Furthermore, a large amount of horns on a vejigante mask is in considered extremely beautiful. This is a clear example of how the purpose and significance of the mask has changed within the folkloric practices of the community. Norberto adds: "The vejigante

\footnotetext{
158 Norberto Martell, Interview by author, Video recording, Ponce, February 6, 2018.

159 Norberto Martell, Interview by author, Video recording, Ponce, February 6, 2018.
} 
mask has been produced in Ponce now for almost 300 years." 160 Even though, 30 years ago the Carnival tradition was prominent with an immense amount of participation from the community, unfortunately, now, with the introduction of the rubber masks, which mainly comes from the USA, there has been a decrease in the use of vejigante mask within the Carnival. 161

\footnotetext{
160 Norberto Martell, Interview by author, Video recording, Ponce, February 6, 2018.

161 Norberto Martell, Interview by author, Video recording, Ponce, February 6, 2018.
} 


\subsubsection{Raquel “Cucha” Rentas}

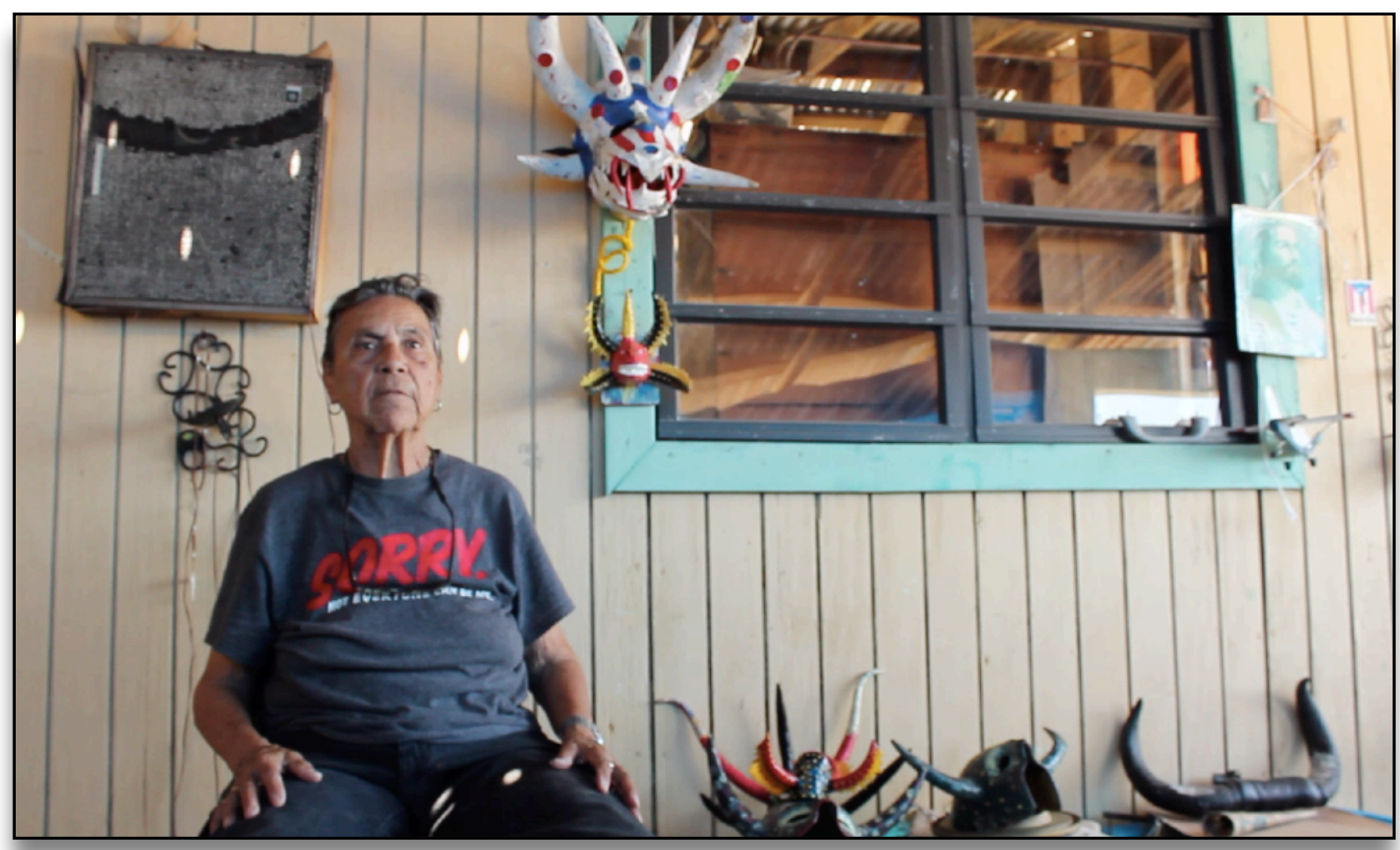

Figure 133 Raquel "Cucha” Rentas, Artisan [digital image]. By Author. February 7, 2018 
Raquel Rentas, known as "Cucha," is a well-known artisan in La Playa de Ponce.

(Figure 133) She is respected in Ponce for her unique style of careta de vejigante. Cucha is one of the few women creating vejigante masks. (Figures 134-135) She is known for her iconic, white vejigante costume and matching mask. (Figure 136) Cucha is an active participant in all the Carnivals in Puerto Rico.

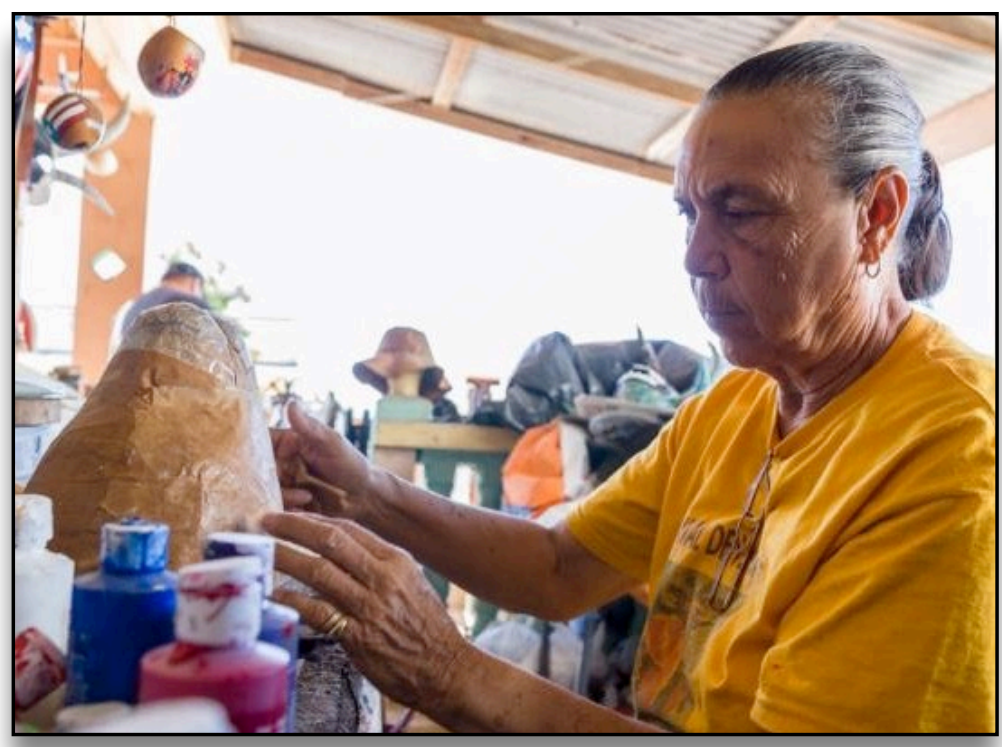

Figure 134 Untitled [digital image]. Retrieved June 20, 2020 from https://www.periodicolaperla.com/mantienen-viva-la-tradicioncontra-viento-y-marea/

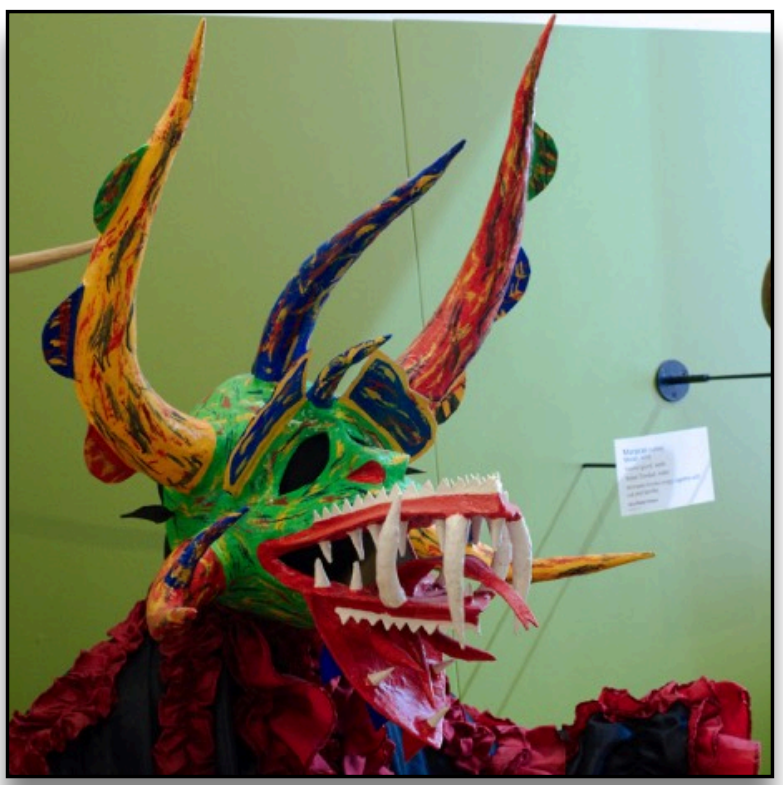

Figure 135 Vejigante mask and costume, Ponce, 2015; Raquel Rentas (mask maker), Juliana Anglero (costume maker) / (C) All rights reserved by Distraction Limited [digital image]. Retrieved June 20, 2020 from https://flic.kr/p/Su3QJm 

Cucha recalls her mother telling her experiences during the Carnival: "Before, women did not dress in vejigante masks, but in masks made out of wire. My mom told me that during her youth when she wanted to dress up as a vejigante she would wear the wire mask." 162 She compares the appearance of the wire mask to the masks used for the caballeros from the Carnival in Loíza Aldea, the Fiesta Santiago Apóstol Loiza. She continues: "Now the vejiga is not used, and the vejigante community are not using them as much. Additionally, the [matadores] sell the vejigas at a higher price. Before, they use to give them away, now it's become a business..."163 (Figure 137) Cucha states that she has also noticed a change in the desfiles, parades. Vejigantes were not just a small comprasa within the parades, but a crowd or mob. Furthermore, during Carnival season, the vejigantes always arrived in the streets at one o'clock in the afternoon and leave at six o'clock in the evening. This was be cause the vejigantes were required by law to take their masks off six o'clock. But now the times have changed, and Cucha has noted the clear shift within the Carnivals in Ponce. ${ }^{164}$

\footnotetext{
162 Raquel Rentas, Interview by author, Video recording, La Playa de Ponce, February 7, 2018.

163 Raquel Rentas, Interview by author, Video recording, La Playa de Ponce, February 7, 2018.

164 Raquel Rentas, Interview by author, Video recording, La Playa de Ponce, February 7, 2018.
} 


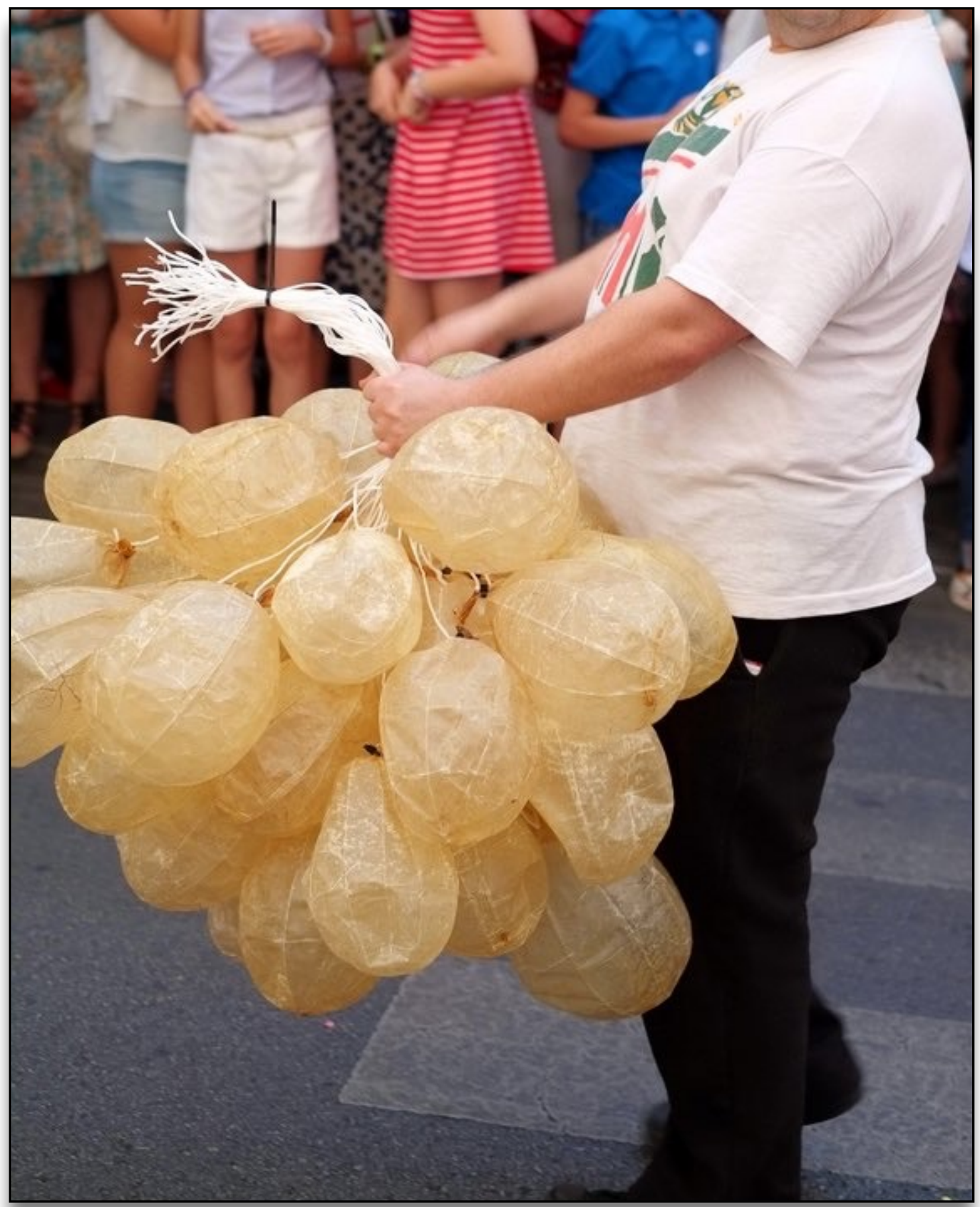

Figure 137 Las Vejigas / (C) All rights reserved by Landhlauts / Some rights reserved by PhotoLanda [digital image]. Retrieved June 20, 2020 from https://flic.kr/p/nKVG2Z 


\subsubsection{Héctor Rodríguez}

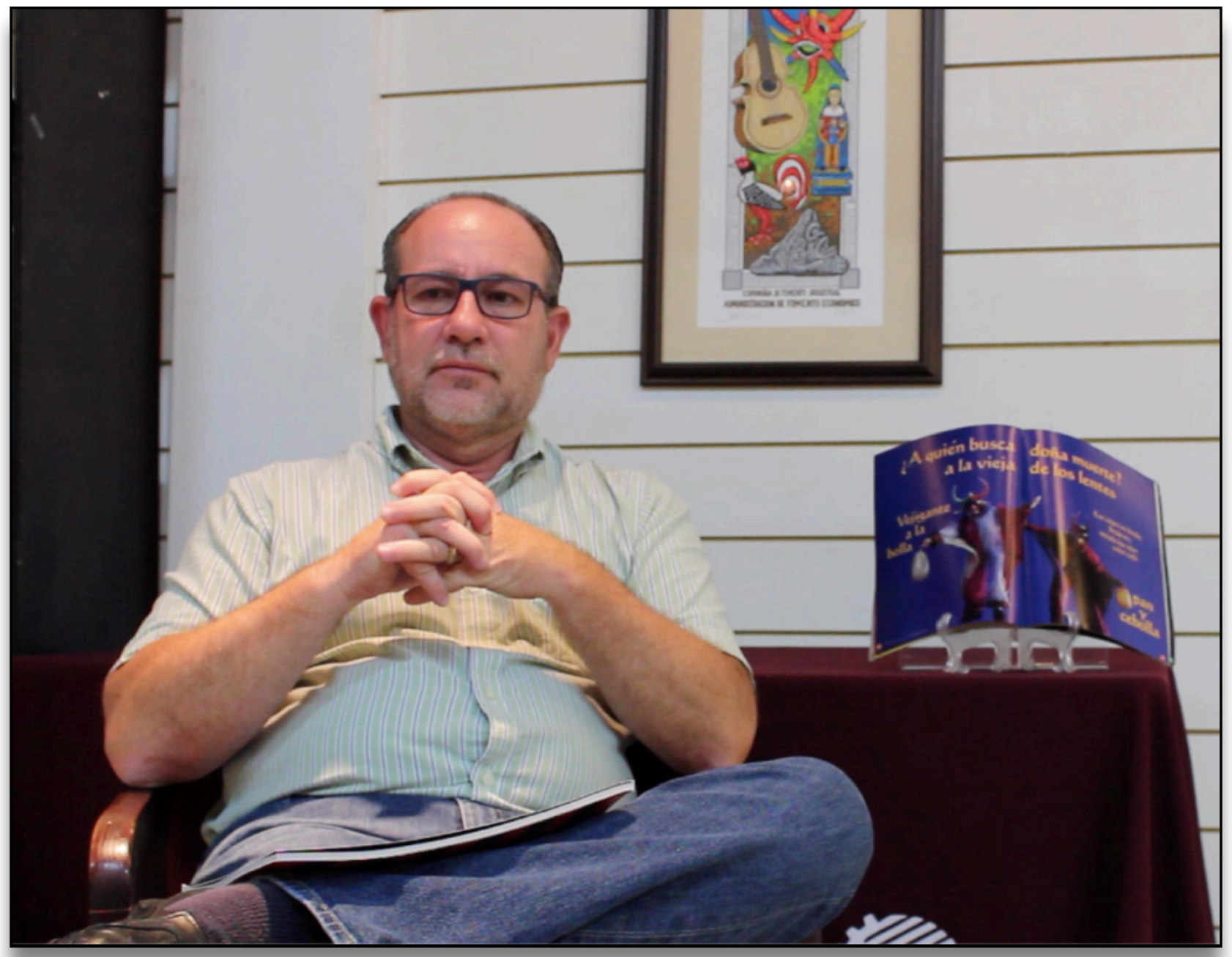

Figure 138 Héctor Rodríguez, Cultural Conservationist [digital image]. By Author. February 5, 2018 
Héctor Rodríguez is a representative of La Escuela Taller de Artesanías de Plaza Del Caribe y La Compañía de Fomento Industrial de Puerto Rico, a government organization located in Plaza del Caribe, shopping mall in Ponce, Puerto Rico. (Figure 138) It focuses on promotion and education of the community in cultural and artistic activities. This is one of few organizations, free to the public, that continues to promote and assists in the preservation of the heritage and folkloric culture of Puerto Rico. He is working on a program called "Aprender para Conservar," learn to conserve. This program focuses on the conservation of artisans and artisanal craft in order to prevent it from obsolesce within Puerto Rico. Héctor describes the Puerto Rico to be very connected to its culture and festivals. And, even though various Carnivals in different cities on the island might seem similar, they are indeed very distinct. The customs and traditions are very rooted by region, and this is one of the factors that has enable the tradition to continue and thrive despite the challenging external factors that are pushing it into extinction. ${ }^{165}$

Héctor was part of the literary project: Las Caretas del Vejigante Ponceño. This work focused on the education of history of the Carnival and its cultural origins, specifically focusing on the vejigante. It was a collaboration between local art historians,

165 Héctor Rodríguez, Interview by author, Video recording, Ponce, February 5, 2018. 
artisans, and artists. Not only does this book discuss history but includes a section that is dedicated to explaining the creative process of the traditional vejigante mask.

Héctor acknowledges that the mask has already begun to move to a contemporary context. There has been a change of definition of elements and a shift of focus towards aesthetics. This change has enabled the artisans to be more creative with their expression, and created an opening for the ability to express their own narrative. 166

166 Héctor Rodríguez, Interview by author, Video recording, Ponce, February 5, 2018. 
4.4 The Artists Participants 


\subsubsection{Miguel Conesa Osuna}

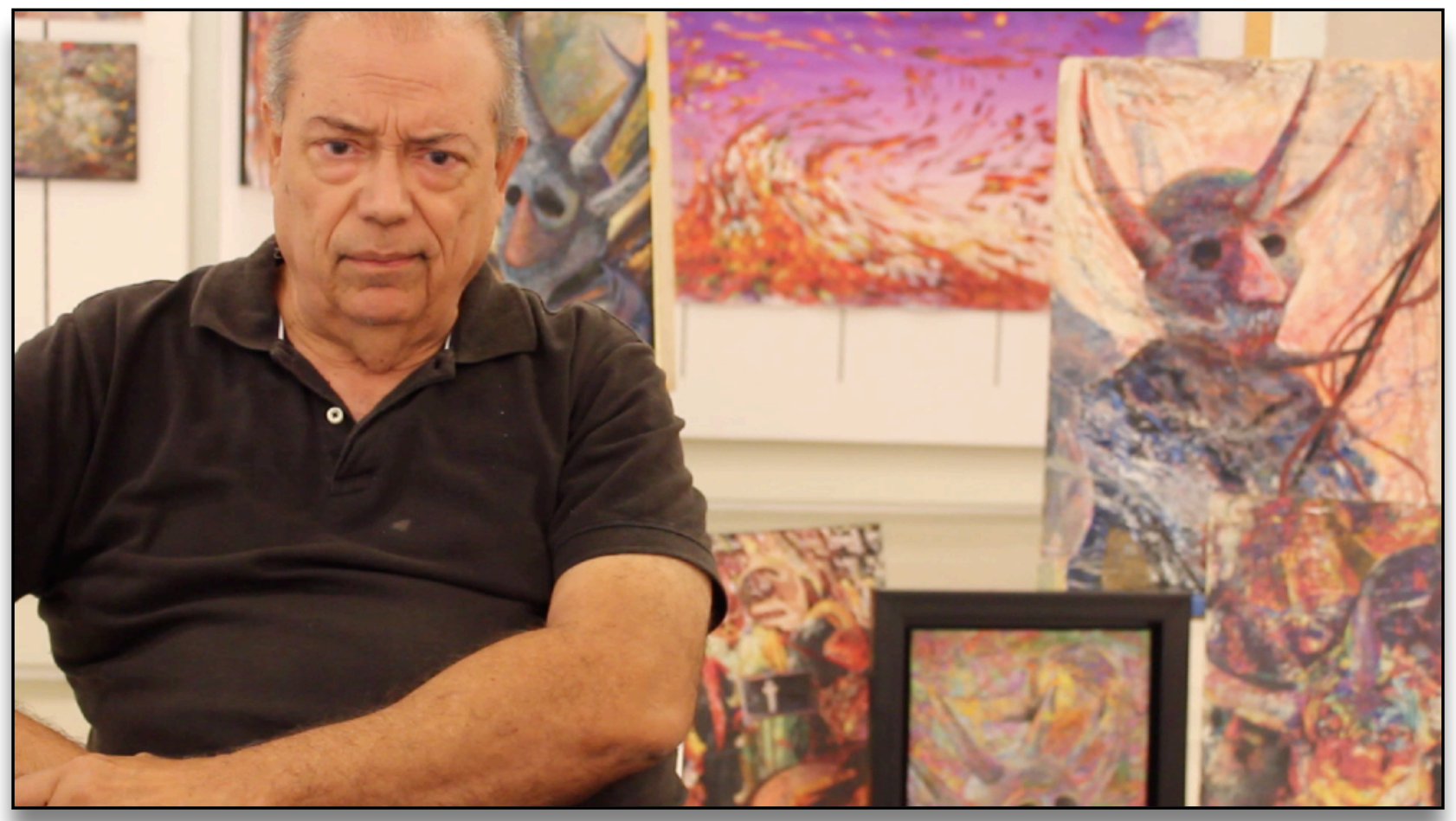

Figure 139 Miguel Conesa Osuna, Artist [digital image]. By Author. February 2, 2018 
Miguel Conesa Osuna has been a practicing artist for 48 years. (Figure 139) His medium of choice is drawings, painting and mixed media. He began his artistic career around the 1970s, and continues to actively create artworks focused on Puerto Rican culture.

In the beginning of the 1980s, Miguel focused his work on the subject of Carnival, specifically the depiction of the vejigante. He explored this theme, but not in a commercial perspective, but as a creative expression. Miguel's vejigantes are depicted with vibrant colors, yet the overall ambiance of the paintings are dark, sobering, and mysterious. (Figure 140) Often in his earlier artistic depictions, you can see the eyes of the vejigante almost always painted as empty, black eyes. (Figure 141) The structure of "...the vacant eye sockets,...lipless mouths, and exposed teeth, evoke[s] [the] human skulls."167 In addition, Miguel adds an additional layer to his paintings that create a misty fog, deterring the viewer and obscuring the image slightly. ${ }^{168}$ He can recall his first experience seeing a vejigante:

About when I was 8-years-old, more or less, we lived on the Calle Trujillo, and I remember the comparsas of vejigantes would pass by my house. One time when I looked out the window of my house, I saw something dressed in a costume and a mask with horns pass by making noise. And regretfully, I see two or three of the masks had realized the opened window and begin to make noise

\footnotetext{
167 Tami Michaeli, ed., "Face to Face: The Oldest Masks in the World," trans. Nancy Benovitz, accessed June 24, 2020 , https://museum.imj.org.il/exhibitions/2014/face-to-face/en/index.html.

168 Miguel Conesa Osuna, Interview by author, Video recording, La Playa de Ponce, February 2, 2018.
} 
at me. I got very scared. And I started to scream because I didn't know what it was. And that I was the first time in my life that I saw a vejigante. ${ }^{169}$

Even though the vejigante is generally depicted as merry, Miguel has been one of the few people to depict this folkloric concept in a different context. His paintings capture the mischievous essence of the character much like his first experience with the vejigante.

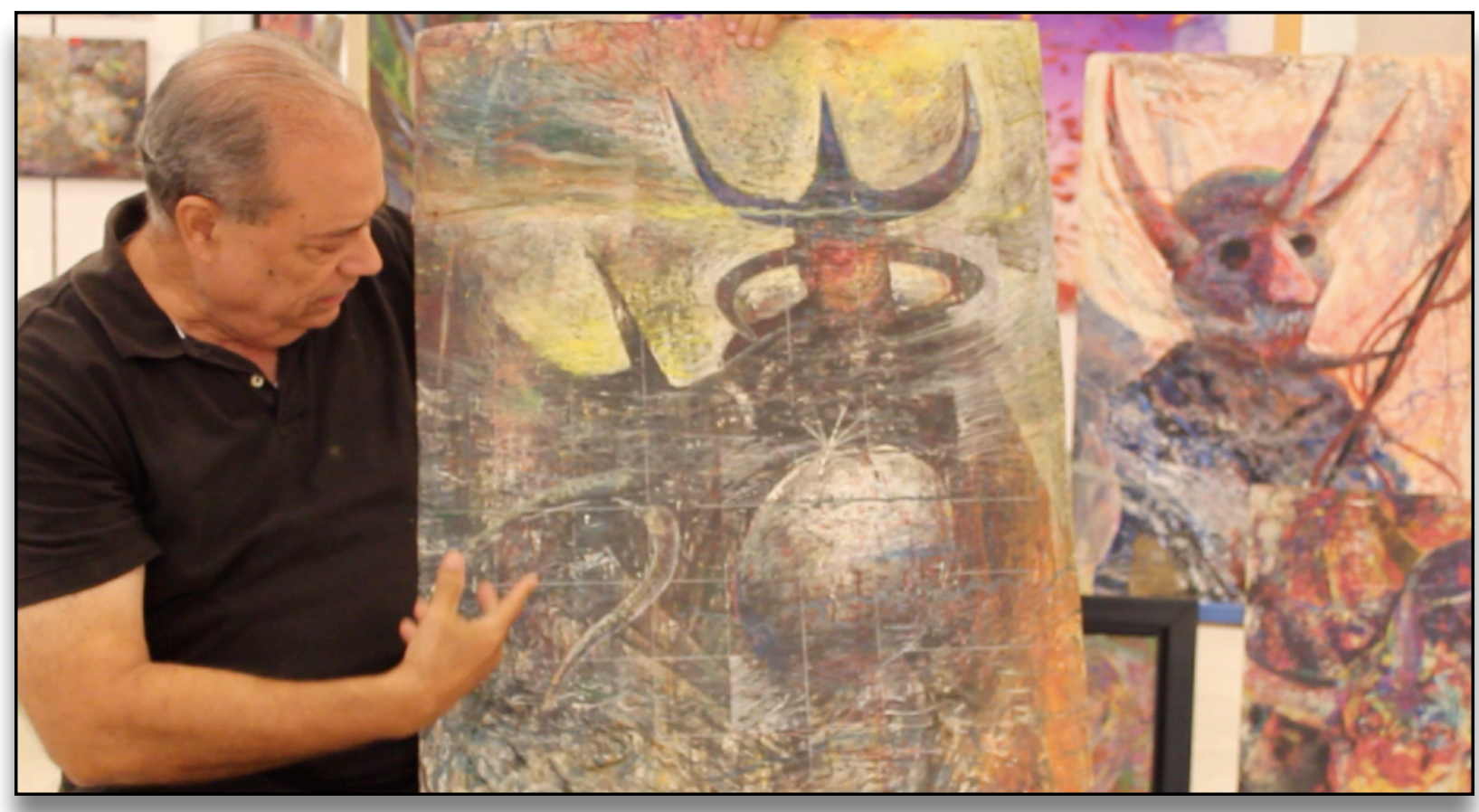

Figure 140 Painting of a Dark and Mysterious Vejigante by Miguel Conesa Osuna [digital image]. By Author. February 2, 2018 


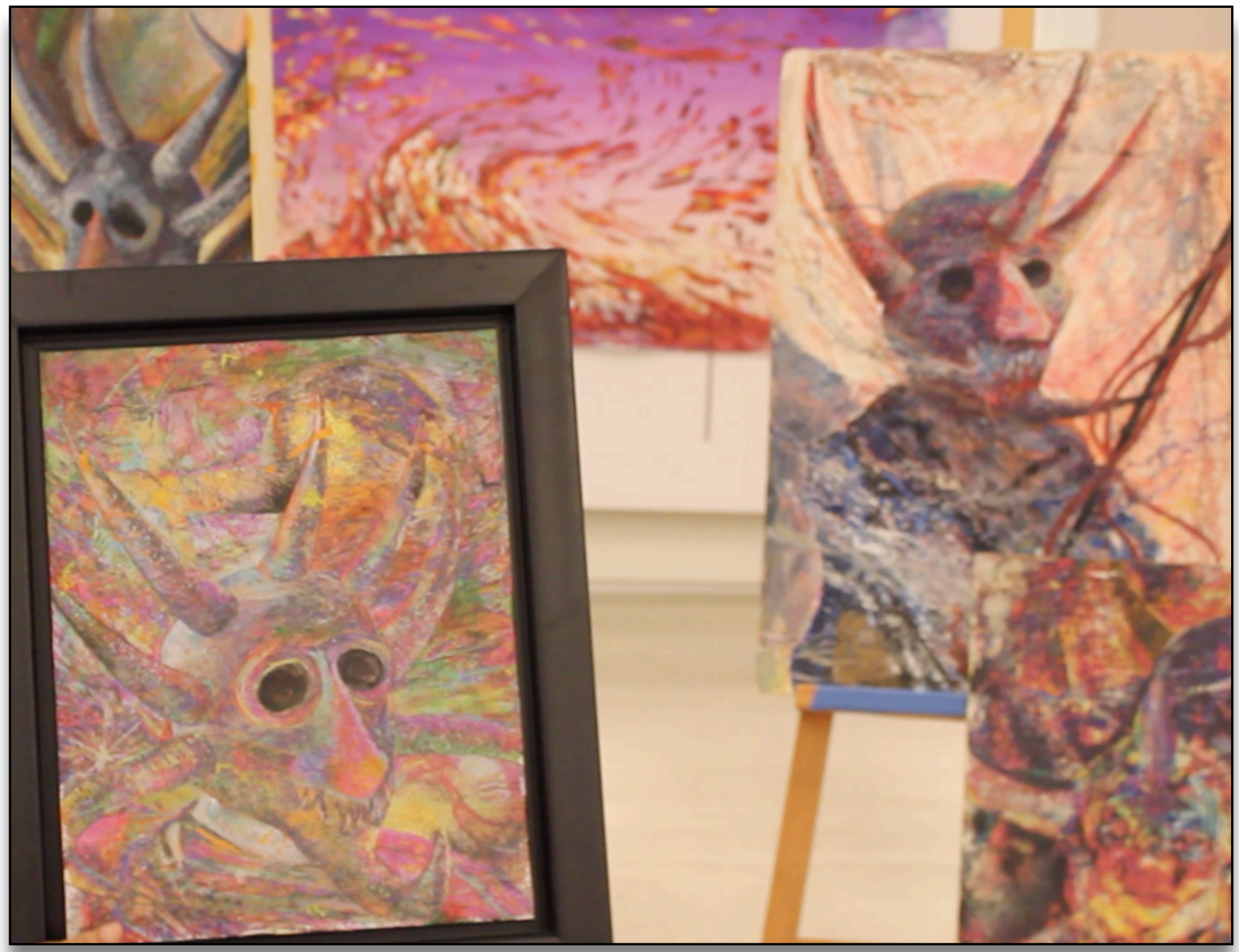

Figure 141 Painting of Vejigante with Vacant Eyes Sockets by Miguel Conesa Osuna[digital image]. By Author. February 2, 2018 


\subsubsection{Luis Alberto Pérez}

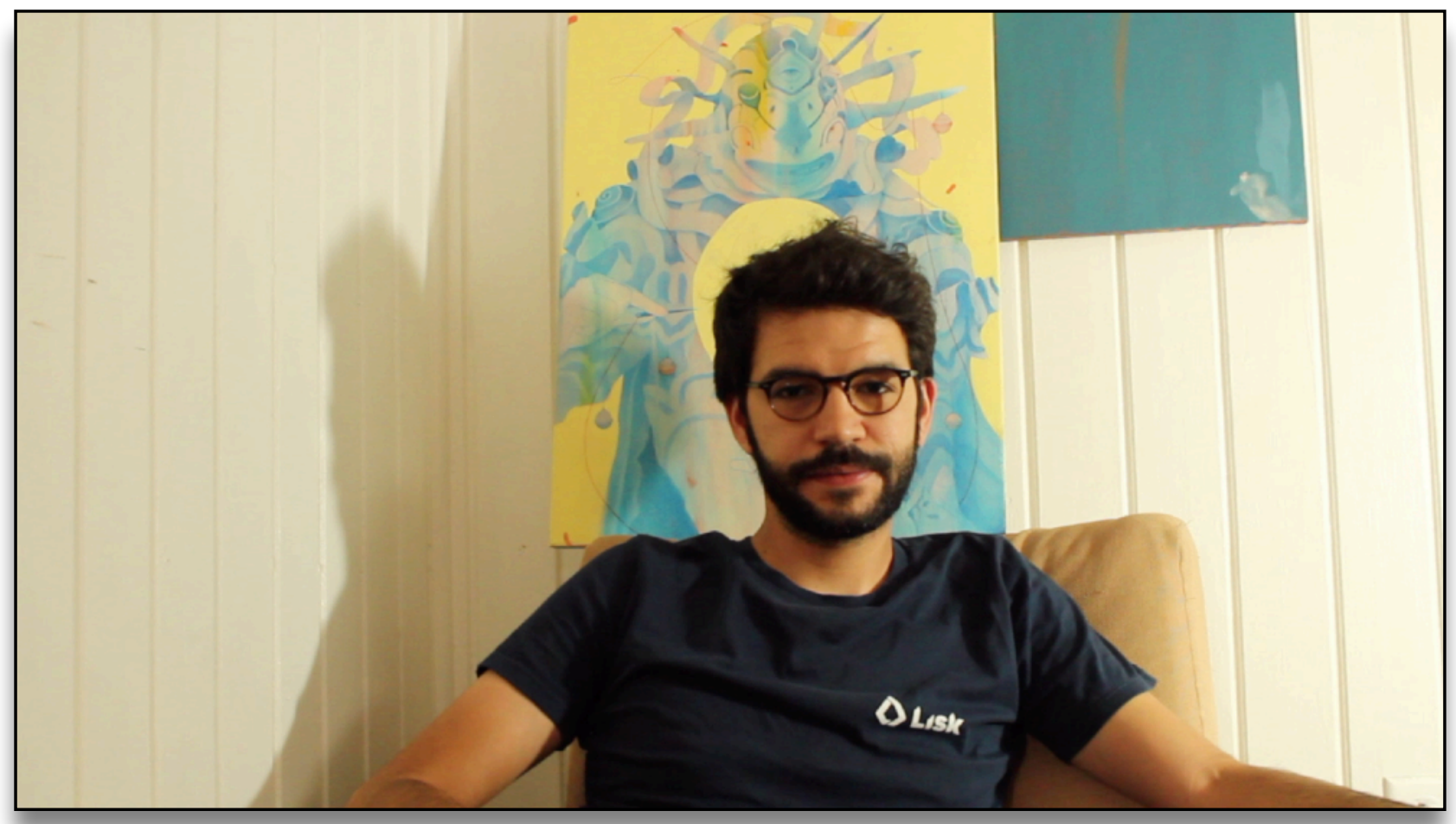

Figure 142 Luis Alberto Pérez, Artist [digital image]. By Author. February 1, 2018 
Luis Alberto Pérez is an artist born and raised in La Playa de Ponce (Figure 142) In his work, one can see the influence of the vejigante and Carnival. During his childhood, he designed vejigante costumes for the Carnival. ${ }^{170}$ Currently, he depicts fantasy figures with extravagant, colorful costumes, indirectly showcasing his influence growing up in Ponce. He participated in the Carnival on many occasions, and has even dressed as a vejigante in the past.

Luis has observes that the use of the careta antigua has become archaic, and further, that Carnival is not been at the same level it once was many years ago. It has changed due to the needs of the people attending the Carnival, i.e. what is expected and desired from this festival:

The problem with the careta antigua is there are not many artisans who are making them at an affordable price for the amount of people who want to dress as a vejigante. And so, the people go to American stores buying a substitute version of the vejigante mask...

Before, the people who participated in the Carnival would go out to the streets the entire month of February. La Playa de Ponce had more than 100 vejigantes walking the streets at twelve midday. You do not see that now, probably because the Carnival is not the same... it is not the same because the people attending the Carnival do not necessarily continue to practice the culture....

...The Carnival used to be very beautiful: people dancing, running and hitting others with the vejiga. It was how it was supposed to be....

...The presence of vejigantes in contemporary art can be seen today because the character is very interesting. It does not matter the time that passes because we

170 Luis Alberto Pérez, Interview by author, Video recording, La Playa de Ponce, February 1, 2018. 
will always try to continue the festival, and to keep vejigante alive with the costumes, the masks, and the art. It will always be a part of the culture of Ponce, Puerto Rico. ${ }^{171}$

Luis used to participate in the Carnival, specifically the Carnaval in La Playa de Ponce. But, now with the change in festivities and its lack of authenticity, he chooses to no longer attend the Carnivals. He noticed a change from folkloric to American culture. Luis reminisces on the older Carnivals that used to excite him. Present-day, he gives his respect to his culture through his artwork, by depicting vejigantes and other reoccurring themes seen in the Carnival. In his painting and drawing, Luis created various interpretations of vejigantes. The influence of Puerto Rico in his work is especially visible through his colorful subject matter of Carnival culture. This is an example of how the character, the vejigante, has been consumed into the contemporary context. ${ }^{172}$ (Figures 143-144)

\footnotetext{
171 Luis Alberto Pérez, Interview by author, Video recording, La Playa de Ponce, February 1, 2018.

172 Luis Alberto Pérez, Interview by author, Video recording, La Playa de Ponce, February 1, 2018.
} 


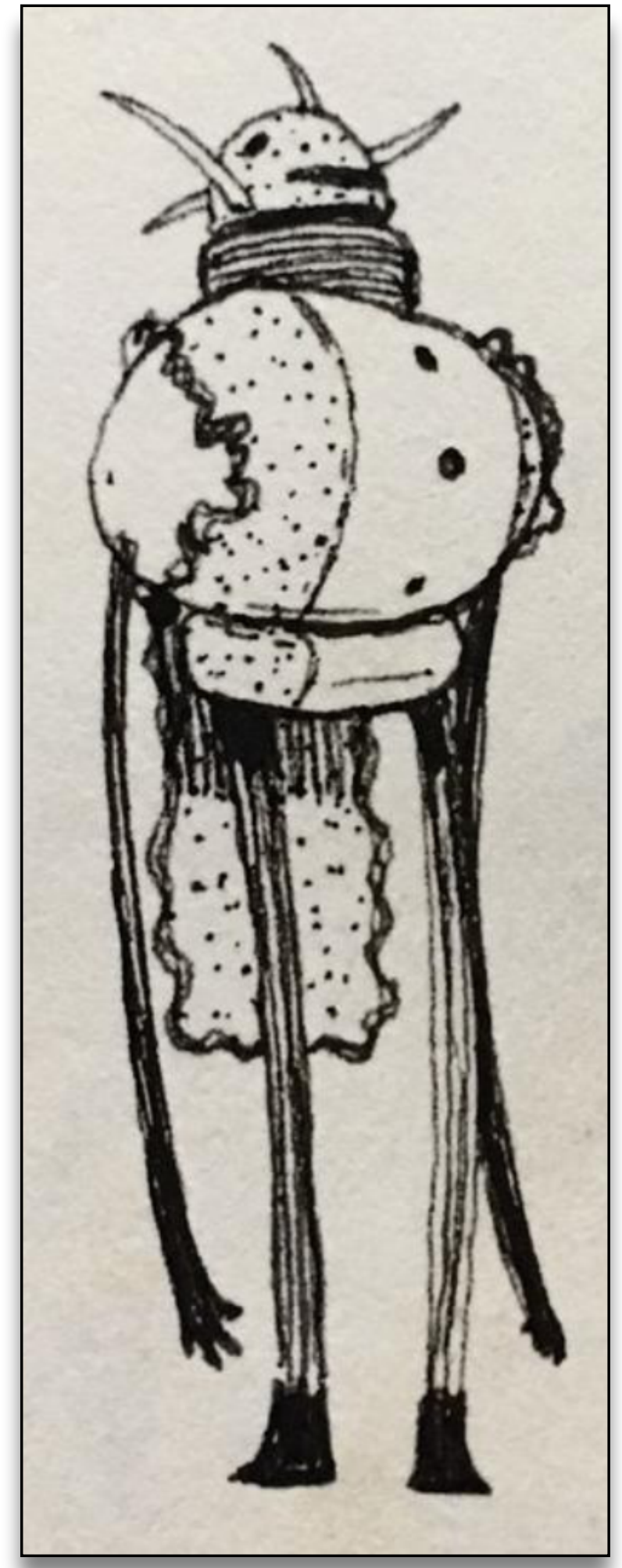

Figure 143 Vejigante by Luis Alberto Pérez [digital image]. By Author. February 1, 2018 


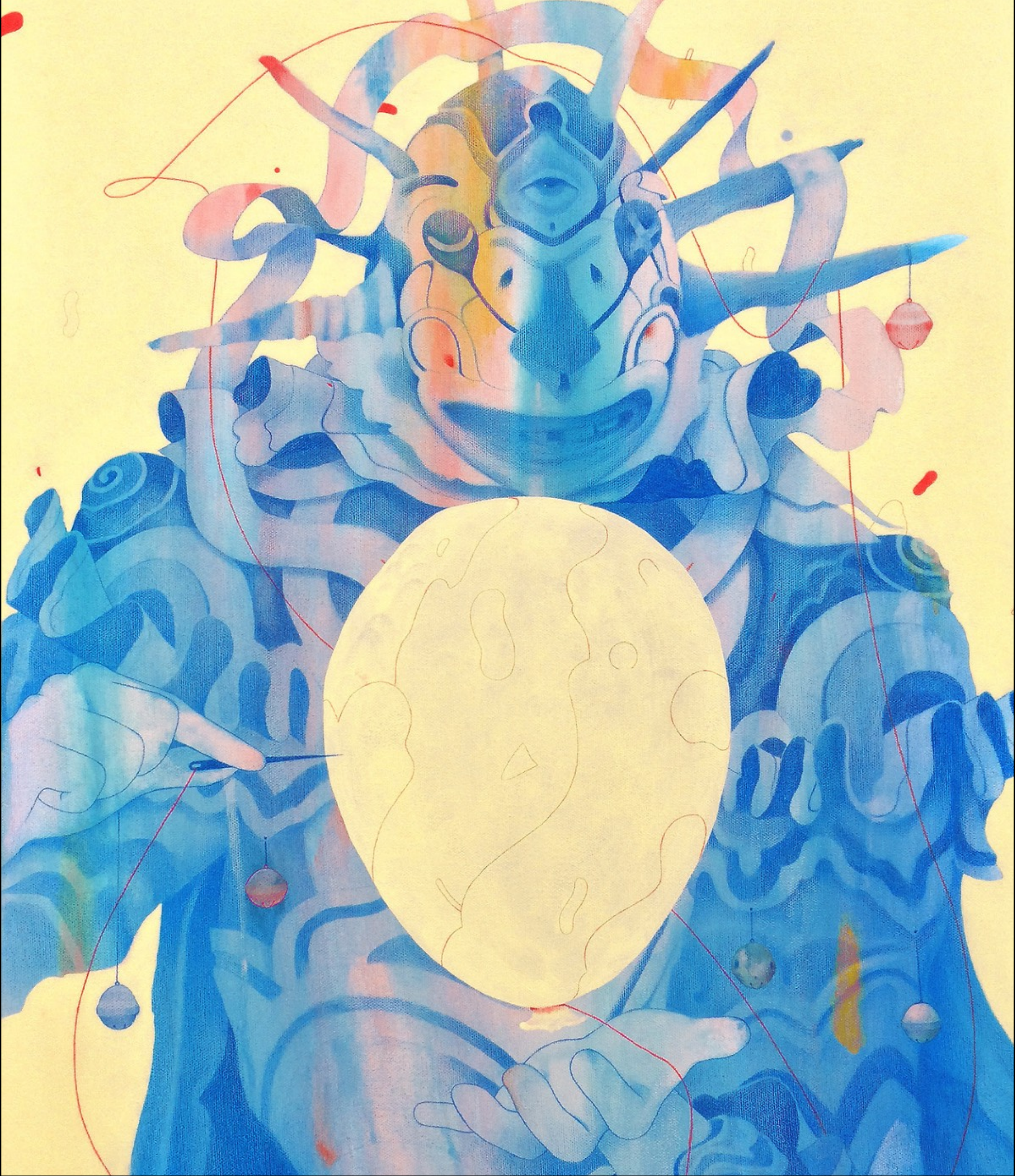

Figure 144 Vejigante by Luis Alberto Peréz [digital image]. Retrieved June 20, 2020 from hhttps://lapstract.tumblr.com/image/ 158932652818 


\subsubsection{Ednisa Torres}

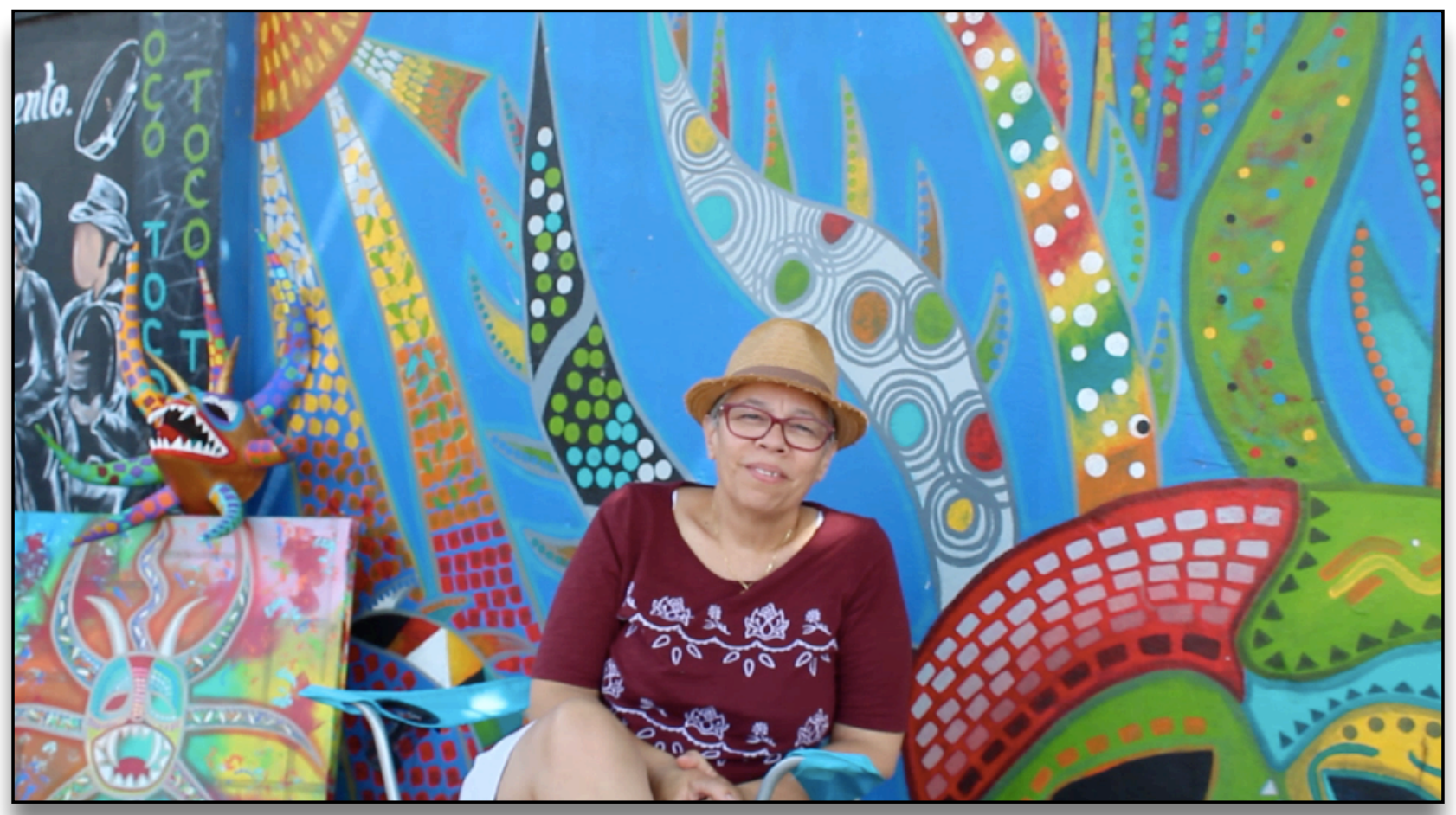

Figure 145 Ednisa Torres, Artist [digital image]. By Author. February 3, 2018 
Ednisa Torres is a painter, muralist, sculptor and professional chemist from $\mathrm{La}$ Playa de Ponce. (Figure 145) She is a self-taught artist. Inspired by La Playa de Ponce's vibrant, colored houses, she acknowledges and credits her surroundings as the most influential factors in her work. ${ }^{173}$ (Figure 146) The vejigante is the focus of Ednisa's artwork. She depicts the vejigante mask with her signature downward, elongated eyes. (Figures 147-148) Additionally, she gravitates towards the use of traditional vejigante colors, yellow and red. Ednisa acknowledges that these colors derive from the Spanish flag, the first world power that colonized the island and an important foundation of the Puerto Rican culture. ${ }^{174}$

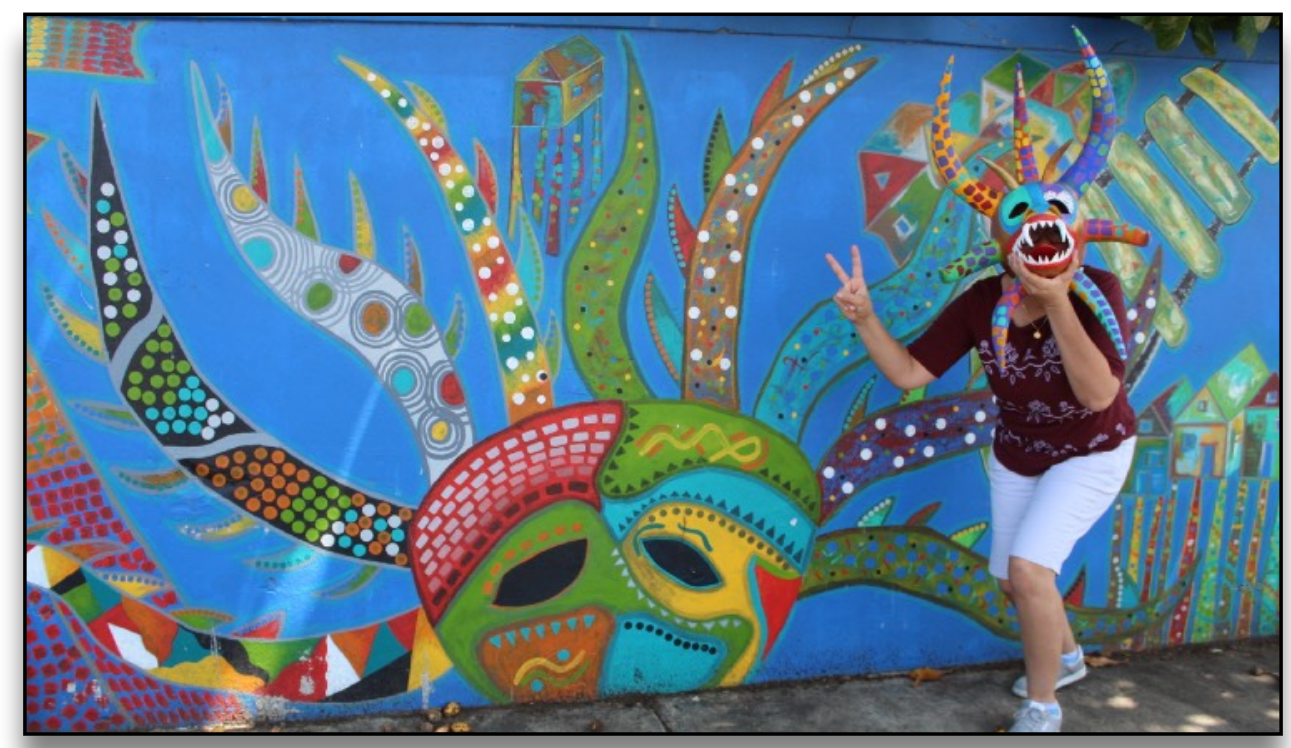

Figure 146 Mural by Ednisa Torres [digital image]. By Author. February 3, 2018

\footnotetext{
${ }^{173}$ Ednisa Torres, Interview by author, Video recording, La Playa de Ponce, February 3, 2018.

${ }^{174}$ Ednisa Torres, Interview by author, Video recording, La Playa de Ponce, February 3, 2018.
} 


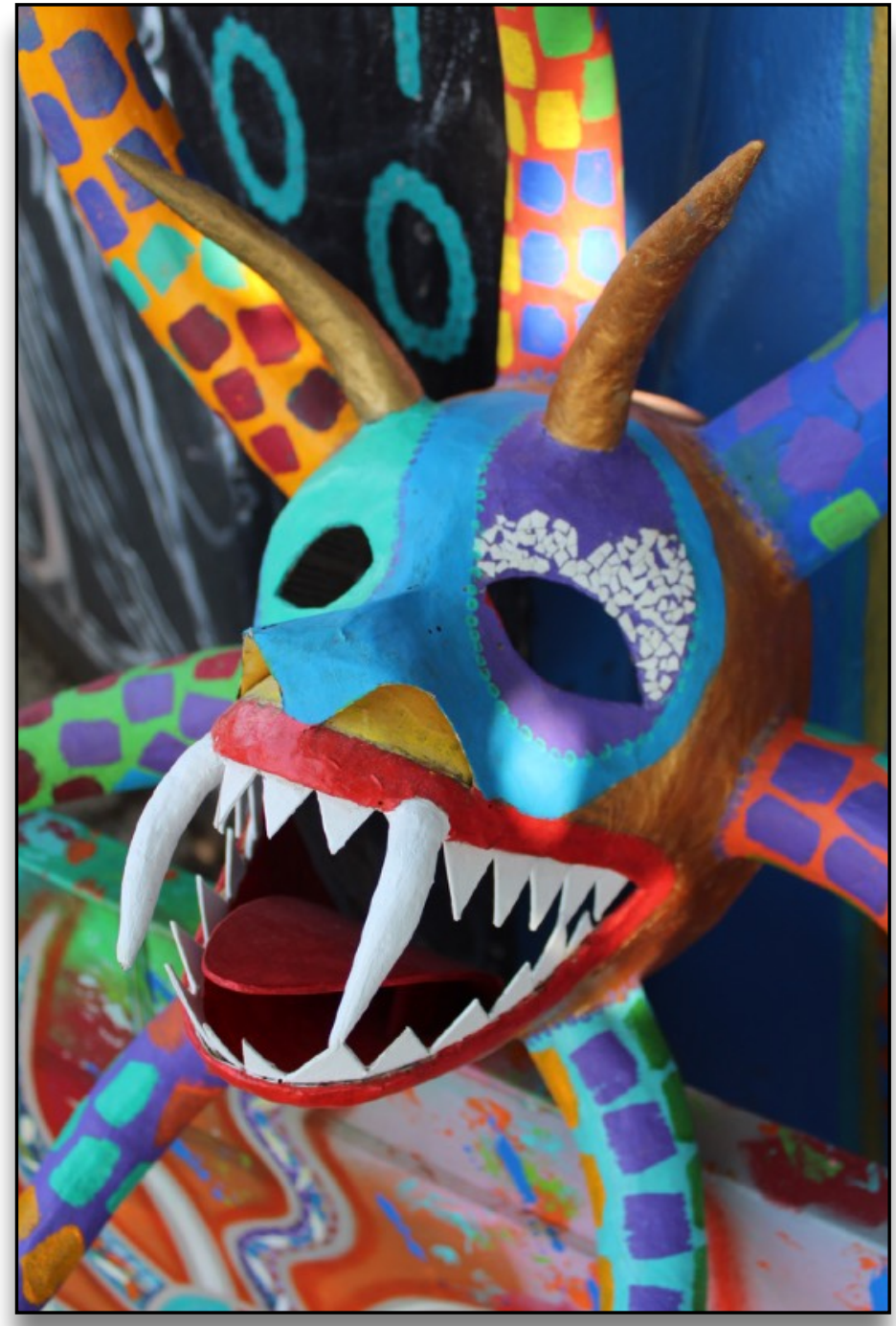

Figure 147 Mask by Ednisa Torres [digital image]. By Author. February 3, 2018

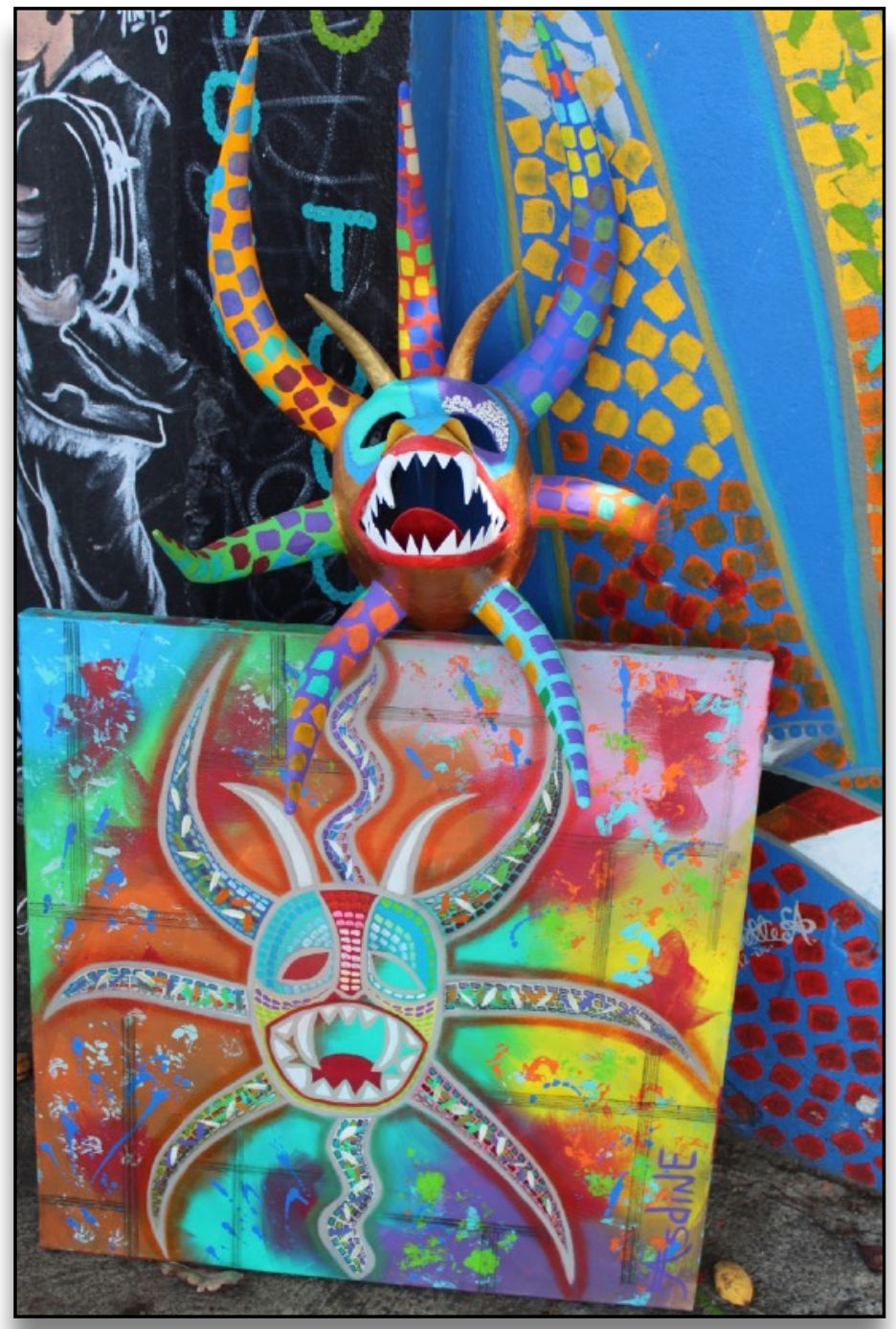

Figure 148 Mask and Painting by Ednisa Torres [digital image]. By Author. February 3, 2018 


\section{Chapter Five: Traditional Creation}




\subsection{Overview}

This chapter covers the traditional course of creation of the careta antigua de vejigante, specifically from Ponce, Puerto Rico. It will explain, in depth, the materials needed and used for the complete process. The chapter additionally include the errors and obstacles one might encounter during the process. In summary, this is a descriptive timeline one must strictly follow in order to create a traditional, durable, and wearable vejigante mask.

The structure of the established process taught in present-day will enable the reader to recognize the continuation of the practice of traditional methods and techniques of mask making in Puerto Rican culture. This review will present the foundation in physical labor and the creativity needed for the creation of vejigante masks. In final, this chapter evaluates and analyzes the method of construction, resources, and elements that are now considered fundamental for the creation of the careta antigua. The investigation should be considered an extensive research that attempts to cover all angles of the process. 


\subsection{Engrudo}

During my workshops with Edwin Muñiz Pérez in La Playa de Ponce, I learned how to make traditional glue known as engrudo or pega. The glue's main ingredient is flour. When making glue, master artisans do not measure precisely but rather look at the mixture until the correct texture is achieved. (Figure 149) It should be stated that engrudo varies from artisan to artisan. And furthermore, certain ingredients are not recommended for use due to health hazards. The process taught in the workshop is as follows: Place cloves in boiling water until the water is dark and smells strongly of cloves. Then the cloves must be strained out and are saved for future use. Cloves are used because it is theorized that the smell of cloves detracts bugs and insects. The clove water is placed in a stock pot and mixed with the flour. Although the clove water added to the ingredients that create the glue is supposed to deter the insects from eating the mask, (Figure 150) this is not always successful. (Figure 151) And finally, white vinegar, salt and boric acid are added to the mixture. Often, the insects and bugs are attracted to the mixture of the engrudo, and will eat the mask because of the flour. One example of an ingredient used to kill, or evade insects is boric acid. Edwin Muñiz Pérez states that boric acid is the most important ingredient, for this is the element that is the most effective at detracting bugs and insects from eating the mask, leaving pinholes and sawdust behind. (Figure 152) This 
weakens the structure of the vejigante mask. Other glue recipes use poison directly in the mixture. Raquel "Cucha" Rentas, from La Playa de Ponce, uses rat poison in the glue formula. This is not a safe ingredient for humans. Also keeping in mind, the mask will be worn on the face, and, again, this can cause health problems. While this is the biggest flaw in the traditional method of creating a vejigante mask, I learned of alternative glues that the people of Ponce, Puerto Rico have tried. Another glue option is to use Mod Podge which is a glue much like a combination of Elmer's Glue and generic wallpaper glue. The Caraballos are one of the artisans known for now using Mod Podge in the traditional creation of masks. Another artisan Luis Rodríguez Munet, began experimenting with Elmer's Glue. The glue is mixed with water to thin the medium to mimic the texture of the original engrudo. The glue is water based, thus when exposed to humidity, the mask can deteriorate rapidly. When using this type of glue, when the mask is completed, the artist must add an outer layer of sealer, preferably varnish. Although these methods both work to eliminate the factor of glue that attracts insects, the newfound techniques to make the vejigante mask increases in price in order to create a more durable product. 


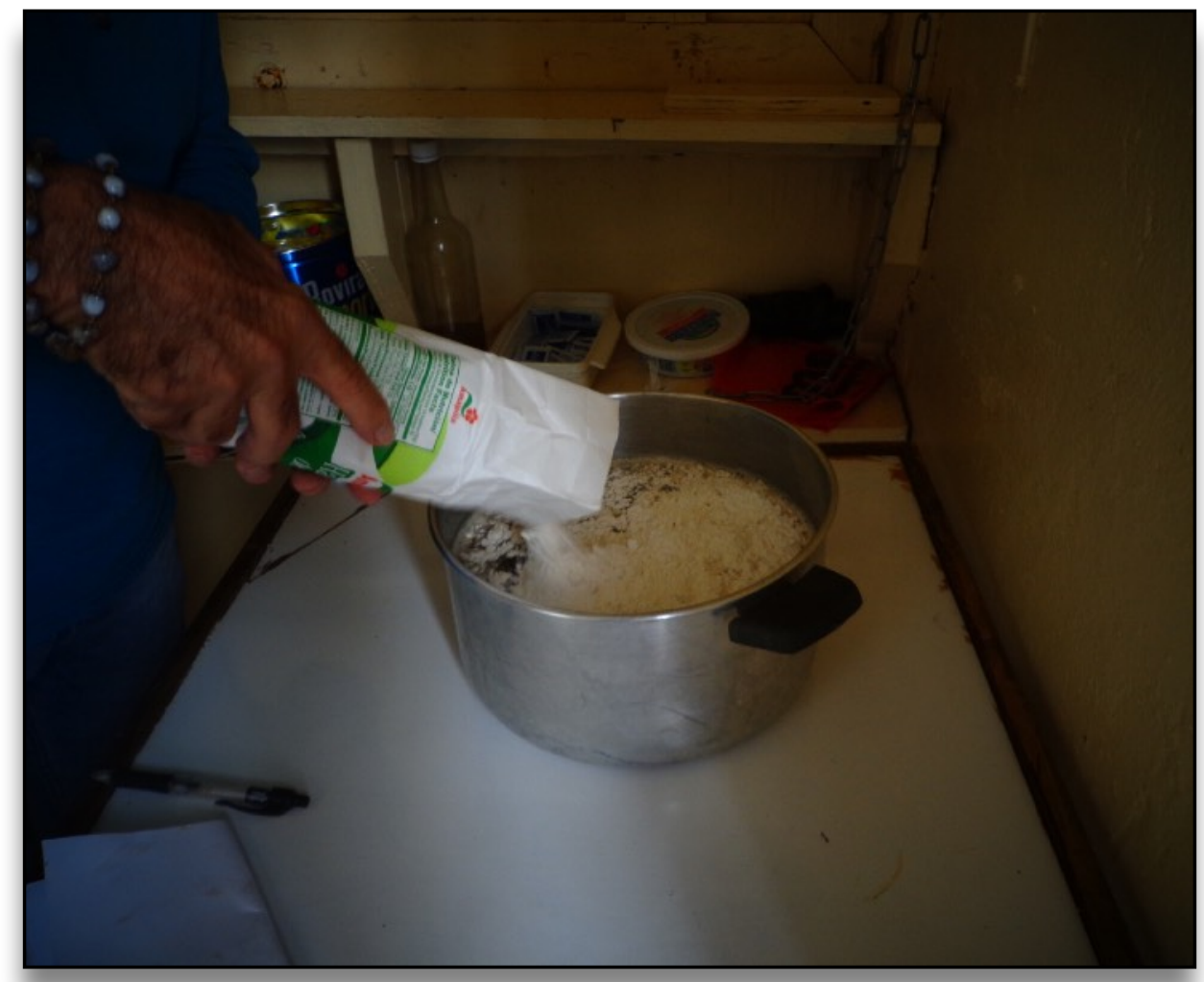

Figure 149 Adding Flour to the Engrudo Mix, La Playa de Ponce Workshop [digital image]. By Author. July 24, 2017

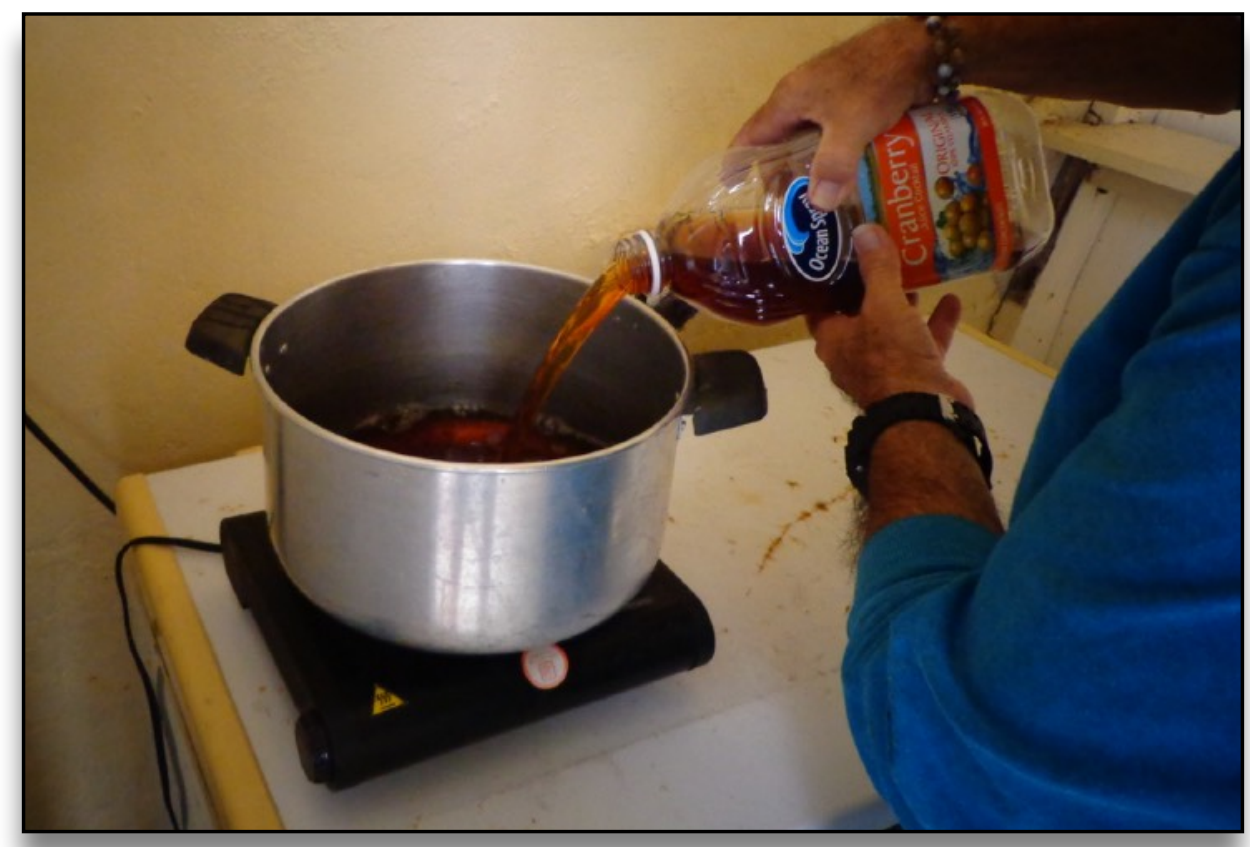

Figure 150 Adding Clove Water to the Engrudo Mix, La Playa de Ponce Workshop [digital image]. By Author. July 24, 2017 


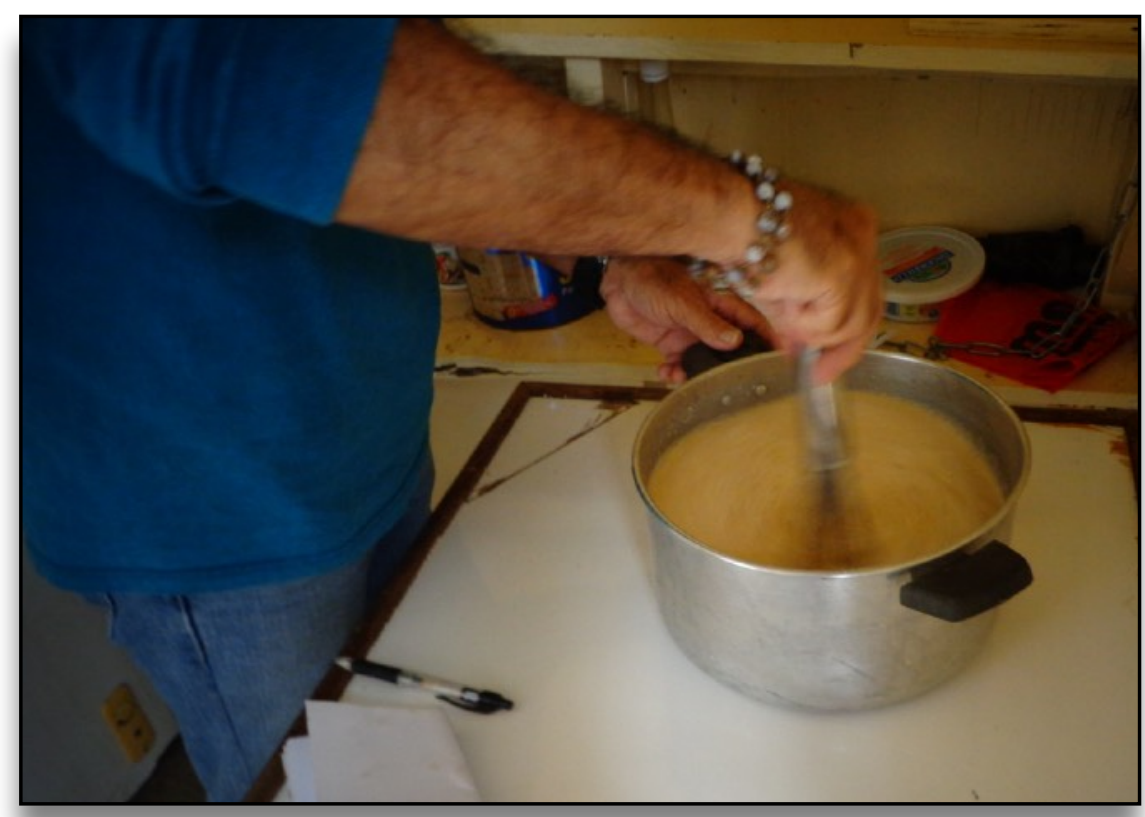

Figure 151 Mixing the Engrudo Ingredients Together, La Playa de Ponce Workshop [digital image]. By Author. July 24, 2017

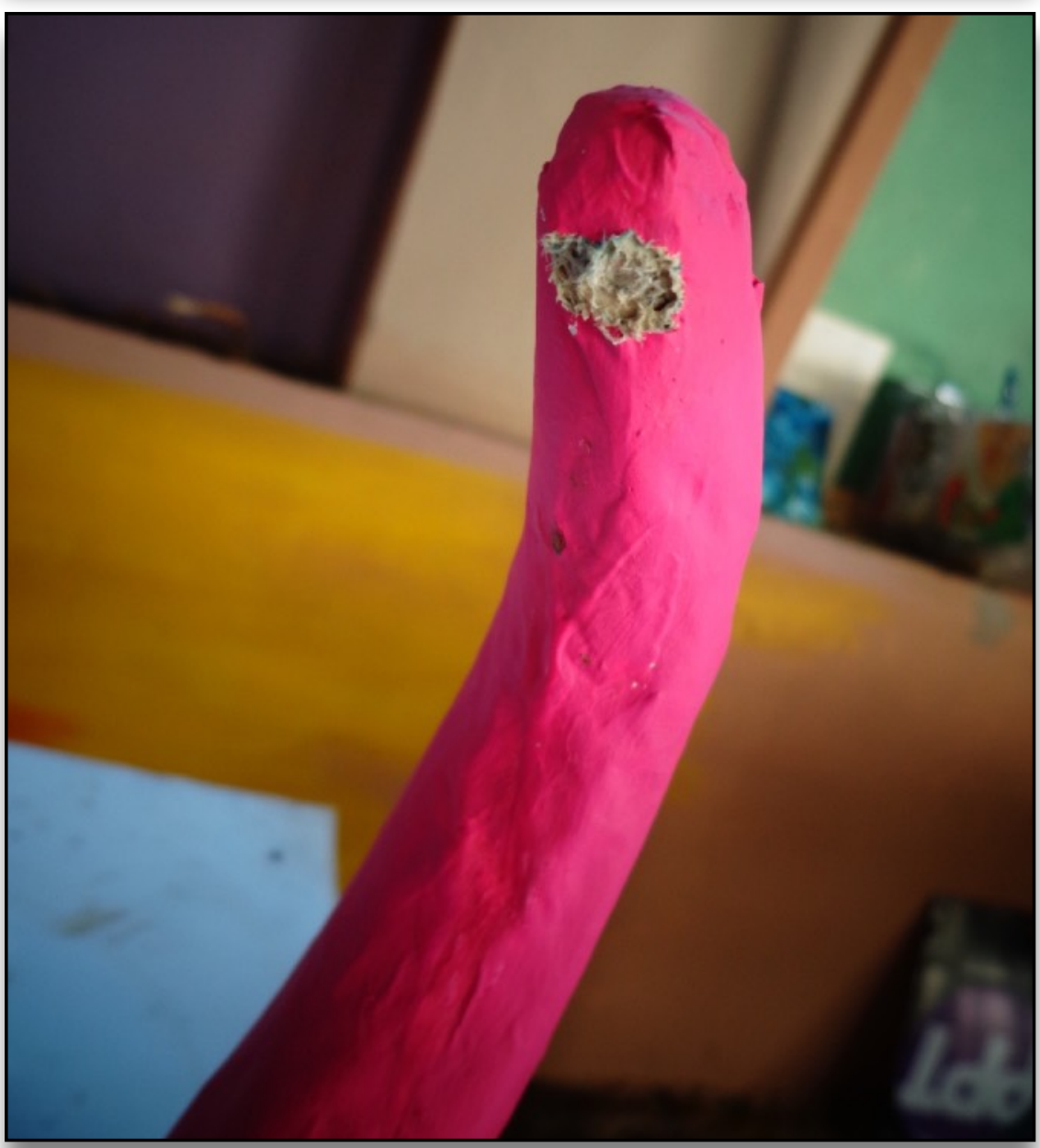

Figure 152 Horn of a Careta eaten by Bugs, La Playa de Ponce Workshop [digital image]. By Author. July 24, 2017 
Insects are drawn to the glue, due to the flour, and begin to burrow and eat the mask. Once the insects find a way to enter the inner layers of the mask, they create small tunnels inside. This enables more insects to enter the mask. If the mask is not treated accordingly, it will slowly deteriorate until it physically disintegrates. The process to patch a hole within a vejigante mask is done with a syringe needle, glue and newspaper. The syringe needle is filled with glue and inserted into the holes. This fills the holes with glue. Then newspaper is covered with glue and is placed over the holes with various layers depending on the severity of the damage. 


\subsection{Material and Process}

The materials needed to make a vejigante careta are the following: engrudo, newspaper or brown paper, molds, sandpaper, varnish, paints and brushes. The first step is to acquire a mold, and if one does not have access to a mold, then a mold must be constructed. Originally, molds were made of cement, or clay. (Figure 153) Nowadays, it is common to make molds out of a mask base, casco, which is the base of the mask that covers the face. Every casco made from a mold will increase in size. This is also used as a method to create larger masks of a preexisting mold. (Figure 154) The engrudo is used to glue aluminum foil to the casco, this is done to deter the new casco of getting attached to the old original mold. (Figure 155) 


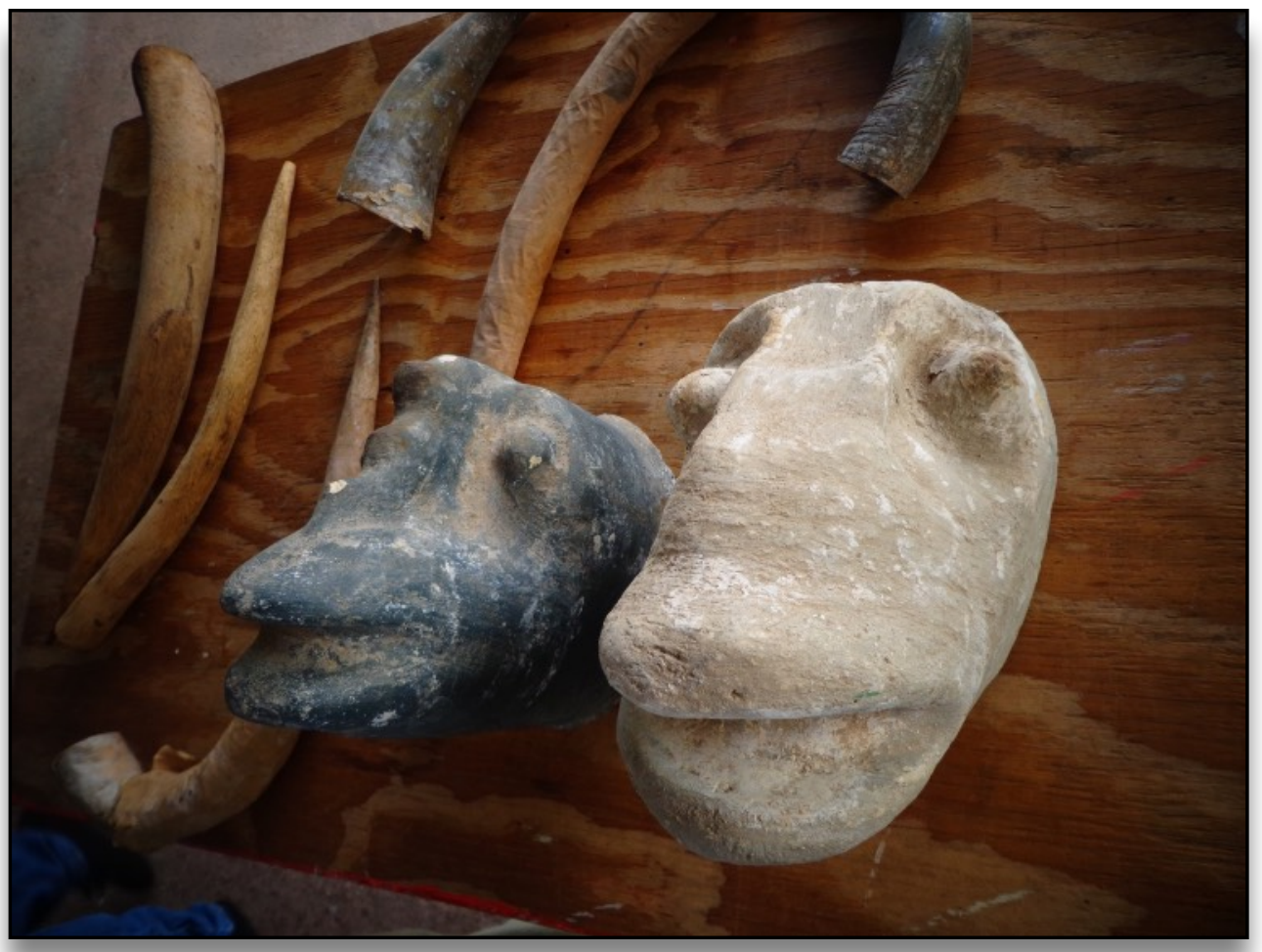

Figure 153 Cement Casco from the 1960s, La Playa de Ponce Workshop [digital image]. By Author. July 24, 2017

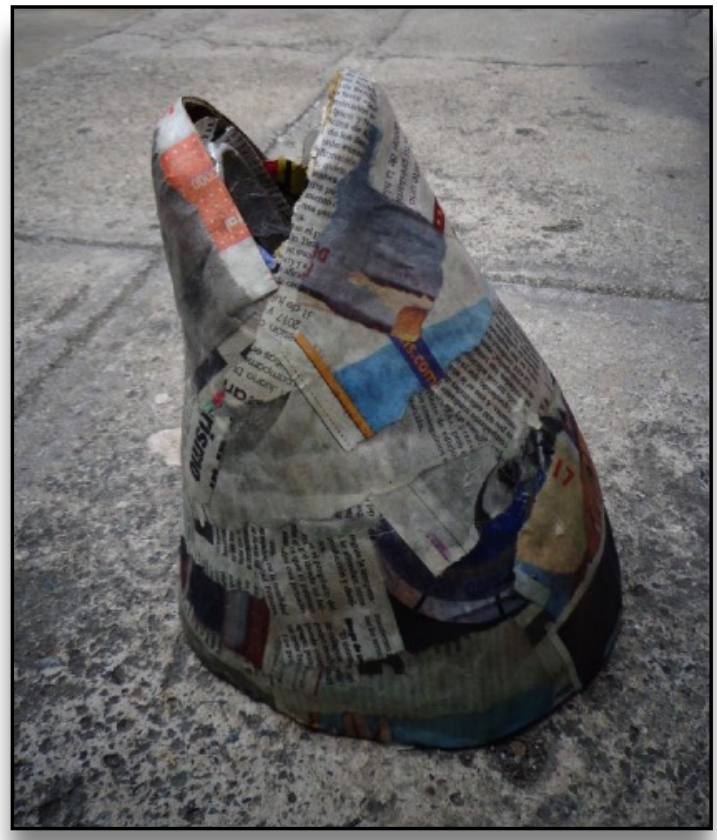

Figure 154 Papier-mâché Casco La Playa de Ponce Workshop [digital image]. By Author. July 24, 2017

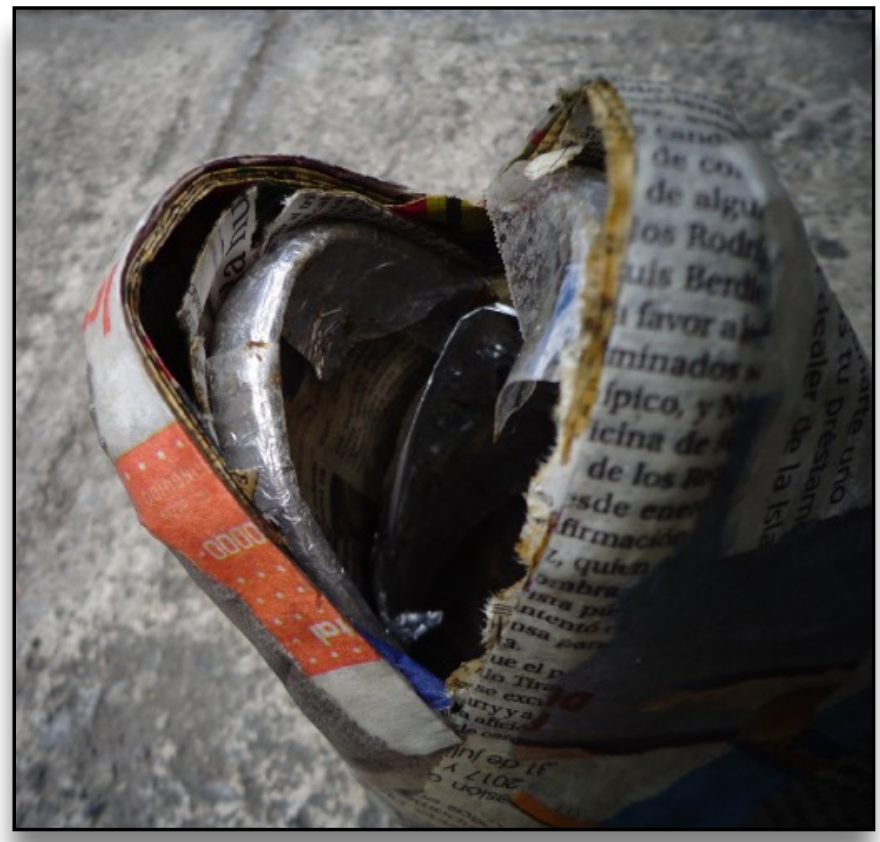

Figure 155 Papier-mâché Casco La Playa de Ponce Workshop [digital image]. By Author. July 24, 2017 
When creating a casco from a mold one must cover the entire foreground starting with large strips of newspaper. (Figure 156) It is important not to concentrate on the presence of imperfections, such as wrinkles in the layers newspaper, for there will be many more layers to correct the flaws throughout the construction process. After this is done, smaller strips of newspaper are used for the first layer of newspaper, and repeated with an additional five to eight layers. A larger strip of newspaper is folded in half and placed at the bottom of the casco to strengthen the edge of the base. This is repeated with every layer. This is also repeated at the opening of the mouth. The repetition of this throughout the mask ensures that the base and the mouth will have stability and durability. This is then left to dry out under the sun, preferably on concrete ground. After 24 hours, the mold is taken off the casco and the process is repeated on the inside of the mask. The casco is left in the sun again to dry the inside. (Figure 157) The final step, when the casco is completely dry, is to test the strength of the casco, checking for consistency. 


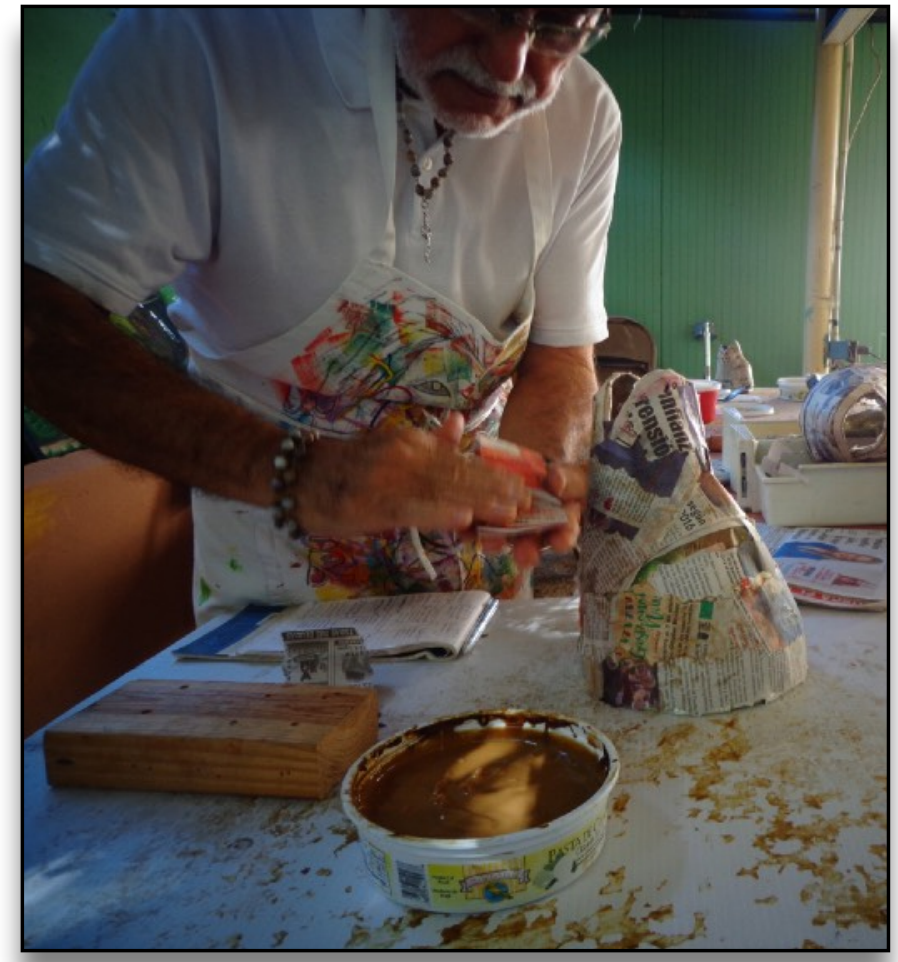

Figure 156 Adding Large Strips of Newspaper to a Casco, La Playa de Ponce Workshop [digital image]. By Author. July 24, 2017

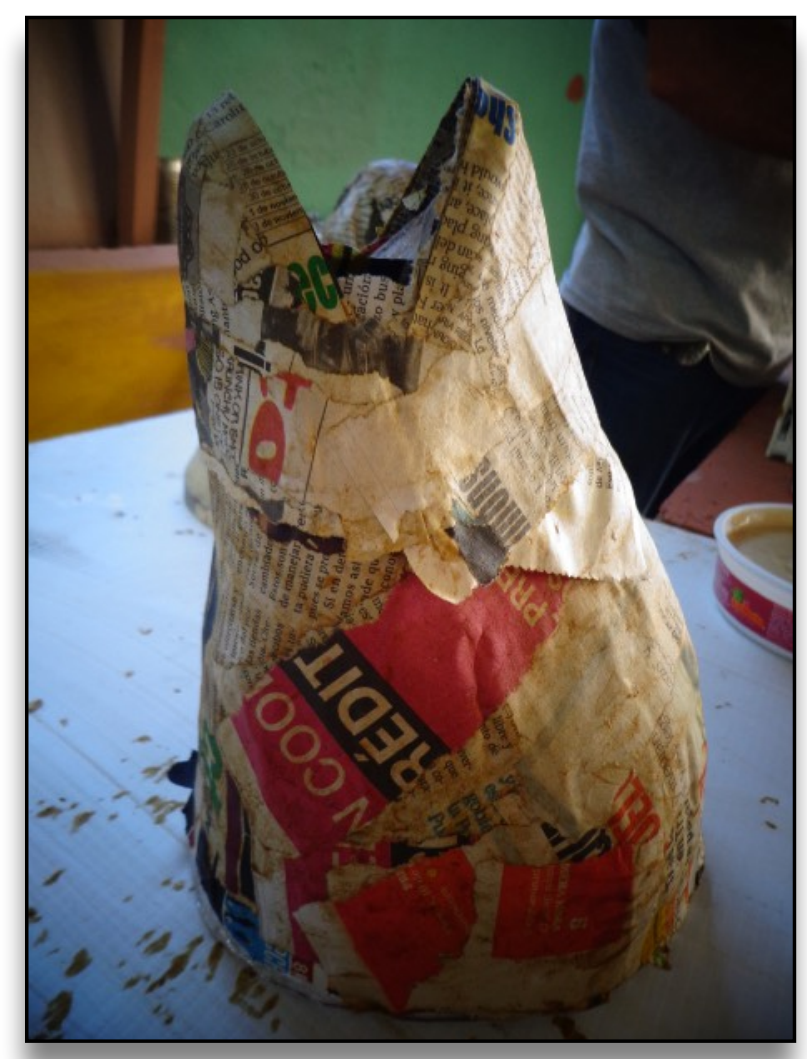

Figure 157 First Layer of the

Casco Drying, La Playa de Ponce Workshop [digital image]. By Author. July 24, 2017 
While the casco is drying for 24 hours, the artisan will move focus to the horns. The structure of the horns is usually made with molds of ox horns. The ox horns are readily available in Puerto Rico because oxen were normally used for agriculture on the island. ${ }^{175}$ Actual animal horns are preferred, as they provide realism to the mask. There are three popular methods used to create papier-mâché, vejigante horns: The first method is by placing strips on the mold from the top to the bottom consistently for six to ten layers. ${ }^{176}$ The second method is by placing large amounts of brown paper over the molds repeating this process four to six times, and later on smoothing the wrinkles and bumps with sandpaper. (Figure 158) This technique was used by Miguel Caraballo, one of the most respected artisans of Ponce. (Figure 159) The third method is by coiling strips of newspaper up and down the molds, and this is repeated six to ten times. (Figure 160) This method is used by Edwin Muñiz Pérez. Although, it is recommended to use ox horns, bull horns and cow horns are also commonly used. (Figure 161) Nowadays, it is also common for artisans to use handcrafted horns, in order to give a signature look and to individualize their masks. Handcrafted horns can be made be carved out of wood, molded with cement/ clay, and formed completely from aluminum foil. One of the most contemporary methods is with aluminum foil, and by compressing it to the desired the shape, this is then glued

\footnotetext{
175 Norberto Martell Morales and Héctor J. Rodríguez Torres, Las Caretas del Vejigante Ponceño, 32. 176 Norberto Martell Morales and Héctor J. Rodríguez Torres, Las Caretas del Vejigante Ponceño, 32.
} 
with engrudo, and tapped with clear large formatted Scotch Tape. After the horns are finished, they must be left to dry in the sun for 24 hours. (Figure 162)

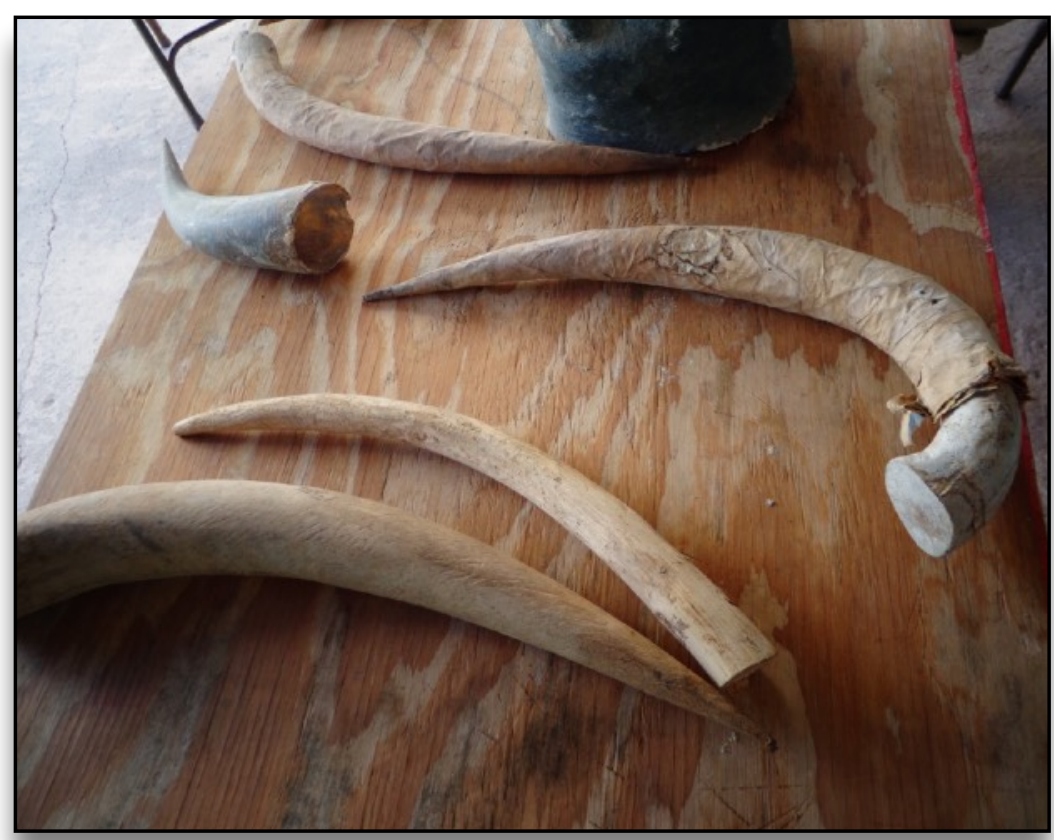

Figure 158 Large Brown Paper papier-mâché wrapped around Wooden Horns, La Playa de Ponce Workshop [digital image]. By Author. July 24,2017

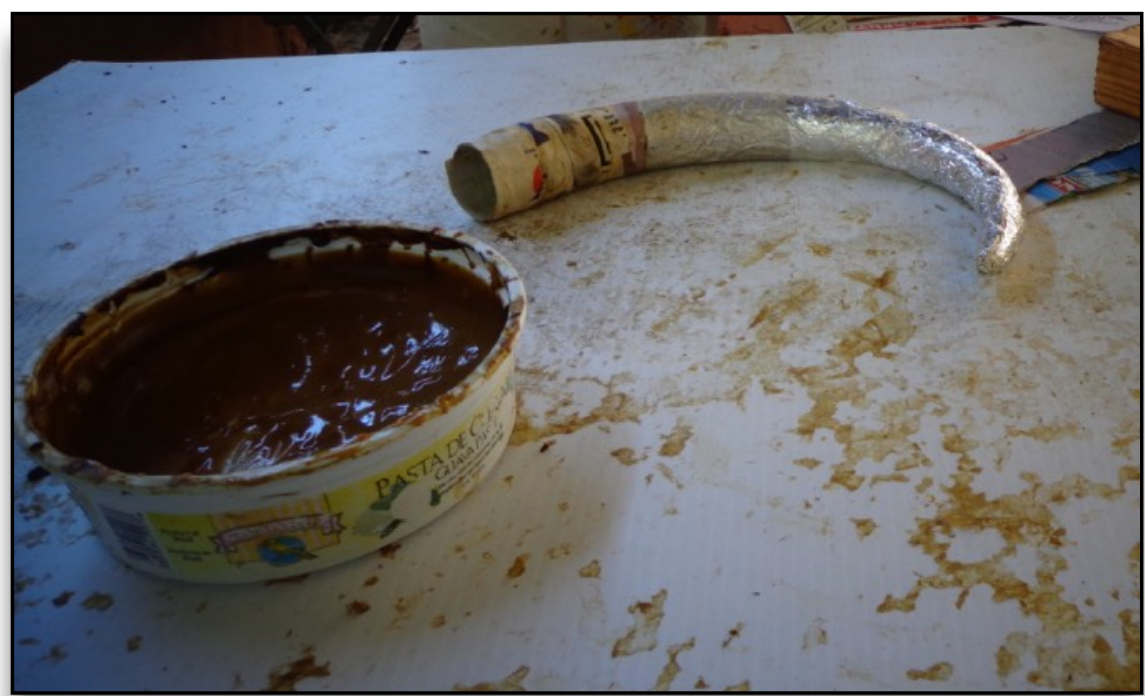

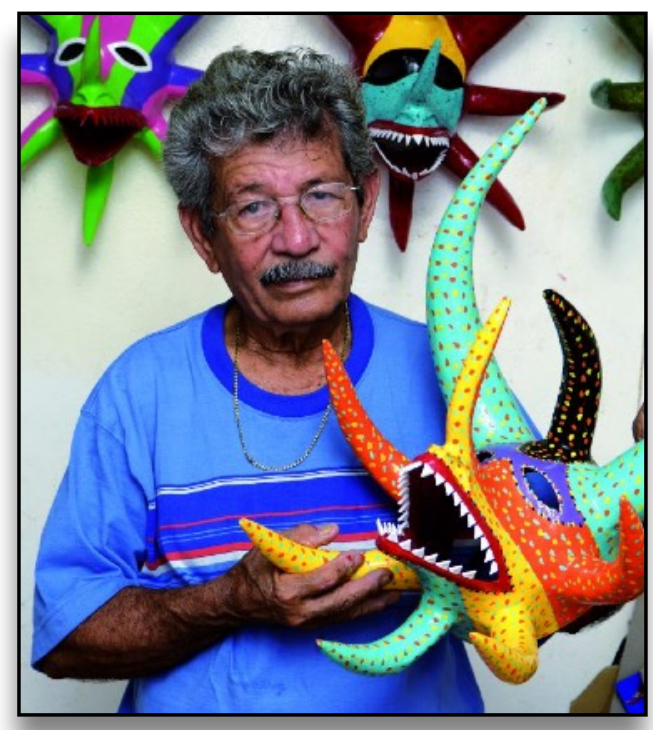

Figure 159 Miguel Caraballo Garcнa Santo Tomás, Ponce, Puerto Rico / Photo: Yessika Mármol [digital image]. Retrieved June 20, 2020 from http:// amigosgrandesmaestros.org/pieza/lasmascaras-de-vejigantes/
Figure 160 First Layer of papier-mâché on the Casco Drying, La Playa de Ponce Workshop [digital image]. By Author. July 24,2017 


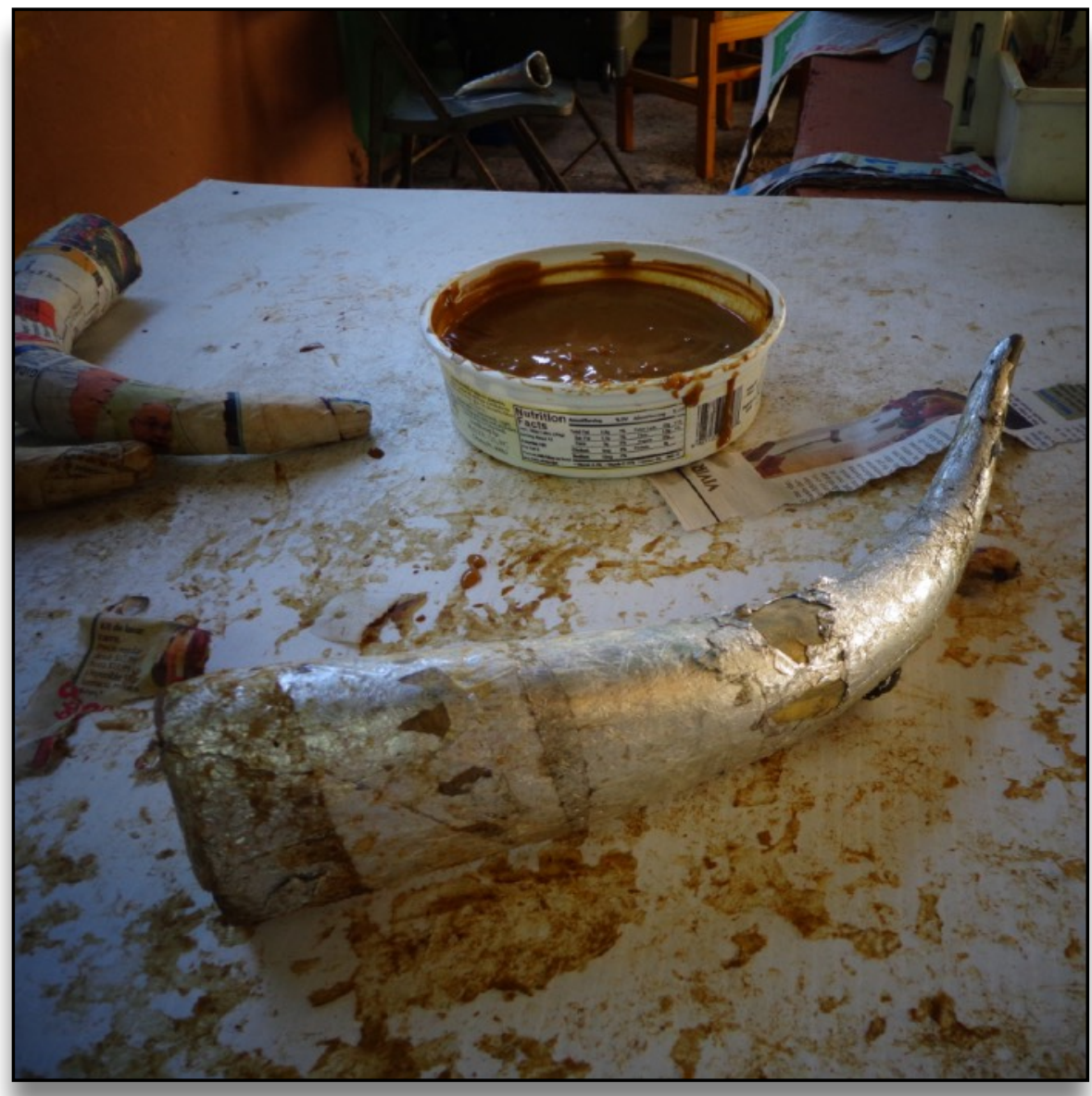

Figure 161 Real Bull Horns for making papiermâché Molds, La Playa de Ponce Workshop [digital image]. By Author. July 24, 2017

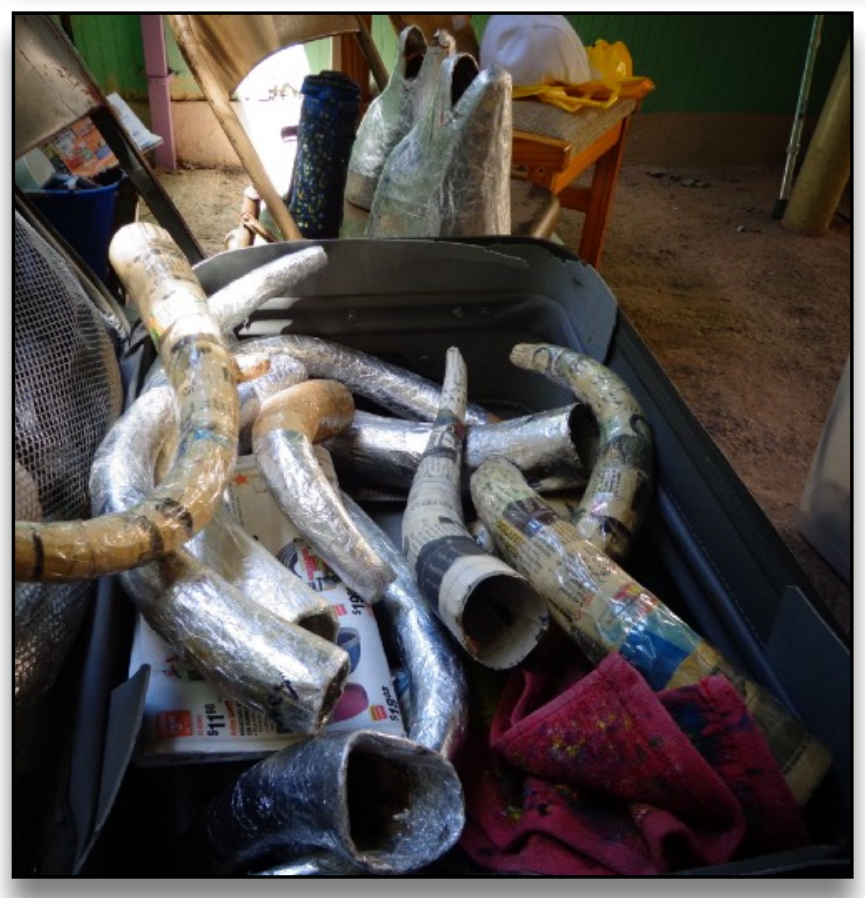

Figure 162 Homemade Foil Molds for making Papier-mâché Horns, La Playa de Ponce Workshop [digital image]. By Author. July 24, 2017 
When the casco is dry, before connecting the horns to the mask, the eyes and mouth must be cut and sanded. The eyeholes are traced with a pencil to achieve the desired shape, and then cut out with a knife/exacto knife. (Figure 163) The cut out of the first eyehole should be saved and used to place the second eyehole but flipped to mirror the first shape. Some artisans save the cut-outs of the eyeholes to create consistency in their masks. This gives a uniform look to the artisan's work and resonates with their tendency and preference for symmetry. After the eyes are cut out, the mouth and the eyeholes are sanded with either sandpaper, or for a faster result, a Dremel, a micro, electrical sander. (Figure 164) After the casco is sanded, it is then ready to attach the horns.

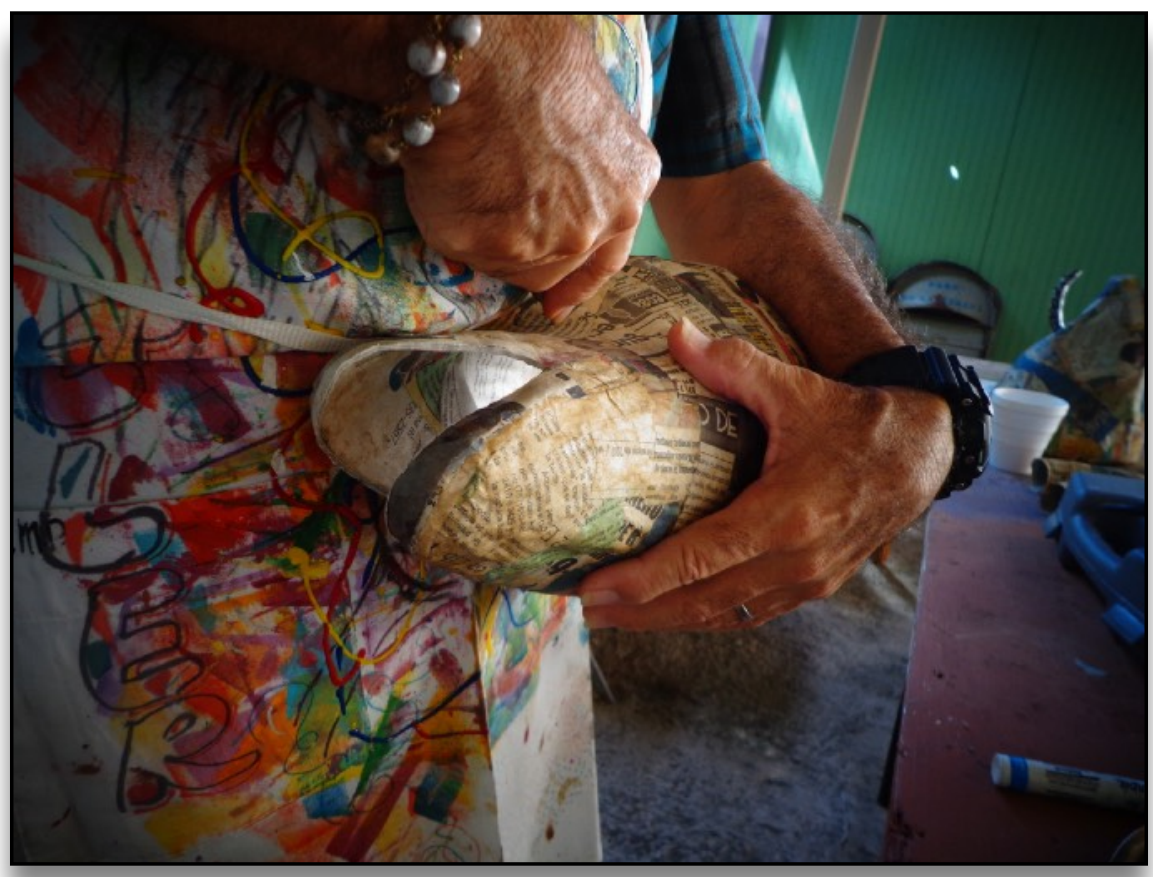

Figure 163 Cutting out the Eyes of the Mask with a Knife, La Playa de Ponce Workshop [digital image]. By Author. July 24, 2017 


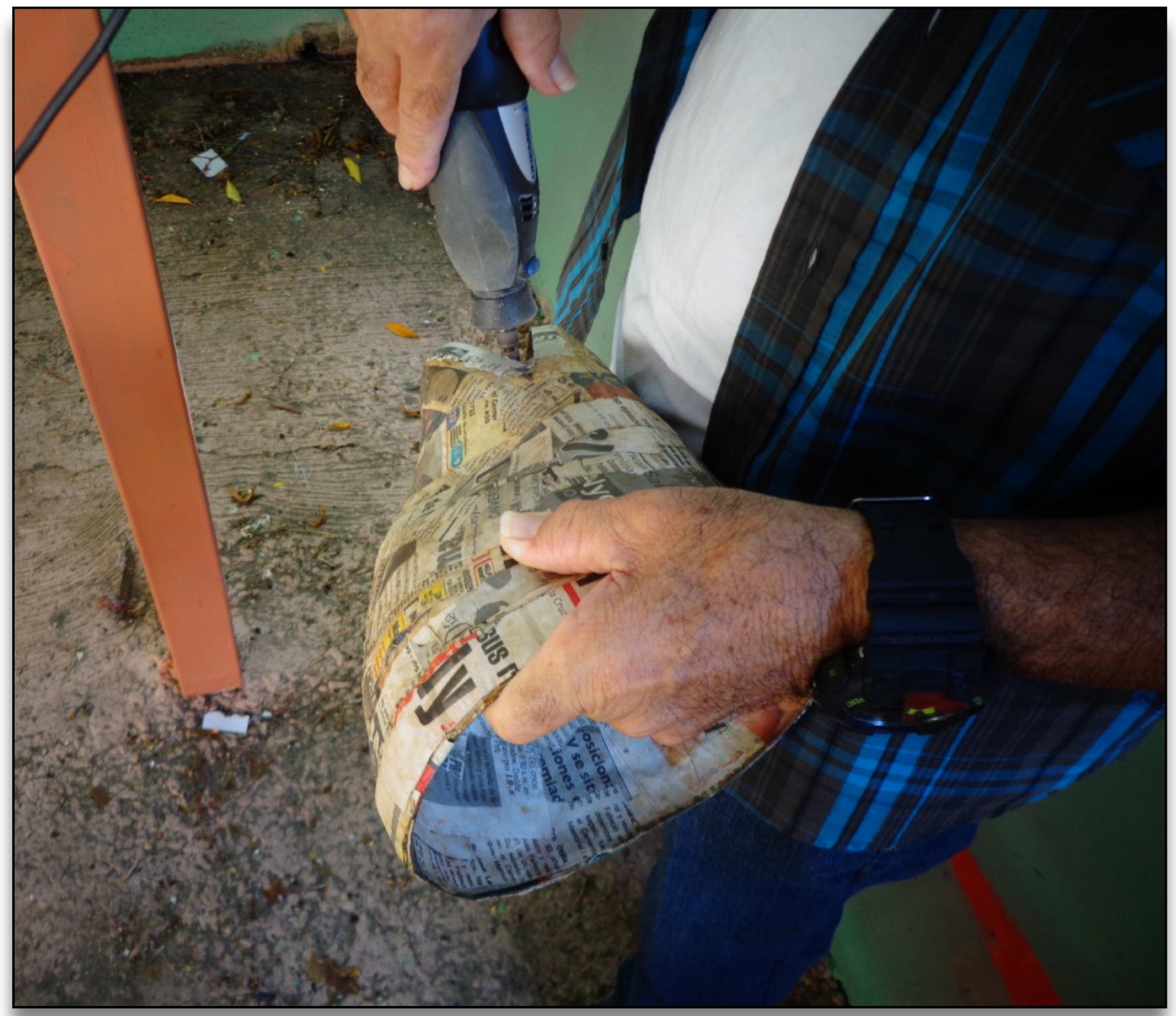

Figure 164 Sanding the Rough Edges of the Mask with a Dremel, La Playa de Ponce Workshop [digital image]. By Author. July 24, 2017 
The horns are joined to the casco by cutting slits from the bottom of the horn up, one inch long and half an inch wide. (Figure 165) These slits allow the end of the horn to open up, imitating a fan, enabling the horn to be joined strongly to the casco. (Figure 166) Engrudo is placed on the inside of the horn and on the base of where the horn will be attached. This section is then covered with seven to ten layers consecutively of shorter strips of newspaper around the entire base of the horn. (Figure 167) The mask is then left to dry in the sun for 24 hours. While one horn is placed on the casco, an additional horn may be placed as well, but keeping in mind to not touch nor move the drying horn. If the horn is moved in the slightest before it is fully set, it will not be durable and eventually detach from the casco.

The quantity of horns is an aesthetic preference and varies from artisan to artisan. Therefore, the amount of horns placed on the casco is a decision completely up to the mask maker. but the vejigante must have a minimum of two horns. The mask can be adorned with as many horns as it is physically possible, but after a certain point, the mask will become excessively heavy to wear, and re-categorized as wall art. 


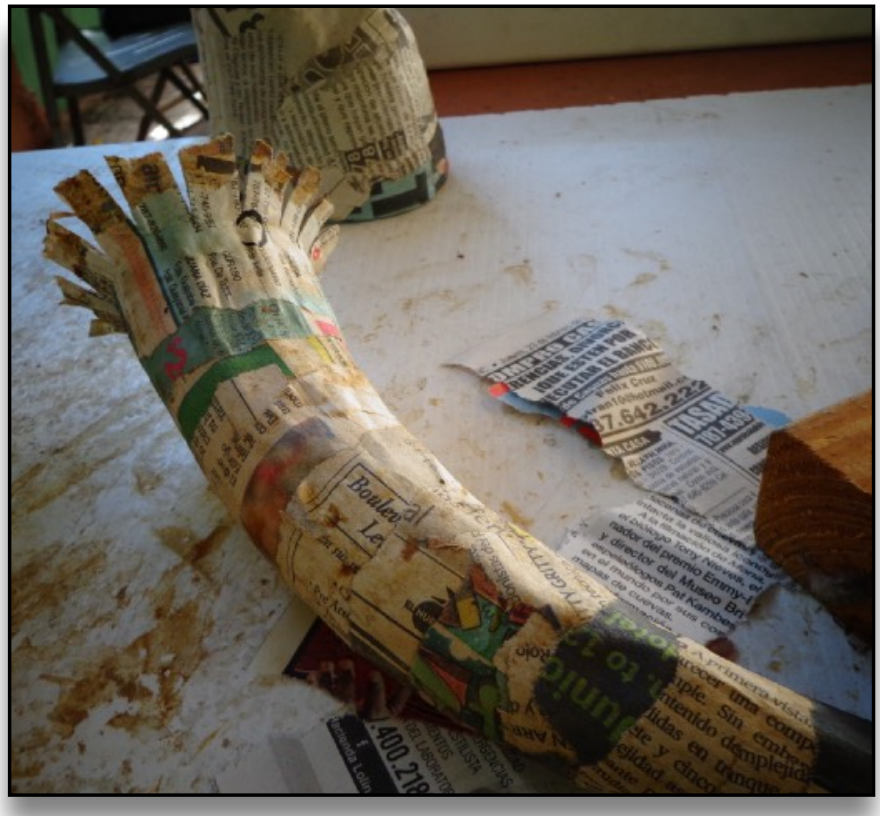

Figure 165 Preparing to attach the Horn to the Casco, La Playa de Ponce Workshop [digital image]. By Author. July 24, 2017

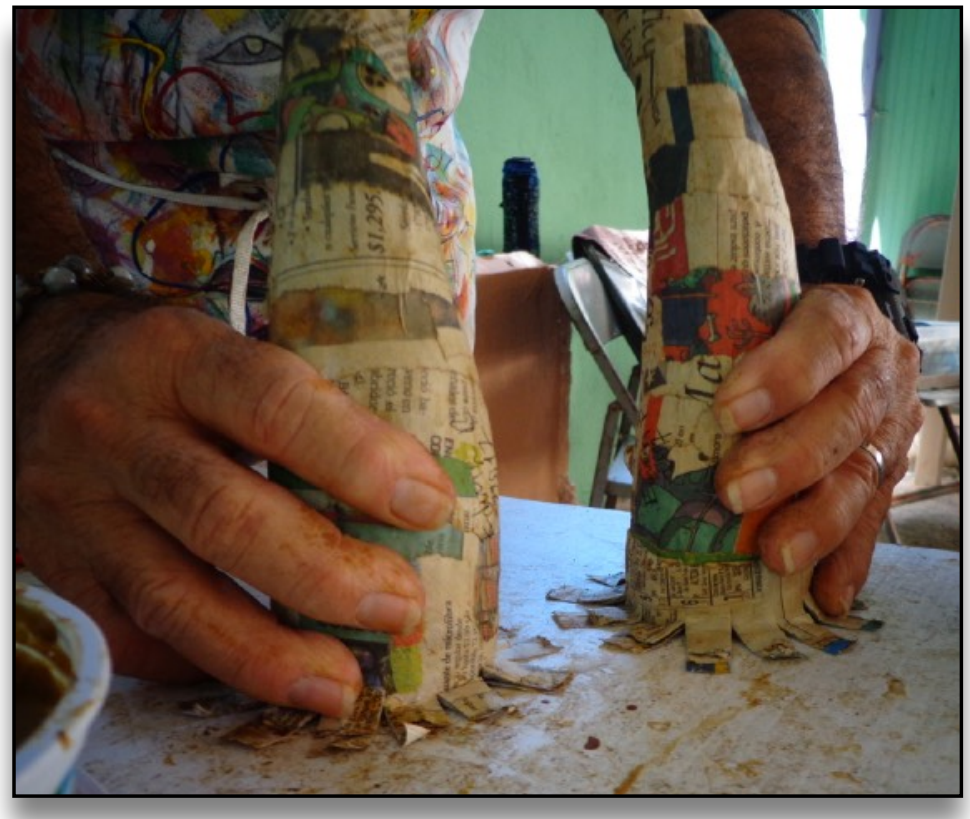

Figure 166 Preparing to attach the Horns to the Casco, La Playa de Ponce Workshop [digital image]. By Author. July 24, 2017

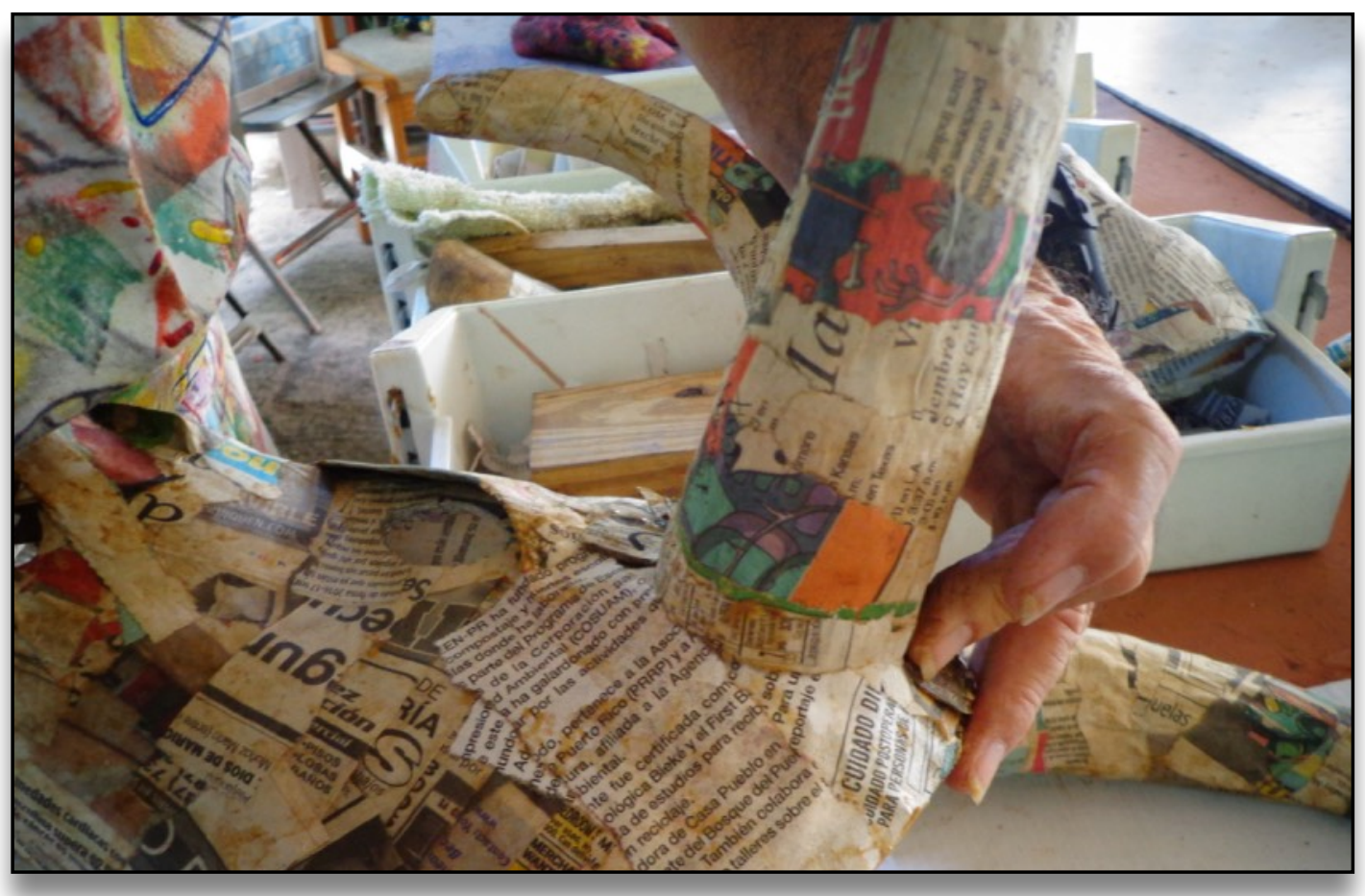

Figure 167 Attaching the Horn to the Casco, La Playa de Ponce Workshop [digital image]. By Author. July 24, 2017 
After the horns are fully set, the next step is the addition of teeth. The teeth can be made by molding newspaper or brown paper into the desired shape, making each tooth individually, allowing for them to dry for 24 hours before gluing them in the mouth. Another technique often used is the method of cutting cardboard paper in the shape of a denture, (Figure 168) strengthening it with brown paper or newspaper, allowing it to dry and set, (Figure 169) then attaching it to the inside the mouth directly at the edge of the opening. (Figure 170) This is the fastest technique for creating teeth, in comparison to the tedious process of creating each individual tooth.

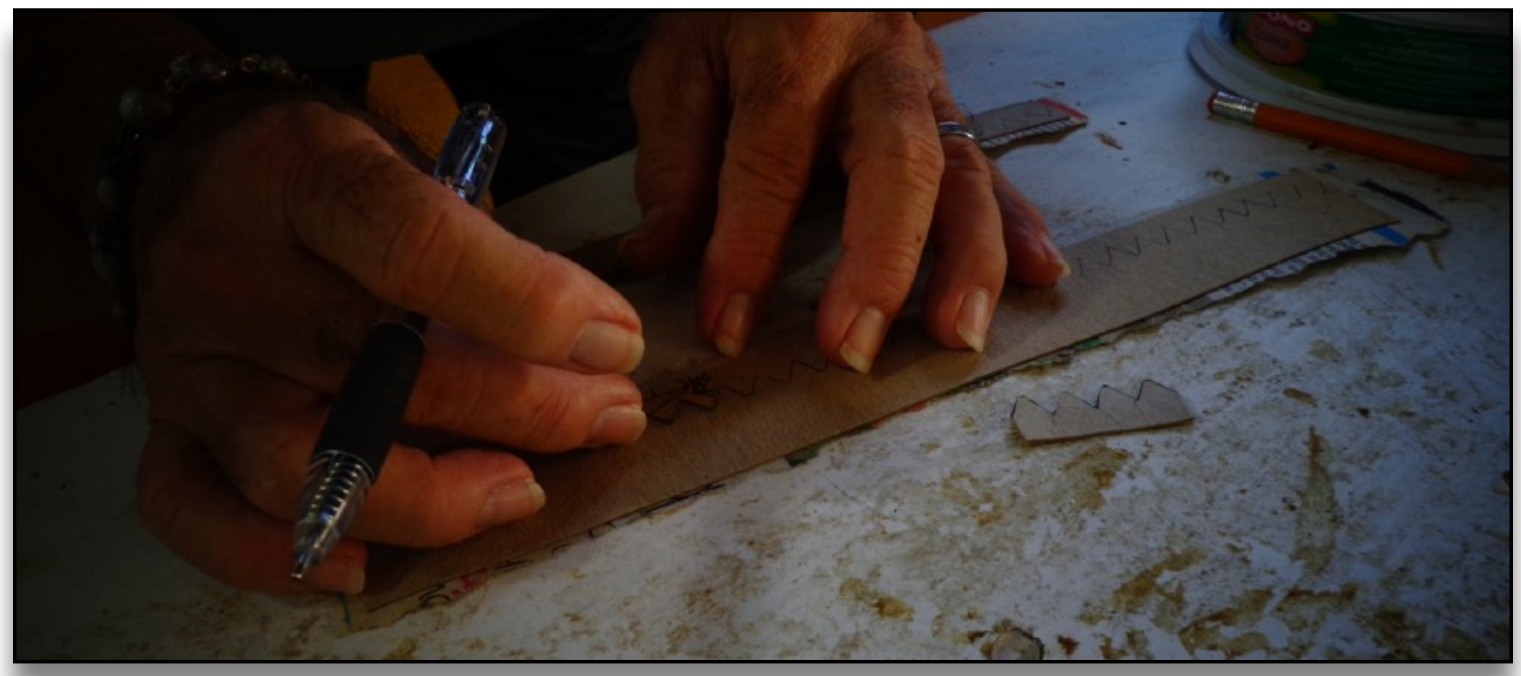

Figure 168 Making Teeth by Cutting Cardboard Paper in the Shape of a Denture, La Playa de Ponce Workshop [digital image]. By Author. July 24, 2017 


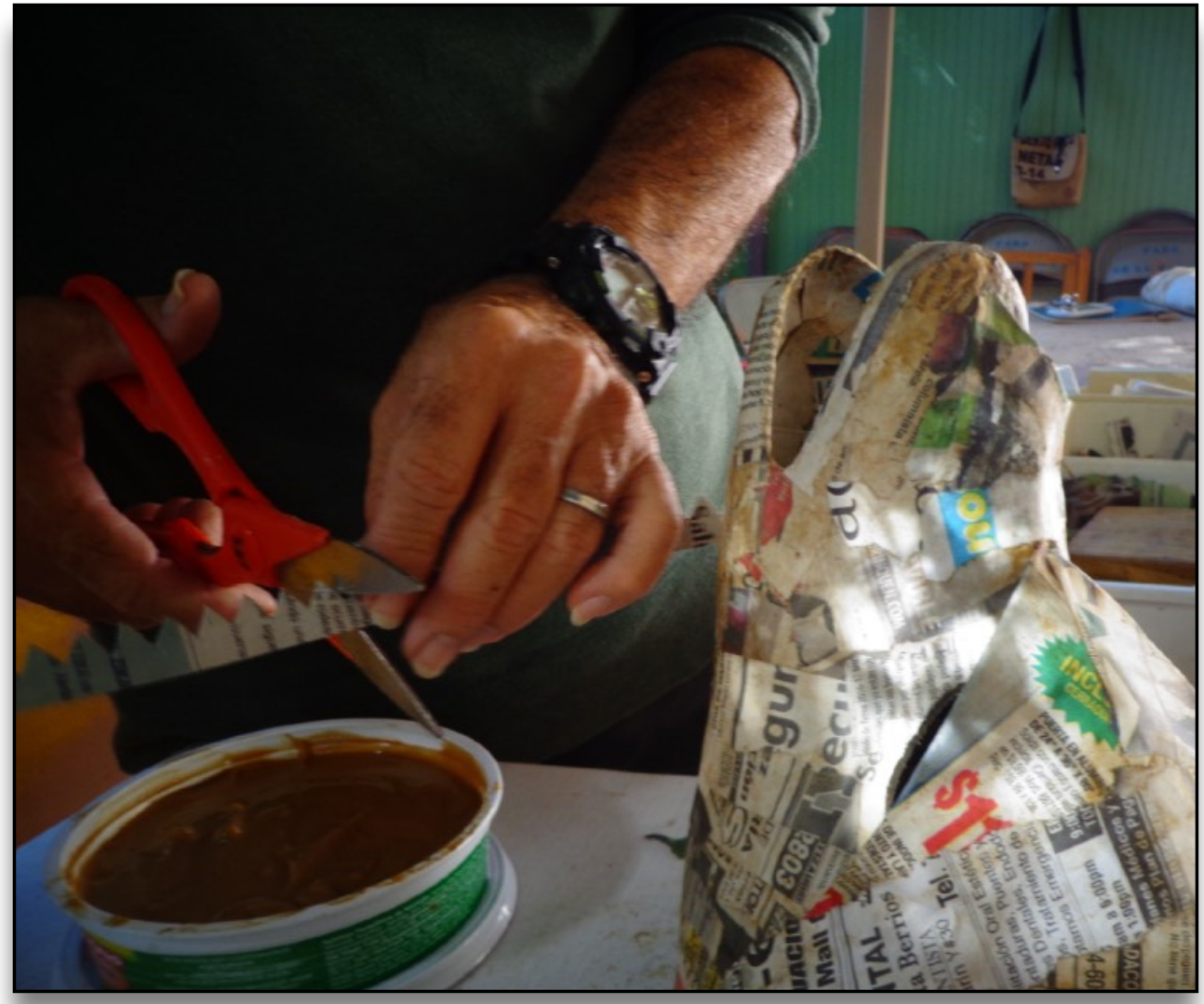

Figure 169 Adding Papier-mâché to the Teeth, La Playa de Ponce Workshop [digital image]. By Author. July 24, 2017

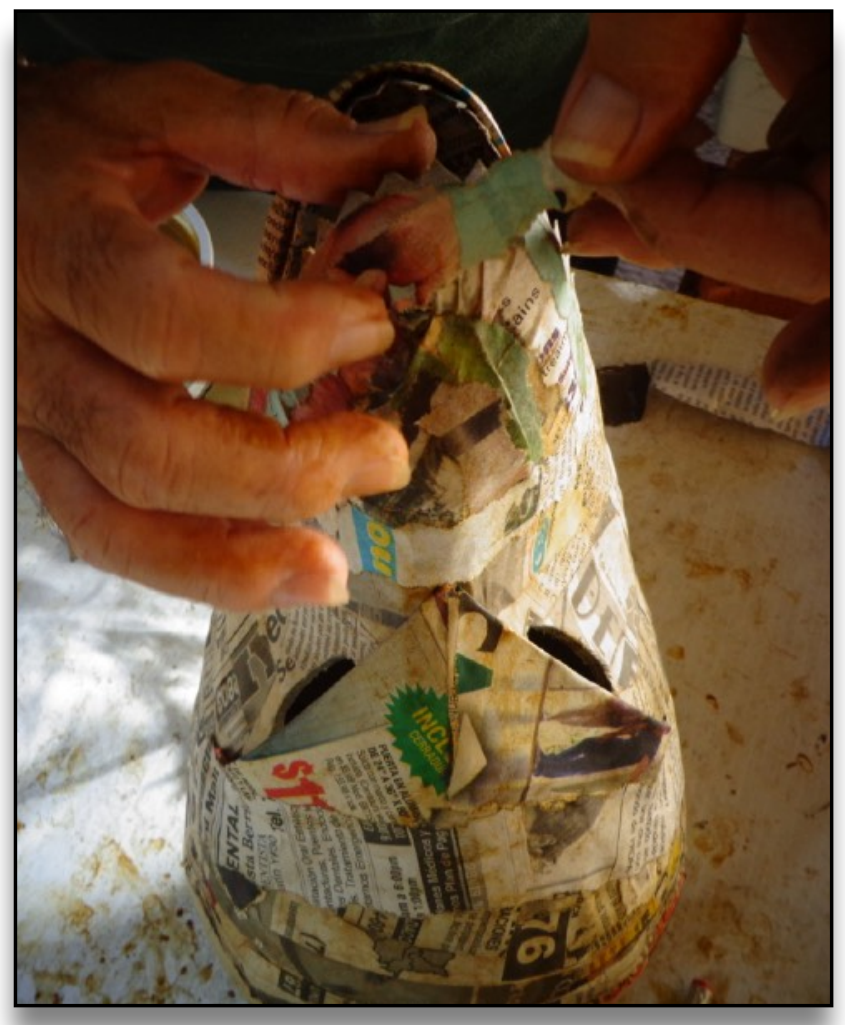

Figure 170 Attaching the Teeth to the Casco, La Playa de Ponce Workshop [digital image]. By Author. July 24, 2017 
The final step in completing the vejigante mask is optional. The mask can include additional facial elements to intensify the mask's expression. Again, these characteristics can vary from artisan to artisan. The added details are mainly seen around the eyes and mouth, such as eyebrows, wrinkles, raising the cheek bones, and/or giving the mask some sort of nose/nostrils, gives the mask individual character. (Figures 171-172)

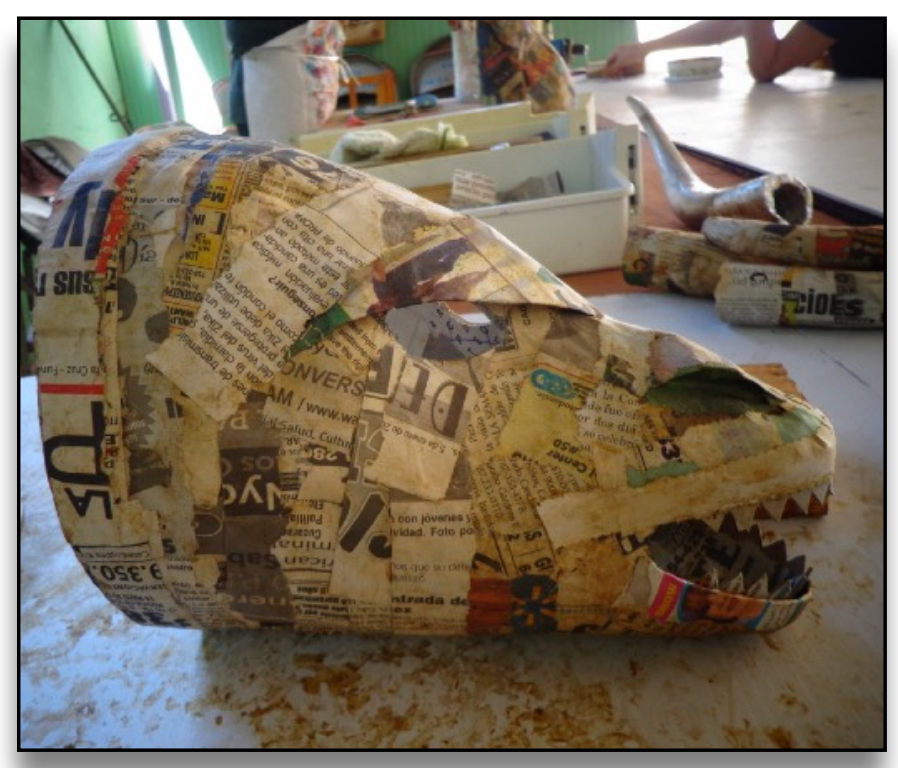

Figure 171 Details added to the Eyes and Mouth of the Casco, La Playa de Ponce Workshop [digital image]. By Author. July 24, 2017

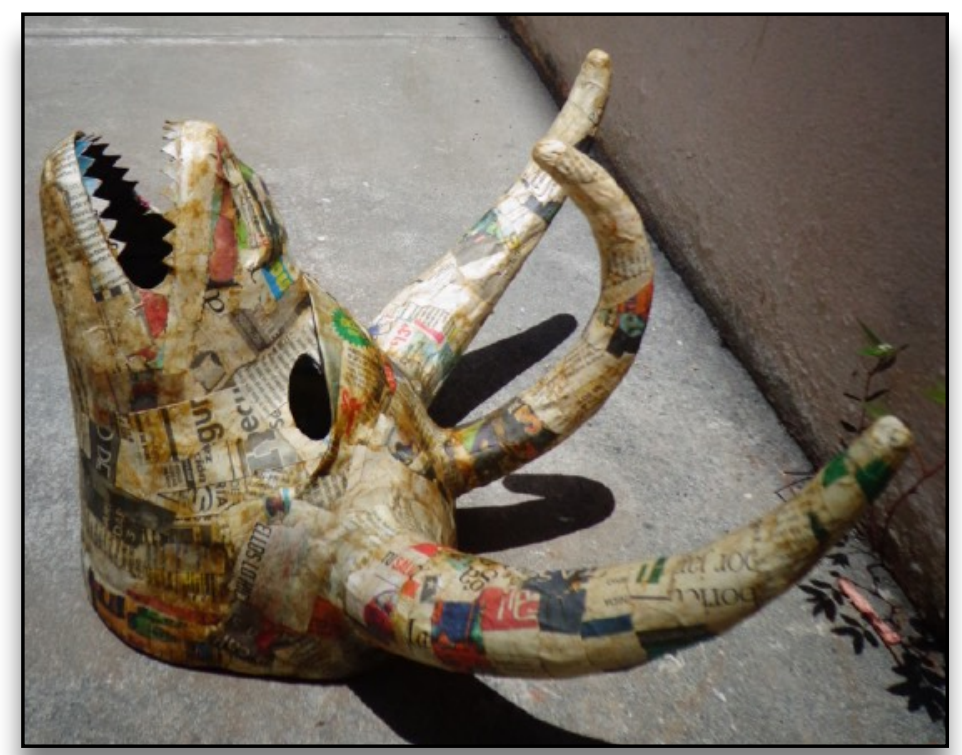

Figure 172 Details on the Mouth and Eyes of the Casco, La Playa de Ponce Workshop [digital image]. By Author. July 24, 2017 
Before painting the mask, it must be prepared for the application. A small section of the mask is cut out of the bottom of the casco for the neck to fit comfortably. This portion is then sanded. The mask is sanded one final time, smoothing out missed imperfections. The mask is either primed, or gessoed, to create a smooth, consistent surface. Although, this is not necessary, but recommended. (Figure 173)

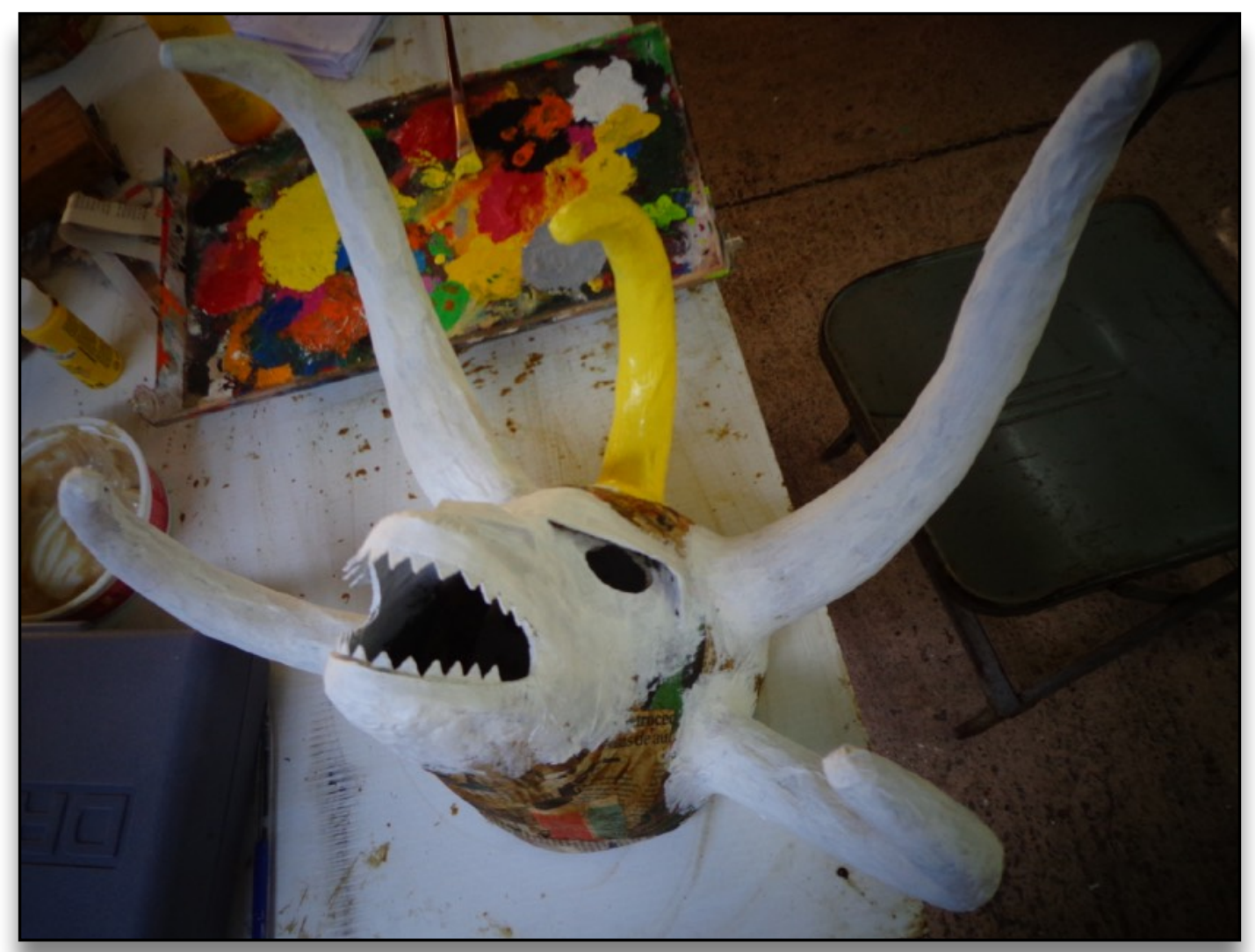

Figure 173 Careta with Gesso, La Playa de Ponce Workshop [digital image]. By Author. July 24, 2017 
Usually the vejigante masks are painted with patterns, either repeated dots and/or repeated lines. The colors often used to paint the base of the mask, the casco, are yellow, red and black. These colors are used because they are the colors of the flag of Ponce, Puerto Rico. Additionally, it should be noted, that these are also the colors of the flag of Spain. Furthermore, the colors yellow, red and black are also in representation of "hellfire," signifying chaos and "damnation."177 (Figure 174) After the mask is painted and decorated, it must be sealed with either varnish or a clear finish. It is more common to see the artisan use wood varnish because of its durability and lasting effect. This process is not recommended due to health hazards, but documented only for the purpose of research. If the mask is going to be worn, straps must be attached to the base. Three holes must be cut into the mask for the straps: one on the top edge of the mask, and two on either side. (Figure 175) Artisans are commonly known to use various materials for the straps of the mask, such as bicycle rubber, (Figure 176) elastic, string or leather buckles to hold the mask to the head. The choice in straps can vary from artisan to artisan, in addition, those who purchase vejigante masks are also known to change the straps to their preferred material to achieve maximum comfort when wearing the careta antigua.

177 Barbara Balleto, ed., Insight Guide: Puerto Rico (Singapore: APA Publications, 1999), 89. 


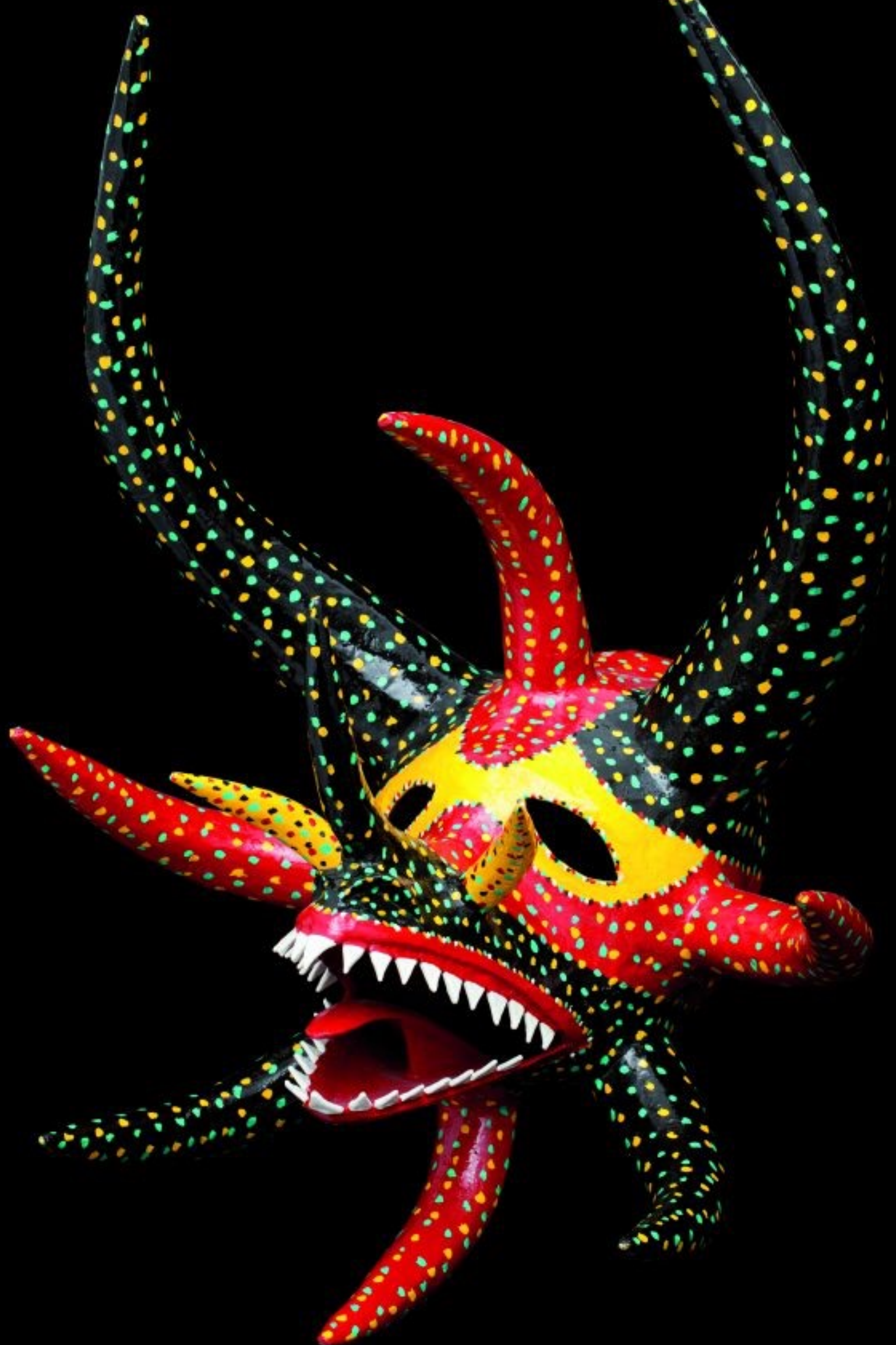




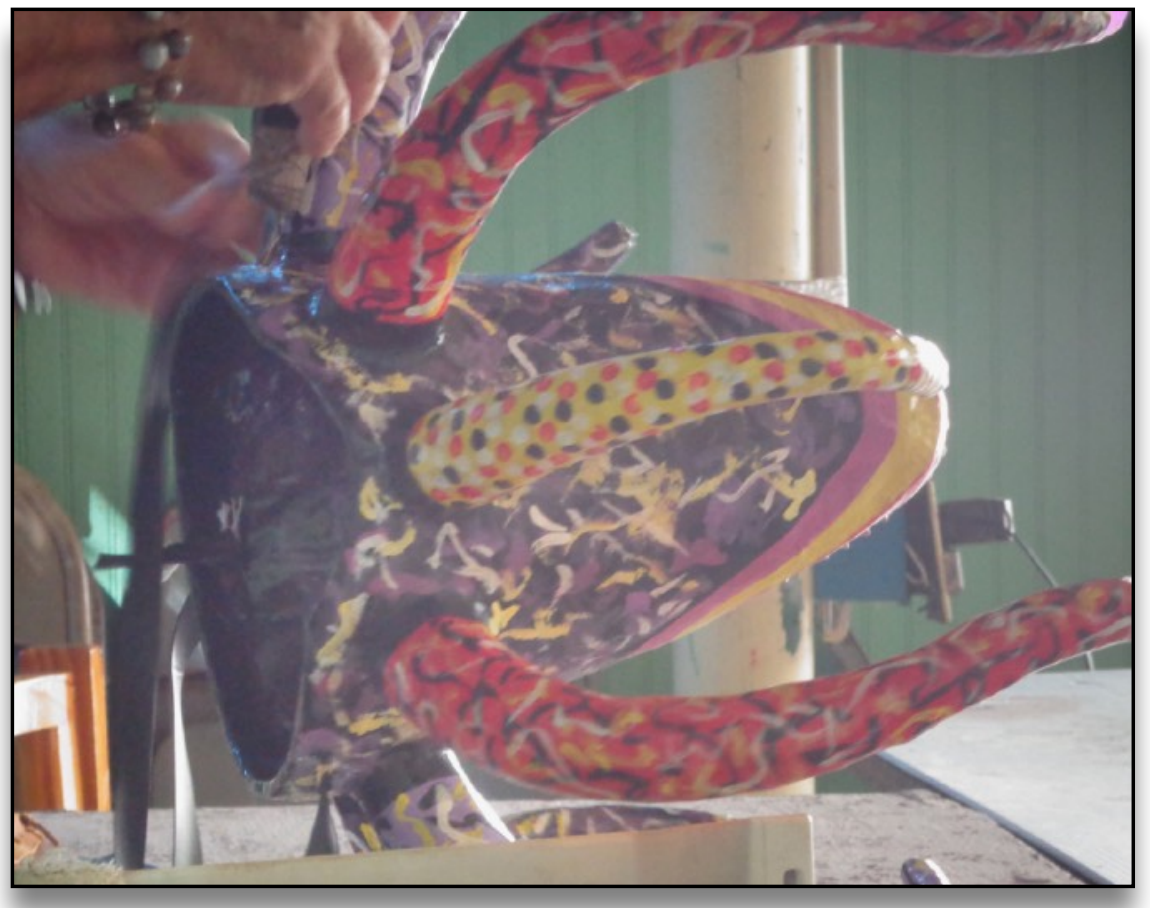

Figure 175 Attaching Bycicle Rubber to a Vejigante Mask, La Playa de Ponce Workshop [digital image]. By Author. July 24, 2017

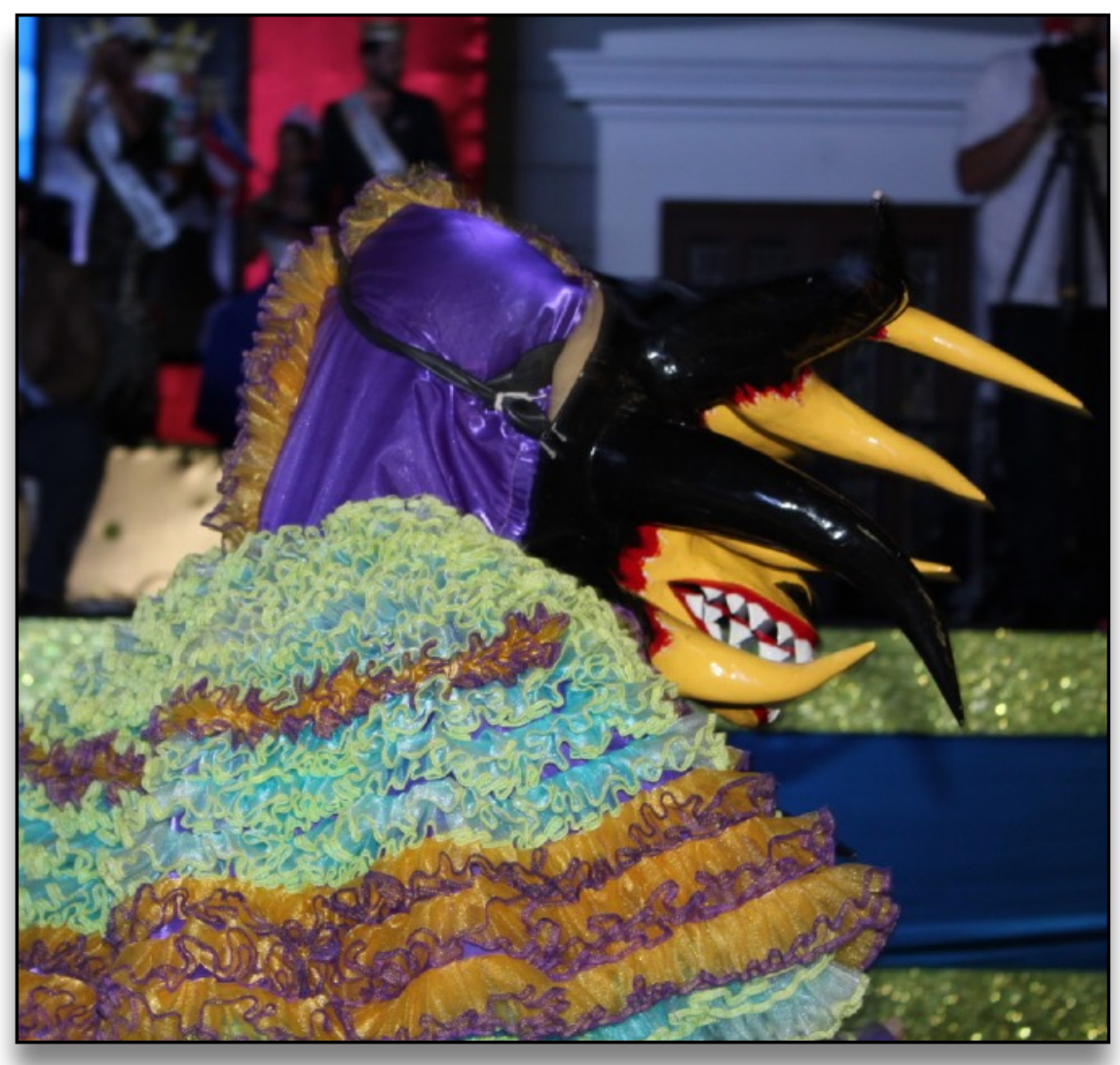

Figure 176 Bicycle Rubber attached to the Vejigante Mask, Carnaval Ponceño 2017 [digital image]. By Author. February 24, 2017 


\subsection{Certification as an Artisan}

During my residency in Ponce, Puerto Rico, I had the opportunity to learn the process of making a vejigante mask traditionally. The local newspaper in Ponce was advertising a workshop in La Playa de Ponce sponsored by Gilberto Limardo, a local lawyer who advocates for the cultural arts of Puerto Rico. Workshops were offered in the taller, translated to workshop, of Edwin Muñiz Pérez, (Figure 177) in La Playa de Ponce. (Figure 178) I began taking classes in June of 2017 until January of 2018. During my studies I learned every aspect of the process of crafting a vejigante mask, such as the engrudo, cascos, molds, etc.

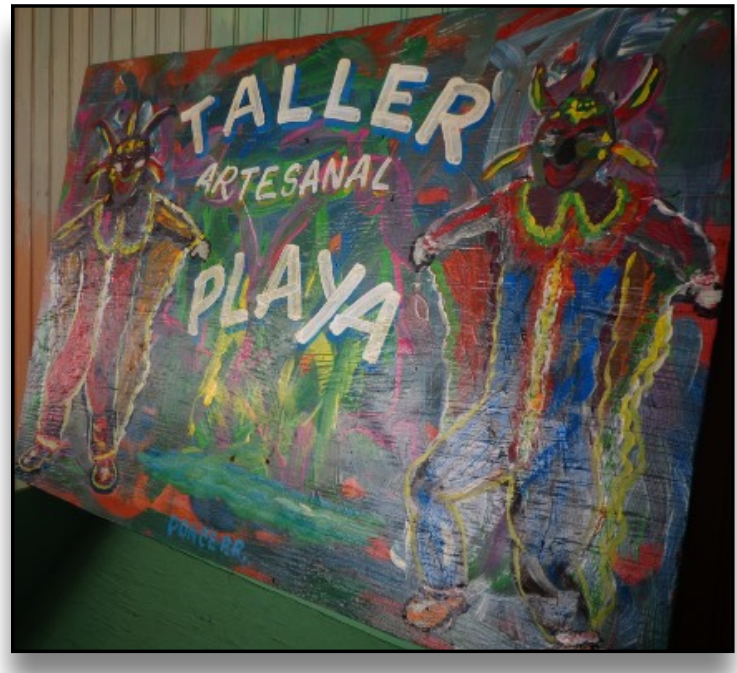

Figure 177 La Playa de Ponce Workshop [digital image]. By Author. July 24, 2017

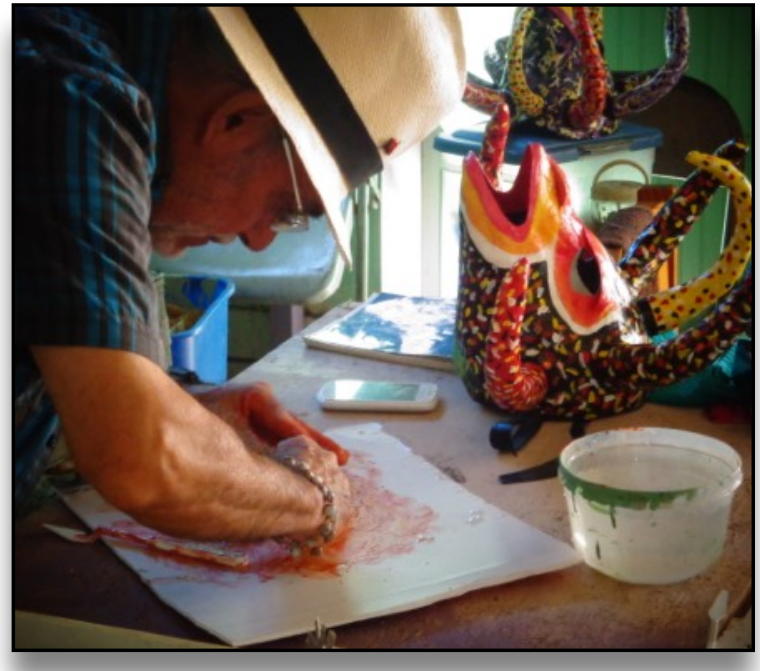

Figure 178 Master Artisan Edwin Muñiz Pérez at La Playa de Ponce Workshop [digital image]. By Author. July 24, 2017 
After my training was completed, I began to create masks independently. I was qualified to apply for certification as an artisan of Puerto Rico. I passed the exam and became a certified artisan of papier-mâché in the subject of caretas. The certification process took place in Ponce, Puerto Rico in Plaza del Caribe in La Escuela Taller de Artesanías de Plaza Del Caribe y La Compañia de Fomento Industrial de Puerto Rico on February, 21st of 2018. My identification number: ID\# 23332. This certification is valid for five years, and is renewable. (Figure 179)

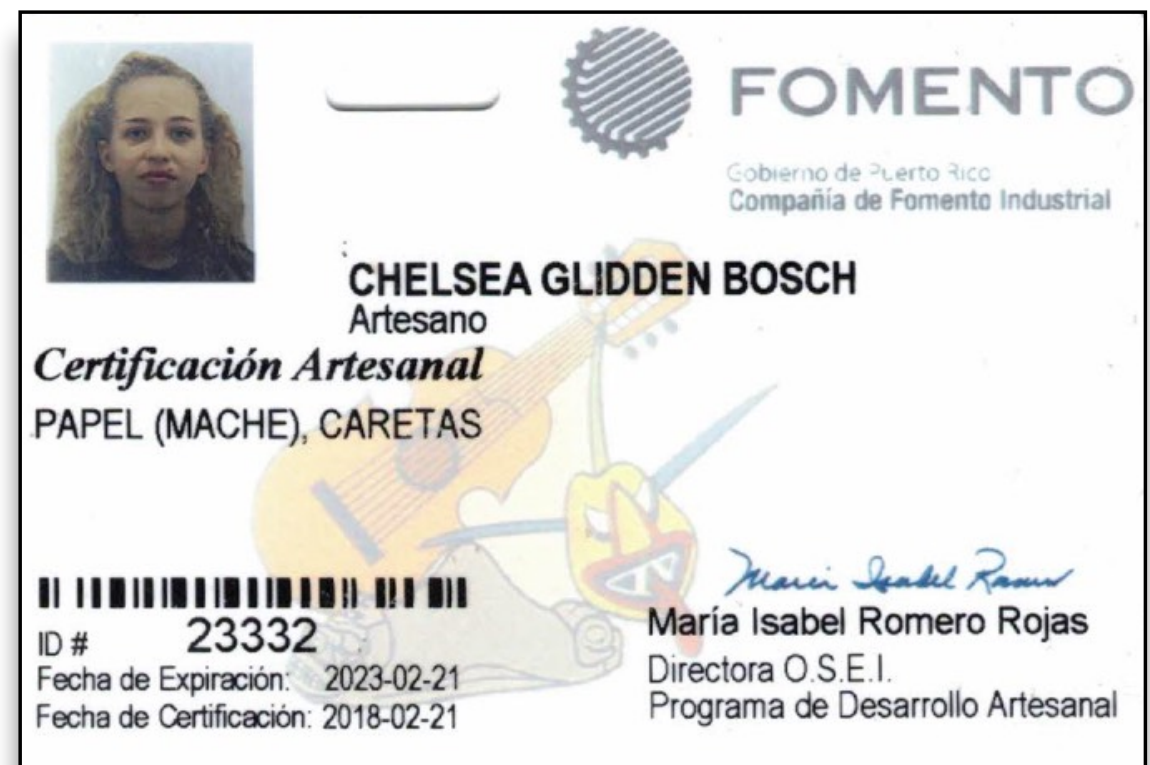

Figure 179 Artisan Certification in Papier-mâché Masks [digital image]. By Author. February 20, 2018 
The structure of my artistic work has been influenced immensely by the traditional techniques of making a vejigante mask. This impacted my choice of materials, as well as, configuration of the sculptural form. The masks I create usually retain aspects of renewable art; renewable art in a sense of re-used or recycled pieces of objects, or materials, often from ordinary life that no longer have a purpose or use. The materials that I choose mainly consist of stimulating textures and details that can be exploited in unfamiliar compositions. Often these materials are overlooked because one cannot see its full potential within its conventional context. In every object, life brings natural eroding which, prospectively, can enable a change in the ideas and guidelines that define fine art.

Through my classical training in fine art, I have been able to experiment with the concept of the vejigante. The process of mask making is frequently associated with the use of molds made out of cement or clay, but I decided to experiment further with the use of found objects as the molds for my vejigante masks. One element I have often used and found interesting are palm trees leaves. Specifically, the base of the palm leaves: the section that connects the leaf to the trunk of the palm tree. I first collected palm tree leaves with interesting shapes in various sizes. Then I cut the section that would be used for the mold. Finally, I used engrudo to paste the aluminum foil around the section, and allowed it to set for 24 hours. I concluded with an additional step of tapping the mold with large formatted Scotch Tape. From my research, it became obvious that his method 
has not been traditionally used. At first, when the local artisans witnessed what I was experimenting with, they did not approve and questioned my methods. (Figure 180) The final outcome created a strange asymmetrical shape, resembling an alligator creature. This experiment resulted in the creation of an individual, one-of-a-kind mask. (Figure 181) While this process of experimentation was challenging, it provided an interesting outcome and, in final, a technique not yet introduced, or rather, accepted, into the community.
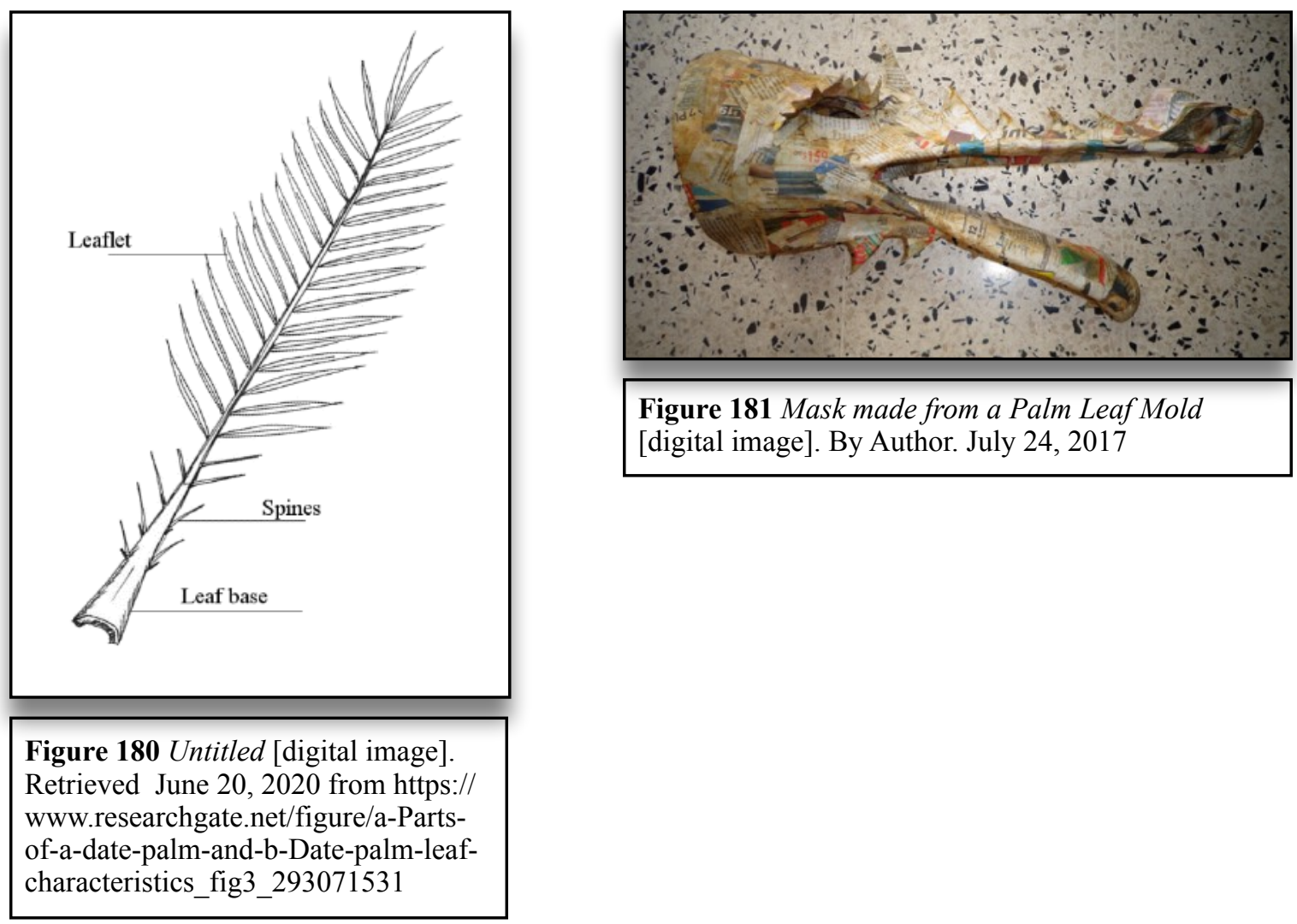

Figure 181 Mask made from a Palm Leaf Mold [digital image]. By Author. July 24, 2017 
My experimental vejigante masks have been exhibited at the Centro Cultural Carmen Solá de Pereira de Ponce on Calle Cristina in Ponce, Puerto Rico. (Figures 182-183) I also had the opportunity to display my vejigante mask in Café Lucero located on Calle Salmón in La Playa de Ponce. (Figure 184) Even though the overall methods used to create the masks were traditional, i.e. engrudo and papier-mâché, the molds, which created the base of the mask, were controversial. My goal for creating experimental masks with the long-established techniques was to reshape the fundamental ideas of creation and challenge the status quo. Furthermore, I was invited to paint two murals, one in La Playa de Ponce in the Museo Abierto de la Playa de Ponce, Open Museum of la Playa de Ponce on Calle Belfin, (Figure 185) and the other in Arecibo, Puerto Rico. Both having themes of Carnival, portraying the vejigantes in a contemporary context. For example, in Arecibo, I combined the most recognized careta, created by Caraballo, with the iconic images of Beetlejuice, a well-known movie from the 1990s. (Figures 186-188) The community showed great interest in the representation of Puerto Rican heritage and culture, but with the contemporary context of USA pop culture. It is very important to depict culture in current contexts. This is a rising movement. Modern themes ensure that culture and heritage do not become mundane, and create a relatable context for to the younger and future generations. 


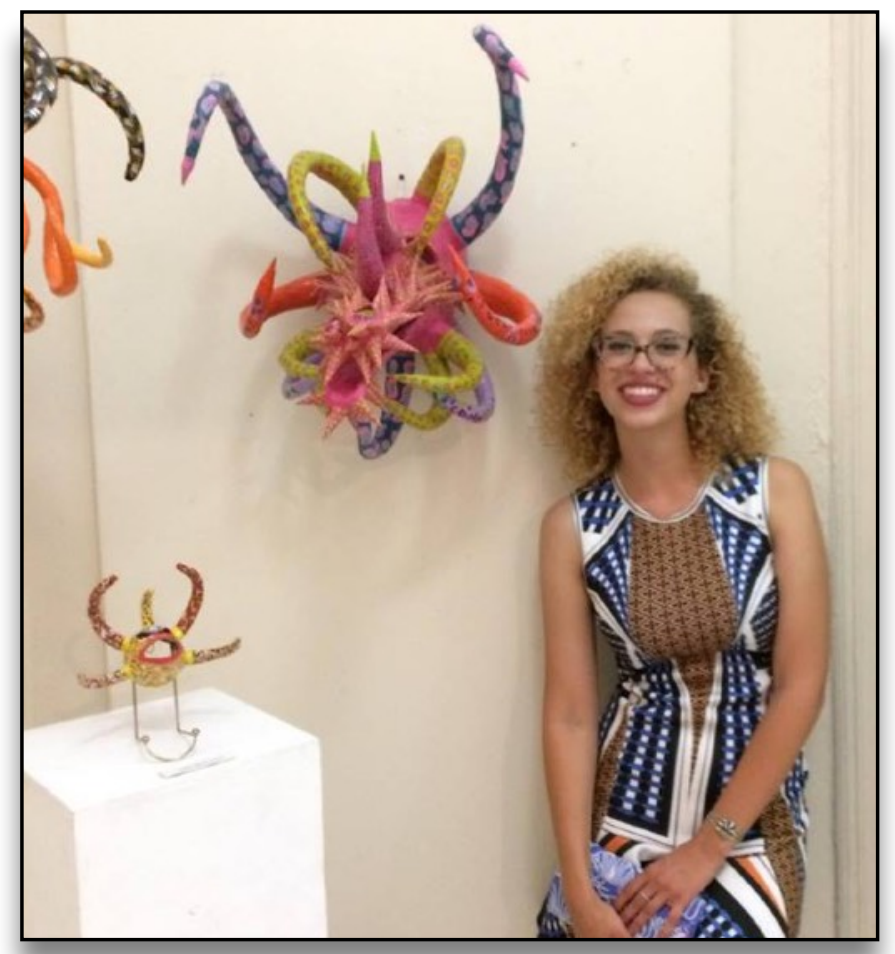

Figure 182 Vejigante Mask by Chelsea Glidden Bosch displayed in Centro Cultural Carmen Solá de Pereira de Ponce in Ponce [digital image]. By Author. June 5, 2018

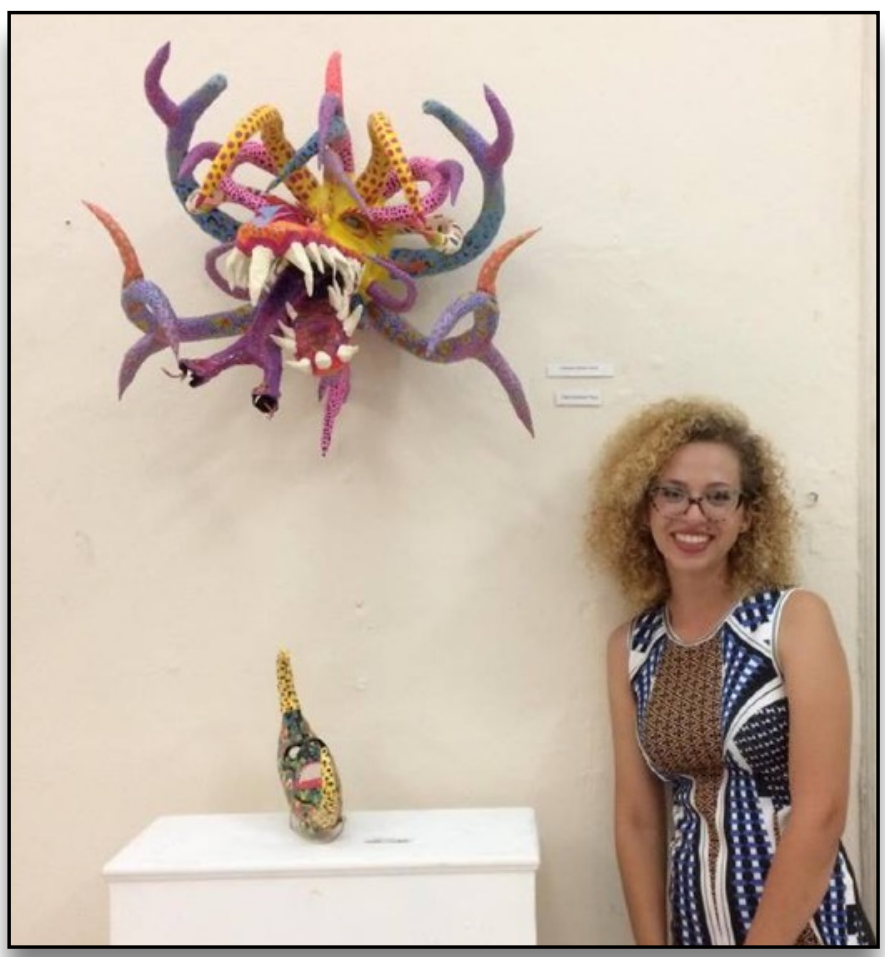

Figure 183 Vejigante Mask by Chelsea Glidden Bosch displayed in Centro Cultural Carmen Solá de Pereira de Ponce in Ponce [digital image]. By Author. June 5, 2018 


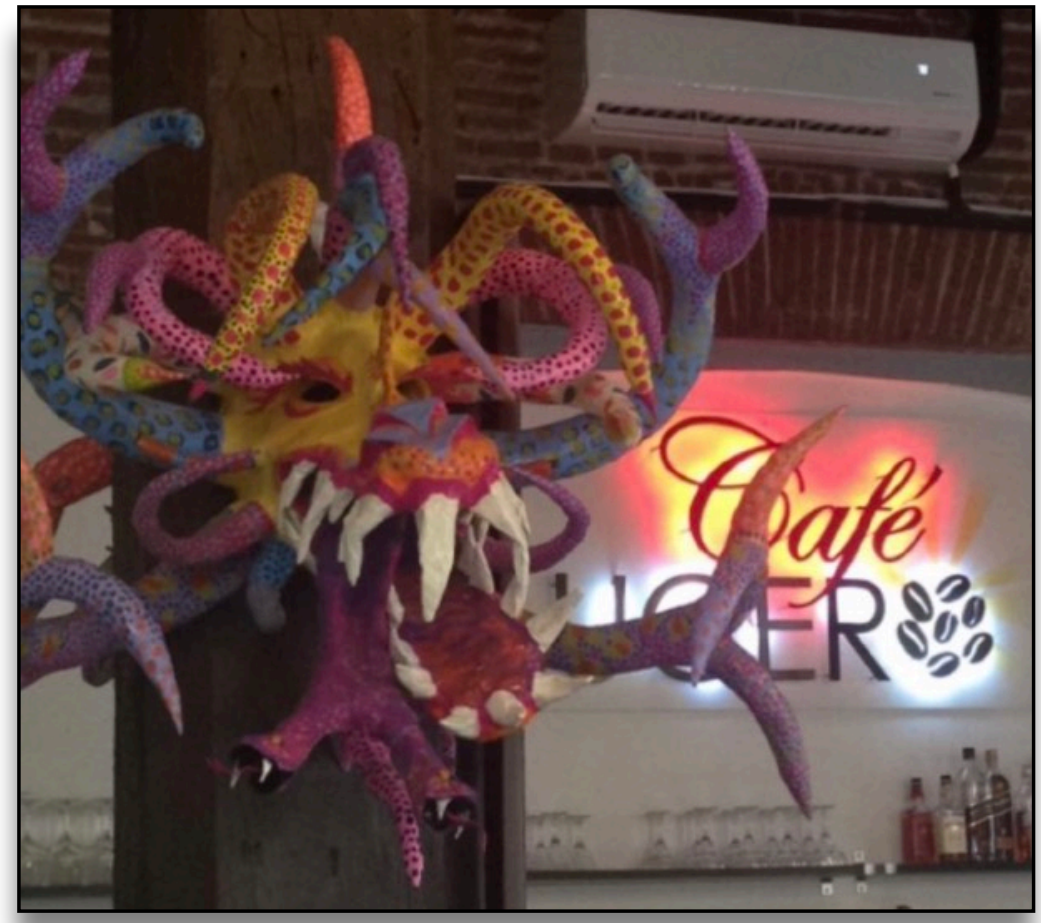

Figure 184 Vejigante Mask by Chelsea Glidden Bosch displayed Café Lucero [digital image]. By Author. June 5, 2018

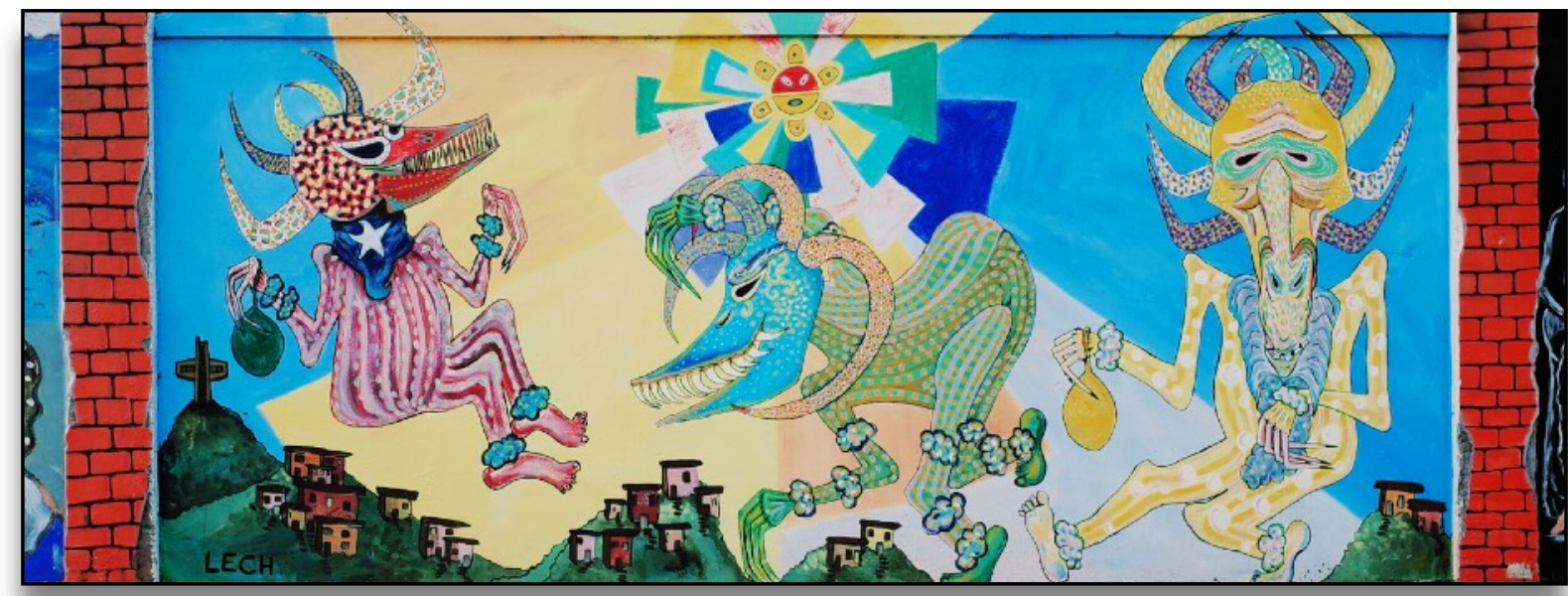

Figure 185 Vejigantes Dancing over Ponce by Chelsea Glidden Bosch, Museo Abierto in La Playa de Ponce [digital image]. By Author. June 5, 2018 


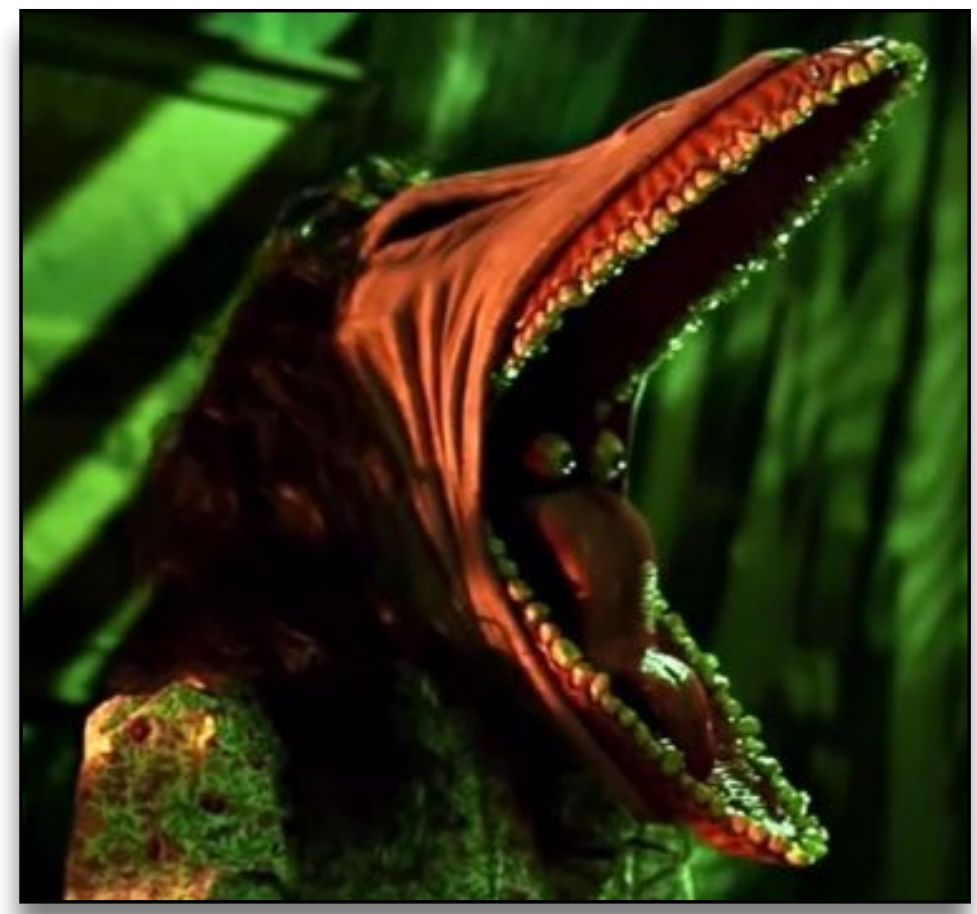

Figure 186 Untitled / Photo: Rubie's

Costume [digital image]. Retrieved June 20, 2020 from https://mikeshouts.com/rubiesbeetlejuice-scary-adam-and-barbara-mask/

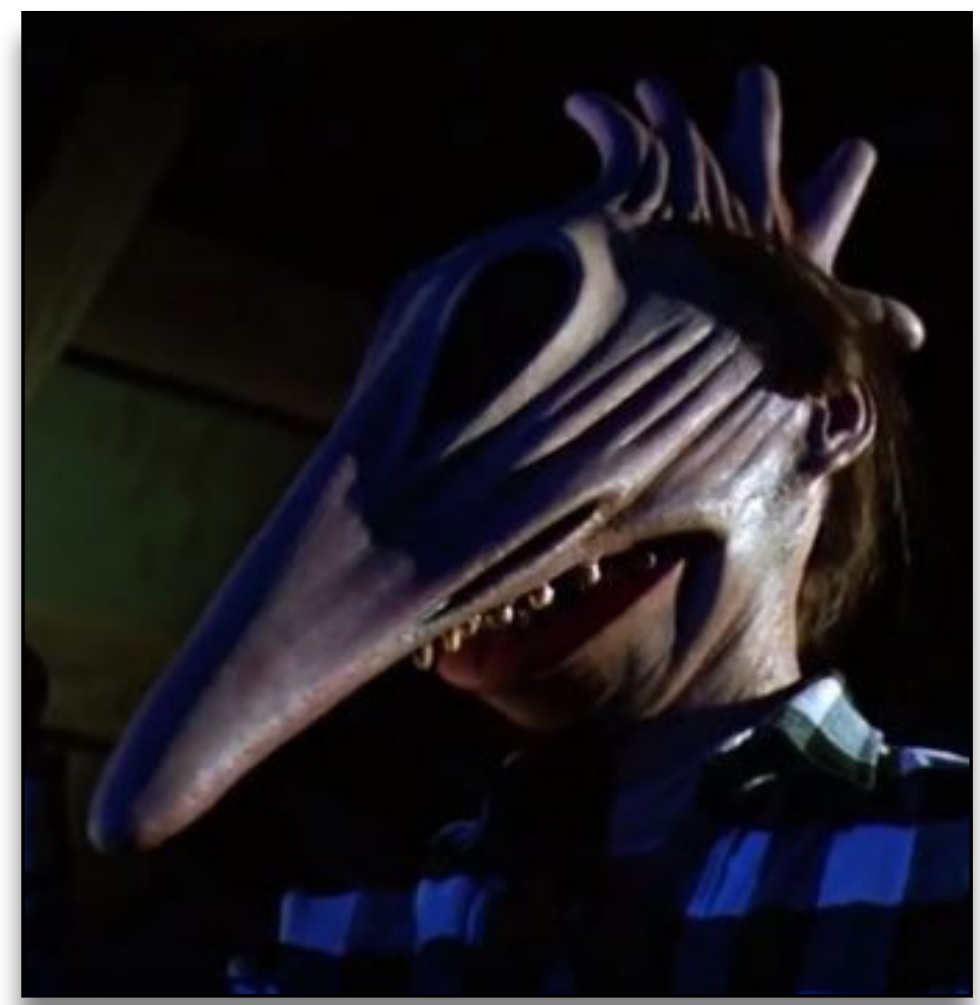

Figure 187 Untitled / Photo: Rubie's

Costume [digital image]. Retrieved June 20, 2020 from https://mikeshouts.com/rubiesbeetlejuice-scary-adam-and-barbara-mask/ 


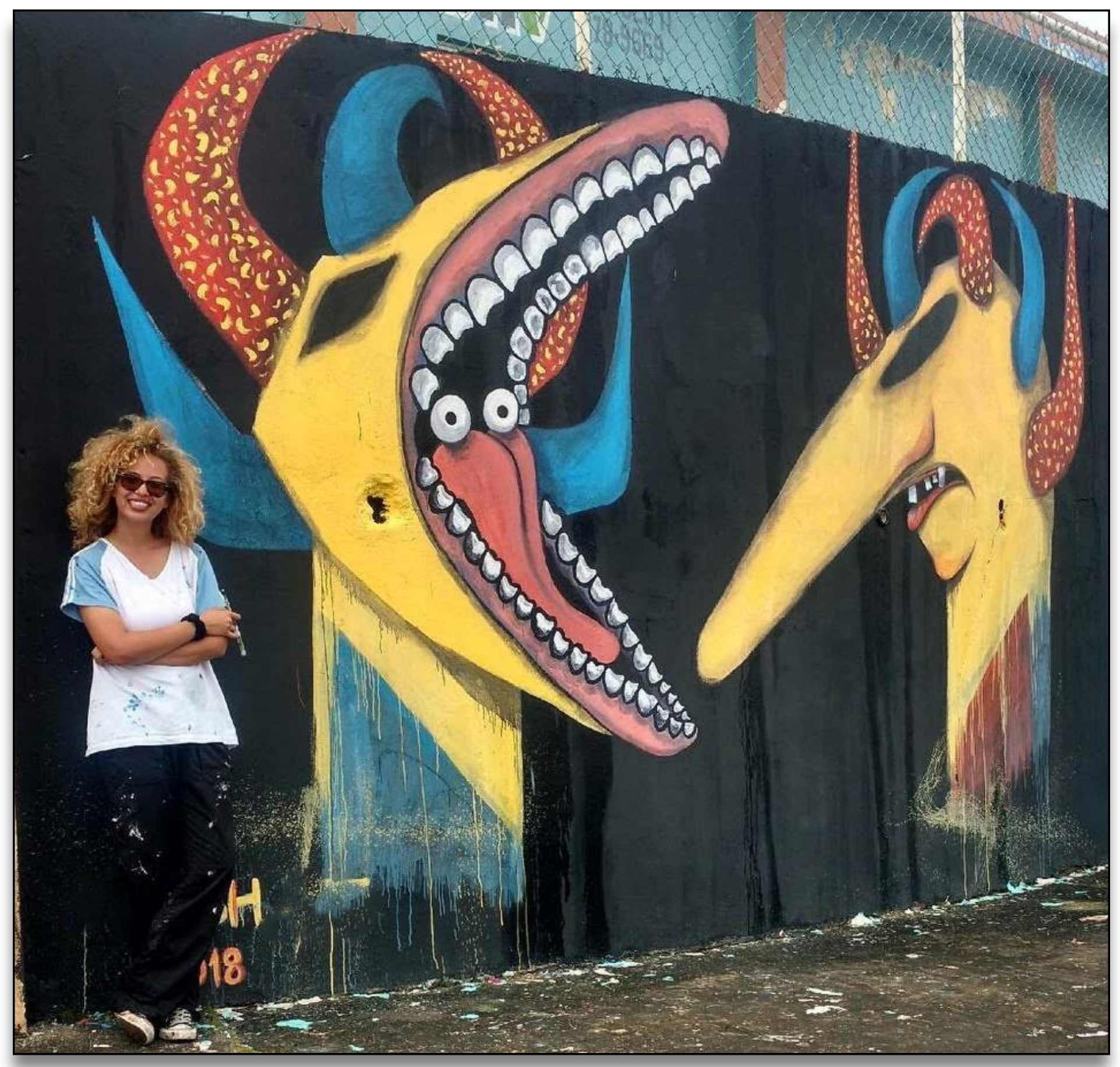

Figure 188 Los Vejigantes de Beetlejuice by Chelsea Glidden Bosch, Arecibo Mural inspired by Adam and Barbaa from Beetlejuice [digital image]. By Author. June 5, 2018 
Chapter Six: Personal Artwork 


\subsection{Overview}

This chapter will cover the personal work that was executed during the research period. This work was done within the same time table frame, hand-in-hand with the historical literature research conducted. It will expand on the techniques used for each individual artwork presented.

Through the artwork, I was able to understand the mindset of the artisan, as well as, step away from the artisanal folkloric object, and indulged in the possibilities of experimentation with form and function. And, in final, the investigative research in combination of the tradition techniques and contemporary experimentation will showcase the direct impact a vejigante mask has as a contemporary art rather than artisanal objects. 


\subsection{Introduction to Personal Artwork}

My exposure to the iconic vejigante mask ignited my interest with Puerto Rican imagery and increased with the multiple visits to my mother's and grandparents' hometown: Ponce, Puerto Rico. The constant close proximity with the mask and its unknown meaning/purpose began my investigation into the topic.

I am a sculptor that resided in Puerto Rico from 2017 to 2019. My artistic training is academically based. I received my Bachelors of Art from Franklin University of Switzerland in Visual Communication Arts with an emphasis in Studio Art, in addition, a Master of Fine Art: Art and Humanities from the University of Dundee.

I consider myself as a creator of identities, a sculptor, and a mask maker. I have always been intrigued by hidden identity and the abilities a mask gives to the user. My work focuses on the interpretation of masks and their cultural contexts. There is a constant dialogue between my research and my creative process. Furthermore, it is very important to understand the history of the methodologies and to practice physical techniques hand-in-hand.

I have established my methods in the Arte Povera movement by using everyday materials combined with found objects to create whimsical characters. Arte Povera, translated to: poor art, is “... a radical Italian art movement from the late 1960s to 1970 s 
whose artists explored a range of unconventional processes and non-traditional 'everyday' materials." 178 And in relation to vejigantes, García Santos stated in his book Vivencias en La Playa de Ponce: "The material to make the...vejigante can be found in the environment." 179 These are the aspects that inspired me to continue to create with progressive material choices. Arte Povera uses “... such throwaway materials ... aimed to challenge and disrupt the values of the commercialized contemporary gallery system."180 My creative process is: Re-use and recycle. Many people believe art must be created with specific materials but I believe art can be created with anything.

My work focuses on the use and integration of organic with ordinary, man-made objects. (Figure 189) This concept is rooted in Arte Povera. The integration of organic and man-made objects allows the materials to compliment each other. Furthermore, this combination of two diverse organisms is a reflection of how we live and engage in the contemporary society.

\footnotetext{
178 Tate, “Arte Povera - Art Term,” Tate, accessed March 15, 2019, https://www.tate.org.uk/art/art-terms/a/arte-povera). 179 Nelson García Santos, Vivencias en La Playa De Ponce: Andadas En Mis Tiempo De Vejigante (Juana Díaz, PR: Imprenta Llorens, Inc., 2009), 16.

180 Tate, “Arte Povera - Art Term,” Tate, accessed March 15, 2019, https://www.tate.org.uk/art/art-terms/a/arte-povera).
} 


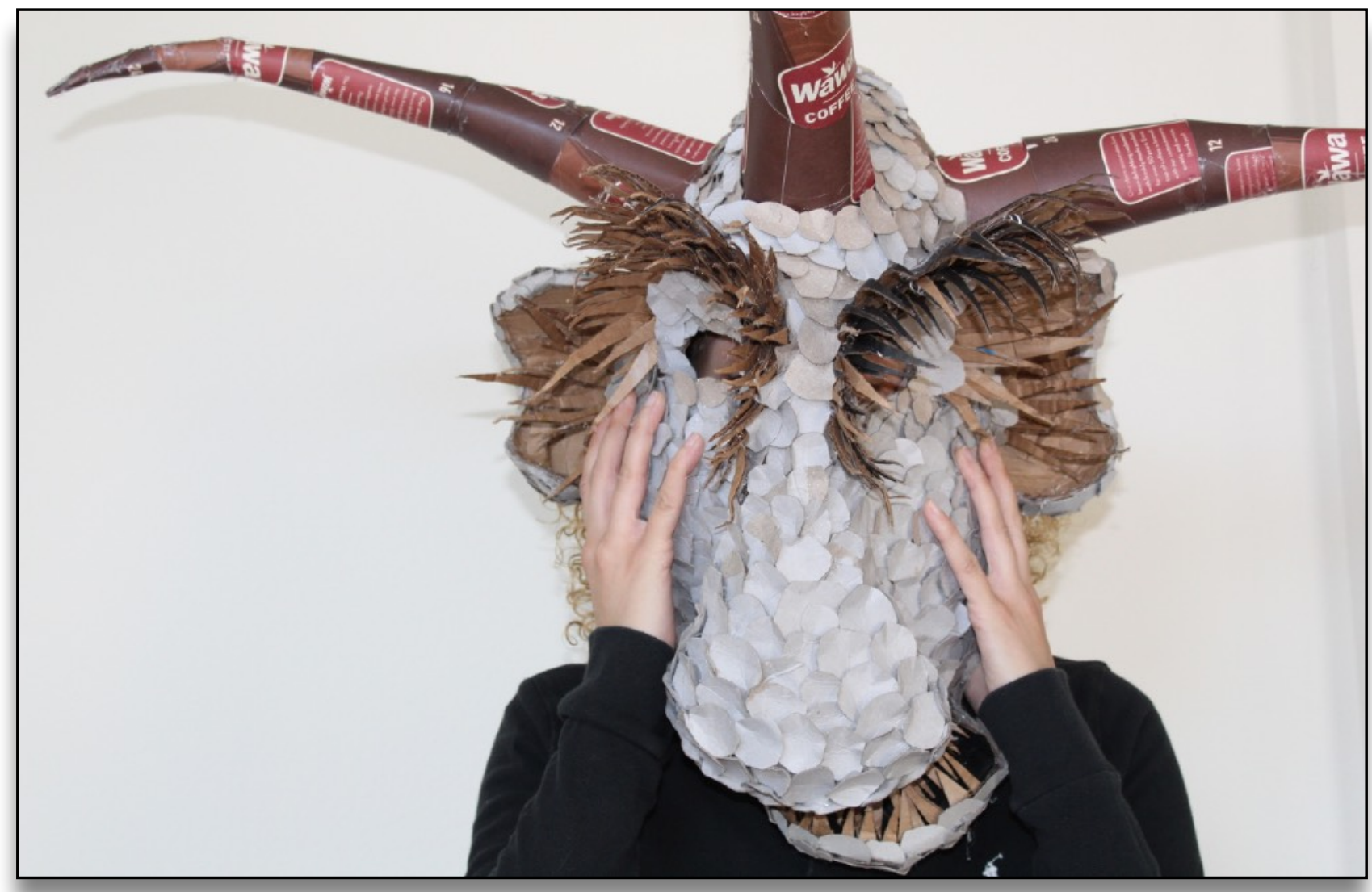

Figure 189 Vejigante Mask made out of Recycled Materials by Chelsea Glidden Bosch [digital image]. By Author. February 24, 2017 


\subsubsection{Traditional Masks}

I was certified as an artisan of papier-mâché vejigante masks recognized by the government of Puerto Rico. This was done through intensive training from June 2017 to January 2018. To be certified, one must present several well-made masks to showcase and explain to the inspector as part of the certification exam.

Through intensive workshops, I learned the process of making the engrudo, the molds and how to construct a vejigante mask. (Figure 190) While the fundamental process was completed, the exploratory development of a new-found, contemporary method began. I was able to use the knowledge of the traditional techniques of artisans to begin to create experimental masks.

First, to analyze the positive and negative aspects of the traditional vejigante mask making: The positive aspects are the ability to gradually build the mask up in layers of newspaper. This allows the artist to experiment and add various elements without the concern of adding massive weight to the sculptural piece. This process gives the possibility to always add further details. The negative aspects are the need for a mold to support the paper to achieve form. And moreover, the mask deteriorates over time due to the exposure to humidity. 


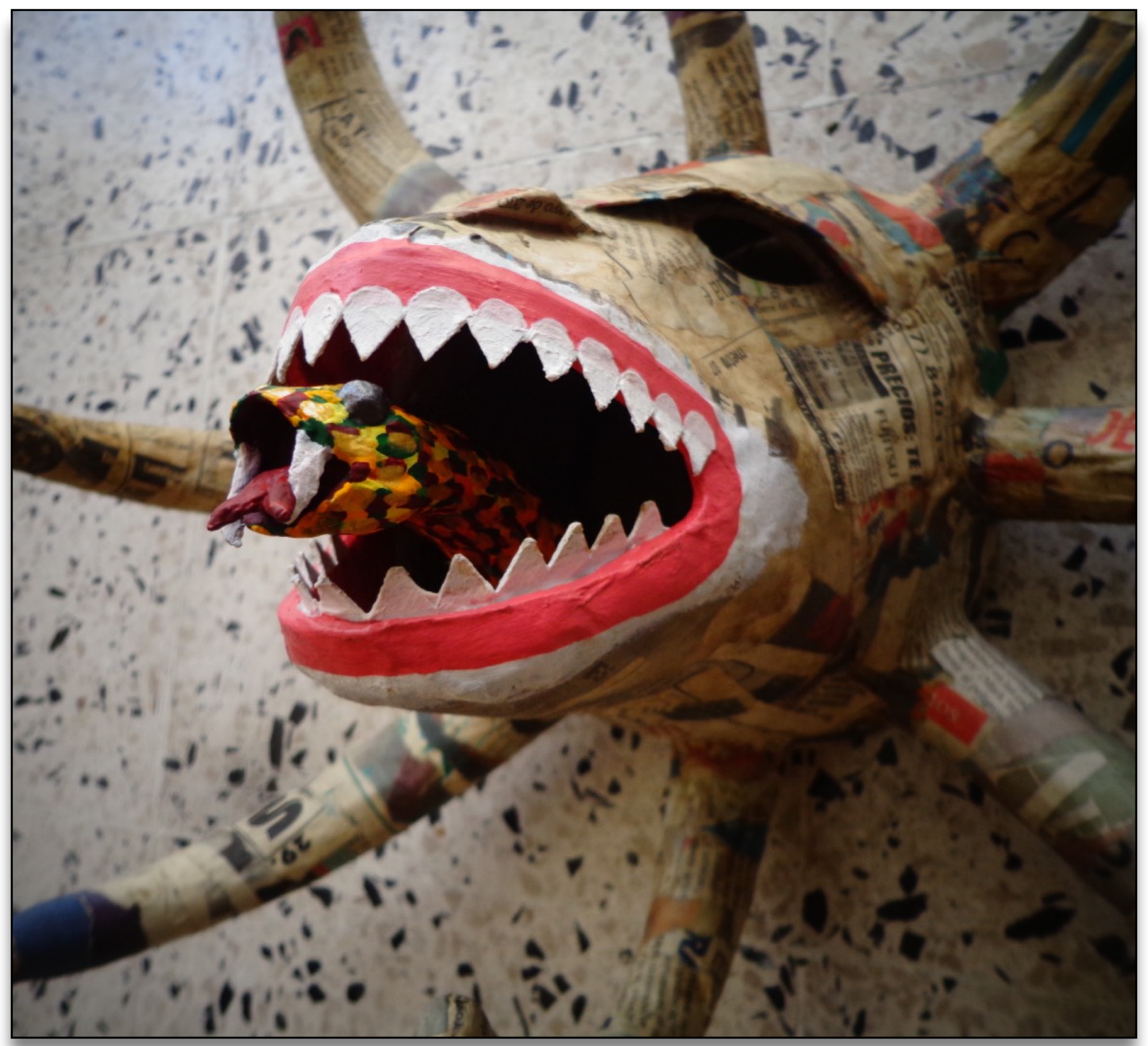

Figure 190 Vejigante Mask in Process with Snake Tongue by Chelsea Glidden Bosch [digital image]. By Author. February 24, 2017 
The first careta antigua I created was guided by the master artisan Edwin Muñiz Pérez. I used his molds to create the mask and the horns. Although the entire form of the figure is traditional, the pattern painted on the mask is non-traditional. (Figure 191) I was inspired by my home-town, Orlando, Florida, and the iconic prints from Lilly Pulitzer. (Figure 192-193) Lilly Pulitzer is a brand that is well-known in the state of Florida. Her prints are distinguished for the use of vivid colors. Lilly Pulitzer was inspired by the spill of lemonade and orange juice, creating a beautiful watercolor, or gouache. I decided to paint my mask with this concept. (Figures 194-195) Although the artisan community usually never strays from the fundamental teachings of the traditional creation of a vejigante mask, I received positive feedback of my careta antigua. With this, I decided to continue to the boundaries of the mask. Along with the research, I continued the exploration into vejigante masks. I was uncertain of the feedback I would receive from the artisans community: Positive or negative. 


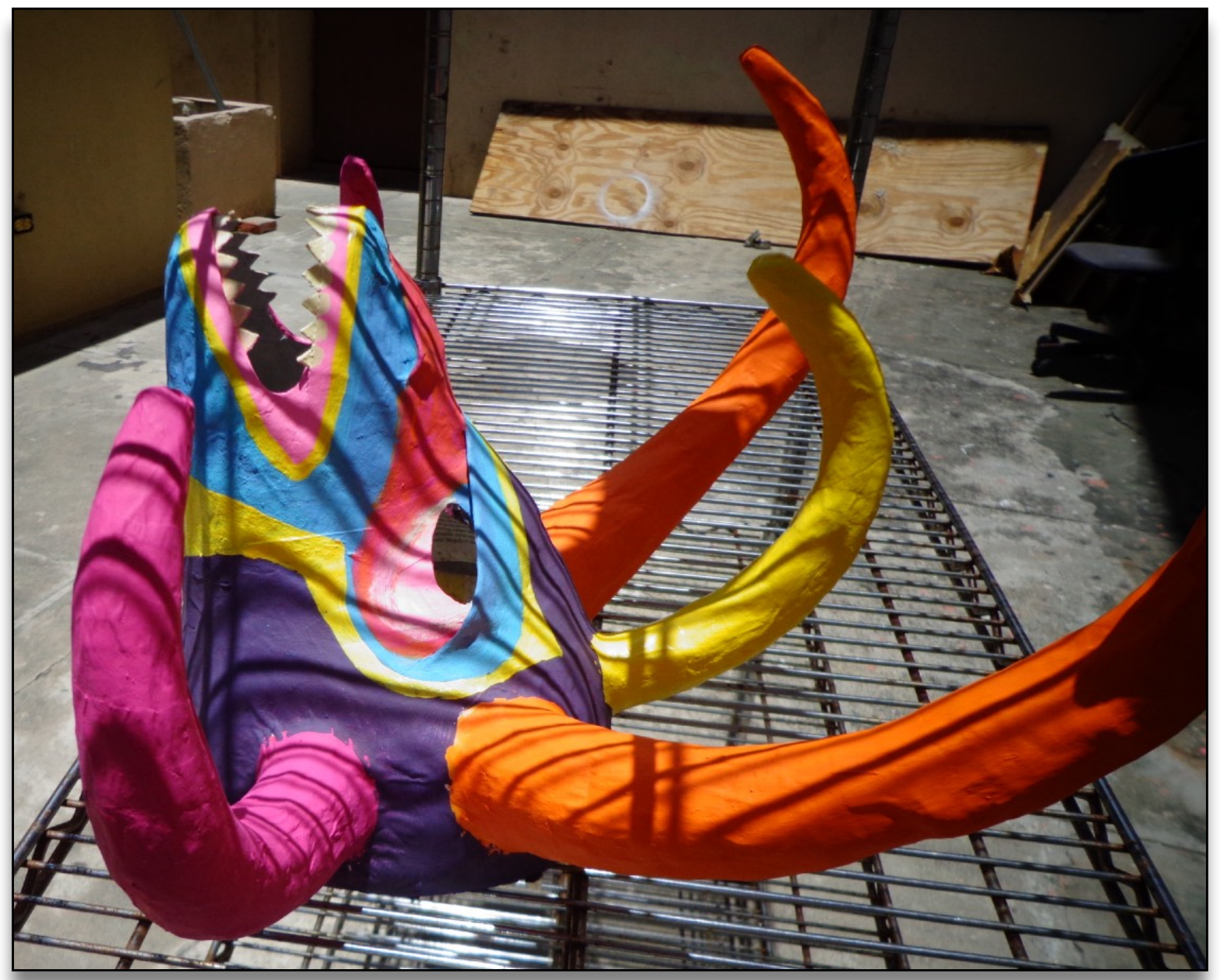

Figure 191 Traditional Vejigante Mask by Chelsea Glidden Bosch [digital image]. By Author. February 24, 2017 


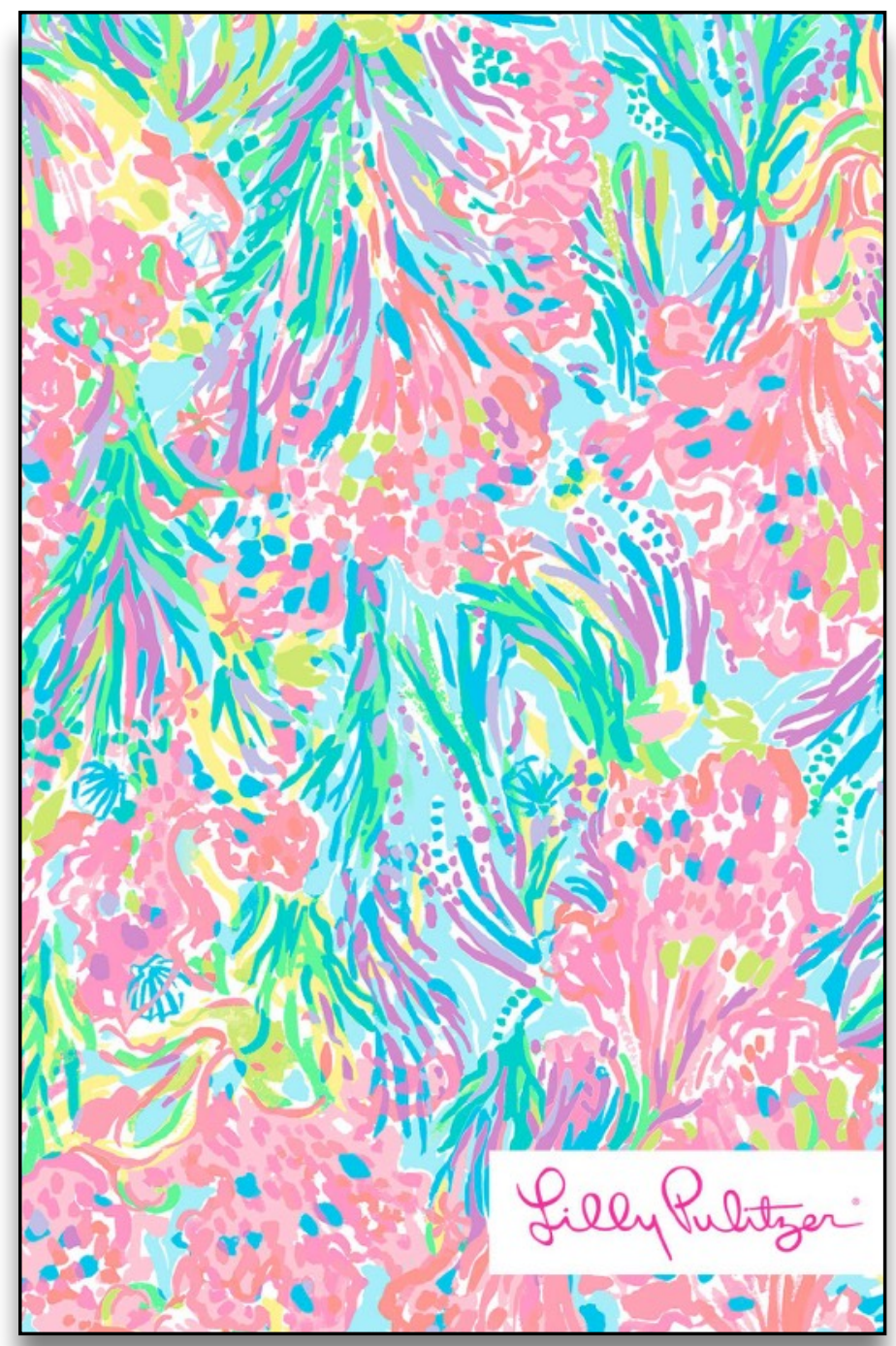

Figure 192 Lilly Pulitzer - Palm Beach Coral [digital image]. Retrieved June 20, 2020 from https://www.pinterest.com/pin/ 319755642280490550/

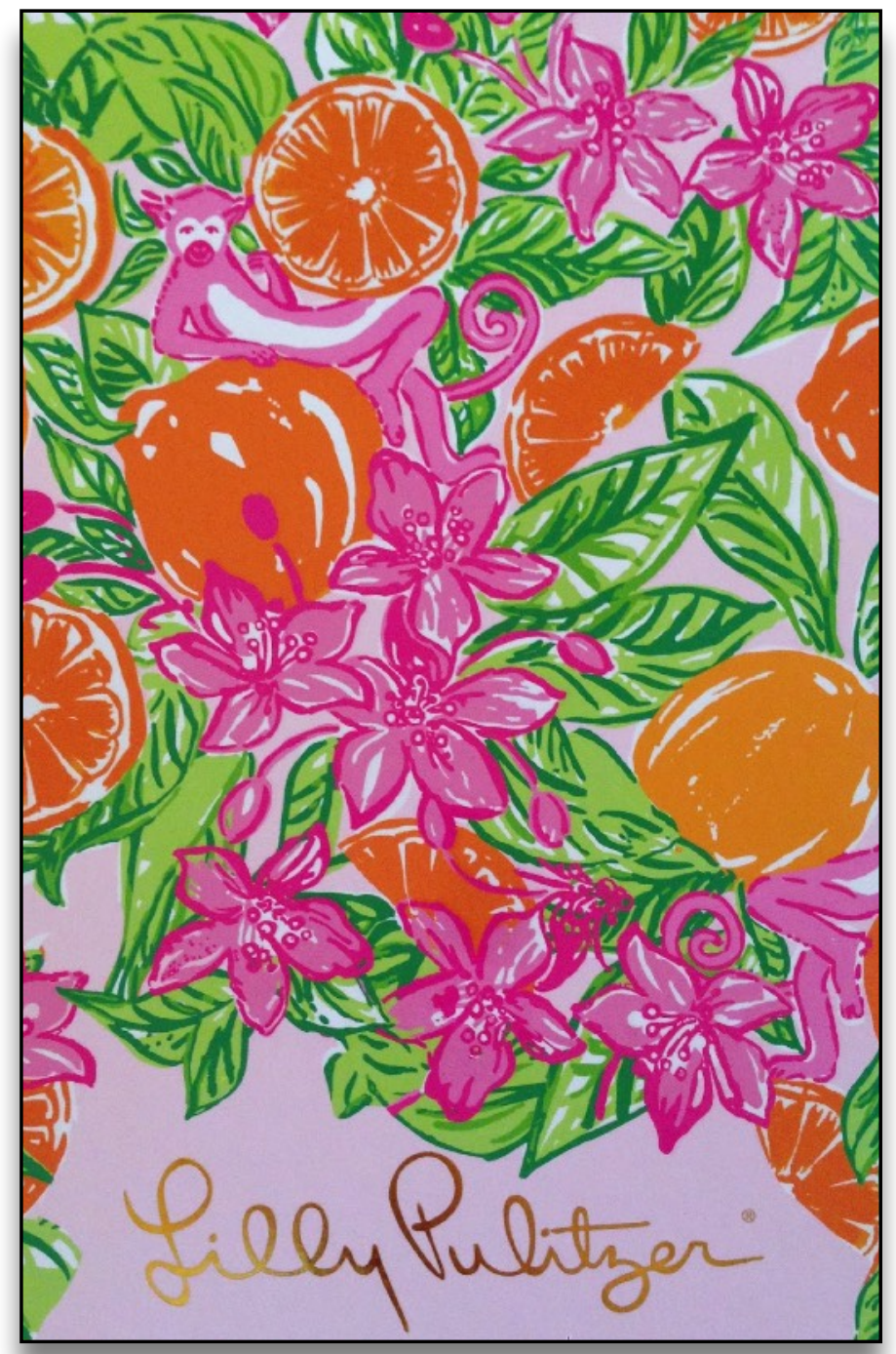

Figure 193 Lilly Pulitzer Large Agenda in the print Peelin' Out. [digital image]. Retrieved June 20, 2020 from http:// jackieoreeb.blogspot.com/2014/09/ 


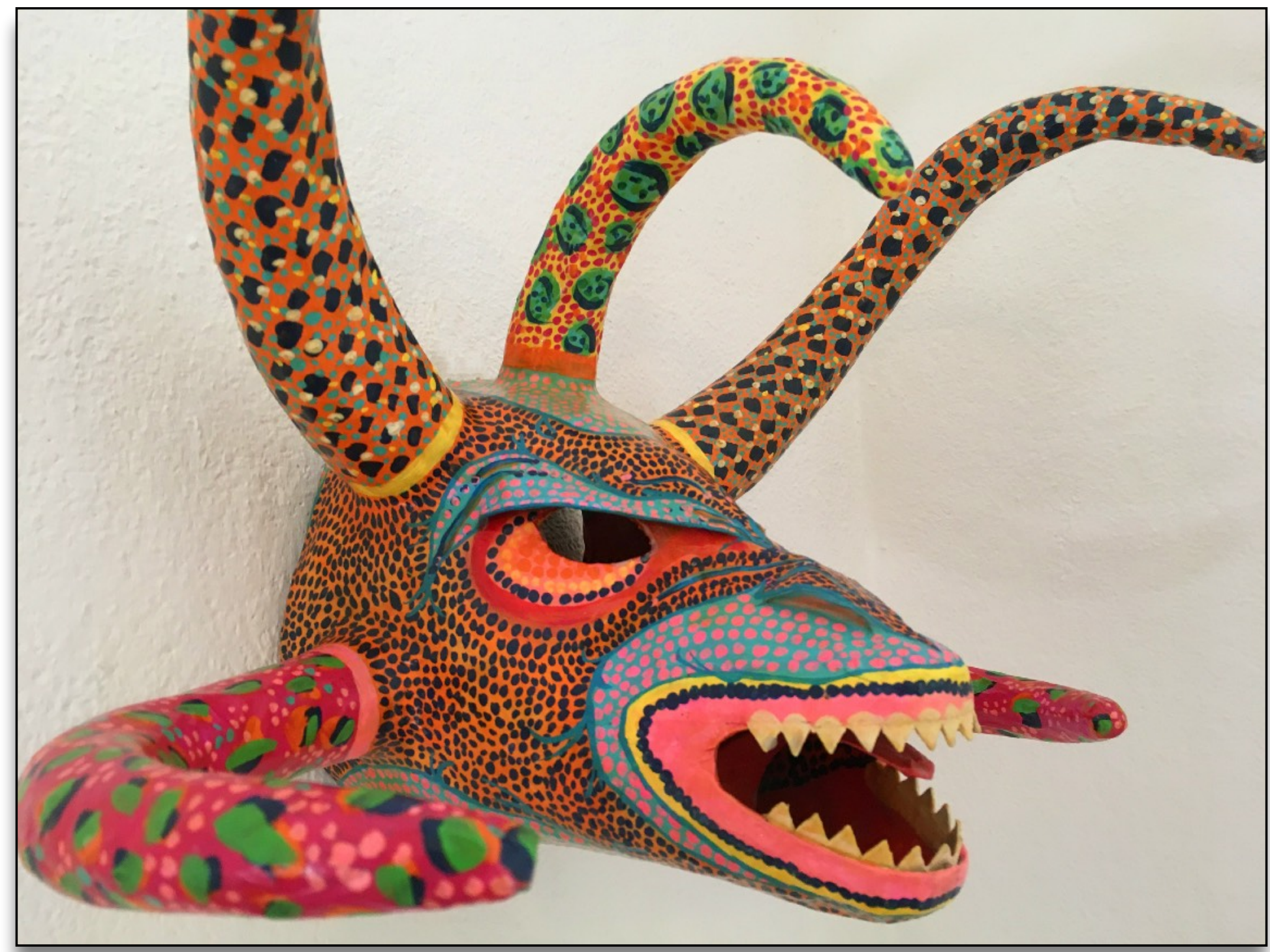

Figure 194 Traditional Vejigante Mask by Chelsea Glidden Bosch [digital image]. By Author. February 24, 2017 
I began to stray away from the traditional techniques, and experimented with various molds. I wanted to include found elements within the structure of the mask. I was inspired by the nature of Puerto Rico, specifically the beaches. The palm trees found on the island beaches naturally shed their palm leaves. The leaves that fall from the palm tree begin to dry and warp in the sun. Interesting forms start to emerge from the base of the dried leaves. (Figure 196) I created a mold out of a leaf base that was found on a beach in Puerto Rico. This created an irregular and asymmetrical form. This was just the beginning of the possibilities of experimentation with the contour of the vejigante mask. (Figure 197) A master artisan, who will not be named, attempted to persuade me to create a more symmetrical mask, but failed. (Figures 198-199) When the vejigante base was completed, (Figure 200-201) I received feedback from the artisanal community of Ponce: Many were displeased with the irregular form, because they favor symmetry. I found this reaction contrasting to the community of contemporary artists, which usually support and promote experimentation. 


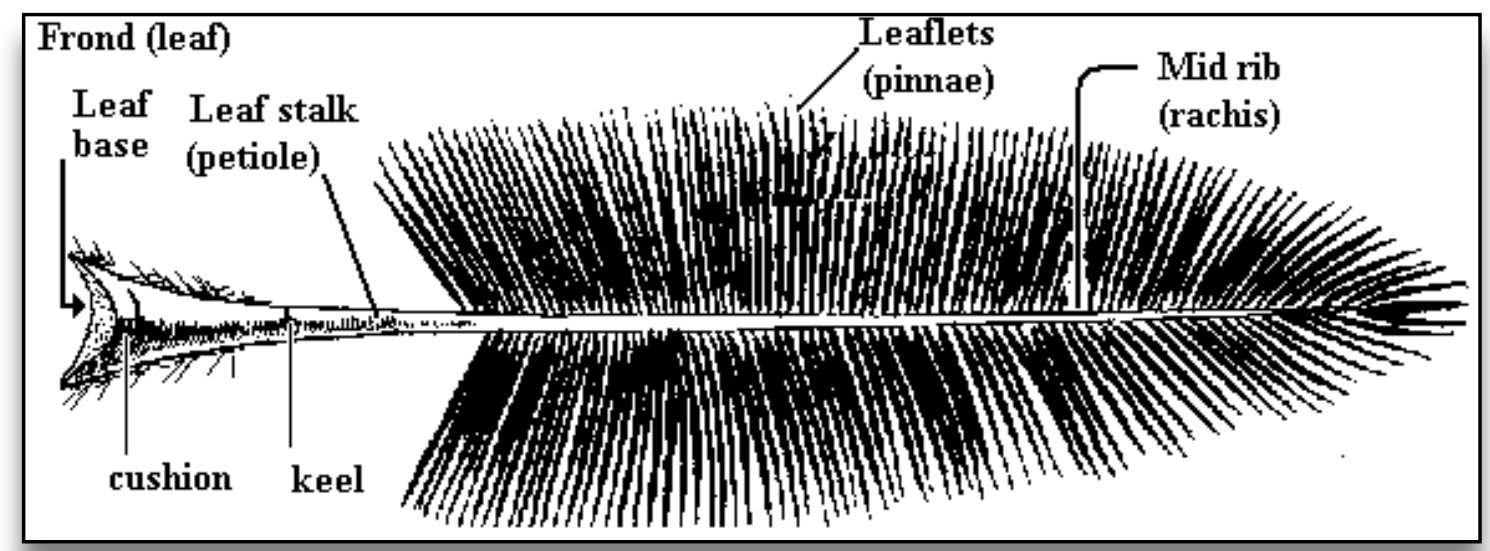

Figure 196 Basic diagram of the frond structure and leaflets. [digital image]. Retrieved June 20, 2020 from https://realpalmtrees.com/palm-tree-store/medium-palm-trees?limit=70

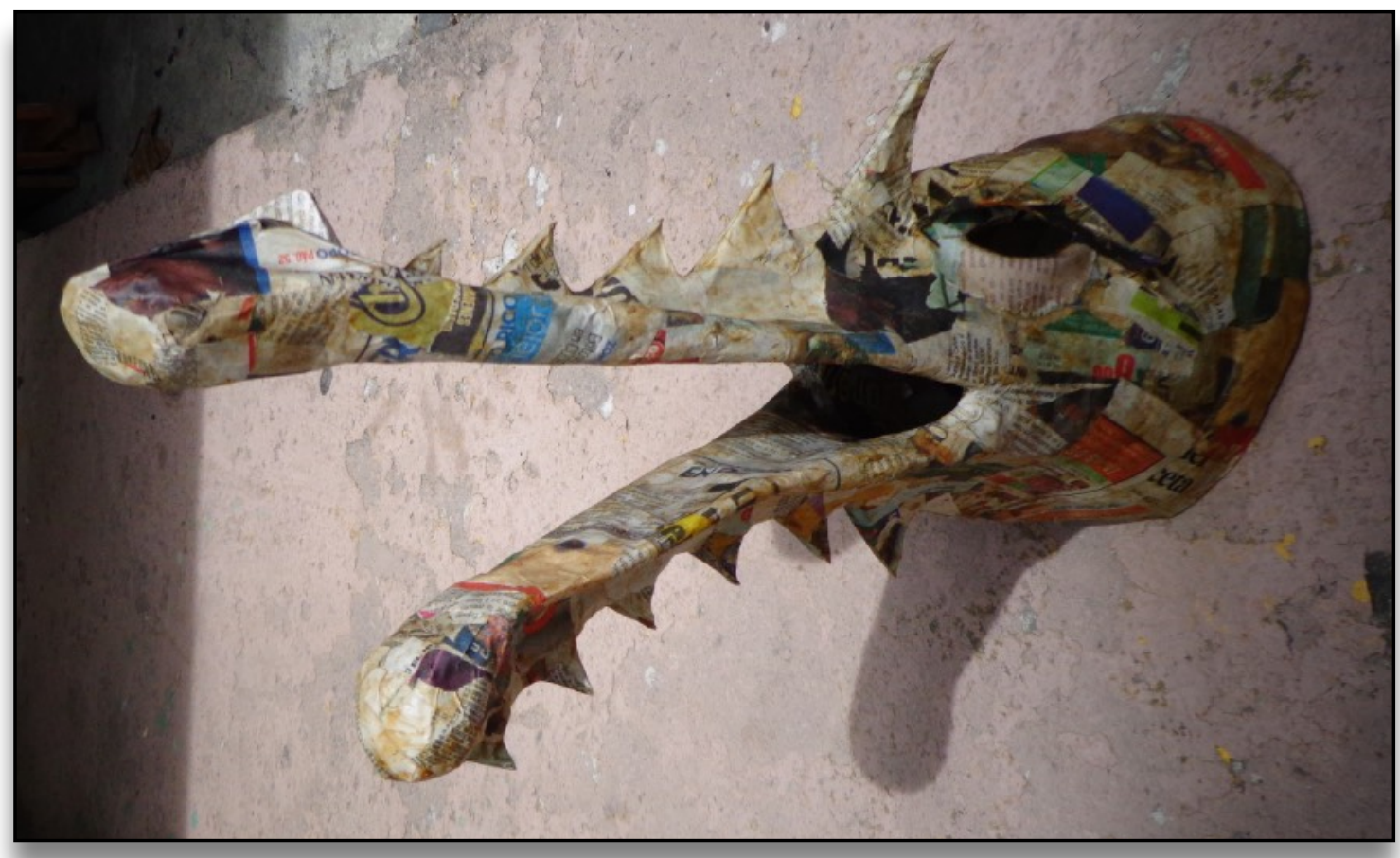

Figure 197 Base of Vejigante Mask made with a Palm Tree Base Mold [digital image]. By Author. February 24, 2017 


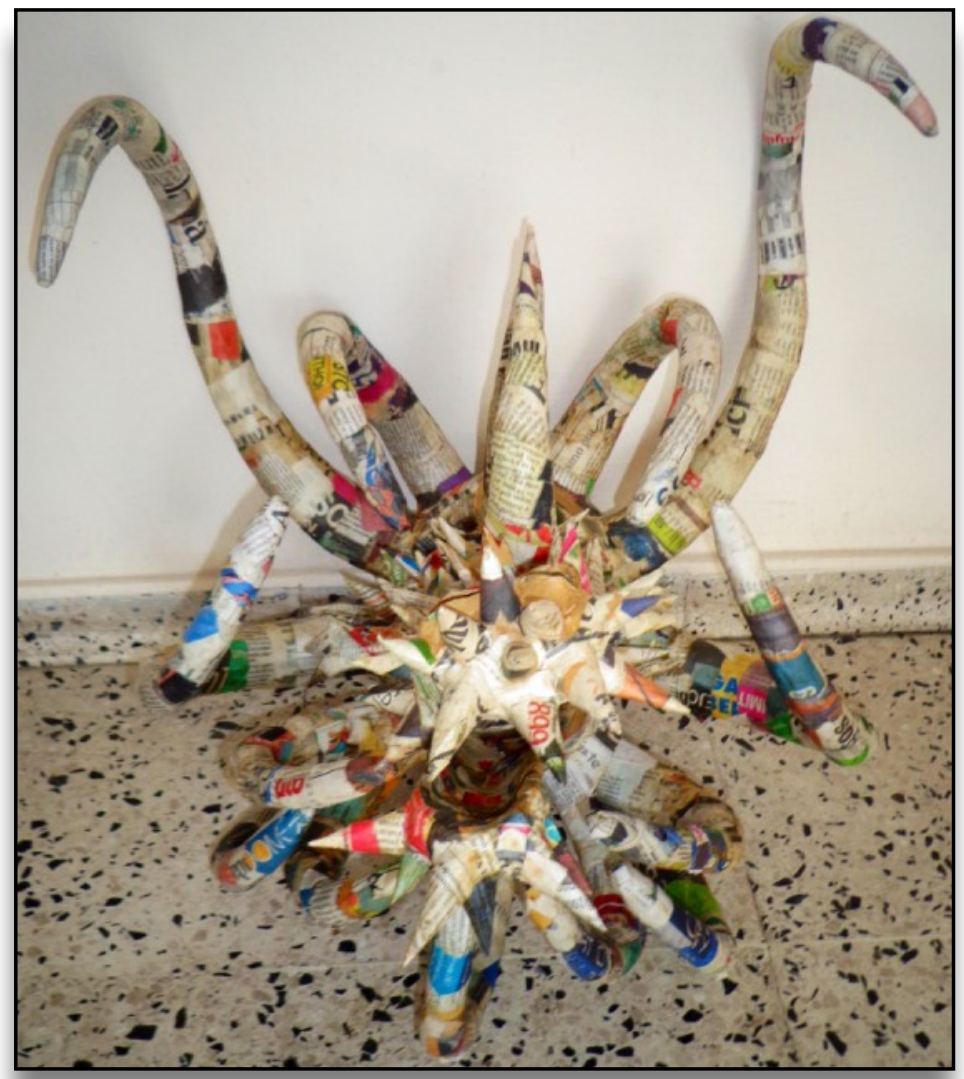

Figure 198 Asymmetrical Vejigante Mask in Process by Chelsea Glidden Bosch [digital image]. By Author.

February 24, 2017

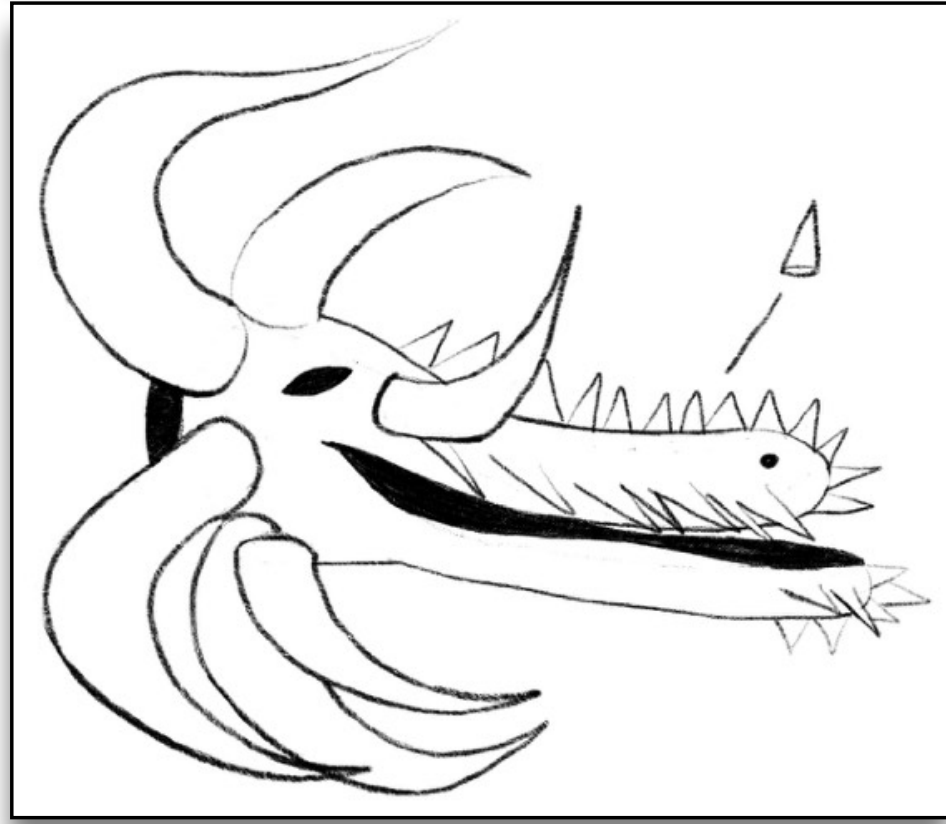

Figure 199 Sketch of Asymmetrical Vejigante Mask in Process by Chelsea Glidden Bosch [digital image]. By Author. February 24, 2017 


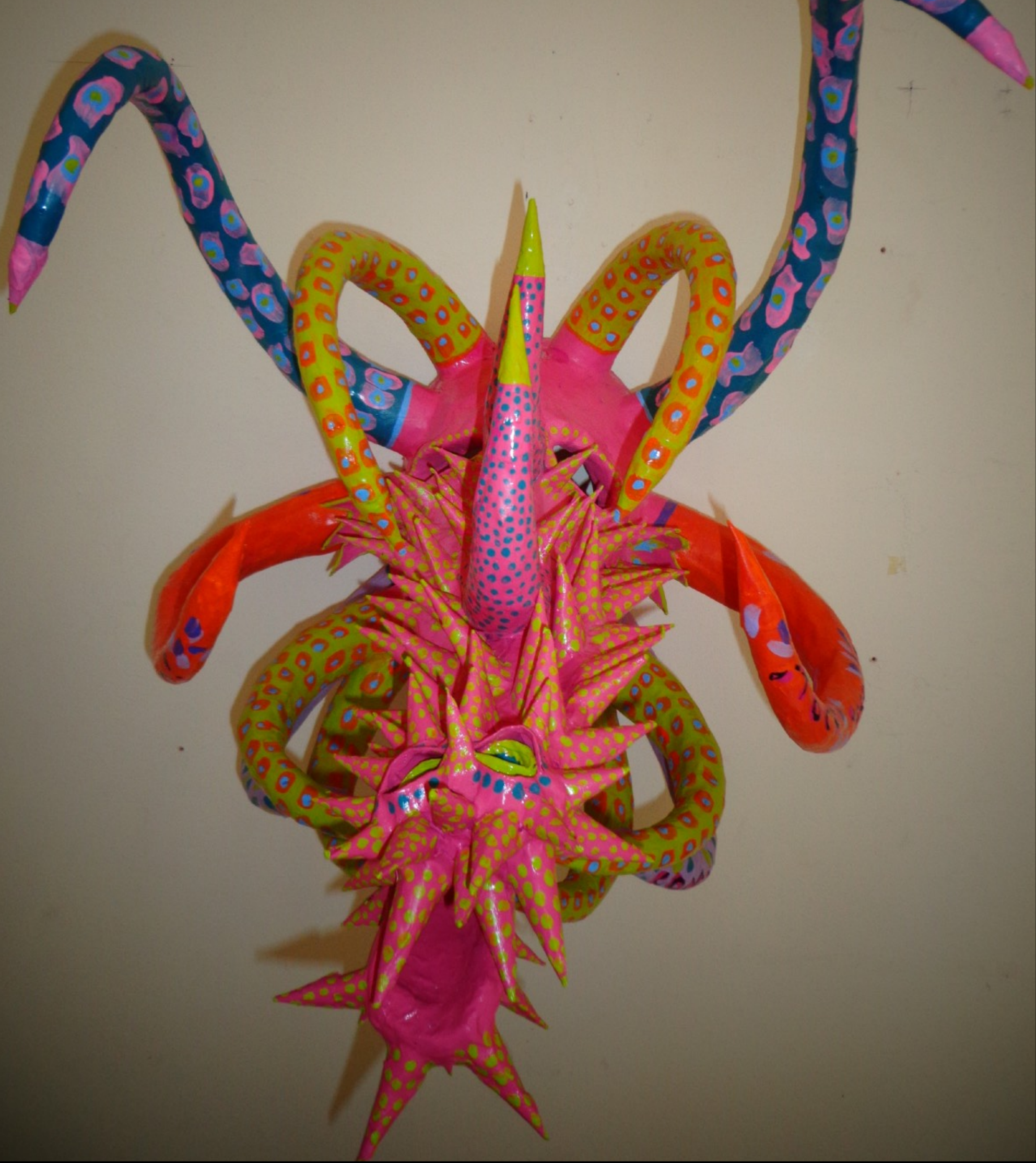

Figure 200 Asymmetrical Vejigante Mask by Chelsea Glidden Bosch [digital image]. By Author. February 24, 2017 


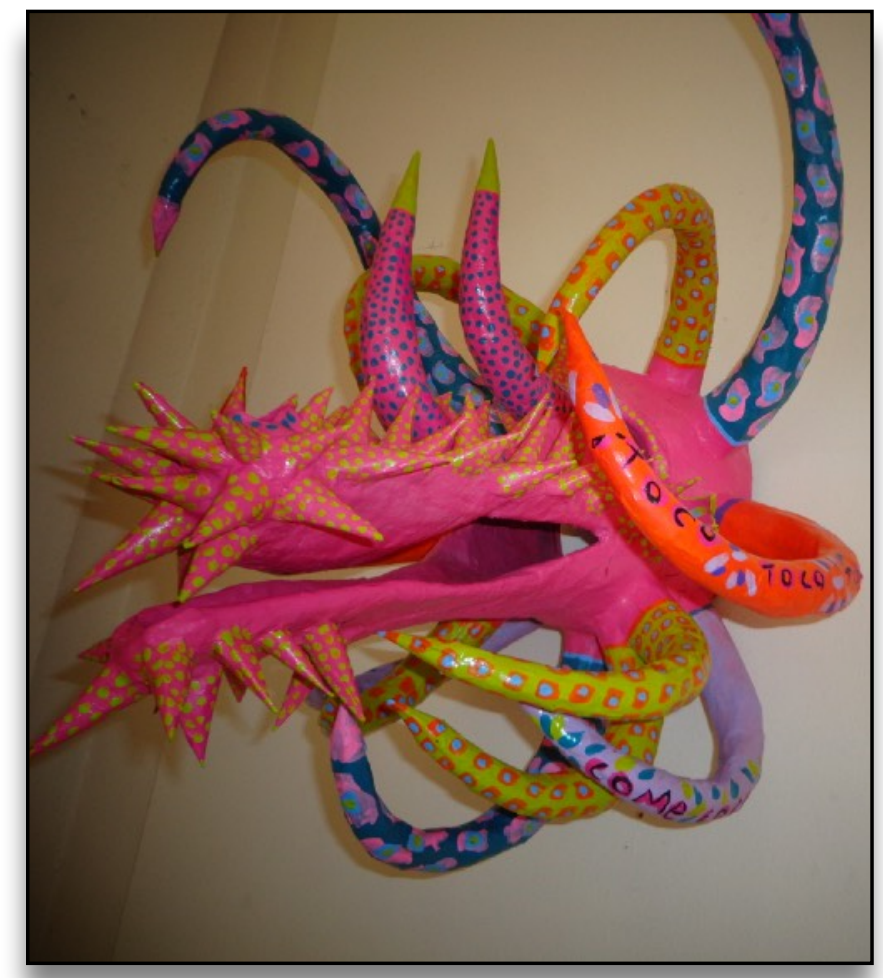

Figure 201 Asymmetrical Vejigante Mask by Chelsea Glidden Bosch [digital image]. By Author. February 24, 2017

Through investigation, I found that I have not been the only one who was subject to this sort of reaction: Artisan Alberto González Negrón has also experienced a similar reaction to his asymmetrical masks. He created experimental masks with asymmetrical features. Alberto was censured by his mentor/master artisan. Because the form of his masks were not traditional but an experimental interpretation of the mask. This is the line an artisan crosses to into contemporary art to become a contemporary artist. Not only does this create character and identity for the vejigante mask, but also contributes contemporary and pop culture relevancy. 
My second experimental mask was also created with the mold based from the palm leaf base discussed previously. I chose another palm leaf base with a slanted form. This was, in hope, to create a mouth in which the upper section leaned to one side, and vice versa. (Figure 202) From the mouth, a tongue with a two-headed snake hangs to one side like a panting dog. (Figure 203) While the base of the vejigante mask was asymmetrical, the horns were symmetrical. (Figure 204) Moreover, I wanted to continue the Lilly Pulitzer inspired theme that was depicted in the first traditional mask I created. I continued this by using the similar colors and an inventive pattern. (Figures 205-206) By using this color scheme, I additionally strayed from the traditional decoration used for a vejigante mask. In final, the mask, overall, received a positive feedback for its colorfulness and uniqueness. Although the majority of the feedback was positive, there was negative feedback surprisingly from various artisans. Unnamed artisans claimed the mask was poorly designed, due to its unbalanced mouth and non-traditional colors. And even though it had the characteristics of a vejigante mask, it was not the careta antigua to the unnamed artisans.

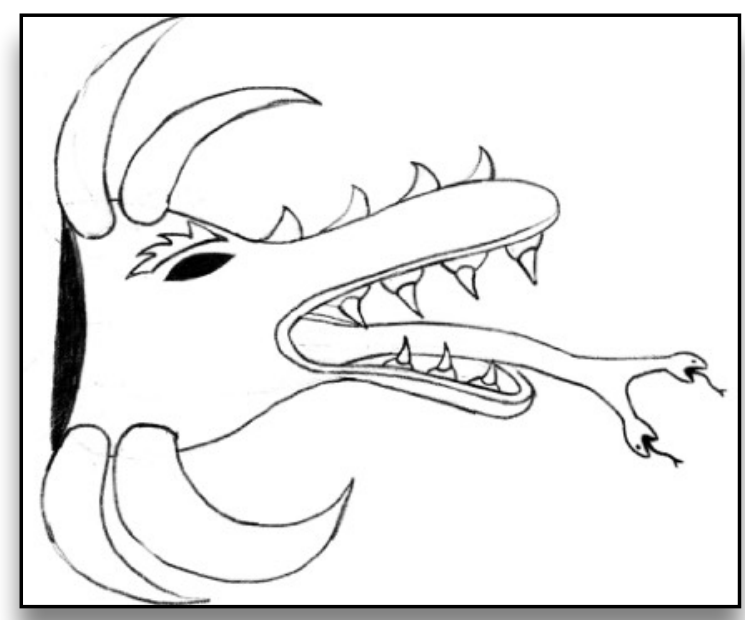

Figure 202 Two-Headed Snake tongue of the Asymmetrical Vejigante Mask by Chelsea Glidden Bosch [digital image]. By Author. February 24, 2017 


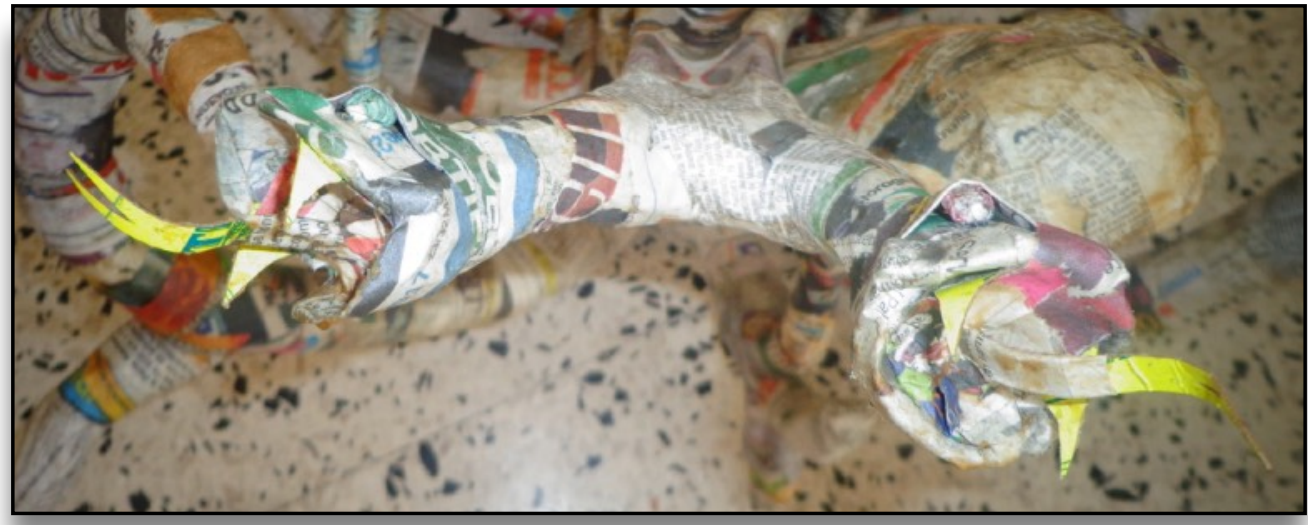

Figure 203 Two-Headed Snake tongue of the Asymmetrical Vejigante Mask by Chelsea Glidden Bosch [digital image]. By Author. February 24, 2017

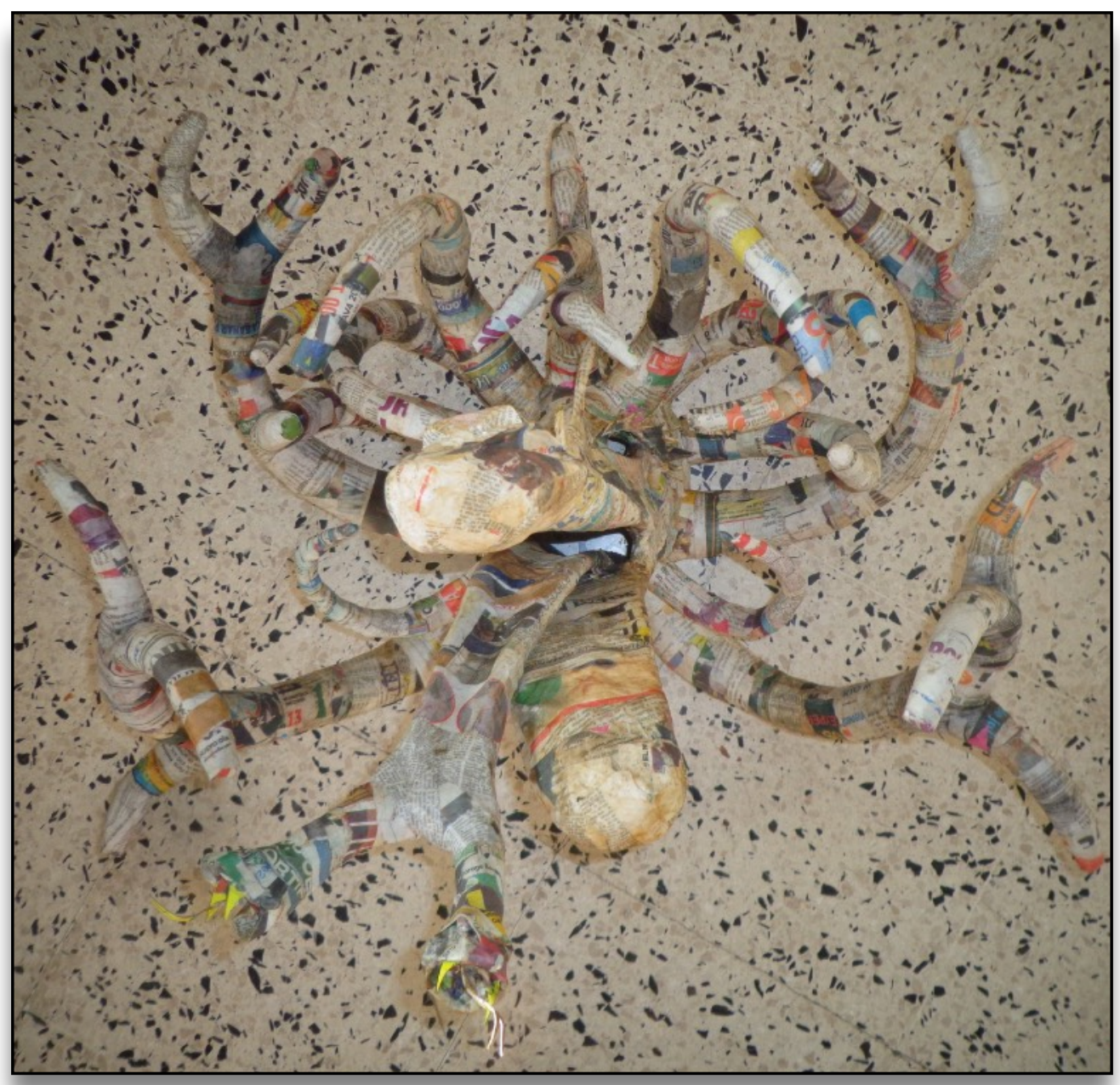

Figure 204 Asymmetrical Vejigante Mask with Two-Headed Snake Tongue by Chelsea Glidden Bosch [digital image]. By Author. February 24, 2017 


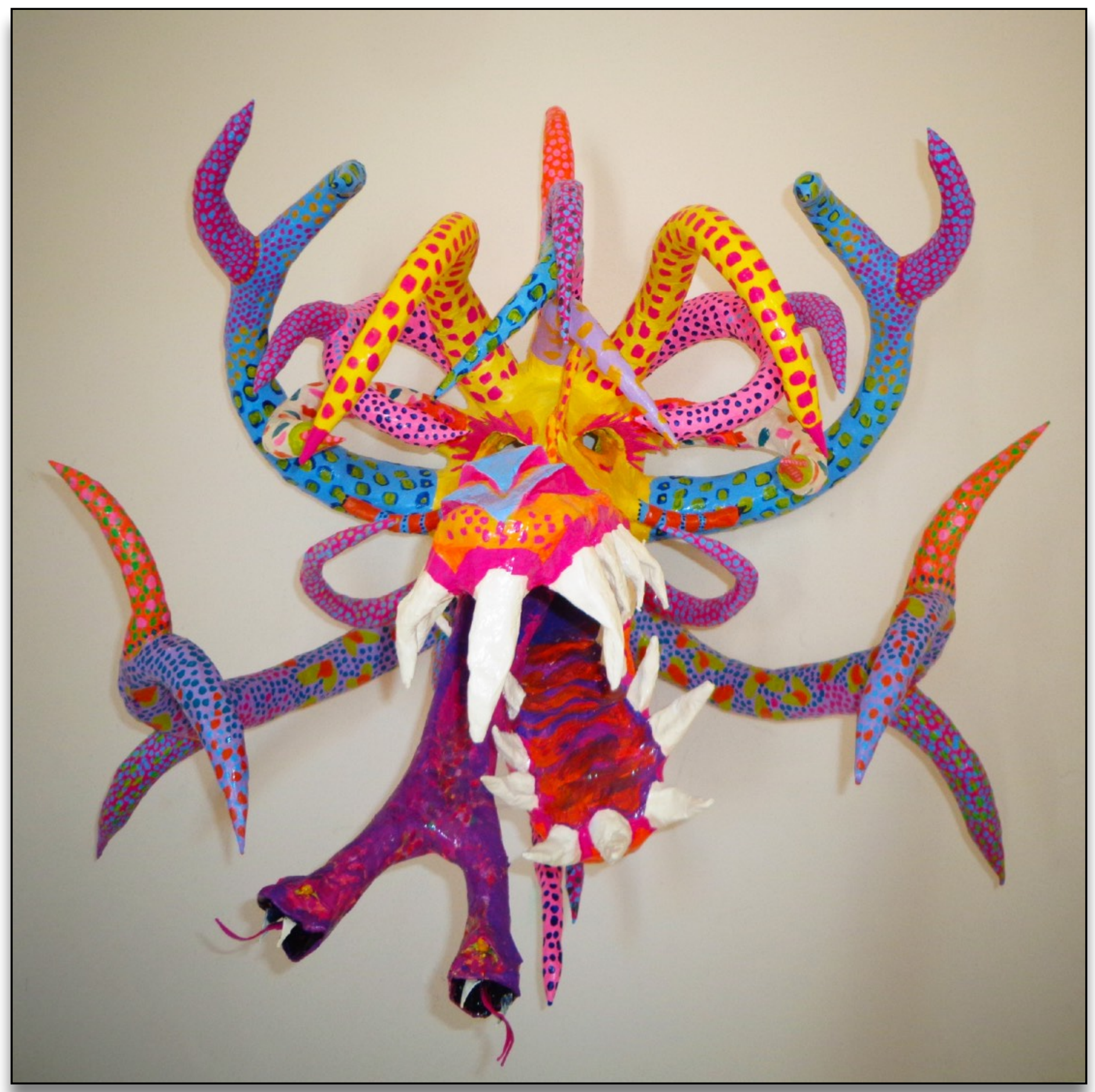

Figure 205 Asymmetrical Vejigante Mask with Two-Heads Snake Tongue by Chelsea Glidden Bosch [digital image]. By Author. February 24, 2017 


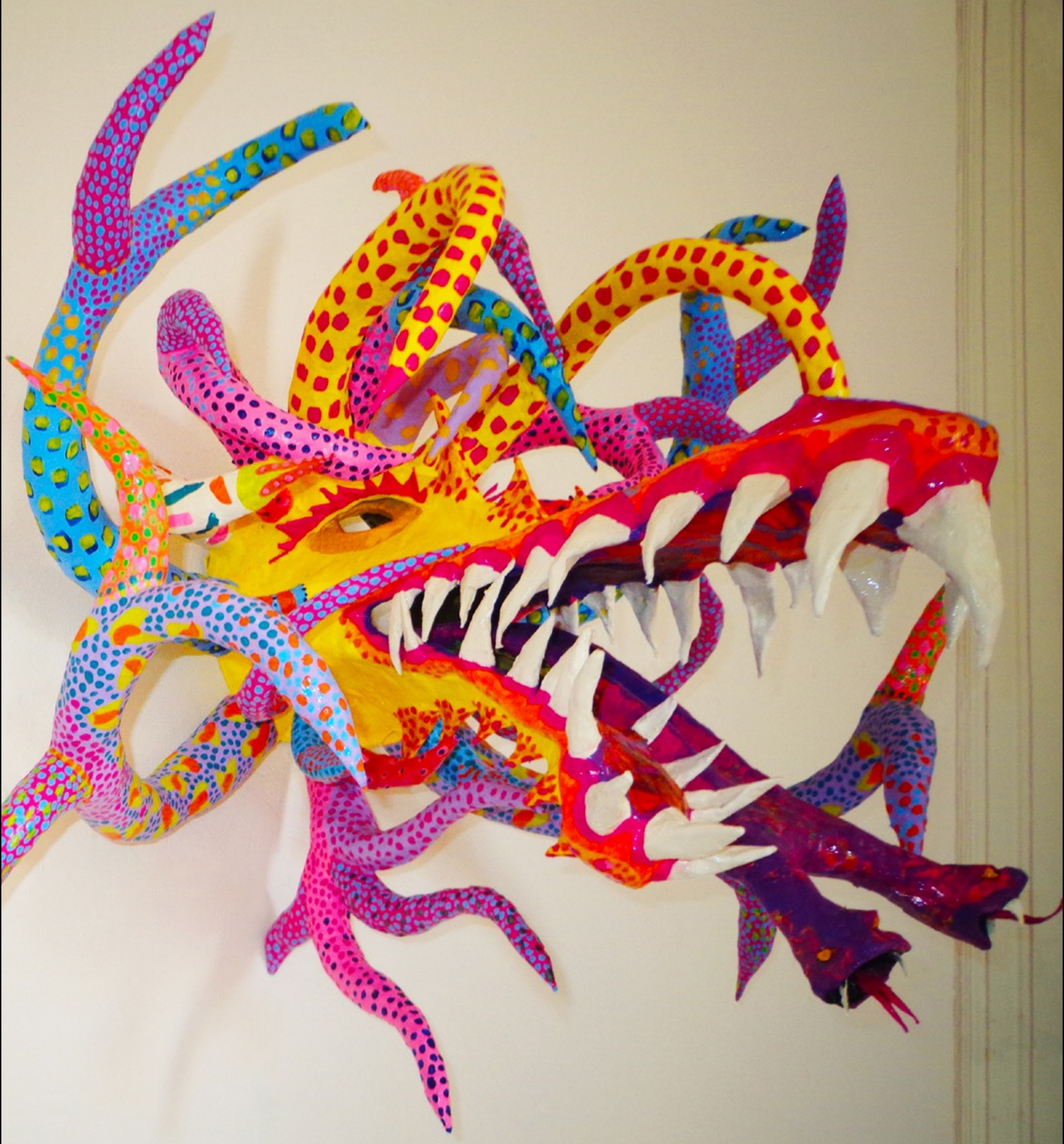

Figure 206 Asymmetrical Vejigante Mask with Two-Heads Snake Tongue by Chelsea Glidden Bosch [digital image]. By Author. February 24, 2017 
Every careta antigua I created was unique. The only constant motif was the use of asymmetrical molds. This allowed the viewer to associate my masks with a signature style as an artisan. The creation of individualistic vejigante masks challenged the artisanal community by establishing a set and style with an original series of artworks. Furthermore, the masks presented in the section were traditionally created, but because the depiction of the vejigante was unconventional, my masks landed on the cusp of artisanal and contemporary. The caretas were able to thrive and be works of art rather than just mass produced, manufactured objects. The vejigante mask has the opportunity and the possibility to enter into the art world, but many artisans continue to limit the possibility of its evolution. This can cause the vejigante mask to remain a stagnant, cultural artifact unable to enter into the contemporary art world. If the artisan community does not encourage students to challenge the fundamentals, the vejigante masks will not move forward into current contexts, and will inevitable cease to exist. 


\subsubsection{Contemporary Masks}

After the learning the traditional techniques of the vejigante mask, I wanted to revisit the method and experiment even further. But before the study began, I drew preliminary sketches of a concept. This was done in order to create a guideline. During the experimental phase, I explored materials. But like any medium, there are limits to what can be manipulated. I simplified the materials to glue and paper, although this was not sufficient to create the structure of a functioning vejigante mask. Therefore, the only alternative was to use a more durable medium. I experimented with construction paper and cardboard. The cardboard created a stable base of the mask, for example All Teeth. The construction paper and cardboard enabled the form to be manipulated into the desired shape. (Figures 207-211) 


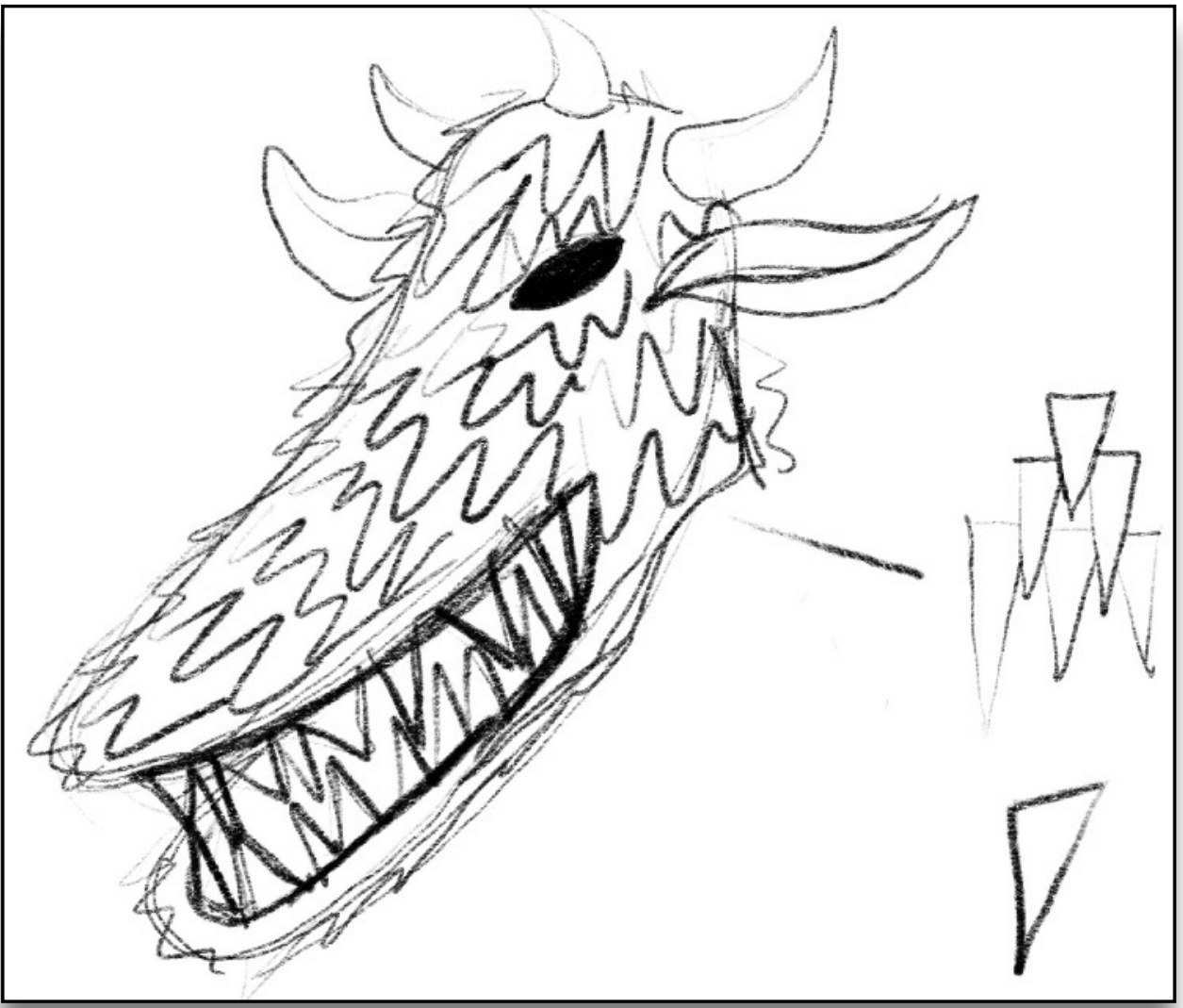

Figure 207 Sketch of All Teeth by Chelsea Glidden Bosch [digital image]. By Author. February 24, 2017

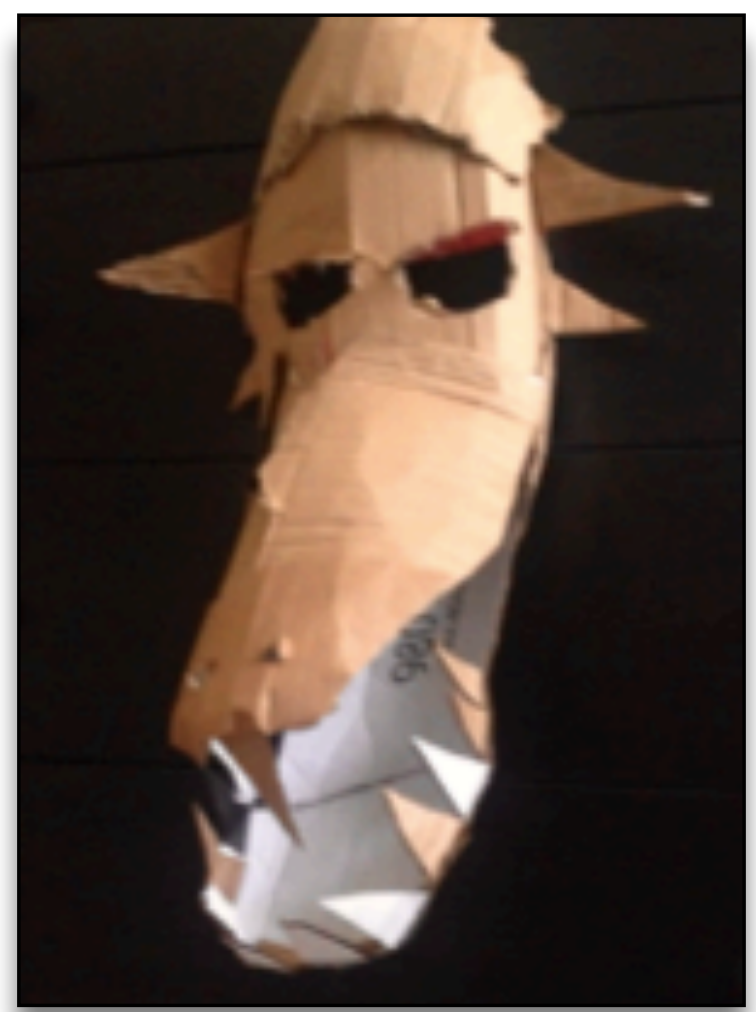

Figure 208 The Base of All

Teeth by Chelsea Glidden Bosch [digital image]. By Author. February 24, 2017 


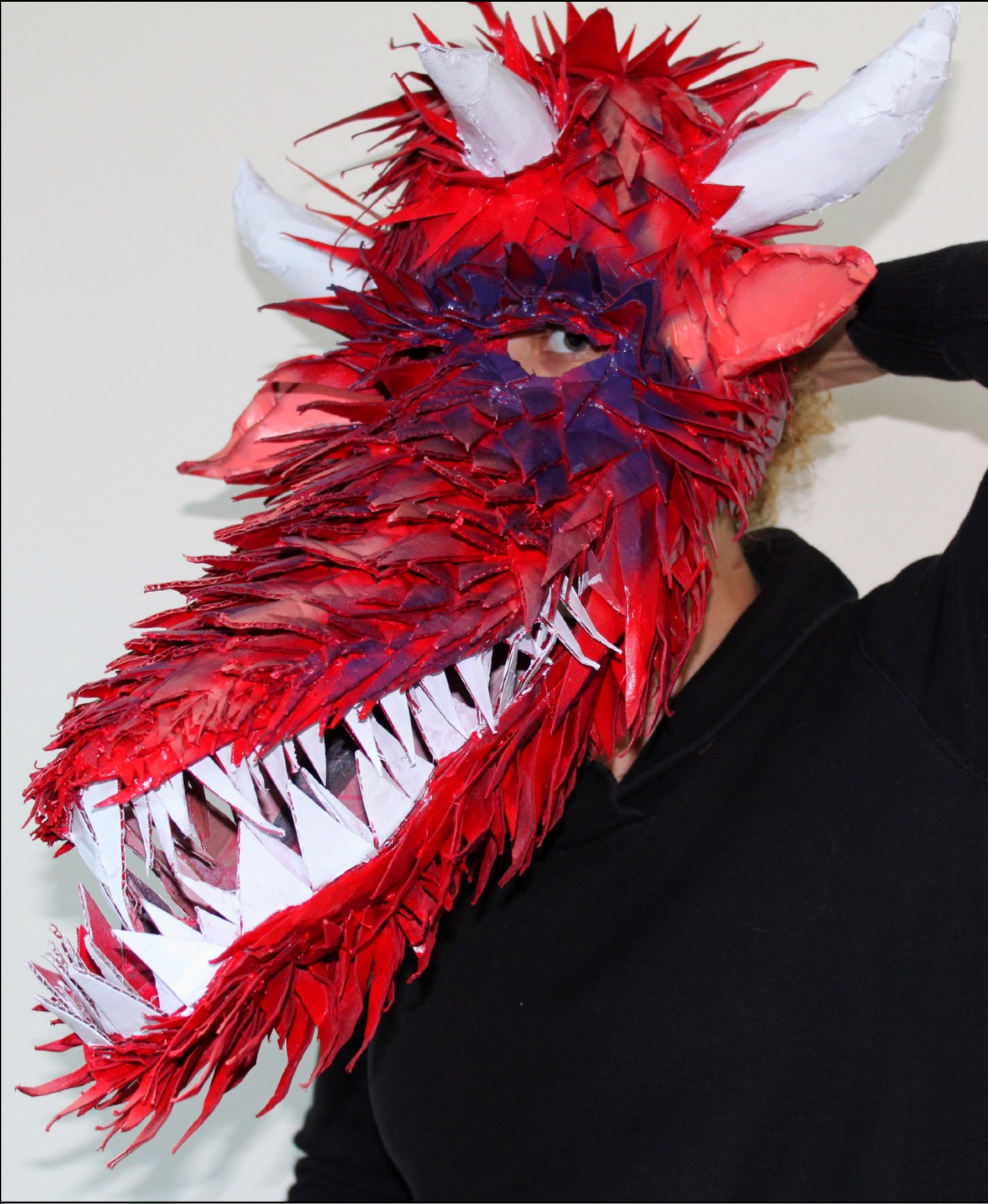

Figure 211 All Teeth by Chelsea Glidden Bosch [digital image]. By Author. February 24, 2017 
Although the cardboard gave substantial structure, there was then a need to disguise the raw base. As seen in the picture, the base was uneven and inconsistent. This was disguised with a pattern of textures. Cutting construction paper into similar shapes, and then using pieces to cover the base of the mask. This created the illusion of scales, or feathers. This technique was inspired by the patterns, i. e. dots, lines, drips, which are often seen on a careta antigua. (Figures 212-213)

The glue that would be used had to create a stronger base. Super glue, or crazy glue, was an option, but the amount needed to construct the vejigante mask was substantial. The best alternative was hot-glue. The hot-glue creates a strong foundation. This type of glue dries quickly and with a plastic sturdy finish. This was the best alternative for the reconstruction of a vejigante mask. (Figure 214-217)

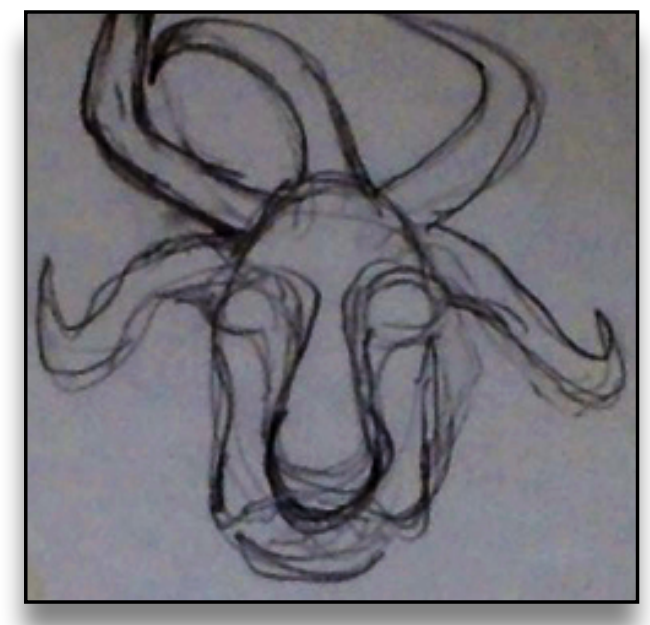

Figure 212 Vianda Sketch by Chelsea Glidden Bosch [digital image]. By Author. February 24, 2017

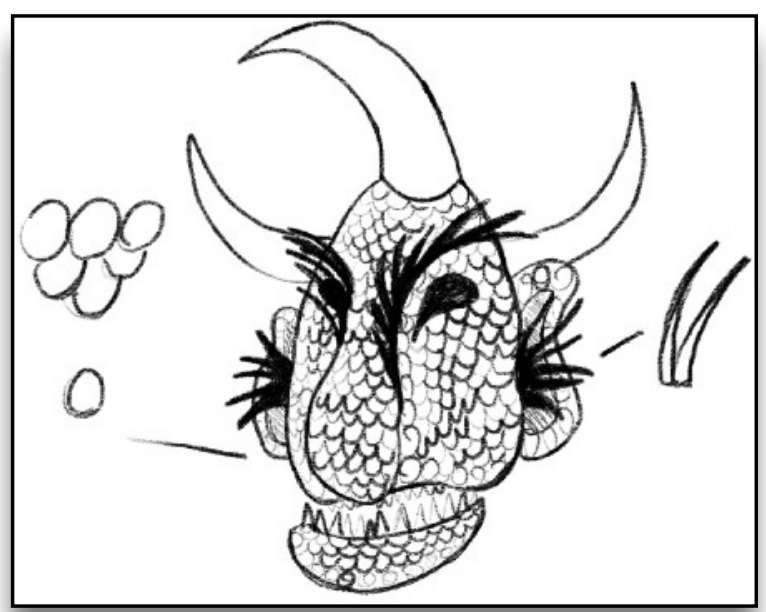

Figure 213 Vianda Sketch by Chelsea Glidden Bosch [digital image]. By Author. February 24, 2017 


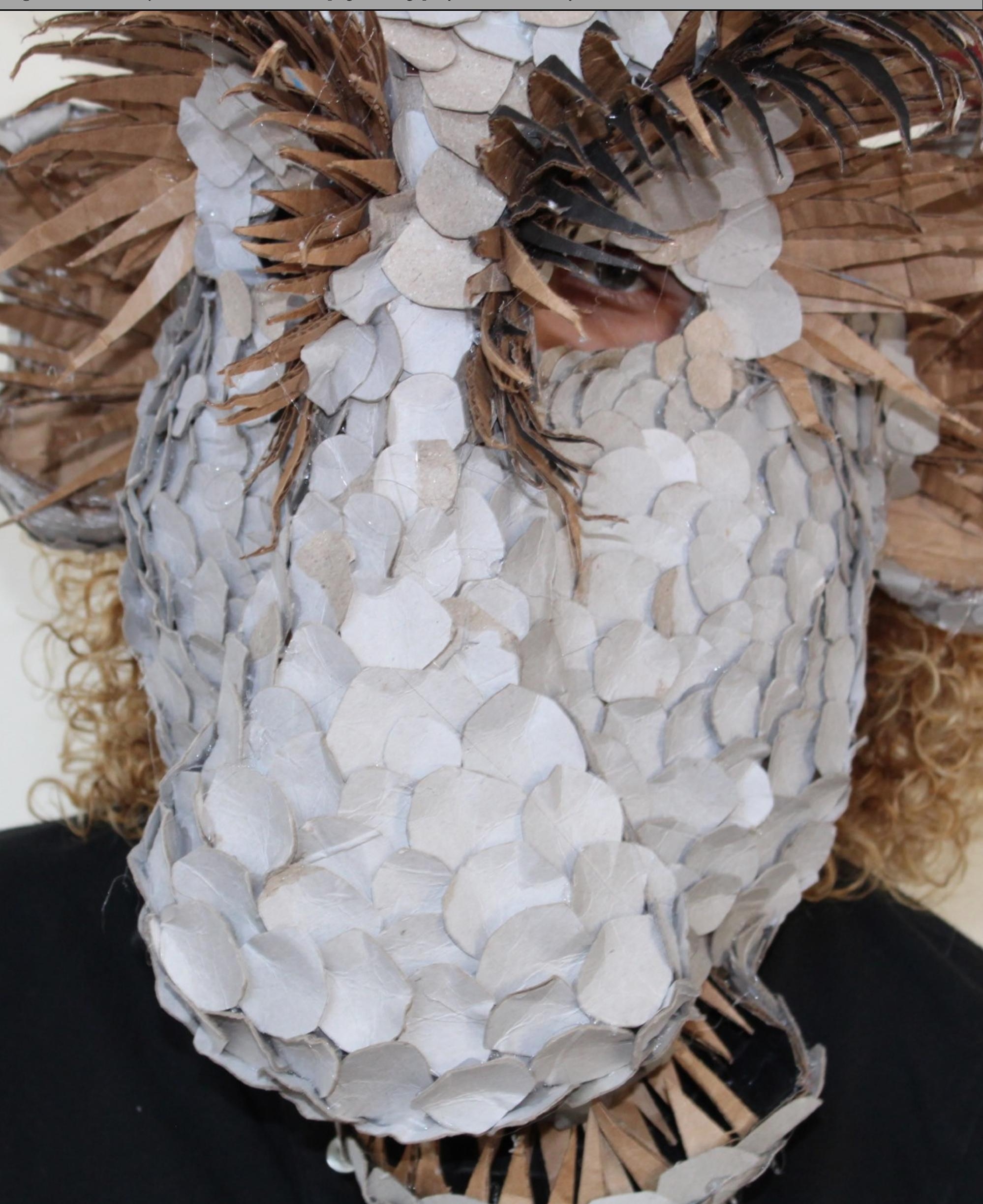

Figure 214 Vianda by Chelsea Glidden Bosch [digital image]. By Author. February 24, 2017 


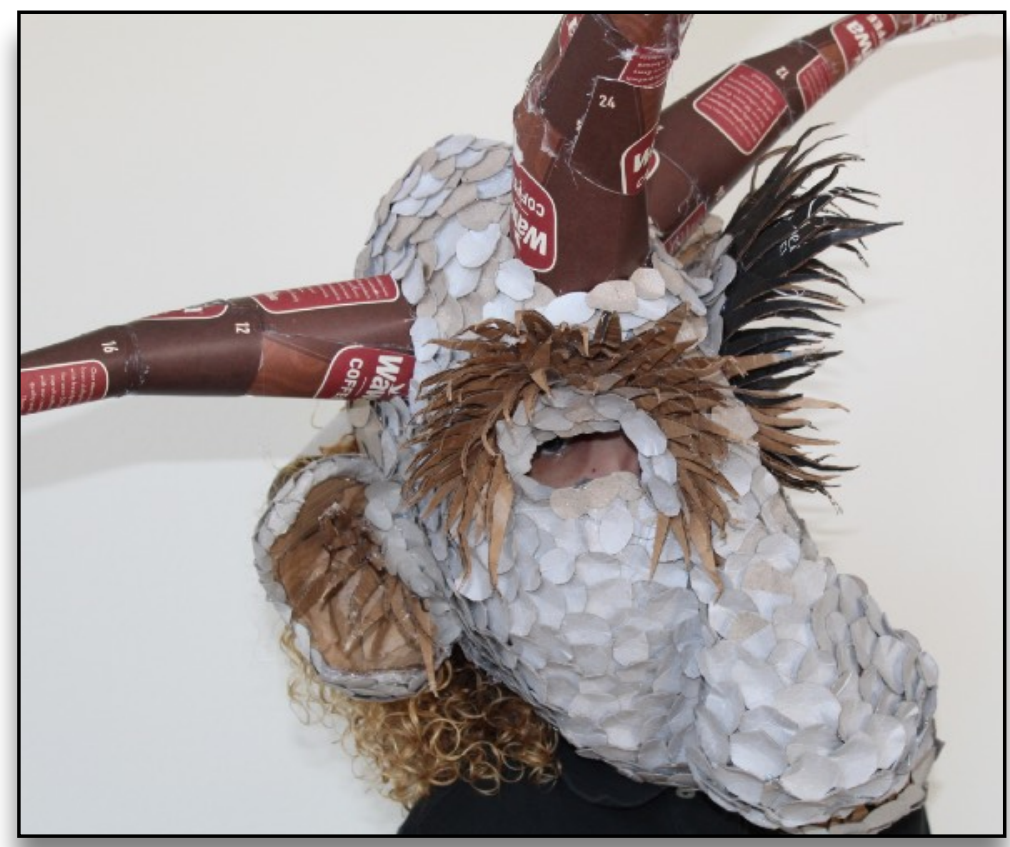

Figure 215 Vianda by Chelsea Glidden Bosch [digital image]. By Author.

February 24, 2017

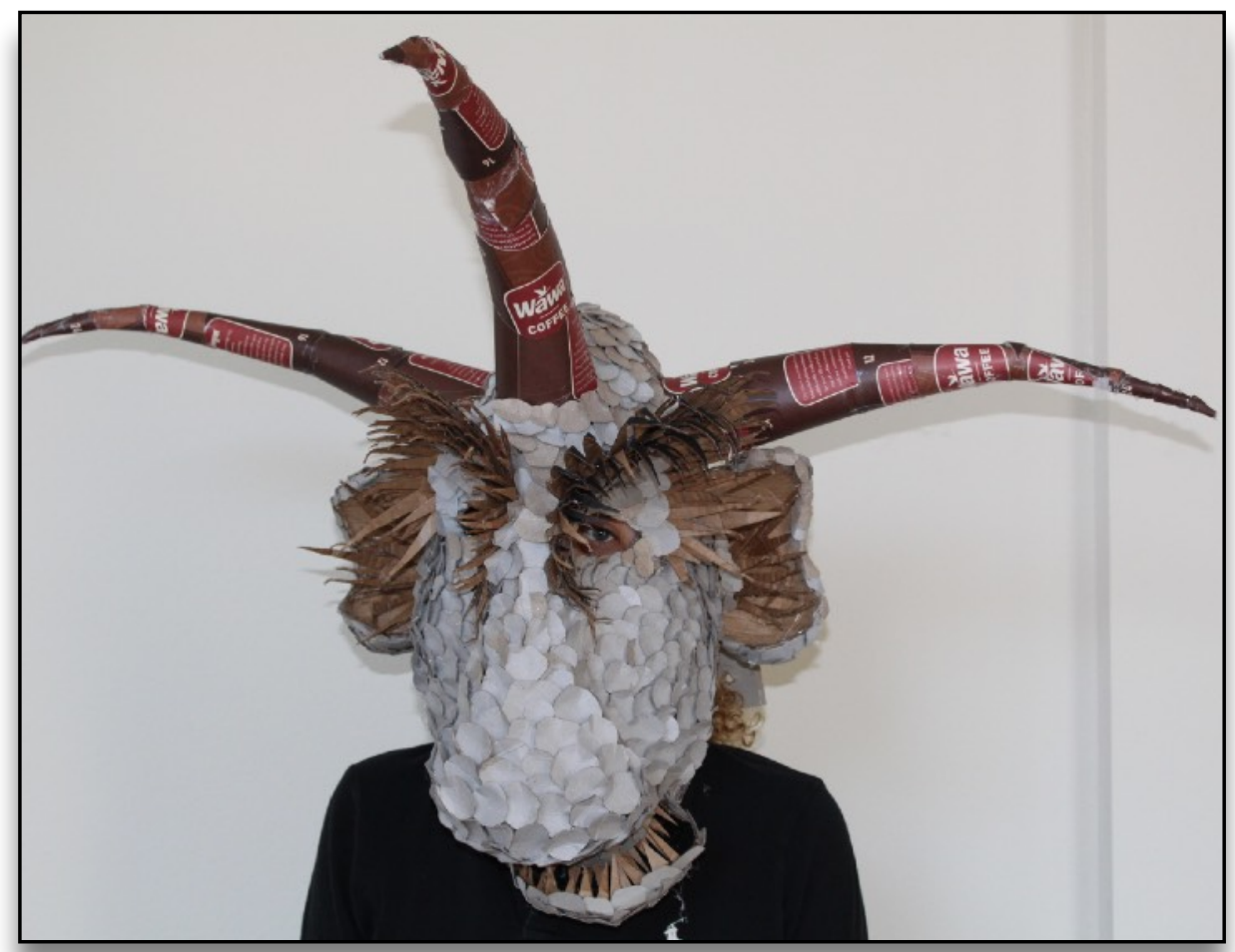

Figure 216 Vianda by

Chelsea Glidden Bosch [digital image]. By Author. February 24, 2017 


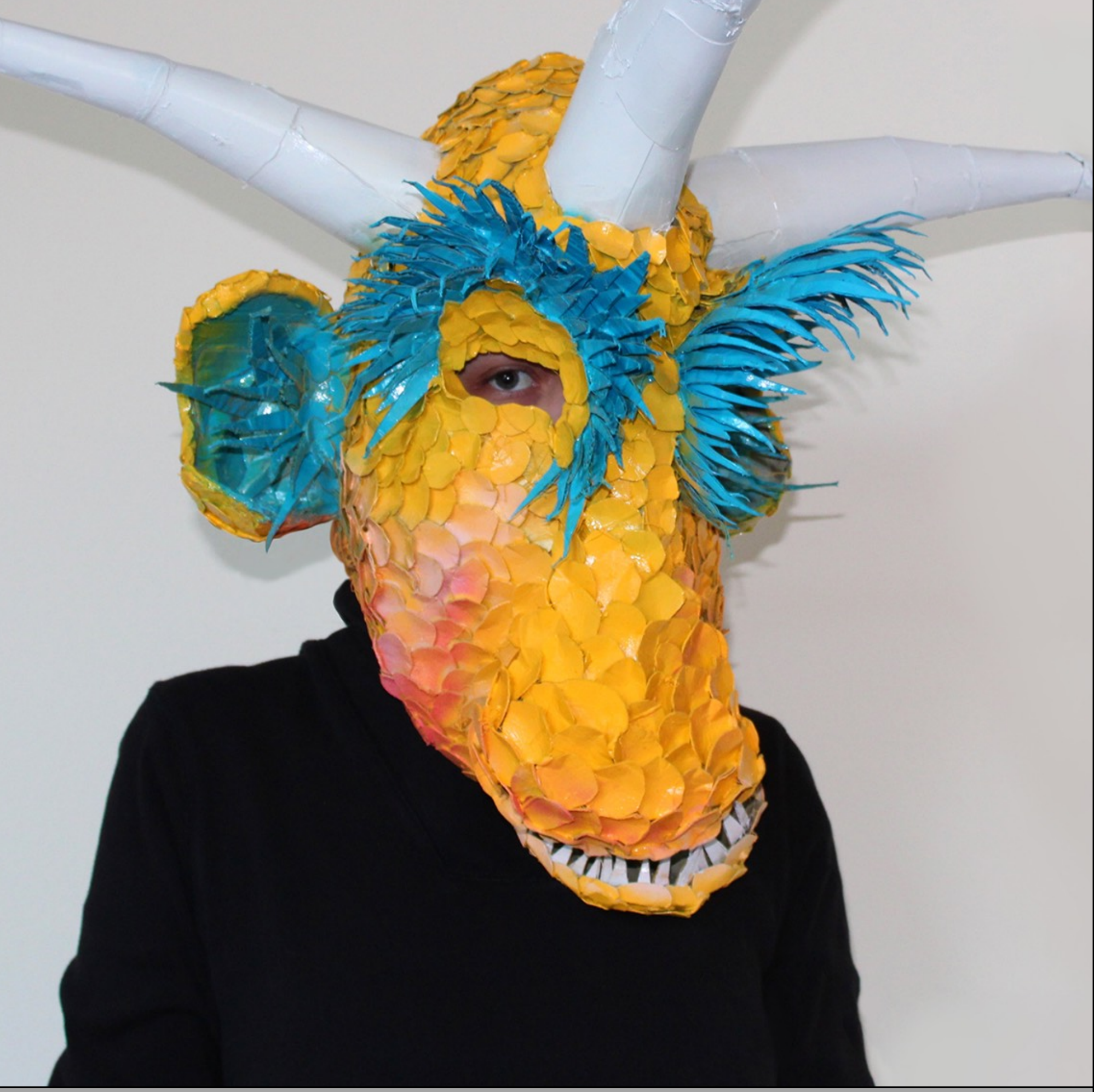

Figure 217 Vianda by Chelsea Glidden Bosch [digital image]. By Author. February 24, 2017 
The variation of the cardboard had to be chosen specifically to ensure the mask would be light weight and wearable. While the heavy-duty cardboard can be used for the base of the mask, the scales/feathers must be created with construction paper. This technique created a lighter, durable mask. (Figures 218-220) In addition, I also discovered that cardboard with a laminated surface does not stick to any other material with the use of hot-glue. The laminated cardboard rejects the hot-glue, and the glue begins to peels off. This was discovered while working with my third mask, Corona. The Corona references to the Corona brand beer boxes used to create the feathers of the mask. (Figures 221-222) I was able to use laminated cardboard to create the vejigante mask. While the front of the cardboard was laminated, the back of the cardboard was raw. This enabled the cardboard to adhere to the base of the mask. This discovery further improved the techniques developed during the experimentation with the concept of vejigante masks. (Figures 223-227)

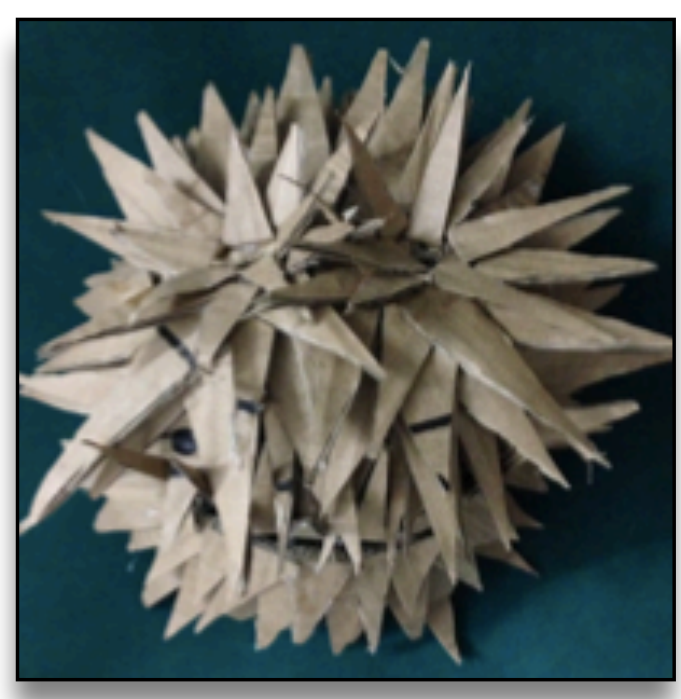

Figure 218 First Version Mask by Chelsea Glidden Bosch [digital image]. By Author. February 20, 2018

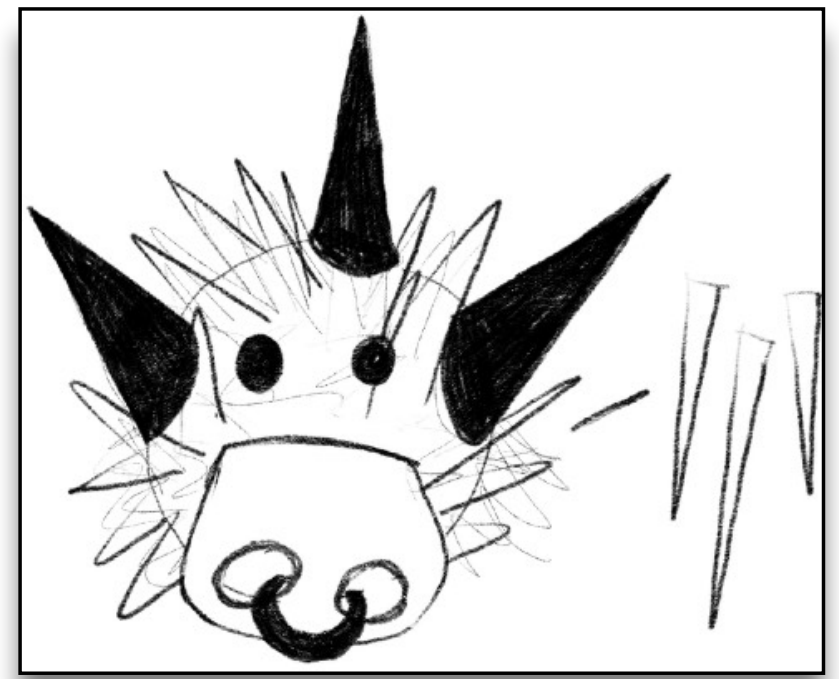

Figure 219 Sketch of Techno Tiger by Chelsea Glidden Bosch [digital image]. By Author. February 20, 2018 


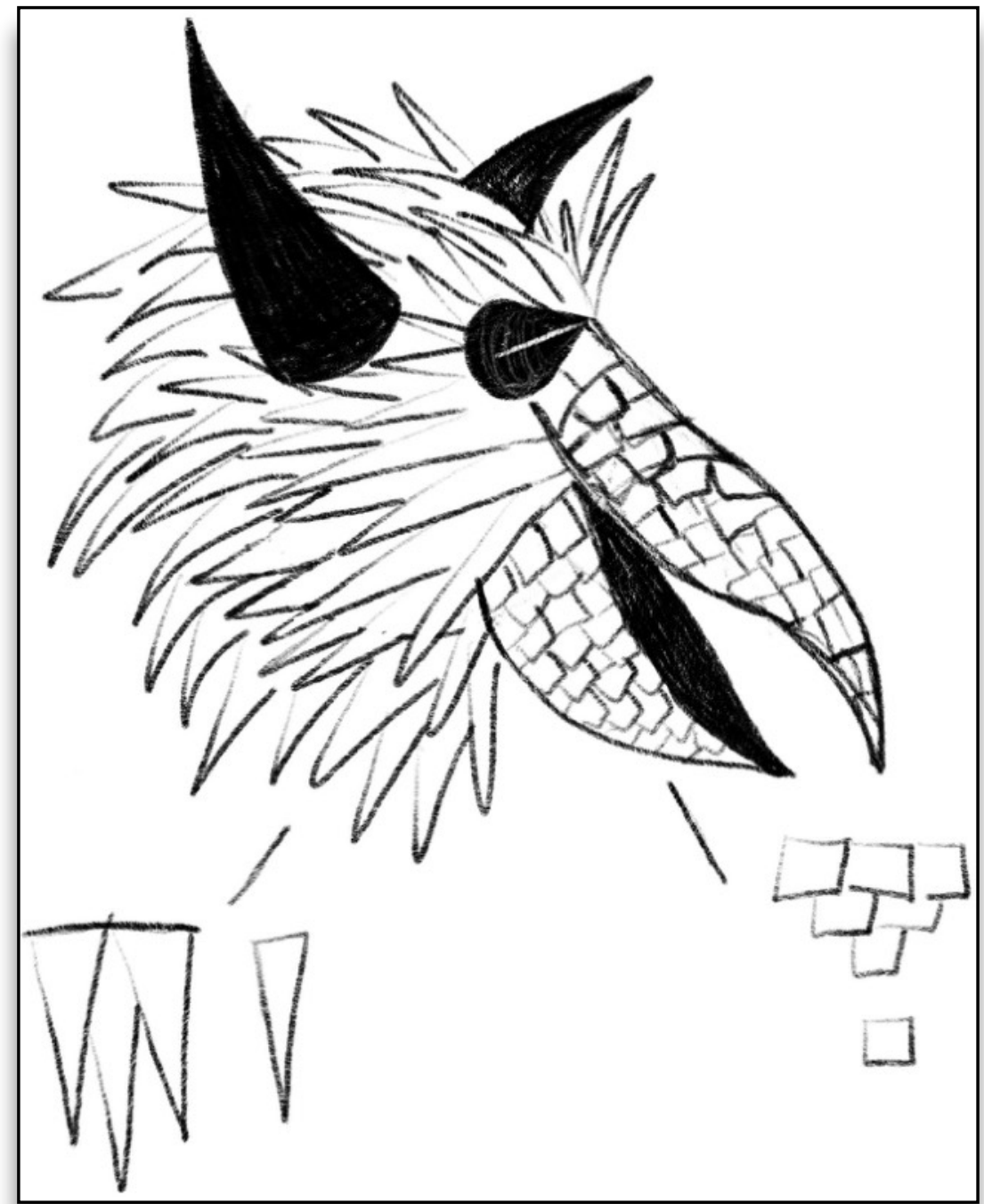

Figure 221 Corona Sketch by Chelsea Glidden Bosch [digital image]. By Author. February 20, 2018

Figure 222 Cerveza CORONA Extra $355 \mathrm{ml} 6$ [digital image]. Retrieved June 20, 2020 from https:// www.devoto.com.uy/cerveza-coronaextra-355-ml-x-6-un-550671/p 


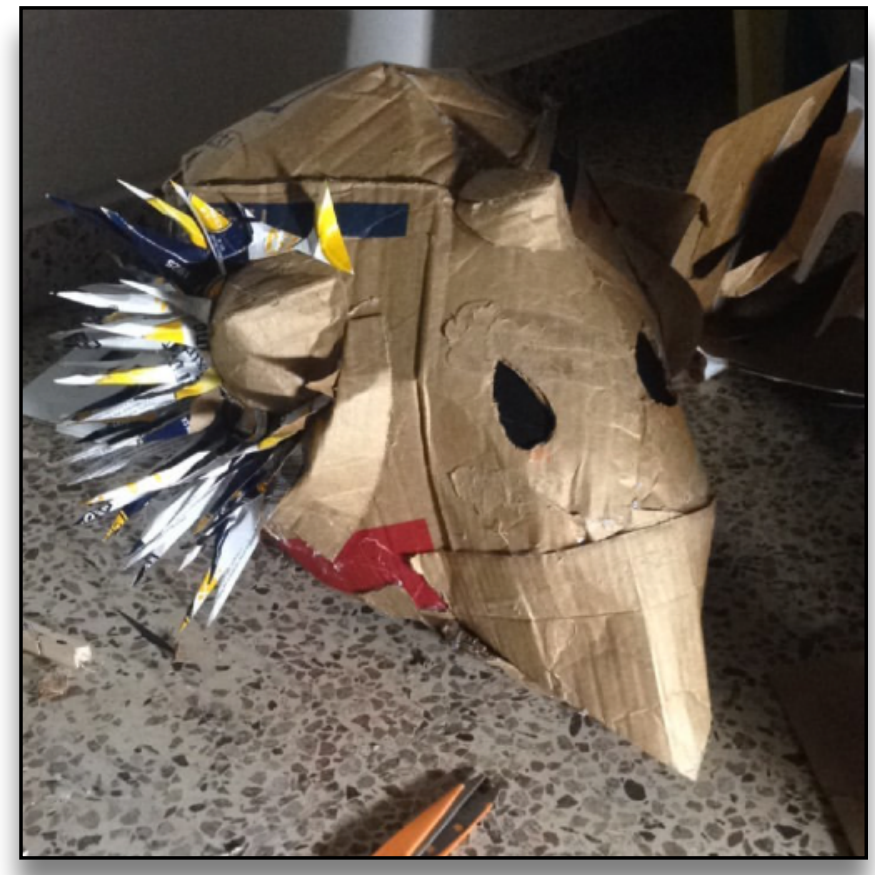

Figure 223 The Base of Corona by Chelsea Glidden Bosch [digital image]. By Author. February 20, 2018

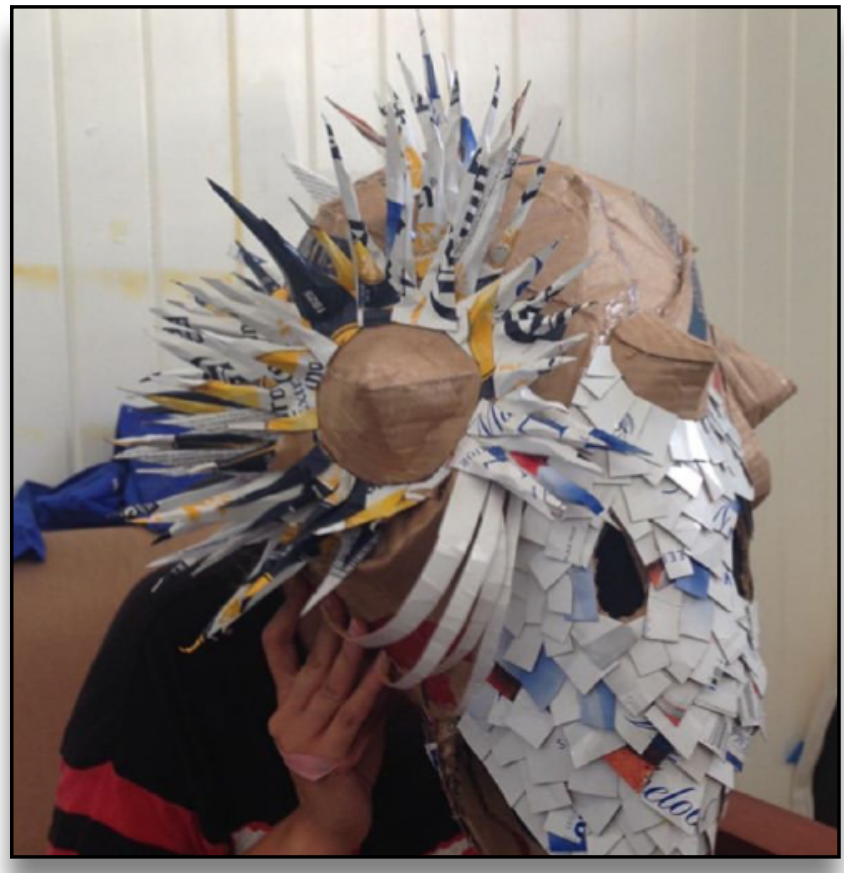

Figure 224 Corona in Process by Chelsea Glidden Bosch [digital image]. By Author. February 20, 2018

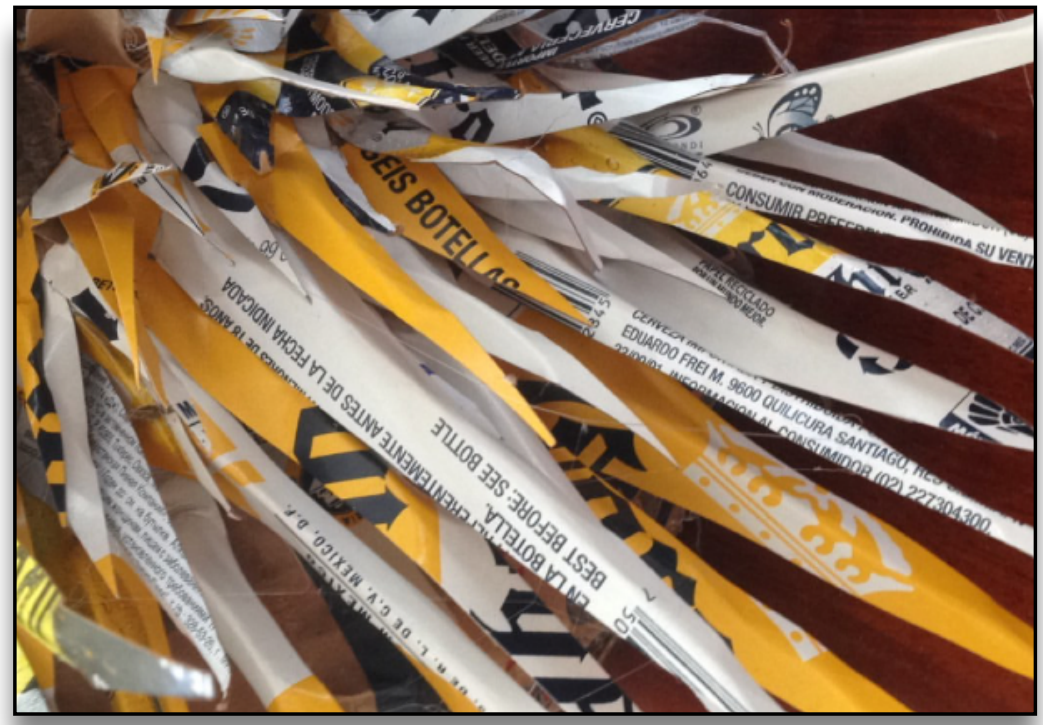

Figure 225 Corona Feathers made from Corona Beer Boxes by Chelsea Glidden Bosch [digital image]. By Author. February 20, 2018 


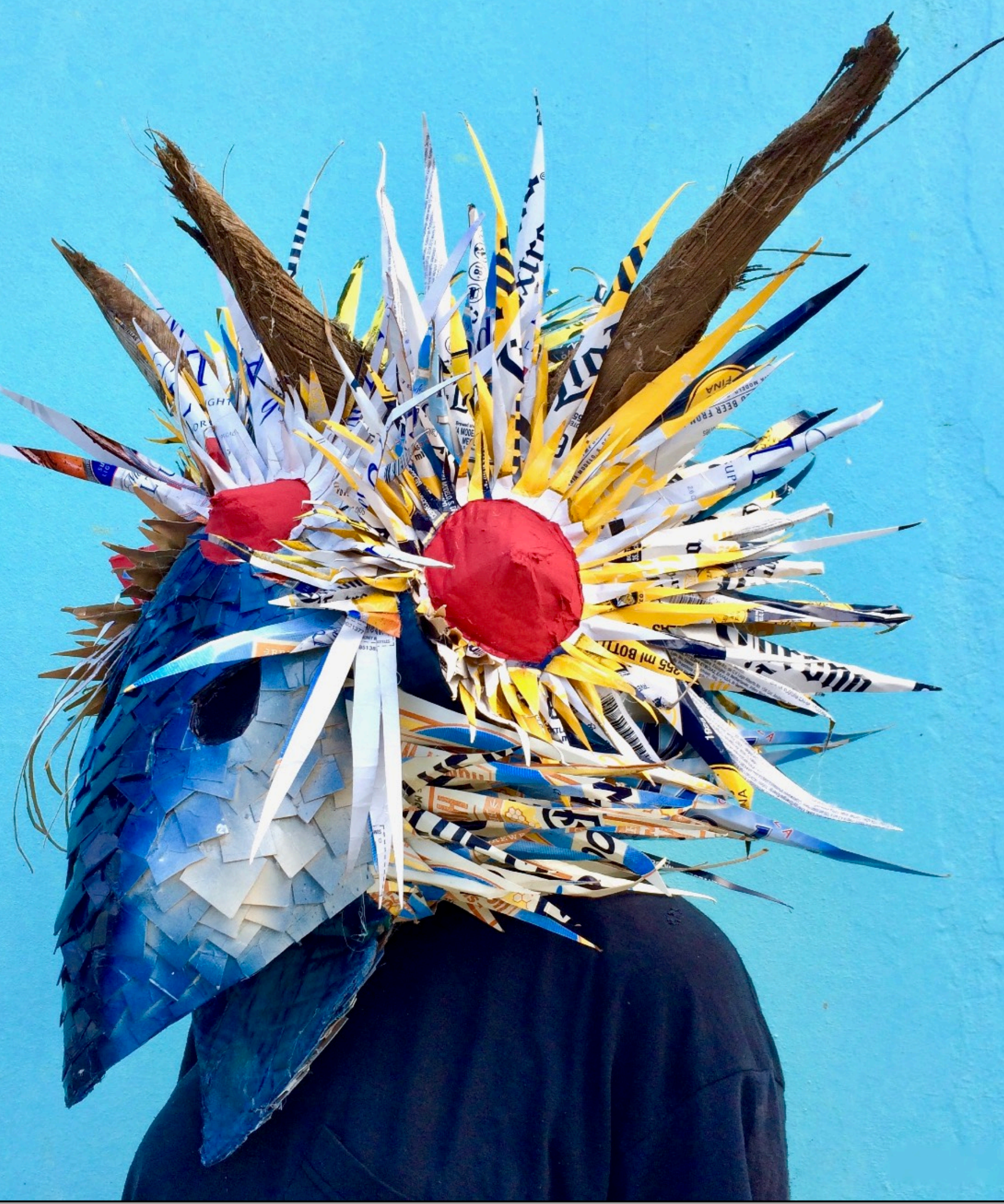

Figure 226 Corona by Chelsea Glidden Bosch [digital image]. By Author. February 20, 2018 


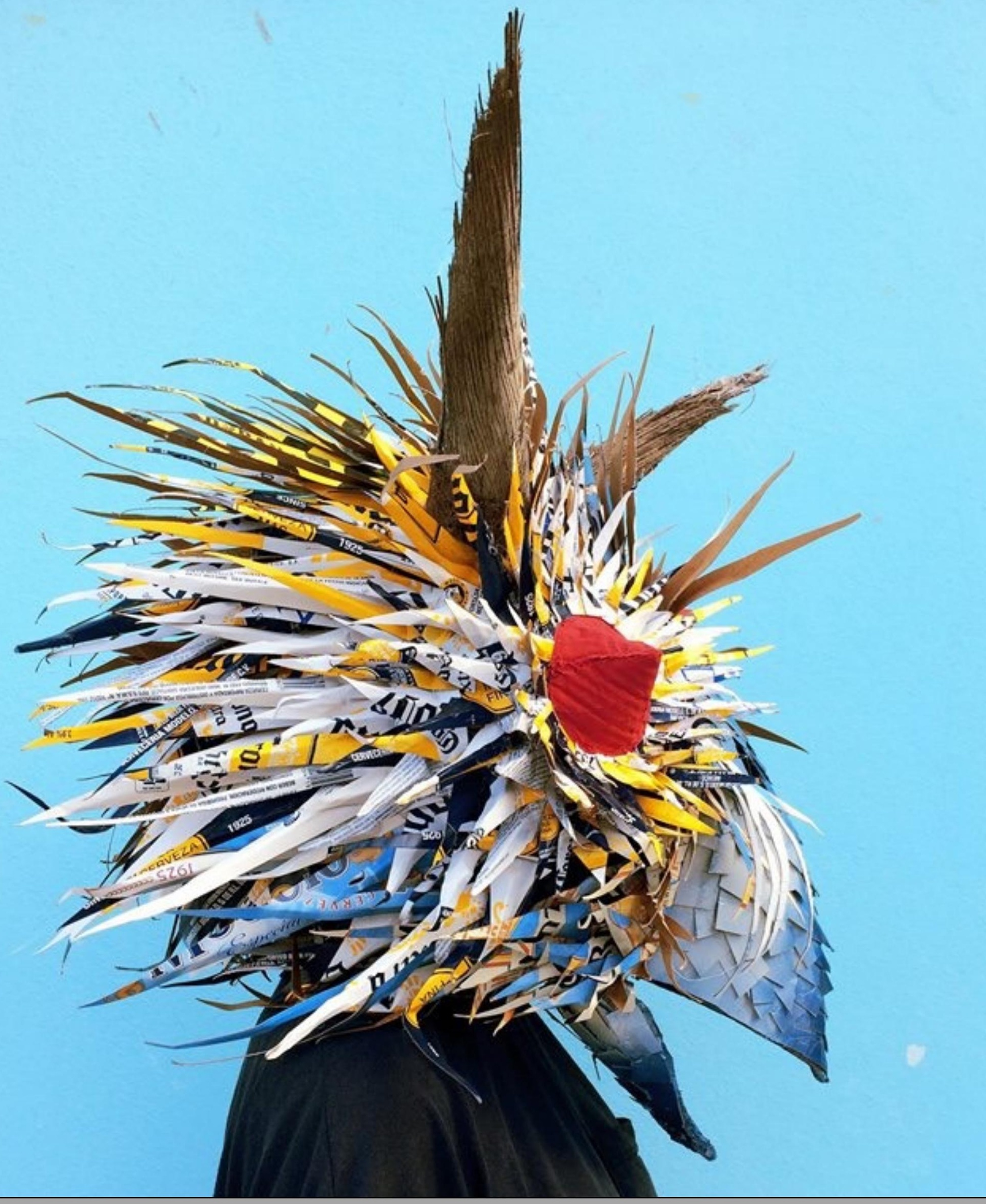

Figure 227 Corona by Chelsea Glidden Bosch [digital image]. By Author. February 20, 2018 
I was invited to display multiple contemporary vejigante masks in international exhibitions. I was chosen as a finalist within the exhibition of Beyond Borders by VeniceLands in Treviso, Italy. (Figure 228) I displayed two masks within the exhibition. (Figures 229-230) I was also invited to participate and exhibit Corona at the opening of a new gallery Outstanding Art Limited in Durham, United Kingdom. Not only was Corona displayed, but the gallery and I coordinated a performance within the town, the mask to be worn in a dance in downtown Durham. (Figures 231-232) I am honored to have represented the Puerto Rican culture in a contemporary, international setting. This has allowed the vejigante mask to enter into a new context and appreciation within modern art.

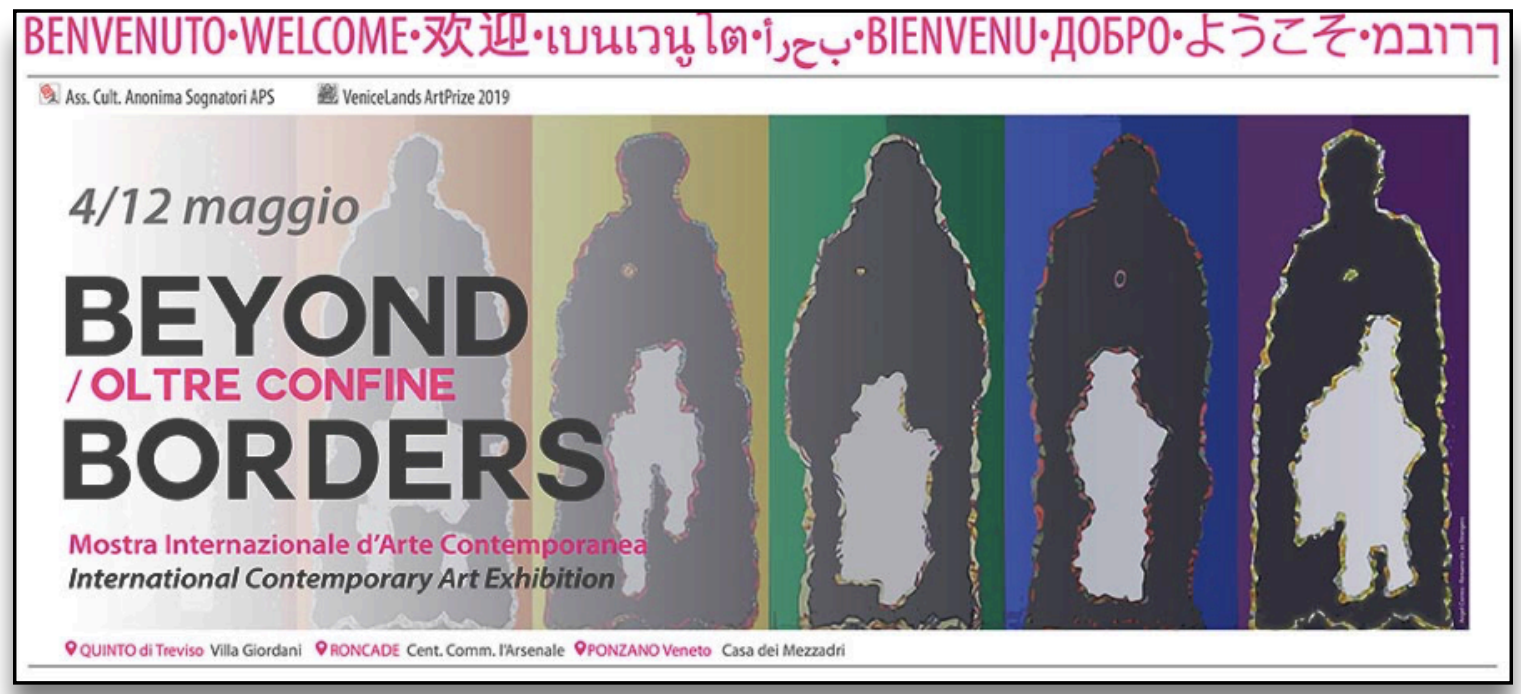

Figure 228 Beyond Borders [digital image]. Retrieved June 20, 2020 from http:// www.anonimasognatori.org 


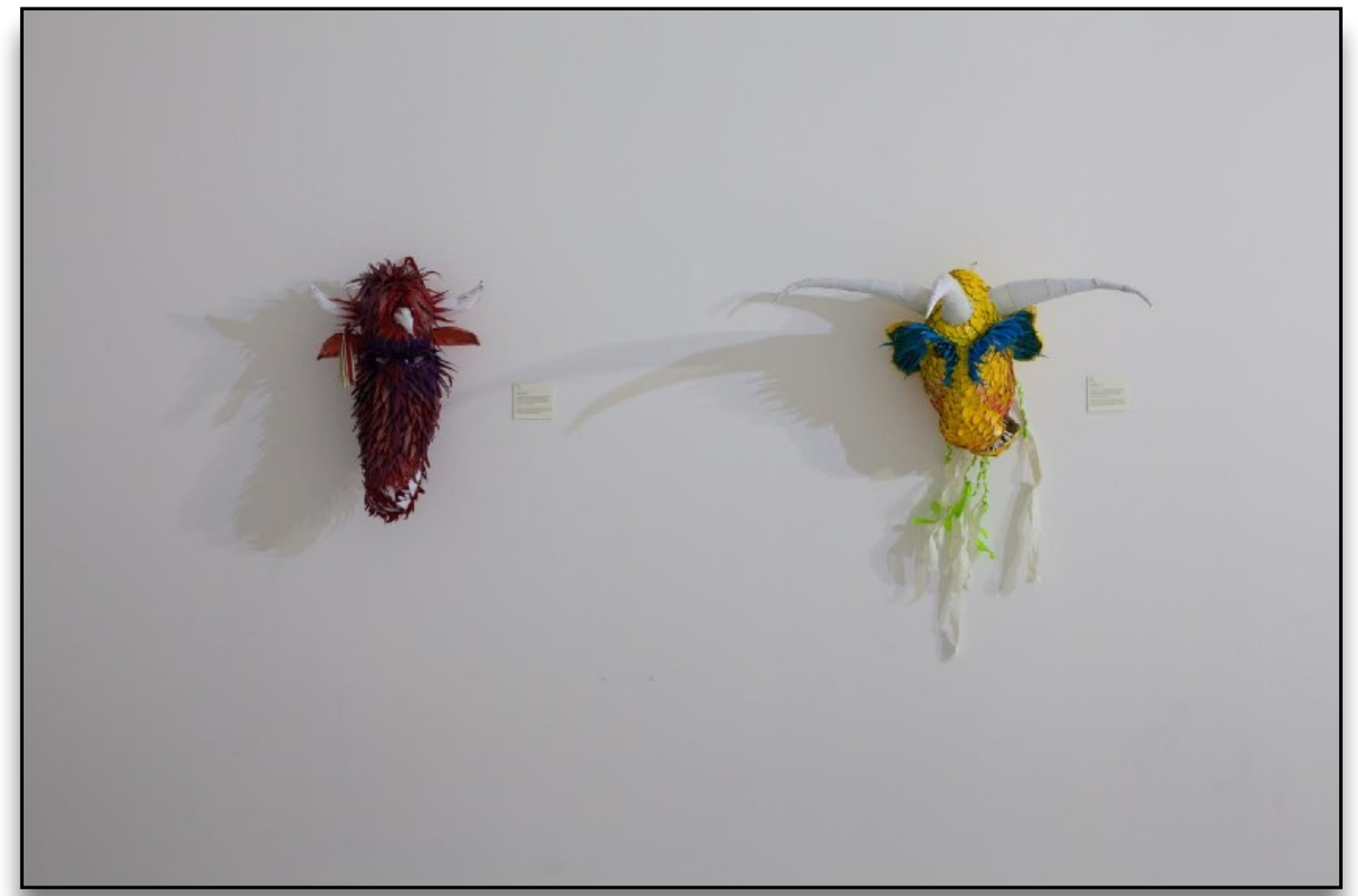

Figure 229 Beyond Borders, Masks by Chelsea Glidden Bosch [digital image]. By Author. February 20, 2018

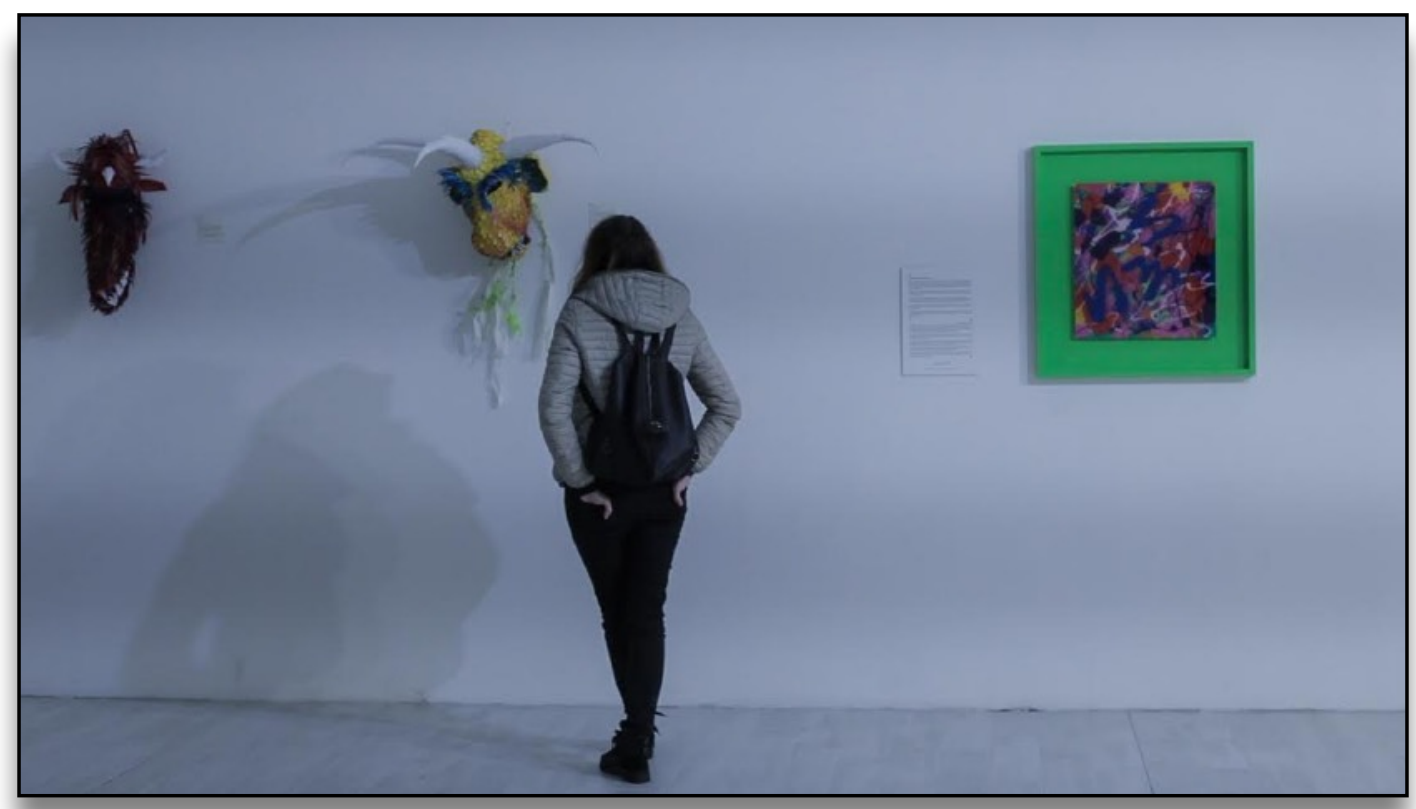

Figure 230 Beyond Borders, Masks by Chelsea Glidden Bosch [digital image]. By Author. February 20, 2018 


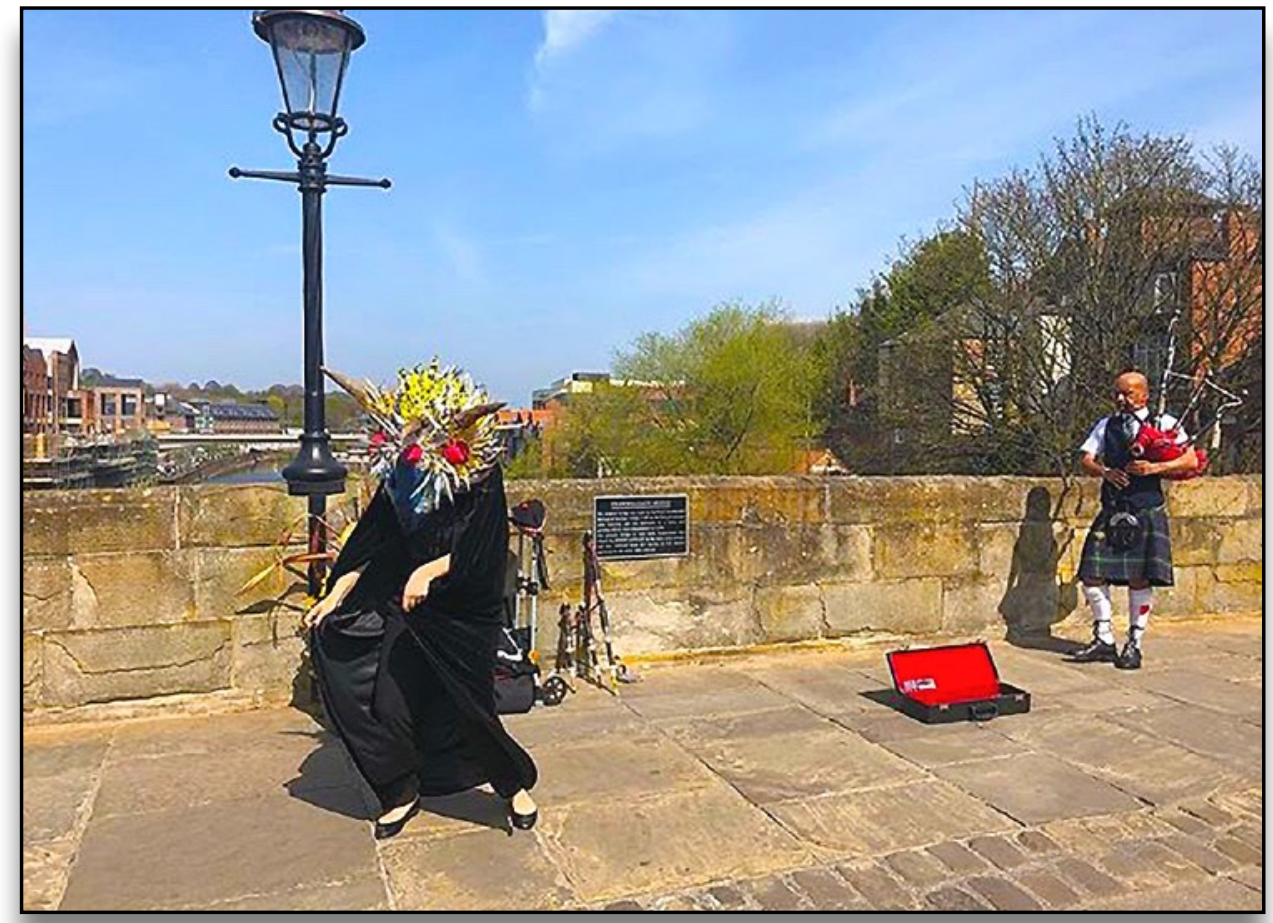

Figure 231 Downtown Durham, Mask by Chelsea Glidden Bosch [digital image]. By Author. February 20, 2018

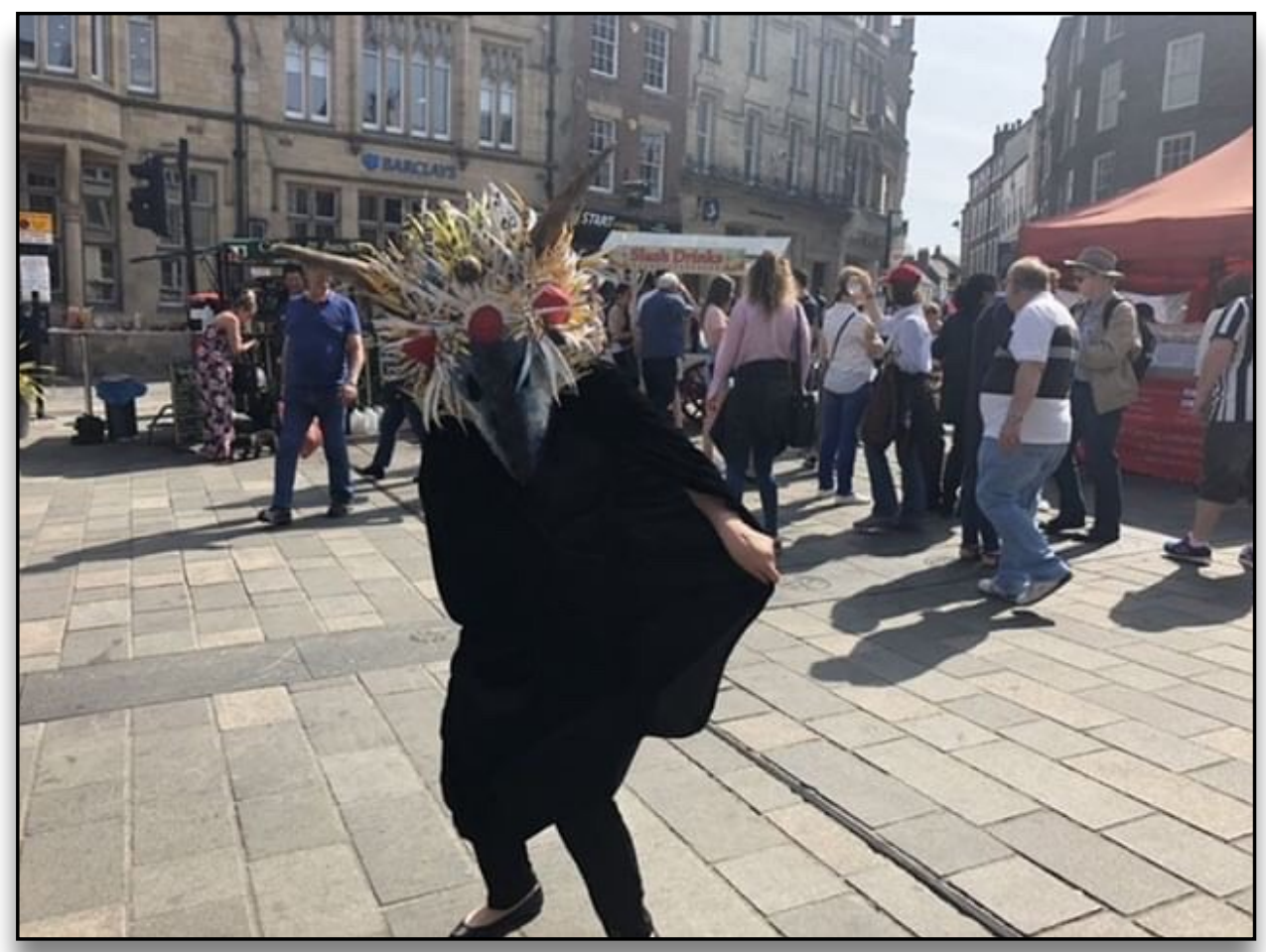

Figure 232 Downtown Durham, Mask by Chelsea Glidden Bosch [digital image]. By Author. February 20, 2018 


\subsection{Public Art}

Public art is artwork that is directly accessible to the public. It has a direct “interrelationship between content and audience." 181 Public art is a prominent phenomenon in Puerto Rico. It is considered the establishment of this art form can be attributed and linked to the petroglyph created by the Tainos in Puerto Rico. The Tainos have a rich history, and are known for their craftsmanship. ${ }^{182}$ The first recorded commission of public art for the city of San Juan was documented in 1996 by Sila María Calderón. Although there obviously had been public art before the year 1996, this was the first official date recorded by the government. ${ }^{183}$ To this day, the practice of public art continues with annual festivals such as Santurce es Ley, Ponce es Ley, and Yaucromatic. Public art in Puerto Rico represents and displays the island's aboriginal customs. It is stated by María M. Domingues that public art creates a "bond between community and art."184 There has always been a dialogue between art and architecture within the community and its surroundings. Public art in Puerto Rico has a constant motif of iconic

\footnotetext{
181 Cher Krause. Knight, Public Art: Theory, Practice and Populism (Malden, Mass: Blackwell, 2009), PREFACE.

182 Kathleen A. Deagan and Cruxent José María, Columbus Outpost among the Taínos: Spain and America at La Isabela, 1493-1498 (New Haven, CT: Yale University Press, 2002), 43.

183 Galván Javier A., Culture and Customs of Puerto Rico (Westport: Greenwood Press, 2009), XXI.

184 Luis Antonio. Cardona, A History of the Puerto Ricans in the United States of America, vol. 2 (Bethesda, MD: Carreta Press, 1995), 292.
} 
representations. Javier A. Galván states "Sometimes architecture cannot be separated from art; they actually flow together." 185 While the architecture points to the historical culture, the public art often point to modernism, the present and future desires:

Populist art is genuinely inclusive of a broader range of people, which does not necessarily mean that its edge is softened, its content tamed, or that it pleases huge audiences. Rather as a framed here, populism is a matter of providing people with the means to feel confident in negotiating relationships with art on their own terms. ${ }^{186}$

It is important to research and understand how public art, or installations, directly influence and impact the community surrounding it. The artist must carefully consider the surroundings when creating a public work of art or installation. "To apprehend the function of populism in public art, we have considered placement, funding and subject matter, and emphasized issues of audience engagement." 187 Engaging with the public's eye is a fundamental of public art, and, furthermore, to understand the preexisting community that the art will live in.

\footnotetext{
185 Galván Javier A., Culture and Customs of Puerto Rico (Westport: Greenwood Press, 2009), 143.

${ }^{186}$ Cher Krause. Knight, Public Art: Theory, Practice and Populism (Malden, Mass: Blackwell, 2009$), 110$.

187 Cher Krause Knight, Public Art: Theory, Practice and Populism (Malden, Mass: Blackwell, 2009), 110.
} 


\subsubsection{Los Vejigantes de Beetlejuice}

During my time in Puerto Rico, I also had the opportunity to part take in Master of Art classes in Pontificia Universidad Católica de Puerto Rico, specifically a graduate level introduction class to Muralismo, muralism. This class focused on the heritage and tradition of public art in Puerto Rico. And in the final outcome, the task was to create various murals around the island. In comparison to the USA, Puerto Rico encourages for murals to be present, especially within the school systems and communities, and continues to endorse public art.

I was invited to paint in the art district of Arecibo, specifically the malecón, the bay. This district has an entire wall, facing the beach, completely devoted to murals. Since I already had the experience within the street art realm, I specifically asked the coordinator for a large-scale wall to challenge myself. The wall was ten feet tall and twenty feet wide. At this time, that was the largest wall I have had the opportunity to paint. I decided to create a vejigante rendition of iconic characters from the famous 1988 movie: Beetlejuice. (Figure 233) I chose to depict the characters Adam and Barbara from Beetlejuice because they have similar features that resemble the vejigante mask. Thus, I decided to use these characters and combine them with the easily identifiable Caraballo careta antigua. (Figure 234) Caraballo's vejigante masks are well-known for the horns 
that point straight up, and his yellow and black color motif. (Figures 235-237) The feedback from the community was positive. One of the factors that enabled such a positive response from the mural was due to the relatability of the cultural icon. Moreover, because of the addition of the contemporary concept of Beetlejuice, various generations were able to identify with the mural. I was honored to present a modern rendition of vejigantes in Arecibo, and, furthermore, to know it was positively received within the community.

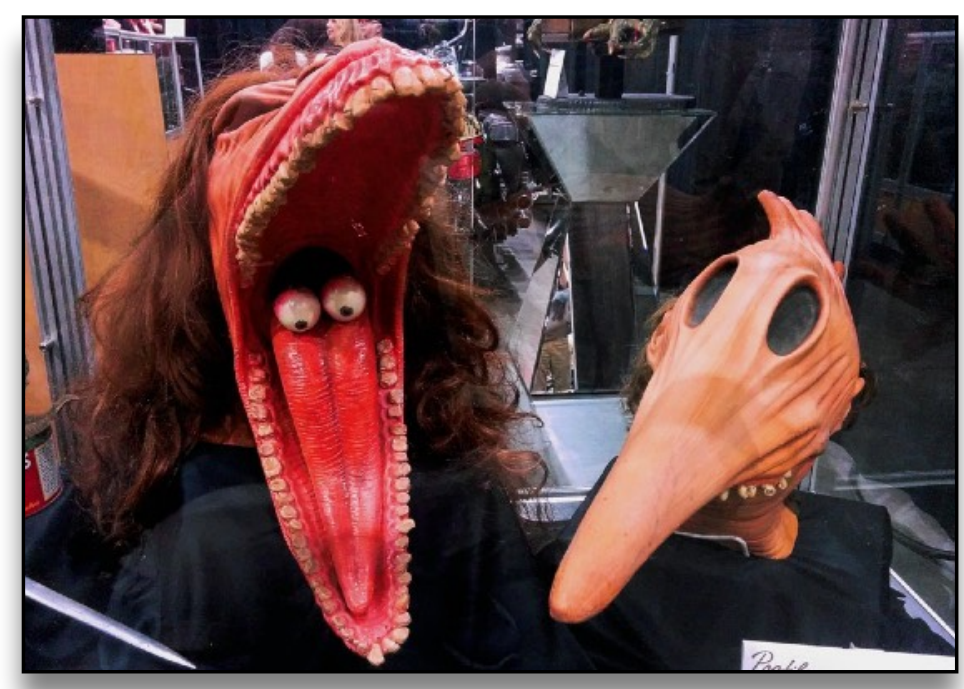

Figure 233 Barbara \& Adam Maitland - Beetlejuice (1988) / (C) All rights reserved by tonurics [digital image]. Retrieved June 20, 2020 from https://flic.kr/p/2756TtY

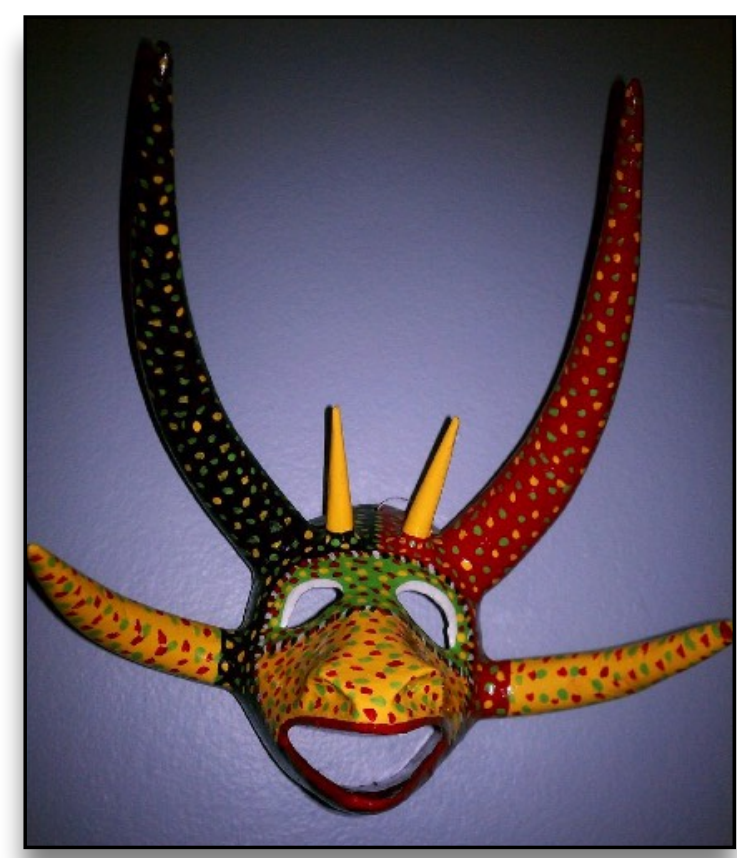

Figure 234 Vejigante de Ponce by Miguel Caraballo, hijo / C All rights reserved by ofglass [digital image]. Retrieved June 20, 2020 fromhttps://flic.kr/p/bBoEuq 


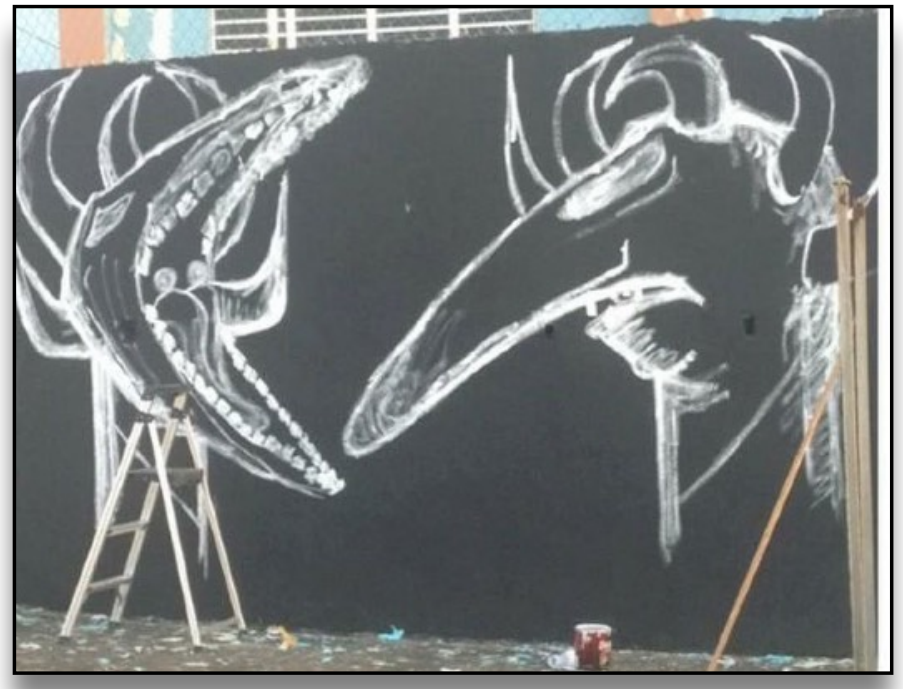

Figure 235 Process of Los Vejigantes de Beetlejuice by Chelsea Glidden Bosch, Arecibo Mural [digital image]. By Author. August 10, 2018

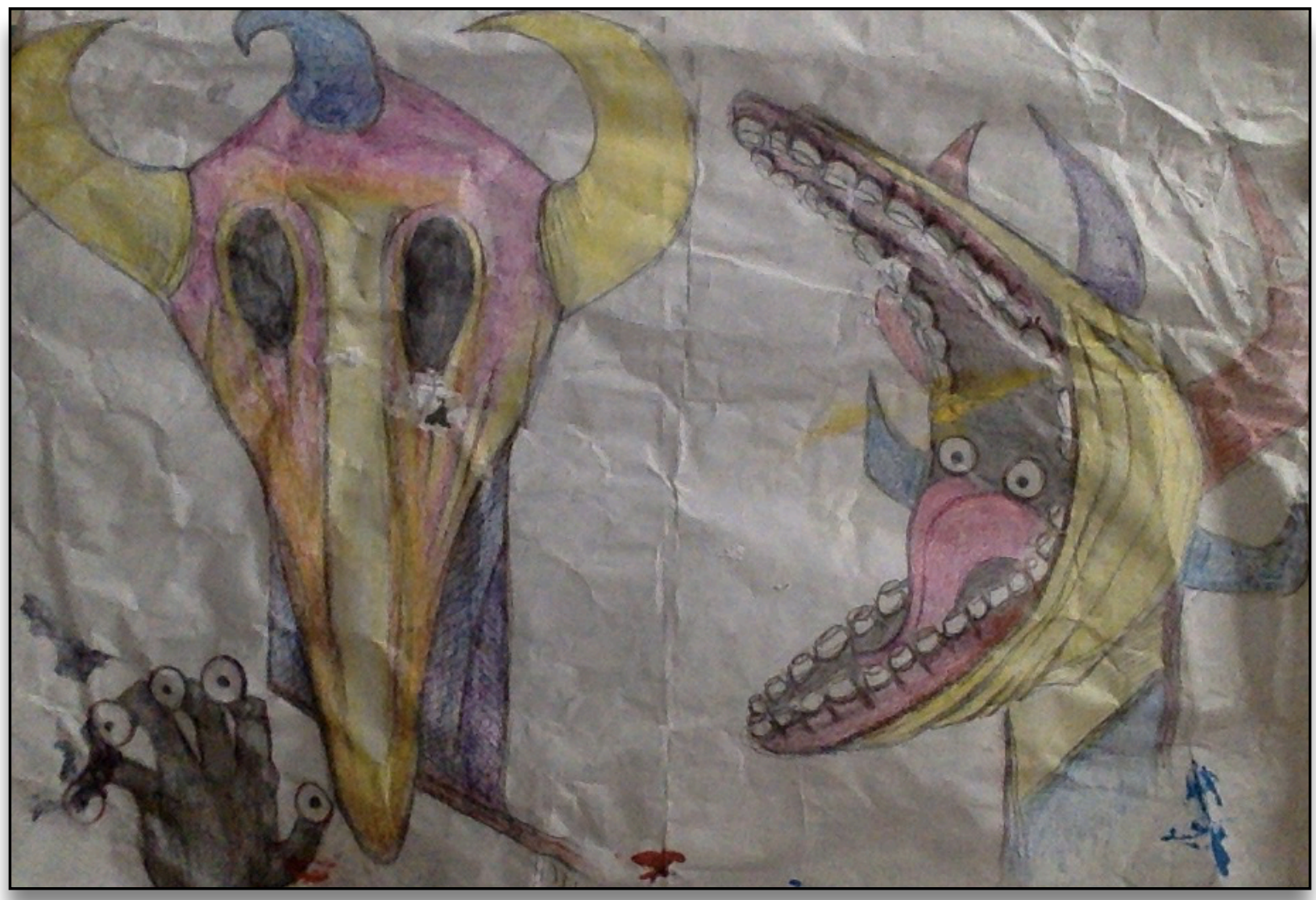

Figure 236 Sketch of Los Vejigantes de Beetlejuice by Chelsea Glidden Bosch, Arecibo Mural [digital image]. By Author. August 10, 2018 


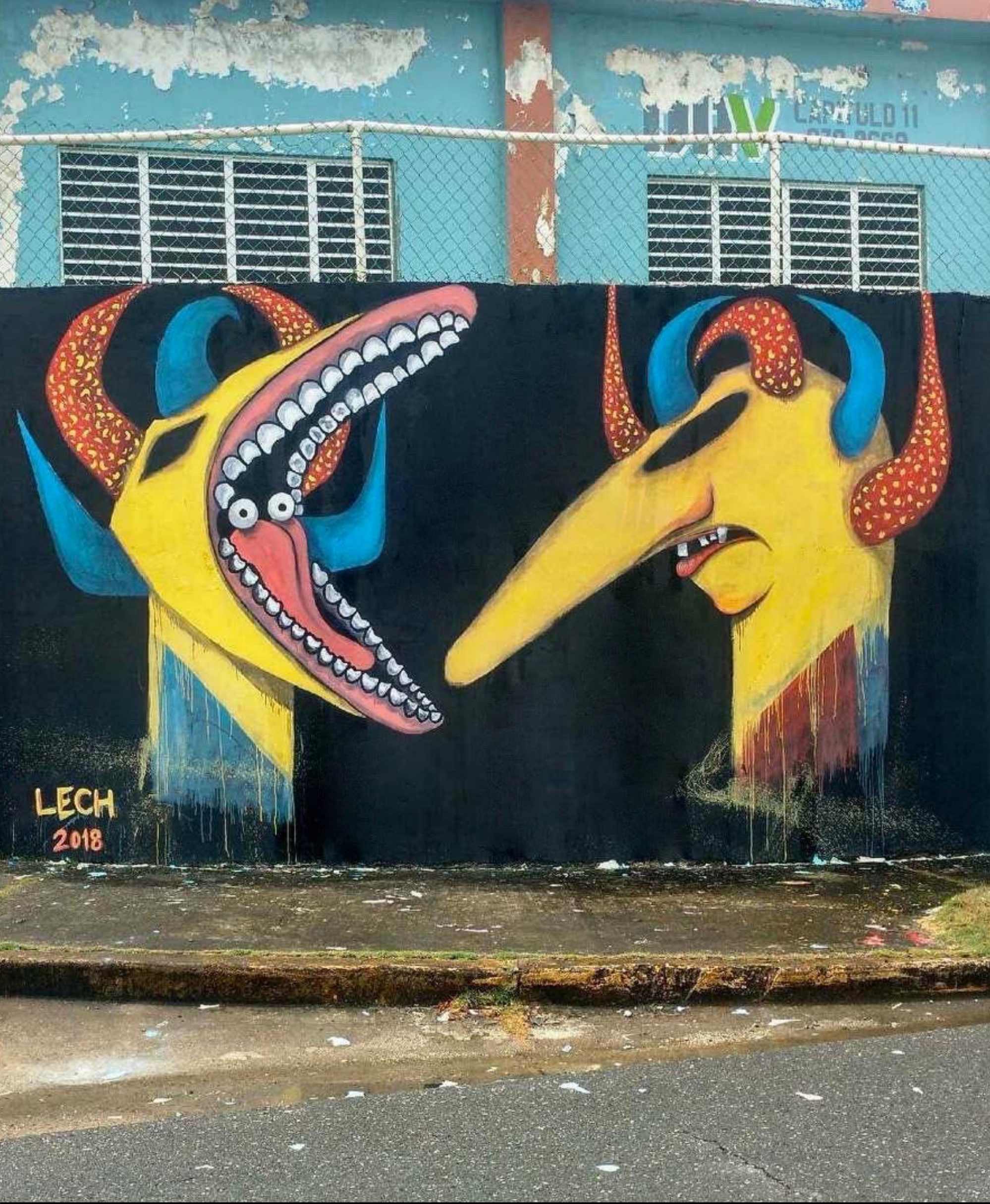

Figure 237 Los Vejigantes de Beetlejuice by Chelsea Glidden Bosch, Arecibo Mural [digital image]. By Author. August 10, 2018 


\subsubsection{Los Vejigantes del Huracán María}

After my exploration into muralism, I was invited to participate in an event hosted by the Escuela de Arquitectura, Pontificia Universidad Católica de Puerto Rico. The project focused on rejuvenation of a park in La Playa de Ponce which was heavily damaged after Hurricane María. I was honored to contribute in an event to uplift the community. I was offered a wall, but instead of accepting one the designated spaces, there were two areas which were not originally to be painted due to their strange shape. The spaces were short in width and long in stature, and in addition, one of these spaces had a door in the center. I thought these two walls would be a great activity to experiment with, as well as, to challenge myself to incorporate existing architecture into the public art.

The process I followed was to first take a picture of the walls and digitally create a composition. It must be noted that this area did not have access to electricity, and the murals had to be drawn onto the wall without the aid of a projector. (Figures 238-239) Therefore, the shapes and forms had to be easily drawn by hand. I continued with my constant theme of vejigantes within contemporary contexts. And, because this area was impacted by Hurricane María, the theme had to contain some aspect that can be related back to this event. These vejigantes would have objects that would remind of us of the natural disaster and what was endured during that time. 
These two murals were painted using a limited palette of colors provided by the Escuela de Arquitectura, Pontificia Universidad Católica de Puerto Rico. With the colors provided, I deliberately attempted to use contrasting combinations that would enable a vibrant character that complimented each other. And by keeping the shapes simple and clean, the final outcome was eye catching.

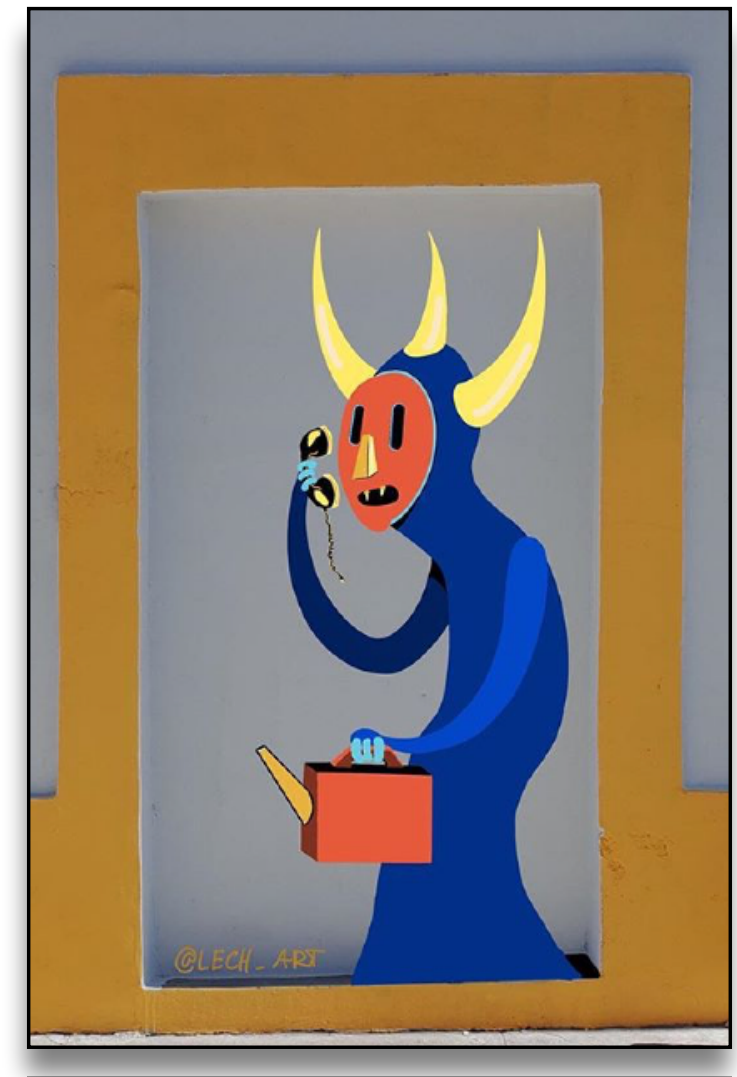

Figure 238 Digital Sketch of Los Vejigantes de Hurricane María by Chelsea Glidden Bosch, Playa de Ponce Mural [digital image]. By Author. September 20, 2018

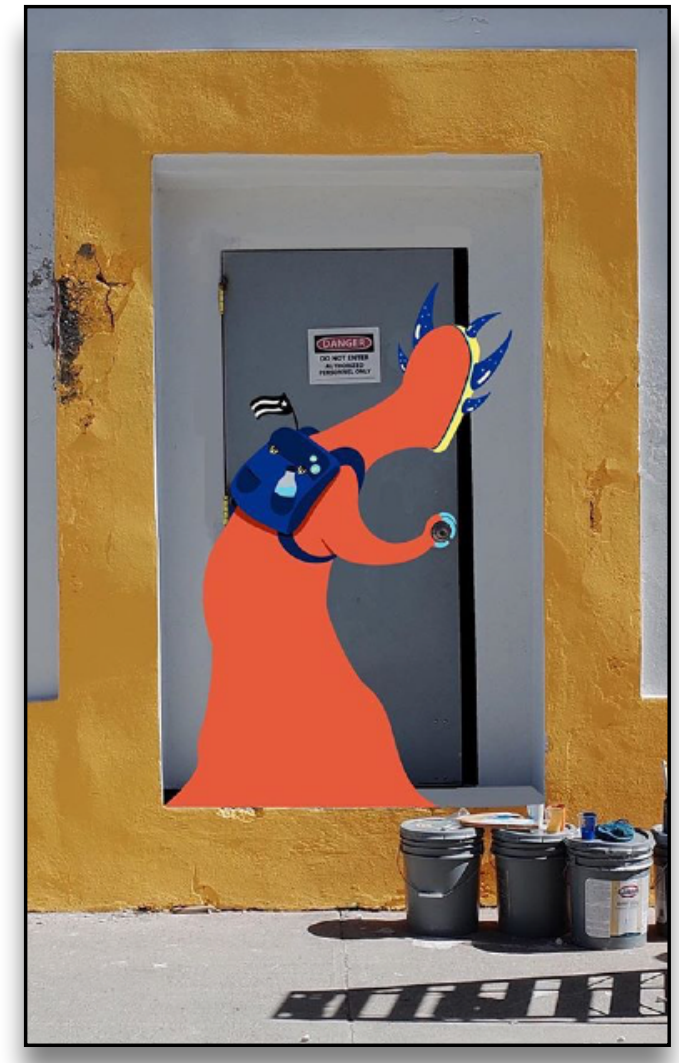

Figure 239 Digital Sketch of Los Vejigantes de Hurricane María by Chelsea Glidden Bosch, Playa de Ponce Mural [digital image]. By Author. September 20, 2018 
The first mural had a backdrop of a door and a sign that said: "Danger. Do not enter. Authorized personnel only." While the sign was originally placed with tape, I experimented with a sign that was more permanent. I decided to print a paper sign in color, identical to the original, and paste it up with glue. The paper was glued to the wall with Elmer's Glue. This technique is used with paste ups. Moreover, I decided to create a vejigante full of curiosity, trying to enter this building. (Figure 240) The figure has his hand already on the handle and the door looks as if it is slightly open already. This is an optical illusion of a shadow created with black paint around the right edge of the door. His essence exudes mystery because his face is not shown. In addition, the vejigante has backpack with a bottle of water, half empty/half full, and a black Puerto Rican flag, known as the resistance flag. The figure was painted with this amount water because, during this time, water was limited. The Puerto Rican resistance flag was painted as protest against the government officials who moderated the resources from the community for political advancements. (i.e. water, food, blue tarps, tools for roof repair, etc.) 


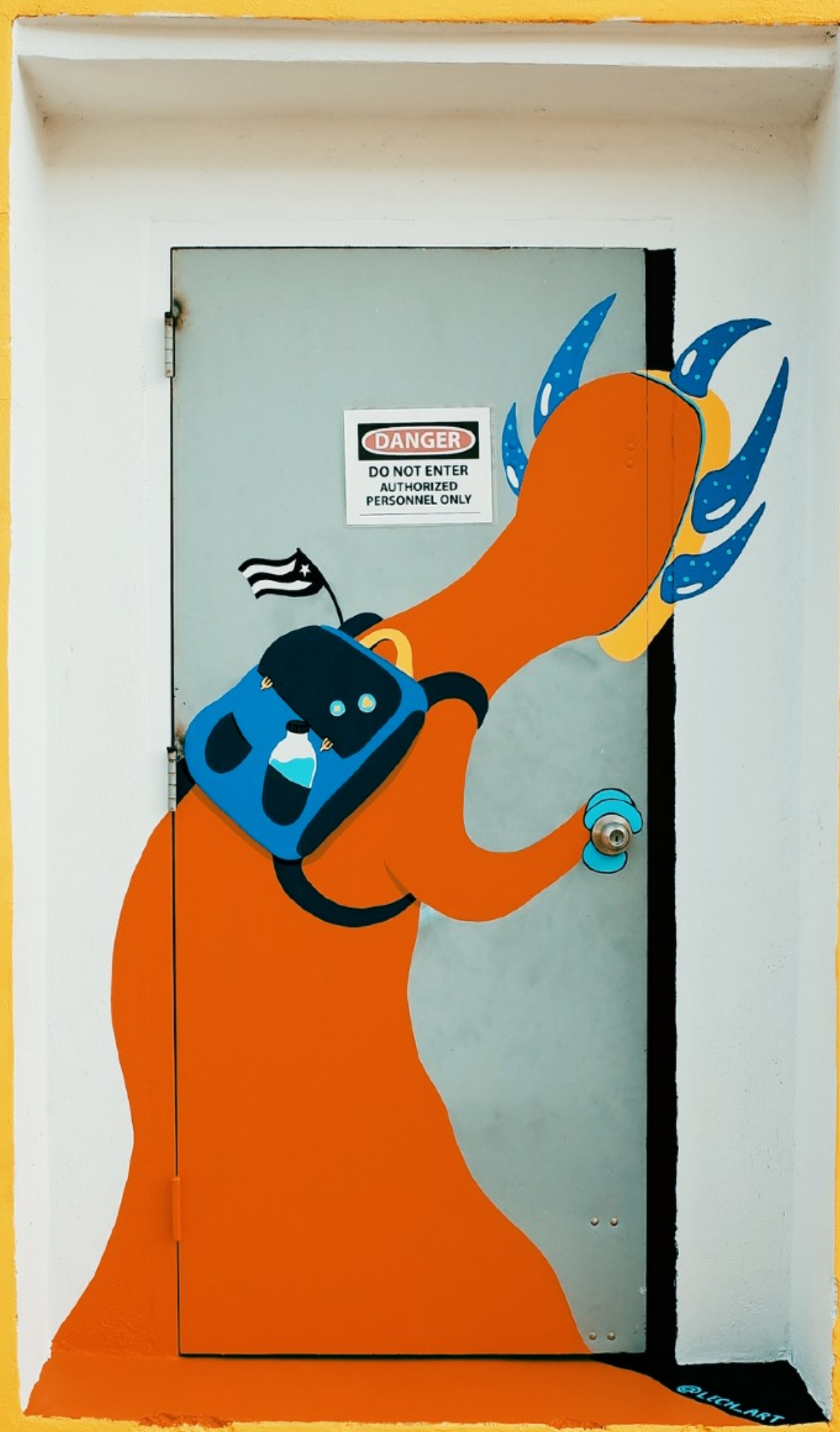

Figure 240 Los Vejigantes de Hurricane Maria by Chelsea Glidden Bosch, Playa de Ponce Mural [digital image]. By Author. September 20, 2018 
The second vejigante has a clear expression of desperation. (Figure 241) This character conveys the anxiety felt by the community during Hurricane María. The figure holds in one hand a landline phone, which is cut at the wire, and in the other hand he holds a gasoline tank lightly, signifying that it is empty. This depiction was composed as a reaction to the experiences during the natural disaster. The majority of Puerto Rico experienced electrical and communications blackouts due to the destruction of power grids and the cellular towers by Hurricane María. In addition, because there was no electricity, the use of generators created a shortage of gasoline island wide. 


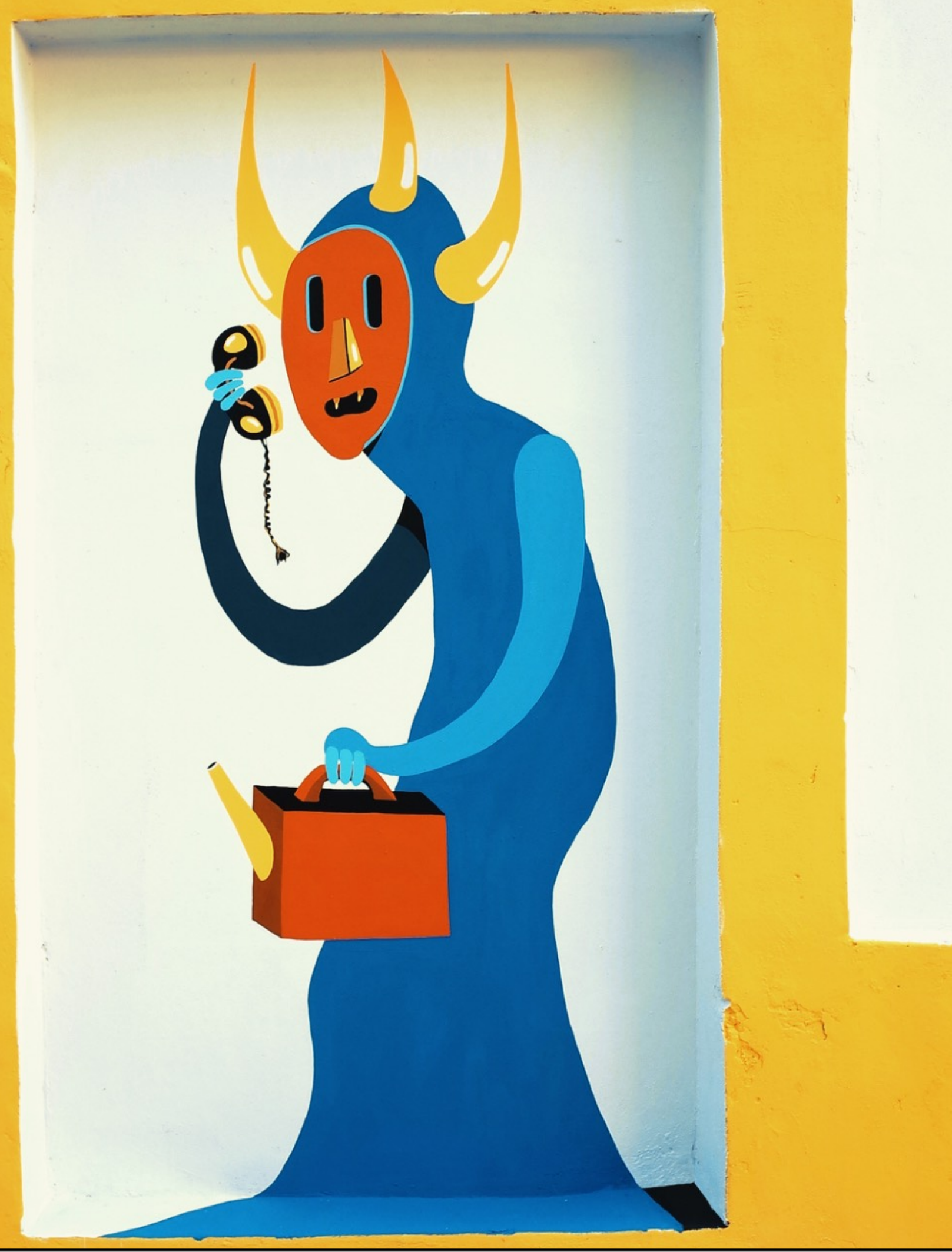

Figure 241 Los Vejigantes de Hurricane Maria by Chelsea Glidden Bosch, Playa de Ponce Mural [digital image]. By Author. September 20, 2018 


\subsubsection{Los Vejigantes: Paste Ups}

After the previous murals in La Playa de Ponce, I was able to scratch the surface of the paste up method: I wanted to experiment further with this method. My first experimentation into this method was the use of a thick styled paper. This was an attempt to eliminate the problem of wrinkles that often develop in the paper when it is applied to a wall. I obtained thick paper for my first official experimentation into paste ups. I painted the paper with acrylic paint and used a POSCA water-based, paint marker to draw the outline. Due to thickness of paper I used, the paint did not absorb properly to the paper and created a rubbery surface. This texture made it difficult to adhere the paste up to the wall. While there are many adhesives suitable for paste ups, I followed a simplified version, which would be more efficient for small scale artwork. This paste up glue was created out of Elmer's Glue and water. The water is mixed into to the glue to create a thin, liquid texture, enabling a smooth application of the paste up to the wall. The glue needed the correct consistency to adhere to the surface. The paste up needs to be slightly damp with the glue mixture, and then the paper is placed on the wall, and finally, the flue is brushed over the artwork completely. In the end, the thick paper could not absorb the glue and did not adhere to the wall correctly. I failed at my first attempt of creating a 
long-lasting paste up. But, nonetheless, I continued to experiment to find the best materials and methods to create a well-made paste up. (Figure 242)

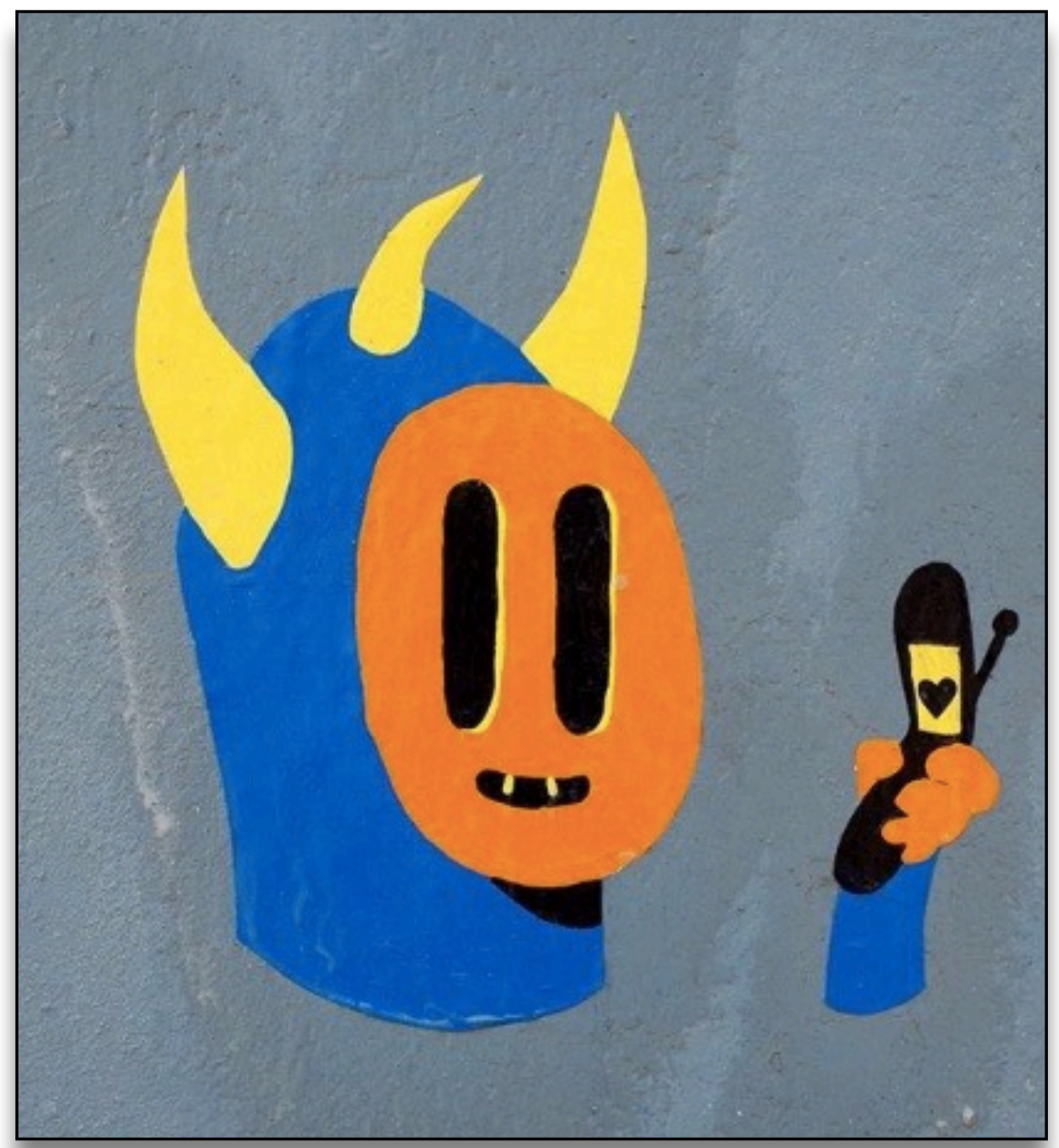

Figure 242 New Message Vejigante by Chelsea Glidden Bosch, Paste Up [digital image]. By Author. December 20, 2018 
Due to the failed first attempt, it was clear thin paper that had to be used in creating a successful paste up. I went to the local art shop to inspect the available paper sold and discovered blank newspaper. This paper was often used for printmaking. This paper was thin, but not translucent. This was the ideal paper for creating paste ups, because of its texture it would absorb the paint extremely well and still have a malleable surface. (Figures 243-244)
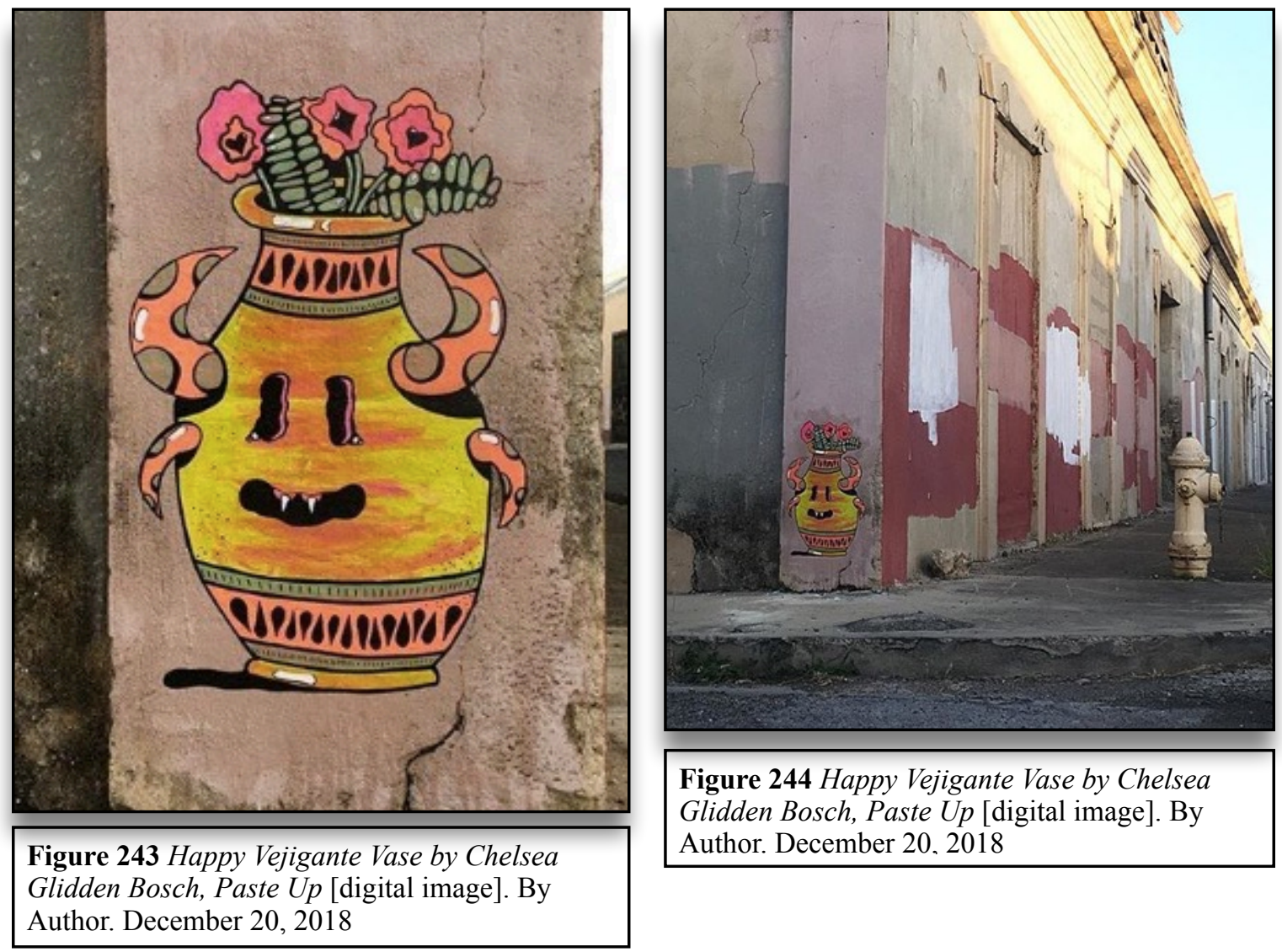

Figure 244 Happy Vejigante Vase by Chelsea Glidden Bosch, Paste Up [digital image]. By Author. December 20, 2018 
The style of brush used to apply the paste up to the wall is immensely important. I first began with inexpensive one inch thick paintbrushes with horse hair bristles. Although a paintbrush was sufficient, I researched other methods and tools to adhere the paste ups. I came across a miniature paint roller, this paint roller was made of foam and had a tube as its handle. This paint roller was ideal for eliminating the need for multiple tools. It had the combination of a refillable tube, for glue, and a roller paintbrush as the applicator. This created a speedy application time and ensured even coverage of the artwork. With the corrections from the first attempt, and the improved materials, my paste up technique matured. (Figures 245-249)

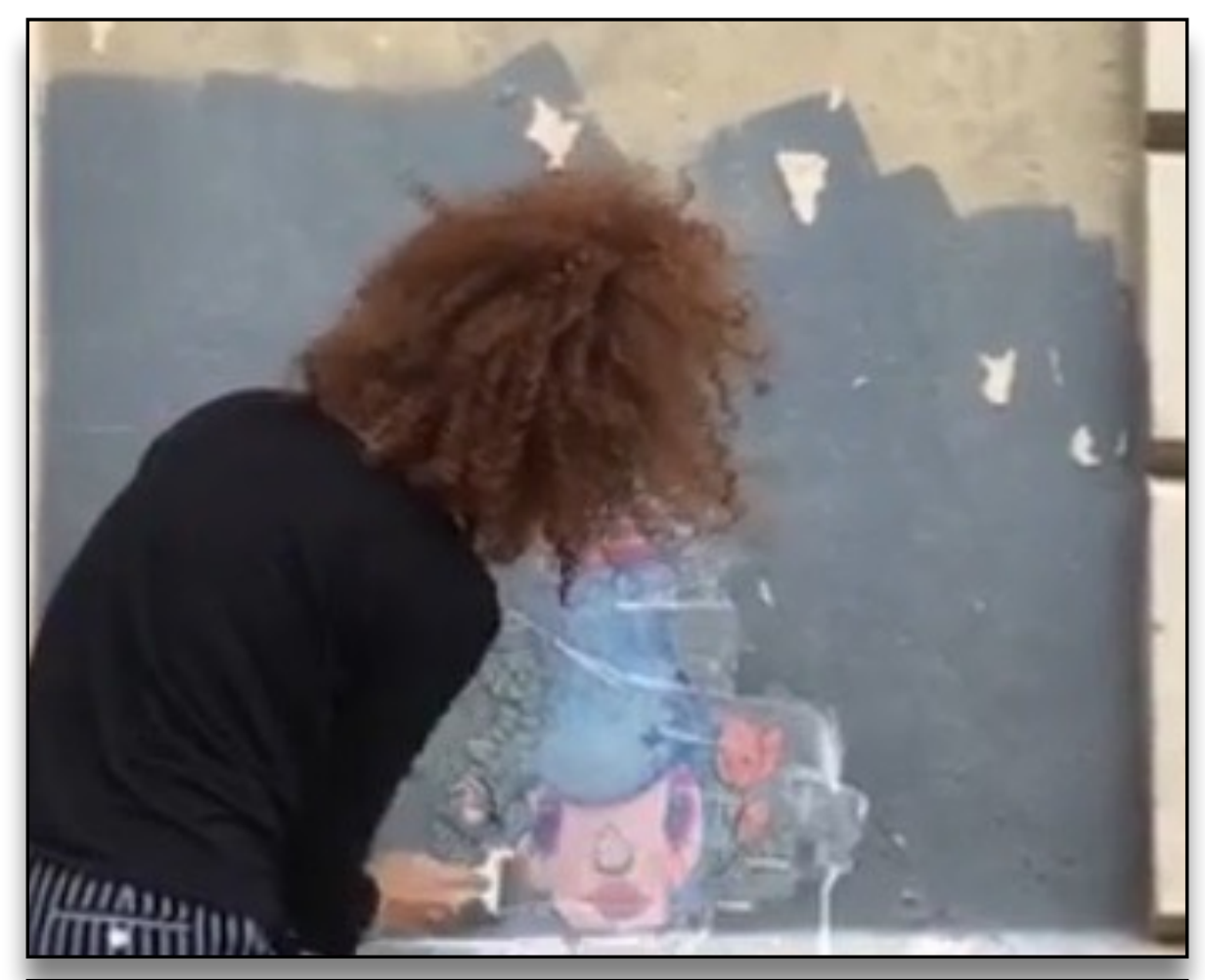

Figure 245 Chelsea Glidden Bosch Using New Tool, Paste Up [digital image]. By Author. December 20, 2018 


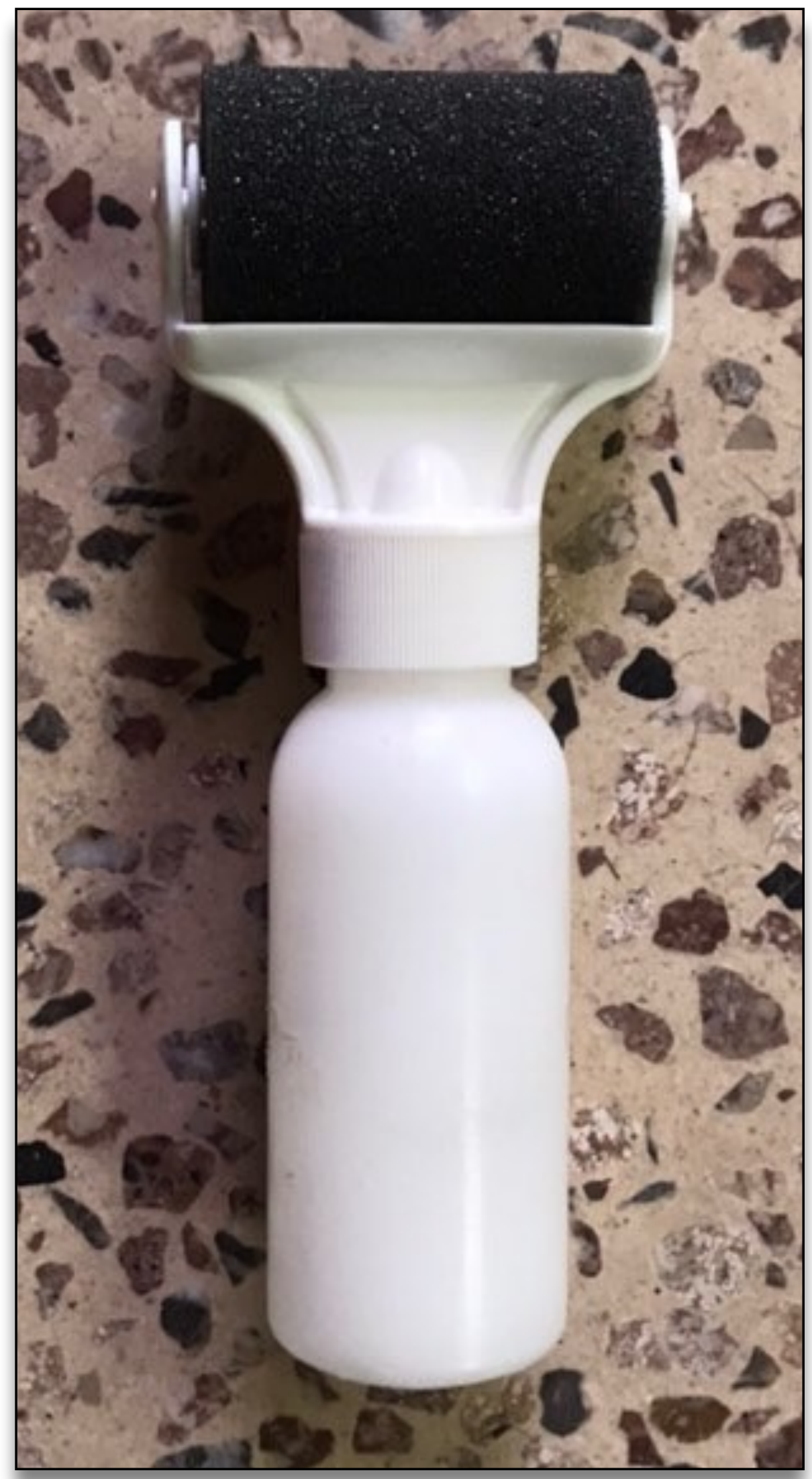




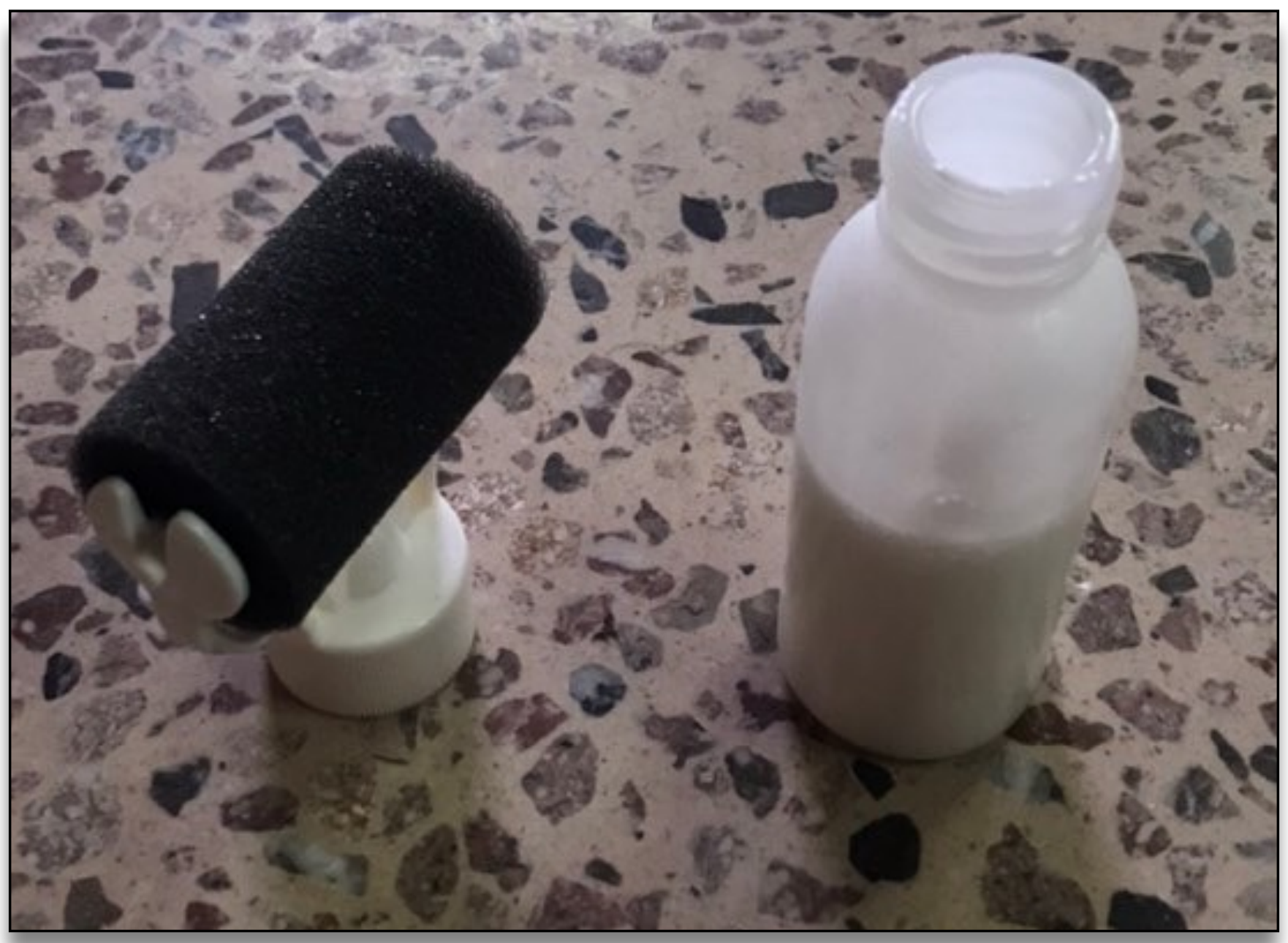

Figure 247 New Tool for Paste Ups [digital image]. By Author. December 20, 2018 


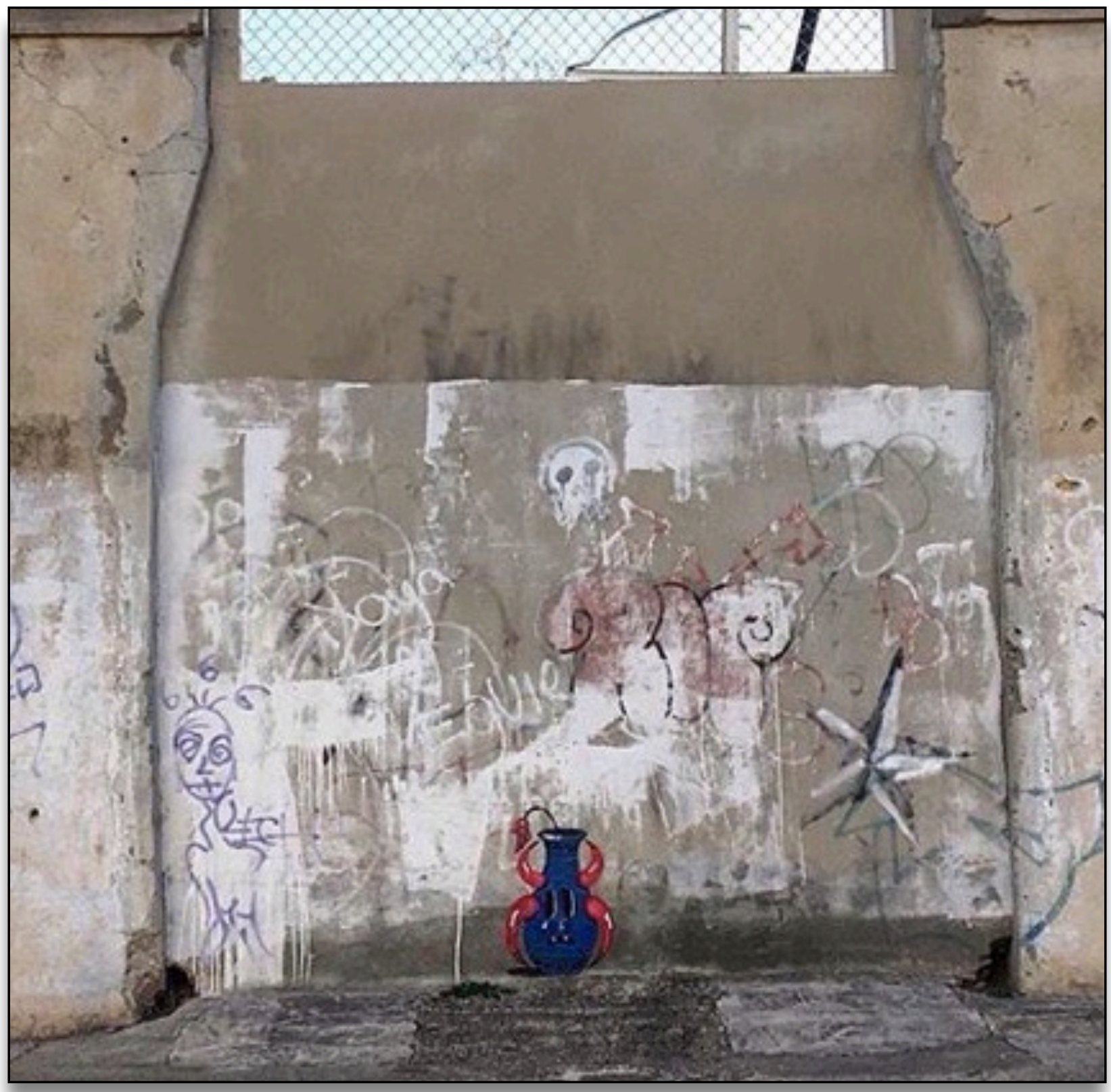

Figure 248 Sad Vejigante Vase by Chelsea Glidden Bosch, Paste Up [digital image]. By Author. December 20, 2018 
Figure 249 Sad Vejigante Vase by Chelsea Glidden Bosch, Paste Up [digital image]. By Author. December 20, 2018

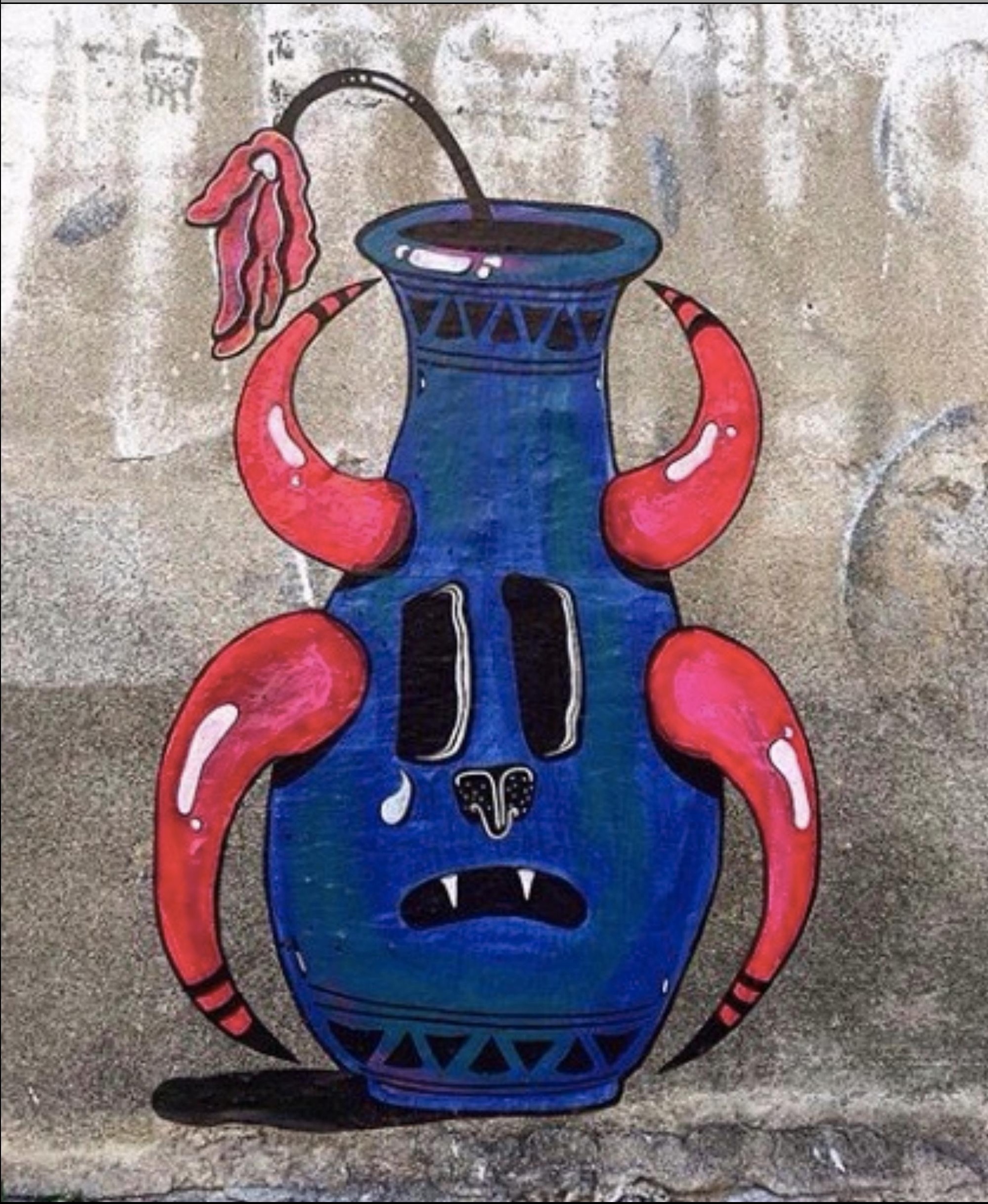




\subsection{Publication of Children's Book: “Carnavalera”}

During my investigation within Puerto Rico, I discovered that the information available on the subject of vejigantes limited. Because of this, I wanted to provide a resource for the younger generations on the subject. I began to create a manuscript for a children's book about vejigantes. The title of the book is Carnavalera, (see Appendix for complete book) meaning Carnival goer. (Figure 250) It provides general knowledge about the Carnival and the vejigante's purpose within the festival. The subject matter encourages artisanal craft of the atuendo and careta antigua. I published this children's book in hope to ignite a cultural interest within the youth in Puerto Rico.

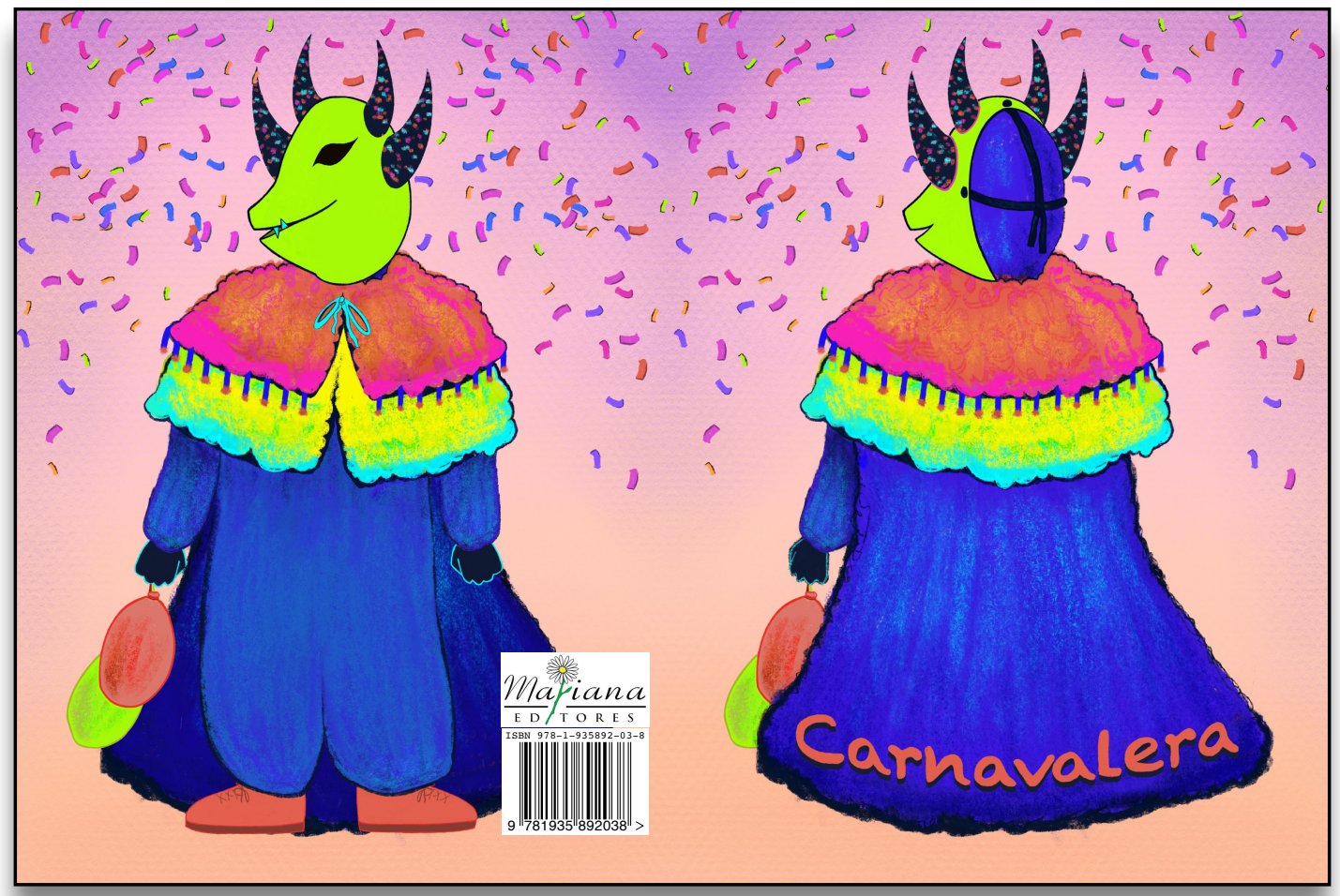

Figure 250 Front and Back Cover of Carnavalera by Chelsea Glidden Bosch [digital image]. By Author. February 25, 2020 
The book begins with the protagonist, Nicolasa, believing she is finally old enough to participate in the upcoming Carnival in La Playa de Ponce. (Figure 251) While her mother, Carmela, suggests she could be a princess, Nicolasa has a different idea. (Figure 252) This conversation is based on my first Carnival, which I was invited to participate in Carnival in La Playa de Ponce. I was invited to be part of the Carnival in La Playa de Ponce. The director recommended I could be a princess, but I was only interested in portraying a vejigante. This experience is the inspiration for the book.

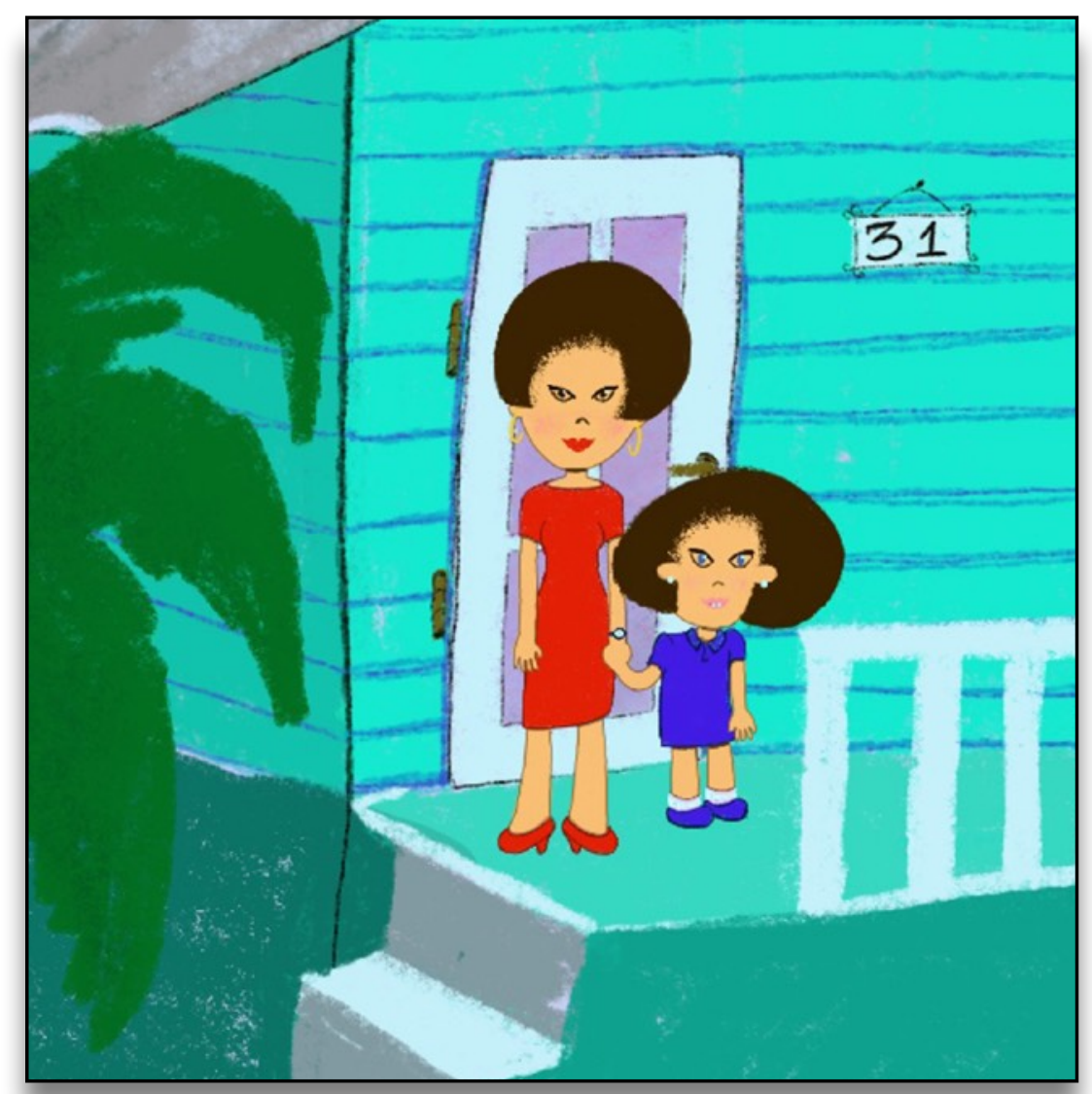

Figure 251 Page 2 from Carnavalera by Chelsea Glidden Bosch [digital image]. By Author. February 25, 2020 


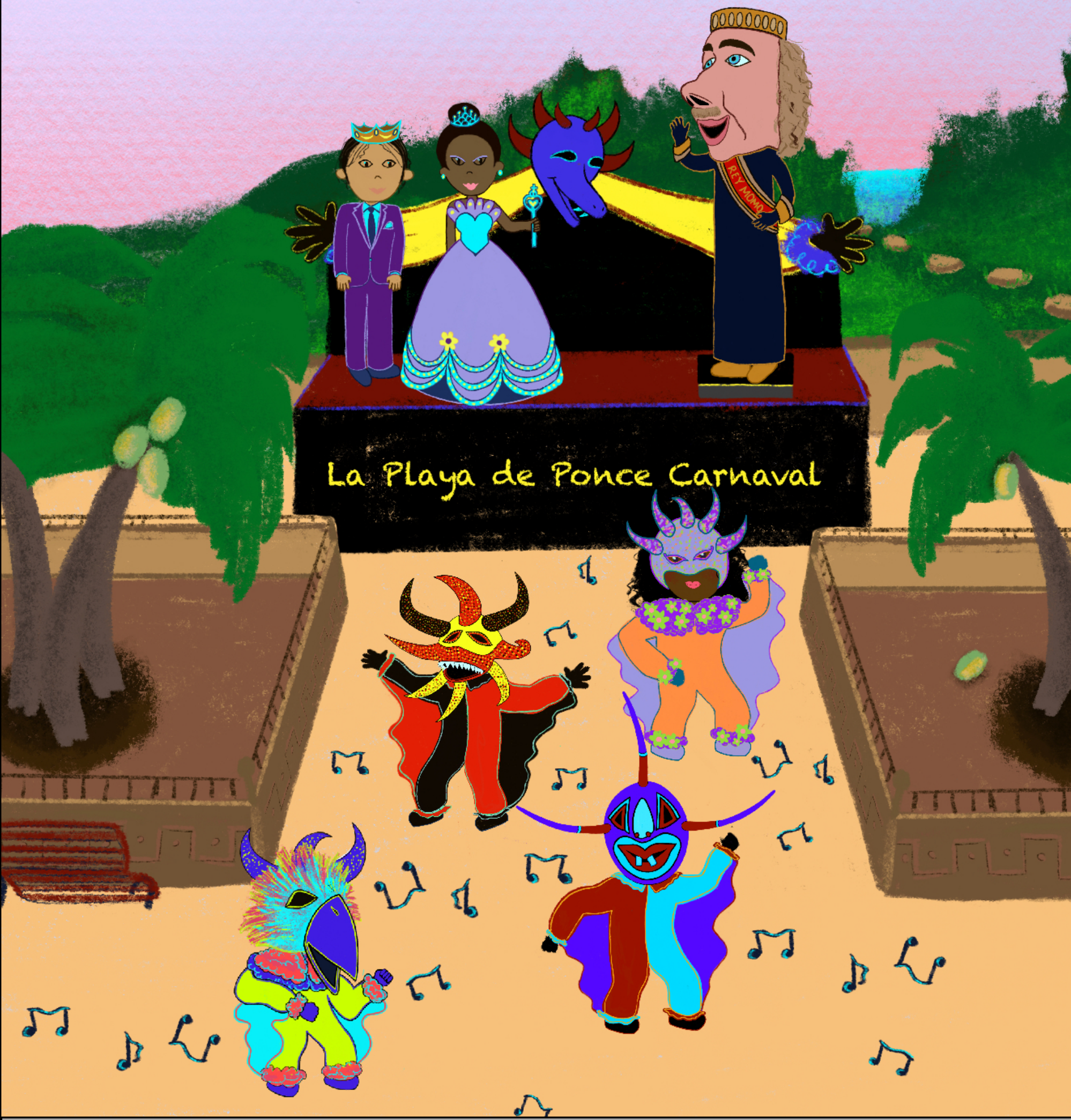

Figure 252 Page 17 from Carnavalera by Chelsea Glidden Bosch [digital image]. By Author. February 25, 2020 
Nicolasa finds her mother's old costume in the closet, and finds out later that her mom made it herself. Discovering her mother's handmade costume ignites the inner artisan within Nicolasa. (Figure 253) She begins to create her own vejigante costume. Although, Nicolasa does not create a traditional atuendo and careta antigua like her mother's, but a modern version. Nicolasa's mask is a contemporary interpretation of the folkloric vejigante. Present-day, while many still continue to use a traditional dress and mask, there are a number of people who create their own modern vejigante. After Nicolasa finished her costume, she dances in the Carnival. While participating in the Carnival, Nicolasa meets various other vejigantes, this part of the narrative is to show that Nicolasa does not know the identities of her comparsa, but enjoys their company. In the final part of the book, Nicolasa tells her mother about the various people she had acquainted within the Carnival. (Figures 254-255) The book illustrates three different vejigante masks and costumes with the faces of her peers revealed. The children are from different parts of Puerto Rico and with different genders and skin colors. This illustrates that the vejigante costume disguised the user. Furthermore, this supports the concept of unity under the celebration of cultural heritage. 


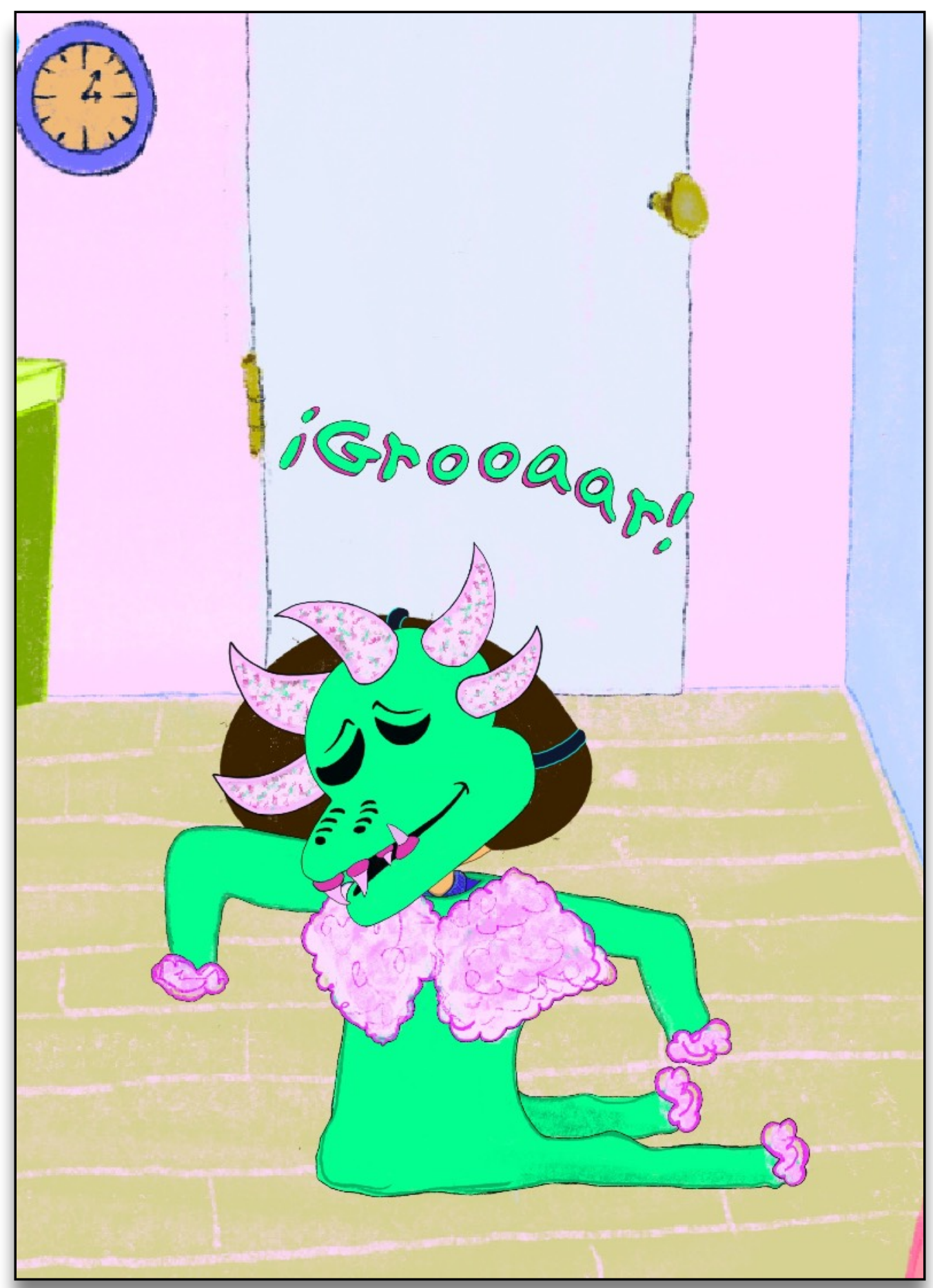

Figure 253 Page 9 from Carnavalera by Chelsea Glidden Bosch [digital image]. By Author. February 25, 2020 
Marisol vive en el campo con su padre y su madre. Su padre es un artesano. isu máscara fue creada por su artesano de máscaras favorito, Caraballo! Cada año baila con su padre en el Carnaval, iEs tradición! Ella espera que algún día pueda ser artesana como Caraballo y su padre.

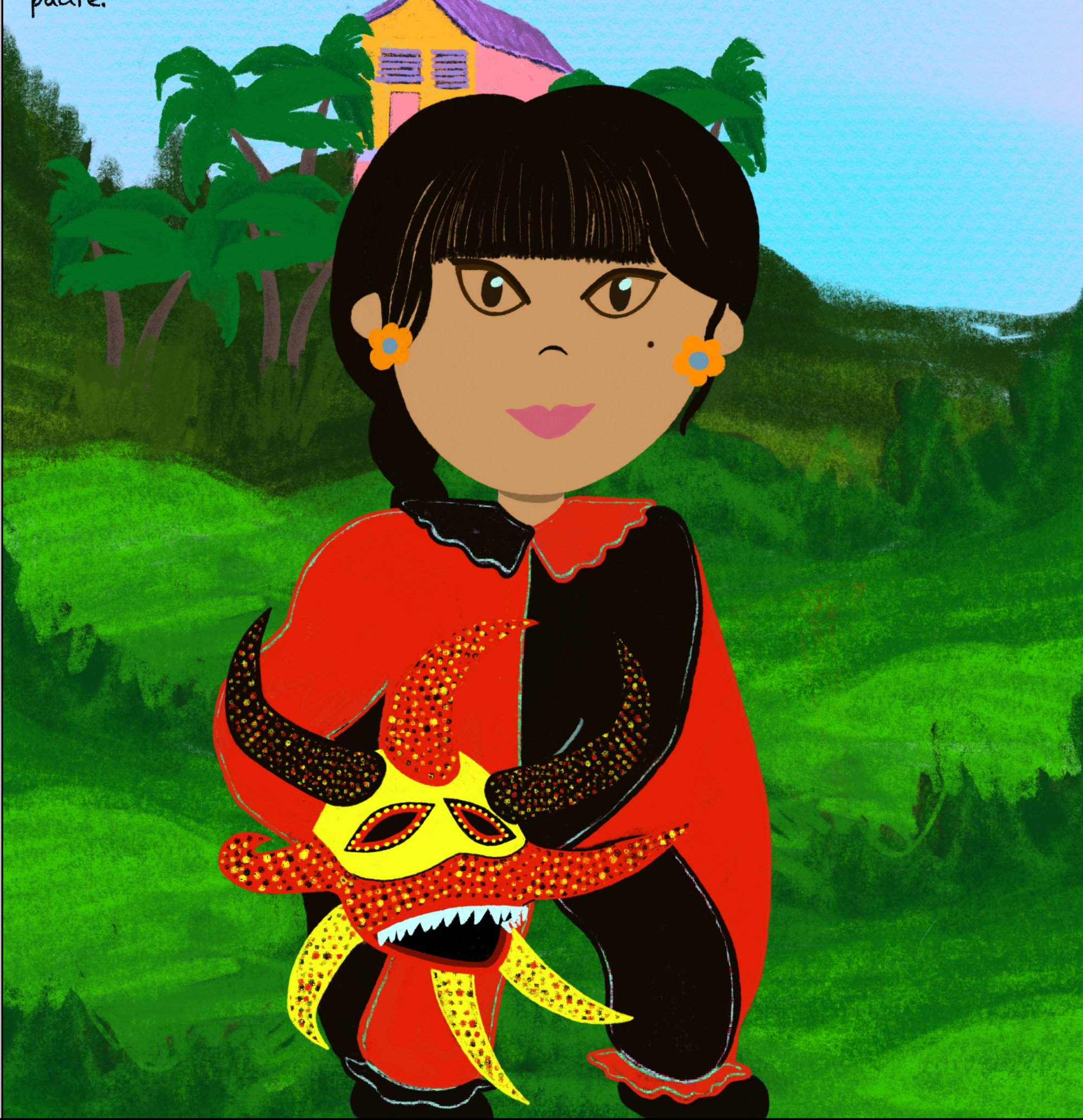


¡Era la primera vez que Juan Antonio bailaba en el Carnaval! El es de 24 Loíza Aldea. El vive en una parcela con su mamá y sus dos gatos. El hizo su máscara y su abuela le hizo el disfraz. Su máscara y disfraz son diferentes a los de Ponce. La máscara está hecha del casco del coco, como es tradicional en Loíza Aldea.

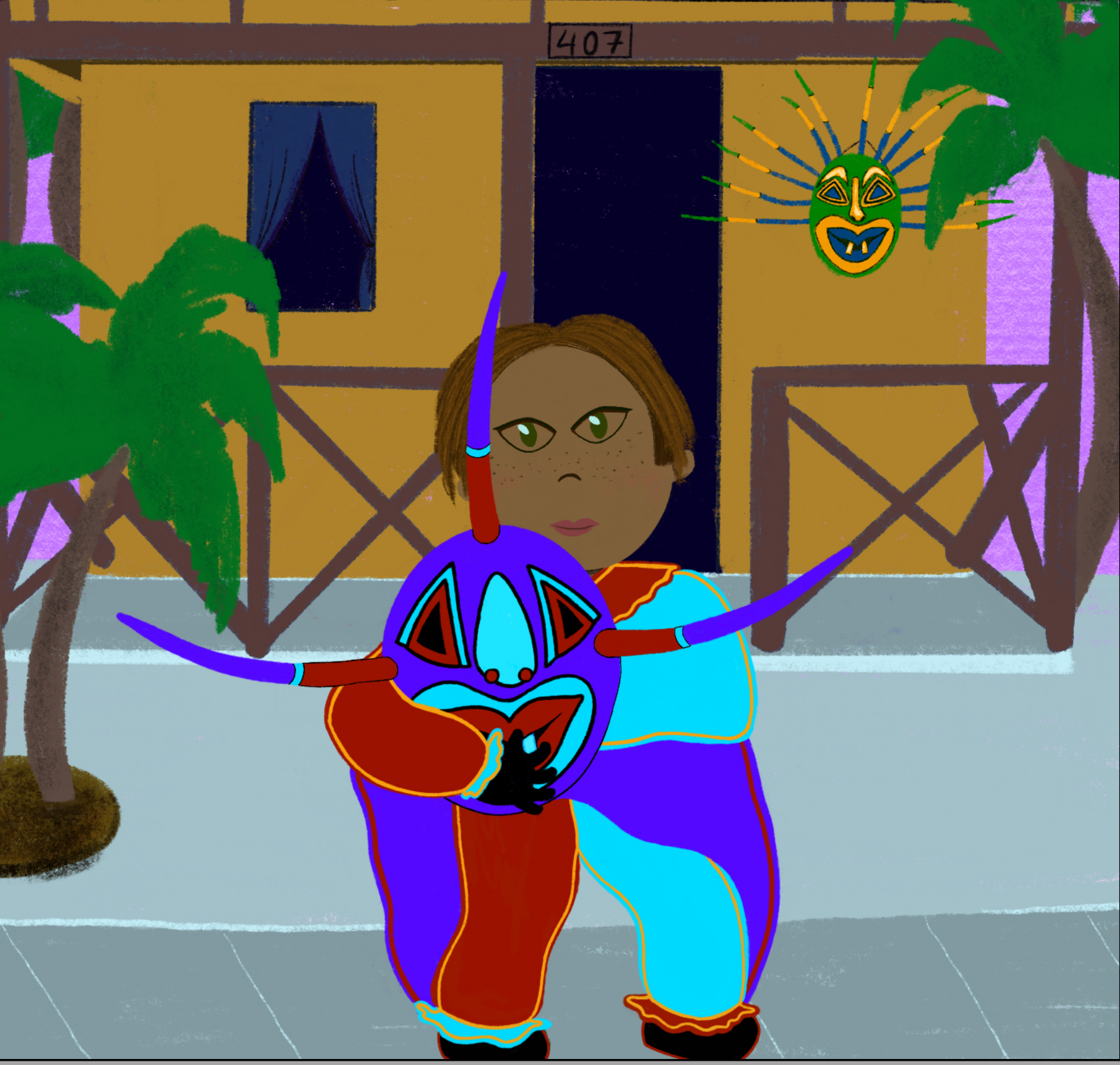

Figure 255 Page 24 from Carnavalera by Chelsea Glidden Bosch [digital image]. By Author. February 25, 2020 


\section{Chapter Seven: Conclusion}




\subsection{Overview}

This chapter presents a summary of the findings. It acknowledges the connections that have inevitably impacted the vejigante masks to the ceremonies due to the exposure to USA American culture, such as: TV, media, Hollywood films, American Chain Stores, tourism and globalization. The experiences of conducting and participating in the investigation provided indisputable evidence of the evolution and juxtaposition of the careta antigua. The hands on experience gave me a deeper understanding of the subject and contexts within it. It is clear that further transformation still continues to take place within the constant progression of the Puerto Rican culture.

A summary will showcase the relevant information which was only attainable by conducting interviews with the art historians, artisans, and artists. There is still an extensive amount of information on the subject that has yet to be documented officially. Through the interviews, a form of word-of-mouth, rare information was discovered on the subject of vejigantes. In final, the research collected supports the conclusion and the future implications. 


\subsection{Findings, Implications, and Future Outlooks}

The experiences of having an ethnographic, hands-on approach provided a personal perspective and developed a deeper understanding of the findings in the investigative research. The information was used to apply myself within activities within the context of the vejigante. The interaction within the research provided a profound comprehension of the Carnival culture and the artisan community. These experiences gave me an intimate appreciation for the vejigante. Furthermore, this perspective enabled me to understand the amount of dedication involved in the preservation of the folkloric traditions in order to honor the culture, and heritage of Puerto Rico. (Figures 256-257)

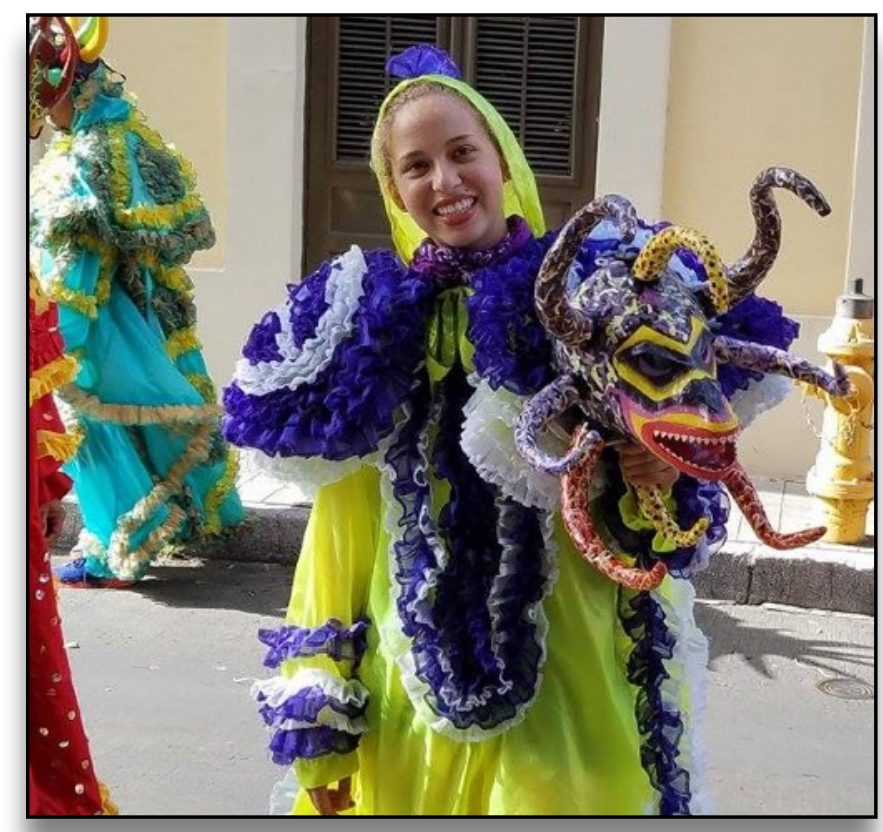

Figure 256 Chelsea Glidden Bosch as a Vejigante, Carnaval Ponceño 2018 [digital image]. By Author. February 24, 2018 


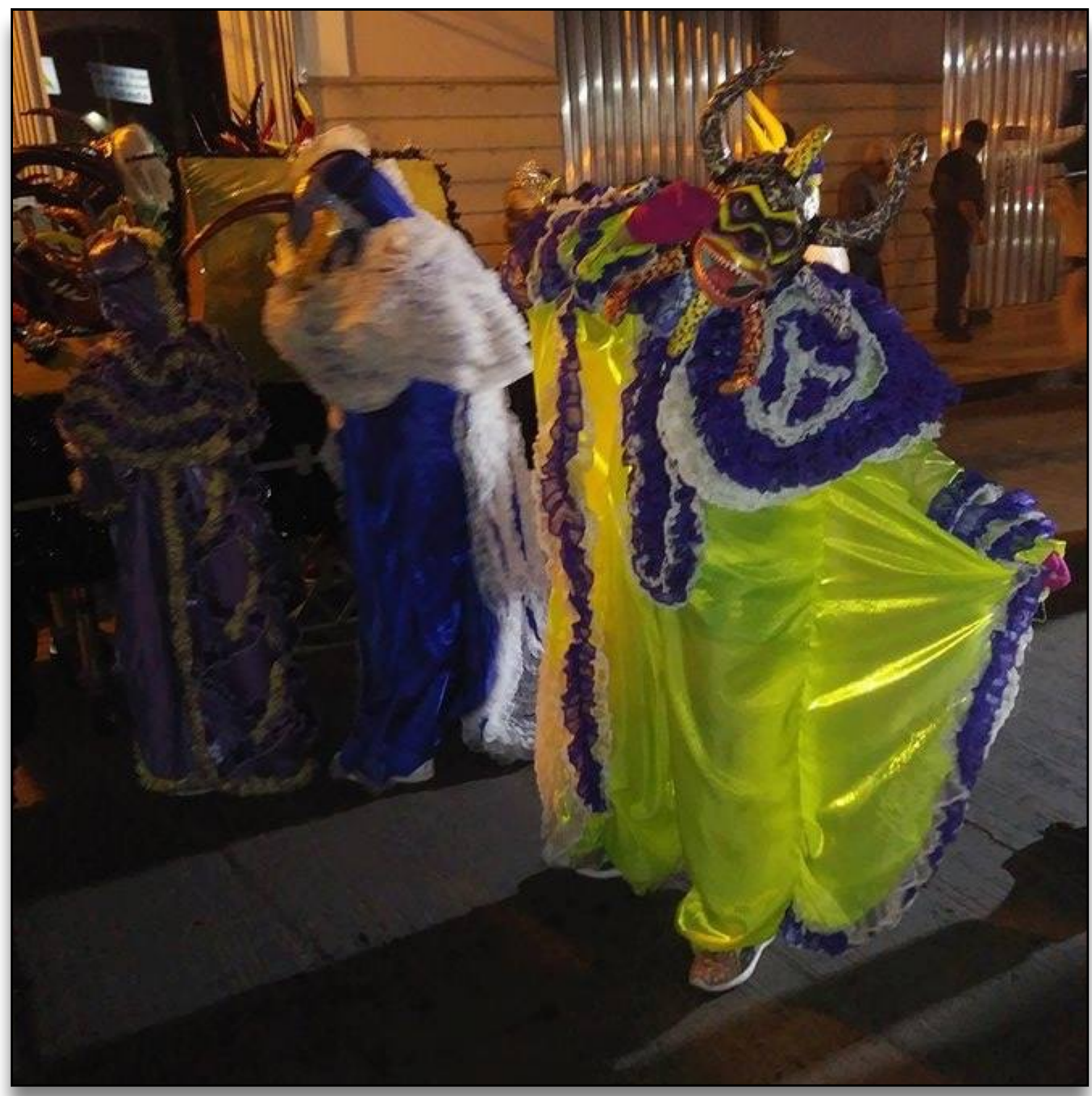

Figure 257 Chelsea Glidden Bosch as a Vejigante, Carnaval Ponceño 2018 [digital image]. By Author. February 24, 2018 
Through the conducted interviews, I was able to gather the information that was not available through documented sources. The investigation uncovered rare information that is not available in any published literature. This research cannot be corroborated any other way but through their personal recants via word-of-mouth. The history of folkloric artifacts and festivals in Puerto Rico is often misrepresented in documentation. While there are some sources available, the information presented is broad and leaves the reader with more questions than answers. Through the combination of investigative research and word-of-mouth, I was able to create a clear framework of the vejigante.

Raquel "Cucha" Rentas spoke about how her mother participated in Carnivals in the past with a mascarita, a small, wire mask. These smaller masks were specifically made for women. Mascaritas were made of wire, therefore they were light weight and easy to see through. But, nonetheless it still obscured the vision of on-looker to see the user of the mask. The only documentation published on the subject of mascaritas is in Las Caretas del Vejigante Ponceño, and moreover, is a brief acknowledgment and description. Cucha was able to provide a description and give a first-hand account of the mask from her family history. Word-of-mouth has enabled the confirmation and further understanding of this undocumented, historical mask. Cucha continues her recount, and states vejigante has depreciated within the Carnival context. (Figure 258) This gradual 
decline of the vejigante's presence in the festival illustrates the diminishment of the community involvement.

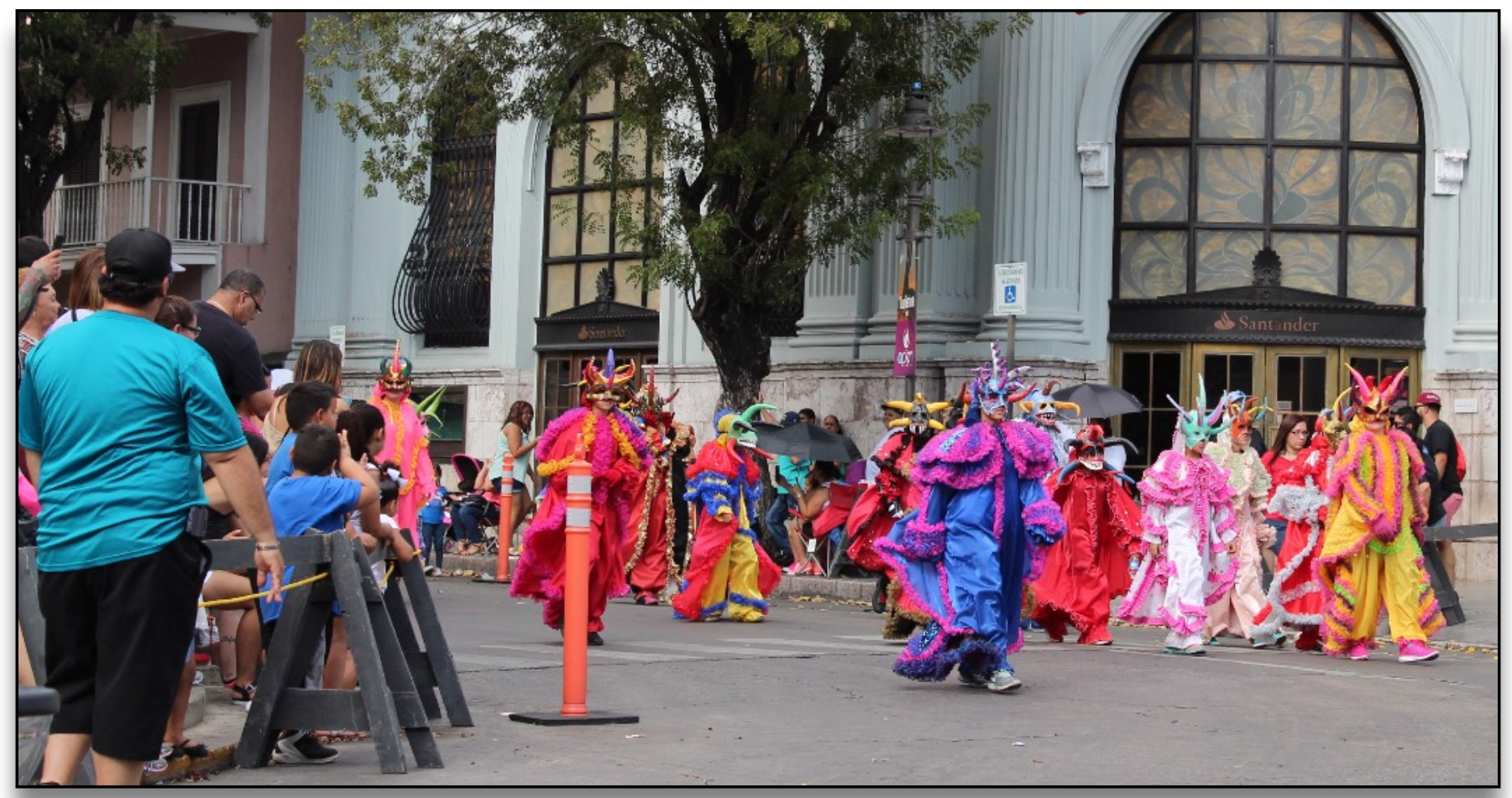

Figure 258 The Entrance of the Vejigantes, Carnaval Ponceño 2017 [digital image]. By Author. February 24, 2017 
Puerto Rico's complex, cultural background creates a fertile foundation for the transformation of masks within the festivities. It is clear the evolution of the vejigante mask and, more importantly, its use has drastically changed over the past fifty years. It was consistently stated by the interviewers that the number of vejigante participants has diminished drastically from hundreds to just a couple dozen per comparsa. Additionally, the availability of inexpensive, Halloween masks has depreciated the careta antigua. The lower consumption rate has pushed the artisan/artist to create larger, extravagant work to entice consumer. But, the more intricate the mask became, it also became less functional. The reduction of wearable masks enabled the vejigante to enter into a contemporary interpretation. (Figures 342-343) Unfortunately, without the accurate representation of this historical mask, the vejigante will become extinct and be reduce to nothing more than a folkloric tale. Furthermore, the oral history passed from generation to generation continues to fade, and if the trend continues, the undocumented knowledge of the vejigantes will continue to dissipate. 


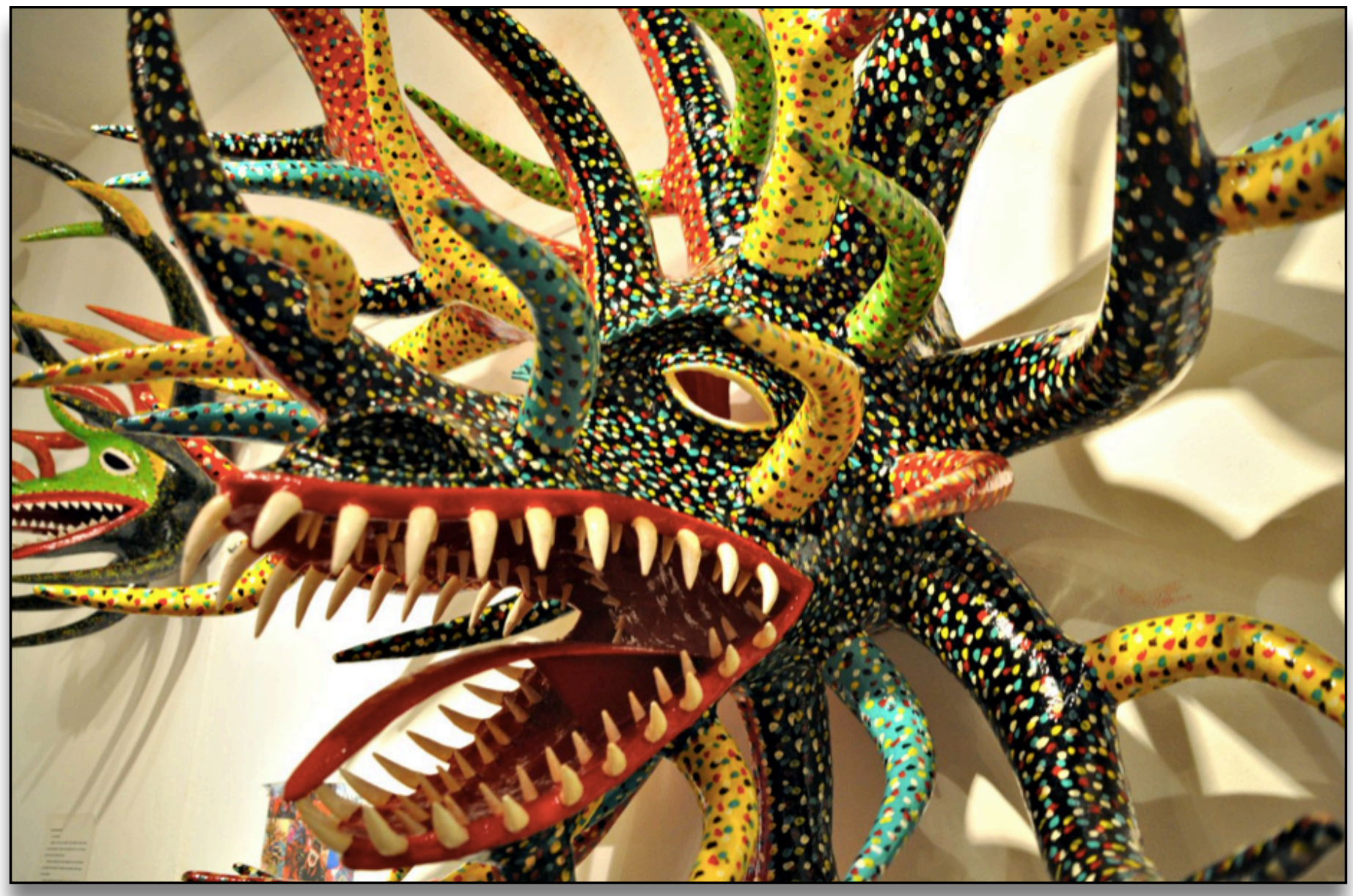

Figure 342 Vejigante [digital image]. Retrieved June 20, 2020 from https://yourblowinfo.blogspot.com/2018/01/vejigante.html 


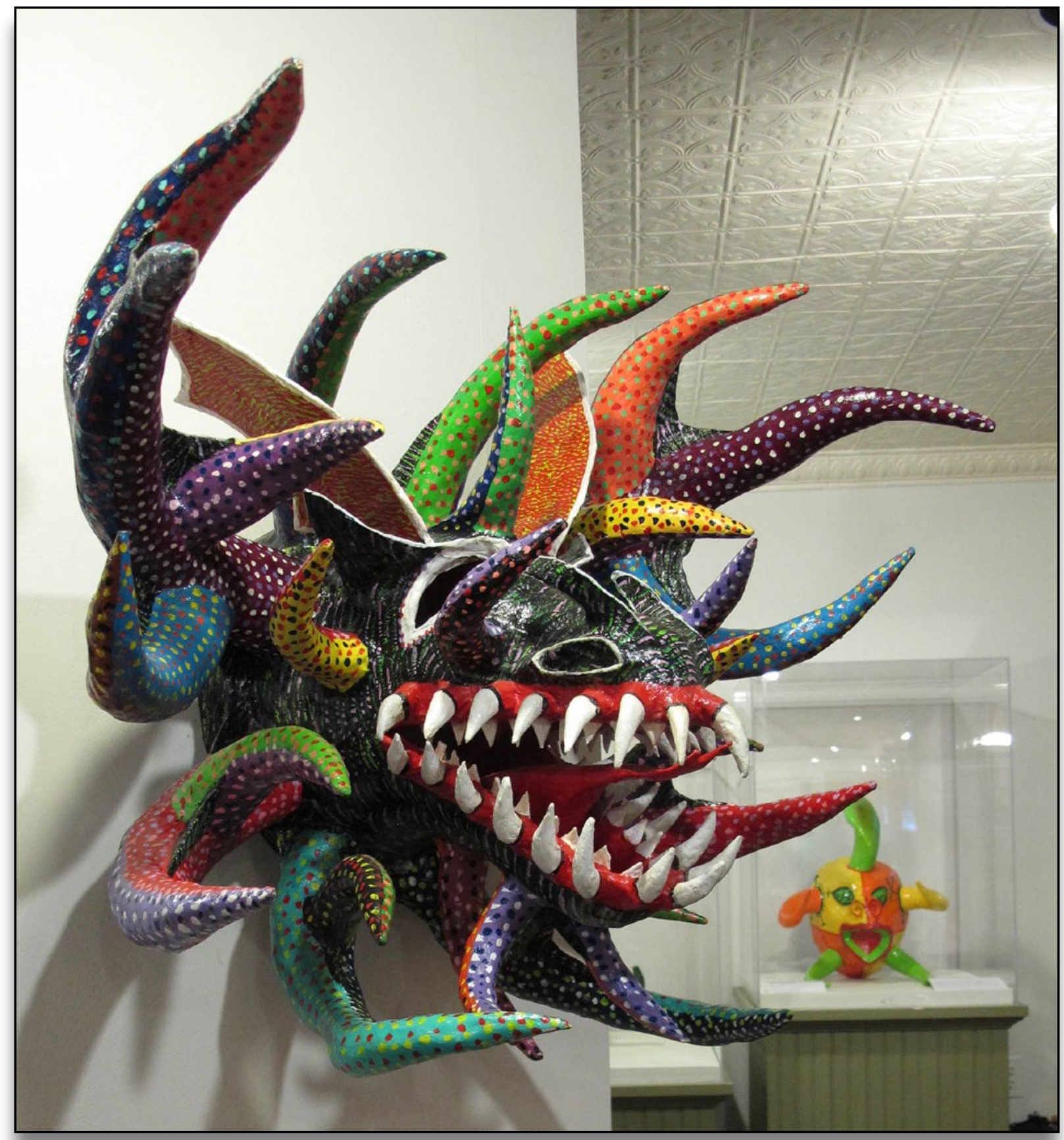

Figure 343 Caribbean Carnival - Dragon mask by Felipe Rangel (Puerto Rico) [digital image]. Retrieved June 20, 2020 from https://indigoarts.com/news/caribbean-carnival-and-sankofa-two-shows-featuring-artscaribbean-and-african-diaspora 
Another unrecorded discourse was provided by Norberto Martell: The change of the meanings of the horns on a vejigante mask. Norberto explained that the horns signified the importance within the group. One horn identified the leader of the comparsa, and two and three horns were for the followers in the group. ${ }^{188}$ Usually, any given mask had a maximum of three horns, while present-day, the horns do not have any significance, other than decorative purposes. (Figure 335) And on the contrary, the more horns adorned on a mask, give the mask more importance, therefore, prominence. This information defining the original, hidden meaning of horns cannot be confirmed with published data. And without the use of this method, word-of-mouth, this information would not have been discovered.

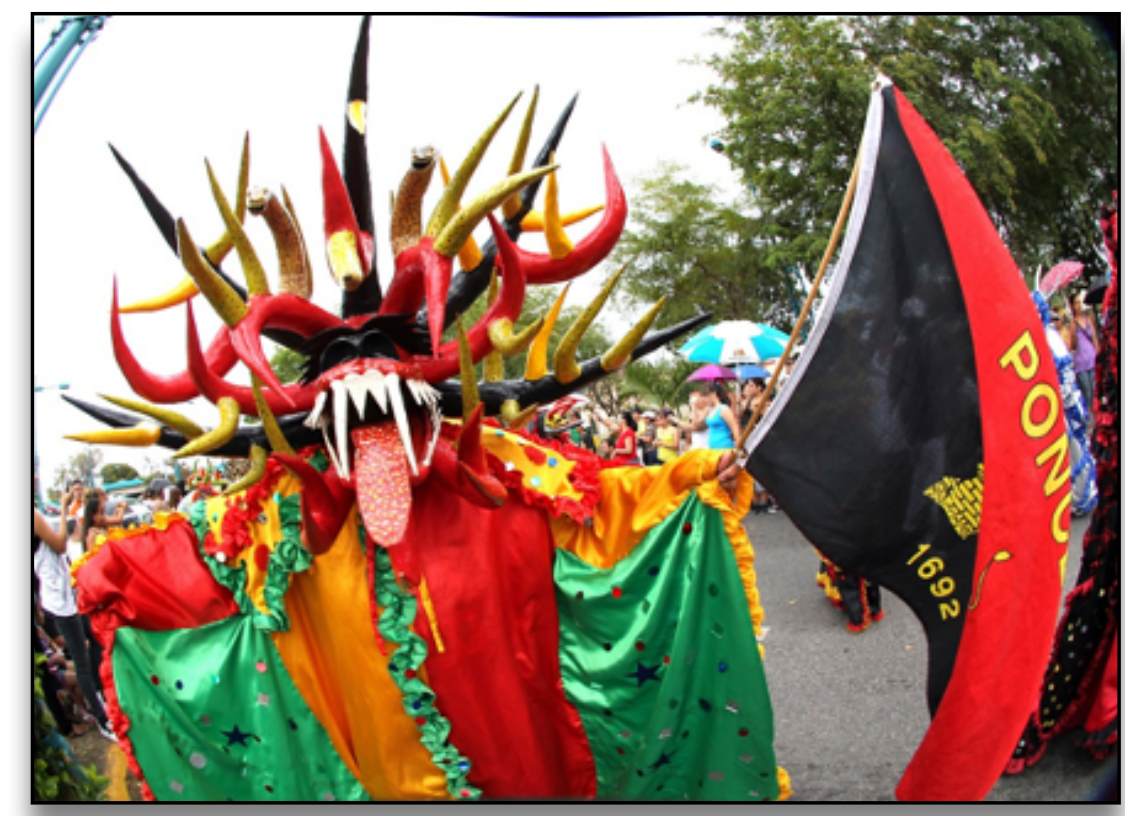

Figure 335 Untitled [digital image]. Retrieved June 20, 2020 from https:// desmily.com/la-historia-detras-de-lasmascaras-de-vejigantes-y-como-estasson-confeccionadas/

188 Norberto Martell, Interview by author, Video recording, Ponce, February 6, 2018. 
The colonization of Puerto Rico, first by Spain and later on by the USA, resulted in a multifaceted heritage. Vejigantes are a result of the culture that emerged during the first colonization. The impact the USA had on the preexisting cross-culture colony, which inevitably further altered the vejigante mask. And although colonialism desecrated an aboriginal society, it has also resulted in a new-found culture, heritage, and art that is unique to Puerto Rico. The vejigante mask originally falls within the guidelines of artisan work, and is not perceived as contemporary art. The mask has experienced a devaluation as an artisanal artifact. The vejigante mask has a diminished presence within the festivities, and the replacement of the traditional masks with Halloween masks. And although Halloween is not a recognized holiday in Puerto Rico, but with the introduction of Halloween themed National level stores result in assimilation of USA culture. (Figures 340-341) The USA has introduced to Puerto Rico an Americanized lifestyle as well as the consumption of inexpensive machine-made masks, which continues to depreciate the vejigante mask. Puerto Rico has a very complicated, economic environment due to the presence of the USA. Although USA assimilation is present in Puerto Rico, Ponce still maintains the tradition of the Carnival. Although external factors, such as assimilation, might affect Carnival rituals, the cultural tradition has endured. Even with a diminishment in the participation rate, artisans and artists alike, help aid to continue to use the vejigante as a source of inspiration and motivation. 
It is important to reiterate: Humberto Figueroa, an advocate for the cultural arts and history of Puerto Rico, strives to communicate to the community of artisans that vejigante masks are valuable artifacts and a product of the cultural traditions of Puerto Rico. Moreover, the mask remains relevant in contemporary art as an object of interest and inspiration. Although, it is necessary to preserve the folkloric tradition of mask making to ensure the continuation of the craft, the artisanal system of creation is closed to the possibility of evolution. Artisanal norms must transform into guidelines and/or suggestions, in addition, the presence of support must be evident for the introduction of artistic experimentation. This aspect is necessary for innovation of the mask. Master artisans, professors, and artists, need to become advocates of the mask in order to launch it to the next level.

As artists introduced the mask into contemporary art by experimenting and venturing beyond the stagnant ideologies and methods, the contextual vejigante started to emerge in the art world as a folkloric object and a work of art. Artists and artisans collectively protect and continue the production of vejigante masks and preserve the traditions of the Puerto Rican culture. The established artifacts within art history, are then interpreted into modern art that honors the past but moves toward the future. 


\section{Bibliography}

Adeleke, Abraham Ajibade. Intermediate Yoruba: Language, Culture, Literature, and Religious Beliefs, Part II. Bloomington, IN: Trafford Pub, 2011.

Admin. "Vejigantes." Nana Abreu, September 28, 2018. http://www.nanaabreu.com/ vejigantes/.

Agencia EFE. “Fiestas Patronales En Santa Isabel.” El Nuevo Dia, July 23, 2003.

Albanese, Lorelei. “Like Father, Like Son.” The San Juan Star, September 14, 1985, 19.

Aldama, Frederick, and Christopher González. Latinx Studies: The Key Concepts. London: Routledge, 2018.

Alegría, Ricardo. "El Culto A Santiago Apóstol En España, América Y Puerto Rico." Edited by Angel Ramos. Puerto Rico Ilustrado, November 25, 1950.

Alegría, Ricardo E. "La Fiesta De Santiago Apóstol En Loíza Aldea." Edited by Néstor Murray Izzary. Boletín De Folklore, no. 1 (1981): 1-18.

Alegría, Ricardo E. La Fiesta De Santiago En Loiza. Commission Puertorriqueña, n.d.

Alegría, Ricardo E. "The Fiesta Of Santiago Apóstol (St. James The Apostle) In Loíza, Puerto Rico." Journal of American Folklore 46, no. 272 (1956): 123-34.

Alegría, Ricardo. “Las Máscaras De La Fiesta De Santiago En Loíza Aldea.” Puerto Rico Ilustrado, December 9, 1950.

Alegría, D., Ricardo E. La Máscara En Las Antillas Mayores. Comisión Puertorriqueña, n.d.

Alverez Curbelo, Silvia. "La Fiesta Del 25 De Julio." Claridad, August 1, 1996. 
"Americanization Definition and Meaning | Collins English Dictionary." Collins Online Dictionary | Definitions, Thesaurus and Translations. Accessed December 27, 2020. https://www.collinsdictionary.com/dictionary/english/ americanization.

Arbasetti, Joel Cintrón. "Puerto Rico First in the World with Walgreens and Walmart per Square Mile." Centro de Periodismo Investigativo, September 29, 2018. https:// periodismoinvestigativo.com/2014/05/puerto-rico-first-in-the-world-withwalgreens-and-walmart-per-square-mile/.

Arnold, Albert J., Julio Rodríguez-Luis, and J. Michael Dash. A History of Literature in the Caribbean: Volume 1: Hispanic and Francophone Regions. Amsterdam/Philadelphia: John Benjamins Publishing Company, 1994.

Artesanias Caraballos. Facebook Interview. May 12, 2021.

Balleto, Barbara, ed. Insight Guide: Puerto Rico. Singapore: APA Publications, 1999.

Banting, Erinn. Puerto Rico: the People and Culture. New York: Crabtree, 2003.

Bloom, Harold and Janyce Marson. eds. Bloom's Modern Critical Views: Nathaniel Hawthorne. Infobase Publishing, 2007.

"Bojiganga - Definition and Synonyms of Bojiganga in the Spanish Dictionary." Educalingo, the Dictionary for Curious People. https://educalingo.com/en/dic-es/ bojiganga.

Canino, Marcelino. La Gran Enciclopedia De Puerto Rico: Folklore: El Folklore En Puerto Rico. Edited by Vincent Baéz. 1st ed. Vol. 12. Madrid, ES: C. Corredera, 1976.

Canaval de Vejigantes De La Playa De Ponce, Inc. Carnaval Y Vejigantes, 2017.

Cardona, Luis Antonio. A History of the Puerto Ricans in the United States of America. 2. Vol. 2. Bethesda, MD: Carreta Press, 1995. 
Cielatkowska, Zofia. "Decolonising Art Criticism.” Kunstkritikk, May 15, 2020. https:// kunstkritikk.com/decolonising-art-criticism/.

Cifre De Loubriel, Estela. “Análasis, Comentarios E Información Complementaria." La Formación Del Pueblo Puertorriqueño: Contribucion De Los Gallegos, Astrurianos Y Santanderinos, 1989, 49-50.

Cifre De Loubriel, Estela. Catálogo De Extranjeros Residentes En Puerto Rico En El Siglo XIX. Rio Piedras, PR: Ediciones De La Universidad De Puerto Rico, 1962.

Cifre de Loubriel, Estela. Instituto de Cultura Puertorriqueña, 1964.

Colón Pagán, Leonardo J. Instagram Interview. May 12, 2021.

Conesa Osuna, Miguel. Interview by author. Video recording. La Playa de Ponce, February 2, 2018.

Covas Quevedo, Waldo D. "Inicia El Conteo Regresivo Para El Carnaval De Vejigantes." La Perla Del Sur, January 23-29, 2019.

Cros, Fernando, Marta Morena Vega, and María Elba Torres Muñoz. Tradiciones Afrocaribeñas: Espiritualidad, Arte Y Resistencia, Tradiciones Afrocaribeñas: Espiritualidad, Arte Y Resistencia $\S(2007)$.

Davis, Martha Ellen. "Cuadros Folklóricos: Santiago Matamoros Es Vencido Por San Patricio.” El Caribe, May 21, 1977.

Deagan, Kathleen A., and Cruxent José María. Columbus Outpost among the Tainos: Spain and America at La Isabela, 1493-1498. New Haven, CT: Yale University Press, 2002.

Deane, Zain. San Juan, Vieques \& Culebra: A Great Destination. Woodstock, VT: Countryman Press, 2011.

Declare, Lulu. Rafi Y Rosi ;Carnaval! 1st ed. New York, NY: HarperCollins Publishers, 2006. 
Declare, Lulu. Vejigante Masquerade. New York City, NY: Scholastic Inc., 1993.

Díaz Soler, Luis M. "El Aborigen De Boriquén.” Puerto Rico: Desde Sus Orígenes Hasta El Cese De La Dominación Espoñola, 1994, 56-59.

Dolores Trelles, Carmen. "Diablos Y Vejigantes: Un Puernte Sobre El Caribe." El Nuevo Dia, November 22, 1992.

Dorsey, Joseph C., Arturo Lindsay, Rafaél L. López Valdés, Angie Gutiérrez Gutiérrez, Henry John Drewal, Jesús Chucho García, Sonya Aracena, et al. Actualidad De Las Tradiciones Espirituales Y Culturales Africanas En El Caribe Y Latinoamérica. Edited by José Carvajal, Actualidad De Las Tradiciones Espirituales Y Culturales Africanas En El Caribe Y Latinoamérica § (2010).

Echevarría Marín, Roberto. "Polifornía Y Otredad.” El Nuevo Dia, August 5, 2007.

“Enero.” Almanaque Puertorriqueño Asenjo, 1939.

Estrada del Campo, Tamara. “Tras El Embrujo De La Careta.” El Vocero, March 15, 2006.

"Fiestas Tradicionales De Santiago Apóstol Programa Oficial." Fiestas Tradicionales De Santiago Apóstol Loiza, 7AD.

Fiet, Lowell. Caballeros, Vejigantes, Locas Y Viejos: Santiago Apóstol Y Los Performeros Afropuertorriqueños. San Juan, PR: Terranova Editores, 2007.

Fiet, Lowell. El Teatro Puertorriqueño Reimaginado: Notas Críticas Sobre La Creación, Dramática Y El Performance. 1st ed. San Juan, PR: Ediciones Callejon, 2004.

Fiet, Lowell. "Fiestas Imparables De Loíza.” Claridad, August 23, 2006.

Figueroa, Humberto. Interview by author. Video recording. Ponce, February 4, 2018.

Figueroa, Humberto. "Mascara: La Faz Revelada.” Mascara: La Faz Revelada. Instituto Cultural Puertorriqueña, 2002. 
Fodor's Travel Guides. Fodor's Puerto Rico. 8. Vol. 8. New York: Fodors Travel, 2014.

Francisco Santiago, Luis. Másccaras De Hatillo: Un Potlatch En La Modernad. Bloomington, IN: Palibrio, 2015.

Galarza, Jose, ed. Los Municipios de Puerto Rico Su Historia Y Su Cultura: Loíza:

Capital De La Tradicion. Estado Libre Asociado de Puerto Rico, 1994.

Galván Javier A. Culture and Customs of Puerto Rico. Westport: Greenwood Press, 2009.

García Santos, Nelson. Vivencias en La Playa De Ponce: Andadas En Mis Tiempo De Vejigante. Juana Díaz, PR: Imprenta Llorens, Inc., 2009.

Gates, Jr., Henry Louis. Africa: The Encyclopedia of the African and African American Experience. Edited by Kwame Anthony Appiah. 1st ed. New York, NY: Basic Civitas Book, 1999.

Gonzalez, Alberto. “Nueva Técnica En Máscaras.” El Reportero, January 8AD.

Green, G. L., and P. W. Scher. Trinidad Carnival: The Cultural Politics of a Transnational Festival. Indiana University Press, 2007.

Hancock, Ralph. Puerto Rico: A Travelers Guide. Princeton, New Jersey: D. Van Nostrand Company, 1962.

Hechavarría, Mónica. “De Fiesta Loíza Por Santiago Apóstol.” El Nuevo Dia, July 23, 2003.

Hedeen, Katherine M. "Decolonizing Culture: Visual Arts, Development Narratives, and Performance in the Americas." Latin American Research Review 40, no. 3 (2005): 244-53. www.jstor.org/stable/3662834.

Hernández, Juan A. “El Hombre De La Máscara.” Claridad, August 10, 1995.

Herrera-Sobek, María. Celebrating Latino Folklore: an Encyclopedia of Cultural Traditions. Santa Barbara, CA: ABC-CLIO, 2012. 
Hilario García, Claudia S. “Febrero Es Vejigantes.” Primera Hora, February 28, 2006.

“Huerto Urbano Del Callejón Trujillo.” Facebook. Accessed November 20, 2019. https:// www.facebook.com/pg/Huertocallejontrujillo/about/?ref=page_internal.

Insight Guides. Insight Guides: Puerto Rico. 109. Vol. 109. Singapore: APA Publications, 2007.

"Juan Alindato." National Endowment for the Arts National Endowment for the Arts. n.d. https://www.arts.gov/honors/heritage/juan-alindato.

Keeling, Stephen, and Alison Roberts. The Rough Guide to Puerto Rico. London: Rough Guides, 2011.

Kindersley, Dorling. Top 10 Puerto Rico. Dorling Kindersley, 2015.

Knight, Cher Krause. Public Art: Theory, Practice and Populism. Malden, Mass: Blackwell, 2009.

Kurlansky, Mark. "SHOPPER'S WORLD; Puerto Rican Carnival Masks." The New York Times, February 11, 1990, 6.

La Redacción. "Invitan A Otra Fiesta Cultural En La Playa.” La Perla Del Sur, May 24-30, 2017.

“La Tradición De Santiago Apóstol En Loíza.” Fiestas Tradicionales De Santiago Apóstol Loíza, 7AD.

“Las Fiestas De Loíza Y Sus Máscaras.” Fiestas Tradicionales De Santiago Apóstol Loíza, 7AD.

“Latin-American.” Merriam-Webster. Merriam-Webster. Accessed March 20, 2019. https://www.merriam-webster.com/dictionary/Latin-American.

Leonor Rivera-Lassén, Carmen. "Loíza Festeja A Santiago Apóstol Tras Cancelación Municipal.” El Nuevo Dia, July 26, 2006. 
Let's Go Inc. Let's Go Puerto Rico. Edited by Noga Leah. Ravid and St. Martin's Press. 3rd ed. Let's Go Publications, 2007.

Levy, Patricia, and Nazry Bahrawi. Puerto Rico. New York: Marshall Cavendish Benchmark, 2006.

Lienhard, Martín R., Jesús R. Morales Bermúdez, Elena R. Lazos Chavero, Julio R. Mendívil, Antonio R. Melis, Grisel R. Cánepa Koch, Yvette R. Jiménez De Báez, et al. Ritualidades Latinoamericanas: Un Acercamiento Interdisciplinario, 5 Ritualidades Latinoamericanas: Un Acercamiento Interdisciplinario § (2003).

López, Ramón. Cuadernos De Cultura: EL Valor Histórico de la Artesanía Puertorriqueña. 2nd ed. Vol. 6. Instituto de Cultura Puertorriqueña, 2001.

López, Rámon. “Evaluación Y Promoción.” Manualidades, Artesanías Y Artes Populares: Conceptos Y Guías De Evalucación, n.d.

López, Rámon. “Identidad Y Valor Cultural.” Manualidades, Artesanías Y Artes Populares: Conceptos Y Guías De Evalucación, n.d.

López, Rámon. "Implicaciones Y Consecuencias.” Manualidades, Artesanías Y Artes Populares: Conceptos Y Guías De Evalucación, n.d.

López, Rámon. “La Evaluación Como Diálogo y Debate.” Manualidades, Artesanías Y Artes Populares: Conceptos Y Guías De Evalucación, n.d.

López, Rámon. “La Evaluación De La Calidad.” Manualidades, Artesanías Y Artes Populares: Conceptos Y Guías De Evalucación, n.d.

Los Municipios de Puerto Rico Su Historia Y Su Cultura: PONCE. Santurce, PR: Departamento de Educación del Estado Libre Asociado de Puerto Rico, 1992.

Lugo Lugo, Herminio. Costumbres Y Tradiciones Puertorriqueñas y El Mundo: Comparación De Nuestras Costumbres Con Las De Otros Países: Un Tratado De Antropología Social Comparada. 1st ed. San Juan, PR: Editorial EDIL, 1995.

Martell, Norberto. Interview by author. Video recording. Ponce, February 6, 2018. 
Martell Morales, Norberto, and Héctor J. Rodríguez Torres. Las Caretas del Vejigante Ponceño. Edited by Pavlova Mezquida Greber and Héctor J. Rodríguez Torres. Translated by Moisés Hernández, Verónica Kicliter, and Helen Rodríguez. 1st ed. Compañía de Fomento Industrial de Puerto Rico, 1999.

"Máscara: La Faz Revelada." Máscara: La Faz Revelada. San Juan, PR: Instituto De Cultura Puertorriqueña, 2002.

Mathews, Thomas G., Olga J. Wagenheim, and Kal Wagenheim. "History." Encyclopædia Britannica. Encyclopædia Britannica, Inc., February 15, 2020. https://www.britannica.com/place/Puerto-Rico/History\#ref515893.

Maynard, Tekina-eiru. “Taino History \& Taino Today.” Puerto Rican Folkloric Dance \& Cultural Center - Music, Dance, Culture, History of Puerto Rico. Last modified 2007. https://www.prfdance.org/taino.history.ALL.htm.

Méndez Santos, Carlos. Tradiciones Ponceñas. 2nd ed. Ponce, PR: Producciones Ceiba, 1973.

Méndez Caratini, Héctor, and Ricardo E. Alegría. Herencia Negra: Loiza. San Juan, PR: Museo De Las Aeméricas, 1996.

Méndez Caratini, Héctor. “Por Dentro: Arte Y Cultura.” El Nuevo Dia, July 23, 2000.

Michaeli, Tami, ed. "Face to Face: The Oldest Masks in the World." Translated by Nancy Benovitz. Accessed June 24, 2020. https://museum.imj.org.il/exhibitions/2014/ face-to-face/en/index.html.

Moran, Lucas. "El Carnaval De Ponce.” El Nuevo Dia, March 1, 1987.

“Notas En Rojo.” Claridad, February 13, 1987.

"Our Lady of the Pillar." Jehannedarc. Accessed June 6, 2020. https:// www.jehannedarc.org/olpilar.html. 
Pauls, Elizabeth Prine. “Assimilation.” Encyclopædia Britannica. Encyclopædia Britannica, Inc., August 21, 2019. https://www.britannica.com/topic/assimilationsociety.

Pérez, Luis Alberto. Interview by author. Video recording. La Playa de Ponce, February $1,2018$.

Petrillo, Valerie, Scott Rattray, and Gail Rattray. A Kids Guide to Latino History: More than 50 Activities. Chicago, IL: Chicago Review Press, 2009.

"Ponce." Art Nouveau European Route : Cities. Accessed February 5, 2020. http:// www.artnouveau.eu/en/city.php?id=44.

Ponte, Alessandra. “Garbage Art and Garbage Housing.” Log, no. 8 (2006): 99-111. http://www.jstor.org/stable/41765594.

"Puerto Rico." Data USA. Accessed October 20, 2020. https://datausa.io/profile/geo/ puerto-rico/?compare=united-states.

"Puerto Rican Bomba and Plena: Shared Traditions - Distinct Rhythms." Smithsonian Folkways Recordings. Accessed December 26, 2020. https://folkways.si.edu/ puerto-rican-bomba-plena-shared-traditions-distinct-rhythms/latin-world/music/ article/smithsonian.

Puerto Rico Day Trips Travel Guide. Accessed September 1, 2019. https:// www.puertoricodaytrips.com/ponce-carnival/.

"Puerto Rican Mask Maker Juan Alindato García Dies." Repeating Islands. Last modified May 29, 2010. https://repeatingislands.com/2010/05/29/puerto-rican-mask-makerjuan-alindato-garcia-dies/.

"Puerto Rico: The World's Oldest Colony." ArtRage Gallery: The Norton Putter Gallery. Accessed June 20, 2020. https://artragegallery.org/puerto-rico-the-worlds-oldestcolony/.

R., Olga, and Kuharets. Venture Into Cultures: A Resource Book of Multicultural Materials and Programs. American Library Association, 2001. 
Raminez De Arellano, Rafael. Folklore Portorriqueño: Cuentos Y Adivinazas: Recogidos De La Tradición Oral. Vol. 2. Madrid, Es: Centro De Estudios Históricos, 1926.

Rentas, Raquel. Interview by author. Video recording. La Playa de Ponce, February 7, 2018.

Reeder, Daniel. Papier-Mache Monsters. Layton: Gibbs Smith, 2009.

Rivera Toro, Quintín. "Una cultura en llamas: arte puertorriqueño de resistencia en el siglo XXI." PhD diss., Universitat Politècnica de València, 2019.

"Rocinante Y Don Quijote Caídos En El Suelo Tras El Susto De Rocinante. La Carreta De Las Cortes... - Banco De Imágenes Del «Quijote» (1605-1915) - QBI." Biblioteca Virtual Miguel De Cervantes. Accessed December 20, 2020. https:// www.cervantesvirtual.com/portales/quijote_banco_imagenes_qbi/ficha_imagen/? id $=6998$.

Rodríguez, Héctor. Interview by author. Video recording. Ponce, February 5, 2018.

Rosario, Frances. "Devoción Llena De Música Y Colorido.” Edited by Vanessa Morales. El Nuevo Dia, July 29, 2003.

Ruíz Vicki, and Korrol Virginia Sánchez, eds. Latinas in the United States: A Historical Encyclopedia. Bloomington: Indiana University Press, 2006.

“Se Prepara Feria De Artesanía En Ponce.” El Mundo, November 9, 1974.

Shafto, Daniel. Carnival. Infobase Publishing, 2009.

Shoenberger, Elisa. "What Does It Mean to Decolonize a Museum?" MuseumNext, June 4, 2020. https://www.museumnext.com/article/what-does-it-mean-to-decolonizea-museum/.

“Simbolismo Del Escudo De Armas Y La Bandera Del Municipio De Loíza." Fiestas Tradicionales De Santiago Apóstol Loíza, 7AD. 
Simpson, Victor C. Colonialism and Narrative in Puerto Rico: a Study of Characterization in the Novels of Pedro Juan Soto. New York: Peter Lang, 2004.

"Sociohistorical." Merriam-Webster. Merriam-Webster. Accessed August 8, 2019. https:// www.merriam-webster.com/dictionary/sociohistorical.

Sólivan Lupiáñez, Héctor. “De Los Símbolos Del Carnaval De Ponce.” Elogio A La Guitarra: Artículos Y Ensayos, 2014, 228-37.

"Stateside | Definition of Stateside by Oxford Dictionary on Lexico.com Also Meaning of Stateside.” Lexico Dictionaries | English. Accessed October 20, 2020. https:// www.lexico.com/definition/stateside.

Tate. “Arte Povera - Art Term.” Tate. Accessed March 15, 2019. https://www.tate.org.uk/ art/art-terms/a/arte-povera.

Tate. "Jackson Pollock 1912-1956." Tate, January 1, 1970. https://www.tate.org.uk/art/ artists/jackson-pollock-1785.

The Editors of Encyclopaedia Britannica. "Carnival.” Encyclopædia Britannica.

Encyclopædia Britannica, Inc., May 8, 2020. https://

www.britannica.com/topic/Carnival-pre-Lent-festival.

The Editors of Encyclopaedia Britannica. "Papier-mâché." Encyclopædia Britannica. Encyclopædia Britannica, Inc., June 20, 2020. https://www.britannica.com/art/ papier-mache.

The Editors of Encyclopaedia Britannica. "Taino.” Encyclopædia Britannica.

Encyclopædia Britannica, Inc., February 15, 2020. https://www.britannica.com/ topic/Taino.

"The History of Carnival - The Story of the World's Oldest Party!" Carnivaland. February 27, 2020. https://www.carnivaland.net/origin-history-carnival-worlds-oldestparty/. 
Tillis, Antonio D., ed. Critical Perspectives on Afro-Latin American Literature. 4. Vol. 4. Routledge, 2012.

Tió, Teresa. “Caras Y Caretas.” El Mundo, January 19, 1984.

Torres, Ednisa. Interview by author. Video recording. La Playa de Ponce, February 3, 2018.

Vargas-Ramos, Carlos, and Antonio M. Stevens-Arroyo. Blessing La Politica: the Latino Religious Experience and Political Engagement in the United States. Westport: Praeger Publishers Inc., 2012.

“Vejigantes in Puerto Rico | UPDATED August 2020." Best Cultural Destinations. Last modified November 15, 2020. https://www.bestculturaldestinations.com/blog/ vejigantes-puerto-rico-mask-making-tradition.

Vidal, Teodoro. El Vejigante Ponceño. San Juan, PR: Universidad De Puerto Rico, 2003.

Vidal, Teodoro. Las Caretas De Cartón Del Carnaval De Ponce. San Juan, PR: Ediciones Alba, 1983.

Vidal, Teodoro. Las Caretas De Los Vejigantes Ponceños: Modo De Hacerlas. 1st ed. San Juan, PR, 1988.

Vidal, Teodoro. "Oraciones Folklóricas De Puerto Rico.” Revista De Dialectología Y Tradiciones Populares 27, no. 3 Y 4 (1971): 411-17.

Zaragoza, Edward C. "The Santiago Apóstol of Loíza, Puerto Rico." Caribbean Studies 23 (1990): 127-39. 


\section{Appendix}

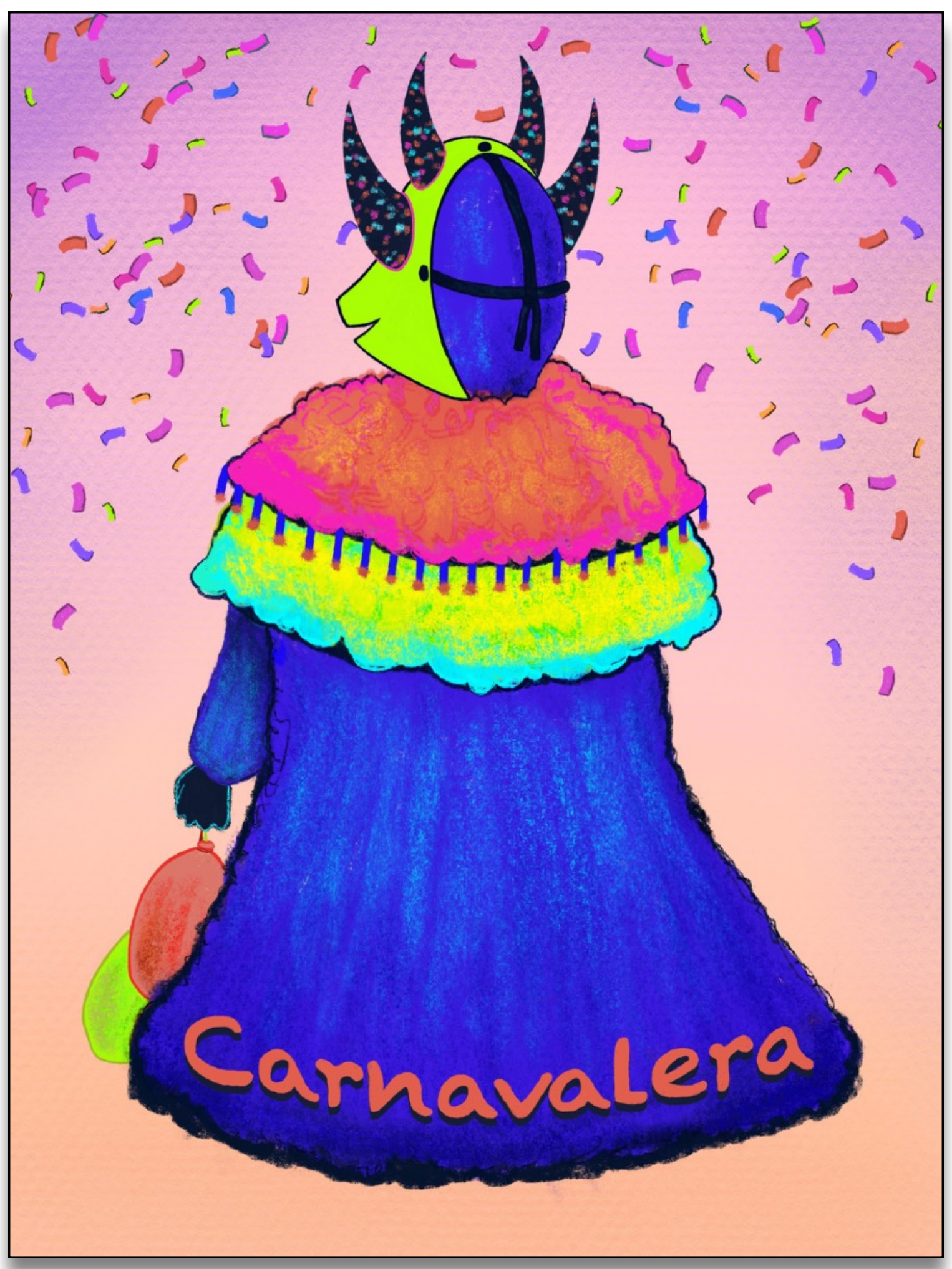




\title{
Carnavalera
}

\author{
Escrito e ilustrado por
} Chelsea Marie Glidden Bosch 
Copyright (e) 2020 Chelsea Marie Glidden Bosch

Reservados todos los derechos sobre los textos y las imágenes, incluido el derecho de reproducción, total o parcial de los contenidos, bajo cualquier forma y por cualquier procedimiento, sin La previa autorización de la autora.

Para más información:

CONTACT@LECH.STUDIO WWW.LECH.STUDIO

ISBN:

Publicado por Mariana Editores.

Mariana Editores

Las Mareas, Calle 8-A \#44

Salinas, Puerto Rico 00751

Primera edición 2020.

Impreso por Scuotto.

Scuotto

Via Tommaso Caravita, \#26

Napoli, Italia 80134

Impreso en Italia. 


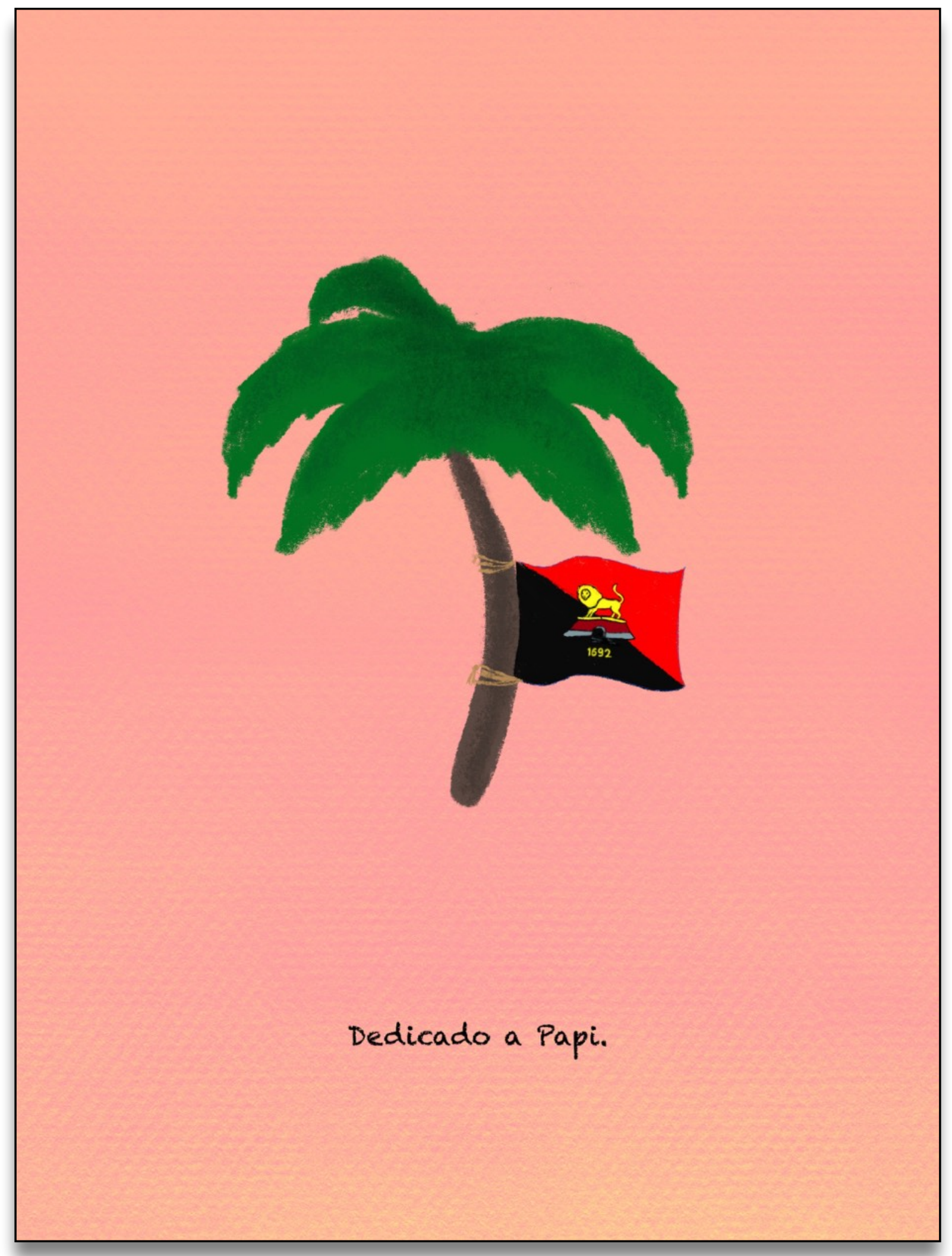




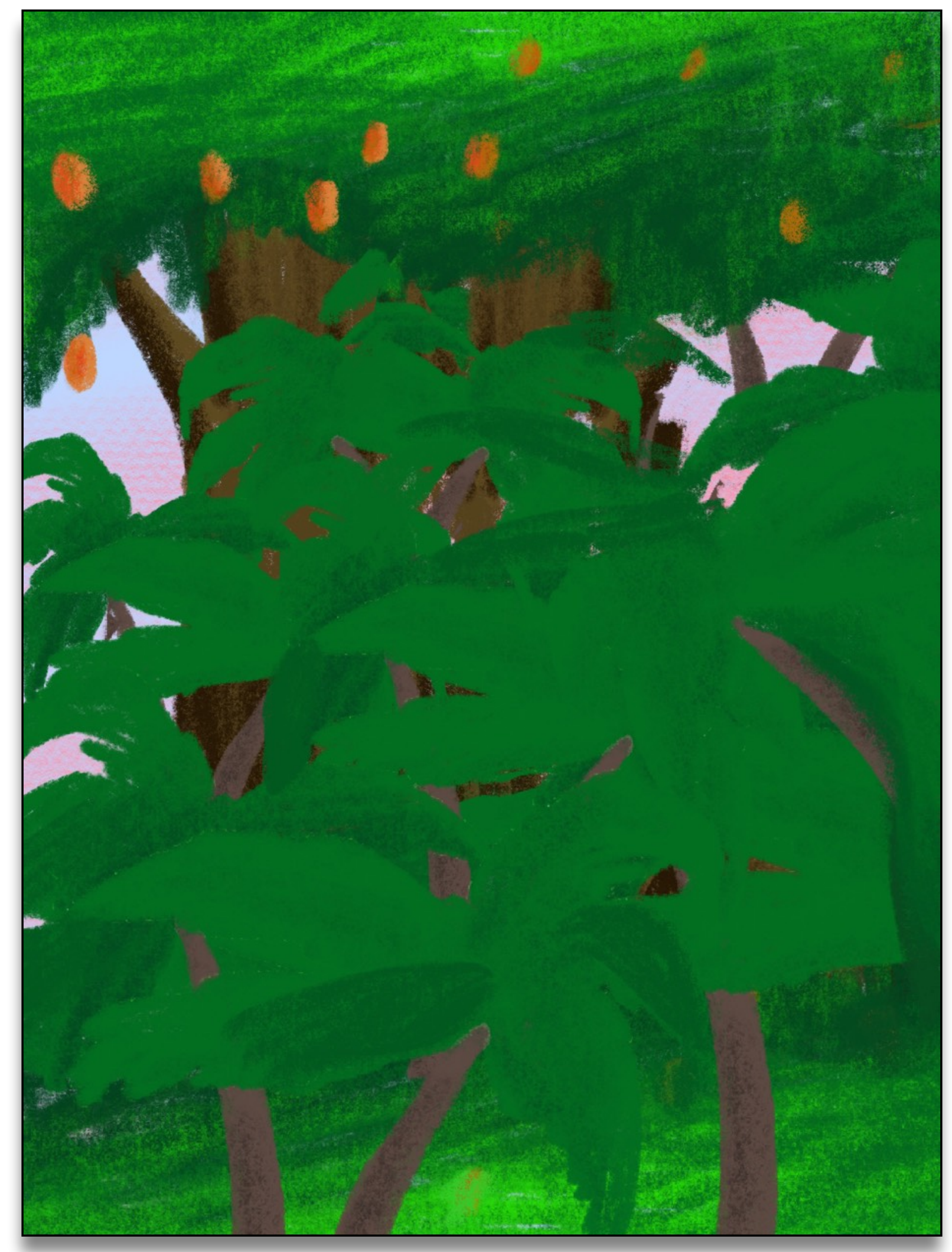




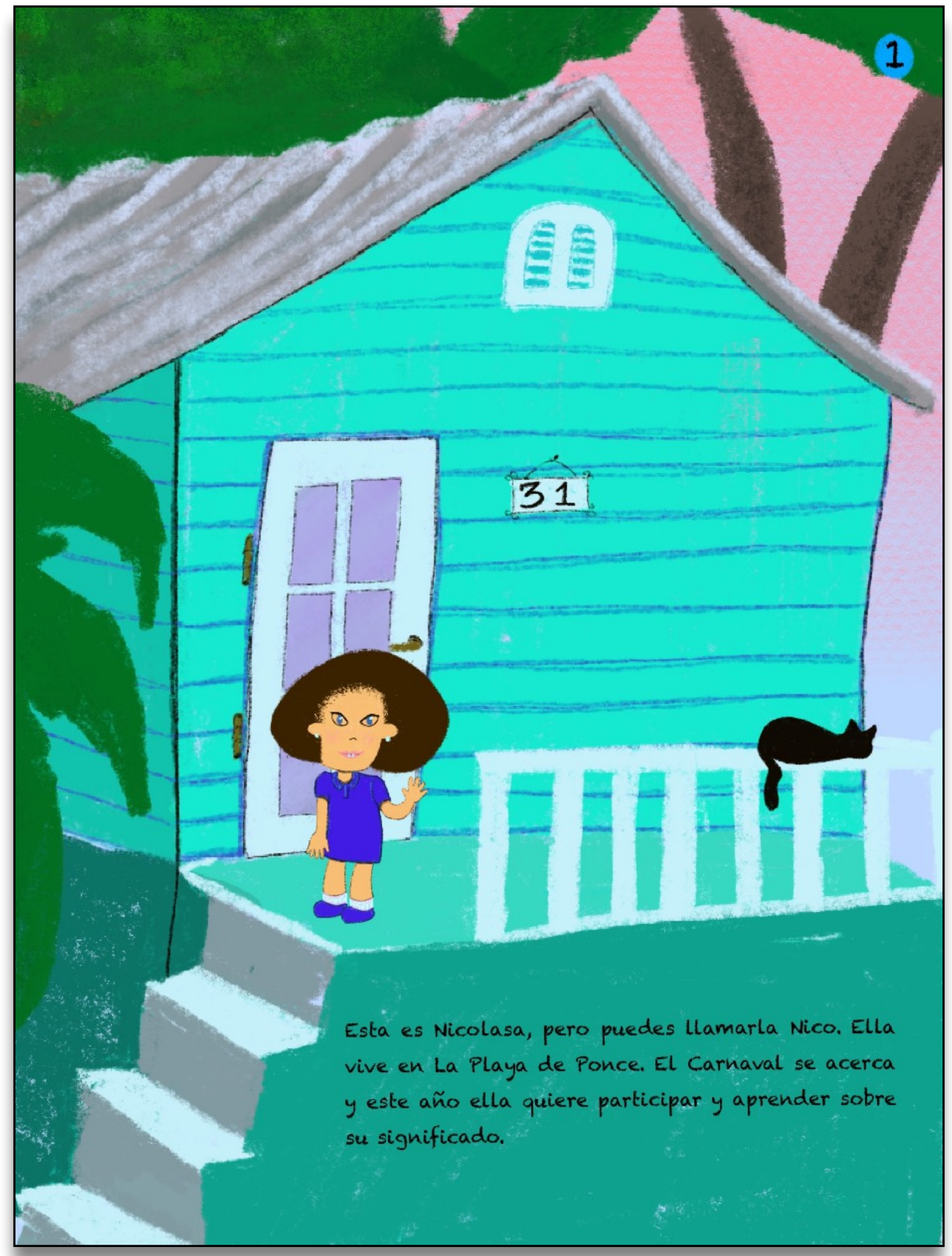




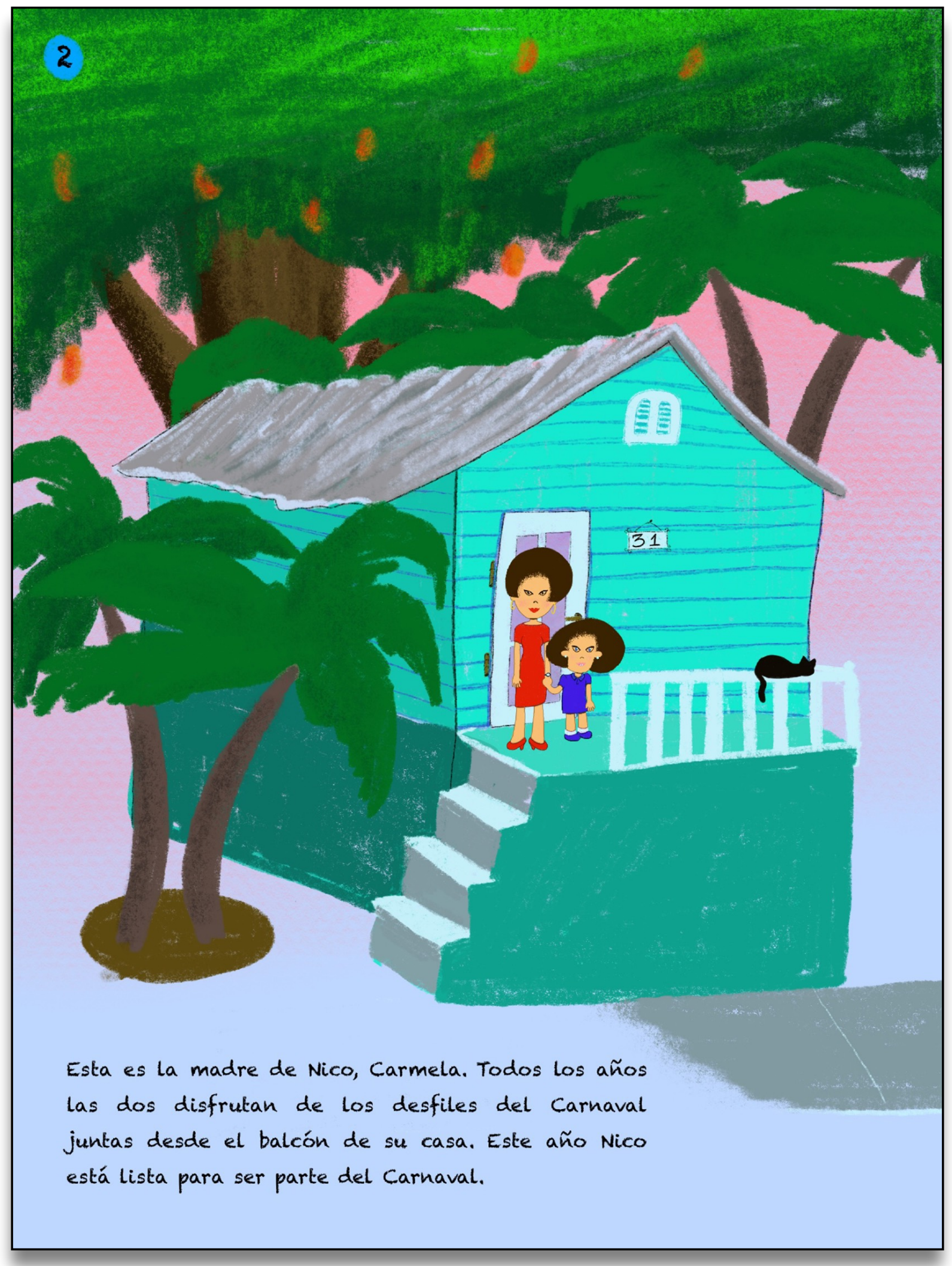


“iMamá! iQuiero participar en el Carnaval este

año! iPor favor! iYa estoy lista para ser parte del Carnaval!"

"Muy bien Nico, irecuerdas lo que te expliqué que representa el Carnaval?"

"icuéntame otra vez, mamá!"
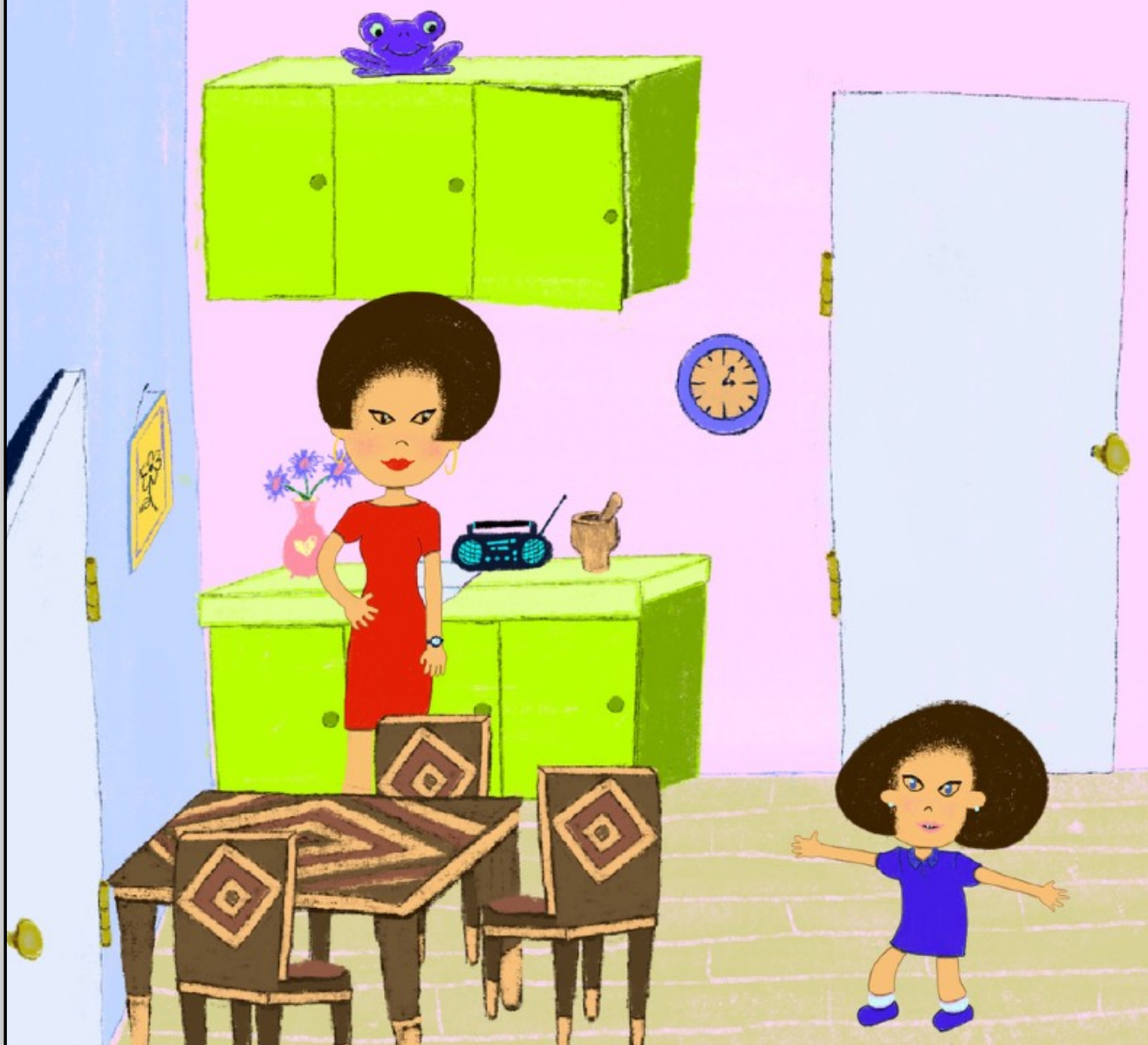


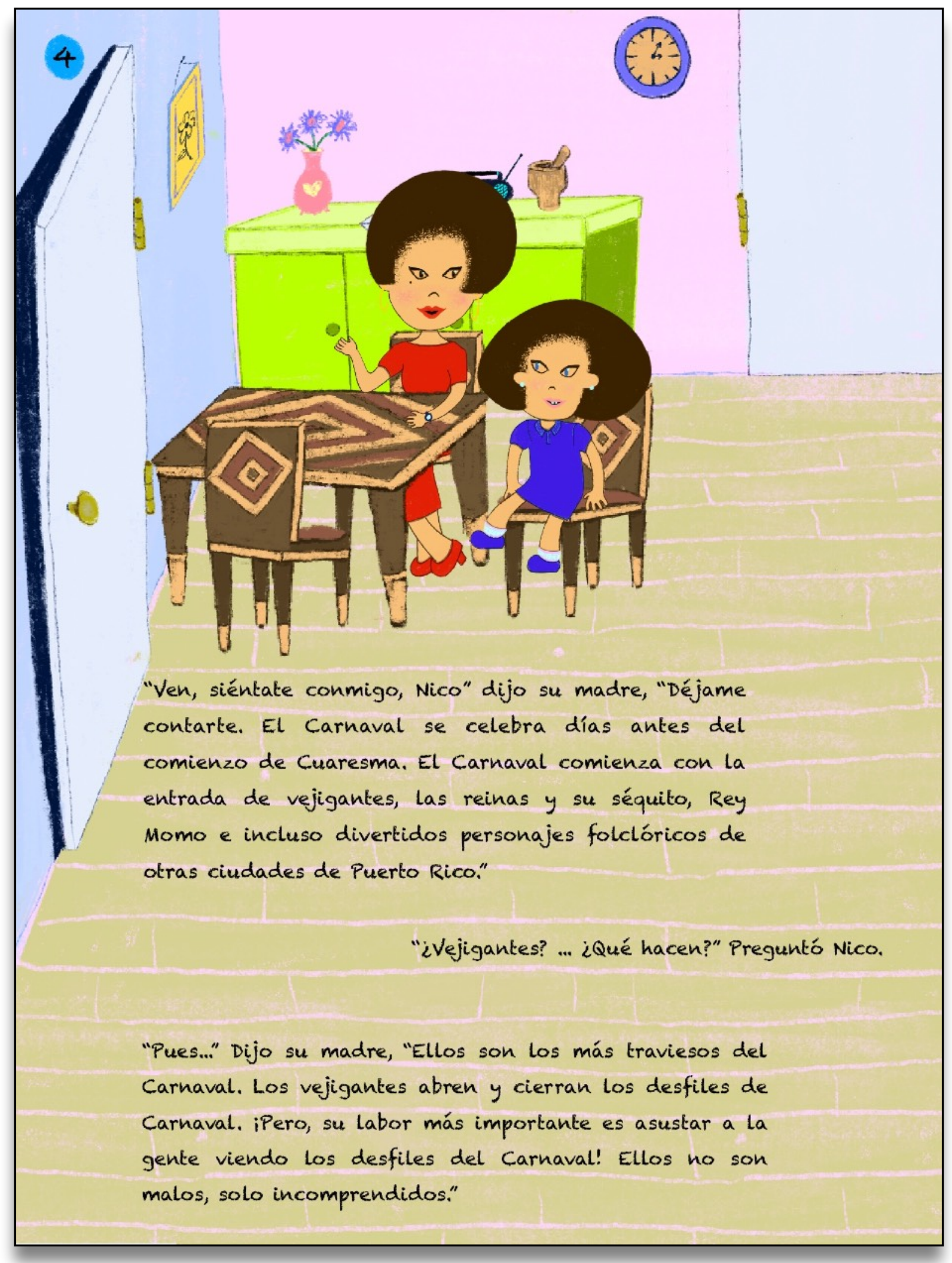




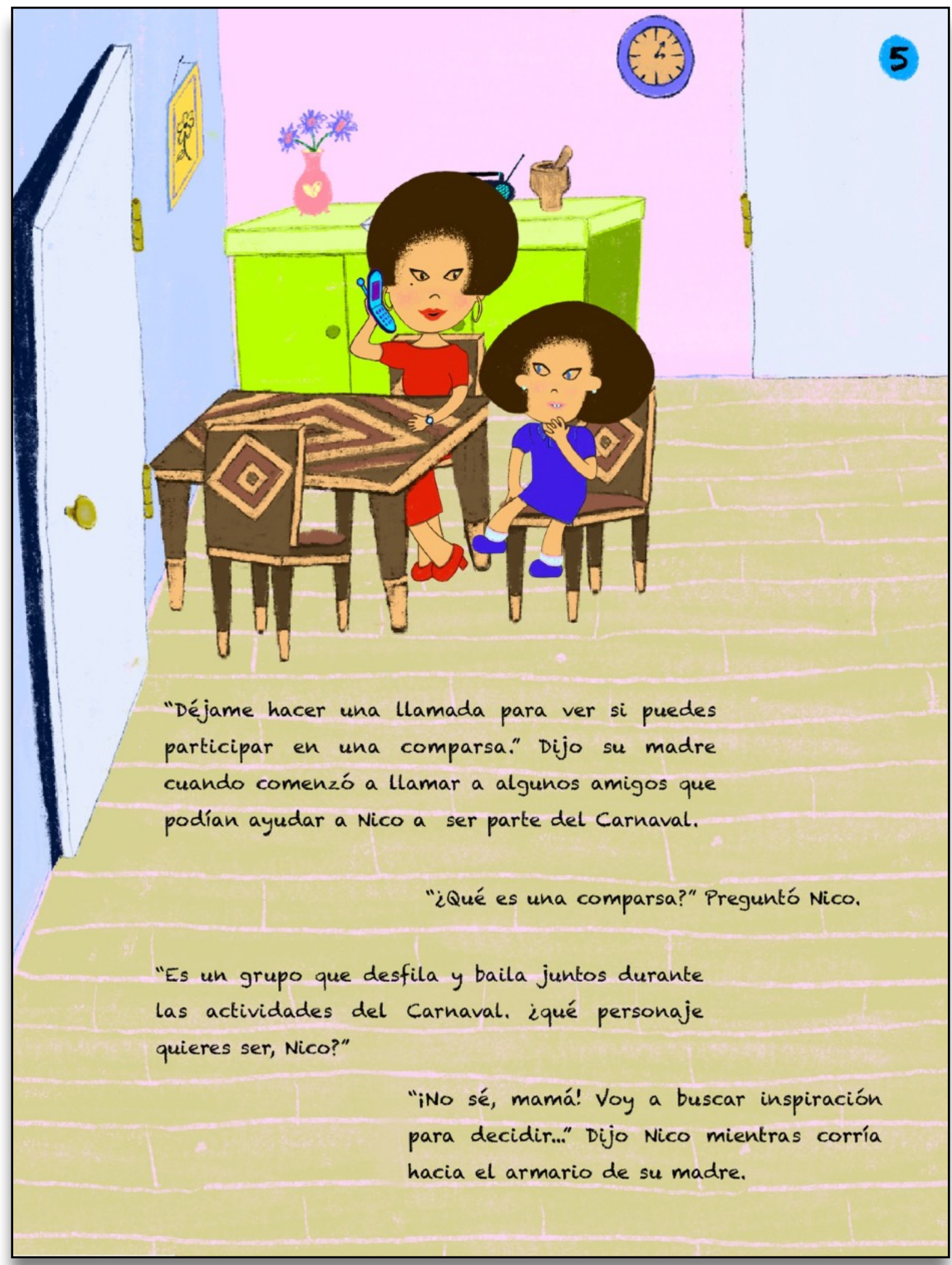


Cuando Nico extendió la mano hacia la puerta del armario, ella tuvo una lluvia de ideas sobre el personaje que quería. Estaba interesada en los Vejigantes pero quería tener su mente abierta a otras posibilidades.
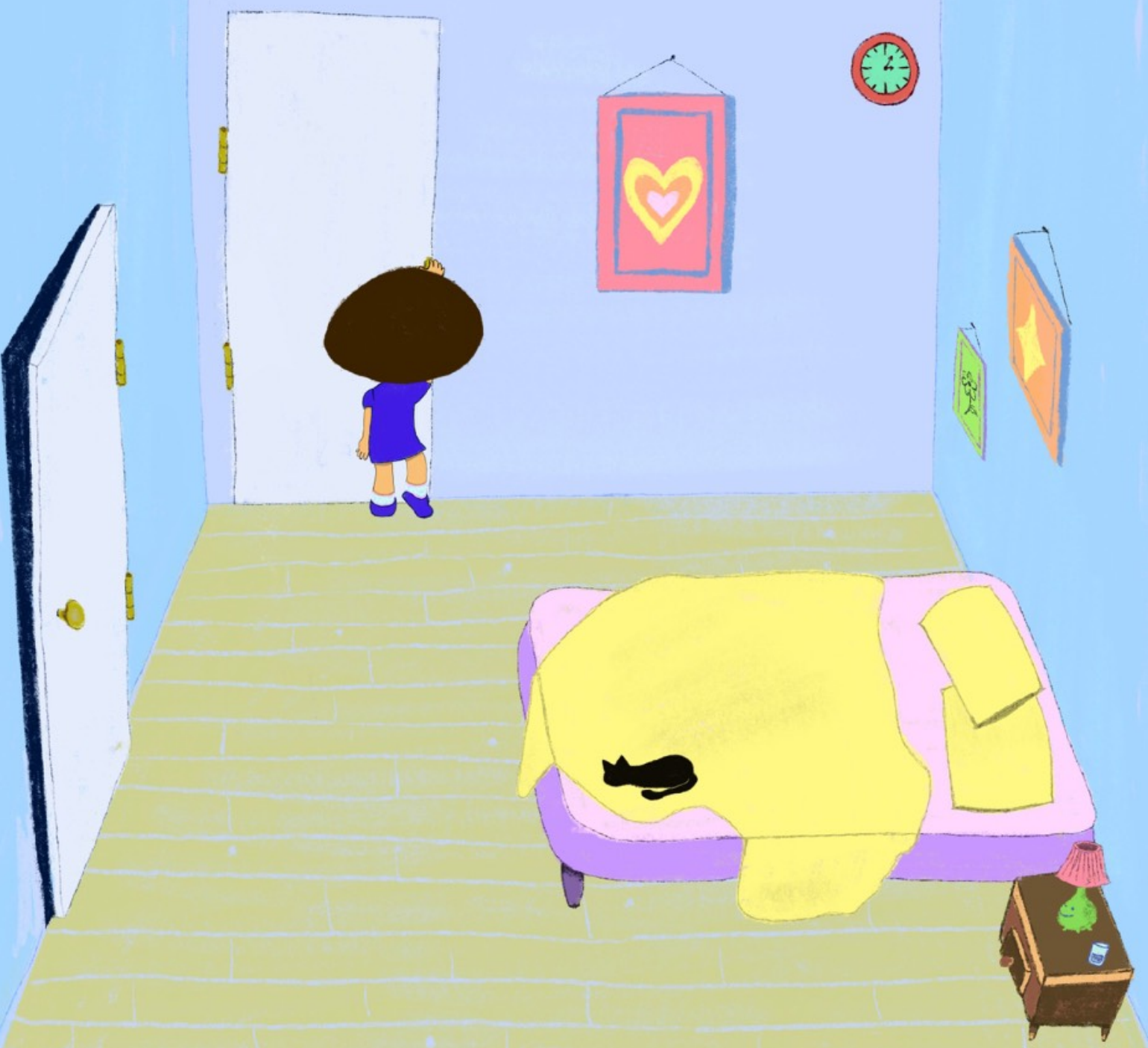
Cuando Nico mira dentro del armario de su madre, ve un artículo de colores brillantes... "¿Qué es esto?" Nico retira el artículo del armario y se da cuenta que es un disfraz. Mira en la tablilla y ve una máscara. iElla siente una gran emoción!

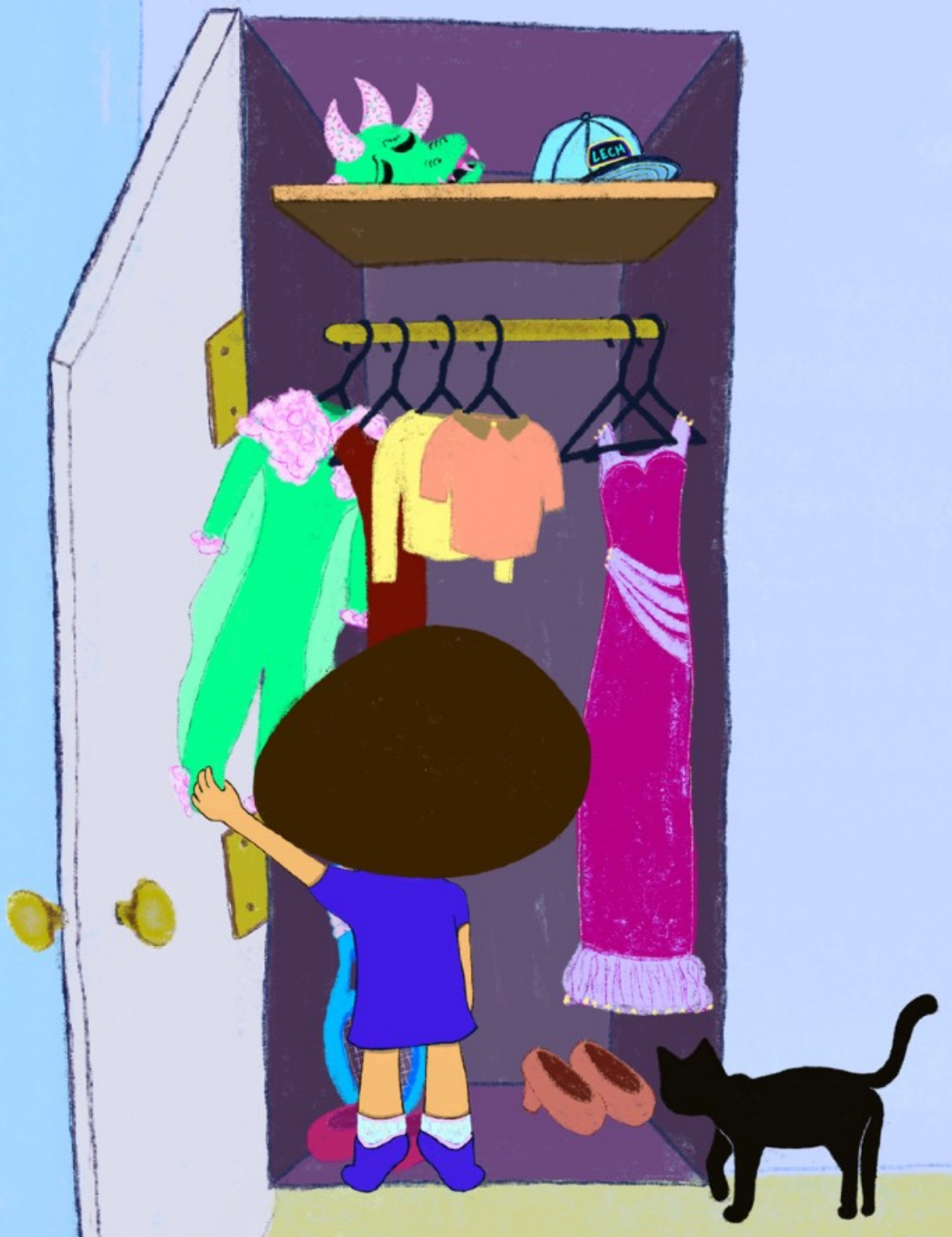




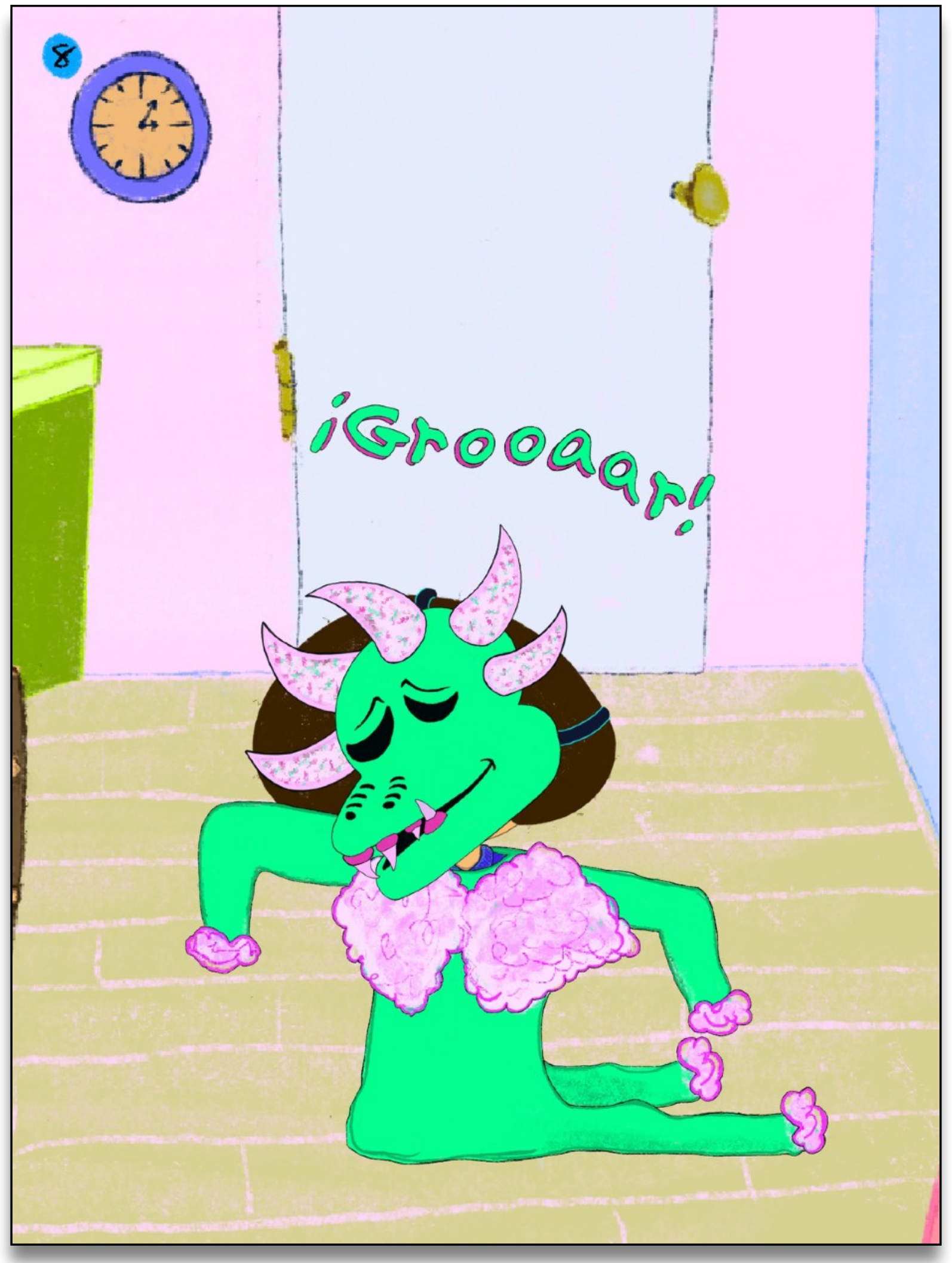


"iMamá! iMira lo que encontré!" Gritó Nico.

"itlacía tiempo que no veía mi viejo disfraz de vejigante!"

"¿Eras un vejigante?"

"Sí, lo era! De hecho, hice mi disfraz yo sola..." Carmela termina su conversación telefónica y le dice a Nico "Hay una oportunidad para ser princesa... ¿Cómo te gustaría?"

"iMama, no! iQuiero ser vejigante como tú!"

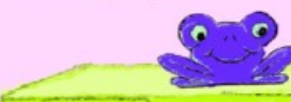




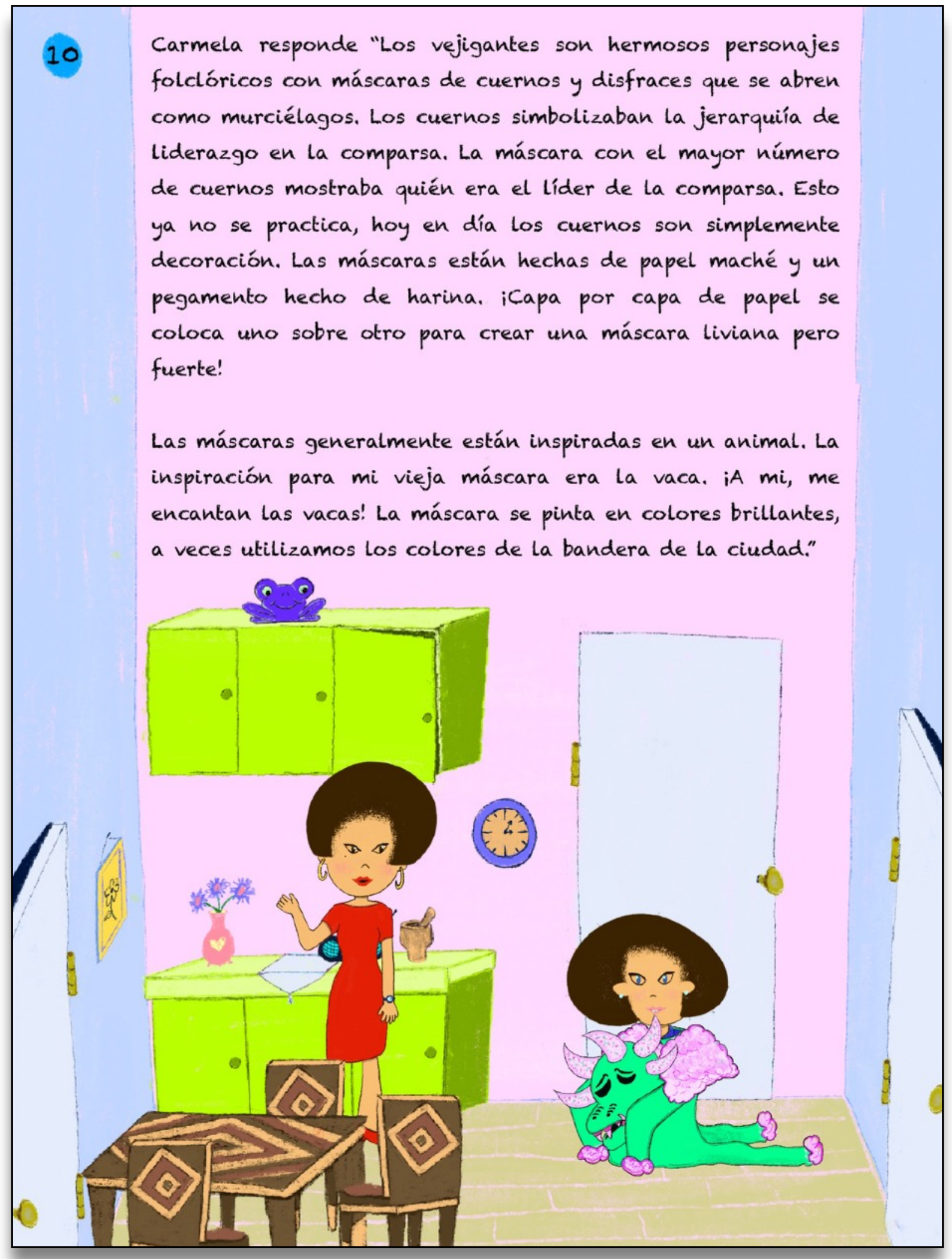


"Las máscaras pueden parecer aterradoras, pero los vejigantes son súper divertidos. Lo único que podía dar miedo era la vejiga que se utilizaba en el pasado. Pero, ya no hay porque preocuparse por ese detalle, llevar vejigas ya no se practica."

"¿Qué es La vejiga?" Preguntó Nico.

"La vejiga era una vejiga de vaca, inflada que parecia un globo. iSolíamos golpear a la gente con ella! Ya esto no se practica. Ahora se usan globos para simular la vejiga y amenazar la gente sin golpearles." Respondió su madre.

"Entonces, ipuedo usar globos...?"

"Claro, ipor qué no!... Mañana seguimos la conversación. Ya se hace tarde, a la cama."
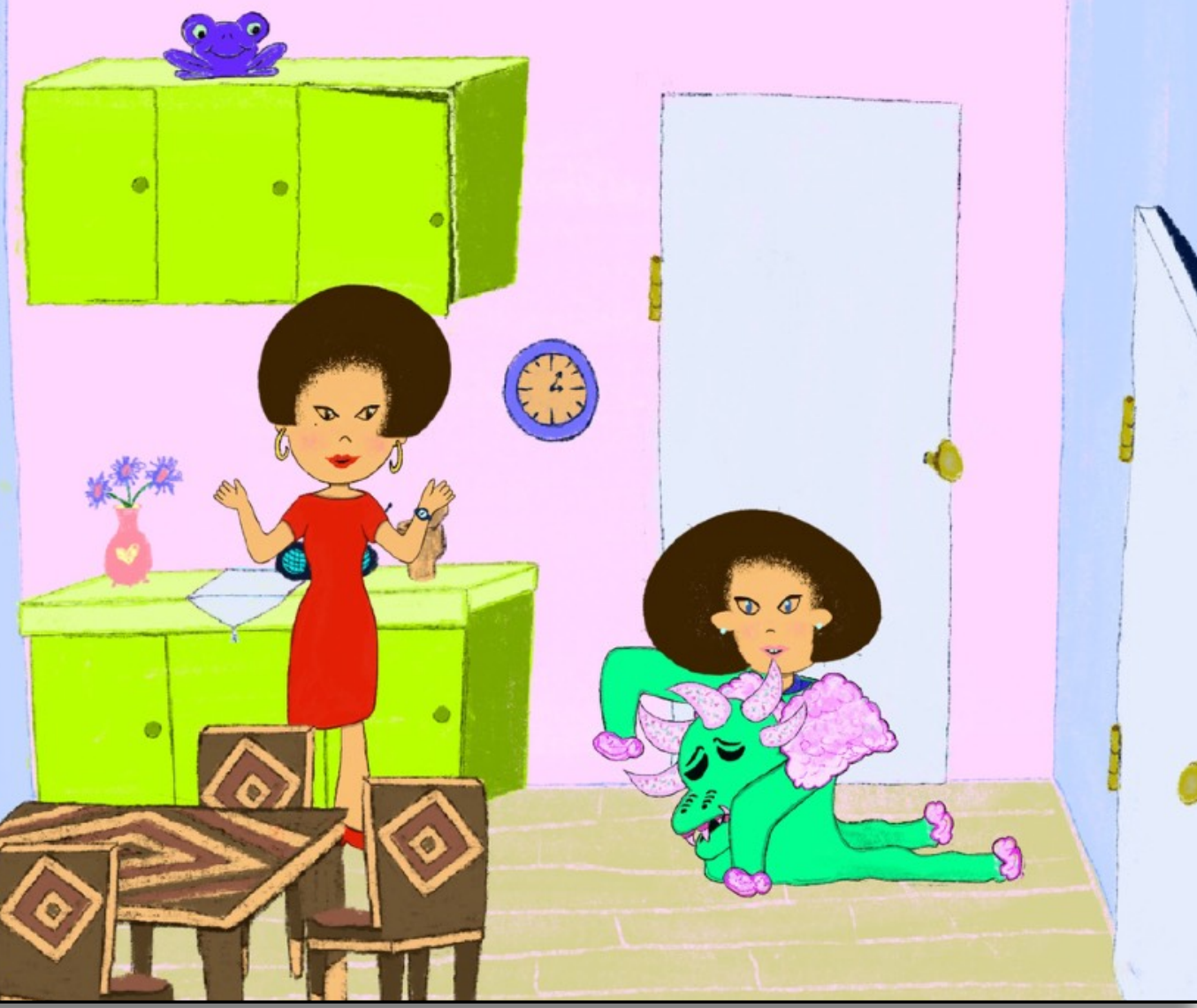


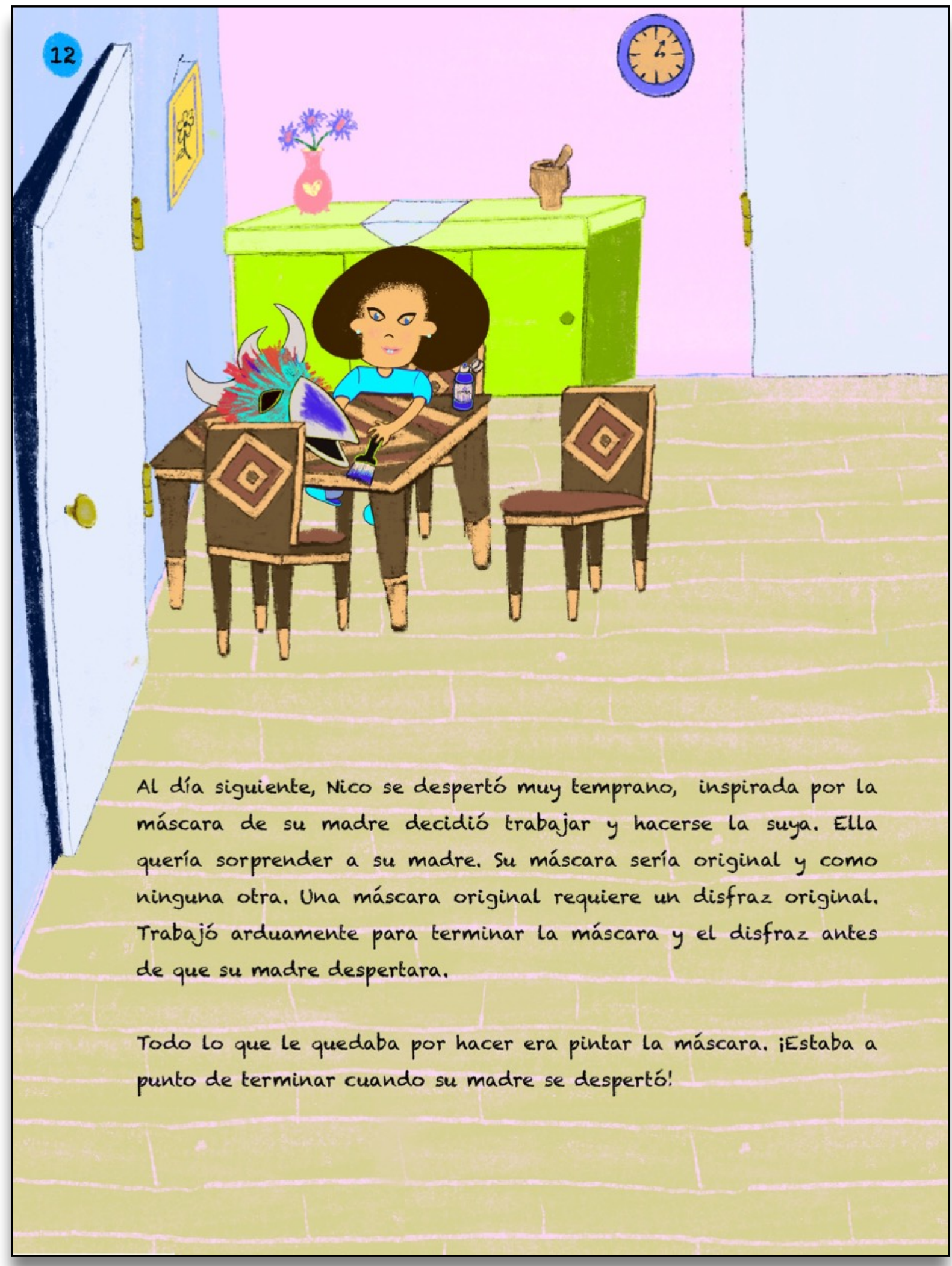




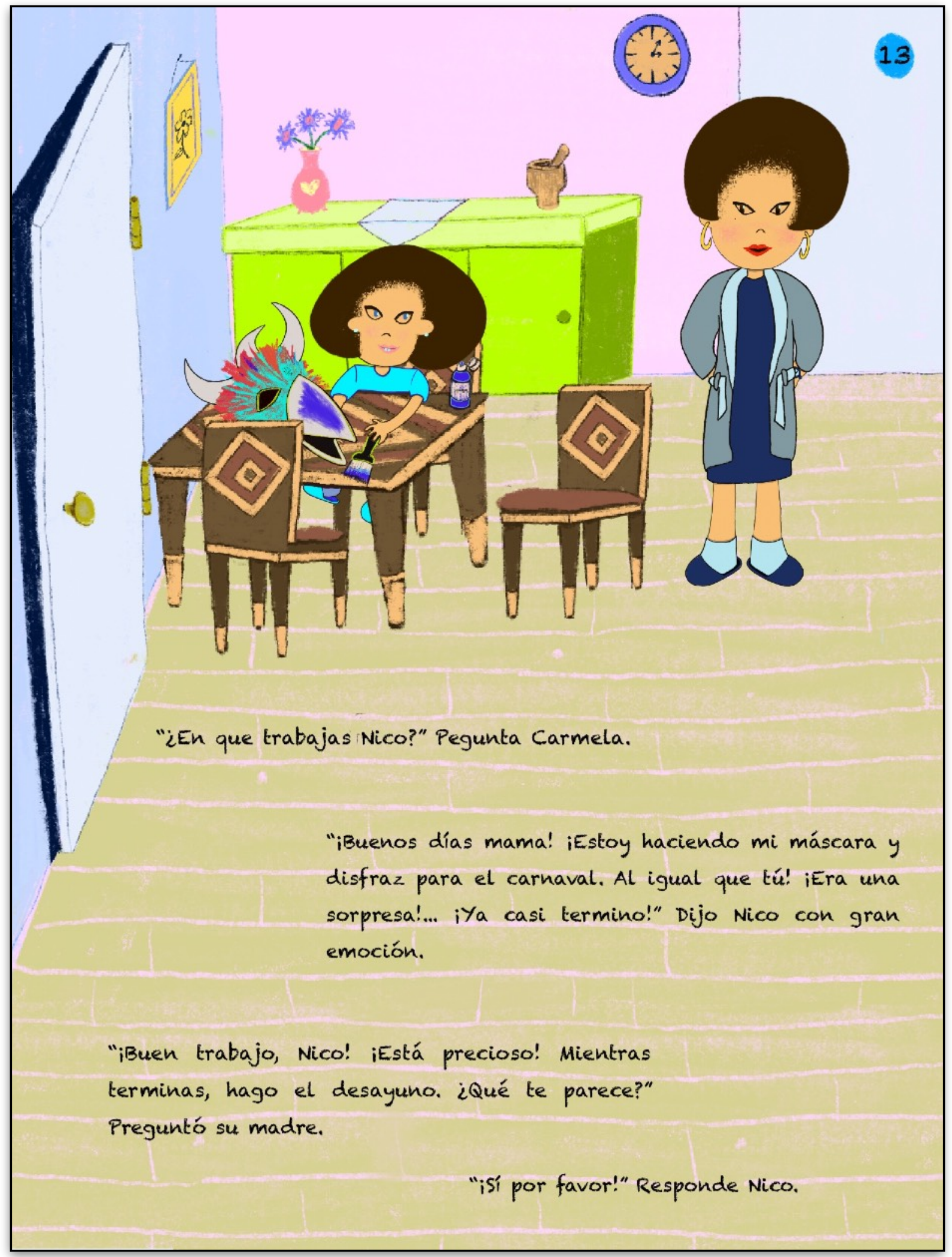


"iMamá! iTerminé mi máscara y traje de vejigante!" Gritó Nico.

"iEstá hermoso! iMe encanta! Es muy original Buen trabajo, Nico. Estoy orgullosa de ti." Dijo su madre. "Ahora, prepárate para el Carnaval... Pero primero..."
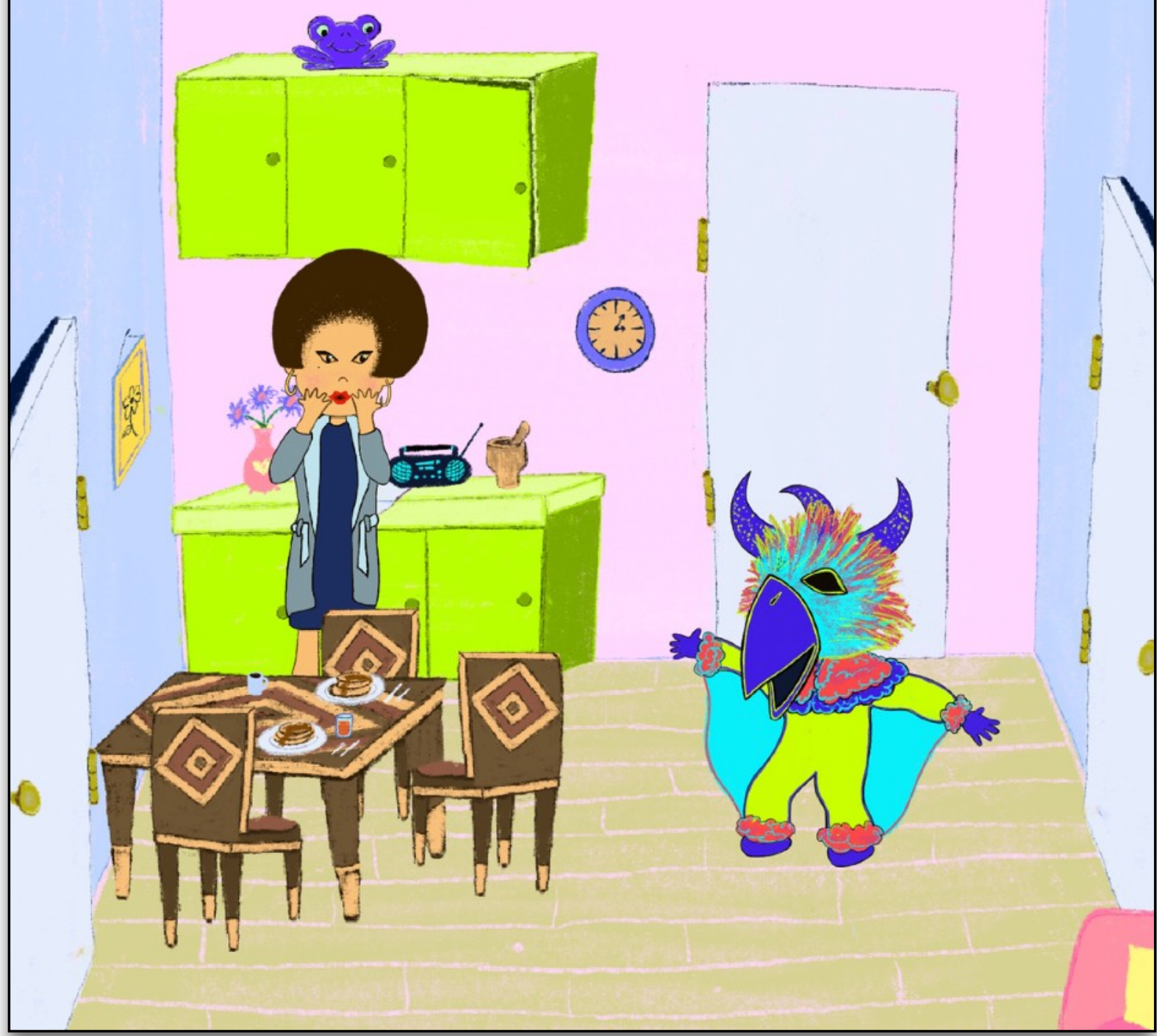
"iVamos a bailar!" Gritó la mamá de Nico.

"¡Baila, baila, baila!" Gritó Nico. 
16

"Ve y disfruta con los otros vejigantes. Baila, baila..."

Le dice Carmela a Nico. La niña corre hacia los otros niños vestidos de vejigantes.

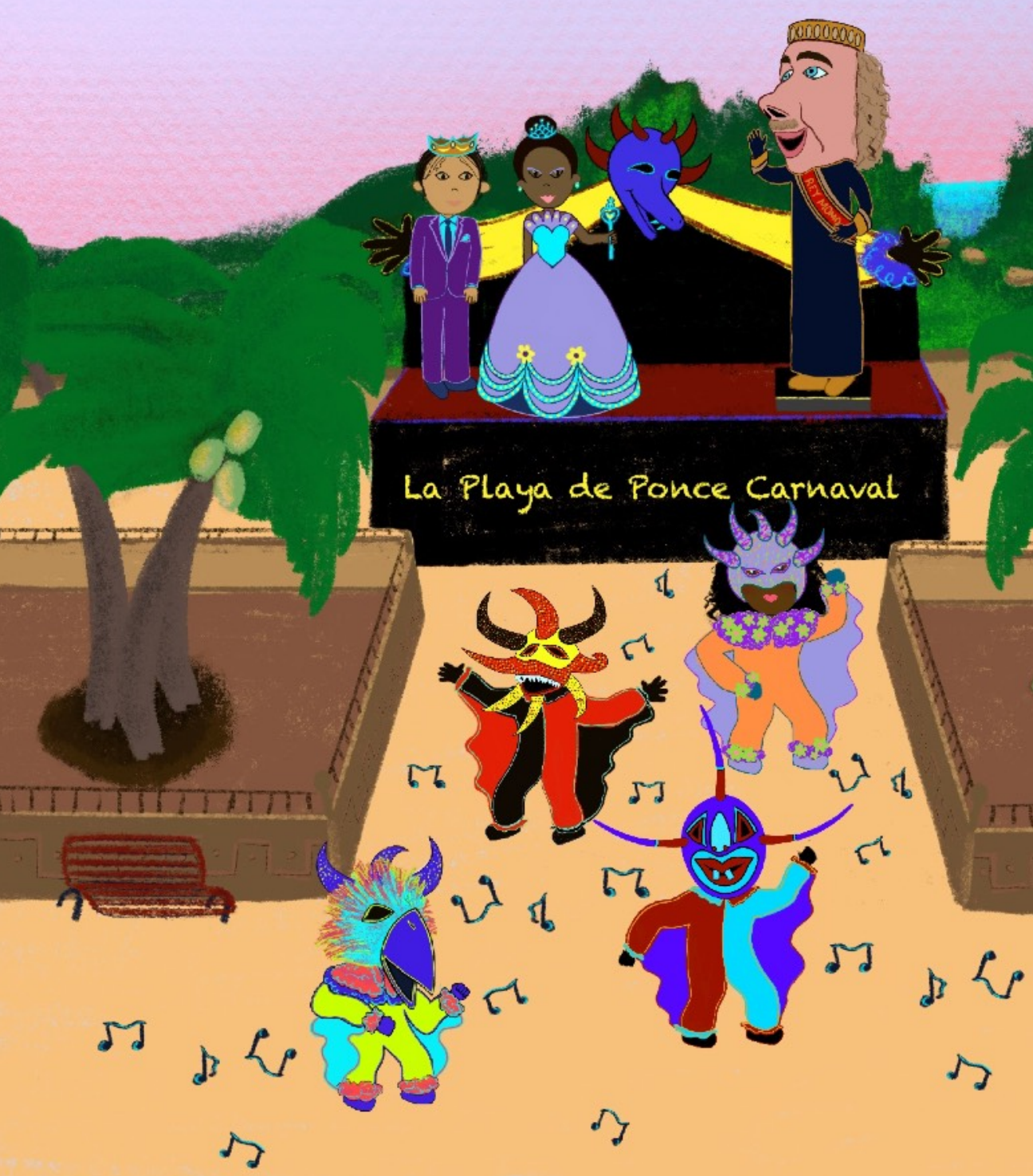


"¿Disfrutaste del carnaval, Nico? Cuéntame mientras

caminamos a casa." Le dice Carmela a su hija.

"iSi! Conocí muchas personas. Todos los disfraces eran diferentes y llenos de color. Todos en la comparsa bailamos juntos y asustamos a la gente viendo el Carnaval. Ahora somos amigos carnavaleros..."

Carmela le pregunta, "iQue divertido! Cuéntame, ¿A quienes has conocido?"

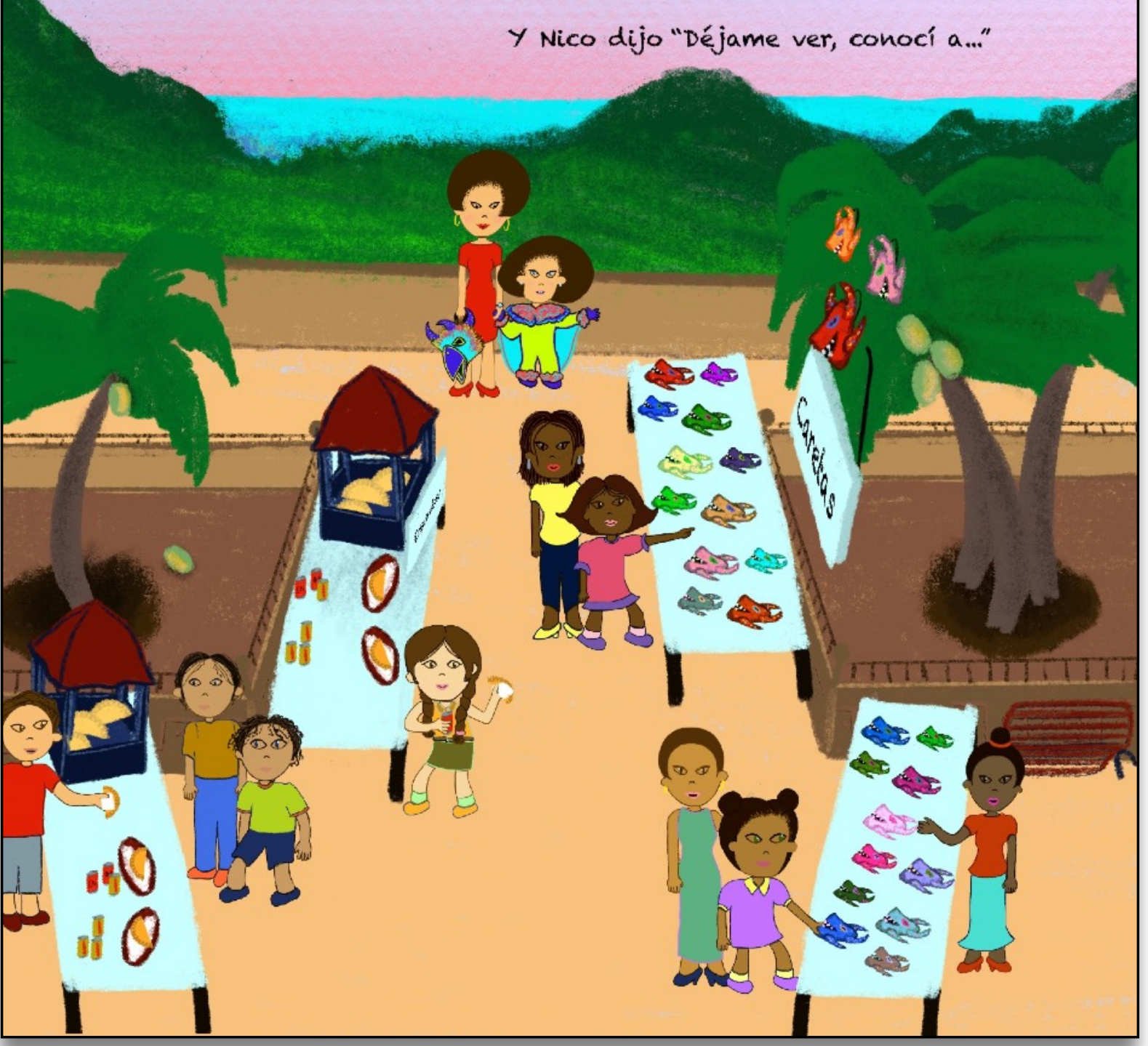


18

iEsta es Marisol!

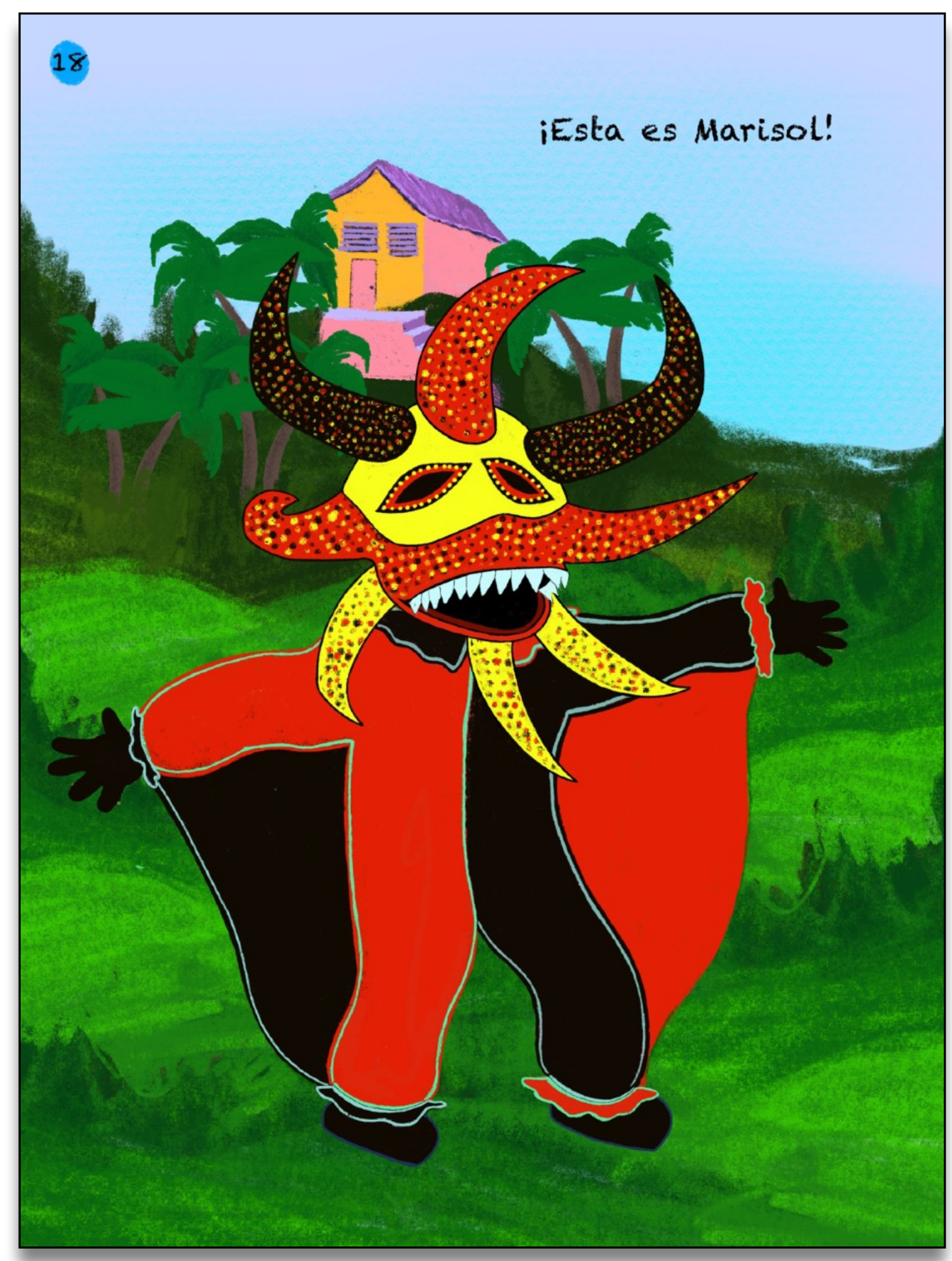


Marisol vive en el campo con su padre y su madre. Su padre es un artesano. isu máscara fue creada por su artesano de máscaras favorito, Caraballo! Cada año baila con su padre en el Carnaval, iEs tradición! Ella espera que algún día pueda ser artesana como Caraballo y su padre.

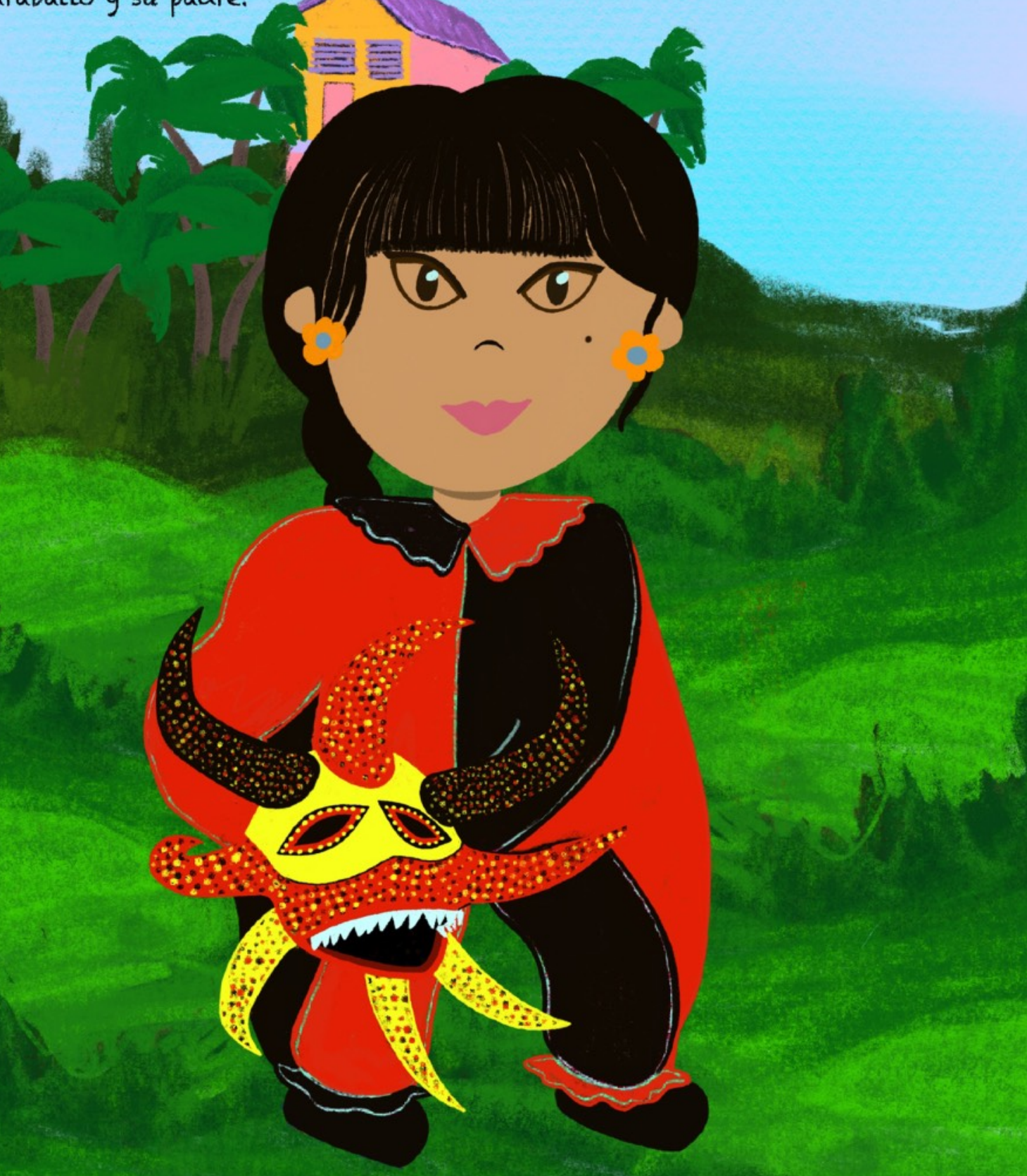




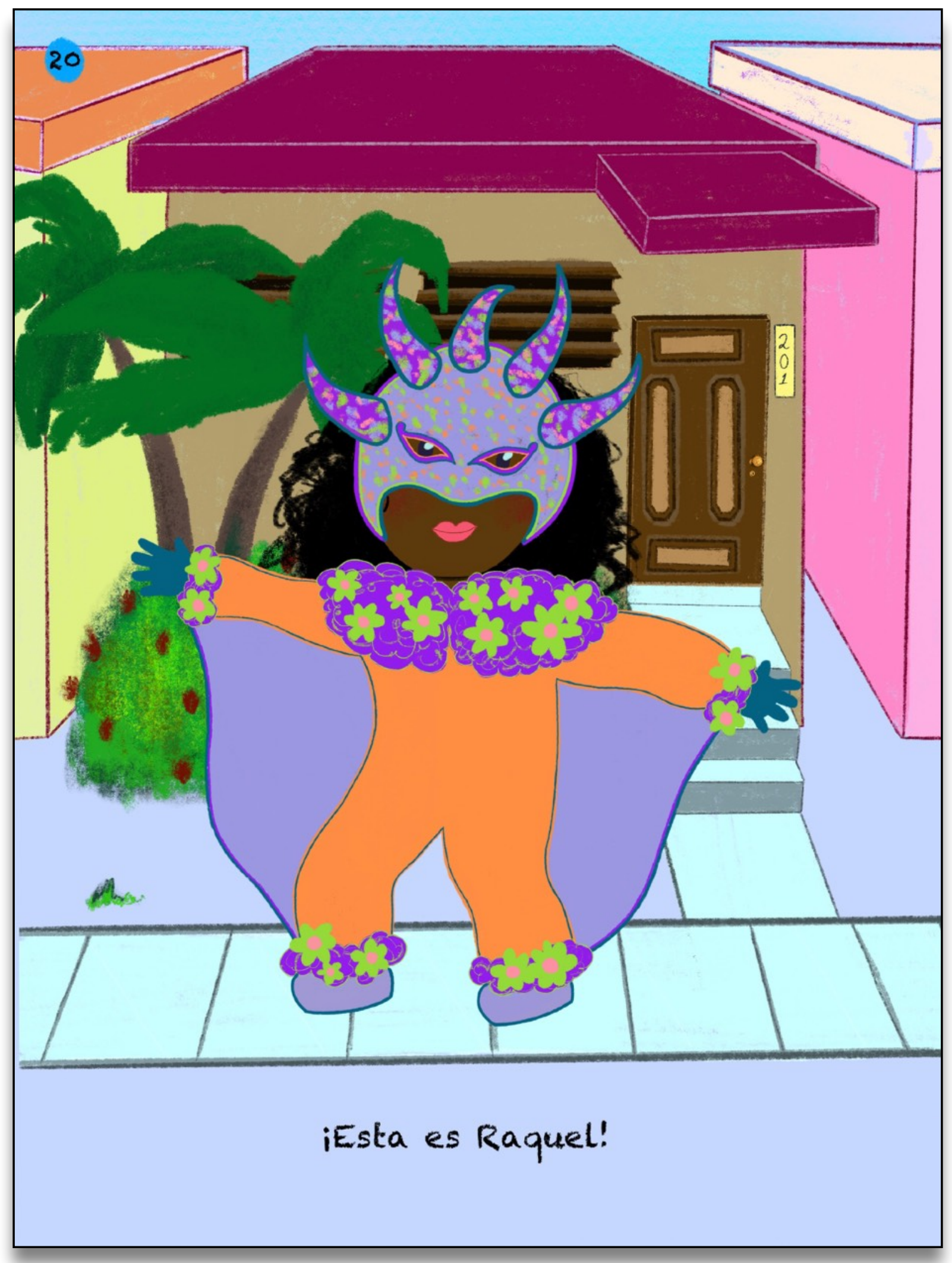




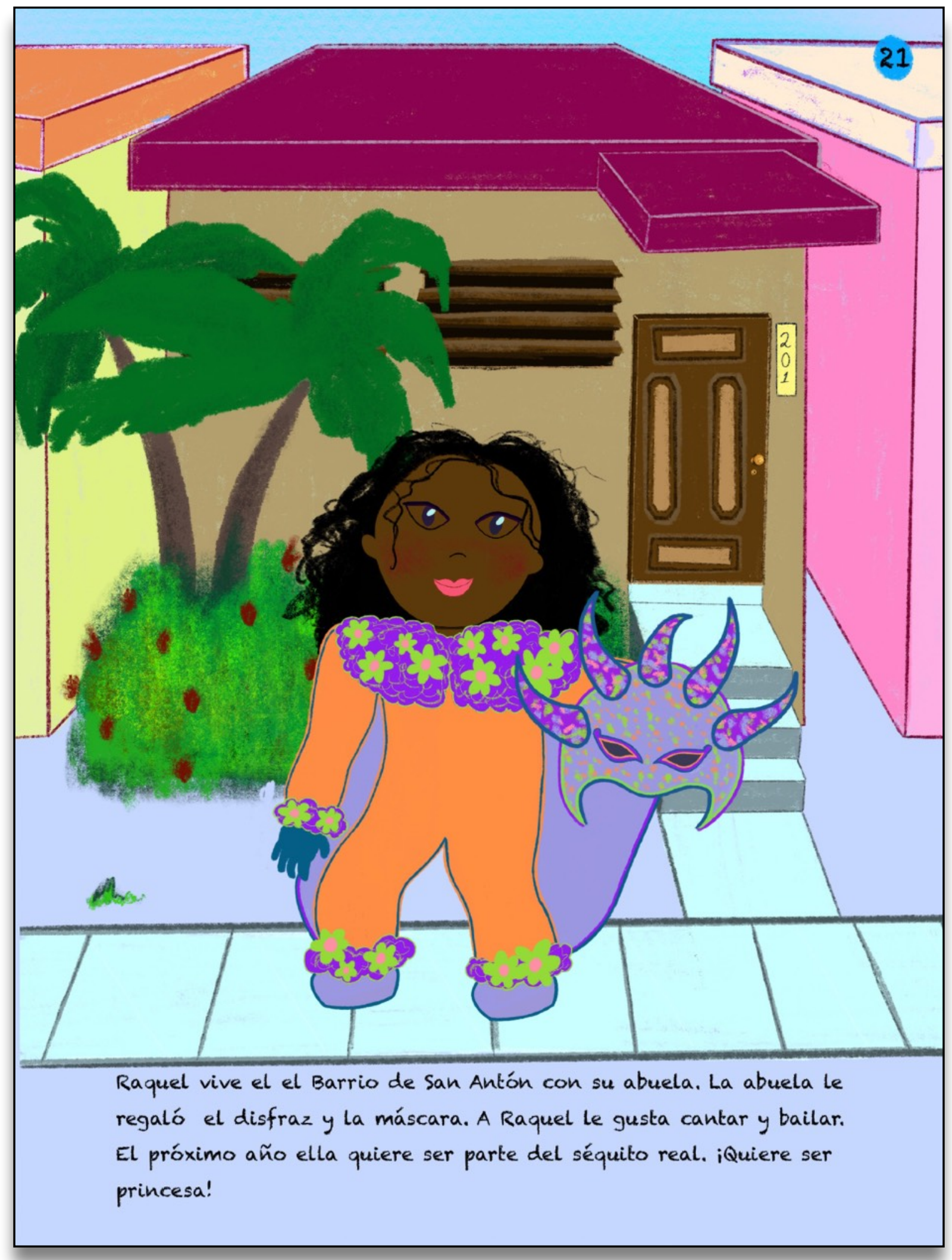




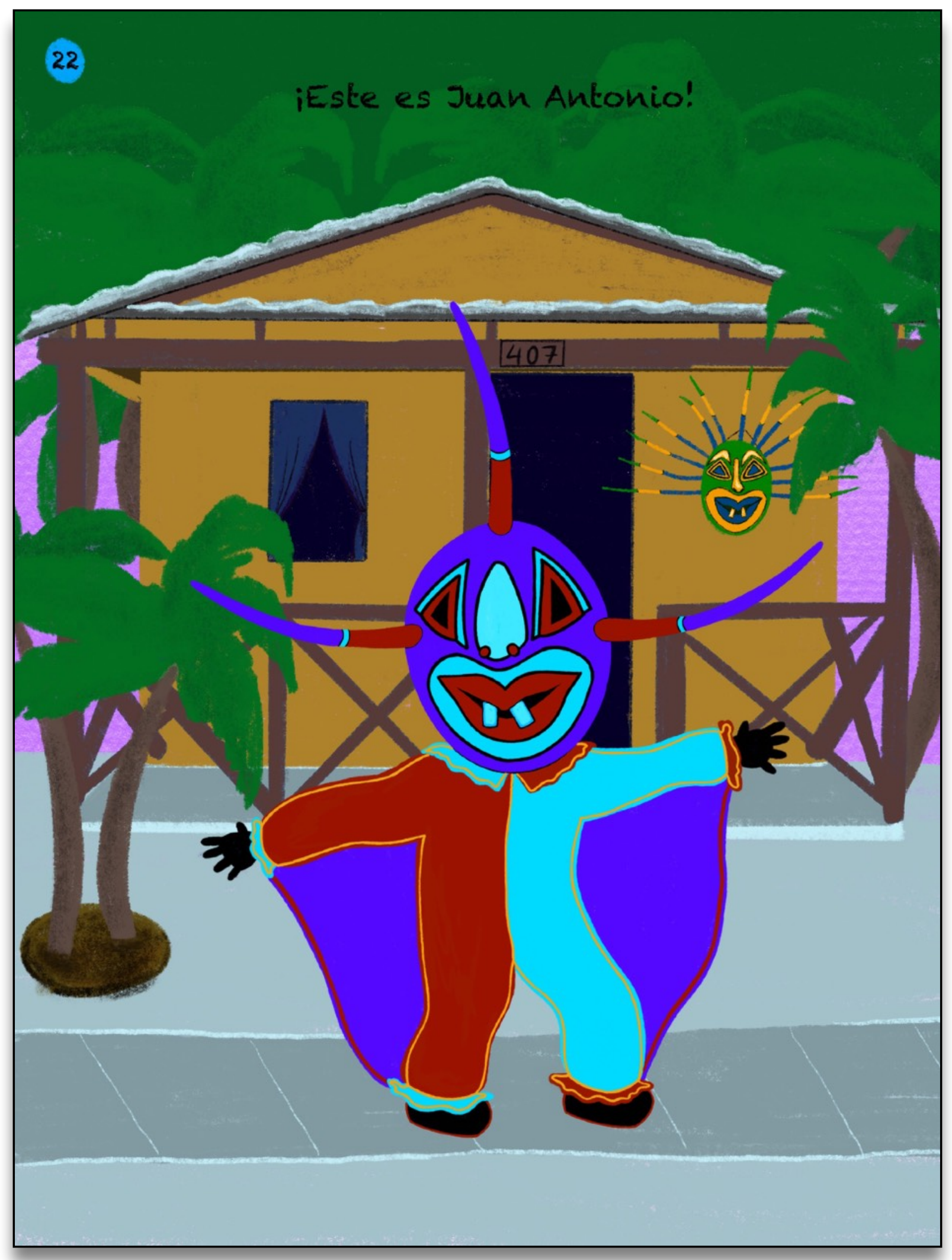


iEra la primera vez que Juan Antonio bailaba en el Carnaval! El es de Loíza Aldea. El vive en una parcela con su mamá y sus dos gatos. El hizo su máscara y su abuela le hizo el disfraz. Su máscara y disfraz son diferentes a los de Ponce. La máscara está hecha del casco del coco, como es tradicional en Loíza Aldea
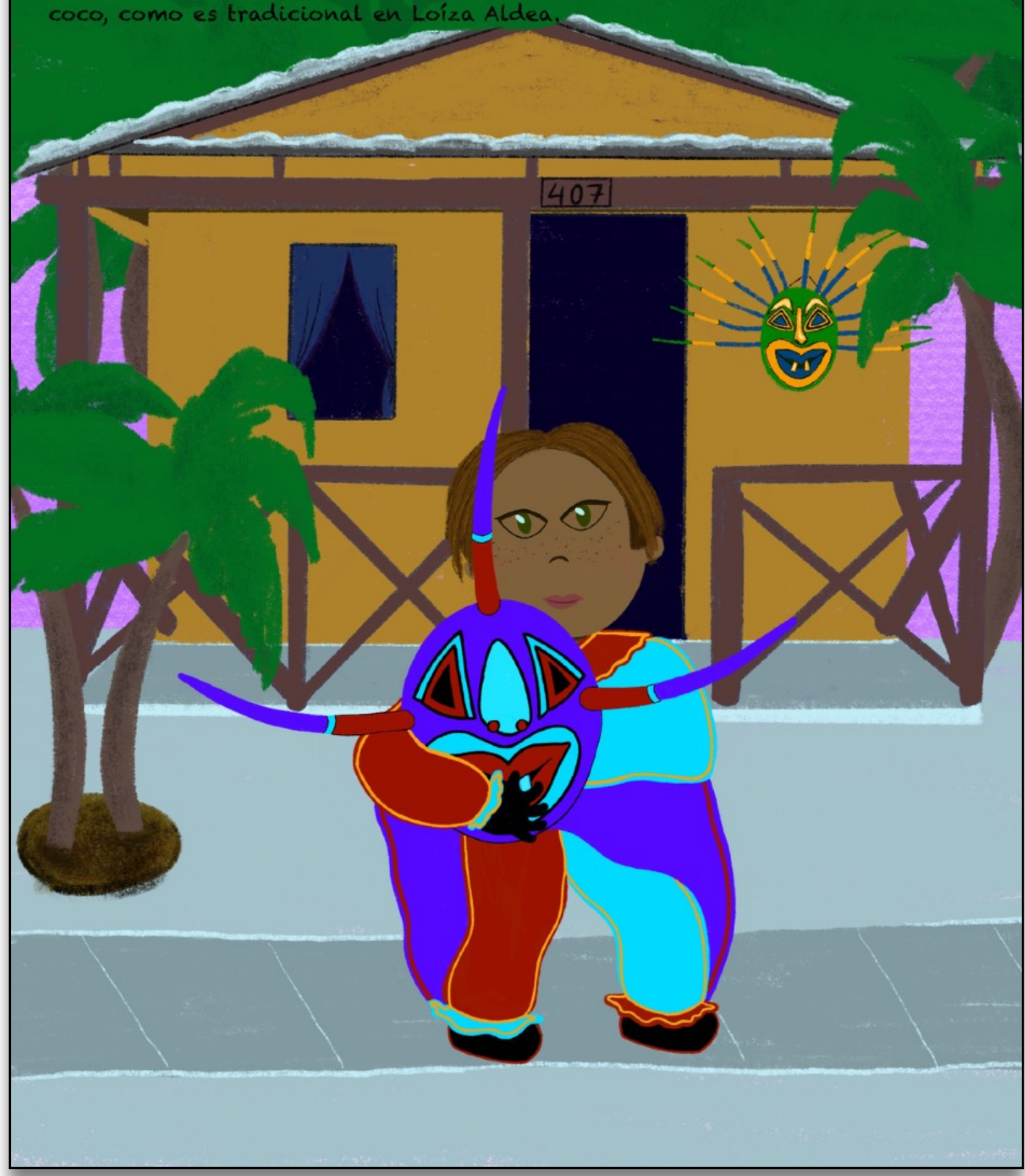


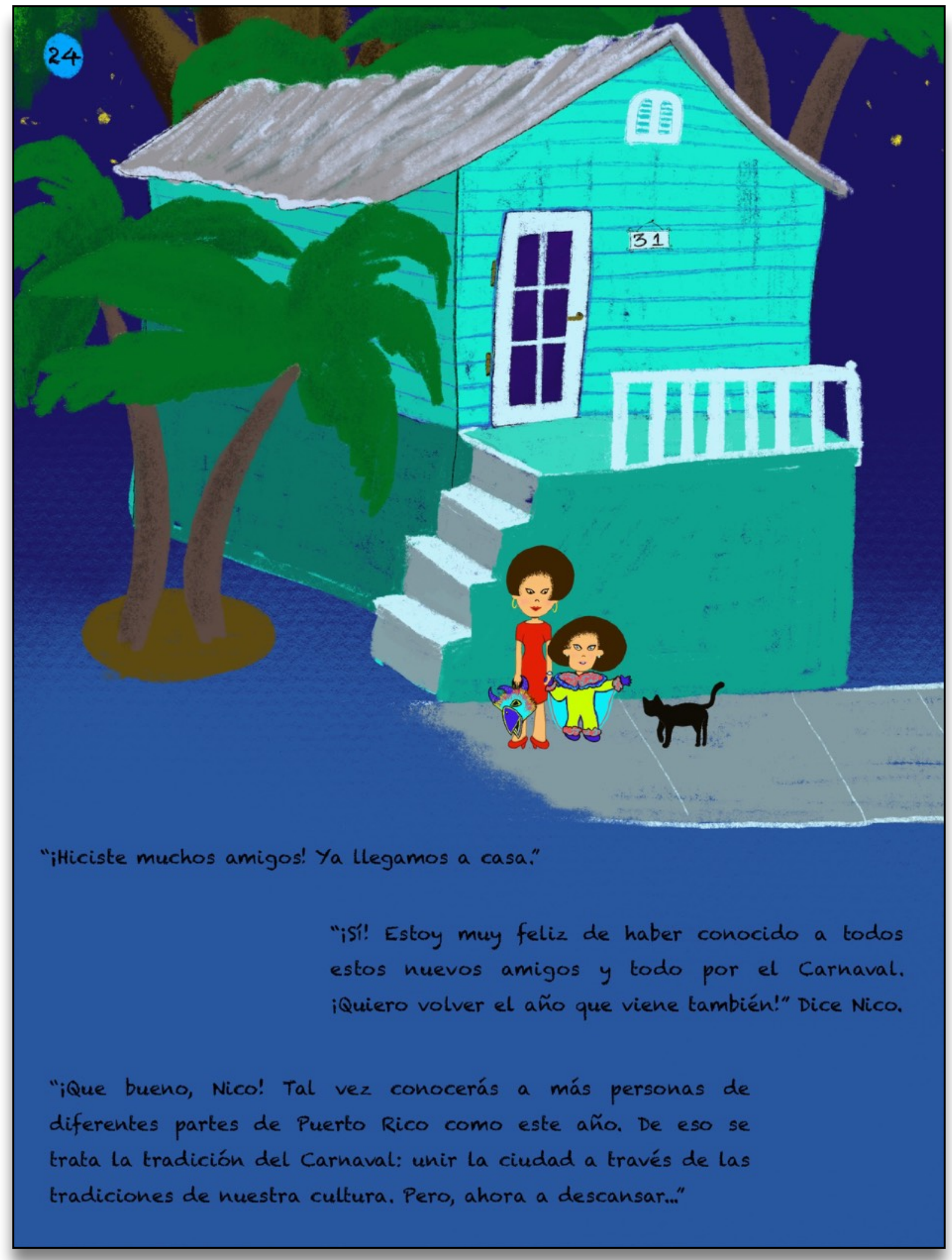




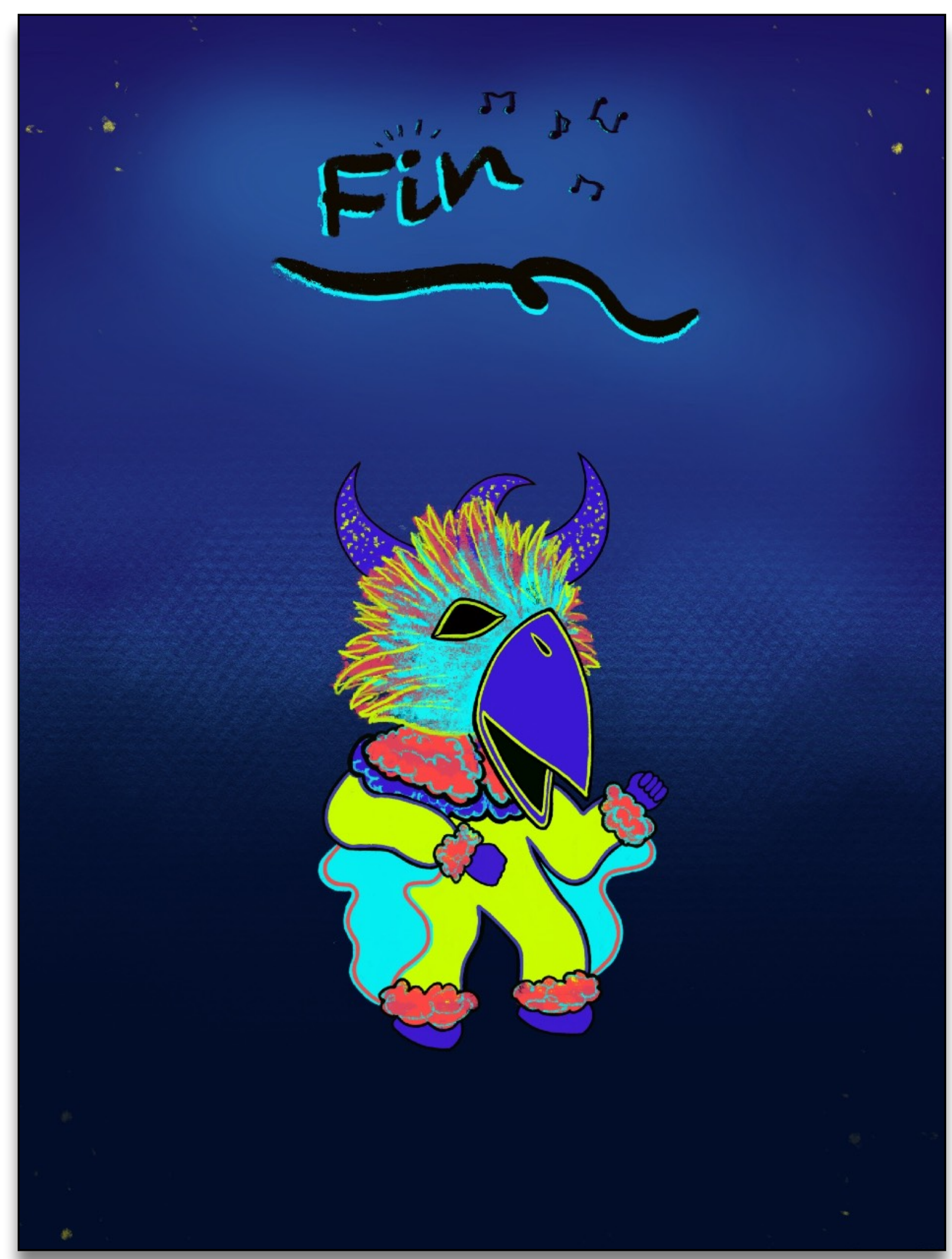




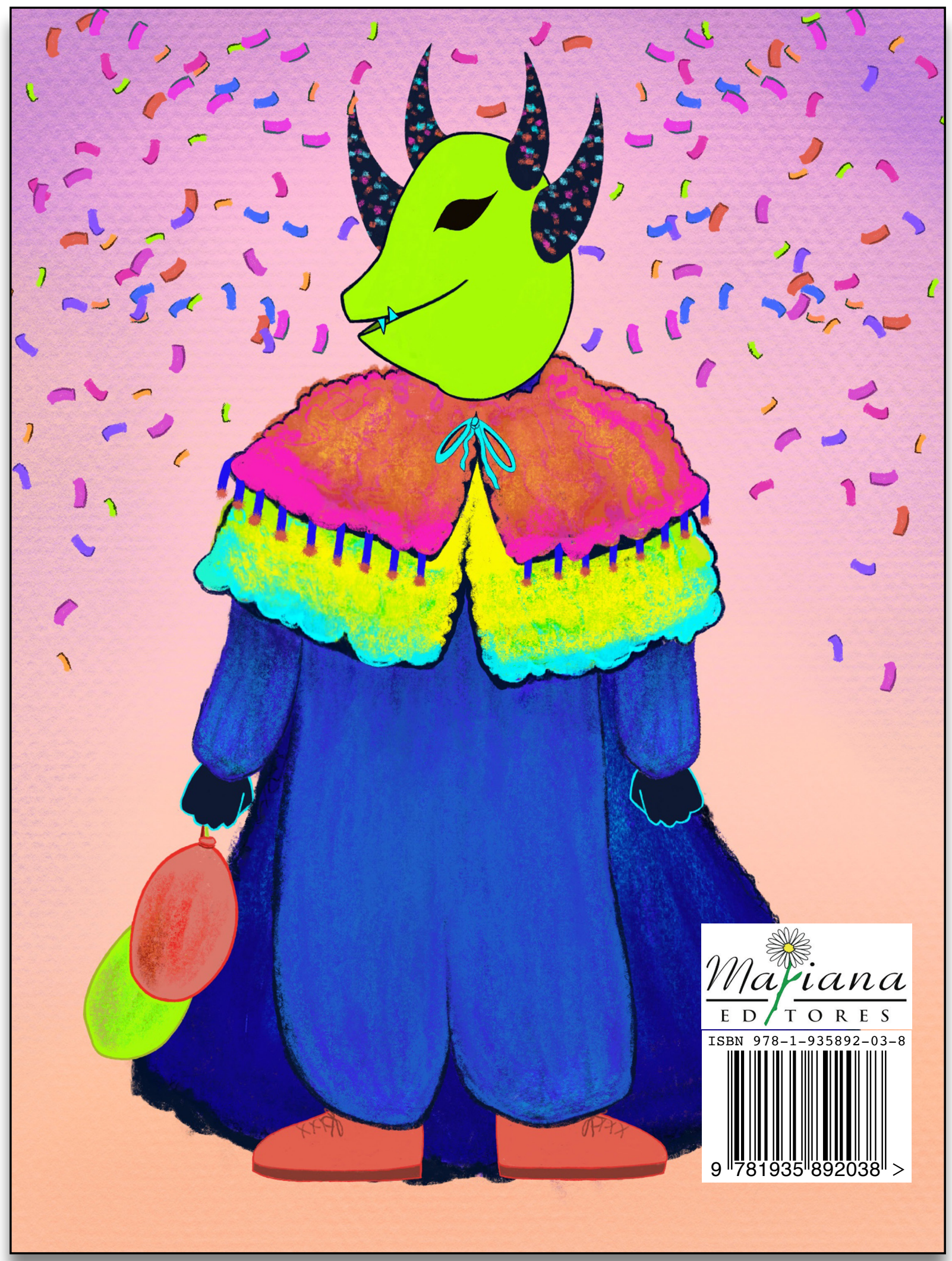

